\title{
Directe democratie in Nederland : een onderzoek naar de mogelijkheden van openbaarheid van bestuur, inspraak, referendum en volksinitiatief in onze rechtsorde
}

Citation for published version (APA):

Koning, H. (1995). Directe democratie in Nederland : een onderzoek naar de mogelijkheden van openbaarheid van bestuur, inspraak, referendum en volksinitiatief in onze rechtsorde. [Doctoral Thesis, Maastricht University]. Sdu Fiscale en Financiele Uitgevers. https://doi.org/10.26481/dis.19950929hk

Document status and date:

Published: 01/01/1995

DOI:

10.26481/dis.19950929hk

Document Version:

Publisher's PDF, also known as Version of record

Please check the document version of this publication:

- A submitted manuscript is the version of the article upon submission and before peer-review. There can be important differences between the submitted version and the official published version of record. People interested in the research are advised to contact the author for the final version of the publication, or visit the DOI to the publisher's website.

- The final author version and the galley proof are versions of the publication after peer review.

- The final published version features the final layout of the paper including the volume, issue and page numbers.

Link to publication

\footnotetext{
General rights rights.

- You may freely distribute the URL identifying the publication in the public portal. please follow below link for the End User Agreement:

www.umlib.nl/taverne-license

Take down policy

If you believe that this document breaches copyright please contact us at:

repository@maastrichtuniversity.nl

providing details and we will investigate your claim.
}

Copyright and moral rights for the publications made accessible in the public portal are retained by the authors and/or other copyright owners and it is a condition of accessing publications that users recognise and abide by the legal requirements associated with these

- Users may download and print one copy of any publication from the public portal for the purpose of private study or research.

- You may not further distribute the material or use it for any profit-making activity or commercial gain

If the publication is distributed under the terms of Article 25fa of the Dutch Copyright Act, indicated by the "Taverne" license above,

Download date: 26 Apr. 2023 
Directe democratie in Nederland 


\section{Omslag:}

schilderij Directe democratie in Nederland van Gerry Vluggen vormgeving omslag: Tony Claessens, Maastricht

Van dit proefschrift verschijnt een handelseditie onder ISBN 9054091010 


\section{Directe democratie in Nederland}

Een onderzoek naar de mogelijkheden van openbaarheid van bestuur, inspraak, referendum en volksinitiatief in onze rechtsorde

\section{PROEFSCHRIFT}

ter verkrijging van de graad van doctor aan de Rijksuniversiteit Limburg te Maastricht, op gezag van de Rector Magnificus, Prof.mr. M.J. Cohen, volgens het besluit van het College van Dekanen, in het openbaar te verdedigen op vrijdag 29 september 1995 om 14.00 uur

door

Henk Koning 
Promotores:

Prof. mr. F.A.M. Stroink

Prof. mr. A.Q.C. Tak

Beoordelingscommissie:

Prof. dr. A.F.A. Korsten (voorzitter)

Prof. mr. J. Boesjes

Prof. mr. L.J.A. Damen (Rijksuniversiteit Groningen)

Dr. G.A.A.J. van den Heuvel 


\section{Voorwoord}

Om een boek te kunnen schrijven, heb je anderen nodig. Enkelen van hen wil ik hier in het bijzonder noemen. Allereerst zijn dat mijn beide promotoren: Frits Stroink en Twan Tak, die mij aanmoedigden en stimulerend weerwerk leverden.

Dan zijn er de leden van de beoordelingscommissie: Arno Korsten, Jan Boesjes, Leo Damen en Grat van den Heuvel. Binnen een tijd van vier weken kwam de commissie tot een oordeel. Enkele leden voegden daar nuttige aanbevelingen en kritiek aan toe.

Wies Rayar maakte van de samenvatting een heldere summary, en Bregtje Schwenke en Nettie Litjens maakten de gehele tekst toonbaar voor de camera.

Veel profijt heb ik gehad van de Maastrichtse Universiteitsbibliotheek. Ze is niet de grootste van Nederland, maar wel een bibliotheek met een mooie en toegankelijke collectie en, wat ook plezierig is, hulpvaardige medewerkers en medewerksters.

En dan is er de thuisbasis: Gerry, Pieter en Tessa, die mij gelukkig altijd weer op andere onderwerpen weten te brengen. Aan hen draag ik dit boek op.

Maastricht, juli 1995 



\section{Inhoudsopgave}

Voorwoord iv

Inhoudsopgave $\ldots \ldots \ldots \ldots \ldots \ldots \ldots \ldots$ vii

Hoofdstuk 1 Democratie

1. Enkele herinneringen $\ldots \ldots \ldots \ldots \ldots \ldots \ldots$

2. De democratische theorie . . . . . . . . . 7

3. Hoe verbeteren we onze democratie? . . . . . 15

Hoofdstuk 2 De opkomst van de openbaarheid

1. Het beginsel van openbaarheid $\ldots \ldots \ldots \ldots 21$

2. De voorgeschiedenis .............. 22

3. De principiële discussie begint. . . . . . . . . 2 29

4. De Commissie Biesheuvel wordt ingesteld . . . . . 3 34

5. De rechtswetenschap en de openbaarheid . . . . . 40

Hoofdstuk 3 Wettelijke regels voor openbaarheid van bestuur?

1. De preadviezen van Donner en Van der Hoeven . . 49

2. Het preadvies van Steenbeek ........... . 56

3. Het rapport van de Commissie Biesheuvel . . . . . 62

4. De reacties op het rapport Biesheuvel . . . . . . 70

Hoofdstuk 4 De Wet openbaarheid van bestuur

1. Het wetsvoorstel ............. 85

2. Voorlopig verslag en memorie van antwoord . . . 993

3. De besluitvorming over het wetsvoorstel . . . . 101

Hoofdstuk 5 Openbaarheid sinds de Wet openbaarheid van bestuur

1. De rechter en de openbaarheid van bestuur .... 111

2. De nieuwe WOB: Eén stap vooruit, twee stappen

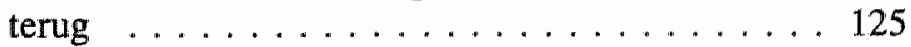


Hoofdstuk 6 De loyaliteit van de ambtenaar, I

(De klassieke leer)

1. Loyaliteit en democratie . . . . . . . . . 139

2. Vooroorlogse opvattingen over ambtelijke loyaliteit 144

3. Friedrich versus Finer $\ldots \ldots \ldots \ldots \ldots \ldots .152$

Hoofdstuk 7 De loyaliteit van de ambtenaar, II (Naar een nieuwe opvatting)

1. Naoorlogse ontwikkelingen in de politieke theorie . 159

2. Naoorlogse opvattingen in de staatsrechtelijke literatuur . . . . . . . . . . . . . . . . 164

3. De ambtenarenrechter en de vrijheid van meningsuiting $\ldots \ldots \ldots \ldots \ldots \ldots \ldots \ldots \ldots$

4. Wat is een loyale ambtenaar? . . . . . . . 183

Hoofdstuk 8 Inspraak

1. Waarom inspraak? . . . . . . . . . . . 191

2. Inspraakregels voor gemeenten, provincies, en waterschappen . . . . . . . . . . . . . . 199

3. Inspraak volgens de Algemene wet bestuursrecht . 209

4. Inspraak, overlegmodellen, en 'eigen' deskundigen $\ldots \ldots \ldots \ldots \ldots \ldots \ldots 216$

5. Wat moet er aan inspraak worden geregeld? . . . 224

Hoofdstuk 9 Referendum en volksinitiatief

1. Referendum en volksinitiatief als sluitstukvan de democratie . . . . . . . . . . . . . . . . 229

2. Voorstellen en ideeën vóór de grondwetsherziening van $1983 \ldots \ldots \ldots \ldots \ldots \ldots . . \ldots 232$

3. De Commissie Relatie Kiezers-Beleidsvorming . . 237

4. De discussie over staatkundige, bestuurlijke en staatsrechtelijke vernieuwing . . . . . . . 247

5. Het referendum volgens de Commissie Biesheuvel 255

6. Het volksinitiatief volgens de Commissie Biesheuvel . . . . . . . . . . . . . 261

7. De wenselijkheid van referendum en volksinitiatief 267 
Hoofdstuk 10 Directe democratie in Nederland

1. De verbetering van onze democratie . . . . . 273

2. De openbaarheid van bestuur ........ 275

3. De loyaliteit van de ambtenaar . . . . . . . 279

4. Inspraak . . . . . . . . . . . . . . . . 283

5. Referendum en volksinitiatief . . . . . . . . 285

6. Een slotakkoord . . . . . . . . . . . . . . . . 289

Summary . . . . . . . . . . . . . . . . . . . . . . . . 293

Stellingen . . . . . . . . . . . . . . . . . . . 307

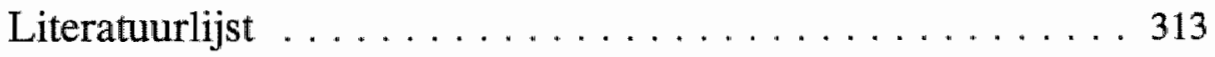

Persoonsregister . . . . . . . . . . . . . . . . . . 319

Curriculum vitae $\ldots \ldots \ldots \ldots \ldots \ldots \ldots \ldots \ldots \ldots$ 


\section{Hoofdstuk 1}

\section{Democratie}

\section{Enkele herinneringen}

Van 1975 tot 1984 ben ik werkzaam geweest bij de Sectie Inspraak en Wijkaangelegenheden van de gemeente Utrecht. Deze sectie was in het begin van de jaren zeventig opgericht als een centraal punt in de gemeenteorganisatie voor de ontwikkeling van inspraakbeleid. Ze adviseerde het gemeentebestuur en de verschillende dienst-onderdelen over inspraak in algemene zin, en de toepassing daarvan in concrete projecten. Ook adviseerde ze over subsidies voor wijk- en buurtcomite's. Daarnaast had de sectie een logistieke taak bij de organisatie van inspraak-bijeenkomsten (zoals zaalruimte regelen, notulisten inschakelen e.d.). De meeste projecten waar de sectie bij betrokken was, hadden te maken met stadsvernieuwing, bestemmingsplannen, nieuwbouw, en verbetering van de woonomgeving. Ook moest er inspraakbeleid tot stand worden gebracht voor omstreden onderwerpen als woonwagenstandplaatsen en opvangcentra voor drugsverslaafden.

Rond 1980 werkten er bij de Sectie Inspraak vijf beleidsmedewerkers, en twee medewerkers voor uitvoerende taken. Daarna kwam, onder invloed van een zich steeds meer verbreidende 'no nonsense'-houding, het werk van de sectie onder druk te staan. Politici en bestuurswetenschappers in ons land kregen hun bekomst van inspraak. Het was kennelijk een te moeilijke materie, die te weinig voor hen opleverde. Onder invloed van de privatiserings- en dereguleringsgedachte ging men liever de aandacht richten op de mogelijkheden van afslanking van de overheid als geheel. Ik kom daar in paragraaf 3 van dit hoofdstuk nog in een wat ruimer verband op terug. Afslanking van de overheid zou voor de burgers niet alleen belastingverlaging opleveren, maar, gecombineerd met een public relationsaanpak, ook een "klantvriendelijke overheid". Wat dat was, wist niemand. En niemand zou het ooit weten. Maar onze politici en bestuurswetenschappers hadden een slogan gevonden, waar men weer een aantal jaren mee vooruit kon. Inspraak raakte uit de mode. Het begrip bleef nog wel bestaan, maar werd in de bestuurspraktijk steeds verder uitgekleed tot kale 
bezwarenprocedures. Die zouden onder de noemer van 'inspraakprocedures' nog in verschillende wettelijke regelingen worden vastgelegd.'

De Sectie Inspraak is in Utrecht eind jaren tachtig opgeheven. Dat gebeurde ongeveer tegelijkertijd met de opheffing van het Centraal Punt Inspraak van de nationale Raad voor de Ruimtelijke Ordening. In beide gevallen werd dezelfde reden angevoerd: Een speciale sectie of speciaal punt voor inspraak-bevordering was niet meer nodig, want 'het experimenteer-stadium van de inspraak' was voorbij. Dat mocht ieder opvatten zoals hij dat zelf wilde.

Inspraak is een luxe-artikel, wordt wel gezegd. Inspraak was mooi in de jaren zeventig, toen men dacht dat het geld niet op kon. Als er geen geld is voor leuke dingen, werkt inspraak alleen maar frustrerend. Want dan wek je bij mensen illusies op, terwijl je ze niets te bieden hebt. Inspraak is dan eigenlijk bedrog, wordt wel beweerd. Maar ik heb in die negen jaar, dat ik inspraak begeleidde, nooit meegemaakt, dat mensen dingen wilden, die per saldo duurder waren dan wat de overheid zelf voorstelde. Waar gaat het dan wel om bij inspraak? Laat ik eens een paar voorbeelden uit de praktijk geven.

\section{Het binnenterreintje in Wijk $C$.}

Ten noorden van het Vreeburg ligt in de Utrechtse binnenstad een wijkje met vanouds een woon- en werkbestemming: Wijk C. De woonbestemming is na de oorlog nogal in de verdrukking geraakt door kaalslag en de bouw van banken, kantoren en warenhuizen. Het oude karakter van de wijk is eigenlijk alleen nog te vinden in omgeving van de Willemstraat, de Bergstraat en de Dirck van Zuylenstraat. Tussen deze straten ligt, omsloten door woninkjes, winkeltjes en enkele café's, een binnenterreintje van naar schatting zo'n vijftig meter lang en, op het breedste punt, zo'n dertig meter breed. Vroeger was daar een drukkerij gevestigd, maar die werd in de zeventiger jaren weggesaneerd. De gemeente kreeg het terreintje in handen, het bedrijfsgebouw werd afgebroken, en op de open plek werd, in afwachting van de definitieve herinrichting tot buurtparkje, gras ingezaaid. De zomer daarop was het gras zo mooi opgekomen, dat buurtbewoners al volop van het nieuwe parkje konden genieten. De kinderen konden er 'grasduinen', volwassenen gingen er op zelf meegebrachte tuinstoeltjes in de zon zitten, en ook omwonenden die in hun eigen tuintje bleven, profi-

1 In het Nederlands Juristenblad van 1990, pag. 1064-1071, heb ik hierover uitgebreider geschreven onder de titel Inspraak volgens nieuwe wetten. In hoofdstuk 8 van dit boek komt het onderwerp ook aan de orde. 
teerden van het parkje. Want nu het bedrijfsgebouw was afgebroken, kon de zon achter het huis schijnen. Kortom, iedereen was blij en tevreden.

De gemeente vond echter, dat ze meer voor de wijkbewoners moest doen. Dat kwam zo: het terreintje was bij het Rijk aangemeld voor verhaal in het kader van de toen nog bestaande Interim-saldoregeling. Dat betekende, dat de gemeente de aankoop- en herinrichtingskosten vrijwel helemaal kon declareren bij het Rijk. Bij die herinrichtingskosten hoorden ook de kosten voor het maken van een inrichtingsplan. Dat gaf de gemeente de gelegenheid om een landschapsarchitect in gemeentedienst voor een flink aantal uren 'rendabel' te maken. Hoe duurder het plan zou zijn, des te meer ontwerp-uren zouden aannemelijk kunnen worden gemaakt. Daarom werd in het plan welhaast een doolhof van voetpaden ingetekend. Daarbij kwam een meubilair dat bestond uit alle mogelijke klimtoestellen voor kinderen, en een groot aantal hardhouten banken in Tudor-stijl voor de grote mensen. Dat alles werd gesitueerd temidden van een verscheidenheid van aan te planten bomen en struiken, waar een gemiddeld provinciaal arboretum jaloers op kon zijn. Een aantal van die bomen en struiken zou zelfs op kunstmatig opgeworpen zandbergjes worden geplant. Maar het pronkstuk zou toch wel de atlantische ceder worden, die aan de kant van de Willemstraat zou worden geplaatst, en bij aanplant al meteen zo'n vijftien meter hoog zou zijn.

Of de wijkbewoners het geen prachtig plan vonden, vroegen de gemeente-ambtenaren op de inspraakavond. De bewoners waren eerder verbaasd dan enthousiast. Hoe was het mogelijk dat de gemeente, die al jarenlang de woonfunctie in de wijk verwaarloosde, nu opeens zo met geld wilde smijten? En waarvoor was dat nodig? Het parkje, zoals dat nu provisorisch was ingericht, voldeed toch al redelijk goed. Enkele houten banken, een eenvoudig wandelpaadje, en een beetje beplanting wilde men er wel hebben. Als daar nog een speelvoorziening voor kinderen bij zou komen, zou dat toch voldoende zijn voor zo'n klein stukje grond. Wat de klimtoestellen betreft, had men een goede tip voor de gemeente. Die konden worden weggehaald bij de hoek van de Jacobsstraat, waar toch niemand zijn kinderen durfde te laten spelen op enkele meters afstand van het drukke autoverkeer. Van gemeentezijde vond men deze reacties nogal negatief. Alleen de suggestie voor de verplaatsing van de klimtoestellen wilde men in overweging nemen. Want 'een heel ander plan' kon de gemeente zich niet permitteren.

Aan het eind van de avond werd het een bejaard echtpaar uit de Willemstraat te machtig. Na de sloop van de drukkerij kon eindelijk de zon eens in hun tuintje schijnen. Dat zou nu weer worden belet, als daar de vijftien meter hoger ceder vlak achter zou worden geplant. Een mee- 
levende ambtenaar stelde voor, dat de ceder wel op de tekening zou blijven staan, maar pas geplant zou worden als de oudjes hun huisje zouden hebben verlaten. Meer kon de gemeente hen niet tegemoetkomen.

\section{Nieuwe huizen voor de Bokkenbuurt}

Ten zuiden van de oude binnenstad, langs de spoorlijn naar Den Bosch, lag een oud buurtje, in het begin van deze eeuw gebouwd, met eenvoudige lage huisjes voor mensen met lage inkomens: de Bokkenbuurt. Hoewel de meeste bewoners de huren van nieuwbouwwoningen niet zouden kunnen betalen, besloot het gemeentebestuur halverwege de jaren zeventig om de oude woningen te vervangen door nieuwe. Voor de Bokkenbuurt moesten bepaalde woning-types worden ontworpen, die ook bruikbaar zouden zijn voor twee andere oude buurten met lage huisjes, ten noorden van de binnenstad. Omdat het in alle drie de buurten om 'vervangende' nieuwbouw ging, zouden er voornamelijk rijtjes met gezinswoningen moeten worden gebouwd. Maar volgens het nieuwe landelijke beleid, dat was vastgelegd in de Verstedelijkingsnota van 1976, moest daarbij wel worden gestreefd naar een 'hoge bouwdichtheid', dus een zo groot mogelijk aantal woningen per hectare.

De aangewezen ontwerpers, een architect van de Dienst Bouwen en Wonen en een stedebouwkundige van de Dienst Ruimtelijke Ordening, vonden het een uitdaging om in een plan met een 'laagbouw-karakter' zoveel mogelijk woningen te projecteren. Er werden rijtjeshuizen in smalle straten getekend. Geheel naar de mode van die tijd zou de voorgevellijn in de rijtjes afwisselend wat naar voren en naar achteren springen. Ruimte voor extra woningen werd gevonden door de strathoeken te "ombouwen" met een uitgekiende constructie van beneden- en bovenwoningen, die de enige mogelijkheid om een winterzonnetje in de achtertuintjes toe te laten, zou afdichten. Een "hoekoplossing" heet zoiets in architectenjargon. Het geheel zou een flink aantal woning-types opleveren. Geen goedkoop ontwerp, beseften de ambtelijke chefs en de gemeentebestuurders. Maar, vonden zij, de stadsvernieuwing mocht best wel wat 'kwaliteit' hebben. En daarvan wisten ze ook het ministerie van VROM te overtuigen, dat bereid was om de uitvoering van het plan te steunen met rijksbijdragen.

Op de inspraakavond bleek, dat de bewoners van de Bokkenbuurt geen overwegende bezwaren hadden tegen het ontwerp. Maar als mensen die gewend waren om hun huisje en hun stoepje helder schoon te houden, misten ze een paar praktische dingen. Een WC met een kaal betonnen vloertje? Dat was in deze tijd toch gewoon "asociaal", zei een verontwaardigde huisvrouw, die duidelijk ook de gevoelens van haar buurtgenoten vertolkte. En dan was er nog iets. Waar moest het water blijven als er 
achter het huis was geschrobt? Een putje om het water af te voeren, ontbrak op de tekeningen. Was dat 'per ongeluk' weggelaten? Nee, legden de gemeente-ambtenaren uit. Het ontwerp was vanwege de stedebouwkundige eisen al zo duur geworden, dat niet nog meer wensen vervuld konden worden. Maar, veronderstelden zij, de meeste mannen in de buurt waren wel handig genoeg, om in hun nieuwe hurwoning zelf even een paar tegeltjes op de WC-vloer te metselen. En wat het ontbreken van een schrobputje betreft; dat was een ongemak dat men voor lief moest nemen. Men kon niet alles hebben.

\section{Het park langs de Vecht}

Aan de noordkant van Utrecht, tussen de spoorlijn naar Hilversum en de rivier de Vecht, is in de jaren zestig en zeventig een nieuw stadsdeel verrezen: Overwecht. Zo'n veertigduizend mensen vonden er een woning. In het noord-westelijk deel bleef langs de Vecht een zone van circa é́n kilometer lang en gemiddeld zo'n tweehonderd meter breed onaangeroerd. Daar zou een groot stadspark komen, hadden de stedebouwkundigen ooit bedacht. Maar voorlopig behield deze grond de kenmerken van het oorspronkelijke polderlandschap. Vlak bij de Vechtdijk lagen hier en daar kleine boerderijtjes en polderhuisjes, tussen weilanden en slootjes. De percelen waren te klein geworden voor het boerenbedrijf. Maar verschillende bewoners hielden er uit liefhebberij nog wel een pony of een paar schapen op na. Langs de rivieroever lagen, over een lengte van zo'n honderdvijftig meter, ligschuitjes, waar vrouwen uitnodigend achter roodverlichte vensters zaten. Verderop langs de oever lagen woonboten, afwisselend geschilderd in kleuren als rood, groen, wit of bruin. Op de dijk liep een smal weggetje, stonden wat iepen, en bij de inrit naar een boerderijtje soms kastanjebomen. Bij de slootjes in de polder groeiden knotwilgen. Achter de weilanden rezen de nieuwe flatgebouwen uit de grond.

Het Rijk had bij de ontwikkeling van de plannen voor Overvecht ooit de toezegging gedaan, dat voor de aanleg van het stadspark een subsidie van zo'n tien miljoen gulden ter beschikking zou worden gesteld. Eind jaren zeventig vond de gemeente het tijd worden om die subsidie binnen te halen. Bij de Dienst Ruimtelijke Ordening werd een ontwerp gemaakt, waarin alle bebouwing, woonboten, weilanden en slootjes werden opgedoekt. Alleen de ligbootjes met de rode lampjes mochten blijven liggen waar ze lagen. Die vervulden voor het stedelijk voorzieningen-niveau een te belangrijke functie. Voor de rest zou het gebied worden omgetoverd in een Veluwe-achtig landschap met heuvels, bosschages en zacht-glooiende ligweides. Daar doorheen zouden brede geasfalteerde wandelpaden worden aangelegd, zodat ook de bewoners van de twee nabijgelegen bejaardente- 
huizen fatsoenlijk hun benen konden strekken. En dat alles zou de gemeente vrijwel niets kosten. De plannenmakers lieten buiten beschouwing, dat het Rijk alleen de aanleg zou subsidiëren. Het onderhoud van het park zou voor rekening van de gemeente zelf blijven.

In de grote zaal van eén van de bejaardentehuizen werd de inspraakavond gehouden. Niet alleen de Overvechtenaren waren daarvoor uitgenodigd, maar ook de bewoners van de an de andere Vecht-oever gelegen woonwijk Zuilen. Via een nog te bouwen fiets-voetbrug zou het toekomstige park ook voor hen bereikbaar worden. De euforie op de avond zelf was toch minder groot dan de gemeentelijke presentatoren hadden gedacht. Dat de bewoners van de woonboten, de boerderijtjes en de polderhuisjes falikant tegen zouden zijn, had men wel verwacht. Maar dat de meeste Zuilenaren niet stonden te trappelen om een fietsbrug naar de gastvrouwen op de ligschuitjes, was toch wel een tegenvaller. En de bejaarden dan? Werd er voor hen geen prachtig wandelgebied aangelegd, vlak voor hun huis? Tja, de oudjes wisten eigenlijk niet zo goed, of het wel zo'n goed plan was. Een wandelingetje was natuurlijk wel fijn. Maar in de andere parken kwam het nogal eens voor, dat de geasfalteerde paden het domein werden van de bromfietsende jeugd. Zou dat hier ook niet gebeuren? Dan zouden veel bejaarden zich er niet veilig voelen. Nee, dan was de bestaande situatie zo gek nog niet. Vanuit hun flatje hadden ze nu een leuk uitzicht op de boerderijtjes, de polderhuisjes en de weilanden. In het voorjaar zagen zij er veulentjes en pasgeboren lammetjes rondhuppelen. Dat mocht, wat hen betreft, wel zo blijven. Kon langs die weilanden niet gewoon een mooi voetpad worden aangelegd, met hier en daar een bankje om even rustig te kunnen zitten?

De opmerkingen van de bezoekers van de inspraakavond waren voor de gemeentebestuurders en de park-ontwerpers geen reden om het plan te wijzigen. Maar de uitwerking tot detail-tekeningen zou nog veel tijd kosten. Toen kort na de inspraakavond een inspraakprocedure tot herziening van het bestemmingsplan van start ging, wisten de woonbootbewoners te bereiken, dat hun ligplaatsen in dat plan werden aanvaard. Wie wil weten wat er intussen van het beoogde park terecht is gekomen; zou er eigenlijk eens moeten gaan kijken. Behalve dat de ligschuitjes en de woonboten zijn gebleven, zijn ook (tot nu toe) de meeste boerderijtjes en polderhuisjes blijven bestaan. Maar de weilanden er om heen zijn grotendeels veranderd in een parklandschap. Vlak achter de rivierdijk en de polderhuisjes rijzen nu kunstmatige heuvels op, bedekt met grasvelden, bosschages, en rozebottelstruiken. Beter ten halve gedwaald dan ten hele gekeerd, moeten de gemeentebestuurders hebben gedacht. 


\section{De democratische theorie}

Wie mocht denken, dat dergelijke gebeurtenissen alleen in de gemeente Utrecht plaatsvinden, vergist zich. In het viersteden-overleg over democratisering, waar ik in die jaren aan deel nam, werden genoeg ervaringen uitgewisseld om te weten, dat het in de drie andere grote steden niet anders toegaat. Maar ik vond het beter, om me hier te beperken tot informatie uit eigen waarneming.

De financiële verhouding tussen Rijk en lagere overheden is intussen veranderd. Er is flink bezuinigd op de specifieke uitkeringen aan die overheden. Ook zijn het meestal geen projektgebonden uitkeringen meer, maar budget-uitkeringen voor bepaalde overheidstaken. De lagere overheden hebben daardoor wat meer vrijheid gekregen, om deze gelden naar eigen inzicht te besteden. Dat garandeert echter niet; dat de gelden ook doelmatiger worden besteed. Want waar een overheidsorganisatie geld aan uitgeeft, wordt nog altijd in sterke mate bepaald door de machtsverhoudingen binnen de organisatie zelf. De burgers staan langs de lijn. En dat geldt meestal ook voor de volksvertegenwoordigers. Maar hoe kan dat? We hebben toch, op alle drie bestuursniveaus: rijk, provincie, en gemeente, een parlementaire democratie?

Hoe in Nederland de parlementaire democratie is ontstaan, en wat daarvan de verschillende kenmerken zijn, is al dikwijls beschreven, zowel in beknopte als in uitgebreide vorm. ${ }^{2} \mathrm{IK}$ wil daar geen eigen versie aan toevoegen. Wel wil ik hier de vraag aan de orde stellen, of de door mij beschreven gebeurtenissen verklaard kunnen worden vanuit de democratische theorie.

\section{Schumpeter en de klassieke leer}

De Utrechtse gebeurtenissen passen in geen geval in de 'klassieke' leer van de democratie. Deze leer is door de naar de Verenigde Staten geëmigreerde Oostenrijkse econoom Schumpeter in 1943 beschreven en bekritiseerd in zijn boek Capitalism, socialism and democracy. De klassieke leer vindt men in een verzameling van uiteenlopende theorieën, die eén gemeenschappelijk kenmerk hebben: democratie wordt opgevat als "die institutionele regeling om tot politieke besluitvorming te komen, waarbij ten behoeve van het algemeen welzijn het volk zelf over strijdpunten beslist

2 Bijvoorbeeld (beknopt) door $\mathrm{H}$. Daalder, De ontwikkeling van de parlementaire democratie in Nederland, in J.J.A. Thomassen (red.), Hedendaagse democratie, Alphen a/d Rijn 1991, pag. 52-81, en (uitgebreider) door Huub Spoormans, Met uitsluiting van voorregt:, Amsterdam 1988. 
door verkiezing van individuen die bijeen moeten komen om de wil van het volk uit te voeren". ${ }^{3}$ Deze opvatting over democratie heeft goed stand kunnen houden, zolang het algemeen kiesrecht een onvervuld ideaal was. Maar als dat ideaal, zo rond de tijd van de Eerste Wereldoorlog, in bijna alle westerse landen is gerealiseerd, slaat de twijfel toe. De wil wan het wolk, die dan volop aan het daglicht zou kunnen treden, blijft zich voor de meeste waarnemers verborgen houden. En men begint zich af te vragen, waarom die niet te voorschijn komt.

Schumpeter legt uit, waar het in de klassieke leer aan schort. Hij wijst er op, dat er niet zo iets bestaat als een "algemeen welzijn, waar alle mensen het over eens zijn of door redelijke betogen het over eens kunnen worden". Maar zelfs als een voldoende duidelijk algemeen welzijn door iedereen zou worden aanvaard, "dan nog zou dat geen even duidelijke antwoorden inhouden op afzonderlijke strijdpunten". Over die strijdpunten zelf wordt beslist in "politieke processen", waarin "een gefabriceerde wil" tot stand komt. Die wil is een "kunstprodukt", zegt Schumpeter. De wil van het volk is dus niet de beweegkracht, maar het produkt van het politieke proces. ${ }^{4}$

Ziet men de wil van het volk als een produkt, dan is het niet meer zo'n grote stap, om de parallel te zien tussen het politieke leven en het economisch leven. Democratie is dan een soort vrije markt. De kiezers geven op die markt hun stem aan de politicus of de partij; van wie ze verwachten dat die hun ideële en/of materiële belangen zal behartigen. De democratische methode, zegt Schumpeter, is de methode "waarbij individuen beslissingsmacht verkrijgen door middel van een concurrentiestrijd om de stemmen van de burgers". Aldus wordt een regering gekozen, of een orgaan dat op zijn beurt een regering voortbrengt. Dan pas komen processen op gang, waardoor uiteindelijk op de verschillende strijdpunten de wil van de meerderheid wordt geformuleerd. Maar kan men dat de wil van het volk noemen? Voor Schumpeter is dat niet vanzelfsprekend. "De wil van het volk is een mozaïek, dat volstrekt niet wordt vertegenwoordigd door de wil van de meerderheid" zegt hij. "Het probleem wordt niet opgelost door beide per definitie gelijk te stellen". ${ }^{5}$

De visie van Schumpeter is sterk beïnvloed door de geschriften van de Duitse socioloog Max Weber; die al vóór 1920 de klassieke leer van de lisme en democratie (vertaald door H. Daudt), Hilversum 1963, pag. 213. De cursivering in het citat is van mijn hand.

4 Id. pag. $214-225$.

5 Id. pag. 228-232. 
democratie onderuit haalde. ${ }^{6}$ Deze visie, waar politicologen als Robert Dahl op voortbouwen, wordt ook wel de economische theorie van de democratie genoemd. Ze geldt als het startpunt van het zogeheten "pluralisme". De kern van deze opvatting is, dat de essentie van democratie bestaat uit een concurrentiestrijd tussen politieke leiders (elites) om de gunst van de kiezer, waarbij de politieke macht over de elites is verdeeld. ${ }^{7}$

\section{Robert Dahl}

Dat wij geregeerd worden door de gefabriceerde wil wan de meerderheid, is op het eerste gezicht best wel verontrustend. In een samenleving zijn meestal duidelijk aanwijsbare (etnische en religieuze) minderheden, die door de wil van de meerderheid kunnen worden onderdrukt. Ook als wij zelf niet tot dergelijke minderheden behoren, maken we wel deel uit van andere, minder opvallende minderheden. Slechts een minderheid oefent hetzelfde beroep uit als wij, een minderheid van onze landgenoten woont in dezelfde stad of streek, een minderheid behoort tot onze eigen leeftijdscategorie, enzovoorts. Volgens Robert Dahl is het verontrustende feit, dat wij zelf allemaal tot minderheden behoren, tegelijk ook een hele geruststelling. De politieke beslissingen worden niet genomen door de meerderheid of door een minderheid, maar door minderheden. Het verschil tussen dictatuur en democratie, zegt Dahl, is "one between government by a minority and government by minorities" ${ }^{8}$ "Wij worden in onze samenleving geregeerd door minderheden, die met elkaar overeenstemming moeten bereiken, om tot meerderheidsbesluiten te kunnen komen. Dat is een democratisch systeem, maar Dahl noemt het liever een polyarchy. De term democracy gebruikt hij om een ideaal, een theoretical limit aan te duiden.

In een politiek systeem, waarin minderheden elkaar nodig hebben om tot meerderheidsbesluiten te komen, of om ongewenste meerderheidsbesluiten te voorkomen, worden die minderheden als het ware van nature beschermd. Ze zijn immers potentiële bondgenoten van elkaar. Ze kunnen elkaar helpen bij het verdedigen van hun belangen. Maar hoe belangrijk die vorm van bescherming ook is, ze zou niet kunnen verhinderen, dat minderheden soms toch in de verdrukking raken. Daarom moet er nog iets anders zijn, waardoor de minderheden worden beschermd. Volgens Dahl is

6 De ideeèn van Max Weber komen in hoofdstuk 6 nog aan de orde, maar dan vooral toegespitst op het verschijnsel bureaucratie.

7 Zie over Schumpeter en Dahll ook David Held, Models of democracy, Cambridge 1987 (herdruk 1990), pag. 164-205, en Percy B. Lehning. De theorie van het pluralisme, in J.J.A. Thomassen (red.); a.w. pag. 107-127.

Robert Dahl, A preface to democratic theory, Chicago 1956, pag. 133. 
dat, in een democratisch systeem, de consensus over een aantal elementaire waarden. Democratische politiek, zegt hij, blijft meestal binnen "the bounds of a consensus set by the important values of the politically active members of society, of whom the voters are a key group. [..] Without such a consensus no democratic system would long survive the endless irritations and frustrations of elections and party competition". beschermt dus niet alleen de minderheden, maar ook het democratisch systeem zelf:

Dat in een samenleving minderheden op elkaars steun zijn aangewezen, en dat er een consensus over elementaire politieke waarden bestaat, is voor het functioneren van het democratisch systeem belangrijker dan mooi geformuleerde "constitutional rules", vindt Dahl. Toch is het volgens hem wel zinvol om zulke regels vast te stellen, al was het alleen om een aantal elementaire waarden in de samenleving expliciet te maken. In zijn boek Polyarchy gaat hij uitgebreider in op die waarden. Dahl beschrijft daar, welke voorwaarden het ontstaan en voortbestaan van een democratisch systeern kunnen begunstigen of beletten. ${ }^{10}$

Willen we een democratisch systeem, zegt Dahl, dan zal er aan drie voorwaarden moeten worden voldaan:

a. De burgers moeten de mogelijkheid hebben om hun voorkeuren te formuleren.

b. Zij moeten de mogelijkheid hebben, om die voorkeuren aan hun medeburgers en aan de overheid kenbaar te maken door middel van individuele en collectieve actie.

c. Al deze voorkeuren moeten in het beleid van de overheid op gelijke wijze worden gewogen, dat wil zeggen, er mag niet worden gediscrimineerd op grond van inhoud of afkomst. ${ }^{11}$

Aan deze drie voorwaarden kan pas worden voldaan, zegt Dahl, als het politieke systeem acht waarborgen ("institutional guarantees") kent. Zo hebben burgers volgens hem pas de mogelijkheid om hun voorkeuren te formuleren, als er sprake is van:

1. Vrijheid van vereniging en vergadering ("Freedom to form and join organizations").

2. Vrijheid van meningsuiting ("Freedom of expression").

$9 \quad$ Id. pag. 132.

10 Robert Dahl, Polyarchy, New Haven and London, 1971.

11 Id. pag. 2. 


\section{Actief kiesrecht ("Right to vote").}

4. Het recht van politieke leiders om te wedijveren voor stemmen en steun ("Right for political leaders to compete for support").

5. Alternatieve, dat wil zeggen, niet-gemonopoliseerde informatiebronnen ("Alternative sources of information").

Willen die burgers ook de mogelijkheid hebben om hun voorkeuren kenbaar te maken aan de medeburgers en aan de overheid, dan moet er bovendien sprake zijn van:

6. Passief kiesrecht, dat wil zeggen verkiesbaarheid voor openbare ambten ("Eligibility for public office"), en

7. Vrije en eerlijke verkiezingen ("Free and fair elections").

De derde voorwaarde voor een democratisch systeem, de voorwaarde dat alle voorkeuren van burgers op gelijke wijze in het overheidsbeleid worden gewogen, kan pas worden vervuld als er ook sprake is van:

8. Regels en gebruiken, die de beleidsworming bij de overheid doen afhangen van stemmen en andere voorkeursuitingen ("Institutions for making government policies depend on votes and other expressions of preference" $) .12$

Als we de door mij beschreven Utrechtse gebeurtenissen willen verklaren vanuit de democratische theorie van Robert Dahl, dan zullen we de zwakke kanten van ons politieke systeem vooral moeten zoeken bij waarborg 5 en waarborg 8. Maar voordat ik daar verder op in ga, wil ik eerst iets vertellen over latere ontwikkelingen in de theorie van Dahl. In de loop van de zeventiger jaren is Dahl zich gaan herbezinnen, omdat hij de indruk kreeg, dat de westerse democratieën zich steeds verder van het door hem gestelde ideaal verwijderden. Die herbezinning heeft geleid tot een denkwijze, die tegenwoordig het "neopluralisme' wordt genoemd.

\section{Het neopluralisme van Robert Dahl}

Het pluralisme van Schumpeter en Dahl was eigenlijk een vrij optimistische theorie. Het ging uit van een samenleving, die uit talloze minderheden bestaat. Die hebben weliswaar allemaal verschillende belangen, maar ze hebben ook een consensus over een aantal elementaire politieke waarden. 
Die waarden zijn in zoverre vastgelegd in "constitutional rules", dat een vrije politieke markt van vraag en aanbod gewaarborgd is. De bekende liberale invisible hand leidt vervolgens tot een optimale realisering van de politieke wensen en voorkeuren van de burgers.

In de loop van de zeventiger jaren kwam Dahl steeds meer tot de conclusie, dat niet alleen de invisible hand onzichtbaar bleef, maar ook de optimale realisering van de politieke wensen en voorkeuren. Een kleine groep mensen in de samenleving werd steeds rijker, terwijl de meerderheid armer werd, en sommige bevolkingsgroepen zelfs verpauperden. Dat verschijnsel deed zich niet alleen in de Verenigde Staten voor, maar in veel meer westerse landen. In de tachtiger jaren zette die tendens in versterkte mate door. Hoe was dat mogelijk?

Kennelijk is er voor een groot aantal burgers op de politieke markt niets te koop waar men beter van wordt. Dahl ging op zoek naar een verklaring, en meende die te kunnen vinden in de economische ongelijkheid van de burgers. Nadat hij dit in verschillende publicaties tot uitdrukking had gebracht, zette hij in 1985 de resultaten van zijn analyse uiteen in zijn boek $A$ preface to economic democracy.

Daarin constateert Dahl, dat economische ongelijkheid sterk bevorderd wordt door het particuliere ondernemerschap ("ownership and control of firms"). Maar, zegt hij, ook de politieke ongelijkheid wordt er door bevorderd, en wel op twee manieren: allereerst schept het particuliere ondernemerschap grote verschillen tussen burgers in rijkdom, inkomen, status, vaardigheden, kennis, controle over informatie en propaganda, toegang tot politieke leiders, en levenskansen. Daardoor wordt het onmogelijk, om als politieke gelijken deel te nemen aan de sturing van de staat ("participating as political equals in governing the state"). Maar bovendien worden particuliere ondernemingen zelf ondemocratisch bestuurd. Daardoor is er grote ongelijkheid tussen burgers voor wat betreft hun mogelijkheden om invloed uit te oefenen op het beleid van ondernemingen ("participating in governing economic enterprises"). ${ }^{13}$

Die ongelijkheden worden volgens Dahl in de moderne westerse wereld nog versterkt door "corporate capitalism". Een betrekkelijk kleine groep van rijke mensen manipuleert, voor eigen gewin, het zakenleven en bedrijfsleven met behulp van regels en trucs uit het rechtspersonenrecht. Dat gebeurt door via beleggingsfondsen, holdings, preferente aandelen en bankcredieten zeggenschap uit te oefenen over talloze grote en kleine ondernemingen. Toch is er in de Verenigde Staten weinig animo, om het 
corporate capitalism aan te pakken, constateert Dahl. Men vindt dat economische vrijheid ook het recht op privé-eigendom omvat, en dat dit recht onder meer betekent, dat eigenaren naar eigen goeddunken hun ondernemingen mogen besturen of Iaten besturen. Zo is men "the corporate structure of modern American capitalism" uiteindelijk gaan zien als een "unalienable right", als een onvervreemdbaar recht. ${ }^{14}$

Voor Dahl is het niet vanzelfsprekend, dat in een systeem van economische vrijheid ook het corporate capitalism moet worden getolereerd. Integendeel, deze vorm van kapitalisme staat op gespannen voet met een ander onvervreemdbaar recht van mensen. Want democratie, zegt Dahl, betekent, dat "people [..] possess a right, an unalienable right to govern themselves by democratic process". Mensen hebben een onvervreemdbaar recht om zichzelf te besturen volgens democratische spelregels. Daarom moet het besluitvormingsproces in bepaalde organisaties zoveel mogelijk aan democratische criteria voldoen. ${ }^{15}$ Maar moet dat ook in particuliere ondernemingen het geval zijn?

In een historische en theoretische vergelijking weegt Dahl de begrippen politieke gelijkheid en economische vrijheid tegen elkaar af. Hij komt dan tot de volgende conclusies:

- Er bestaan geen overtuigende argumenten, om privé-eigendom te zien als een "fundamental right", een grondrecht, dat op eén lijn zou kunnen staan met "the fundamental right to self-government".

- De bestaande argumenten waarmee privé-eigendom kan worden gerechtvaardigd, rechtvaardigen niet een recht op onbegrensde verwerving van privé-eigendom. Hooguit rechtvaardigen zij een recht op verwerving van "the resources necessary to life, liberty, the pursuit of happiness, the democratic process, and primary rights", dus een recht op verwerving van de middelen die nodig zijn, om te leven in vrijheid, geluk na te streven, en inhoud te geven aan de democratie en de grondrechten.

- Geen van de bestaande argumenten voor privé-eigendom kan de privéeigendom van ondernemingen ("corporate enterprises") rechtvaardigen.

Daarom, meent Dahl, mag de samenleving langs democratische weg regels geven voor de eigendom en de bestuursvorm van ondernemingen. Daarbij moet er wel naar worden gestreefd om recht te doen aan waarden als democratie, rechtvaardigheid, efficiency, waardering van goede menselijke

15 Id. pag. $56-57$. 
eigenschappen, en persoonlijke aanspraak op een minimum aan middelen dat nodig is voor "a good life".

Dahl zoekt de opheffing van de economische en politieke ongelijkheden niet in "bureaucratic socialism". Want daarin gaan menselijke en democratische waarden al even zeer ten onder als in "corporate capitalism". We moeten het anders aanpakken, zegt hij. Er moet een "right to democracy within firms" worden vastgelegd. De ondernemingen zelf moeten van binnenuit een democratisch bestuur krijgen. Volgens Dahl kan dat het beste gebeuren door ze om te vormen tot coöperaties, waarin de medewerkers de stemgerechtigde leden zijn. Ondernemingen worden dan, wat hij noemt, "self-governing enterprises". De werkers krijgen zelfbestuur. De democratie is daar dubbel bij gebaat: de economische ongelijkheden tussen de burgers worden kleiner, en daardoor zullen vanzelf ook de politieke ongelijkheden kleiner worden. ${ }^{17}$

Aan het begin van deze paragraaf heb ik de vraag gesteld, of de door mij beschreven Utrechtse gebeurtenissen verklaard kunnen worden vanuit de hedendaagse politieke theorie. Met het neopluralisme van Robert Dahl als uitgangspunt komen we, denk ik, een heel eind. Dahl ziet de politiek als een wrije markt. Maar in zijn neopluralistische periode is hij tot het inzicht gekomen, dat het op die markt niet zo eerlijk toegaat. Sterke klanten duwen voor de kraampjes andere klanten opzij, en eisen de beste koopwaar op. Willen we de politieke markt eerlijker maken, dan moet de verhouding tussen de sterke en de minder sterke klanten worden rechtgetrokken. Dahl stelt voor, om alle ondernemingen van enige omvang de vorm van een coöperatie te geven, waarin de medewerkers de stemgerechtigde leden zijn. Persoonlijk vind ik dit een zinvolle en sympathieke gedachte, die verdere uitwerking verdient. De economische ongelijkheid tussen de burgers zal in zo'n vrije sector van self-governing enterprises sterk verminderen. Daardoor zal ook de politieke gelijkheid toenemen: Maar zijn daarmee ook alle problemen van de democratie opgelost?

Laten we ons nog even dat beeld van die zogenaamde vrije politieke markt van vraag en aanbod voor ogen houden. Kunnen de handelaren, en daarmee bedoel ik de politici en de ambtenaren, niet gemakkelijk achter de toonbank met elkaar afspraken maken? Want laten we niet vergeten, die handelaren hebben in het openbaar bestuur ook eigen belangen, zoals zelfhandhaving, goede collegiale verhoudingen, en carrière. Uit dat oog-

17 Id. pag. $136-163$. 
punt zijn afspraken met collega's en superieuren voor hen waak interessanter dan de gunst van de kiezer of de waardering van de burger. Dus ook al zou de verhouding tussen de klanten voor de kraampjes worden rechtgetrokken, er blijft een democratisch probleem.

\section{Hoe verbeteren we onze democratie?}

De realisering van een vrije sector van self-governing enterprises volgens het model van Dahl zou al een belangrijke verbetering van onze democratie betekenen. Maar, zoals gezegd, zijn we er daar mee nog niet. Daarom is het zinvol, om ook eens naar andere moderne theorieën te kijken.

\section{Neoconservatisme, neoliberalisme, en participatie-democratie}

Voordat Dahl zelf zijn pluralistische denkbeelden ging bijstellen, hadden anderen daar al kritiek op geleverd. Neoconservatieven en neoliberalen betoogden vanaf het begin van de zeventiger jaren, dat de 'ongevraagde' expansie van de overheidssector in de na-oorlogse periode had laten zien, dat men de politieke markt niet op één lijn kon stellen met de economische markt. En de marxisten hadden altijd al geweten, dat het kapitalisme zich niet zomaar door democratische besluitvorming de wet zou laten stellen. Moderner en meer geëngageerd was de kritiek van auteurs als Carole Pateman, die de elitaire aspecten van het pluralisme aan de kaak stelden. Immers, een polyarchie is een representatie-democratie. Het zijn vooral de elites van de diverse minderheden, die de politiek bepalen. Pateman en haar medestanders bepleitten een participatie-democratie, een democratie van geëmancipeerde mensen, die zich niet door partij-elites of andere elites laten vertegenwoordigen, maar veel meer zelf de politieke besluitvorming beïnvloeden. ${ }^{18}$ Een vergelijkbaar standpunt werd ingenomen door Wolfgang Beck, een duitser die in het begin van de jaren zeventig andragogie ging doceren in Amsterdam. Zijn boek Democratie in de wijken, een bewerking van zijn duits-talige dissertatie, inspireerde in Nederland veel buurtwerkers bij het organiseren van bewoners-acties in stadsvernieuwingswijken. ${ }^{19}$

De kritiek van de neoconservatieven en de neoliberalen heeft de afgelopen vijftien jaar veel invloed gehad op de politiek in de westerse wereld. Het Amerikaanse Reaganism en het Engelse Thatcherism gingen

19 Wolfgang Beck, Democratie in de wijken, Amsterdam 1974 (eerste druk). 
ook op het Europese vasteland met het verstand van heel wat politici en wetenschappers aan de haal. Afslanking van de overheid werd tot de hoogste wijsheid verheven. Toverwoorden werden lastenverlichting, privatisering en deregulering. Schaamteloze pleidooien voor denivellering van de inkomens kwamen daar nog boven op. Waar dat alles toe heeft geleid, wordt met de dag duidelijker: de welvaart in de samenleving is afhankelijk geworden van het beleid van autocratisch bestuurde multi-nationale ondernemingen. Een groot aantal mensen komt op de arbeidsmarkt niet meer aan bod. Velen zijn blijvend onder de armoede-grens terechtgekomen. De afgeslankte overheid kan steeds minder voor deze mensen doen. Door bezuinigingen laat ook de vervulling van andere belangrijke overheidstaken, zoals de zorg voor de leefbaarheid en de infrastructuur, het onderwijs, en de misdaadbestrijding, veel te wensen over. Het ideaal van een politiek systeem, waarin gelijkwaardige burgers samen de rechtsnormen en de koers van de samenleving bepalen, verdwijnt steeds verder uit het gezichtsveld. Zo hebben het neoconservatisme en neoliberalisme de ontwikkeling van onze democratie op een zijspoor gerangeerd.

De participatie-gedachten Carole Pateman en Wolfgang Beck zijn wél gericht op een grotere politieke gelijkwaardigheid van de burgers. Het democratiseringsproces zien deze schrijvers vooral als een leerproces. Door op de werkplek en in hun woonbuurt zelf voor hun belangen op te komen, leren mensen, met vallen en opstaan, hoe zij invloed op hun eigen leefomstandigheden kunnen uitoefenen. Ook mensen met weinig opleiding en een bescheiden inkomen zullen zo, op den duur, mondige burgers worden, die in de politieke besluitvorming hun partijtje kunnen meeblazen. Uit deze denkbeelden spreekt in elk geval een warme belangstelling voor de democratie. Pateman en Beck hebben in de zeventiger jaren, en ook daarna nog, veel mensen geïnspireerd om actie te voeren voor verbetering van werk- en woonomstandigheden. Maar wat heeft dat uiteindelijk opgeleverd? Natuurlijk zijn er talloze kleine succesjes en overwinninkjes behaald, Maar de overheid bleek ook tegenstrategieën te kunnen ontwikkelen. Mensen liepen vast in procedures, werden van het kastje naar de muur gestuurd, of bedolven onder dikke rapporten, terwijl een hogere overheid intussen snel 'randvoorwaarden' dicteerde, waar bestuurders en ambtenaren zich tegenover de burgers achter konden verschuilen. In het bedrijfsleven ging het niet veel anders. De energie die veel mensen voor actievoeren, overleg en inspraak moesten opbrengen, stond meestal in geen
verhouding tot het resultaat.

Zijn de participatie-ideeën van schrijvers als Carole Pateman en Wolfgang Beck daarom waardeloos? Dat geloof ik niet. Maar de praktijk heeft bewezen, dat het mondig maken van burgers niet voldoende is. Wil 
men de democratie versterken, dan moet het openbaar bestuur, met zijn bestuurlijke en ambtelijke organisatie, ook zódanig functioneren, dat de wensen en ideeën van de burgers een eerlijke kans op realisatie krijgen.

\section{De verbetering van het openbaar bestuur}

De verbetering van onze democratie moet dus eigenlijk op drie fronten worden aangepakt. De economische ongelijkheid tussen de burgers moet worden teruggedrongen, waardoor de politieke gelijkheid wordt bevorderd. De ideeën van Robert Dahl geven, naar mijn mening, daartoe een veelbelovende aanzet. Maar ook ongelijkheid in kennis en vaardigheden tussen (groepen van) burgers moet worden verminderd. De participatietheorieën van schrijvers als Carole Pateman en Wolfgang Beck bieden daartoe een goed perspectief. Mensen moeten er ook zelf wat voor doen, om mondige burgers te worden.

En dan is er tenslotte het derde front: het openbaar bestuur zelf: Dat zou met zijn bestuurlijke en ambtelijke organisatie zo moeten functioneren, dat de wensen en ideeën van de burgers een eerlijke kans op realisatie krijgen. Het is dit front, waar ik in dit boek verder de aandacht op wil richten: het front, waar politici en ambtenaren niet alleen over de toonbank heen zaken doen, maar, met elkaar, ook achter de toonbank.

Mijn boek beschrijft een onderzoek op het gebied van het staats- en bestuursrecht. Maar het recht staat in een samenleving niet op zichzelf. Het wordt gevoed door ideeën en door het leven van alledag in die samenleving. Een jurist, die zich afvraagt, of bepaalde rechtsregels (nog) wel voldoen, zal zich daarom ook in die ideeën en in de dagelijkse praktijk moeten verdiepen. Voor mijn onderzoek betekent dit, dat ik mijn conclusies niet alleen op juridische kennis en eigen waarnemingen kan baseren, maar hier en daar ook een beroep zal moeten doen op de stand van wetenschap in de politicologie en de bestuurskunde. Ik gebruik deze wetenschappen daarom als hulpwetenschap bij mijn juridisch onderzoek. De lezer is gewaarschuwd, dat hij in mijn boek niet tegelijk ook een integraal politicologisch of integraal bestuurskundig onderzoek naar de mogelijkheden van directe democratie in Nederland aantreft.

In mijn onderzoek heb ik verder voor een nogal 'historische' benaderingswijze gekozen. Allereerst heb ik bij de onderwerpen die ik behandel, de geldende rechtsregels bestudeerd. Dat is een voorwaarde om tot voorstellen voor verandering te kunnen komen. Maar daar heb ik het niet bij gelaten. Rechtsregels hebben een geschiedenis. Als je je afvraagt of een juridische regeling nog wel voldoet, is het goed om ook van die geschiedenis kennis te nemen. Je krijgt dan een beeld van de moeilijkheden en de 
gevoeligheden, die bij de totstandkoming van de regeling een rol hebben gespeeld. En als je de geschiedenis tot het heden volgt, kom je er ook achter, in hoeverre die moeilijkheden en gevoeligheden ook nu nog aan de orde zijn. Daar kun je bij het formuleren van verbeteringsvoorstellen je voordeel mee doen. Bovendien kun je dan ook een meer op de werkelijkheid afgestemde argumentatie bij die voorstellen geven.

\section{Openbaarheid en inspraak}

In het staatkundige debat wordt tegenwoordig veel aandacht besteed aan ons kiesrecht en kiesstelsel, en in verband daarmee, aan het vraagstuk van de gekozen minister-president en de gekozen burgemeester. Misschien zijn dat inderdaad belangrijke onderwerpen. Maar het overheidsgedrag dat ik in de eerste paragraaf heb geschetst, heeft meer te maken met andere tekortkomingen in ons politieke systeem. Dahl noemde als waarborgen voor de democratie onder meer: alternative sources of information en institutions for making government policies depend on votes and other expressions of preference. Die twee waarborgen zijn in Nederland nogal zwak ontwikkeld. Ik wil onderzoeken, of we ze niet wat kunnen versterken. De burgers zouden daardoor meer directe invloed en correctie-mogelijkheden op het openbaar bestuur kunnen krijgen. Dus meer directe democratie.

Allereerst is het dan van belang om de openbaarheid van bestuur te vergroten. Dat er op de politieke markt zaken worden gedaan achter de toonbank, zal nooit kunnen worden uitgebannen. Het is ook de vraag, of dat wel wenselijk is. Maar als politici en ambtenaren weten, dat het publiek recht heeft op inzage, dan zullen zij zich niet zo gauw inlaten met zaken, die het politieke daglicht niet kunnen verdragen. Openbaarheid betekent, dat men in het openbaar ter verantwoording kan worden geroepen. Dat heeft een zuiverende werking. Maar er is nog een reden, om de openbaarheid van bestuur te vergroten. Kennis is macht. En kennis waar de overheid over beschikt is politieke macht. Slechts een bevoorrechte groep van bewindslieden, bestuurders en ambtenaren heeft toegang tot die kennis. Dat schept een machtsongelijkheid, die een goed functioneren van de democratie in de weg staat.

Vanaf de jaren vijftig zijn volksvertegenwoordigers, wetenschappers, en later ook staatscommissies, op een grotere openbaarheid van bestuur gaan aandringen. Dat heeft in 1980 geresulteerd in de invoering van de Wet openbaarheid van bestuur. Die vestigde in ons land het principe van openbaarheid van bestuur. Maar juist de meest interessante politieke documenten, zoals ambtelijke adviezen en rapporten, en bedrijfsinformatie, werden vrij rigoureus van openbaarheid uitgezonderd. Daardoor veranderde er in de praktische mogelijkheden van politieke beïnvloeding niet zo 
veel. Mijn onderzoek laat zien, wat er bij de tot standkoming van de wet, daarna in de rechtspraak, en ten slotte bij de latere wijziging van de wet, verkeerd is gegaan. Ik zal daarbij ook aangeven, wat er naar mijn idee verbeterd moet worden.

Eén van de wenselijke verbeteringen betreft het schrappen van de principiële geheimhouding van stukken, die zogenaamd bestemd zijn voor intern beraad. Het zal blijken, dat we daarbij het spoor verder moeten terugvolgen. De geheimhouding van dat soort stukken is terug te voeren op een verouderde opvatting over ambtelijke loyaliteit. Ik zal de geschiedenis van die opvatting beschrijven, en haar vervolgens tegen het licht houden van moderne bestuurskundige theorieën. Dat zal onder meer resulteren in een voorstel tot aanpassing van het ambtenarenrecht, waardoor ambtenaren tegelijk ook ten opzichte van de burgers meer verantwoordelijk worden gemaakt voor hun doen en laten.

Met meer openbaarheid van adviezen en rapporten die in de politieke besluitvorming een rol spelen, en meer ambtelijke verantwoordelijkheid ten opzichte van de burgers, zal inspraak voor die burgers werkelijk iets kunnen gaan betekenen. Dat zal ik in dit boek uiteenzetten in een speciale beschouwing over inspraak. Thans heeft inspraak te zeer een procedureel karakter. Na een avondje "Roept u maar!", of een terinzagelegging van een ontwerp-besluit, hebben de bestuurders meestal aan hun inspraakplichten voldaan, en kunnen ze verder hun eigen gang gaan. Ik zal een poging doen, om inhoudelijke criteria te formuleren, waarmee getoetst kan worden, of inspraak in voorkomende gevallen ook werkelijk het karakter van overleg heeft. Alleen dan draagt inspraak bij aan de verbetering van onze democratie.

\section{Referendum en volksinitiatief}

In mijn onderzoek zal ik ten slotte ook de mogelijkheden van referendum en volksinitiatief betrekken. Dat zijn politieke middelen, waarmee de bevolking beslissingen of nalatigheden van haar volksvertegenwoordigers rechtstreeks kan corrigeren. Die volksvertegenwoordigers mogen dan in elk geval tot de eerstvolgende verkiezingen op hun plaats blijven zitten. Maar besluiten die niet overeenstemmen met de wensen van de meerderheid van de bevolking, worden teruggedraaid. En nalatigheden van de volksvertegenwoordigers worden ondervangen met een rechtsstreeks door de kiezers genomen overheidsbesluit.

De discussie over de mogelijkheden van referendum wordt in ons land al vele tientallen jaren gevoerd. Al voor de Eerste Wereldoorlog werd er door de socialisten in de Tweede Kamer voor gepleit. Kort na die oorlog hoefde het referendum van hen niet meer zo nodig, maar werd het bepleit 
door de toenmalige Staatscommissie voor de Grondwetsherziening, en door de liberalen in de Tweede Kamer. $\mathrm{Na}$ de Tweede Wereldoorlog zijn de rollen weer gewisseld. De PvdA en D66 gaan steeds meer voor het referendum voelen, terwijl de VVD zich tot de felste tegenstander zal ontpoppen. De PvdA wordt in die periode ook voorstander van het volksinitiatief. En in 1985 verschijnt het eindrapport Relatie kiezers-beleidsvorming van de Commissie Biesheuvel, waarin zowel voor het referendum als voor het volksinitiatief wetsvoorstellen worden gedaan. Daarna buigt het parlement zich over deze onderwerpen in de discussie over de Staatkundige, bestuurlijke en staatsrechtelijke vernieuwing. Men komt er niet uit. Het kabinet-Kok heeft kort na zijn aantreden een ministeriële commissie ingesteld, om de wenselijkheid van referendum en volksinitiatief te bestuderen. In mijn boek volg ik de geschiedenis van de verschillende voorstellen voor referendum en volksinitiatief vanaf het begin van deze eeuw, en probeer ik te achterhalen, waar bij politici en wetenschappers de moeilijkheden en de gevoeligheden liggen. Dat onderzoek rond ik af met een eigen standpuntbepaling.

\section{Zwerftocht}

In het laatste hoofdstuk van dit boek worden de belangrijkste conclusies van mijn onderzoek, en mijn aanbevelingen, nog eens op een rij gezet. De lezer die tot dan toe het boek heeft overleefd, zal er niet door worden verrast. Hij is door mij meegenomen op een zwerftocht langs politieke en bestuurskundige theorieën, kamerdebatten, regeringsstandpunten, rapporten van staatscommissies, rechterlijke uitspraken, preadviezen van de Nederlandse Juristenvereniging, en een bonte verzameling van oraties, dissertaties en tijdschriftartikelen. Het zal hem daarbij niet zijn ontgaan, dat ik mij onderweg niet altijd heb kunnen inhouden, om hier en daar flinke sneren uit te delen. 


\section{Hoofdstuk 2}

\section{De opkomst van de openbaarheid}

\section{Het beginsel van openbaarheid}

In 1980 werd in Nederland, door de afkondiging van de Wet openbaarheid van bestuur, het beginsel van openbaarheid op het gebied van het bestuur ingevoerd. Op het gebied van rechtspraak en wetgeving was dit beginsel al veel langer wettelijk vastgelegd. Het beginsel van openbaarheid van rechtspraak kennen we in ons land sinds de Grondwet van 1848, zowel in de burgerlijke als in de strafrechtspraak. ${ }^{20}$ Ook het beginsel van openbaarheid van wetgeving of, beter gezegd, van volksvertegenwoordiging dateert uit de negentiende eeuw. In de Grondwet van 1815 werd de openbaarheid ingevoerd voor de vergaderingen van de Tweede Kamer. Sinds 1848 bepaalt de Grondwet; dat ook de vergaderingen van de Eerste Kamer en van Provinciale Staten openbaar moeten zijn. Voor gemeenteraden werd de openbaarheid van de vergaderingen vastgelegd in de gemeentewet van 1851.21

Pas in de jaren zestig van de twintigste eeuw komt in ons land een principiële discussie op gang over de wenselijkheid van openbaarheid van bestuur. In dit hoofdstuk wordt de beginfase van die discussie behandeld, een fase die wordt afgesloten met de instelling van de Commissie Heroriëntatie Overheidsvoorlichting (Commissie Biesheuvel). Omstreeks die tijd is ook in de rechtswetenschap de belangstelling voor de openbaarheid van bestuur gewekt. In hoofdstuk 3 worden drie preadviezen van de $\mathrm{Ne}$ derlandse Juristenvereniging besproken. Daarna komen in dat hoofdstuk het rapport van de Commissie Biesheuvel en de reacties daarop van rege-

20 Grondwet 1848, art. 156 (openbaarheid van terechtzittingen). De Grondwet van 1815 schreef voor, dat vonnissen gemotiveerd moeten worden, en met open deuren worden uitgesproken.

21 Grondwet 1815, art. 108 (Tweede Kamer), resp. Grondwet 1848, artt. 96 (Eerste Kamer) en 126 (Prov. Staten), en Gemeentewet 1851, artt, 43 en 44. Pas sinds 1983 zijn de gemeenteraden ook grondwettelijk verplicht om in het openbaar te vergaderen. 
ring en parlement aan de orde. De daarop volgende ontwikkelingen, die uiteindelijk zullen leiden tot de invoering van de Wet openbaarheid van bestuur, worden in hoofdstuk 4 besproken. In deze hoofdstukken zullen met name die aspecten van de openbaarheid worden belicht, die van belang zijn voor de ontwikkeling van gedachten over inspraak en andere vormen van directe democratie.

De periode waarin de idee van openbaarheid van bestuur levend wordt en uiteindelijk in wettelijke vorm gestalte krijgt, is een periode waarin ook gewerkt wordt aan een algehele herziening van de Grondwet. In 1966 publiceert de minister van Binnenlandse Zaken een Proeve van een nieuwe Grondwet. In deze proeve wordt nog niet over openbaarheid van bestuur gesproken. Maar de daarna ingestelde Staatscommissie van Advies inzake de Grondwet en de Kieswet kan er in haar eindrapport van 1971 niet meer omheen. De discussie over de wenselijkheid van wetgeving ten aanzien van openbaarheid van bestuur verloopt in de hier behandelde periode dan ook langs twee sporen. Het ene spoor zal leiden tot een antwoord op de vraag of het beginsel van openbaarheid van bestuur moet worden opgenomen in de Grondwet. Het tweede spoor leidt tot een antwoord op de vraag welke regels de wet moet geven voor openbaarheid van bestuur. Want dat de bestaande wetgeving tekortschiet, en meer garanties voor openbaarheid moet bieden, daar zijn de meeste schrijvers het in die tijd al vrij snel over eens.

Beide sporen zullen hieronder worden gevolgd. We zullen zien dat ze elkaar ook een enkele keer zullen kruisen. Maar ik vertel nu eerst iets over de voorgeschiedenis van de discussie.

\section{Voorgeschiedenis}

\section{De Commissie Van Heuven Goedhart}

Als in de tweede helft van de jaren zestig de discussie over openbaarheid van bestuur van start gaat, hebben in de na-oorlogse Nederlandse politiek een aantal incidenten plaatsgevonden, die een duidelijk raakvlak met dit onderwerp hebben. Als eerste incident noem ik de voorlichtings-affaire rond Schermerhorn, die van juni 1945 tot juni 1946 minister-president was. De Staten-Generaal bestonden toen voornamelijk uit wat er nog over was van de leden die in 1940 waren gekozen. Nieuwe verkiezingen zouden pas in mei 1946 plaatsvinden. Vooral omdat Schermerhorn de StatenGeneraal weinig representatief vond, wilde hij rechtstreekse communicatielijnen met de bevolking. Daartoe richtte hij bij de toen nog zo geheten Regeringsvoorlichtingsdienst een 'Afdeling Oog en Oor' op, die hij op een 
nogal in het oog lopende wijze bemande met politieke geestverwanten. De afdeling had zowel tot taak om op plaatselijk niveau het beleid van de regering te 'verklaren', als om de regering in te lichten over 'de stemming in het land'. Het geheel werd nog eens opgeluisterd met het wekelijkse radioprogramma "Praatjes op de Brug", waarin Schermerhorn persoonlijk de bevolking toesprak.

Het hoeft niet te verbazen dat deze wijze van communiceren bij parlementsleden, (maar ook bij anderen) nogal wat irritatie opriep. In een fel parlementair debat, op 31 januari 1946 , wordt de regering met zoveel woorden verweten voorlichting en propaganda door elkaar te hutselen. Schermerhorn wordt gedwongen bij de RVD enige personele veranderingen door te voeren en, wat voor ons onderwerp belangrijker is, een commissie in te stellen, die wordt belast met het uitbrengen van advies over het beleid van de overheid inzake de voorlichting. Deze commissie is bekend geworden als de Commissie Van Heuven Goedhart, genoemd naar de toenmalige hoofdredacteur van het Parool, die voorzitter van de commissie was. De commissie constateert dat overheidsvoorlichting onontbeerlijk is, maar dat deze zich dan wel moet beperken tot het geven van de nodige inlichtingen. In tijden waarin de pers in vrijheid spreekt, en de volksvertegenwoordiging haar taak verricht, behoort regeringsvoorlichting niet alleen een beperkt, maar ook typisch een aanvullend en incidenteel karakter te hebben. Voorlichting is een onderdeel van overheidsbeleid en valt onder de ministeriële verantwoordelijkheid. Maar gebruik van voorlichting voor politieke doeleinden is uit den boze, aldus de commissie. Hoewel in de praktijk niet alle aanbevelingen van de Commissie Van Heuven Goedhart worden opgevolgd, kan toch worden gezegd, dat het voorlichtingsbeleid van de regering voortaan zal varen op het door deze commissie uitgezette kompas. ${ }^{22}$

\section{Openbaarheid bij adviescolleges}

Ruim tien jaar later, in 1957, doen zich een paar andere incidenten voor op het gebied van de openbaarheid van bestuur. Allereerst is er dan de kwestie van de openbaarheid van adviezen van de vaste colleges van advies en

22 Meer informatie over deze affaire, en ower de Commissie Van Heuven Goedhart,

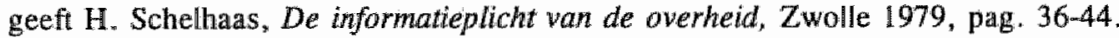
Beknopte en meer algemene informatie over het kabinet Schermerhorn-Drees windt men bij J. Bosmans, Staatkundige vormgeving in Nederland, deel $I I_{v}$ Zwolle 1990 , pag. 24-33. 
bijstand aan de regering. ${ }^{23}$ Deze kwestie vangt aan als op 31 januari 1957 het Tweede Kamerlid Vrolijk de staatssecretaris van Onderwijs, Kunsten en Wetenschappen verzoekt om een rapport van de Radioraad te publiceren over zendtijd voor politieke partijen. De Staatssecretaris, Höppener, antwoordt op 22 februari dat de Radioraad een vast college van advies en bijstand aan de regering is. De adviezen van de raad worden dus uitsluitend aan de regering uitgebracht. Daarom zou publicatie alleen kunnen plaatsvinden wanneer zwaarwichtige redenen daartoe zouden mopen en alleen na overleg met de Radioraad.

Dit antwoord valt verkeerd bij Romme, in die tijd de leider van de Tweede-Kamerfractie van de KVP. Romme vraagt op 28 februari 1957 aan minister-president Drees om een overzicht te geven van de bestaande colleges van advies aan de regering, met vermelding van de gedragslijnen der regering met betrekking tot de al dan niet openbaarmaking van de adviezen van elk van deze colleges. Op 4 april zendt Drees het gevraagde overzicht toe. In de begeleidende brief wijst Drees erop, dat het in vele gevallen noodzakelijk is publicatie achterwege te laten, om de regering in staat te stellen in alle vrijheid haar standpunt ten opzichte van de adviezen te bepalen. Bovendien kan de wetenschap dat een advies zal worden gepubliceerd, invloed hebben op de inhoud daarvan. En dat kan nadelig zijn, aldus Drees in zijn schrijven aan de Kamer. Uit het overzicht blijkt dat bij 30 van de 53 vaste colleges de adviezen nooit of zelden openbaar worden gemaakt. Bij 16 colleges worden de adviezen soms gepubliceerd. Slechts bij 7 colleges is publicatie van de adviezen regel.

In oktober 1957, bij de algemene politieke beschouwingen over de rijksbegroting 1958, komt Romme op de zaak terug. Het schrijven van de minister-president heeft hem "onthutst" ${ }^{\text {t" }}$ zowel wegens de feitelijke situatie die daarin wordt blootgelegd, als wegens de argumentatie die de ministerpiesident eraan heeft verbonden. In een democratie, die op openbaarheid steunt, dienen de adviezen van de vaste colleges van advies en bijstand als regel openbaar te zijn. Er dienen zwaarwichtige redenen te zijn, wil publicatie achterwege kunnen blijven. Want omdat geen minister voor de gedragingen van deze colleges verantwoordelijk is, zouden ze anders

Deze zaak wordt, met de verdere nasleep ervan, uitvoeriger besproken door I.M. Kan, in zijn bijdrage Openbaarheld van de rapporten van de vaste colleges van advies en bijstand aan de regering, in B. de Goede en H.Th.J.F. van Maarseveen (red.), Hoe openbaar wordt ons bestuur?. Den Haag 1969, pag. 92 e.v. Zie voor de discussies tussen Romme en Drees en de tekst van de motie-Romme: Hand. TK $1957-1958$ pag. 192-193, 224-226, 236-237, Hand. TK 1958-1959 pag. 82 en 108,
en bijlage $5322 \mathrm{nr}$. 1 . 
ontsnappen aan iedere publieke verantwoordingsplicht, aldus Romme. Hij dringt aan op een enquête onder de colleges, om hun mening te weten te komen over de wenselijkheid van publicatie van hun adviezen. Ministerpresident Drees bestrijdt in zijn antwoord het uitgangspunt van Romme. De vaste colleges van advies en bijstand zijn colleges die advies aan de regering uitbrengen. Een publieke verantwoordingsplicht van dergelijke adviesinstanties laat zich moeilijk denken. Uiteindelijk verklaart Drees zich wel bereid om aan het kabinet de suggestie van Romme voor te leggen om de colleges zelf naar hun mening over een mogelijke openbaarheid van hun adviezen te vragen.

Als een jaar later de zaak nog niets verder is gekomen, dient Romme, gesteund door de handtekeningen van de kamerleden Burger, Oud, Bruins Slot en Andriessen, op 30 september 1958 een motie in. De tekst daarvan luidt: "De Kamer, van oordeel, dat de adviezen der vaste Colleges van Advies en Bijstand als regel openbaar behoren te worden gemaakt; nodigt de Regering uit, dienovereenkomstig te handelen, en gaat over tot de orde van de dag". Het verweer van minister-president Drees in de Tweede Kamer is niet erg sterk. Sommige adviescolleges brengen wel duizenden adviezen per jaar uit, vaak van persoonlijke aard, zegt Drees, die nog eens beklemtoont dat de colleges alleen de regering adviseren. (Niemand in de Kamer had overigens op publicatie van adviezen van persoonlijke aard aangedrongen, HK.). Drees wijst er voorts nog op dat er ook gemengde adviescolleges zijn waarin ambtenaren zitting hebben. Als openbaarheid regel zou worden, zou men zich in tal van gevallen in het vragen van adviezen beperken. Het verweer van de minister-president mag echter niet baten. Op 1 oktober 1958 wordt de motie Romme met een zeer ruime meederheid in de Tweede Kamer aanvaard.

Een jaar later is het kabinet Drees opgevolgd door het kabinet De Quay. En Romme vraagt dan bij de algemene politieke beschouwingen over de rijksbegroting 1960 ook maar het standpunt van de nieuwe regering over de wenselijkheid van openbaarheid van de adviezen van de vaste colleges van advies en bijstand. ${ }^{24}$ Minister-president De Quay antwoordt op 30 september 1959. Hem is gebleken dat zijn ambtsvoorganger (Drees) zich op 30 oktober 1958 tot zijn ambtsgenoten heeft gewend met het verzoek om zoveel als mogelijk was met de in de motie Romme tot uiting gekomen wens van de Kamer rekening te houden. De Quay zegt toe de 
kwestie nog eens in de ministerraad aan de orde te zullen stellen. Zijn persoonlijke mening is het in elk geval, "dat men zoveel mogelijk de bekendmaking van dergelijke adviezen moet bevorderen en dat men dit alleen moet nalaten, wanneer daaraan reële en ernstige bezwaren verbonden zijn, waaromtrent [..] allereerst de betrokken bewindsman een oordeel moet kunnen uitspreken." Dit antwoord klinkt veelbelovend, maar de Kamer zal nog bijna een vol jaar op het standpunt van de regering moeten wachten.

Dat standpunt wordt verwoord in een brief die De Quay op 20 september 1960 , aan de vooravond van de algemene politieke beschouwingen over de rijksbegroting 1961, aan de Tweede Kamer schrijft. Wie naar aanleiding van de woorden van de minister-president in 1959 een koerswijziging had verwacht, komt bedrogen uit. Allereerst vindt de regering, dat het in het algemeen niet verantwoord zou zijn adviezen voor publicatie vrij te geven voordat de betrokken minister over de zaak (en over het advies) een standpunt heeft bepaald. Eerdere publicatie zou bij het publiek verwachtingen kunnen wekken die zouden blijken niet altijd in vervulling te kunnen gaan. Maar ook als de regering of de betrokken minister wel een standpunt over een advies heeft bepaald, hoeft publicatie van dat advies nog geen vaste regel te zijn. Met name vindt de regering het onjuist om "rapporten over vertrouwelijke (waaronder persoonlijke) kwesties" te publiceren. Wat de regering verder nog onder "vertrouwellijke kwesties" verstaat, blijkt niet uit de brief. Voorts vindt de regering het bezwaarlijk om tot openbaarmaking over te gaan als het betrokken adviescollege zelf daarentegen bedenkingen heeft. Alleen rapporten en adviezen over aangelegenheden van algemene aard van colleges die als representatief orgaan kunnen worden aangemerkt (bijv. de SER) komen in de regell voor openbaarmaking in aanmerking, althans nadat de regering of de betrokken bewindsman daarover een standpunt heeft bepaald. Voorzover geen wettelijke verplichting tot openbaarmaking bestaat, zal de regering of de betrokken bewindsman daarover van geval tot geval beslissen, aldus de brief van de minister-president.

Op 4 oktober 1960 komt Romme in de kamer bij de algemene politieke beschouwingen op deze brief terug. Hij onderstreept nog eens het belang van openbaarheid voor de versterking van ons democratisch bestel, en vervolgt: "Ik mag misschien zeggen, dat ik niet helemaal met onverdeeld genoegen die brief heb gelezen. Er komen dingen in voor, die men in de praktijk van het leven - dat gebeurt weleens meer - wat ruimer en wat enger kan uitleggen [..] Maar ik stel mij wel voor, dat de Kamer de praktijk van de heren Ministers nauwlettend zal volgen. Ik heb mij in ieder geval voorgenomen dit te doen, om na enige tijd erop terug te komen, 
hetzij in lovende, hetzij in hernieuwd kritische zin". Het zal de laatste keer zijn dat Romme over de openbaarheid het woord voert. In februari 1961 bedankt hij op medisch advies als kamerlid.

\section{Het incident Faas}

Ik keer nu even terug naar 1957 voor een andere affaire op het gebied van de openbaarheid van bestuur. Die affaire vangt aan als de Volkskrantjournalist Faas aan de vooravond van Prinsjesdag "een tamelijk juiste prognose" geeft van de inhoud van de troonrede en miljoenennota die de volgende dag bekend worden. ${ }^{25}$ Minister-president Drees heeft voor deze prognose dermate weinig waardering, dat de betrokken journalist voor én jaar de toegang tot de ministeries en de daaronder ressorterende diensten wordt gezegd. Bovendien zal Faas gedurende die tijd worden uitgesloten van elke informatieverstrekking. Het Tweede-Kamerlid Vrolijk stelt over deze zaak schriftelijke vragen aan de minister-president. Maar die wil niet op zijn besluit terugkomen. De handelingen van de journalist hebben afbreuk gedaan "aan de betekenis van de ontmoeting tussen het Staatshoofd en de Staten-Generaal op de derde dinsdag in september, die het hoogtepunt vormt van het parlementaire jaar", schrijft hij in zijn antwoord aan de Kamer. Romme, die zelf hoofdredacteur van de Volkskrant is geweest, en die we zojuist al tegenkwamen als pleitbezorger van openbare advisering door adviescolleges, kan de zaak niet zomaar over zijn kant laten gaan. Op 15 oktober 1957 stelt hij in de Tweede Kamer het incident aan de orde tijdens de algemene politieke beschouwingen over de rijksbegroting 1958 (in dezelfde toespraak als waarin hij ook zijn onthutsing uitspreekt over de geheimzinnigheid rond de adviezen van adviescolleges). Romme noemt de maatregel van de minister-president "een straf, die geen recht doet wedervaren aan de journalistenstand en die in strijd is met de nodige zorgvuldigheid met betrekking tot de persvrijheid". Maar minister-president Drees blijft bij zijn standpunt.

De Federatie van Nederlandse Journalisten stelt naar aanleiding van deze affaire een commissie in, die het vraagstuk van de uitsluiting van journalisten door de overheid nader moet bestuderen. In november 1958 publiceert deze commissie haar rapport onder de titel "Recht op nieuwsga-

Het tussen aanhalingstekens geplaatste understatement komt uit de oratie van $M$. Rooy, De vrijheid van de journalist, Leiden 1958, pag. 4. Zie over deze affaire ook J.M. de Mey, Het recht op informatie van de burger, in B. de Goede en H.Th.J.F. van Maarseveen (red.), a.w. pag. 216 e.v., waar bovendien gedetailleerd de lijdensweg wordt beschreven van het naar aanleiding van deze zaak uitgebrachte advies van de Persraad. 
ring". In dit rapport wordt een recht op informatie ten opzichte van de overheid geconstrueerd uit artikel 10 lid 1 EVRM (de wrijheid om inlichtingen of denkbeelden te ontvangen) en artikel 19 van de Universele Verklaring van de Rechten van de Mens (de vrijheid [..] inlichtingen en denkbeelden op te sporen, te ontvangen). Deze visie wordt enige maanden later bestreden door Th. W. van Veen, die in die tijd nog geen hoogleraar in het strafrecht is, maar redakteur van het Vrije Volk. "Zolang de journalist prijs stelt op zijn van de overheid onafhankelijke positie, dient hij nimmer de eis te stellen dat op zijn vragen ook geantwoord moet worden", meent Van Veen. ${ }^{26}$ Intussen heeft de regering ook aan de Persraad gevraagd om over de affaire advies uit te brengen. De regering ontvangt dit advies in februari 1960, maar merkwaardig genoeg zal het pas in april 1968 worden gepubliceerd. Omdat ik de gebeurtenissen zoveel mogelijk in chronologische volgorde wil bespreken, zal ik pas in een volgende paragraaf op dit advies terugkomen.

\section{De Televizier-affaire}

In een arrest van 25 juni 1965 (NJ 1966, 115), het zogeheten Televizierarrest, gaat de Hoge Raad expliciet in op de stelling dat uit artikel 10 EVRM een verplichting zou voortvloeien om inlichtingen te verstrekken. Wat was het geval? Het weekblad Televizier, uitgegeven door een gelijknamige NV, publiceerde wekelijks en gelijktijdig met de omroepbladen, de programma's voor radio en TV. Hoe Televizier aan de informatie kwam, is niet helemaal duidelijk. Maar in elk geval eisten de omroepen (dat wil zeggen AVRO, KRO, NCRV, VARA en VPRO) en hun gezamenlijke Stichting Centraal Bureau voor de Omroep, dat Televizier de publicatie van de programma's zou staken.

Als het tot een rechtzaak komt, eist Televizier in reconventie dat de omroepen en hun Centraal Bureau aan Televizier de programma-informatie geven, die zij onderling ook aan elkaar doorgeven. Televizier baseert deze eis op de stelling, dat de omroeporganisaties in Nederland een publiekrechtelijke inslag hebben, en dat daarom het in artikel 10 EVRM gegeven recht op vrije nieuwsgaring hen de plicht oplegt om de gevraagde gegevens te verstrekken. De rechtzaak leidt uiteindelijk tot twee gelijk-gedateerde arresten van de Hoge Raad: één over de eis in conventie, en één over de eis in reconventie. In dit laatste arrest wijst de Hoge Raad de eis van Televizier af, omdat naar zijn mening uit artikel 10 EVRM niet de ver- 
plichting kan worden afgeleid om inlichtingen waarover men beschikt aan derden te verstrekken. Behoudens uitzonderingsgevallen staat het een ieder vrij om hetgeen hem bekend is aan anderen door te geven. Dit geldt zowel voor overheidslichamen als voor andere rechtspersonen en natuurlijke personen, zodat het niet terzake doet, of en in hoever de omroeporganisaties een publiekrechtelijke inslag hebben, vindt de Hoge Raad. Naar de mening van dit rechtscollege geeft het recht op vrije nieuwsgaring dus geen recht om bij een overheid informatie te claimen.

\section{De principiële discussie begint}

Pas in de jaren zestig komt er, onder invloed van een wereldwijde vernieuwingsbeweging, een principiële discussie op gang over de wenselijkheid van openbaarheid van bestuur. In deze paragraaf wordt daar wat nader op ingegaan. Als ik het goed zie, wordt in ons land in 1966 de aftrap voor de discussie gegeven door de policoloog A. de Swaan, met de publicatie van zijn artikel Geheimhouding van de openbare zaak in het juninummer van De Gids. ${ }^{27}$ Hiermee is niet gezegd dat vóor of omstreeks de publicatie van dit artikel nooit andere wetenschappers hun licht over de openbaarheid van bestuur hebben laten schijnen. Maar dat gebeurde dan ofwel in de marge van een ander onderwerp, ofwel met nogal beperkte pretenties. Ik wil hier een paar van zulke studies noemen.

\section{De oratie van Rooy}

Allereerst is daar de oratie uit 1958 , warmee $M$. Rooy het ambt van hoogleraar in de perswetenschap aanvaardde in de Faculteit voor Politieke en Sociale Wetenschappen van de Universiteit van Amsterdam. Ik heb in de vorige paragraaf al uit de oratie geciteerd toen ik de affaire rond de Volkskrant-journalist Faas ter sprake bracht. De rede, getiteld De vrijheid van de journalist, behandelt ook het recht van de pers op informatie. $\mathrm{Na}$ gesteld te hebben dat dit recht niet besloten ligt in artikel 10 EVRM merkt Rooy terloops op, dat de overheid dit recht zou "kunnen erkennen in naleving van normen van behoorlijk bestuur". Maar die overheid zal dan zeker nog een terrein van "freies Ermessen" overhouden, aldus Rooy. ${ }^{28}$ 


\section{De dissertatie van Boukema}

Een tweede studie die ik hier wil noemen dateert uit 1966 zelf. Het is de dissertatie van P.J. Boukema, getiteld Enkele aspecten van de vrijheid van meningsuiting in de Duitse Bondsrepubliek en in Nederland. ${ }^{29}$ Boukema stelt, dat de eerbiediging van de vrijheid van nieuwsgaring, als bedoeld in artikel 10 EVRM, met zich meebrengt, dat de overheid ook zelf gegevens verschaft. Weigering om gegevens te verstrekken betekent aantasting van het recht op nieuwsgaring. En aantasting van dat recht is alleen toegestaan voorzover die zich verdraagt met de voorwaarden die daarvoor in artikel 10 zijn gesteld. Zo kan bijvoorbeeld een journalist geen recht doen gelden op gegevens van vertrouwelijke aard. Maar wanneer een overheid besluit om toch vertrouwelijke informatie te verstrekken, is discriminatie ten aanzien van bepaalde media of personen wel in strijd met normen van behoorlijk bestuur. En wanneer door een discriminerende maatregel een journalist ook zou worden uitgesloten van andere dan vertrouwelijke informatie, is sprake van strijd met artikel 10 zelf, tenzij aan de daar vermelde voorwaarden is voldaan, aldus Boukema. Hij construeert dus uit artikel 10 EVRM een recht voor de burger om bij de overheid informatie te claimen, behoudens de in dat artikel genoemde beperkingsmogelijkheden. Zoals we eerder hebben gezien, had een commissie van de Federatie van Nederlandse journalisten in 1958 deze constructie ook al bepleit, naar aanleiding van de Volkskrant-affaire. Maar de Hoge Raad had haar in 1965 , in de Televizier-zaak, ondeugdelijk bevonden. Het best wel sympathieke pleidooi van Boukema kreeg aldus het karakter van een achterhoedegevecht.

\section{De $M e i j$}

Als derde studie noem ik hier de eveneens uit 1966 daterende bijdrage van J.M. de Meij in Bestuurswetenschappen. ${ }^{30}$ De titel daarvan luidt: Openbaarheid van overheidsdocumenten in Scandinavië. Het is een studie die wel helemaal over openbaarheid van bestuur gaat, maar niet over de situatie in ons land. Wellicht daarom heeft de bijdrage niet zoveel aandacht getrokken als het artikel van De Swaan. Maar ook de strekking van de studie is nogal bescheiden. De Meij noemt in de inleiding het beginsel van openbaarheid een rechtsinstelling die van eminent belang kan zijn voor "de rechtsbescherming van de burger tegen de overheid". Maar hij laat zich niet uit over het belang van openbaarheid voor de versterking van de 
democratie. Eén en ander neemt niet weg dat de inhoud van zijn artikel zeer de moeite waard is, en latere auteurs over openbaarheid hebben er ook dankbaar gebruik van gemaakt.

\section{De Swaan}

Dan kom ik nu toe aan het al genoemde artikel van de Swaan, dat in 1966 in De Gids wordt gepubliceerd. Men moet bedenken dat De Gids in die tijd een blad was waarin het politiek engagement de boventoon voerde. Schrijvers als A.L. Constandse, W.L. Brugsma en Harry Mulisch vulden een goed deel van het blad met artikelen over Zuid-Amerika of Vietnam, de politieke rol van West-Europa, en de rellen in Amsterdam. Literatuur was maatschappijkritiek. En maatschappijkritiek was literatuur. Vandaar dat De Gids niet alleen door liefhebbers van literatuur werd gellezen, maar in minstens even grote mate door intellectuelen met politieke belangstelling. Het artikel van De Swaan, dat oorspronkelijk werd geschreven als doctoraal-scriptie voor de studie Politieke Wetenschappen, paste helemaal in de formule van het blad.

In Geheimhouding van de openbare zaak wordt uitgelegd hoe funest geheimhouding is voor de democratie. Het geheimhoudingsbeginsel, betoogt De Swaan, is in Nederland ingevoerd zonder dat daar ooit een principiële discussie, laat staan een principiële besluitvorming over heeft plaatsgevonden. Wet en Grondwet bepalen in Nederland niet wat geheim moet blijven, maar wat uitdrukkelijk openbaar moet zijn. De wet regelt de openbaarheid via de volksvertegenwoordiging en door openbare afkondiging of bijzondere inzage. De bevoegdheden van de rechter breiden de sfeer der openbaarheid nauwelijks uit. Al het overige is gunstbetoon, berust op regels die het bestuur zichzelf gegeven heeft en die het ook weer kan intrekken. Bezwaren die tegen het stelsel van bestuurlijke geheimhouding worden aangevoerd, worden gewoonlijk met een drietel dooddoeners afgedaan, aldus De Swaan. De eerste dooddoener is dat iedereen met enige moeite over het bestuur gewaar kan worden wat hij weten wil: hij hoeft daartoe met zijn vragen maar naar een kamerlid te gaan om langs de weg van het parlementaire vragenrecht antwoord te krijgen. "En de volksvertenwoordiger heeft daar tijd voor", smaalt De Swaan, en hij vervolgt: "Geen 150 leden van de Tweede Kamer, geen 250 leden van de StatenGeneraal kunnen met hun vragen een apparaat omvatten waarin honderdduizenden werken aan het welzijn van miljoenen met besteding van miljarden". (pag. 4).

Een tweede dooddoener is dat alles wat binnen het Nederlandse bestuur gebeurt toch zijn rechtvaardiging vindt in een algemene regel die weer te herleiden is op een wet. De burger kan het overheidshandelen door 
rechter of beroepsinstantie laten toetsen op rechtmatigheid. Daar zit iets in, vindt De Swaan. Maar hij wijst er meteen op dat de rechtsbescherming tegen de overheid in Nederland (anno 1966) nog zeer onvolledig is.

Een derde dooddoener, zegt De Swaan, is de redenering dat de beslotenheid van het bestuur toch niemand verhindert om zich een oordeel te vormen over de politieke werkelijkheid. Immers, op het beslissende moment zijn publiek en pers aanwezig: als de grote lijnen van het beleid worden vastgelegd in wetten die in openbaar debat behandeld worden. De Swaan brengt daar tegen in, dat er in de Staten-Generaal niet zo vaak in principiële zin over een onderwerp wordt gesproken. En dat in openbare zittingen alleen de grote trekken van een wetsvoorstel ter discussie worden gesteld. De vele details worden in voorbereidende en veelal besioten commissies behandeld. Daar worden de compromissen gebakken, wat dan ook weer afbreuk doet aan de betekenis van de openbare behandeling in het parlement. Trouwens, de betekenis van het parlement zelf is in de afgelopen jaren ook minder geworden. Vooral door de uitbreiding van de staatstaak heeft het accent zich verlegd van het parlement naar de regering. En deze accentverlegging wordt nog eens versterkt door besluitvorming op het internationale niveau, waar regeringsdelegaties de zaken bedisselen. De Swaan is niet de eerste die dit signaleert, maar hij denkt door over de consequenties die dit voor de burger heeft om kennis te kunnen nemen van belangrijke politieke feiten. "Dit houdt in", zegt hij, "dat het parlementair openbaarheidsbeginsel, dat garanderen moest dat de grote staatszaken elke kiezer ter kennis kwamen, niet langer werkt" (pag. 5).

De Swaan maakt duidelijk, dat het hem niet gaat om het hoge goed van rechtsbescherming voor de afzonderlijke burger - "dat kan ook anderszins gewaarborgd worden" -, maar om de fundamentele betekenis van de openbaarheid voor de medezeggenschap van de geregeerde in zijn regering. Het openbaarheidsbeginsel volgt uit de grondslagen van de democratische theorie, aldus De Swaan. Hij zegt zich te baseren op de Duits-Amerikaanse politicoloog Friedrich, die politieke gelijkheid pas aanwezig acht, als in een gemeenschap iedereen evenveel gelegenheid heeft om deel te nemen aan het politieke leven en om te trachten macht te verwerven. Met andere woorden: het gaat om gelijke gelegenheid tot deelneming aan het politieke bedrijf. Op deze eis van gelijke gelegenheid tot participatie grondvest De Swaan het openbaarheidsbeginsel. Geheimhouding geeft aan enkele ingewijden een machtspositie en verdraagt zich dus niet met de politieke gelijkheid. In de democratische opvatting is openbaarheid dus een belang van de burger als politiek wezen. Voor wie democratie een wenselijke 
toestand acht, is dat belang tevens een norm. ${ }^{31}$ Eén en ander betekent volgens De Swaan echter niet dat openbaarheid altijd boven alles gaat. Want openbaarheid kan in strijd zijn met doelmatigheid van bestuur. Deze doelmatigheid is een voorwaarde voor de handhaving van elke politieke orde. Dus ook voor de handhaving van de democratische orde. De doelmatigheid van bestuur verzet zich tegen openbaarheid als daarmee het effect van zijn maatregelen teloorgaat. De Swaan noemt als bestuursaktiviteiten, waar de kans groot is dat dit gebeurt, met name de landsverdediging, de diplomatieke betrekkingen, onderhandelingen met de overheid als partij, de monetaire politiek, misdaadbestrijding en inspectie (pag. 10).

Is op deze gronden eenmaal de noodzaak van geheimhouding erkend, dan is tegelijk een criterium gevonden voor de mogelijkheid van openbaarheid, aldus De Swaan. Als het effect van de maatregelen er niet mee geschaad wordt, kunnen ambtelijke plannen te allen tijde openbaar gemaakt worden. Hij laat vervolgens een paar veelgehoorde argumenten tegen openbaarmaking van ambtelijke stukken de revue passeren, om ze daarna meteen naar de prullenmand te verwijzen. Het zou ambtenaren overlast aandoen, rompslomp en tijdverlies, is het eerste argument tegen openbaarheid. Dat hoeft niet, repliceert De Swaan, als je de nodige organisatorische maatregelen treft. Het tweede argument tegen openbaarheid luidt: als de openbare mening van begin af aan in alle voornemens gekend zou worden, zouden de ambtenaren voortdurend aan kritiek en campagnes blootstaan. Een kwestie van wennen, vindt De Swaan, en bovendien kan kritiek nuttig zijn. Van meet af aan kunnen alle belangstellenden meedenken met de beleidsvorming, suggesties doen en al dadelijk misstappen voorkomen. Het derde argument tegen openbaarmaking is van staatsrechtelijke aard: aan de ministeriële verantwoordelijkheid zou afbreuk worden gedaan als eventuele meningsverschillen tussen de minister en een deel van zijn staf naar buiten toe bekend zouden worden. De Swaan bestrijdt ook dit argument. "Als er onder het Nederlands publiek nog zijn die denken dat de ambtelijke wereld geen verschil van mening kent, dan eisen 'weloverwogen presentatie' en 'goed begrip', dat zij terstond van het geloof in dit eensgezinde monstrum worden afgeholpen", sneert hij. In een democratie is het de normaalste zaak dat een minderheid tijdens de besluitvorming de voorgestelde beleidslijn hartgrondig kritiseert, maar na het vallen van de beslissing loyaal meewerkt aan de uitvoering. Dat mag je ook van ambtenaren verwachten.

31 Hoewel hij Friedrich bij naam noemt, geeft De Swaan hier geen vindplaats. In hoofdstuk 6 zal ik een polemiek tussen Friedrich en Finer bespreken, waarin de betekenis van openbaarheid voor de democratie vanuit een wat andere invalshoek wordt benaderd. 
Het enige staatsrechtelijke gevaar dat zich hierbij kan voordoen, is dat een minister zich bij het falen van zijn beleid beroept op ambtelijke tegenstand. Maar een dergelijk excuus is voor elke volksvertegenwoordiging onaanvaardbaar, vindt De Swaan. De minister heeft machtsmiddelen genoeg om tegenover zijn ondergeschikten zijn zin door te drijven (pag. 13).

Aan het slot van zijn betoog roept De Swaan het parlement op om zich met de kwestie van de bestuurlijke geheimhouding bezig te houden. Daarmee kan ook het debat in het land op gang worden gebracht. "Het belang van openbaarheid vindt in het bestuur zelf nergens voorspraak, alleen een halfhartige verdediger bij de voorlichtingsambtenaren". Er moet volgens De Swaan uiteindelijk een wet komen die de openbaarheid van het bestuur als algemene norm voorschrijft en duidelijke maatstaven geeft voor de geheimhouding. Want: "Democratie eist openbaarheid. Zonder opening van zaken geen toezicht op de bestuurders, zonder volledige informatie geen toereikende meningsvorming" (pag. 16).

Het pleidooi van De Swaan om openbaarheid van bestuur tot algemene norm te verheffen, is sterk, al zullen de argumenten die hij de tegenstanders van openbaarheid in de mond legt nog vele jaren daadwerkelijk weerklinken. Een zwak punt in het verhaal van De Swaan vind ik zijn formulering van een algemeen geheimhoudingskriterium: Geheimhouding mag, als door openbaarmaking het effekt van (democratische) bestuursmaatregelen zou worden geschaad. Hoewel de voorbeelden die hij noemt, wel reëel zijn - "Als de keuringsdienst van waren van tevoren zijn inspectieroutes bekend makkte, konden wij alleen van voedselvergiftiging gevrijwaard blijven wanneer de keurmeesters alle ten verkoop aangeboden waar zelf tot de laatste hap opaten:" - leent dit criterium zich naar mijn smaak toch te gemakkelijk voor politiek misbruik. In het volgende hoofdstuk zullen we zien dat Van der Hoeven ditzelfde criterium, in iets andere bewoordingen, zal aanprijzen in zijn preadvies voor de vergadering van de NJV in 1969. Ik kom er dan nog iets uitvoeriger op terug.

\section{De Commissie Biesheuvel wordt ingesteld}

Het artikel van De Swaan wordt in de wetenschappelijke wereld niet meteen opgepakt. Het lijkt wel of men er niet goed raad mee weet. In elk geval houden de juristen zich voorlopig heel stil. Er is kennelijk een politiek incident voor nodig, om de discussie nieuw leven in te blazen. 


\section{De affaire Korsten}

Zo'n incident vindt plaats als op 16 september 1967 het weekblad De Haagse Post een interview publiceert met de 'mannetjesmaker' Ben Korsten. $^{32}$ Korsten is een particuliere public-relationsman, die diensten verricht voor een groot aantal KVP-politici, waaronder ook minister-president De Jong en defensieminister Den Toom. Zo vertelt hij in het interview onder meer hoe hij Den Toom's memorie van toelichting bij de defensiebegroting heeft herschreven. "Je moet zo'n stuk aardig weten te brengen. Dat is het geheim, anders pikt de Kamer het niet en het publiek nog minder", vertrouwt hij de interviewer toe. Ook beweert hij invloed te hebben gehad bij de benoeming van het hoofd van de Voorlichtingsgroep Ontwikkelingshulp op het Ministerie van Buitenlandse Zaken. Dezelfde dag verschijnt ook in De Volkskrant een artikel over Korsten. Het publiek en de politiek reageren. De oud-premiers De Quay en Drees verklaren in de pers, dat het aanwenden van public relations nooit bedoeld mag zijn om beleid te verkopen of om propaganda te bedrijven. En Boot, Tweede- Kamerlid voor de KVP, stelt op 26 september 1967 schriftelijke vragen aan ministerpresident De Jong. Hij wil weten hoe de feitelijke gang van zaken is geweest, en of de regering een doeltreffender organisatie van het voorlichtingsbeleid overweegt. ${ }^{33}$

De minister-president geeft in zijn antwoord van 6 oktober 1967 de grote invloed van Korsten feitelijk toe, maar merkt er wel bij op dat "op verzoek van de heer Korsten" de relaties per 1 oktober 1967 zijn beëindigd. De premier is niet van mening, "dat de grondslagen van de overheidsvoorlichting en de organisatie van het apparaat vooralsnog wijziging behoeven". Maar, voegt hij daaraan toe, "Gelet op de snelle ontwikkeling en de uitbreiding van de publiciteitsmedia bezint het kabinet zich wel op de vraag hoe het bestaande voorlichtingsapparaat daarop doeltreffender kan aansluiten." Kamerlid Boot vindt dit antwoord niet toereikend. Op 18 oktober stelt hij opnieuw schriftelijke vragen: "Heeft de Minister er begrip voor, dat [..] nog in betekenende mate gebrek aan inzicht bestaat bij belanghebbenden in de zienswijze van de Regering omtrent de taak en de wenselijke werkwijze en organisatie van de overheidsvoorlichting?" wil Boot weten. En hij besluit met een bijna retorische vraag: "Acht de Regering overigens niet de tijd gekomen, nu het laatste openbare rapport omtrent het overheidsbeleid inzake voorlichting van het jaar 1946 dateert, 
opnieuw een desbetreffend rapport te doen uitbrengen door een commissie, waarvan ook niet-ambtelijke deskundigen deel uitmaken?" Ministerpresident De Jong schrijft op 7 november, dat het niet mogelijk is deze vragen binnen de gebruikelijke termijn te beantwoorden. Dat gebeurt pas een half jaar later.

Intussen is de premier dan in het parlement nog een aantal keren aan de zaak herinnerd. Met name bij de behandeling van hoofdstuk III (Algemene Zaken) van de rijksbegroting, op 18 december 1967 . De Kamerleden Visser (D66) en Wiegel (VVD), beiden refererend aan een rede die $M$. Rooy enkele dagen daarvoor gehouden heeft op een congres van het Instituut voor Bestuurswetenschappen (een rede waarin gepleit wordt voor een wettelijke regeling van een algemene voorlichtingsplicht voor de overheid), dringen bij de regering aan op een standpuntbepaling. Het kamerlid Van Beek (KVP) sluit zich daarbij aan en herinnert de premier nog eens aan de vraag van zijn partijgenoot Boot, om een studiecommisssie in te stellen. Minister-president De Jong antwoordt dat de zaak veel haken en ogen heeft, en dat het kabinet inderdaad denkt aan een commissoriale opdracht. ${ }^{34}$ Twee maanden later, op 15 februari 1968, stelt Wiegel ook nog eens schriftelijke vragen aan de premier. Hij wil expliciet weten, of de door de premier in het vooruitzicht gestelde commissie ook zal worden opgedragen "zich te beraden over een wettelijke regeling van een algemene voorlichtingsplicht voor de overheid, regelingen met betrekking tot de toegankelijkheid van ambtelijke documenten, de positie van voorlichtingsambtenaren, en de opleiding tot overheidsvoorlichter" ${ }^{35}$ Het antwoord op de schriftelijke vragen van Boot en Wiegel komt op 24 april 1968. Maar eerst moet de regering nog een vuiltje wegpoetsen dat resteert van een vorig politiek incident: de affaire met de Volkskrant-journalist Faas, en het naar aanleiding van deze affaire al in 1960 uitgebrachte advies van de Persraad. Dat advies is in 1968 nog altijd niet gepubliceerd.

\section{De regering en het advies van de Persraad}

Het is vandaag de dag niet meer goed voor te stellen, wat voor een koudwatervrees vier achtereenvolgende kabinetten (De Quay, Marijnen, Cals/ Vondeling en Zijlstra) ervan weerhouden heeft om het advies van de Persraad openbaar te maken. Zelfs een man als Vrolijk die als lid van de Persraad aan de opstelling van het advies heeft meegewerkt, en als PvdAkamerlid in 1961 op publicatie van het advies heeft aangedrongen, durft 
het niet te publiceren, als hij in 1965 minister van CRM is geworden. En als het nu om een revolutionair advies ging! In heel gematigde bewoordingen onderschrijft de Persraad de stelling uit de oratie van Rooy, dat uit normen van behoorlijk bestuur voortvloeit, dat de overheid de toegankelijkheid van het nieuws zoveel mogelijk dient te vergemakkelijken. "Ook voor de overheid gelde", zegt de raad, "dat openbaarheid regel zij en dat alleen het algemeen belang of de bescherming van een bijzonder belang geheimhouding kan rechtvaardigen". Weliswaar wordt hier de openbaarheid tot principe verheven, maar geen recht op informatie voorgesteld, want daarvoor is de uitzonderingsgrond "het algemeen belang" te weinig een rechtsnorm. Wat de uitsluiting van journalisten betreft, is de raad van mening dat de overheid daartoe pas mag overgaan, als zij eerst een beoordeling van het gedrag van de betrokken journalist heeft uitgelokt bij de Raad voor de Journalistiek. Met andere woorden: uitsluiting mag, maar het bestuur mag daarbij niet helemaal rechter in eigen zaak spelen ${ }^{36}$

In de brief waarmee de minister van CRM, mevrouw Klompé, het advies van de Persraad uiteindelijk op 19 april 1968 naar de Tweede Kamer zendt, deelt zij mee dat de regering zich kan aansluiten bij het pleidooi voor een grote openbaarheid, voorzover deze openbaarheid geen schade toebrengt aan het algemeen belang of aan bijzondere belangen van personen of groepen. De minister voegt daar veiligheidshalve aan toe: "mits het algemeen belang voldoende ruim wordt verstaan en daaronder mede wordt begrepen hetgeen in de betrekkingen tussen de onderscheidene constitutionele organen, met name parlement en regering, gebruikelijk is". Met een rol voor de Raad voor de Journalistiek in situaties waarin de regering een journalist van informatie wil uitsluiten, heeft de regering grote moeite. Het blijkt nu dat de regering al in 1962 aan een "werkgroep" van drie hoogleraren, te weten G.E. Langemeijer, C.H.F. Polak en A.J.P. Tammes, de vraag heeft voorgelegd of uitsluiting van journalisten in strijd is met artikel 10 EVRM. Laatstgenoemde hoogleraar was ook voorzitter van de Persraad toen deze in 1960 zijn advies aan de regering uitbracht.

Het advies dat de werkgroep in mei 1963 aan de regering heeft toegezonden, en nu bij de brief van minister Klompé aan de kamer is gevoegd, kan niet bepaald een schoolvoorbeeld van helderheid worden genoemd. De regering heeft de werkgroep de vraag voorgelegd, of het de overheid vrijstaat om iemand, wie dan ook, opzettelijk te verhinderen om mededelingen

Het advies van de Persraad is, met het advies van de "werkgroep van hoogleraren" en de begeleidende brief van de minister van CRM te vinden in TK 1967-1968, 9572. 
"off the record" en "background information" te ontvangen of door te geven, zonder dat een wet in formele zin de overheid tot het doen van een dergelijke stap heeft gemachtigd. De werkgroep antwoordt: "er is geen reden om aan te nemen, dat de overheid zulke mededelingen die zij ook geheel achterwege had mogen laten, niet zou mogen doen onder restricties wat betreft het verder mededelen daarvan." Men hoeft geen cursus Logica te hebben gevolgd om in te zien, dat dit geen antwoord op de gestelde vraag is.

Ook van de overige antwoorden van de werkgroep wordt men niet veel wijzer. De lezer van het advies zal tevergeefs een antwoord zoeken op de vraag of een journalist, die informatie uit een lek heeft gepubliceerd, daarom door de overheid mag worden uitgesloten van informatie die andere journalisten wel krijgen. En om die vraag ging het toch, toen Faas zijn "tamelijk juiste prognose" in de Volkskrant wereldkundig had gemaakt. Niettemin schrijft minister Klompé in 1968 in haar brief aan de Tweede Kamer, dat de rechtsgeleerden de juistheid van de opvatting der regering hebben bevestigd. De regering acht derhallve verbreking of beperking van haar betrekkingen met een journalist of blad "een rechtens niet uitgesloten reactie op een eventuele schending van vertrouwen". Gezien het ingrijpend karakter van een dergelijke reactie acht de regering het gewenst om zich in voorkomende gevallen van een deskundig advies te voorzien. Maar zij denkt daarbij niet in de eerste plaats aan een oordeel van de Raad voor de Journalistiek.

\section{De installatie van de Commissie Biesheuvel}

Nu het "incident Faas" hiermee is afgesloten, acht de regering kennelijk de weg vrij om de schriftelijke vragen van de kamerleden Boot en Wiegel te beantwoorden. Op 24 april 1968 zendt premier De Jong daartoe twee afzonderlijke brieven aan de kamer. ${ }^{37}$ De minister-president signaleert daarin, dat er na het rapport van de Commissie Van Heuven Goedhart een duidelijke verschuiving is opgetreden van de passieve naar de actieve overheidsvoorlichting, ten gevolge van de zozeer toegenomen vraag om informatie vanuit de matschappij. De regering acht inderdaad een herbezinning op de grondslagen van de overheidsvoorlichting nodig, "waarbij wordt uitgegaan van de vraag hoe de voorlichting van de overheid zowel dienstbaar kan zijn aan de taak van de overheid als aan het belang van de burger om zo goed mogelijk geïnformeerd te worden." Het ligt in de bedoeling, dat na interne voorbereiding een commissie van niet-ambtelijke 
en ambtelijke deskundigen zal worden ingesteld, die tot opdracht heeft ten principale na te gaan welk standpunt in Nederland met betrekking tot deze vraagstelling dient te worden ingenomen. In zijn antwoord aan het kamerlid Wiegel voegt de minister-president daar nog onder meer aan toe, dat die commissie zich ook zal hebben te beraden over een wettelijke regeling van een algemene voorlichtingsplicht voor de overheid en regelingen met betrekking tot de toegankelijkheid van ambtelijke documenten.

Op 13 september 1968 wordt het besluit van de minister-president om een commissie in te stellen daadwerkelijk genomen. ${ }^{38}$ De commissie krijgt als naam: Commissie Heroriëntatie Overheidswoorlichting. Voorzitter wordt de ARP-politicus mr. Biesheuvel. De PvdA-politicus mr. Vrolijk wordt vice-voorzitter. Verder telt de commissie nog zeven leden, waaronder kopstukken uit de wereld van de pers en de omroepen, en beoefenaren van de parlementaire geschiedenis, de politicologie en van public relations. Opvallend genoeg zitten er geen rechtswetenschappers tussen. Dat is des te vreemder, als men bedenkt dat de commissie zich op niets minder heeft te beraden dan op een wettelijke regeling van een algemene voorlichtingsplicht voor de overheid en van de toegankelijkheid van ambtelijke documenten. Dat zijn toch onderwerpen, waarbij belangrijke staatsrechtelijke en bestuursrechtelijke vragen aan de orde komen. Opvallend is ook, dat de commissie geen ambtelijke leden kent. Wel worden er een aantal "vertegenwoordigers" van ministers aangewezen.

In zijn installatierede van 23 september 1968 benadrukt premier De Jong zeer sterk het democratisch belang van het werk dat de commissie moet gaan doen. "De maatschappelijke ontwikkeling is sedert 1945 zo snel gegaan en de wijzigingen zijn zo fundamenteel en omvangrijk, dat de regering behoefte gevoelt opnieuw bestek op te maken. Het is de taak van iedere generatie, maar dan zeker van de onze, te trachten aan de democratie optimale inhoud te geven. Het accent bij de vraagstelling ligt niet op de problemen van organisatie of werkwijze. Wat van uw commissie wordt gevraagd - en waar de regering behoefte aan heeft - is een maatschappelijke herwaardering van het contact van burger en overheid (de centrale overheid in casu) en het aangeven van de plaats en de betekenis daarbij van de voorlichting en al datgene wat openheid van bestuur kan bevorderen. De regering vraagt derhalve niet minder van u dan een bezinning op de huidige ontwikkeling van de democratie en hetgeen aan democratische

Zie Openbaarheid Openheid, rapport van de Commissie Heroriëntatie Overheidsvoorlichting (Commissie Biesheuvel), Den Haag 1970, pag. 222 e.v., waar ook de installatierede van de minister-president en het antwoord daarop wan de voorzitter van de commissie is afgedrukt. 
ontwikkeling in de komende jaren kan worden verwacht." Aan het slot van zijn rede spreekt de premier nog eens zijn hoge verwachtingen uit: "De regering hoopt dat $u$ baanbrekend werk zult verrichten voor het verbeteren van de communicatiewegen, die leiden van de basis naar de top en, omgekeerd, van de top naar de basis. Zo doende, zult u de democratie een grote dienst bewijzen."

In zijn antwoord op de installatierede van de minister-president onderkent voorzitter Biesheuvel zowel het bestuursrechtelijke als het staatsrechtelijke belang van de opdracht. "Zie ik het goed," zegt hij, "dan heeft de mens in tweeërlei opzicht belang bij informatie: als burger en als staatsburger. De minister-president wees erop, dat de overheid steeds dieper ingrijpt in de levenssfeer van de burger. [..] Het verlangen van de ene burger naar openheid van het dossier kan gemakkelijk op gespannen voet staan met het belang van de andere burger bij een grote mate van discretie van bestuur ten aanzien van hem regarderende feiten en zakelijke belangen. De eisen van zorgvuldigheid en openheid moeten dan tegen elkaar worden afgewogen." Maar, vervolgt hij: "Ook de staatsburger gevoelt in toenemende mate behoefte aan meer kennis en inspraak omtrent het staatkundig gebeuren. Lange tijd meenden wij, dat met de invoering van het algemeen kiesrecht aan die behoefte was voldaan. Tegenwoordig is de roep om participatie vooral bij de jonge generatie algemeen. En inspraak veronderstelt informatie!" Er zijn echter ook grenzen aan de informatie voor de staatsburger, vindt Biesheuvel: "Bij een optimale werking van de democratie behoort naast controle evenzeer een snel en consistent bestuur. Een democratie met een gekortwiekt bestuur is niet optimaal. Ook zal de beleidsvoorbereiding, die aan de beleidsvoering vooraf gaat zich nooit in volledige openbaarheid kunnen voltrekken." Met kennisneming van deze ambivalente gedachten van de voorzitter begint de commissie aan haar studie.

\section{De rechtswetenschap en de openbaarheid}

$\mathrm{Na}$ de installatie van de Commissie Biesheuvel kan de staatsrechtelijke wereld niet meer om de openbaarheidsdiscussie heen. De rechtswetenschappelijke reacties beginnen eindelijk los te komen. Als eerste doet de Nijmeegse rector magnificus en hoogleraar in het staats- en bestuursrecht S.F.L. van Wijnbergen een poging het denken van de juristen een eind op
weg te helpen. 


\section{De diesrede van Van Wijnbergen}

Van Wijnbergen houdt op 18 oktober 1968 in Nijmegen een diesrede over openbaarheid van overheidsdocumenten. ${ }^{39}$ Behalve op de eerder genoemde artikelen van De Meij en De Swaan en op enkele meer anekdotische dan bruikbare uitspraken van Thorbecke, kan hij daarbij alleen maar steunen op het werk van buitenlandse auteurs. Na een korte balans te hebben opgemaakt van geheimhouding en openbaarheid in de Nederlandse bestuursdienst, richt Van Wijnbergen zijn blik dan ook al snel op andere westerse landen. Met name verdienen volgens hem het $Z$ weedse en het Amerikaanse openbaarheidssysteem positieve aandacht. Zowel in Zweden als in de Verenigde Staten wordt het recht op overheidsinformatie als een eis van democratie gezien. Het Zweedse systeem kent een beperkt aantal tamelijk precies omschreven geheimhoudingsgronden. In het Amerikaanse systeem zijn de geheimhoudingsgronden wat ruimer geformuleerd, maar stelt de rechter hoge eisen aan het bewijs dat geleverd moet worden om gegevens geheim te mogen houden. Na deze verkenningstocht geeft Van Wijnbergen een beschouwing over wat wenselijk zou zijn voor ons land. Hij neemt dan allereerst de nog zeer verbreide opvatting op de korrel, dat de burgers toch via de parlementaire democratie voldoende worden geïnformeerd. "Op burgerijdagen trachten gemeentebesturen de jonge kiezers duidelijk te maken, dat in de vertegenwoordigende colleges hùn zaken worden behartigd. Hoe kan men dan diezelfde kiezers willen doen geloven, dat wat er buiten die colleges aan overheidsactiteit plaatsvindt, hen niet zou aangaan?" vraagt hij zijn toehoorders en lezers, en hij concludeert: "Wil men de mondigheid van de burger aanvaarden, dan zal men deze terughouding moeten laten varen. Voor regering en bestuur bestaat er geen terrein van privacy, waaruit men buitenstaanders mag weren. Er zijn immers geen buitenstaandlers." 40

Van Wijnbergen stelt vervolgens afzonderlijk de wenselijkheid van openbaarheid van adviezen van adviescolleges en van ambtelijke stukken aan de orde. Hij hekelt de argumentatie, waarop geheimhouding van de adviezen van de Raad van State dan nog altijd steunt: publikatie van adviezen zou in veel gevallen het de regering moeilijk maken en aan de oppositie argumenten tegen de regeringsvoorstellen in handen spelen. "Daaruit zou voortvloeien", reageert Van Wijnbergen, "dat aan de StatenGeneraal en aan de publieke opinie alleen die elementen uit het onderzoek, 
dat de regering deed instellen, zouden moeten worden medegedeeld, die voor het standpunt van de regering pleiten. De regering schijnt geen bezwaar te zien in het feit dat zij door deze handelwijze de Staten-Generaal, die uiteindelijk toch ook de volledige verantwoording voor de maatregel op zich moeten nemen, onvolledig voorlicht en dat zij aan de publieke opinie maar een gedeeltelijk inzicht geeft in de motieven, die de regering tot haar voorstellen hebben gebracht. Tot die motieven moeten immers ook gerekend worden de argumenten, die tot afwijzing van andersluidende adviezen hebben geleid." 41

Met betrekking tot eventuele publikatie van ambtelijke adviezen doemen andere vragen op, zoals: kan de ministeriële verantwoordelijkheid werken bij openbaarheid van ambtelijke adviezen? Van Wijnbergen meent van wel: "Zeker $90 \%$ of meer van alle overheidsmaatregelen komen voort uit de creatieve arbeid van dit ambtelijk apparaat. Is het dan aanvaardbaar, dat van deze invloed niets naar buiten blijkt, dat wij in veel gevallen niet weten waar nu eigenlijk de ideeën, die de overheid gaat verwerkelijken, vandaan komen? [..] Men kan de burger het recht niet ontzeggen te weten wie die invloed uitoefenen en welke hun opvattingen zijn. Tot dusverre gebeurt dit te hooi en te gras. Uit die incidentele gevallen is in ieder geval af te leiden, dat de bezwaren ervan niet overwegend behoeven te zijn. [..] De ministeriële verantwoordelijkheid komt niet in het gedrang indien bekend wordt welke ambtenaren aan het tot stand komen van maatregelen, waarvoor de minister verantwoordelijk is, hebben bijgedragen. "42 $\mathrm{De}$ wenselijkheid van openbaarheid van de ambtelijke dienst, zegt Van Wijnbergen, wordt ook nog benadrukt door iets anders: het feit dat één taak van de Staten-Generaal, te weten het uitoefenen van controle op het regeringsen bestuursapparaat, eigenlijk onverenigbaar is met hun voornaamste taak: het aangeven van de algemene politieke lijn, volgens welke de regering moet regeren. "De noodzakelijke kritiek op een minister wegens fouten van zijn apparaat, kan gepaard gaan met de wens diezelfde minister politieke steun te verlenen. Bij dit dilemma zal de controletaak het veld moeten ruimen voor de algemene politieke functie." Invoering van het beginsel van openbaarheid van overheidsdocumenten zal de regerings- en bestuursactiviteit doorzichtig maken, zodat de burger zal weten waarom de overheid handelt zoals ze handelt, betoogt Van Wijnbergen aan het slot van

42 Id. pag. 17 en 18. 
zijn rede. De dringend nodige controle zal er pas goed mogelijk door worden. ${ }^{43}$

Ik wijs er hier alvast op, dat Van Wijnbergen's aanbevelingen uit 1968 verder gaan dan wat de Wet openbaarheid van bestuur ons vandaag de dag te bieden heeft. Nog altijd wil de wetgever niet de gedachte aanvaarden, dat voor de burger - of zelfs maar voor de volksvertegenwoordiger - kenbaar zou moeten zijn, welke ambtenaren welke adviezen hebben uitgebracht. Ambtelijke adviezen worden in het algemeen opgesteld te behoeve van "intern beraad", en over "persoonlijke beleidsopvattingen" wordt dan geen informatie gegeven, bepaalt artikel 11 van de WOB. Onder "persoonlijke beleidsopvattingen" verstaat de wet, naar ook in de jurisprudentie wordt aangenomen, beleidsopvattingen die tot personen te herleiden zijn. Ik kom daar in een volgend hoofdstuk nog op terug.

\section{De bundel van De Goede en Van Maarseveen}

In de loop van 1969 verschijnt er een belangrijke bundel met juridische opstellen over openbaarheid van bestuur, onder redactie van B. de Goede en H.Th.J.F. van Maarseveen. De titel luidt: Hoe openbaar wordt ons bestuur? ${ }^{44}$ Van de elf opstellen zijn er tien waarin toch wel in meer of mindere mate gepleit wordt voor een grotere openbaarheid.

Eén bijdrage valt in dat opzicht nogal uit de toon: die van de $\mathrm{Nij-}$ meegse hoogleraar in het staatsrecht F.J.F.M Duynstee, over openbaarheid van de werkzaamheden van de kamers der Staten-Generaal. Het is ronduit een tirade tegen het openbaarheidsstreven van die tijd. Een paar van zijn argumenten wil ik de lezer niet onthouden. Duynstee stelt voorop, dat als men meer openbaarheid wil, men niet moet beginnen met adviezen van ambtenaren en van adviescolleges openbaar te maken, maar de besluitvorming in het kabinet en in het parlement. De onbevangen lezer krijgt dan even de indruk, dat Duynstee van dat laatste een voorstander is. Maar dat blijkt niet het geval te zijn. Integendeel. Duynstee wil wel toegeven dat door de pas vergrote openbaarheid van de debatten van de Tweede Kamer de discussie levendiger is geworden, en zaken meer in gewone taal worden besproken. "Maar aan de andere kant gaan de debatten menigmaal sterk lijken op die van een politieke debatingclub [..] De normale eis is, dat de Tweede Kamer vóór kerstmis gereed moet zijn met de begrotingsbehandeling. Thans echter is het erger dan het ooit is geweest [..] Dit gaat een

Id. pag. 18.

44 B. de Goede en H.Th.J.F. van Maarseveen (red.), Hoe openbaar wordt ons bestuur?, Den Haag 1969. 
beetje lijken op de zich zelf eindeloos herhalende discussieorgiën, welke in bepaalde studentenkringen als de meest ideale tijdspassering opgeld doen. "4s

Verder blijkt, dat Duynstee het al helemaal niet begrepen heeft op openbaarheid van ambtelijke adviezen en van adviezen van de Raad van State. "Kan er in redelijkheid aan getwijfeld worden, dat geen regering mogelijk is als zij zich niet in een sfeer van verzekerde vertrouwelijkheid zou kunnen laten adviseren?" vraagt hij de lezer. Aan het slot van zijn betoog geeft hijzelf het antwoord: "De betwisting van die bevoegdheid zou, naar het mij voorkomt, wel eens blijk kunnen zijn van in sommige kringen bestaande onmacht, om als mens enig vertrouwen te geven aan n'importe wie, die in die kringen geacht worden te behoren tot datgene wat zij noemen en verwerpen als het 'establishment" ". ${ }^{46}$ Duynstee waarschuwt dan ook "dat wij, door te regelen vanuit die onmacht tot vertrouwen, stap voor stap zouden gaan naar anarchie en hiermede naar een onvermijdelijke reactie welke anarchie oproept."

In de opstellen van de overige auteurs in de bundel wordt minder ingespeeld op de angstgevoelens van de lezer. Op twee van die bijdragen wil ik hier nader ingaan: die van J.M. Kan, destijds lid van de Raad van State, over de openbaarheid van de rapporten van de vaste adviescolleges aan de regering, en die van de Utrechtse hoogleraar in het staats- en bestuursrecht J.G. Steenbeek, over de openbaarheid van adviezen en rapporten van ambtenaren.

\section{De bijdrage van Kan}

Naar de bijdrage van J.M. Kan heb ik al verwezen, toen ik hier eerder schreef over de weigering in 1957 van de staatssecretaris van Onderwijs, Kunsten en Wetenschappen om een advies van de Radioraad te publiceren, en over de reacties die daarop volgden. Kan schrijft in zijn opstel, dat hij over die zaak nog eens een mondelinge gedachtenwisseling met Romme heeft gehad. Hij heeft daaruit begrepen, dat Romme destijds in de kamer voornamelijk het oog had op vaste colleges die in hoofdzaak zijn samengesteld uit vertegenwoordigers van belanghebbenden. Romme ziet zulke colleges niet als staatsorganen, maar als representanten van hun maatschappelijke sector, als matschappelijke organen. Voor hun doen en laten is geen minister verantwoordelijk, tenzij voor zover dat doen of laten voort- 
vloeit uit de betrokken wettelijke regeling of de door de minister te hanteren beïnvloeding daarvan. De leden van die colleges zijn verantwoordelijk tegenover hen die ze representeren. En de colleges zelf zijn verantwoordingsplichtig als maatschappelijke colleges; waarbij als forum de publieke opinie fungeert. Vanuit die gezichtshoek hecht Romme grote waarde aan de openbaarheid van hun adviezen.

Kan ziet dat anders. Hij wil de maatschappelijke verantwoordelijkheid van de colleges niet ontkennen, maar hij vindt dat ze toch zodanig in het staatsbestel zijn geïntegreerd, dat ze moeten worden beschouwd als staatsorganen, belast met een adviserende functie. Dat brengt met zich mee, aldus Kan, dat uitsluitend de betrokken minister(s) door de StatenGeneraal verantwoordelijk kan (kunnen) worden gesteld voor hetgeen door een adviescollege is verricht of nagelaten of, meer algemeen gesteld, voor de wijze waarop het college en zijn leden de opgedragen taak verrichten. Maar omdat ter zake van de taakuitoefening van zo'n college de minister(s) in de regel geen directe zeggenschap zal (zullen) hebben, zal ook de ministeriële verantwoordelijkheid slechts een beperkte werking hebben. Volgens Kan geeft openbaarheid dan de mogelijkheid om een minister ook op die verantwoordelijkheid aan te spreken. En zo komt hij langs een andere weg dan die van Romme toch tot dezelfde conclusie: de adviezen van de vaste adviescolleges dienen in principe openbaar te zijn. Want: "De openbaarheid der uitgebrachte adviezen kan er, in dit licht bezien, toe bijdragen, dat het publiek en de kamers precies weten, hoe in elk afzonderlijk geval de kaarten liggen en met name wat het aandeel is van het college en dat van de minister in een bij de Tweede Kamer aanhangig gemaakt wetsontwerp of een door de regering genomen beslissing. Aldus vindt ook in politiek opzicht in zekere zin een verantwoording plaats van het college en dikwijls van groepen daarin." 47

Kan ziet het liefst dat de openbaarmaking van een advies vergezeld gaat van een 'voorlopig' standpunt van de regering. Aldus wordt voorkomen, dat bij het publiek verwachtingen worden verwekt, die op regeringsniveau niet kunnen worden verwerkelijkt. Maar, zegt Kan, de nadruk moet dan well worden gelegd op het woord "voorlopig", daar het niet uitgesloten moet worden geacht, dat bij de publieke discussie aspecten naar voren zullen komen, die de regering tot andere gedachten zullen brengen. In gevallen waarin veel tijd gemoeid is met het bepalen van een voorlopig regeringsstandpunt, bijvoorbeeld omdat eerst aan andere overheidslichamen hun mening over het advies moet worden gevraagd, ligt de zaak 
echter anders. Dan is het beter om het advies zo spoedig mogelijk nadat het is uitgebracht, openbaar te maken en daarbij mee te delen dat de regering haar standpunt "met bekwame spoed" bekend zal maken.

Opmerkelijk is, dat Kan vindt dat de wenselijkheid van openbaarheid niet geldt voor de adviezen van de Raad van State. Die zijn anno $1969 \mathrm{nog}$ altijd geheim. Openbaarmaking is wel mogelijk, maar niet verplicht. En terecht, vindt Kan. Van Wijnbergen, die er in zijn diesrede op had gewezen dat in Belgiè de adviezen van de Raad van State wel steeds bij de publicatie van wetsontwerpen bekend worden gemaakt, heeft hem wat dat betreft niet kunnen overtuigen. De argumenten die Kan voor zijn eigen standpunt aandraagt zijn echter niet erg sterk te noemen. ${ }^{48}$ Hij voert aan dat de Raad van State "een geheel eigen plaats in ons staatsbestel inneemt en niet zonder meer op één lijn gesteld kan worden met de "gewone" colleges van advies". Dat zou blijken uit het feit dat de Raad de bevoegdheid heeft de Kroon van zijn gevoelen te doen blijken over aangelegenheden, die naar zijn oordeel van bijzondere betekenis zijn. En uit het feit dat ministers, in wier handen de adviezen worden gesteld, daarop reageren "bij tot de Koningin gericht vertrouwelijk schrijven". Ook het feit dat de Raad niet zomaar is samengesteld uit belanghebbenden of deskundigen, maar uit "personen, die ieder op een specifiek terrein van het openbaar bestuur de nodige ervaring hebben opgedaan en met elkaar een college vormen, dat het gehele terrein van 's lands wetgeving kan overzien", is in de ogen van Kan een argument tegen verplichte openbaarmaking van 's Raads adviezen. Ik vraag mij af, of Kan zich hier niet een beetje teveel laat meeslepen door een staatsradelijk chauvinisme. Hoe dan ook, juist dit laatstgenoemde argument is door de Commissie Biesheuvel gehanteerd om voor openbaarheid van de adviezen te pleiten. In 1980 heeft de wetgever die openbaarheid voor bijna alle adviezen van de Raad ingevoerd (behoudens de uitzonderingsgronden van artikel $10 \mathrm{WOB}$ ).

\section{De bijdrage van Steenbeek}

De bijdrage van mijn Utrechtse leermeester Steenbeek, over openbaarheid van adviezen en rapporten van ambtenaren, is ook nu nog heel verfrissend om te lezen. Steenbeek vindt dat niet te moeilijk moet worden gedaan over de openbaarheid van dergelijke documenten. Schermen met het argument dat de politieke bestuurder toch verantwoordelijk is, is niet voldoende om geheimhouding te rechtvaardigen. Want niet alleen ambtenaren met geattribueerde bevoegdheden treden op eigen naam naar buiten, maar ook 
talloze ambtenaren met gemandateerde bevoegdheden doen dat, zij het namens een politiek college of een politieke bestuurder. Voor iedereen is in zulke gevallen kenbaar welke ambtenaar de beslissing heeft genomen, en wie daar politiek voor aanspreekbaar is. De stap naar het openbaar maken van ambtelijke adviezen en rapporten is dan ook niet zo groot. Maar zij moet wel zorgvuldig worden genomen.

Steenbeek vertelt dat hijzelf, in zijn tijd als waterstaatsambtenaar, goede ervaringen heeft opgedaan met ambtelijke openbaarheid. Als voorzitter van een ambtelijke werkgroep voor waterschapsfinanciën heeft hij meegemaakt, dat de regering het rapport van deze werkgroep publiceerde. Dit ging vergezeld van de verklaring dat zij (de regering) nog geen standpunt had gekozen, maar eerst eens wilde vernemen hoe men buiten de departementen over het vraagstuk dacht. Steenbeek heeft het als positief ervaren, dat hij daarbij ook in de gelegenheid werd gesteld om zelf publiekelijk over het ambtelijke standpunt te discussiëren. Dat heeft zowel voor hemzelf als, naar hij hoopt, voor de geïnteresseerden nuttige informatie opgeleverd. Hij erkent wel, dat het openbaar maken van ambtelijke adviezen en rapporten onvermijdelijk leidt tot enerzijds een zelfstandige verantwoordelijkheid van de ambtenaar naar buiten, en anderzijds tot meer afstand van zijn beleidschef. Men kan deze consequenties op zichzelf niet ongezond achten, zegt Steenbeek, maar te veel van het goede zou wel eens kunnen schaden. Als het zo ver komt, dat de minister in principe niet meer een vertrouwelijk advies van zijn ambtenaren kan krijgen, bijvoorbeeld om zich een duidelijk beeld van achtergronden enzovoort te kunnen vormen, werkt dat desintegrerend op de ambtelijke dienst. ${ }^{49}$

De rest van Steenbeeks betoog is dan ook vooral een beschouwing over de vraag welke ambtelijke stukken wel en welke niet openbaar zouden moeten zijn. Althans, in principe openbaar, want de auteur beoogt geen doorbreking van geheimhouding in zaken van staatsveiligheid, van privacy, en van economische concurrentiemogelijkheden en dergelijke. Een zekere mate van tweeslachtigheid van de functie van het ambtelijk apparaat moet worden aanvaard, vindt Steenbeek. "Het is, in abstracto, bijzonder te betreuren, dat veel ambtelijke kennis, wetenschap en combinatievermogen slechts dienst doen voor de bestuurder zelf, terwijl zovele anderen door daaromtrent ingelicht te zijn aan het proces van de democratische besluitvorming zouden kunnen bijdragen, of voor eenmaal genomen besluiten meer begrip zouden kunnen opbrengen". Daarnaast zou openbaarheid van ambtelijke opinies nog een tweetal voordelen opleveren, aldus Steenbeek: 
"enerzijds wordt door zulk een openbaarheid de bestuurder gedwongen zich uiterst objectief op te stellen, en anderzijds kan worden voorkomen dat de ambtenaar in de publieke opinie ten onrechte medeverantwoordelijk wordt gesteld voor besluiten die de verantwoordelijke bestuurder zelf heeft genomen". Op dit stuk kan openbaarheid de ambtenaar dan de bescherming bieden, die hem door de ambtenarenrechter lang niet altijd kan worden gegeven. ${ }^{50}$ Steenbeek zegt er echter bij, dat dit laatste maar een nevenaspect is. Het hoofdaspect ligt in de positieve bijdrage aan de openbare meningsvorming.

Twee criteria zijn volgens hem van belang om uit te maken of een ambtelijk advies of rapport in principe openbaar zou moeten zijn: de voldragenheid van het stuk, en de verantwoordelijkheid van de ambtenaar in de organisatie. Steenbeek komt dan tot de stelling, "dat het principe van openbaarheid moet gelden voor die - schriftelijke - adviezen en rapporten die afkomstig zijn van of althans gefiatteerd zijn door die ambtenaren, die in het ambtelijke een zekere zelfstandige verantwoordelijkheid op het aan de orde zijnde terrein dragen". ${ }^{51}$ Ontwerpen voor adviezen, commentaren daarop en dergelijke zouden dan buiten de openbaarheid dienen te blijven, omdat zij nog niet als voldragen kunnen worden beschouwd, en alleen maar verwarring kunnen stichten. Net als Van Wijnbergen gaat Steenbeek dus verder dan wat de Wet openbaarheid van bestuur ons nu geeft. Want deze wet zondert persoonlijke (lees: tot personen te herleiden) beleidsopvattingen van ambtenaren van openbaarheid uit, tenzij die ambtenaren met openbaarmaking instemmen. Steenbeek denkt daar duidelijk anders over. Vergeleken met Van Wijnbergen zijn zijn denkbeelden wat meer uitgewerkt, en daardoor ook wat meer genuanceerd.

Het selecteren van ambtelijke stukken die in de opvatting van Steenbeek in principe openbaar zouden moeten zijn, hoeft volgens hem niet veel problemen op te leveren. Die zijn er nu ook niet als bijvoorbeeld een geschil voor het ambtenarengerecht of voor de Raad van State dient en daarvoor stukken moeten worden geselecteerd. Dan moet datzelfde ook mogelijk zijn voor een algemener doel. Aan de behoefte aan openbaarheid van ambtelijke adviezen en rapporten kan aldus worden tegemoetgekomen zonder dat aan de werking van het ambtelijke apparaat essentieel afbreuk wordt gedaan.

51 Id. pag. 177. 


\section{Hoofdstuk 3}

\section{Wettelijke regels voor openbaarheid van bestuur?}

\section{De preadviezen van Donner en Van der Hoeven}

Als in de jaren 1968 en 1969 de juridische wetenschap belangstelling opvat voor de openbaarheid van bestuur, speelt intussen ook de discussie over een algehele grondwetsherziening. In 1966 is de Proeve van een nieuwe Grondwet gepubliceerd, en daarna is de Staatscommissie van advies inzake de Grondwet en de Kieswet (de commissie Cals/Donner) geïnstalleerd, om met voorstellen voor een algehele herziening van deze wetten te komen. De vraag wordt dan ook opgeworpen, of de nieuwe Grondwet bepalingen over openbaarheid van bestuur moet bevatten. De Nederlandse Juristenvereniging behandelt die vraag in haar jaarvergadering van 27 juni 1969 , als zij discussieert over twee preadviezen van resp. A.M. Donner en J. van der Hoeven. ${ }^{52}$ Beide auteurs zijn lid van de commissie Cals/Donner. Onderwerp van de preadviezen is de vraag: Dient de uitoefening van de grondrechten, welke meningsvorming, meningsuiting en informatie betreffen, grondwettelijk nader te worden geregeld? Het vraagstuk van de openbaarheid van bestuur wordt hierdoor gekoppeld aan het vraagstuk van de vrije meningsuiting. De beide preadviezen zijn zeer verschillend van karakter.

\section{Donner}

Het betoog van Donner doet uiterlijk nogal conservatief aan. Hij voelt geen enkele behoefte om mee te doen met de trend die na het Verdrag van Rome sterk is opgekomen, om grondrechten te formuleren als mensenrechten, als rechten die gebaseerd zijn op de waardigheid van de mens. "Voor deze kijk op de grondrechten kan ik niet warmlopen, want daarvoor ben ik van die waardigheid van 'de mens' niet genoeg doordrongen" schrijft hij. Even verder vervolgt hij dan: "Mijn uitgangspunt, als ik het zo mag noemen, is

52 Hand. NJV 1969, I, tweede stuk, pag. 6-54 (preadvies Donner) en pag. 55-121 (preadvies Van der Hoeven). 
dan ook een ander. Terwijl mijn enthousiasme voor de vrijheid helemaal niet ontwonkt bij het zien op de waarde van mensen (integendeel; wanneer men ziet welk gebruik sommige van onze voorlichters van hun vrijheid van meningsuiting en van de te hunner beschikking staande media maken, dan wordt men nog het meest herinnerd aan een aap met een scheermes losgelaten in een vriendelijke woning), begint het pas te ontbotten, wanneer het oog wordt gericht op de vrijpostigheden, die overheden zich in het verleden en heden (en, wanneer zij de kans krijgen, in de toekomst) tegenover hun onderdanen en de burgerij wel veroorloven en tot welke stompzinnige eigengerechtigheden zij dan wel niet in staat zijn. ${ }^{153}$ In de vergadering zal P.J. Boukema, als intervenient, naar aanleiding van deze woorden opmerken dat ze wel eens beledigend voor de apen zouden kunnen zijn.

Uit dit uitgangspunt vloeit voor Donner voort, dat grondrechten, althans in nationale grondwetten, vooral geformuleerd moeten worden als rechten om gevrijwaard te blijven van bepaalde overheidsinterventies. Alleen op die wijze kunnen grondrechten een specifieke meerwaarde krijgen bowen de geldende mensenrechten-verdragen. "Men zou in eerbied voor de ernst en het gewicht van de internationale regelingen tekortschieten en terugvallen op ouderwetse dualistische constructies, wanneer men het werkelijk nodig vond om alles wat in die internationale regelingen staat, in de nationale constitutie nog eens te herhalen" schrijft hij. "Dat moet alleen gebeuren op die punten, waar het mogelijk is om aan die internationale normen in national verband iets toe te voegen of te verbeteren". ${ }^{54}$ Wat dit aangaat, verschilt het standpunt van Donner principieel van dat van Van der Hoeven en van de meeste intervenienten ter vergadering, die de grondrechten in de Grondwet bij voorkeur willen formuleren als universele mensenrechten.

Donners uitgangspunt brengt hem tot een opvatting - en dat erkent hij ook zelf - waarin eigenlijk geen ruimte is voor een horizontale werking van de in de Grondwet opgenomen grondrechten. Want dit zijn rechten tegenover het staatsgezag. Een heel beperkte opvatting dus, zou men op het eerste gezicht denken. Maar het is wel een opvatting, die de mogelijkheid biedt om in de Grondwet de burger op een aantal specifieke punten een sterke positie ten opzichte van de overheid te geven. Dat blijkt dan ook bij zijn behandeling van het recht op vrije meningsuiting en van het recht op informatie. Wat het recht op informatie betreft, voelt Donner er niets 
voor om een soort "recht van nieuwsgaring" in de Grondwet op te nemen. Vrij overtuigend weet hij te verwoorden, hoe daarmee in de grondrechtensfeer een wig zou worden gedreven tussen de pers en het publiek, en welke afbakeningsproblemen er dan zouden ontstaan. Men moet de zaken van een andere kant aanvatten, meent Donner. "Het punt waar het op aan komt, is dat de overheid zelf niet zo geheimzinnig moet doen en, niet zozeer aan de journalist, want die is maar tussenpersoon, maar aan het publiek in het algemeen de voorlichting en informatie moet verschaffen, die nodig zijn om de openbare zaak te kunnen volgen en begrijpen en aan haar behandeling op passende wijze te kunnen deelnemen. Wil men meer openbaarheid, dan moet men niet aan de pers een soort 'snuffelrecht' geven, maar de verplichting der overheid tot opening van zaken opnemen of versterken". 55

Donner gaat in zijn preadvies niet zover, dat hij voorstelt om in de Grondwet voor de overheid een algemene plicht tot informatieverstrekking op te nemen. Maar in de vergadering zelf laat hij zich in zijn weerwoord toch kennen als een voorzichtige voorstander van een dergelijke bepaling, die dan niet bij de grondrechten maar bij de bepalingen over de inrichting van de staat en van het bestuur zou moeten worden opgenomen. ${ }^{56}$

\section{Van der Hoeven}

Het preadvies van Van der Hoeven klinkt in aanvang veel positiever dan dat van Donner. Zijn vertrekpunt is een beschouwingswijze, waarin grondrechten gezien worden als pre-constitutionele normen, die grondwet en wet wel kunnen - en behoren te - erkennen, doch die voor hun bestaan niet van de (grond)wettelijke erkenning afhankelijk zijn. ${ }^{57}$ Men plaatst volgens Van der Hoeven een grondrecht als het recht van vrije meningsuiting dan ook in een te eng kader, als men er alleen maar een vrijwaringsrecht tegenover de overheid in ziet. Aanspraak op garantie tegen inbreuk door derden is in beginsel geen andere dan die op garantie tegen inbreuk door de overheid. ${ }^{58} \mathrm{Na}$ aldus zelf het recht van vrije meningsuiting in een ruimer kader te hebben geplaatst, voelt Van der Hoeven zich genoodzaakt om op zoek te gaan naar de kern van dit recht.

56 Handelingen NJV 1969, II, pag. 32.

57 Preadvies Van der Hoeven, pag. 60.

58 Id. pag. 67. 
Hij komt dan tot een onderscheid dat sterk doet denken aan de beeldspraak in een opstel uit 1960 van Dresen. ${ }^{59}$ Dresen, een jezuïtenpater en evenals Van der Hoeven een leerling van Van den Bergh, schetst daarin het recht op vrije meningsuiting als een drieluik; het middenpaneel bevat het recht om gedachten en gevoelens te openbaren; het linker zijpaneel de mogelijkheid om die gedachten en gevoelens te vormen door de garantie van vrije nieuwsgaring en van toegang tot de nieuwsbronnen (freedom of information); en het rechter zijpaneel het recht om de geopenbaarde gedachten en gevoelens te verspreiden. Wat Dresen het middenpaneel noemt, heet bij Van der Hoeven het "kernrecht". Hij omschrijft dit recht als "de vrijheid van de mens om wat in hem leeft aan denkbeelden en gevoelens naar verkiezing en op eigen verantwoordelijkheid te vormen en daaraan naar eigen inzicht al dan niet uiting te geven". ${ }^{60}$ Om deze vrijheid te kunnen genieten is communicatie met anderen noodzakelijk. Er moet dus ook een zekere communicatievrijheid bestaan, Van der Hoeven stelt voor om die vast te leggen in een grondwetsbepaling, die als volgt zou kunnen luiden: "Ieder is, binnen de grenzen der wet, vrij zich inlichtingen te verschaffen, deze te ontvangen of door te geven, mits daardoor geen inbreuk wordt gemaakt op het recht van anderen tot eerbiediging van hun persoonlijk leven". ${ }^{61}$ Deze vrijheid, die volgens Van der Hoeven ook een zekere plicht tot informatieverstrekking impliceert, is in zijn opvatting "dienstbaar" aan het kernrecht. Bij botsing met andere kernrechten, zoals bijwoorbeeld het recht op privacy, zou ze moeten wijken.

Het kernrecht van vrije meningsuiting neemt, althans in een democratische samenleving, een geprivilegeerde positie in tegenover het gemeenschapsbelang. Geldt dat ook voor het recht om zich inlichtingen te verschaffen? Niet zonder meer, vindt Van der Hoeven, maar: "Hoofdbeginsel dient te zijn, dat uit hoofde van het gemeenschapsbelang alleen dan enig gegeven mag worden teruggehouden, wanneer het gemeenschapsbelang, zoals dit in een democratische samenleving wordt benaderd, dit bepaald vordert." 62 Even eerder heeft Van der Hoeven uiteengezet wat hij onder het gemeenschapsbelang verstaat. Volgens hem kan dit in concreto nooit iets anders zijn dan datgene wat volgens een bepaald oordeel door het belang van de gemeenschap wordt gevorderd. Wiens oordeel? Ook dat is voor Van der Hoeven een duidelijke zaak. Wanneer het er om gaat een aangeboden aan Prof. mr. dr. G. wan den Bergh, Alphen a/d Rijn 1960, pag. 32-58. Preadvies Van de Hoeven, pag. 74.

61 Id. pag. 99.

62 Id. pag. 92. 
bepaald kriterium ter bescherming van het gemeenschapsbelang in een wettelijke regeling neer te leggen, dan is het oordeel van de betrokken wetgever bepalend. En wanneer aan een bestuursorgaan een marge van vrijheid van oordeel is gelaten, dan wordt door de dragers van het betrokken ambt binnen deze marge beslist wat het belang van de gemeenschap vordert.

Het klinkt allemaal heel mooi en democratisch. Grondrechten zijn geen rechten die men alleen maar tegenover de overheid kan doen gelden, maar (pre-constitutionele) mensenrechten, rechten met een universele strekking. En democratisch gekozen of dito benoemde overheidsorganen mogen in zaken die tot hun competentie behoren, uitmaken wat het gemeenschapsbelang vordert. Maar wat blijft er dan over van een recht op informatie? Van der Hoeven verklaart, dat hij voorstander is van het principe van openbaarheid van bestuur. Hij vindt zelfs, dat met subsidie werkzame personen of instellingen, en personen of instellingen werkzaam in publiek kader, voorzover die werkzaamheid strekt, an eenzelfde informatieplicht onderworpen dienen te zijn als de overheid. ${ }^{63}$ Maar, meent Van der Hoeven, "Dat de openheid, door de overheid te betrachten, in een algemene wettelijke regeling zou kunnen worden neergelegd, lijkt niet mogelijk. Men zal er veeleer van moeten uitgaan, dat aan het openbaarheidsbeginsel in de toekomstige bestuurlijke wetgeving recht zal moeten wedervaren, op ieder speciaal terrein naar de daar bestaande omstandigheden en mogelijkheden". 64

Dus verder geen grondwetsbepaling over openbaarheid van bestuur? $\mathrm{Nu}$ komen we op een punt waar Van der Hoeven in zijn preadvies toch wel een beetje een vreemde draai makt. Want zonder echt een aanloop te nemen, stelt hij dan plotseling de volgende grondwetsbepaling voor: "De wet stelt regels omtrent de openbaarheid van overheidsdocumenten alsmede van door de wet daarmee op één lijn gestelide documenten en omtrent de beperkingen waaraan deze openbaarheid in het algemeen belang kan worden onderworpen. "65 Waarom nu dit voorstel? Komt Van der Hoeven hier terug van zijn zojuist ingenomen stelling, dat een algemene wettelijke regeling voor openbaarheid van bestuur niet mogelijk is? Aan het slot van zijn preadvies komt de aap (met scheermes) uit de mouw.

Zoals we hebben gezien, heeft Van der Hoeven voorgesteld om in de nieuwe grondwet het recht op te nemen, om "zich inlichtingen te verschaf-

65 Id. pag. 105. 
fen". In de tijd waarin het preadvies geschreven is, staat echter ook een andere constitutionele vraag volop in de belangstelling: Moet de rechter de mogelijkheid krijgen om wetten te toetsen aan de Grondwet, althans aan de (constitutionele) grondrechten? Zonder zich daarvan voorstander te tonen, gaan zowel Donner als Van der Hoeven er in hun preadvies vanuit, dat zo'n toetsingsrecht er zal komen. Dit zou dan betekenen dat de rechter, bij verzoeken om informatie, wetten kan gaan toetsen aan het grondrecht om zich inlichtingen te verschaffen. De toegankelijkheid van het bestuur en de openbaarheid van documenten zijn immers, zoals Van der Hoeven zelf ook meent, een "sequeel" van dit recht. ${ }^{66}$. Maar van rechterlijke bemoeienis met de taak van de wetgever wil hij, zeker in dit geval, niets weten. "Het is immers heel wat anders om te beoordelen of in een bepaald geval de wetgever een terrein heeft betreden, waarvan hij verre had dienen te blijven, dan om een oordeel te vellen over de vraag, of de wetgever een grondrecht op de juiste wijze heeft gerealiseerd of gegarandeerd". Dat laatste vertrouwt Van der Hoeven de rechter niet toe. Vandaar zijn voorstel om in de nieuwe grondwet te bepalen, dat de wet regels stelt omtrent de openbaarheid van overheidsdocumenten. Dan kan er geen misverstand over bestaan, dat de rechter op dit punt geen toetsingsrecht heeft. ${ }^{67}$

De afloop van de discussie

In de NJV-vergadering van 27 juni 1969 blijft de vraag, of de Grondwet de wetgever moet opdragen bepaalde waarborgen voor de vrijheid van meningsuiting te scheppen, zoals het "recht om inlichtingen te garen, te ontvangen", onbeslist. Vervolgens wordt, wat de openbaarheid van bestuur betreft, gestemd over twee vraagpunten:

a. Dient de Grondwet bepalingen te bevatten omtrent de openbaarheid van overheidsdocumenten?

b. Dient de Grondwet bepalingen te bevatten omtrent de plicht tot het verschaffen van informatie door de overheid in het algemeen? ${ }^{68}$

Id. pag. 104. Zoals we cerder in dit hoofdstuk hebben gezien, heeft P.J. Boukema al in 1966 in zijn dissertatie de gedachte bepleit; dat het grondrecht om zich inlichtingen te verschaffen, de overheid een zekere plicht oplegt om inlichtingen te verstrekken. Dit vloeide volgens Boukema voort uit artikel 10 EVRM. In datzelfde jaar heeft echter de Hoge Raad die gedachte afgewezen in zijn Televizier-arrest (NJ $1966,115)$.

67 Of toch wel? Voor alle zekerheid stelt Van der Hoeven op pag. 121 van zijn preadvies voor, om de beoogde bepaling, dat de wet regels stelt omtrent de openbaarheid van overheidsdocumenten, uitdrukkelijk van het toetsingsrecht uit te zonderen.

Handelingen NJV 1969, II, pag. 41-42. 
De eerste vraag wordt door de meerderheid bevestigend beantwoord, en de tweede vraag ontkennend. Hoewel de discussie in de vergadering een grote verdeeldheid toont tussen conservatieven die geen enkele verandering nodig vinden, en hooggestemde voorvechters van mensenrechtenformuleringen, blijkt men elkaar toch te kunnen vinden in een standpunt van constitutionele vrijblijvendheid. Idealen zijn mooi, maar het moeten wel idealen blijven, schijnt men in beide kringen te denken. Het voorstel om in de Grondwet een overheidsplicht, in algemene zin, tot informatieverschaffing in te voeren, is daarmee van de tafel geveegd.

\section{Gevolgen voor de Grondwet}

Uit het eindrapport van de commissie Cals/Donner kan men opmaken, dat in die commissie ook stevig over dit onderwerp is gediscussieerd. ${ }^{69}$ Het eindrapport stelt voor om een nieuw artikel 71 in de Grondwet op te nemen, met als tekst: "De overheid betracht bij de uitvoering van haar taak openbaarheid volgens regels bij de wet te stellen." Deze tekst vinden we nu in artikel 110 van de Grondwet. Behalve een onduidelijk recht om "inlichtingen te garen, te ontvangen", wilde de commissie in de Grondwet geen norm voor openbaarheid opnemen. Een minderheid van vijf commissie-leden, waaronder Donner, wilde dat wel. Hun voorstel luidde: "De overheid betracht bij de uitvoering van haar taak zoveel mogelijk openbaarheid. De wet regelt de wijze waarop deze bij de uitoefening van overheidsbevoegdheden wordt in acht genomen." In de toelichting bij het (meerderheids-) voorstel van de commissie wordt nog even de relatie ter sprake gebracht tussen het voorgestelde artikel 71 en het eerder door de commissie voorgestelde artikel 8 . De tekst van dat laatste artikel luidt: "Niemand heeft voorafgaand verlof nodig om door geschrift gedachten of gevoelens te openbaren, of om inlichtingen te garen, te ontvangen en door te geven, onverminderd ieders verantwoordelijkheid volgens de wet. Bij of krachtens de wet kan het recht om inlichtingen te garen worden beperkt" ${ }^{70}$ Nogal hypocriet merkt de commissie over deze relatie op: "een bepaling als artikel $8 \mathrm{krijgt}$ stellig een nog belangrijker inhoud, wanneer de Grondwet elders de plicht der overheid om openbaarheid te betrachten vastlegt". ${ }^{71}$ Dat laatste is nu precies wat de commissie niet heeft willen voorstellen.

Eindrapport van de Staatscommissie van Advies inzake de Grondwet en de Kieswet, Den Haag 1971, pag. 177-180.

70 Tweede Rapport van de Staatscommissie wan Advies inzake de Grondwet en de Kieswet, Den Haag 1969, pag. 69.

71 Eindrapport pag. 180. 
In de voorstellen tot wijziging van de Grondwet, die de regering in 1976 naar de Tweede Kamer stuurt, komt het recht "om inlichtingen te garen, te ontvangen" niet meer voor. Bij de behandeling van het voorstel voor artikel 110 van de Grondwet vertelt de regering nog eens expliciet, waarom dat recht uit de voorstellen is geschrapt. De regering meent, "dat een zodanige grondwetsbepaling - zij het onbedoeld - de onjuiste indruk zou wekken, dat rechtstreeks uit het recht inlichtingen van de overheid te vergaren en te ontvangen, de plicht van de overheid tot informatieverschaffing zou voortvloeien". "2 Een dergelijke plicht wil de regering niet in de Grondwet hebben. De Kamer accepteert deze uitleg. Zo'n plicht mag men dus ook niet in artikel 110 lezen. De overheid betracht alleen openbaarheid volgens bij wet te stellen regels. Zo wordt in 1983, met de invoering van artikel 110 , de openbaarheid van bestuur al "gedeconstitutionaliseerd' voordat ze ooit in de Grondwet heeft gestaan.

\section{Het preadvies van Steenbeek}

Er mag dan geen enkele juridische wetenschapper zitting hebben in de Commissie Biesheuvel, toch is er omstreeks 1969 in rechtsgeleerde kringen een zeker zelfbewustzijn ten aanzien van het vraagstuk van de openbaarheid van bestuur gegroeid. De Nederlandse Juristenvereniging vindt dan, dat de rechtswetenschap haar partijtje in de politiek-juridische discussie moet meeblazen. We zagen dit gebeuren op de jaarvergadering van de NJV in 1969, waar de constitutionele regeling van de openbaarheid aan de orde werd gesteld, als deelonderwerp bij de regeling van de vrijheid van meningsuiting. In 1970 staat voor de jaarvergadering de wettelijke regeling van de openbaarheid van bestuur, als zelfstandig onderwerp, op de agenda. Preadviseur is prof. mr. J.G. Steenbeek, wiens bijdrage over openbaarheid van adviezen en rapporten van ambtenaren, in de bundel van De Goede en Van Maarseveen, hierboven al aan de orde is geweest. De vraagstelling van het preadvies luidt: Welke beginselen betreffende de openbaarheid van vergadering en toegankelijkheid van stukken behoren ten grondslag te liggen aan de wettelijke regelingen op het stuk van de openbare diensten $?^{73}$ Van het rapport van de Commissie Biesheuvel heeft dan nog niemand kennis kunnen nemen.

72 TK 1979-1980, 14348, nr. 10, Nota n.a.v. het eindverslag, pag. 2. (Afgedrukt in Naar een nieuwe grondwet, deel $28(=\mathrm{Vb})$, pag. 206.) Minder expliciet is A.A.L. Beers, in P.W.C. Akkernans, A.K. Koekkoek, de Grondwet, Zwolle 1992, p. 970. Handelingen NJV 1970, deel 1, eerste stuk, pag. $37-78$ (preadvies Steenbeek). 
Steenbeek geniet als voormalig beleidsambtenaar bij Binnenlandse Zaken en bij Waterstaat groot vertrouwen in ambtelijke kringen, en ligt ook bij wetenschappers goed. ${ }^{74}$ Gezien de reacties die op zijn preadvies zullen volgen, slaagt hij er ook uitstekend in, om naar beide kanten dat vertrouwen te behouden. Naar de ambtelijke wereld toe doet hij dat met zinnen als "Het is 'in' vóór openbaarheid of toegankelijkheid te pleiten. Zonder ernstig probleem blijven deze en dergelijke geluiden niet [..] Deze zaak ligt het bestuursapparaat - het meest hierbij betrokken - kennelijk en terecht hoog" (pag. 65) en "Als wij het principe van openbaarheid van stukken willen doorvoeren zullen wij dit behoedzaam moeten doen ten einde te vermijden dat de overheidsdienst ontwricht wordt en teneinde aan die dienst de gelegenheid te bieden zich op het nieuwe principe in te spelen" (pag. 72). Maar intussen pleit Steenbeek wel stevig voor verdergaande openbaarheid. De lijn die hij eerder uitzette in zijn bijdrage in de bundel van De Goede en Van Maarseveen, gaat een nog groter gebied omspannen. Naast de openbaarheid van ambtelijke adviezen betrekt hij nu ook de openbaarheid van adviezen van commissies en van vergaderingen van bestuurscolleges in zijn beschouwingen. Uitgangspunt is voor Steenbeek de verbetering van de democratie. Hij probeert geen definitie te geven van dit begrip, maar constateert eenvoudigweg dat wij in Nederland een vorm van democratie nastreven, waarin iedere burger gelijkelijk de mogelijkheid wordt geboden zich te doen gelden als staatsburger. De representatieve democratie is daarbij aanvaard als een redelijk stelsel; een directe democratie kan voor grotere eenheden niet een redelijke oplossing bieden. De afstand tussen kiezer en gekozene die een representatief stelsel nu eenmaal medebrengt kan wellicht worden bestreden door een passend stelsel van openbaarheid. ${ }^{75}$ En dat probeert Steenbeek te vinden.

\section{Openbaarheid van vergaderingen van bestuurscolleges}

Steenbeek brengt allereerst de wenselijkheid van openbaarheid van vergaderingen van bestuurscolleges ter sprake. Dat de vergaderingen van gekozen vertegenwoordigers openbaar zijn, vindt iedereen vanzelfsprekend. Maar als het om bestuurscolleges gaat; denkt men vaak anders. Is het nog steeds aanvaardbaar, dat de beraadslagingen van zulke colleges plaatsvinden achter gesloten deuren, vraagt Steenbeek zich af. Van oudsher was het

74 In het Nederlands Juristenblad van 6 juni 1970, waarin J.M. Kan het preadvies bespreekt, wordt Steenbeek door deze geprezen als "goed kenner van ons staats- en administratief recht, tevens weleer een sieraad van het rijksambtenarenapparaat en dus mede op de hoogte van de eisen van de publieke dienst" (pag. 661).

Preadvies Steenbeek, pag. 51 . 
afleggen van verantwoording aan het volkswertegenwoordigend college een aanvaardbaar equivalent voor openbaarheid van vergaderingen van bestuurscolleges. Nu we echter een vérgaande machtsverschuiving van algemene vertegenwoordigende colleges naar bestuurscolleges zien optreden, komt deze zaak anders te liggen. Steenbeek vindt, dat de openbaarheid van vergaderingen als het ware die reële machtsverschuiving moet volgen. Maar niet zonder meer, want ieder die wel eens deel heeft uitgemaakt van een bestuurscollege, weet ook dat de beslotenheid der vergadering veel voordelen biedt uit een oogpunt van openhartigheid, bereidheid tot compromis, en dergelijke. Vertrouwelijk beraad moet daarom mogelijk blijven, al zal de verantwoording daarvan wel zo moeten gebeuren, dat de kiezers of degenen die verantwoording kunnen vragen, zich een voldoende beeld kunnen vormen van de verrichtingen van hun vertrouwenslieden in de bestuurscolleges. Niettemin zouden bestuurscolleges over bepaalde kwesties gewoon in het openbaar moeten vergaderen, zegt Steenbeek. Hij denkt daarbij met name aan situaties waarin een bestuurscollege gebruikmaakt van een overgedragen bevoegdheid tot regelgeving. ${ }^{76}$ Deze gedachte sluit aan bij hetgeen Steenbeek juist daarvoor heeft opmerkt over de machtsverschuiving van algemene vertegenwoordigende colleges naar bestuurscolleges. Bij de stemming in de NJV-vergadering toont wonderwel een grote meerderheid zich voorstander van dit idee.

\section{Openbaarheid van vergaderingen van adviescommissies}

Vervolgens komt Steenbeek te spreken over de openbaarheid van vergaderingen van adviescommissies. Hij makkt daarbij onderscheid tussen commissies die voorbereidend werk doen voor vertegenwoordigende organen (zoals Tweede Kamer-commissies, raadscommissies e.d.) en overige adviescommissies. De commissies die voorbereidend werk doen voor vertegenwoordigende organen zouden in principe in het openbaar moeten vergaderen. Ook van commissies die bijvoorbeeld taken van een gemeenteraad overnemen (op grond van artikel 82 e.v. Gemeentewet), ligt het voor de hand, dat zij in principe in het openbaar vergaderen. Voor de overige adviescommissies is dat veel minder het geval, al heeft ook daar het denkbeeld van openbare beraadslaging aantrekkelijke kanten als het gaat om de voorbereiding van zeer belangrijke vragen van beleid. Openbaarheid van de vergadering is dan niet per se nodig, als maar wel de adviezen openbaar worden gemaakt. ${ }^{\text {. }}$

77 Id. pag. 62 . 


\section{De toegankelijkheid van documenten}

Tot slot stelt Steenbeek de toegankelijkheid van documenten aan de orde. De openbaarheid van stukken nadat de beslissing is genomen, is belangrijk, meent hij, ook al zal die openbaarheid nooit een motivering kunnen vervangen. De motiveringsplicht blijft bij het nemen van beslissingen dus ten volle bestaan. Maar, stelt Steenbeek, voor een belanghebbende is de toegankelijkheid van de stukken voordat de beslissing valt, nog belangrijker. Behoudens in specifieke gevallen is die toegankelijk echter niet erkend. Bovendien, wie bepaalt welke burger belanghebbende is? Het oordeel van de burger daarover kan afwijken van het officiële oordeel. "Deze moeilijkheid ontloopt men als de toegankelijkheid van de stukken niet slechts voor belanghebbenden bestaat, maar voor iedereen die zich wenst te oriënteren" meent Steenbeek. Daarom moet er algemene openbaarheid van stukken zijn, ook in de fase voordat de beslissing valt. "Een openbaarheid die dan aan iedere burger, dus ook de pers, de mogelijkheid biedt het overheidsbedrijf op de voet te volgen en daarin het zijne bij te dragen. Uit een oogpunt van participatie zijn we dan waar wij wezen moeten" ${ }^{78}$ Elders in zijn preadvies maakt Steenbeek duidelijk waar die openbaarheid haar begrenzing moet vinden: in de bescherming van, onder meer, de privacy van de burger, economische belangen, en de veiligheid van de staat. ${ }^{79}$

Welke stukken moeten nu openbaar zijn? In Steenbeeks opvatting zijn dat allereerst de adviezen van adviescommissies. Het vaak genoemde bezwaar dat publikatie van zulke adviezen verkeerde verwachtingen kan wekken en daardoor de bewegingsvrijheid van de beslissende instanties kunnen belemmeren, acht hij, in navolging van Kan, niet erg zwaarwegend. ${ }^{80}$ Ook het bezwaar dat openbaarheid kan leiden tot vermindering van de openhartigheid van de adviezen, maakt geen grote indruk op Steenbeek. Anders dan Kan, vindt hij dat ook de adviezen van de Raad van State openbaar zouden moeten zijn, zeker als het gaat om adviezen over wetsontwerpen en ontwerpen voor algemene maatregelen van bestuur. $\mathrm{Nu}$ adviezen van de Raad ook al moeten worden gepubliceerd als er een contrair besluit op volgt, kan de theorie over de onschendbare Koning en

79 Id. pag. 78.

80 Zie de eerder besproken bijdrage van J.M. Kan, over de openbaarheid van de rapporten van de vaste colleges wan advies en bijstand aan de regering, in de bundel van De Goede en Van Maarseveen, a.w. pag. 92-108. 
de verantwoordelijke minister geen argument meer vormen tegen openbaarheid in andere gevallen. ${ }^{81}$

Dan komt Steenbeek uiteindelijk terecht bij het onderwerp waar hij in de bundel van De Goede en Van Maarseveen een apart opstel over schreef: de openbaarheid van ambtelijke stukken. Het blijkt dat hij van de conclusies die hij in dat opstel formuleerde, niets heeft prijsgegeven. Ook nu weer maakt hij van het begrip "stukken" een belangrijk punt. In navolging van het Zweedse openbaarheidssysteem zoekt hij een criterium in het "finale" van een stuk. "Finaal dan in die zin begrepen dat het stuk een eindfase van een deel van het bestuursproces voorstelt, bijvoorbeeld een ingekomen brief, een afgesloten rapport, een deskundigenbericht, een specialistenadvies, een op papier weergegeven telefonische feitelijke mededeling, een geformuleerde conclusie van bepaald ambtelijk overleg, kortom stukken die een zelfstandige rol in het besluitvormingsproces spelen. Concepten, voorlopige notities, kladberekeningen, zakelijk niet relevante uitlatingen enz. spelen zulk een rol niet en kunnen dan daarom buiten beschouwing blijven" ${ }^{82}$

\section{De politiserende ambtenaar}

Zoals hierboven al werd opgemerkt, vindt Steenbeek dat de openbaarheid van door hem bedoelde stukken behoedzaam moet worden ingevoerd, om niet de overheidsdienst te ontwrichten, en de dienst de gelegenheid te bieden op het nieuwe principe in te spelen. Even verderop blijkt dat hij daarmee bedoelt, dat het hele proces van besluitvorming in de overheidsdienst systematisch moet worden ontwikkeld, met de beginselen van behoorlijk bestuur als invalshoek. "Als komt vast te staan dat in beginsel geen beslissingen kunnen worden genomen dan op gegevens die in principe openbaar zijn, legt men van de weg tot openbaarheid een geweldig gedeelte af", zegt Steenbeek. ${ }^{83}$ Maar zal de openbaarheid van de overheidsdienst niet tot volstrekte verlamming en frustratie leiden? Zal niet elk gezond initiatief gesmoord worden? Zal de openbaarheidseis niet ook een remmende invloed hebben op de mogelijkheid kwaliteitskrachten voor de overheidsdienst te recruteren? Steenbeek stelt deze vragen zelf, en beantwoordt ze ook. Hij meent dat op dit gebied veel nodeloze zorg bestaat. Maar één consequentie kan met zekerheid worden aangegeven, nl. dat de ambtenaren nog altijd tegenstander van de openbaarheid van de adviezen van de Raad van State, Preadwies Steenbeek, pag. 72 . Id. pag. 73. 
zelf niet meer in de gebruikelijke, aan de geheimhouding verbonden anonimiteit zullen kunnen blijven. Zij zullen onvermijdelijk naar buiten treden als lieden die een eigen oordeel hebben dat kan afwijken van dat van hun verantwoordelijke bestuurlijke chefs. De vrees dat dit zal leiden tot het verschijnsel van de politiserende ambtenaar, die de loyaliteit tegenover de bestuurlijke niet al te hoog zal schatten, en zich via de publieke opinie zonodig tegen die chef zal keren, lijkt Steenbeek een boemangedachte. Dat verschijnsel zal zeker niet algemeen worden. Er bestaan ook disciplinaire mogelijkheden om daartegen in voorkomende gevallen op te treden. De openbaarheid zal er niet toe mogen leiden dat de overheidsdienst als zodanig aan samenhang en intern vertrouwen verliest. ${ }^{84}$

\section{De stemming in de NJV-vergadering}

In de eerste zitting van NJV-vergadering van 12 juni 1970 , die aan het preadvies van Steenbeek is gewijd, wordt diens voorstel dat bestuurscolleges bij besluiten van wetgevende aard in de openbaarheid moeten vergaderen, met een grote meerderheid van stemmen aangenomen. ${ }^{85}$

Het is jammer, dat de formulering van de overige vraagpunten, waarover gestemd moet worden, niet goed aansluit bij de inhoud van het preadvies. Bij vraagpunt 2 wordt gevraagd, of alle stukken die voor het besluit van belang zijn, openbaar moeten worden gemaakt. Daar wordt door een grote meerderheid, geheel in lijn van wat Steenbeek betoogd heeft, uiteraard ontkennend op geantwoord. Vervolgens wordt de vraag aan de orde gesteld, of alhans die stukken openbaar moeten zijn, waarvan het voorafgaan aan het besluit is voorgeschreven. Daar wordt door de vergadering wel bevestigend op geantwoord. Maar de belangrijke stelling van Steenbeek, dat in principe alle stukken die in het besluitvormingsproces een zelfstandige rol spelen, openbaar moeten worden gemaakt (voordat een overheidsbesluit wordt genomen), keert in geen enkel vraagpunt terug. Daarover zullen we het standpunt van de vergadering dan ook niet te weten komen.

85 Handelingen NJV 1970, deel 2, pag. 26. 


\section{Het rapport van de Commissie Biesheuvel}

Op 9 juni 1970 verschijnt het rapport Openbaarheid Openheid, van de Commissie Biesheuvel. Het is een rapport van ruim 200 bladzijden, waarin de politieke en juridische aspekten van openbaarheid en voorlichting op het niveau van de centrale overheid tamelijk volledig worden belicht. Het rapport bevat ook een ontwerp voor een Wet openbaarheid van bestuur, met een ontwerp-memorie van toelichting. De Commissie Biesheuvel heeft, naar eigen zeggen, het grondprobleem van haar studie in de eerste plaats willen zien als een probleem van politieke democratisering. Gelet op haar opdracht lag deze zienswijze ook voor de hand. ${ }^{86}$ Van daaruit heeft de commissie haar aandacht vooral gericht op de vraag: in welke mate en op welke wijze kan en moet informatie, waarover de regering beschikt, aan de burgers ter beschikking komen? ${ }^{87}$ Ik zal mij hieronder beperken tot een bespreking van wat de commissie op deze vraag antwoordt. De uitwijdingen in het rapport over zaken als voorlichtingsmanagement, communicatie- en kopieertechnieken, en de égards waarmee buitenlandse journalisten naar de mening van de commissie moeten worden behandeld, wil ik buiten beschouwing laten.

\section{Politieke democratisering}

De Commissie Biesheuvel signaleert in haar rapport, dat de Nederlandse overheid beschikt over bevoegdheden en machtsmiddelen, waarvan een vorige eeuw slechts kon dromen. Maar niet alleen de macht van de overheid is toegenomen, constateert de commissie. Ook die van de burgers ten opzichte van de overheid is gegroeid. De burgers beschikken veelal over een inkomen en een sociale zekerheid die hen minder manipuleerbaar maken. Hun opleidingsniveau stijgt. $\mathrm{Zij}$ hebben vele rechten, en bedienen zich van organisaties en communicatiesystemen als machtsmiddelen. Tenslotte wordt hun macht versterkt door tal van nieuwe denkbeelden, die gericht zijn tegen regenten-mentaliteit en paternalisme en gericht op inspraak en medezeggenschap. ${ }^{88}$

Wat kan politieke democratisering in onze tijd betekenen, vraagt de commissie zich af. Zij vindt het niet moeilijk op dit terrein voorbeelden te geven van rechten die de moderne Nederlander ontbreken, rechten die hij zou kùnnen hebben. "De Nederlandse burger heeft niet het recht om ge-

87 Rapport Openbaarheid Openheid, pag. 2.

88 Id. pag. 3 en 4. 
raadpleegd te worden bij het ontwerpen van een beleid waarmee hij direct te maken heeft. Hij mag zelfs niet weten door wie en in welke zin de regering over onderdelen van het beleid is geadviseerd. Hij heeft niet het recht om motivering van de afzonderlijke maatregelen te verlangen, hij heeft geen recht op voorlichting over allerhande regelingen die voor hem van belang kunnen zijn. Hij heeft niet de mogelijkheid om gebruik te maken van informaties, waarover wellicht het rijk op grond van door de belastinggelden mogelijk gemaakte aktiviteiten beschikt" ${ }^{89}$ Het spreekt voor zich, dat de commissie in de rest van haar rapport probeert die rechten en mogelijkheden, die de burger zou kùnnen hebben, wat precieser te omschrijven, althans voor wat betreft de centrale overheid. Want tot deze overheid beperkt de commissie zich.

\section{Openbaarheid en ministeriële verantwoordelijkheid}

De commissie stelt allereerst de relatie tussen openbaarheid en ministeriële verantwoordelijkheid aan de orde. Is die verantwoordelijkheid tegenover de in het openbaar functionerende volksvertegenwoordiging toereikend om de openbaarheid van het bestuurlijk, het ambtelijk bedrijf in voldoende mate te garanderen? De Commissie Van Heuven Goedhart had die vraag in 1946 nog bevestigend beantwoord; overheidsvoorlichting zou slechts een aanvullend karakter mogen hebben. Maar voor de Commissie Biesheuvel is de vraag bijna een retorische. ${ }^{90}$ De verschuiving in de verhouding tussen regering en parlement die reeds vóor de oorlog zichtbaar werd, heeft zich na de bevrijding in versterkte mate voortgezet, constateert de commissie. De mogelijkheden tot parlementaire controle op de executieve zijn geleidelijk verminderd door delegatie van bevoegdheden aan de Kroon. Van groot belang is ook het verschijnsel van de toenemende "internationalisering' van verschillende beleidssectoren, die zich daardoor meer of minder aan de greep van het nationale parlement zijn gaan onttrekken. Daarnaast en daarmee samenhangend zijn macht, invloed en zelfstandigheid van het ambtenarenapparaat sterk toegenomen.

Dit aspekt wordt door de commissie vervolgens nog wat nader belicht. Zij wijst erop, dat bewindslieden in sterke mate zijn aangewezen op de informatie van hun ambtenaren, als ze die informatie al krijgen. "Men behoeft geen min of meer pejoratieve kwalificaties als "bureaucratie', 'geheimzinnige regent achter de schermen', 'vierde macht" e.d. in de mond te nemen, noch Kafka te hulp te roepen om duidelijk te maken dat

90 Id. pag. 16 e.v. 
deze ontwikkeling uit democratisch oogpunt haar kwalijke kanten heeft. Kabinetten en ministers komen en gaan, maar het ambtelijk bestuursapparaat blijft en consolideert zichzelf voortdurend. Het is qua ervaring en technische kennis van zaken veelal de meerdere van de ministeriële passanten en beinvloedt alleen al daardoor hun politieke beslissingen. Het is, alle staatsrechtelijke theorieën ten spijt, geworden tot een factor, die de politieke beleidsvorming medebepaalt. Des te onbevredigender is het ontbreken van een direkte publieke beoordelingsmogelijkheid, door openbaarheid gegarandeerd ". .91

De conclusie die de commissie uit dit alles trekt, ligt voor de hand: invoering van het openbaarheidsbeginsel in het bestuur is dringend nodig om de gebleken tekorten in de effectuering van de ministeriële verantwoordelijkheid te corrigeren. De minister zal door openbaarheid van bestuur veel meer over zijn eigen departement te weten komen, waardoor de ministeriële verantwoordelijkheid wordt versterkt. En voor de burger zal door openbaarheid van ambtelijke beleidsadviezen het proces van besluitvorming een stuk doorzichtiger kunnen worden.

Die openbaarheid mag echter niet afhankelijk worden gemaakt van ministeriële instemming. "Het is goed om dat hier te onderstrepen" zegt de commissie, "want een taai leven blijkt te zijn beschoren aan de mening, dat verschillen in opvatting tussen een minister en zijn ambtenaren, hoe louter zakelijk ook, tot elke prijs voor de buitenwereld verborgen moeten blijven, omdat onthulling ervan ernstige gevolgen zou kunnen hebben voor de ministeriële verantwoordelijkheid. Van alle ficties echter die ons staatsrecht kent, is die van het naar buiten volstrekt eensgezinde departementale apparaat dat nooit iets denkt of schrijft wat de minister inhoudelijk niet met zijn verantwoordelijkheid wil dekken, principieel en praktisch de minst houdbare" .92 Men ziet, de commissie heeft het in het vorige hoofdstuk besproken artikel Geheimhouding van de openbare zaak van De Swaan goed bestudeerd.

\section{Primeurrecht voor parlement}

Het standpunt dat openbaarheid van bestuur noodzakelijk is, leidt de commissie nog naar een andere conclusie: het parlement heeft, wat het ontvangen van informatie betreft, geen primeurrecht. "Consequentie van de aanvaarding van het openbaarheidsbeginsel voor het bestuur is, dat burgers op een gegeven moment eerder en beter dan de volksvertegen-

92 Id. pag. 23 . 
woordiging geïnformeerd kunnen zijn over wat zich in dat bestuur afspeelt", zegt de commissie, "Nogmaals: aan de taak van het parlement doet dat in geen enkel opzicht afbreuk. Integendeel, voor haar medewetgevende en toetsende arbeid is de volksvertegenwoordiging juist zeer gebaat bij voorafgaande openbaarmaking aan publiciteitsmedia en bevolking. Ze kan dan in het allervroegste stadium kennisnemen van de reacties der publieke opinie en deze in haar standpuntbepaling verdisconteren. Openbaarheid van bestuur zal haar ook beter in staat stellen haar controlerende taak uit te oefenen"..$^{93}$

$\mathrm{Na}$ een hoofdstuk met nog altijd behartenswaardige aanbevelingen over openbaarheid bij kabinetsformaties, worden vervolgens drie hoofdstukken gewijd aan resp. het recht op informatie, de openbaarheid van adviezen van colleges van advies en bijstand, en de openbaarheid bij beleidsvoorbereiding. Die zal ik nader bespreken.

\section{Het recht op informatie}

In hoofdstuk VI, Het recht op informatie, gaat de Commissie Biesheuvel in op het systeem van geheimhouding, dat in 1970 nog door de rijksdienst wordt gehanteerd. Als geheimhouding dan al gemotiveerd wordt, gebeurt dat meestal met termen als "het algemeen belang" of "het staatsbelang". De commissie vindt deze begrippen, vanwege hun onbepaaldheid, niet geschikt om als geheimhoudingsgronden dienst te doen in het door haar bepleite systeem van principiële openbaarheid. "In een democratisch bestuurssysteem, waarin de staat fungeert als behartiger van de gemeenschappelijke belangen van de burgers en als bemiddelaar indien deze belangen botsen, is in beginsel geen plaats voor een staatsbelang tegenover de belangen der burgers" ${ }^{\mathrm{m}}$, stelt de commissie. ${ }^{94}$ Geheimhouding kan alleen gerechtvaardigd zijn als de belangen die door openbaarheid worden geschaad meer specifiek worden aangeduid. De commissie noemt dan zelf een aantal geheimhoudingsgronden, die later in iets andere bewoordingen, of iets anders geordend, in de Wet openbaarheid van bestuur zullen terugkeren: Openbaarmaking kan volgens de commissie achterwege blijven voorzover zij:

* de eenheid van de Kroon naar buiten toe in gevaar zou kunnen brengen;

* de veiligheid van de staat zou kunnen schaden;

94 Id. pag. 61. 
de goede betrekkingen van Nederland met vreemde mogendheden zou kunnen schaden;

de economische of financiële belangen van de Staat in ernstige mate zou kunnen schaden;

bij de aangelegenheid betrokken personen of derden onevenredig in hun belangen zou kunnen bevoordelen of schaden;

terwijl bovendien gevraagde informatie kan worden geweigerd indien:

* het verzoek betrekking heeft op een aangelegenheid ten aanzien waarvan de voorbereiding van de besluitvorming nog niet is afgerond;

* het verzoek betrekking heeft op documenten waarvan de inhoud in al of niet gewijzigde vorm is opgenomen in documenten van latere datum. ${ }^{95}$

Ik heb deze geheimhoudingsgronden hier letterlijk herhaald omdat de Commissie Biesheuvel als eerste een poging doet om zulke gronden expliciet en uitputtend te formuleren. De op één na laatste geheimhoudingsgrond is natuurlijk wel erg opmerkelijk voor een commissie die inspraak hoog in haar vaandel heeft staan. $\mathrm{Zij}$ verduidelijkt even verderop haar standpunt als volgt:

"a. de overheid dient te worden verplicht, bestuursvoornemens, hetzij in afgeronde, hetzij in voorlopige vorm, openbaar te maken zodra met het oog op een goede en democratische bestuursvoering opinievorming daarover van belang is.

b. voor het overige kan informatie, die betrekking heeft op angelegenheden, ten aanzien waarvan de voorbereiding van de besluitvorming nog niet is afgerond, worden geweigerd".96

Hier ligt de basis van de dubbelzinnige constructie die we vandaag de dag nog altijd in de Wet openbaarheid van bestuur tegenkomen. Wat gebeurt er, als belangstellende burgers vóór de afronding van de besluitvorming informatie willen hebben, maar de betrokken overheid het niet nodig vindt die te verschaffen? Is de rechtsplicht voor de overheid om informatie te verschaffen zodra dit in het belang is van een goede en democratische bestuursvoering, alleen een instructienorm of ook een waarborgnorm? De commissie spreekt zich daar niet expliciet over uit. Maar rechtzoekende burgers die een beroep op deze thans in artikel 8 van de WOB is neerge- 
legde rechtsplicht deden, hebben daarmee bij de Afdeling Rechtspraak of de Afdeling Bestuursrechtspraak nog nooit succes gehad. ${ }^{97}$

\section{De openbaarheid van advisering door adviescolleges}

In hoofdstuk VII, De openbaarheid van adviezen, gaat de commissie allereerst uitvoerig in op de al dan niet gewenste openbaarheid van de adviezen van de Raad van State. In 1970 wordt kennisneming van de adviezen van dit college nog altijd niet aan de wetgever als geheel toegestaan; alleen de regering krijgt inzage. In het vorige hoofdstuk heb ik al geschreven, dat J.M. Kan ervoor pleitte dat zo te houden, maar dat J.G. Steenbeek in zijn preadvies voor de NJV zich voorstander van publicatie van de adviezen had getoond. De Commissie Biesheuvel stelt zich op hetzelfde standpunt als Steenbeek. "Het ligt voor de hand" zegt ze, "zeker indien wordt gelet op de samenstelling van de raad, dat openbaarmaking van de adviezen kan bijdragen tot verrijking van de openbare discussie over de onderwerpen die in het geding zijn". ${ }^{98}$ Daarmee gebruikt de commissie een argument voor openbaarheid, dat Kan juist tegen openbaarheid aanvoerde. $\mathrm{Ze}$ is niet onder de indruk van de gedachte dat leden van de Raad, in het vooruitzicht van publicatie van hun adviezen, zich mogelijk anders zullen opstellen dan wanneer zij erop kunnen rekenen dat hun adviezen geheim blijven. "Vergeleken met andere adviesinstanties verkeert de Raad van State wat dit betreft onmiskenbaar in een gunstige positie", merkt ze op, want "De leden hebben geen zitting als vertegenwoordigers van bepaalde politieke partijen of maatschappelijke organisaties. Zij worden niet gekozen, maar voor het leven benoemd. $\mathrm{Zij}$ kunnen zich derhalve in grote vrijheid opstellen" ${ }^{99}$

Maar heeft publicatie van de adviezen dan niet als bezwaar, dat de regering daarna niet meer in volle vrijheid haar standpunt kan bepalen? Ten aanzien van dit aspekt maakt de commissie een vergelijking met andere belangrijke adviesorganen (bijv. de SER), waarvan de rapporten in de regel wel worden gepubliceerd. Veelvuldig doen zich daarbij een eerlijke confrontaties van uiteenlopende standpunten voor. Maar kan men zeggen, dat de vrijheid van de regering daardoor te veel wordt belemmerd? Voor- en nadelen tegen elkaar afwegend vindt de commissie, dat publicatie van de adviezen verre valt te verkiezen boven geheimhouding.

Wat betreft de methode van publicatie van de adviezen van de Raad van State zijn verschillende mogelijkheden denkbaar. De meest doelmatige

99 Id. pag. 84 en 85. 
is volgens de Commissie Biesheuvel die, waarbij het advies over een wetsontwerp, met het gemotiveerde standpunt van de regering over het advies, tezamen met het wetsontwerp wordt gepubliceerd. Ten aanzien van algemene maatregelen van bestuur zou openbaarmaking van het advies plaats kunnen hebben tezamen met de afkondiging van de maatregel in het Staatsblad. 100

Deze beide voorstellen van de commissie zouden misschien niet zo opmerkelijk zijn, als zij even verderop niet een veel direktere publicatiemethode zou aanbevelen voor de adviezen van de overige colleges van advies en bijstand. Uiteraard vindt de commissie, dat de adviezen van deze colleges ook openbaar moeten zijn. Al was het alleen omdat het vooruitzicht, dat de adviezen niet worden gepubliceerd, de leden van de adviesorganen aan het twijfelen kan brengen over de zin van hun arbeid. ${ }^{101}$ Maar de openbaarmaking van die adviezen hoeft niet te wachten totdat de regering haar standpunt heeft bepaald. "Voor zover als bezwaar mocht gelden dat door vroegtijdige openbaarmaking van adviezen verwachtingen worden gewekt, die wellicht niet kunnen worden gehonoreerd, moet worden erkend, dat dit gevolg zich inderdaad kan voordoen" schrijft de commissie, "maar ook door het indienen van wetsontwerpen en beleidsnota's bij de Staten-Generaal worden verwachtingen gewekt. In deze gevallen wordt het genoemde bezwaar niet als reëel ervaren". ${ }^{102}$ Waarom echter de adviezen van de Raad van State niet onmiddellijk na ontvangst door de regering zouden hoeven te worden gepubliceerd, legt de commissie niet uit.

\section{Openbaarheid bij de beleidsvoorbereiding}

In hoofdstuk VIII, dat speciaal gewijd is aan openbaarheid bij beleidsvoorbereiding, komt het vraagstuk van de inspraak aan de orde. De overheidsdiensten staan sterk in hun bezwaren tegen inspraak, constateert de Commissie Biesheuvel, "zij kunnen staande houden dat hun werkwijze voldoet aan de wettelijke eisen, de wettelijke voorschriften inzake openbaarheid inbegrepen; zij kunnen bogen op hun technisch inzicht; zij kunnen wijzen op de langdurige en degelijke voorbereiding van het projekt; zij kunnen herinneren aan de hoge kosten die met de verwezenlijking zijn gemoeid; zij kunnen aantonen dat het zoeken van een alternatieve oplossing in dit stadium zal leiden tot verlies van tijd en geld. Maar", zegt de 
commissie, "ook de burger staat sterk. Hij kan zeggen, en met recht, dat de overheidsdiensten er zijn ten dienste van de burgers. En dat naar de mening en de wensen van de burger in het geheel niet is gevraagd. Hij zal wellicht zeggen dat hem van openbaarmaking niets was gebleken. Hij zal er mogelijk aan toevoegen, dat hij zeker een alternatieve oplosing had aangedragen als hij tijdig op effectieve wijze was geïnformeerd en geraadpleegd. En hij zal tenslotte naar voren brengen dat het verlies van tijd en geld bepaald niet op zijn rekening kan worden geschreven" ${ }^{103}$

Deze overwegingen tezamen brengen de commissie tot een inspraakbelijdenis. $\mathrm{Zij}$ vindt het van groot belang dat in beginsel ieder beleidsvoornemen dat de belangen van de burgers raakt in openbare discussie kan komen in een stadium dat nog zinvol over alternatieven kan worden gesproken. ${ }^{104}$ De commissie denkt daarbij in elk geval aan plannen op het gebied van de ruimtelijke ordening, maar bijvoorbeeld ook aan beleidsvoornemens ten aanzien van PTT-tarieven, studietoelagen, belastingregelingen, ziekenhuisbouw, onderwijsmaatregelen en kunstbeleid. Vervolgens doet zij een aantal concrete voorstellen tot verbetering van de openbare meningsvorming op de terreinen van wetgeving, ruimtelijke ordening, rijkswaterstaat en cultuurtechnische dienst.

De commissie erkent dat de verwezenlijking van haar voorstellen kan leiden tot tijdverlies, onrust en speculatie. Maar dat kan naar haar oordeel niet opwegen tegen de bezwaren die dikwijls aan de huidige procedures zijn verbonden. De overheidsinstellingen zijn er ten behoeve van de burgers. Indien hun belangen onderling tegenstrijdig zijn, dient de belangenafweging in het openbaar te gebeuren, en wel op een wijze die de burgers in staat stelt zelf de voorgenomen beslissingen op hun juistheid te beoordelen. Bovendien, zegt de commissie, treedt ook nu reeds herhaaldelijk tijdverlies op, namelijk wanneer plannen op onoverkomelijk verzet stuiten bij de burgers. ${ }^{105} \mathrm{Te}$ gemakkelijk, naar mijn mening, erkent de commis sie dat openbaarheid van bestuur ook speculatie in de hand zal werken. Speculatie wordt juist bevorderd als sommige mensen over meer informatie beschikken dan anderen. Openbaarheid daarentegen bevordert dat iedereen evenveel informatie krijgt. 


\section{Public relations}

Aan het einde van haar rapport gaat de Commissie Biesheuvel nog in op een onderwerp dat de eigenlijke aanleiding was voor het instellen van de commissie: de onduidelijkheid over de verhouding tussen voorlichting en public relations. De commissieleden komen hierover niet tot een eensluidend standpunt: ${ }^{106}$ Een aantal leden, met name zij die afkomstig zijn uit de wereld van de politiek, de wetenschap en de omroepen, vinden dat overheildswoorlichting geen onderdeel of middel mag zijn van public relations. Wel zou de overheid de burgers van de juistheid van een beleid mogen overtuigen indien de democratische besluitvorming geheel ten einde is gebracht, en daarbij ook de wenselijkheid van een dergelijke aanprijzing uitdrukkelijk aan de orde is gesteld. Andere commissieleden, voornamelijk afkornstig uit de wereld van de pers en van de public relations zelf, zien eventuele door of in opdracht van de overheid ondernomen public relations-aktiviteiten positiever. De diensten van p.r-adviseurs hoeven naar hun mening niet uitsluitend betrekking te hebben op voorlichtingsprojecten over zaken die niet meer controversieel zijn. Hoewel het er natuurlijk een beetje van afhangt hoe men het begrip "public relations" definieert, zou ikzelf voor het standpunt van het eerstgenoemde deel van de commissie willen kiezen. Het onderscheid dat het andere deel van de commissie maakt tussen het bevorderen "van goede verhoudingen" (doel van voorlichting) en het bevorderen "van een goede verstandhouding" (doel van public relations), lijkt mij te gekunsteld. Voorlichting en public relations kunnen dan te gemakkelijk door elkaar gehutseld worden. En dat is niet wenselijk, als we de openbaarheid van bestuur willen vergroten.

\section{De reacties op het rapport Biesheuvel}

De reacties op het rapport van de Commissie Biesheuvel lopen sterk uiteen. Minister-president De Jong spreekt bij de in ontvangst name van het rapport op 9 juni over "een openhartigheid, die de besluitvorming frustreert". Voorzitter Biesheuvel verklaart op een direkt daarop volgende persconferentie, dat de minister-president halverwege is blijven steken op de weg naar openbaarheid. ${ }^{107}$ De meer doordachte reakties volgen natuurlijk later. Ik zal hier het advies van Raad van State en de mede daarop gebaseerde regeringsnota "Openheid en openbaarheid van bestuur" behan-

107 Zie H. Schelhas, De informatieplicht van de overheid, Zwolle 1979. pag. 55. 
delen, de reakties in de Tweede en in de Eerste Kamer, en nog enkele reakties in de wetenschappelijke pers. Maar eerst wil ik hier het verslag bespreken van de speciaal naar aanleiding van het rapport Openbaarheid Openheid ingestelde Werkgroep Aantjes. ${ }^{108}$

\section{De Werkgroep Aantjes}

Deze werkgroep, bestaande uit een aantal Tweede-kamerleden, heeft het rapport van de Comissie Biesheuvel vooral bezien op mogelijke consequenties voor de werkwijze van de Tweede Kamer, en brengt daarover op 16 september 1970 verslag uit. Opmerkelijk is, dat de Werkgroep Aantjes er geen enkele moeite mee heeft, dat de commissie een streep haalt door het primeurrecht van het Parlement. Het parlement, zo stelde de Commissie Biesheuvel, heeft geen recht van primeur op kennisneming van door de regering openbaar te maken besluiten, verrichtingen, voorstellen, feitenmateriaal enz. "Daargelaten" schrijft de Werkgroep Aantjes "of de toelichting - met name op pag. 37 - aan de historische en huidige situatie geheel recht doet, acht de werkgroep deze stelling zelf eveneens juist: geen claim op primeurrecht". Als een kamerlid over een bepaalde aangelenheid schriftelijke vragen aan een bewindsman heeft gesteld, mag dat voor het betrokken departement geen reden zijn om vragen van journalisten of anderen over deze zaak niet te beantwoorden, stelde de Comissie. Biesheuvel. De Werkgroep Aantjes acht ook deze stelling juist. Wel moeten volgens haar de inlichtingen, vooruitlopend op een definitief antwoord, ook aan de Kamer worden meegedeeld. Behoudens kritiek op enkele détails is de werkgroep vrij positief over het rapport Openbaarheid Openheid. Ze beveelt dan ook aan het gehele Reglement van Orde opnieuw onder ogen te zien en aan de geest van het rapport te toetsen.

\section{Het advies van de Raad van State}

Heel anders van toon is advies van de Raad van State over het rapport van de Commissie Biesheuvel. ${ }^{109}$ De Raad beklemtoont dat hij slechts "aanvankellijke overwegingen" naar voren brengt. Bij een definitieve oordeelsvorming zou hij ook het oordeel van de Staatscommissie van Advies voor de Grondwet en de Kieswet, en van de Commissie van Advies inzake het Rechtskarakter van de Ambtenaarsverhouding willen betrekken. Misschien

108 TK 1970-1971, 10947 nrs. 1-3.

109 Het advies van de Raad van State treft men aan achter de regeringsnota Openheid en openbaarheid, van 8 oktober 1970; zie woor beide stukken TK 1970-1971, 10946, nrs. 1-3. 
juist ook ondat het om aanvankelijke overwegingen gaat, voelt de Raad van State zich niet geremd om flink uit te pakken.

De Commissie Biesheuvel heeft de probleemstelling "verengd", vindt de Raad al meteen. De minister-president had in zijn openingstoespraak de hoop uitgesproken, dat de commissie baanbrekend werk zou verrichten "voor het verbeteren van de communicatiewegen, die leiden van de basis naar de top en, omgekeerd, van de top naar de basis". De commissie heeft echter, omdat ze anders, naar eigen zeggen, "vrijwel het gehele proces van besluitvorming zou moeten onderzoeken", haar aandacht vooral gericht op de beantwoording van de vraag: "In welke mate en op welke wijze kan en moet de informatie, waarover de regering beschikt, aan burgers ter beschikking komen?" Maar, houdt de Raad van State de commissie voor, het Nederlandse staatkundig leven voltrekt zich in de polariteit tussen twee elementen: het gezag van de overheid en de invloed van het volk. Zonder de taak en de positie van de Staten-Generaal ook maar enigermate te willen aantasten, is de Raad van oordeel, dat de politieke democratisering behalve door het verstrekken van informaties aan de burgers, vooral versterkt behoort te worden door ..."enerzijds een decentralisatie in geografische zin van bestuurlijke bevoegdheden en anderzijds door stichting van functionele organisaties en kleinere gemeenschappen, kortom door overzienbare eenheden waarvoor de burger zich direkt verantwoordelijk kan weten" [..] "Mede daarom moet worden betreurd, dat het rapport der commissie - overigens in overeenstemming met de haar gegeven opdracht - zich beperkt tot de centrale overheid".

Maar ook los van dit laatste heeft de Commissie Biesheuvel, in de ogen van de Raad van State, het vraagstuk van openheid/openbaarheid onvoldoende gerelateerd aan de Nederlandse staatkundige verhoudingen. De Raad heeft de indruk, dat die onvoldoende relatering verband houdt met de samenstelling van de commissie, en citeert met instemming de ouddirekteur van de Rijkswoorlichtingsdienst, dr. G.J. Lammers, die in ESB had geschreven: "Het journalistieke element was sterk vertegenwoordigd en dat is merkbaar in de wijze waarop het vraagstuk van de openbaarheid van bestuur is aangevat". "10 Zelf heb ik er in het vorige hoofdstuk ook al mijn verwondering over uitgesproken, dat in de Commissie Biesheuvel

110 Zie ESB 1970, pag. 763. Lammers vermeldt in zijn bijdrage in ESB ook, dat overwogen is voor het yragstuk van de openbaarheid van bestuur een aparte, onder de minister van Binnenlandse zaken ressorterende commissie van staatsrechtgeleerden in te stellen. Maar hij vertelt er niet bij waarom daarvan is afgezien. Overigens is Lammers in zijn oordeel over het rapport van de Commissie Biesheuvel veel positiever dan de Raad van State. 
geen enkele staatsrecht-geleerde zitting had. Maar achteraf bezien komt dat de regering De Jong best wel goed uit. Want nu kan zij, evenals de Raad van State, vanuit de zogenaamde "staatsrechtelijke invalshoek". vrij schieten op het rapport van de commissie. En van die gelegenheid maken beide volop gebruik. Hoe de regering dat doet, zal dadelijk nog worden toegelicht. Eerst zall ik hier mijn bespreking van het advies van de Raad van State afronden.

De Raad acht het niet uitgesloten, dat uit een nadere inventaristie van de wetgeving en van haar tekorten op het stuk van de openbaarheid zou blijken, dat deze openbaarheid op verschillende deelterreinen meer is gediend door het toespitsen van openbaarheidsvoorschriften op de desbetreffende onderdelen van de wetgeving dan door een algemene regeling, die onvoldoende recht doet aan de verscheidenheid van onderwerpen en belangen.

Uit die overweging van de Raad blijkt eigenlijk zijn hele houding van de tegenover de strekking van het rapport. De Raad "wil er geen twijfel over laten bestaan, dat een grotere openheid en openbaarheid ook naar zijn oordeel met kracht bevorderd moeten worden". ${ }^{111}$ Maar hij voelt er niets voor om zich uit te spreken voor het principe van openbaarheid van bestuur. Die tegenzin blijkt ook als de Raad vervolgens de afzonderlijke voorstellen van de commissie onder de loep neemt, bij voorbeeld bij het voorstel om het primeurrecht van het parlement af te schaffen. We hebben zojuist gezien dat de Werkgroep Aantjes, uit de Tweede Kamer zelf, daar geen moeite mee had. Maar de Raad van State vindt dat het voorstel "te ongenuanceerd is om als uitgangspunt te kunnen dienen." De vraag kan naar zijn mening niet met een simpel ja of nee worden beantwoord: "Het antwoord hangt nauw samen met de aard en het gewicht van het onderwerp en kan afhankelijk zijn van de omstandigheden. [..] Daarbij zal een zorgvuldige afweging van enerzijds de constitutionele positie van de Staten-Generaal en anderzijds de eis, waar mogelijk de burgers zo snel en doeltreffend mogelijk in te lichten, moeten plaatsvinden." 112 Het is een fraai voorbeeld, hoe de Raad van State in zijn eigen onwil verstrikt raakt. Want juist als je het antwoord op de vraag, wie als eerste informatie moet krijgen, wilt laten afhangen van de aard en het gewicht van het onderwerp en van omstandigheden, moet je het parlement geen primeurrecht geven. Daarom ook wilde de Commissie Biesheuvel dit recht afschaffen.

111 TK 1970-1971, 10946 nr. 3, pag. 15.

112 ld, pag. 18. 
Van belang zijn ook de reacties van de Raad van State op twee andere voorstellen van de Commissie Biesheuvel: de openbaarheid van ambtelijke adviezen en die van adviescolleges. Wat de openbaarheid van ambtelijke adviezen betreft, hebben we al gezien, dat de Commissie Biesheuvel daar niet erg scheutig mee is geweest. Met name niet in situaties, waarin de besluitvorming nog niet is afgerond. De plicht tot openbaarmaking is dan gekoppeld aan het belang van "een goede en democratische bestuursvoering".

De Raad van State heeft grote moeite met de gedachte van de commissie, dat als de besluitvorming wel is afgerond, de gevraagde informatie over ambtelijke stukken in principe moet worden verstrekt. De Raad vindt dit niet nodig en niet wenselijk. Niet nodig omdat, in tegenstelling tot wat de Commissie Biesheuvel beweert, niet zomaar kan worden gesteld dat de mogelijkheden van parlementaire controle op het bestuur zijn verminderd. Maar openbaarheid als door de commissie bepleit, is ook niet wenselijk, vindt de Raad van State. Als wordt gesteld, dat het op departementen nogal eens schort aan de meest elementaire vormen van departementale communicatie, dan is de openbaarheid toch wel een vreemd middel om de communicatie tussen een bewindsman en zijn ambtenaren te verstevigen. Een bewindsman en zijn ambtenaren zouden dan via de pers tegen elkaar kunnen worden uitgespeeld. Maar een groter bezwaar is nog, vindt de Raad, "dat door de steeds boven het hoofd van de beleidsambtenaren hangende mogelijkheid van openbaarmaking van interne adviezen, de positie van de ambtenaar in belangrijke mate zal worden gewijzigd. [..] de goede beleidsambtenaar tracht zich ongeacht zijn politieke opvattingen steeds zoveel mogelijk met de bewindsman te vereenzelvigen. Gevreesd moet echter worden, dat, als het beginsel van openbaarheid van ambtelijk bestuur zou worden doorgevoerd op de wijze als de commissie voorstelt, zich juist een scheiding tussen bewindsman en ambtenaren zal voltrekken, met alle daaraan verbonden consequenties, waaronder het gevaar dat de huidige neutrale opbouw van het ambtelijk apparaat beïnvloed wordt door politieke tendenties". ${ }^{113}$ Alleen adviezen die vergelijkbaar zijn met adviezen van niet-ambtelijke instanties komen naar de mening van de Raad van State voor openbaarmaking in aanmerking. De Raad denkt daarbij an rapporten van interdepartementale commissies, en aan adviezen van ambtenaren, die in de wet geregelde "eigen" bevoegdheden hebben. ${ }^{114}$ 
Vooral in de passage over de "goede beleidsambtenaar", die zich zoveel mogelijk met zijn bewindsman "vereenzelvigt", meen ik de schrijvende hand te herkennen van staatsraad J.M. Kan. Eerder dat jaar had hij in het Nederlands Juristenblad, in zijn bespreking van De vierde macht van $R$. Crince le Roy gesteld, dat "de doorsnee-Nederlandse beleidsambtenaar" er naar streeft zich zo goed mogelijk te "identificeren" met zijn minister. ${ }^{\text {"s }}$ Over de vraag inhoeverre dat streven naar identificatie wenselijk is, kom ik verderop terug in de twee hoofdstukken over ambtelijke loyaliteit. Elders heb ik al geschreven, dat ambtenaren mensen zijn "die - gelukkig meestal zelf ook een mening hebben over wat in hun sector goed is voor de samenleving". ${ }^{116}$ Voor dit moment wil ik volstaan met de woorden te memoreren, die Steenbeek in zijn preadvies voor de NJV-vergadering van 1970 schreef: "Ik geloof inderdaad dat wij dergelijke bezwaren niet te licht moeten nemen maar zelf ben ik van mening dat op dit stuk veel nodeloze zorg bestaat. Eén consequentie kan met zekerheid worden aangegeven, nl. dat de ambtenaren zelf niet meer in de gebruikelijke, aan de geheimhouding verbonden anonimiteit zullen kunnen blijven. Zij zullen onvermijjdelijk naar buiten treden als lieden die een eigen oordeel hebben dat kan afwijken van dat van hun verantwoordelijke bestuurlijke chefs". ${ }^{117}$ Wie in het rapport van de Commissie Biesheuvel de "staatsrechtelijke invalshoek" mocht hebben gemist, kan in het preadvies' van Steenbeek ruimschoots aan zijn trekken komen.

Wat betreft de openbaarheid van adviezen van adviescolleges maakt de Raad van State, in navolging van de Commissie Biesheuvel, onderscheid tussen de eigen adviezen en die van de andere colleges. De commissie stelde voor, dat de wetgevingsadviezen van de Raad tegelijk met de publicatie van de betreffende wetsontwerpen openbaar moeten worden gemaakt; en adviezen over algemene maatregelen van bestuur tegelijk met de toelichting bij de afkondiging van deze maatregelen. De Raad van State wil dit voorstel nog niet onderschrijven. Eerst moet kennis kunnen worden genomen van wat de Commissie Cals/Donner daarover zal opmerken. "Daarbij zal men zich in de eerste plaats rekenschap dienen te geven van de bijzondere positie, welke de Raad van State in ons staatsbestel inneemt als laatste, vertrouwelijke adviseur van de Kroon, inzonderheid voor wat betreft de toetsing van het voorgenomen beleid aan de beginselen van de

115 NJB 1970, pag. 155.

116 H. Koning, Inspraak volgens nieuwe wetten, NJB 1990, pag. 1065.

117 J.G. Steenbeek, Welke beginselen betreffende de openbaarheid van vergadering en toegankelijkheid van stukken behoren ten grondslag te liggen aan de wettelijke regelingen op het stuk van de openbare diensten, Zwolle 1970, pag. 75. 
rechtsstaat", voegt de Raad daar zonder bescheidenheid aan toe. ${ }^{118}$ Wel wordt ingestemd met het voorstel van de Commissie Biesheuvel, dat de regering de adviezen van andere adviescolleges openbaar maakt "onmiddellijk" nadat deze aan haar zijn uitgebracht.

\section{Het voorlopig standpunt van de regering}

Het advies van de Raad van State geeft de regering De Jong de nodige rugdekking om zich op een aantal punten van het rapport van de Commissie Biesheuvel te kunnen distantiëren. Met het oog op het belang van een gedachtenwisseling tijdens de algemene beschouwingen over de begroting 1971, geeft de regering op 8 oktober 1970 in een nota alvast haar voorlopige standpunt. ${ }^{119}$ Evenmin als de Raad van State wil de regering het principe van openbaarheid omhelzen. "Zij wil een grote mate van openbaarheid, en ook een wettelijke plicht daartoe, maar zij wenst niet een in beginsel onbeperkte openbaarheid. Bij de begrenzing van het openbaarheidsbegrip, dat zij voorstaat, heeft voorop gestaan de gedachte dat de openbaarheid moet worden gezien als een middel tot betere communicatie tussen overheid en burger en niet als doel op zichzelf. Het informatiemateriaal, dat een functie vervult in dit communicatieproces, behoort dus in beginsel openbaar te zijn, het overige niet", zegt de nota. ${ }^{120}$

Verder dienen bij de begrenzing van het openbaarheidsbeginsel andere evenwaardige democratische belangen te worden gerespecteerd. De nota licht toe, wat dit onder meer betekent: "In de Nederlandse staatkundige verhoudingen overgezet: het is de minister die beslist, na afweging van een aantal belangen en adviezen, die gemakkelijk onderling tegenstrijdig kunnen zijn. Hij kiest na die afweging voor een beleid, en is bereid zich tegenover het parlement voor dat beleid te verantwoorden. [.. ] Anders gezegd: de ambtelijke adviezen en de interne gedachtenwisseling - waaronder ook de bijdrage van de minister - spelen wel een rol, maar niet naar buiten. Openbaarmaking ervan betekent, dat ze in de politieke discussie kunnen terechtkomen. Het komt de regering voor dat hierbij ook de positie van het parlement is betrokken. In de verhouding regering/volksvertegenwoordiging loopt er een duidelijke verantwoordelijkheidslijn van de minister naar het parlement met betrekking tot het gehele in het beleid van de verantwoordelijke bewindsman geconcentreerde functioneren van het ambtelijk apparaat. Ombuiging of vervaging van deze lijn zou naar het

119 Nota Openheid en operbaarheid van bestuur, TK 1970-1971, $10946 \mathrm{nr} .2$.

120 Id. pag. 4. 
oordeel van de regering de juiste staatsrechtelijke verhoudingen niet ten goede komen". ${ }^{121}$ Bij een openbaarheid zoals door de Commissie Biesheuvel bepleit, zou ook de positie van de ambtenaar fundamenteel veranderen. Er zouden gemakkelijk conflicten kunnen ontstaan, en de openheid in de verhouding van de ambtenaar tot de politiek verantwoordelijke bewindsman zou in het gedrang kunnen komen. Bovendien zouden de efficiency en de slagvaardigheid van het bestuur worden geschaad, meent de regering.

Het is duidelijk welke conclusie de regering uit dit alles meent te moeten trekken: de uitzonderingsgronden, die de Commissie Biesheuvel geeft, zijn veel te beperkt. De belangen van de eenheid van beleid, van ministeriële verantwoordelijkheid tegenover het parlement, en van doelmatigheid van bestuur, kunnen daarin niet.worden meegewogen. De regering meent dan ook niet te kunnen overgaan tot het "systeem van openbaarheid" dat de commissie voorstaat. Wel wil de regering, dat veel van de openbaarheid die zich tot nu toe geleidelijk en vrijblijvend kon ontwikkelen, verplicht wordt gesteld. Maar dan niet omdat de burgers daar zonder meer recht op zouden hebben. Zij formuleert voor passieve openbaarheid (informatieverstrekking op verzoek) een criterium dat in het verlengde ligt van dat voor aktieve openbaarheid (spontane informatieverstrekking). Aktieve openbaarmaking - dat is de regering met de Commissie Biesheuvel eens - moet plaatsvinden "zodra met het oog op een goede en democratische bestuurswoering opinievorming daaromtrent van bellang is". En passieve openbaarmaking van besluiten - met de motieven en feitelijke gegevens, die daartoe hebben geleid - zou dan volgens de regering verplicht moeten worden "voorzover deze van belang zijn voor het inzicht van de burger in het gevoerde bestuur". 122

Het werkelijke verschil van mening tussen de commissie en de regering wordt door deze formulering versluierd. Want natuurlijk heeft de informatieverstrekking die de Commissie Biesheuvell voorstaat, ook geen ander doel dan het inzicht van de burger in het gevoerde bestuur te vergroten. Maar anders dan de regering, wil de commissie het oordeel over de vraag of bepaalde informatie het inzicht van een burger zal vergroten, overlaten aan die burger zelf. Als hij om informatie verzoekt, zou die informatie moeten worden verstrekt, tenzij daartegen een concrete en objectief geformuleerde weigeringsgrond kan worden aangevoerd. En dát "systeem van openbaarheid" gaat het kabinet-De Jong te ver.

122 Id. $\operatorname{pag} 7$. 
Wat betreft de adviezen van (niet-ambtelijke) adviescolleges kan de regering akkoord gaan met het voorstel van de Commissie Biesheuvel dat die adviezen, onmiddellijk nadat ze aan de regering zijn uitgebracht, openbaar moeten worden gemaakt. Over de openbaarheid van de adviezen van de Raad van State wil de regering echter nog geen uitspraak doen. Zij vindt, net als de Raad zelf, dat daarover eerst het rapport van de Staatscommissie Cals/ Donner moet worden afgewacht.

\section{Reacties in de Tweede Kamer}

Zoals gezegd, heeft de regering haar nota over het rapport van de Commissie Biesheuvel op 8 oktober 1970 naar de Tweede Kamer gestuurd, om de leden van deze kamer in de gelegenheid te stellen er nog bij de algemene beschouwingen over de rijksbegroting 1971 op in te gaan. Van die gelegenheid wordt, ondanks de korte inleestijd, op 13 oktober door bijna alle fractie-woordvoerders gebruik gemaakt. En wat opvallender is, kamerbreed wordt ongeveer dezelfde kritiek geleverd. Men vindt het regeringsstandpunt te behoudend. Den Uyl (PvdA) haalt met instemming enige woorden van commissie-voorzitter Biesheuvel aan, en vervolgt: "Als ik dat in mijn termen vertaal, zeg ik: Het gaat de regering niet om politieke democratisering, om een andere verdeling van macht en zeggenschap - in dit geval van kennis en informatie -, maar om het glad strijken van plooien, die het huidige beeld ontsieren, met handhaving van de bestaande machtsverdeling. Daar ligt het verschil in uitgangspunt ${ }^{n}{ }_{123}$ Van Mierlo (D66) is niet veel milder over de houding van de regering, als hij zegt: "Het gemak, waarmee vernieuwingscommissies worden ingesteld, is ongeveer evenredig aan dat, waarmee hun adviezen worden genegeerd. De hemel zij dank, is het de heer Biesheuvel zelf geweest, die het rapport gemaakt heeft, zodat we er op z'n minst wat schoten voor de boeg aan overhouden". ${ }^{124}$

Ook de woordwoerders van de regeringspartijen spreken meer sympathie uil voor het rapport dan voor het regeringsstandpunt, al formuleert de eén het wat diplomatieker dan de ander. Schmelzer (KVP) zegt: "Mijn fractie onderschrijft van harte het uitgangspunt van het rapport van de commissie-Biesheuvel, dat openbaarheid regel en geheimhouding uitzondering dient te zijn. Voor de uitvoering van hetgeen de commissie heeft aanbevolen, heeft het kabinet thans een eerste stuk informatie aan de kamer doen toekomen. Wij zullen dat gaarne nader bestuderen - dit kost ons nog 
even tijd - en zo snel mogelijk onze mening geven"1.25 Voor de ARP is het Biesheuvel zelf, die in de kamer het woord voert. Hij is van alle fractie-woordvoerders het meest uitvoerig in zijn kritiek. "De regering hanteert een veel beperkter standpunt, waar zij openbaarheid ziet als een middel tot communicatie tussen overheid en burger, dat ingrijpend nawerkt in haar beleidsconclusies. De Commissie ziet openbaarheid als een grondprobleem van politieke democratisering", zegt Biesheuvel. Vervolgens betrekt hij ook de Raad van State in zijn kritiek: "De Raad denkt sterk in bestaande staatsrechtelijke verhoudingen, en heeft daardoor een andere kijk op de maatschappelijke ontwikkeling. De Commissie daarentegen heeft vooral functioneel gedacht. $\mathrm{Zij}$ heeft zich afgevraagd waaraan de samenleving behoefte heeft. De samenleving is er niet voor de instituties en ten behoeve van een ongerepte handhaving van staatsrechtelijke verworvenheden", houdt Biesheuvel de kamer voor. En dan leest hij de regering de les: "De opvattingen van de Raad, overgenomen door de Regering, over de positie van ambtenaren bij openbaarheid, zijn evenzeer sterk institutioneel gedacht. Gevreesd wordt o.m., dat het gezag en de positie van de overheid door grotere openbaarheid zou worden aangetast. Maar wordt dat gezag niet veeleer aangetast door nodeloze geheimhouding? De Regering laat zich evenwel negatief uit over de gevolgen van grotere openbaarheid voor de werkwijze van ambtenaren. $\mathrm{Zij}$ heeft te weinig vertrouwen in de prudentie van ons ambtelijk apparaat." Biesheuvel belooft, dat van de zijde van de ARP bij de integrale behandeling van de nota "een sterk kritische benadering" mag worden verwacht. ${ }^{126}$

De woordvoerders van de twee andere regeringspartijen, zijn iets milder, maar toch ontevreden over het regeringsstandpunt. Mellema (CHU) drukt het aldus uit: "Ik betreur het, mijnheer de Voorzitter, dat er tussen de Commissie en de Regering zulk een evident verschil heerst. Hoewel mijn fractie ook twijfelt aan de passieve openbaarmaking, zoals die in het rapport Biesheuvel wordt ontvouwd, is vooralsnog het standpunt van de Regering naar het mij voorkomt toch well wat mager uitgevallen". ${ }^{127}$ Geertsema (VVD) heeft nog geen "gefundeerd oordeel" kunnen vormen. Maar, zegt hij: "Ik wil wel als mijn voorlopig oordeel uitspreken dat ik dichter bij de commissie sta dan bij het kabinet". ${ }^{128}$

126 Id. pag. 275 en 276.

127 Id. pag. 277.

128 Id. pag. 283. 


\section{Minister-president De Jong}

Twee dagen later, op 15 oktober 1970, antwoordt premier De Jong zijn critici in de Tweede Kamer. Na te hebben gesteld, dat hij "verheugd" is dat verschillende geachte afgevaardigden zich hebben uitgesproken voor een afzonderlijke behandeling van de regeringsnota Openbaarheid van Bestuur, wuift de premier de meeste bezwaren weg. Door het bestuur genomen besluiten worden, in de gedachtengang van de regering, "voor een ieder, die redelijk geïnteresseerd is in de publikatie, toegankelijk"t. Premier De Jong wil hierbij twee dingen onderstrepen: "In de eerste plaats is de redelijk geïnteresseerde in onze gedachtengang niet alleen de man of vrouw, die bij het besluit belang heeft, maar in beginsel iedere burger of journalist, die zijn inzicht in het gevoerde bestuur wil vergroten. In de tweede plaats krijgt de burger of de journalist in onze gedachtengang niet alleen toegang tot de inhoud van het besluit, maar evenzeer tot de motieven en de feiten, die eraan ten grondslag liggen en zelfs tot de relevante overwogen alternatieven. Mijnheer de Voorzitter! Dit alles betekent niet het gladstrijken van plooien of halfheid, dit betekent niet minder dan dat de rijksoverheid voor haar feitelijk bestuurshandelen het beginsel van openbaarheidsplicht introduceert. En zij wil, voorzover het van haar afhangt, die plicht nog in deze periode in een wet vastleggen". Slechts op één belangrijk punt brengt de regeringsnota een nuancering aan in de voorstellen van de Commissie Biesheuvel, meent de premier. Dat is de vertrouwelijkheid van het interne beraad. "Ik heb hier nog een bijna persoonlijk gevoel bij. Ik wil nl. mijn eventuele opvolgers niet een taak overlaten, die ik zelf onuitvoerbaar acht", voegt hij daar bewogen aan toe, om even later zijn lofrede op de regeringsnota af te sluiten met de woorden: "Mij lijkt dat dit een evolutie is die verder gaat dan enkele jaren terug nog voor mogelijk werd gehouden. Ik prijs mij gelukkig dat deze belangrijke versterking van het democratisch gebeuren in deze tijd, van het verminderen van de afstand tussen burger en overheid, tot stand kon komen dank zij de commissieBiesheuvel, die op initiatief van dit kabinet tot stand kwam". ${ }^{129}$

Zover zal het echter niet komen. Hoewel het kabinet-De Jong de volle rit uitzit, zal het geen wetsvoorstel voor openbaarheid van bestuur bij de Tweede Kamer indienen. Zelfs de afzonderlijke behandeling van de regeringsnota, waar de minister-president zich zo op had "verheugd", zal nooit plaatsvinden. Kennelijk ligt de zaak, zowel bij de regering als bij het parlement, toch erg gevoelig. 


\section{Reacties in de Eerste Kamer}

Op 9 februari 1971 wordt in de Eerste Kamer hoofdstuk III (Departement van Algemene Zaken) van de begroting 1971 aan de orde gesteld. Twee senatoren, Van Lieshout en Boukema, betrekken de regeringsnota dan uitgebreid in hun beschouwingen. $\mathrm{Zij}$ hebben inmiddels ruimschoots de tijd gehad om de nota goed te lezen, en vragen zich af, hoe het met de openbaarheid verder moet gaan.

Van Lieshout (KVP) is verontrust over de inhoud van het rapport van de Commissie Biesheuvel en, meer algemeen, over de roep om openbaarheid. Over inspraak en openbaarheid bestaan veel "misverstanden", die helaas in het rapport van de commissie niet uit de weg worden geruimd. Zoals de Raad van State al eerder had gedaan, citeert ook Van Lieshout met veel instemming de woorden van de oud-direkteur van de Rijksvoorlichtingsdienst, G.J. Lammers, over het "journalistieke element", dat te sterk in de commissie vertegenwoordigd zou zijn geweest. De staatsrechtelijke invalshoek is onderbelicht, en daar wil Van Lieshout toch well even de schijnwerper op richten. "De burger kiest vertegenwoordigende lichamen. $\mathrm{Zij}$ moeten in het openbaar vergaderen, zodat iedere kiezer kan weten wat de vertegenwoordiger doet en zegt en eventueel ook niet zegt. Deze openbaarheid betekent dan tevens voor de kiezer het middel om te weten, hoe hij de volgende maal zijn stem zal uitbrengen. Een en ander betekent, dat de openbaarheid al zo oud is als de staatsinrichting, die wij thans hebben, en dat zij al lange en lange jaren een wezenlijk element vormt van onze democratie. Waarom dan thans weer de openbaarheid in discussie brengen? Bestaat daarvoor gerede aanleiding?" vraagt hij zich af. Inspraak is een "modewoord" geworden, vindt Van Lieshout, dat ten onrechte vaak verward wordt met medezeggenschap. De wijze waarop de Commissie Biesheuvel daarover spreekt, maakt de verwarring alleen maar groter. "Nogmaals, laat men zich toch bewust zijn van het feit, dat met een overtrokken openheid en openbaarheidsidee de dreiging, dat met het badwater ook het kind wordt weggegooid, levensgroot aanwezig is", houdt Van Lieshout de premier en de Eerste Kamer voor. ${ }^{130}$

Senator Boukema (ARP), wiens dissertatie, getiteld Enkele aspecten van de vrijheid van meningsuiting in de Duitse Bondrepubliek en in Nederland, in het vorige hoofdstuk aan de orde is gekomen, heeft vooral kritiek op de regering. Met name de stelling in de regeringsnota, dat de ministeriële verantwoordelijkheid wordt ondergraven door de burger inzicht te geven in ambtelijke adviezen, moet het bij Boukema ontgelden. "Wat 
bedoelt men nu eigenlijk?", vraagt hij de premier. "Bedoelt men, dat ambtelijke adviezen tegen de Minister kunnen worden uitgespeeld? Dat kan natuurlijk, maar hetzelfde is bij voorbeeld het geval met het rapport van de commissie-Biesheuvel. Hoe stelt men zich dat uitspelen voor? Als de Minister het eens is met de aanbevelingen, die in de adviezen zijn opgenomen, dan valt er weinig uit te spelen. Is hij het er niet mee eens, dan heeft hij goede argumenten en zo niet, dan wordt de Minister terecht aan kritiek onderworpen. Het is uiteraard steeds de Minister, die verantwoordelijk blijft en er zal geen parlementariër zijn, die dat zal willen ontkennen". Boukema heeft grote moeite met de gedachtengang van de regering, dat het de overheid zelf is die bepaalt, of informatiemateriaal een functie vervuld in het communicatieproces. Hij koppelt, zoals eerder in zijn dissertatie, het recht op informatie aan de vrijheid van meningsuiting. Men denkt daarover niet op dezelfde wijze, erkent Boukema. "Er kan echter niet worden ontkend, dat een grondrecht als dat van vrije meningsuiting veel van zijn waarde verliest, als men de mensen de informatie onthoudt, op basis waarvan zij tot een mening moeten komen. Dat betekent op zijn minst, dat het recht op informatie moet worden erkend als een recht, dat een dienende functie vervult ten aanzien van de vrijheid van meningsuiting; een standpunt, dat blijkens het optreden in het kader van de V.N. naar het schijnt al zo ongeveer 10 jaar geleden door de Regering werd gedeeld". ${ }^{131}$

\section{Nogmaals premier De Jong}

De volgende dag, op 10 februari, antwoordt premier De Jong. Helaas is het er vanwege de vele werkzaamheden, die de Tweede Kamer had te verrichten, nog niet van gekomen om de regeringsnota met die kamer te bespreken, deelt hij mee. Maar de regering is intussen al "een heel eind gevorderd" met een wetsontwerp. De indiening van dit ontwerp wil de regering niet laten wachten op een kamerdebat over de nota. De premier vindt, dat Boukema in zijn betoog een beetje langs de bezwaren van de regering is gegaan. Als een minister met zijn ambtenaar van mening verschilt, "dan heeft hij daarvoor argumenten, over de waarde waarvan men ook in de Kamers verschillend kan denken. In ieder geval is de Minister verplicht schriftelijk zijn persoonlijke argumenten telkens te formuleren en daardoor komt de ambtenaar, die zijn Minister die last bezorgt te dezen, in een vervelende verhouding te staan. De Minister wordt daardoor persoonlijk dermate zwaar belast, zo hij weer niet andere 
ambtenaren gebruikt om de tegenargumenten te formuleren, dat hij minder aan de hoofdzaken toekomt".

Wie gaat er nu langs de bezwaren van wie, vraag ik mij af. De laatste bewering van de premier is in ieder geval niet erg geloofwaardig. Zeker als het meningsverschil tussen de minister en zijn ambtenaar over hoofdzaken gaat, moet de minister toch aan die hoofdzaken kunnen toekomen. Trouwens, ook de eerste bewering, dat men in de kamers verschillend kan denken over de waarde van de argumenten van de minister, klopt niet als men het stelsel aanhoudt dat de regering voorstaat. De kamers komen dan immers helemaal niet te weten, dat de minister van het advies van zijn ambtenaar is afgeweken. Dus hoeft hij ook niet te beargumenteren, waarom hij dat gedaan heeft.

Voor wat betreft de grondwettelijke kant van de openbaarheid van bestuur krijgt Boukema van premier De Jong de verzekering, dat bij de opstelling van het wetsontwerp rekening zal worden gehouden met de adviezen van de Commissie Cals/Donner. ${ }^{133}$ Maar de premier will al bij voorbaat laten weten, dat het hem wat ver gaat om uit het recht van vrije meningsuiting het recht op openbaarheid van bij voorbeeld ambtelijke notities af te leiden.

\section{Reacties in de rechtswetenschap}

Deze antwoorden van premier De Jong vormen de afsluiting van de gedachtenwisseling tussen de regering en de Staten-Generaal over het rapport van de Commissie Biesheuvel. Noch in de Tweede Kamer, noch in de Eerste Kamer zal het tot een afzonderlijke bespreking van het rapport komen.

Besteedt de volksvertegenwoordiging er dus weinig aandacht aan, de rechtswetenschap is al even zwijgzaam. Het Nederlands Juristenblad zal noch in 1970, noch in 1971 een artikel of bijdrage aan het onderwerp wijden. Kort na de publikatie van het rapport verschijnt het eerder genoemde artikel van G.J. Lammers in ESB, en wijdt H. Schelhaas in TVO een beschouwing aan het rapport. In de Nederlandse Gemeente, van 25 juni 1971, verschijnt nog een "kritische beschouwing" van de hand van

132 Id. pag. 592.

133 In het vorige hoofdstuk, aan het slot van de bespreking van de preadviezen van Donner en Van der Hoeven ${ }^{\text {is }}$ al beschreven wat het Eindrapport van de Commissie Cals/Donner ower opembaarheid van bestuur voorstelit. 
J.M. de Meij. ${ }^{134}$ Het kan wel zijn, dat de Commissie Biesheuvel het allemaal goed bedoeld heeft, vindt De Meij, maar zij had dan toch duidelijker moeten zijn, met name in haar voorontwerp. "Persoonlijk ben ik volstrekt niet overtuigd door de argumenten die hier tegen openbaarheid worden aangevoerd, maar het door de regering gewenste resultaat is heel gemakkelijk te bereiken door, zoals in Denemarken en Noorwegen, interne correspondentie binnen elk overheidsorgaan in beginsel van openbaarheid uit te sluiten. Indien de binnenkomende en uitgaande stukken openbaar zijn is er toch al heel wat gewonnen, te meer nu de regering zich wel uitspreekt voor het openbaar maken van besluiten en de motieven en het feitenmateriaal, die tot die besluiten hebben geleid", laat hij daarop volgen.

Misschien bedoelt De Meij het zelf allemaal ook wel goed. Maar de helpende hand die hij hier de regering toesteekt, vind ik maar moeilijk te rijmen met zijn even verderop geuite verdachtmaking, dat de regering haar "zeer beperkte" visie snel in een wet wil vastleggen voordat de gedachten over openbaarheid zich in Nederland verder ontwikkelen. ${ }^{135}$ En aan de fundamentele betekenis, die staatsrecht-geleerden als Steenbeek en Boukema aan de openbaarheid van ambtelijke stukken toekennen, gaat De Meij helemaal voorbij. Inmiddels zijn er weer Tweede-Kamerverkiezingen geweest, en is het kabinet De Jong demissionair geworden. Van het snel indienen van een wetsontwerp kan dus geen sprake meer zijn.

134 H. Schethaas, Openbaarheid een vanzelfsprekendheid, TVO 1970, pag. 220 e.\%., resp. J.M. de Meij, Openbaarheid of communicatie, De Nederlandse Gemeente 1971, pag. 293-299.

135 De Meij, a.w. pag. 298 resp. 299. 


\section{Hoofdstuk 4}

\section{De Wet openbaarheid van bestuur}

\section{Het wetsvoorstel}

Het kabinet De Jong wordt in juli 1971 opgevolgd door het kabinet Biesheuvel. De voorzitter van de Commissie Herorientatie Overheidsvoorlichting is nu zelf minister-president geworden, en een snelle totstandkoming van openbaarheidswetgeving lijkt verzekerd. Het zal echter anders uitpakken.

\section{Het kabinet Biesheuvel}

Bij de beschouwingen over de rijksbegroting voor 1972 in de Tweede Kamer brengt mevrouw Kappeyne van de Coppello, kamerlid voor de VVD, op 19 oktober 1971 de openbaarheid van bestuur ter sprake. Zij merkt op, dat in de begrotingsvoorstellen nauwelijks wordt gerept over hoe het daarmee verder moet. Premier Biesheuvel antwoordt, dat hij bij zijn ambtsaanvaarding opdracht heeft gegeven de voorbereidingen voor een wetsontwerp met spoed af te ronden. Hij hoopt dit ontwerp omstreeks 1 januari 1972 bij de kamer te kunnen indienen. ${ }^{136}$ Maar als de premier op 8 februari 1972 in de Eerste Kamer door de heer Schwarz (D66) aan zijn goede voornemen wordt herinnerd, is zijn houding toch wel wat veranderd. "Waarom zou ik het rapport van de oude heer Biesheuvel een andere behandeling geven dan al de rapporten, die de nieuwe heer Biesheuvel bereiken?" vraagt de intussen niet meer zo kersverse premier zich af. Hij noemt als oorzaken van vertraging het feit, dat er sinds de nota van het kabinet De Jong "een lawine van publikaties" over het onderwerp is verschenen, en voorts dat door "deskundige ambtenaren" de verschillende mogelijkheden worden onderzocht en tegen elkaar afgewogen. Hoewel de opstelling van een wetsontwerp, naar zijn zeggen, nu "zeer snel" vordert, 
wil de premier "niet zo haastig zijn", dat hij niet een verantwoord wetsontwerp zou kunnen indienen. ${ }^{137}$

Anderhalve maand later contrasigneert minister Geertsema, van Binnenlandse Zaken, een koninklijk besluit waarin de Verordening Openbaarheid van Bestuur van de gemeente Gorinchem gedeeltelijk wordt vernietigd. ${ }^{138}$ De gemeenteraad wilde daar met een eigen regeling alvast vooruitlopen op de aangekondigde openbaarheidswet. Als reden voor de vernietiging voert de regering aan, dat een gemeenteraad geen autonome regels mag stellen over de wijze waarop $B$ en $W$, en ook de burgemeester, hun medebewindstaken moeten uitoefenen. De openbaarheid van bestuur lijkt dus zelf geen rol te spelen in de motivering wan het vernietigingsbesluit. Maar niettemin wordt het KB door voorstanders van openbaarheid wel opgevat als een veeg teken. Korte tijd later valt het kabinet door interne ruzies uiteen. Er worden nieuwe verkiezingen uitgeschreven. Maar dat weerhoudt de regering er niet van, om op 8 augustus 1972 in de Staatscourant de Aanwijzingen inzake ambtelijk optreden (extern) te publiceren, die door de minister-president zelf zijn vastgesteld. De vrije meningsuiting van ambtenaren wordt daarin nogal restrictief uitgelegd. ${ }^{139}$

Op 8 november 1972 komt premier Biesheuvel in de Eerste Kamer, bij de behandeling van de rijksbegroting voor 1973, weer over het nog steeds niet ingediende wetsontwerp te spreken. Antwoordend op opmerkingen van de heer Schwarz deelt de premier mee, dat het voor hem een persoonlijke teleurstelling is, dat hij zijn werk, juist op dit punt, niet heeft kunnen afmaken. Hij waarschuwt echter, dat ook de bewindsman die straks de draad zal moeten opnemen, niet op een snel, vlot en overzichtelijk resultaat mag rekenen. Biesheuvel zegt misschien wel geen "wiser and sadder man", maar in elk geval een "wiser man" te zijn geworden: "omdat ik in het afgelopen jaar in het interdepartementale overleg heb gemerkt, hoe ingewikkeld de materie is". ${ }^{140}$

137. Hand. EK 1971-1972, pag. 353 en 354. In het vorige hoofdstuk heb ik betoogd, dat het met die "lawine" nog well meeviel. L.E.M Klinkers haalt in zijn dissertatie Openbaarheid van Bestuur (Den Haag 1974, pag. 102) als verklaring voor het uitblijven van een wetsontwerp een zekere Duyverman aan, die beweerde dat, met ển uitzondering, alle secretarissen-generaal vernietigend adviseerden over" de opvattingen van de Commissie Biesheuvel.

$138 \mathrm{~KB}$ van 27 maart 1972, Stb. 164. Zie voor kamervragen over deze kwestie en beantwoording: Hand. TK 1971-1972, Aanh. pag. 2599.

139 Stcrt. 1972. nr. 152. In hoofdstuk $7 \mathrm{ga}$ ik nog wat nader in op de inhoud van deze Aanwijzingen.

140 Hand. EK 1972, pag. 154. 


\section{Het kabinet Den Uyl}

$\mathrm{Na}$ de Tweede-Kamerverkiezingen van november 1972 duurt het tot mei 1973 voordat het kabinet Den Uyl aantreedt. Het is een kabinet dat gesteund wordt door de progressieve partijen (PvdA, D66 en PPR), en gedoogd wordt door twee confessionele partijen (KVP en ARP). Op 9 oktober 1973 vraagt de heer Terlouw (D66) bij de algemene beschouwingen over de rijksbegroting voor 1974 in de Tweede Kamer, expliciet waar "een wetsontwerp-Biesheuvel" blijft. Premier Den Uyl antwoordt de volgende dag, dat naar zijn mening de in het voor-ontwerp van de Commissie Biesheuvel gegeven uitwerking "tot grote moeilijkheden zou leiden wanneer het tot wet werd, omdat de criteria die hierin worden genoemd voor de regeling van de openbaarheid te weinig exact zijn". Niettemin is zijn streven erop gericht, om in de loop van hetzelfde parlementaire jaar met concrete voorstellen bij de kamer te komen. ${ }^{141}$

$\mathrm{Bij}$ de behandeling van hoofdstuk III van de begroting (Algemene Zaken) komen de kamerleden Kappeyne van de Coppello (VVD), Terlouw (D66), Stoffelen (PvdA) en Fiévez (KVP) op de zaak terug. Terlouw verwacht "van een progressieve regering, die er de onvermijdelijkheid van ziet dat de overheid meer en meer regelend optreedt, een beleid dat er op is gericht de nadelige effecten van dat meer en regelend optreden zoveel mogelijk teniet te doen door openheid en openbaarheid van bestuur te bevorderen". En Stoffelen benadrukt, dat beleidsbeïnvloeding pas goed mogelijk is, als de burgers en hun vertegenwoordigers beschikken over alle informatie, die zij voor hun oordeelsvorming denken nodig te hebben. Hij begrijpt niet, na al het voorwerk dat de Commissie Biesheuvel heeft gedaan, wat de moeilijkheden zijn. "Het begint er op te lijken," zegt Stoffelen "dat de achtereenvolgende drie minister-presidenten erin slagen, voor iedere oplossing een probleem te vinden". ${ }^{142}$

Ondanks alle aandringen vamuit de kamer en goede voornemens van de regering, blijft de indiening van een ontwerp voor een openbaarheids wet in dat parlementaire jaar nog uit. Maar op 29 oktober 1974, bij de behandeling in de Tweede Kamer van de rijksbegroting voor 1975, heeft premier Den Uyl toch een primeur: een wetsontwerp voor de regeling van de openbaarheid van bestuur is nog in het afgelopen parlementaire jaar voor advies naar de Raad van State verzonden. Het lijkt de premier niet erg juist, hangende het advies van de Raad van State, over de inhoud van het wetsontwerp al te veel te zeggen. Maar het is, naar zijn mening, "een

142 Hand. TK 1973-1974, pag. 462 (Terlouw) en pag. 464 (Stoffelen). 
ontwerp van een in wezen vrij vergaande strekking". Een vraagstuk waar het in te dienen wetsontwerp uitvoerig op in gaat, is dat van de publikatie van ambtelijke adviezen, zo deelt hij mee; dit gebeurt in samenhang met het vraagstuk van de ministeriële verantwoordelijkheid. "Het is werkelijk geen simpel vraagstuk" ${ }^{\prime \prime}$, verzucht de minister-president in de kamer. ${ }^{143}$

\section{Het wetsontwerp dat naar de Raad van State ging}

Laten we nu eens dit wetsontwerp bekijken, zoals het in 1974 voor advies naar de Raad van State is verzonden. ${ }^{144}$ In de memorie van toelichting lezen we, dat het ontwerp vier zaken wil regelen: in de eerste plaats het actief openbaar maken van adviezen die zijn uitgebracht door niet-ambtelijke adviesinstanties; in de tweede plaats de openbaarmaking van de adviezen van de Raad van State; in de derde plaats de totstandkoming van aanwijzingen aan de departementen over meer openheid en openbaarheid bij de voorbereiding en uitvoering van beleid; en in de vierde plaats de instelling van een Raad voor de openbaarheid. ${ }^{145}$ Het is dus kennelijk niet de bedoeling om in de wet zelf normen te geven voor openheid en openbaarheid bij de voorbereiding en uitvoering van beleid. Dat moet gebeuren, zegt artikel 2 van het ontwerp, in aanwijzingen die door de minister-president worden vastgesteld, in overeenstemming met het gevoelen van de ministerraad. En alleen maar voor de departementen en diensten van de centrale overheid. Ten aanzien van provincies en gemeenten bepaalt het wetsontwerp slechts, dat die de adviezen van niet-ambtelijke adviesinstanties moeten publiceren op overeenkomstige wijze als de centrale overheid (artikel 5).

De niet-ambtelijke adviezen, uitgebracht aan Rijk, provincie of gemeenten, moeten volgens artikel 1 van het ontwerp worden gepubliceerd binnen drie weken nadat ze zijn ontvangen. Maar openbaarmaking blijft achterwege als eén van de in artikel 3 genoemde geheimhoudingsgronden zich voordoet. De daar genoemde gronden stemmen grotendeels overeen met de geheimhoudingsgronden, die thans in artikel 10 van de WOB worden genoemd.

De Raad van State krijgt in het ontwerp een aparte behandeling. We vinden er de oorspronkelijke versie van het thans bekende artikel 25a van de Wet op de Raad van State, dat de openbaarmaking van bepaalde advie-

143 Hand. TK 1974-1975, pag. 811.

144 Dit is mogellik, omdat dit ontwerp, samen met het advies van de Raad van State, tijdens de parlementaire behandeling van de WOB bij de MvA is gepubliceerd (als bijlage $13418 \mathrm{nr} .13)$ :

145 TK 1976-1977, 13418, ni. 13, pag. 15. 
zen van de raad voorschrijft. Opmerkelijk is, dat in deze versie geen tijdstip wordt genoemd, waarop de adviezen van de raad moeten worden gepubliceerd. Maar wel wordt bepaald, dat openbaarmaking geschiedt tezamen met de aan de Raad voorgelegde tekst. We zullen nog zien hoe deze laatste zinsnede tijdens de parlementaire behandeling zall worden geperverteerd.

Over de in het ontwerp voorgestelde Raad voor de openbaarheid van bestuur kan ik kort zijn. De raad zou moeten adviseren over de inhoud en toepassing van de door de minister-president te geven aanwijzingen, en jaarlijks een soort evaluatie-rapport moeten uitbrengen. Het voorstel tot instelling van deze raad zal in de loop van de parlementaire behandeling, om redenen die dadelijk nog aan de orde komen, uit het wetsontwerp worden geschrapt.

Men ziet, het wetsontwerp schuift de beantwoording van wat premier Den Uyl "werkelijk geen simpel vraagstuk" noemde, helemaal voor zich uit. De publikatie van ambtelijke adviezen zal geregeld moeten worden in aanwijzingen van de minister-president. De burger krijgt, wat deze stukken betreft, dus geen recht op openbaarheid.

\section{De kritiek van de Raad van State}

Dat de burger geen recht op openbaarheid krijgt, is eén van de belangrijkste kritiekpunten in het advies van de Raad van State. "Het ware gewenst dat duidelijker tot uitdrukking wordt gebracht hoe het kabinet zich de afweging tussen het belang van een goede bestuursvoering en het beginsel van openheid en openbaarheid voorstelt. [..] Een en ander klemt temeer, nu het wetsontwerp de omvang in concreto van de te betrachten openheid en openbaarheid niet zelf bepaalt", zegt de raad. De normstelling wordt helemaal overgelaten aan de minister-president. Om dat enigzins te ondervangen, stelt de Raad voor in de wet te bepalen, dat de aanwijzingen "worden vastgesteld door de Kroon bij of krachtens algemene maatregel van bestuur, of althans gehoord de Raad van State". 146

Een ander belangrijk kritiekpunt van de Raad van State betreft het feit, dat het wetsontwerp een weinig overtuigend onderscheid maakt tussen drie soorten overheidslichamen. De voorgestelde regeling geldt in volle omvang eigenlijk alleen voor de rijksoverheid; de gemeenten en provincies 
hoeven slechts de adviezen van niet-ambtelijke adviesinstanties openbaar te maken; en voor de overige openbare lichamen wordt niets geregeld. ${ }^{147}$

Een derde kritiekpunt betreft de wijze waarop het wetsontwerp de openbaarheid wil regelen van de adviezen van de Raad van State zelf. Het ontwerp zou duidelijkheid moeten verschaffen over het moment van publikatie van die adviezen, vindt de Raad. Daartoe zou een onderscheid moeten worden gemaakt tussen adviezen over wetsontwerpen, en adviezen over voorgenomen algemene maatregelen van bestuur. De publikatie van een advies zou dan moeten geschieden bij de indiening van het betreffende wetsontwerp, respectievelijk bij de afkondiging van de algemene maatregel van bestuur. "Het ware te overwegen een daartoe strekkende bepaling in de wet op te nemen met een voorbehoud voor spoedgevallen", zegt de Raad van State. ${ }^{148}$ Daarnaast wil de Raad in de wet vastgelegd zien, dat bij de publikatie van het advies mede wordt overgelegd de tekst van het ontwerp en de memorie van toelichting, "zoals deze luidden bij de aanhangigmaking bij de Raad van State". En tenslotte, ook als blijkens het nader rapport aan het staatshoofd een voorstel buiten verdere behandeling zal worden gelaten, zou het advies van de Raad niet van openbaarmaking moeten worden uitgesloten. Want, zegt de Raad: "Het kan voor de beoordeling van een ontwerp van belang zijn ook vroegere ontwerpen en de daaromtrent uitgebrachte adviezen te kennen". ${ }^{149}$

\section{De Overijsselse openbaarheids-regeling}

Het kabinet heeft na de ontvangst van het op 27 november 1974 gedateerde advies van de Raad van State nog een klein half jaar nodig om het ontwerp bij te stellen. Intussen weet de buitenwereld niet meer dan dat er aan het stuk gesleuteld wordt. Noch het ontwerp zelf, noch het advies van de Raad van State zijn openbaar gemaakt. Gedeputeerde staten van Overijssel, die het wachten een beetje moe zijn, besluiten met ingang van 1 januari 1975 te gaan experimenteren met een eigen provinciale interimregeling voor openbaarheid van bestuur. Daarin wordt bepaald, dat ambtelijke adviezen en ook stukken van derden, in bezit van de provincie, op verzoek openbaar worden gemaakt, behoudens een aantal weigeringsgronden,; die vergelijkbaar zijn met die van het ontwerp van de Commissie Biesheuvel. De verplichting tot openbaarmaking lijdt volgens de interimregeling voorts uitzondering, "wanneer de voorbereiding van de besluitvorming nog niet in

148 Id. pag. 3. Cursivering van mij, HK.

149 Id. pag. 8. 
een zodanig stadium verkeert, dat op dat moment openbaarheid in redelijkheid van belang geacht kan worden voor een goede en democratische bestuursvoering". De bij de provincie berustende stukken van derden kunnen slechts openbaar worden gemaakt met instemming van die derden. Daarom worden de relaties van de provincie in december 1974 aangeschreven met de vraag, of zij ermee instemmen dat hun stukken desgerraagd openbaar worden.

De vraag bereikt uiteraard ook de rijksoverheid, en het is zowaar de minister-president zelf die antwoordt. Hij zegt liever te zien, dat Overijssel haar regeling opschort. Gedeputeerde staten delen hem echter mee, dat daar geen sprake van kan zijn. Op vragen van de senatoren Eisma (D66) en Troostwijk (PvdA) mag premier Den Uyl op 11 februari 1975 in de Eerste Kamer eens precies uitleggen, hoe hij tegen de zaak aankijkt. De minister-president uit dan zijn vrees, dat niemand in Nederland meer zal weten waar hij aan toe is, als alle overheidsorganen eigen regelingen treffen. Daarom heeft hij gedeputeerde staten "allervriendelijkst" verzocht te wachten tot de indiening van een wetsontwerp. Maar overigens tilt hij niet te zwaar aan het Overijsselse experiment. "Het is geen aangelegenheid om messen over te trekken", verzekert de premier. Op de vraag van Eisma of in het wetsontwerp ook de openbaarheid wordt geregeld van documenten van andere besturen dan de centrale overheid, antwoordt hij: "Dat is inderdaad de bedoeling, zij het niet over de hele linie". ${ }^{150}$ Strikt onwaar is dit antwoord niet. Maar het geeft ook niet echt een juiste voorstelling van zaken.

\section{De indiening van het wetsontwerp bij de Tweede Kamer}

Op 26 mei 1975 wordt het ontwerp voor een Wet openbaarheid van bestuur bij de Tweede Kamer ingediend. ${ }^{151}$ Het blijkt, dat de regering de hierboven genoemde kritiek van de Raad van State op een aantal punten ter harte heeft genomen.

Allereerst wordt nu, zij het met een royale ontsnappingsclausule, aan de burger een recht op informatie gegeven. Het eerste lid van artikel 1 van het ontwerp bepaalt, dat een verzoek om informatie, gericht tot een orgaan van de centrale overheid, wordt ingewilligd, tenzij daartegen bezwaar bestaat op één van de in artikel 4 genoemde gronden. Dit artikel 4 bevat specifieke weigeringsgronden die vrijwel overeenkomen met die van

150 Hand. EK 1974-1975 pag. 246-258. Zie ook H. Schelhảs, De informatieplicht wan de overheid, Zwolle 1979 "pag. 74-77.

151 TK 1974-1975, 13418 nrs. $\mathbb{t} / \mathrm{m} 4$. 
artikel 3 van het eerdere ontwerp, en grotendeels dezelfde zijn als die van artikel 10 van de huidige wet. Maar het tweede lid van artikel 1 van het ontwerp voegt daar nog een facultatieve weigeringsgrond aan toe: "Op een verzoek om informatie kan afwijzend worden beslist indien inwilliging daarvan in redelijkheid niet in overeenstemming kan worden geacht met de eisen van een goede en democratische bestuursvoering". Die mogelijkheid levert natuurlijk gevaar voor bestuurlijke willekeur op. En om dat enigzins te beperken, luidt het derde lid: "Bij of krachtens algemene maatregel van bestuur worden regelen gesteld omtrent de toepassing van het bepaalde in het eerste en het tweede lid". Bovendien, zo stelt de memorie van toelichting. zal de burger bij weigering van informatie in beroep kunnen gaan bij de Afdeling rechtspraak van de Raad van State, die in 1976 als algemene administratieve rechter zal gaan fungeren. ${ }^{152}$

Buiten deze plicht tot informatieverstrekking op verzoek, formuleert het ontwerp in artikel 2 de ministeriële plicht om uit eigen beweging informatie te verschaffen, "zodra dit in het belang is van een goede en democratische bestuursvoering." En schept artikel 3 de plicht om adviezen van niet-ambtelijke adviesinstanties binnen drie weken na ontvangst te publiceren; althans die adviezen, die "met het oog op het te vormen bestuursbeleid" zijn uitgebracht, en voor zover de geheimhoudingsgronden van artikel 4 niet van toepassing zijn. ${ }^{153}$

Het advies van de Raad van State heeft de regering er niet toe kunnen overhalen, om in het ontwerp ook een algehele openbaarheidsregeling voor de lagere overheden voor te stellen. Want, zo lezen we in de memorie van toelichting, zolang nog geen ervaring is opgedaan met een rijksregeling voor openbaarheid, is één regeling voor alle overheidslagen onverantwoord. De regering vindt zelfs het wenselijk, dat de lagere overheden terughoudendheid betrachten totdat, na afsluiting van het overleg over het ontwerp met de Staten-Generaal, het overleg met de overige openbare lichamen een aanvang kan nemen. ${ }^{154}$

De regering heeft in het ontwerp wel een aantal suggesties van de Raad van State verwerkt, om tot een scherpere regeling van de openbaarheid van de adviezen van de Raad te komen. Zo wordt nu voorgesteld, om de adviezen inderdaad gelijktijdig met de indiening van de wetsontwerpen, respectievelijk met de afkondiging van algemene maatregelen van bestuur te publiceren. Maar de ontsnappingsclausule, om bij spoedgevallen eerder

153 De woorden: "met het oog op het te vormen (bestuurs)beleid" betekenen volgens pag. 17 van de Mv'T, dat het niet om adviezen over individuele gevallen gaat. 
te publiceren; acht de regering niet nodig, lezen we in het nader rapport aan de Koningin. Volgens datzelfde rapport honoreert de regering wel de wens van de Raad van State, dat ook adviezen over voorstellen die buiten verdere behandeling blijven, kunnen worden gepubliceerd. ${ }^{155}$ Maar de tekst van artikel 9 van het ontwerp, dat als artikel 25 a van de Wet op de Raad van State zal worden ingevoerd, is nogal twijfelachtig op dit punt, en zal later anders worden uitgelegd.

\section{Voorlopig verslag en memorie van antwoord}

$\mathrm{Na}$ ontvangst van het wetsontwerp stelt de Tweede Kamer een bijzondere commissie in, en deze organiseert, ter voorbereiding van het voorlopig verslag over het ontwerp, op 10 december 1975 een openbaar gehoor.

\section{De hoorzitting in de Tweede Kamer}

Verschillende maatschappelijke organisaties brengen tijdens die zitting hun zienswijze naar voren: de Vereniging van Voorlichtingsambtenaren van lagere publiekrechtelijke lichamen, de Raad van Nederlandse Werkgeversbonden, de Nederlandse Vereniging van Journalisten, de gezamenlijke centrales van overheidspersoneel, en een aantal samenwerkende instellingen voor begeleiding van inspraakprojecten. Het verslag van dit openbaar gehoor maakt al duidelijk wat de controversiële punten tijdens de verdere parlementaire behandeling zullen zijn. ${ }^{156}$

De Nederlandse Vereniging van Journalisten en de samenwerkende inspraakinstellingen hebben groot bezwaar tegen de facultatieve weigeringsgrond van artikel 1 lid 2 van het ontwerp; die bepaling kan zonder meer worden geschrapt, vindt de journalistenvereniging, die bovendien meent, dat aan de burger niet alleen recht op informatie, mar ook recht op inzage in de stukken zelf moet worden gegeven. Evenals de Vereniging van Voorlichtingsambtenaren van lagere publiekrechtelijke lichamen, hebben de journalisten en de inspraakinstellingen ook grote moeite met artikel 6, dat de openbaarheid bij lagere overheden beperkt tot publicatie van niet-ambtelijke adviezen, en experimenten bij deze overheden lijkt te verbieden. En voorts zijn de inspraakinstellingen weinig gelukkig met het voorstel om een Raad voor de openbaarheid van bestuur op te richten:

155 Nader rapport aan de Koningin van 15 mei 1975, "TK 1976-1977, 13418 nr. 13, resp. pag. 31 en 34 .

156 TK 1975-1976, 13418, nr. 5. 
"Immers de bevordering van de openbaarheid van bestuur vereist telkens politieke initiatieven en een politieke controle. Het optreden van een algemene raad op dit gebied zal een neutraliserend effect hebben".

De centrales voor overheidspersoneel zijn bang, dat het wetsontwerp door zijn vage formuleringen en raamwet-karakter de positie van de ambtenaar zal aantasten. Om het ontwerp goed te kunnen beoordelen, zouden eerst ontwerpen voor de uitvoeringsmaatregelen ter tafel moeten komen, die duidelijk maken wanneer het verstrekken van informatie "in redelijkheid niet in overeenstemming kan worden geacht met de eisen van een goede en democratische bestuursvoering". De centrales vinden in elk geval, dat de plicht tot openbaarmaking van thans nog interne stukken "de vertrouwensbasis waarop een loyaal ambtenarenapparaat aan het overheidsbeleid meewerkt, kan aantasten". En de raad van werkgeversbonden heeft twijfels over artikel 4 van het wetsontwerp. De daarin genoemde geheimhoudingsgronden zouden te weinig zekerheid bieden voor de geheimhouding van door het bedrijfsleven vertrouwelijk aan de overheid verstrekte gegevens.

\section{Het voorlopig verslag}

Op 6 maart 1976 verschijnt het voorlopig verslag van de bijzondere kamercommissie. Het blijkt dan, dat de kamerfracties goed nota hebben genomen van wat er bij de verschillende maatschappelijke groeperingen leeft ten aanzien van het ontwerp voor de Wet openbaarheid van bestuur. ${ }^{157}$ Ter rechter zijde plaatst de SGP vraagtekens bij de noodzaak en urgentie van het ontwerp, en heeft het GPV moeite met de gedachte, dat de macht van de burger tegenover de overheid moet worden vergroot. En ter linker zijde leeft bij PPR en PSP de grootste twijfel, of de regering werkelijk wel "de macht met de burgers wil delen", en of het ontwerp verdergaande openbaarheid niet zal afremmen, in plaats van bevorderen. ${ }^{158}$ Daartussenin richten de fracties van de grotere partijen hun kritiek vooral op bepaalde punten wan het ontwerp. Zo zegt bijvoorbeeld de KVP het te betreuren, dat het wetsontwerp niets bepaalt over de openbaarheid van kabinetsformaties, en zich ook niet uitlaat over eventuele openbaarheid van vergaderingen van de ministerraad. ${ }^{159}$

Alle fracties, inclusief die van SGP, GPV, PPR en PSP, verklaren grote moeite te hebben met artikel 1 lid 2 van het ontwerp, dat het moge-

158 De CPN laat in het verslag geen eigen geluid horen.

159 VV pag. 1 en 2. 
lijk maakt verstrekking van informatie te weigeren, wanneer die verstrekking "in redelijkheid niet in overeenstemming kan worden geacht met de eisen van een goede en democratische bestuursvoering". Maar de bezwaren tegen deze bepaling hebben een verschillende achtergrond. KVP, CHU en VVD zijn vooral bezorgd voor de onduidelijkheid die artikel 1 lid 2 in het leven roept met betrekking tot de positie van de ambtenaar. Het individuele aandeel van ambtenaren in de voorbereiding van de besluitvorming moet buiten de sfeer van de openbaarheid worden gehouden, vindt de VVD. De positie van de ambtenaar komt in het gedrang, als geheimhouding van zijn adviezen niet is verzekerd, betoogt de $\mathrm{CHU}$, die bovendien vindt, dat de regering duidelijk moet maken, wat zij onder het begrip "documenten" verstaat. En de KVP wil meer weten over de positie van de "politiserende ambtenaar", voordat de geest uit de fles wordt gelaten. PvdA, PPR, PSP en D66 tonen zich daarentegen meer bezorgd over de onduidelijkheid die het artikel voor de burger zal scheppen met betrekking tot diens recht op informatie. D66 vindt dat ambtelijke stukken in het algemeen best openbaar kunnen zijn. Ze pleit voor de Overijsselsche regeling die bepaalt dat, behoudens specifieke geheimhoudingsgronden, de stukken wel openbaar zijn, behalve "wanneer de voorbereiding van de besluityorming nog niet in een zodanig stadium verkeert, dat op dat moment openbaarheid in redelijkheid van belang kan worden geacht voor een goede en democratische bestuursvoering". In elk geval zijn alle fracties het erover eens dat de ongenormeerde delegatiebepaling van artikel 1 lid 3, die simpel zegt dat "bij of krachtens algemene maatregel van bestuur" regelen worden gesteld omtrent de toepassing van het eerste en tweede lid, eigenlijk niet acceptabel is. Althans niet, voordat de regering middels een ontwerp-algemene maatregel heeft laten zien, hoe zij die bepaling denkt uit te werken. ${ }^{160}$

Voor vrijwel alle fracties is ook artikel 6 , dat de openbaarheid bij gemeenten en provincies lijkt te beperken tot adviezen van niet-ambtelijke adviesinstanties, een onverteerbare bepaling. Het zou voor de bestaande openbaarheid in veel gemeenten en provincies een achteruitgang betekenen, en bovendien de mogelijkheid voor experimenten afsnijden, is de algemene opvatting. Verschillende fracties betwijfelen, of de wet op dit gebied nu al iets voor deze overheden moet regelen. En als dat all moet, dan vinden de fracties van PvdA, KVP, ARP, en CHU de Provinciewet en de Gemeentewet daarvoor de aangewezen plaats. ${ }^{161}$ 


\section{Absolute en relatieve geheimhoudingsgronden}

Bijna alle fracties plaatsen vraagtekens bij de specifieke geheimhoudingsgronden, die in artikel 4 worden genoemd. Het ontwerp makt daar onderscheid tussen absolute en relatieve geheimhoudingsgronden. Van een relatieve geheimhoudingsgrond is sprake, als het belang van openbaarheid in een concrete situatie niet opweegt tegen een ander belang, bijvoorbeeld de goede betrekkingen van Nederland met andere landen (in artikel 4 onder $c$ in het ontwerp). De vragen zijn er veelal op gericht om toelichting te krijgen, maar soms ook kritisch van aard. Zo zijn de fracties van KVP, ARP, CHU en GPV er niet gerust op, dat de geheimhouding van vertrouwelijk door bedrijven aan de overheid verstrekte gegevens, voldoende wordt verzekerd door de relatieve weigeringsgrond van artikel 4 onder $h$. Die zegt, dat openbaarmaking van gegevens achterwege blijft, als het belang daarvan niet opweegt tegen het belang van het voorkomen van bevoordeling of benadeling van bij de aangelegenheid betrokken personen of derden. De fracties verlangen op dit punt een nadere toelichting van de regering. ${ }^{162}$

\section{Overige punten in het voorlopig verslag}

Een belangrijk punt van aandacht is ook de openbaarheid van de adviezen van de Raad van State. De kamercommissie merkt daarover fijntjes op, "dat de Regering in de geest van het wetsontwerp zou hebben gehandeld wanneer zij tegelijk met de indiening van het wetsontwerp het advies dat de Raad van State ter zake heeft uitgebracht aan de Kamer zou hebben overlegd". [..] "Nu de Regering daartoe niet op eigen initiatief is overgegaan, zou de commissie haar willen uitnodigen het advies alsnog over te leggen, vanzelfsprekend tezamen met de oorspronkelijk aan de Raad voorgelegde tekst van het wetsontwerp alsmede het nader rapport". ${ }^{163}$ Verder heeft met name de KVP-fractie bedenkingen tegen de bepaling, dat de adviezen van de Raad die betrekking hebben op algemene maatregelen van bestuur pas tegelijk met de afkondiging van die maatregelen openbaar zullen worden gemaakt. De openbaarmaking zal dan "altijd te laat zijn om vanuit de samenleving en/of de Staten-Generaal tot wijziging van de maatregel te kunnen komen", constateert de fractie. De fractie van de CHU toont zich bezorgd, of de openbaarmaking van door de Raad spontaan uitgebrachte adviezen wel voldoende verzekerd is. Artikel 9 van het

163 Id. pag. 28. De regering zal aan deze uitnodiging gehoorgeven door de gevraagde stukken bij de memorie van antwoord aan de Kamer over te leggen. 
ontwerp, dat als artikel 25a in de Wet op de Raad van State zal worden ingevoerd, spreekt daar niet over. De CHU neemt echter aan, dat in die situaties artikel 3 van het ontwerp van toepassing is, waarin een algemene regeling wordt gegeven voor de openbaarheid van adviezen van niet-ambtelijke adviesinstanties. Maar dat zou betekenen, dat de openbaarmaking alleen maar hoeft te worden bekendgemaakt in de Staatscourant. Dat lijkt de CHU-fractie niet voldoende. Zij vindt het noodzakelijk, dat de wet voorschrijft, dat de bekendmaking in alle landelijke dagbladen plaatsvindt. ${ }^{164}$

Tenslotte nemen een aantal fracties het voorstel voor de instelling van een "Raad voor de openbaarheid van bestuur" onder schot. PvdA, VVD, ARP, PPR en GPV zeggen "in het geheel niet overtuigd te zijn van de noodzaak tot instelling" van zo'n raad. Zij menen, dat de regering de waarschuwing van de WRR tegen de wildgroei van beleidsvoorbereidende organen in de wind slaat. De D66-fractie ziet wel een bestaansreden voor een raad, mits deze de taak krijgt om bij klachten van burgers "op zeer korte termijn een bindend advies" aan de regering uit te brengen. ${ }^{165}$

\section{De memorie van antwoord}

In de memorie van antwoord, die de Tweede Kamer op 13 oktober 1976 ontvangt, gaat de regering in op de in het voorlopig verslag gemaakte opmerkingen. ${ }^{166}$ De betrokken bewindslieden, premier Den Uyl en minister van Binnenlandse Zaken De Gaay Fortman, hebben met voldoening kennis genomen van het feit, dat met name de fracties van PvdA, KVP en ARP hun instemming met het wetsontwerp hebben betuigd. Op de concrete vraag van de KVP over openbaarheid ten aanzien van de ministerraad antwoorden de bewindslieden, dat het niet in de bedoeling ligt de angenda van die raad te publiceren. Maar de wekelijkse persconferentie na afloop van de ministerraad heeft naar hun indruk inmiddels wel "burgerrecht verkregen". ${ }^{167}$ Wat betreft het opnemen van een openbaarheidregeling in de nieuwe Grondwet, iets waarop door de fracties van de PvdA en de PPR is aangedrongen, wordt meegedeeld dat de regering inderdaad voornemens is, ook een algemeen openbaarheidsartikel in de Grondwet op te nemen. ${ }^{168}$

166 TK 1976-1977, $13418 \mathrm{nrs.} 7$ en 8.

167 MvA pag. 3.

168 Id. pag. 7. De bewindslieden verwijzen hierbij ook naar de Nota inzake het grondwetsherzieningsbeleid (TK 1973-1974, 12944 nr. 2). 
De bewindslieden komen in de memorie van antwoord al snel te spreken over artikel 1 lid 2 van het wetsontwerp. De brede kritiek op de bepaling, dat een verzoek om informatie kan worden afgewezen als inwilliging "in redelijkheid niet in overeenstemming kan worden geacht met de eisen van een goede en democratische bestuursvoering", heeft de regering nog eens aan het denken gezet. En inmiddels heeft zij uit verschillende bronnen ook genoeg kennis verworven, om ter uitwerking van artikel 1 een voorontwerp van een algemene maatregel van bestuur op te stellen. Dat. voorontwerp hebben de bewindslieden als bijlage bij de memorie van antwoord gevoegd. De fracties kunnen zich nu zelf overtuigen van de goede bedoelingen van de regering. Bovendien is het facultatieve karakter van de wetsbepaling, dat afwijzend kan worden beslist, weggenomen door het woordje "kan" te schrappen.

Kijken we nu in het voorontwerp van de algemene maatregel van bestuur, die als titel draagt "Regelen betreffende de openheid en openbaarheid van bestuur", dan vinden we daar in artikel 4 een bepaling die enigszins doet denken aan de Overijsselsche interimregeling. De in artikel 1 lid 2 van het wetsontwerp genoemde weigeringsgrond wordt daar beperkt tot verzoeken om informatie, vervat in documenten die zijn opgesteld ten behoeve van intern beraad. Zulke verzoeken worden volgens het voorontwerp ingewilligd behoudens voor zover zij betrekking hebben op:

a. gegevens, die nog in bewerking zijn of die, hoewel gereed, een onjuist beeld zouden geven omdat zij nog met andere moeten worden aangevuld;

b. persoonlijke beleidsopwattingen van bewindslieden, bestuurders of ambtenaren. Over de in deze documenten vervatte beleidsalternatieven wordt echter wel informatie verstrekt.

Verschil met de Overijsselsche regeling is echter, dat die niet de onder b genoemde weigeringsgrond kent.

Letten we op dit verschil, dan wordt meteen duidelijk waar voor de regering en, zoals uit het voorlopig verslag al bleek, voor verschillende fracties de schoen wringt: de positie van de ambtenaren. Want dat zijn toch vooral degenen die stukken opstellen ten behoeve van intern beraad. De regering verklaart in de memorie van antwoord dan ook nadrukkelijk, dat zij niet wil dat het wetsontwerp een principiële verandering in de positie van de ambtenaar teweeg zal brengen. De burger moet op de hoogte kunnen komen van alle informatie, inclusief de overwogen beleidsalternatieven, waarover hij moet kunnen beschikken om het beleid te kunnen beoordelen. Maar de ambtenaar blijft in de uitoefening van zijn functie uitsluitend verantwoording verschuldigd aan zijn bewindsman of bestuur- 
ders, en wordt niet betrokken in de politieke strijd op thet gebied van zijn functie. Ook de Centrale Ambtenarenorganisaties verwachten, aldus de regering, dat deze constructie "aanvaardbare waarborgen biedt voor de bescherming van de ambtelijke rechtspositie". ${ }^{169}$ Van KVP-zijde is er op gewezen dat een ambtelijk stuk, dat in de openbaarheid komt; door "iedere handige journalist" geïdentificeerd kan worden, zodat het niet helpt om bij die stukken de namen van de betrokken ambtenaren niet te vermelden. De regering zegt in haar memorie van antwoord: "Dit is echter nu ook al zo.[..] Aan de rechtspositie van de ambtenaar wordt hierdoor geen schade berokkend omdat bewindslieden of bestuurders voor de inhoud van deze geschriften de verantwoordelijkheid dragen". ${ }^{170}$

Op vragen van de PSP-fractie, hoe een burger moet weten naar welke documenten hij moet vragen, antwoordt de regering, dat de burger niet naar documenten hoeft te vragen. Volgens artikel 2 van het voorontwerp Regelen betreffende de openheid en openbaarheid van bestuur vermeldt hij bij zijn verzoek "de aangelegenheid waarover hij informatie wenst te ontvangen". En ter beantwoording van vragen van de KVP-fractie wijst de regering gelijk ook op artikel 6 van hetzelfde voorontwerp: bij het kiezen tussen de vormen van informatie richt het overheidorgaan zich naar de voorkeur van de verzoeker, met dien verstande dat het belang van een vlotte voortgang der werkzaamheden in de overweging wordt betrokken, en het verstrekken van informatie over documenten die zijn opgesteld ten behoeve van intern beraad "in objectiverende vorm geschiedt". ${ }^{171}$

In de memorie van antwoord blijkt ook, dat de regering zich nog eens goed heeft beraden op de kritiek, dat het wetsontwerp de openbaarheid bij provincies en gemeenten minimaliseerde tot openbaarheid van adviezen van niet-ambtelijke adviesinstanties. Slotsom is, behalve dat term "adviesinstantie" vervangen wordt door "adviescommissie", dat voor provincies en gemeenten nu eenzelfde openbaarheidsregime zal gaan gelden als voor de rijksoverheid. De suggestie van de fracties van PvdA, KVP, ARP en $\mathrm{CHU}$, om de openbaarheid bij die lagere overheden te regelen in de Provinciewet en de Gemeentewet, is door de regering niet gevolgd: "De algemene bepalingen over openbaarheid [..], die zowel voor het Rijk als

170 Id. pag. 18.

171 Id. pag. 31, 32, 37 en 38. Met "in objectiverende vorm" wordt bedoeld, dat geen informatie wordt gegeven over de standpunten van bepaalde bestuurders of ambtemaren. 
voor de provincies en gemeenten gelden, horen naar onze mening thuis in een algemene wet en wel in een wet openbaarheid van bestuur". ${ }^{172}$

\section{Nogmaals de absolute en relatieve geheimhoudingsgronden}

Wat betreft de specifieke geheimhoudingsgronden van artikel 4 van het wetsontwerp, wil de regering nog wel het een en ander toelichten, maar eigenlijk niet veel meer veranderen. Naar aanleiding van de vraag van de SGP-fractie, of de meeste van die gronden niet politiek zijn bepaald, zegt de memorie van antwoord, dat dat nauwelijks een bezwaar kan zijn. Immers, de toepassing van deze bepalingen zal worden getoetst door de Afdeling Rechtspraak van de Raad van State. Ook het bezwaar van de fracties van KVP, ARP CHU en GPV dat het wetsontwerp niet garandeert, dat vertrouwelijk aan de overheid verstrekte gegevens geheim zullen blijven, wordt door de regering niet gedeeld. Natuurlijk moet het belang van degene die wenst dat door hem verstrekte gegevens geheim worden gehouden, zwaar wegen. Maar dat het kenbaar maken van die wens zelf al een absolute geheimhoudingsgrond zou opleveren, gaat de regering te ver. "Particulieren zouden, op deze wijze handelende, het effect van de wet voor een groot deel teniet kunnen doen", zegt de memorie van antwoord. ${ }^{173}$

\section{Overige punten in de memorie van antwoord}

Vervolgens stelt de memorie de openbaarheid van de adviezen van de Raad van State aan de orde. Op het bezwaar van de KVP-fractie tegen de bepaling, dat de adviezen van de Raad die betrekking hebben op algemene maatregelen van bestuur, pas tegelijk met de afkondiging van die maatregelen openbaar worden gemaakt, heeft de regering een tweeledig antwoord. Zij blijft van mening, dat de wet niet als vaste regel moet voorschrijven, dat dergelijke adviezen eerder moeten worden gepubliceerd. Het karakter van de algemene maatregel van bestuur als zodanig zou dan veranderen. "Materieel zouden de Staten-Generaal er een zekere medeverantwoordelijkheid voor gaan dragen". Anderzijds erkent de regering, "dat er bijzondere omstandigheden kumnen zijn, die het vooraf overleggen van de tekst van voorontwerp-algemene maatregel van bestuur aan de Statengeneraal wenselijk maken". Maar die figuur moet "beperkt blijven tot gevallen, waarin daartoe aanleiding is". De regering acht het "onwenselijk 
haar algemeen verplicht te stellen". ${ }^{174}$ Tijdens de algemene beraadslagingen in de Tweede Kamer zall blijken, dat de regering hiermee bedoeld dat een dergelijke stuk zonodig spontaan openbaar kan worden genaakt. Ik kom daar in de volgende paragraaf nog op terug bij de bespreking van het amendement-Kappeyne van de Coppello.

Het gewijzigd wetsontwerp, dat bij de memorte van antwoord wordt gevoegd, bevat over de vraag, welke teksten openbaar moeten worden gemaakt, geen erg duidelijke formulering. In het wetsontwerp was aanvankelijk bepaald, dat openbaarmaking van de adviezen van de Raad van State geschiedt "te zamen met de aan de Raad voorgelegde tekst". In het gewijzigd ontwerp wordt daaraan toegevoegd: "voor zover daarin wijzigingen zijn aangebracht nadat het advies is gevraagd". Sinds de privatisering van de Staatsuitgeverij wordt "de aan de Raad voorgelegde tekst" gewoonlijk niet meer bij de kamerstukken afgedrukt, maar in enkelvoud ter inzage gelegd bij de leeszaal van de Tweede Kamer.

Over het plan voor een Raad voor de openbaarheid van bestuur, en de negatieve reacties daarop in het voorlopig verslag; merkt de regering op, dat de raad niet meer nodig is. De raad was bedoeld als tegenwicht tegenover de vaagheid van artikel 1 van het wetsontwerp. Nu inmiddels ter concretisering van dit artikel een voorontwerp voor een algemene maatregel van bestuur tot stand is gekomen, "is een belangrijk argument voor de instelling van een dergelijk college vervallen". ${ }^{175}$ In plaats van de instelling van een raad, schrijft het gewijzigd ontwerp nu voor, dat de ministerpresident en de minister van Binnenlandse Zaken binnen drie jaar, en vervolgens om de vijf jaar aan de Staten-Generaal een evaluatie-verslag moeten zenden over de toepassing van de wet.

\section{De besluitvorming over het wetsvoorstel}

Het eindverslag van de Tweede Kamer over het ontwerp voor een Wet openbaarheid van bestuur en het antwoord van de regering in haar nota naar aanleiding van het eindverslag bevatten grotendeels een herhaling van zetten. ${ }^{176}$ Op de vraag van de kamercommissie, wanneer een voorstel voor een algemeen openbaarheidsartikel in de nieuwe Grondwet zal worden ingediend, antwoordt de regering dat zij nooit heeft gesteld, dat in de

176 Eindverslag van 8 december 1976, TK 1976-1977, $13418 \mathrm{nr}$. 14, resp. Nota naar aanleiding van het eindverslag, ontwangen op 29 december 1976, TK 13418 nr. 15. 
Grondwet een algemeen recht op informatie zou worden opgenomen. De kwestie van het recht om inlichtingen te garen en te ontvangen is inmiddels behandeld in het schriftelijk overleg over wetsontwerp 13872 (grondwetswijziging inzake grondrechten). De regering heeft zich daar op het standpunt gesteld, dat er onvoldoende aanleiding is dit recht in de Grondwet op te nemen. De Kamer, zegt de regering, heeft toen niet voorgesteld zo'n recht wél op te nemen. 177 De vraag van de kamercommissie, of documenten die betrekking hebben op kabinetsformaties ook documenten zijn in de zin van de beoogde Wet openbaarheid van bestuur, wordt in de nota positief beantwoord. Maar daarmee is uiteraard nog niet gezegd dat die documenten openbaar zijn. ${ }^{178}$

\section{Gevoelige onderwerpen}

In het eindverslag worden ook weer beschouwingen gewijd aan artikel 1 lid 2 van het gewijzigd wetsontwerp. Dit artikel bepaalt nu, dat een verzoek om informatie moet worden afgewezen, als inwilliging daarvan in redelijkheid niet in overeenstemming kan worden geacht met de eisen van een goede en democratische bestuursvoering. Om aannemelijk te maken, dat de regering hiermee geen al te grote beleidsvrijheid aan bewindslieden en bestuurders wil geven, heeft zij bij de memorie van antwoord al een voorontwerp van een algemene maatregel van bestuur aan de kamercommissie overgelegd. Daarin wordt; zoals we eerder hebben gezien, de weigeringsgrond beperkt tot stukken die zijn opgesteld ten behoeve van intern beraad. Bovendien wordt in dit voorontwerp aangegeven, wanneer de eisen van een goede en democratische bestuursvoering in het geding zijn. Dat zou het geval zijn als het gaat om gegevens die nog in bewerking zijn of een vertekend beeld geven, of als het gaat om persoonlijke beleidsopvattingen van bewindslieden, bestuurders of ambtenaren. De fracties van KVP, ARP, CHU, SGP en VVD vragen zich nu af, of de woorden waarmee artikel 1 lid 2 in de beoogde algemene maatregel van bestuur is uitgewerkt, niet beter in de wet zelf kunnen worden opgenomen. Aldus zou het wetsontwerp voor een belangrijk deel zijn "raamwet"-karakter verliezen, en aan de burger een veel concreter recht op informatie geven. ${ }^{179}$

Niettemin blijven met name de KVP, ARP en CHU bezord over de positie van de ambtenaar. Dat de regering opmerkt, dat de verantwoordelijkheid voor ambtelijk optreden naar buiten blijft berusten bij de betrok-

Nota n.a.v. eindverslag pag. 1.

178 Id. pag. 2.

179 Eindverslag pag. 2-3. 
ken bewindsman of bestuurder, juichen de fracties van deze partijen natuurlijk toe. Maar hoe verhoudt deze opmerking zich tot de stelling van de regering, dat een minister geen bezwaar meer zal kunnen maken, als een ambtenaar straks informatie verschaft overeenkomstig de bepalingen van de nieuwe openbaarheidswet? En vreest de regering niet, dat het "uitermate moeilijk" zal zijn, om onderscheid te maken tussen door een ambtenaar naar voren gebrachte beleidsalternatieven en persoonlijke beleidsopvattingen? ${ }^{180}$ Uit deze vragen blijkt wel, dat de fracties van deze partijen zich eigenlijk nog niet kunnen voorstellen, wat het betekent om de burger een recht op informatie te geven.

De regering zegt in de nota naar aanleiding van het eindverslag te willen vasthouden aan een constructie, waarin niet in de wet zelf, maar in een algemene maatregel van bestuur wordt uitgewerkt, wat eisen van een goede en democratische bestuursvoering zijn. Aldus kan op onvoorziene casus-posities snel en soepel worden gereageerd: ${ }^{181}$ Voorts is de regering niet bang, dat in de praktijk geen onderscheid zal kunnen worden gemaakt tussen beleidsalternatieven en persoonlijke beleidsopvattingen. Wel kan het voorkomen, dat een ambtelijk stuk, waarvan de opsteller mocht aannemen dat het niet in de openbaarheid zou komen, eigenlijk niet te "depersonifieren" is. In zo'n geval is voor publikatie de instemming van de betrokkene vereist. Overigens kan bijvoorbeeld een bewindsman zijn voornemen tot integrale publikatie van een stuk ook kenbaar maken, vóórdat ambtenaren aan de totstandkoming daarvan hun bijdrage leveren. In alle gevallen blijft de bewindsman politiek verantwoordelijk voor het stuk en de publikatie daarvan, vindt de regering. Dat geldt niet minder, als het ambtenaren zelf zijn, die op grond van de bepalingen van de nieuwe wet informatie (moeten) verschaffen. ${ }^{182}$

Op de vraag van de PvdA-fractie, of het niet ongrondwettig is om, buiten de Provinciewet en Gemeentewet om, voor provincies en gemeenten openbaarheidsvoorschriften vast te stellen, wordt door de regering ontkennend geantwoord. Er zijn genoeg andere wetten, zoals bijvoorbeeld de Ambtenarenwet en de Wet kapitaaluitgaven publiekrechtelijke lichamen, die deze overheden ook aan voorschriften binden, zegt de nota naar aanleiding van het eindverslag. ${ }^{183}$

Ook de vraag van KVP, ARP en CHU, hoe het openbaar maken van correspondentie met particulieren, te rijmen valt met "het goede gebruik in

181 Nota n.a.v. het eindverslag pag. 3.

182 Id. pag. 4-5.

183 Id. pag. 3. 
ons land", om zulks niet te doen zonder de instemming van betrokkenen, levert voor de regering geen nieuw gezichtspunt op. Brieven van particulieren kunnen niet zonder meer openbaar worden gemaakt als het bevoegd gezag dit wenst, schrijven de bewindslieden. Op grond van artikel 4 van het wetsontwerp zullen brieven dikwijls geheim moeten blijven. Eerbiediging van de persoonlijke levenssfeer, en voorkoming van onevenredige bevoordeling of benadeling zijn in deze gevallen de meest voor de hand liggende weigeringsgronden. Maar het zijn geen absolute weigeringsgronden. Het belang van openbaarmaking kan in bepaalde gevallen zó groot zijn, dat het bevoegd gezag dit zwaarder moet laten wegen. ${ }^{184}$

Een verwarrend onderwerp blijft de openbaarheid van de adviezen van de Raad van State, en van de stukken die om advies aan deze raad worden toegezonden. De fracties van KVP, ARP en CHU willen wel eens de mening van de regering weten over een voorstel van P.J. Boukema, in het dagblad Trouw van 16 februari 1976, om wetsontwerpen aan de Raad van State voor te leggen vóórdat zij in de ministerraad worden behandeld. In de nota naar aanleiding van het eindverslag zegt de regering hier niets voor te voelen. In ons staatsbestel adviseert de Raad van State de regering in laatste instantie. "Toezending van ontwerpen vóór behandeling in de Ministerraad zou derhalve impliceren dat men de raad tweemaal om advies zou moeten vragen", schrijven de bewindslieden. De regering heeft er geen bezwaar tegen als de hoofdzaken van het beleid, zoals deze in een wetsontwerp zijn neergelegd, bekend worden gemaakt, nadat de ministerraad daarmee akkoord is gegaan. $\mathrm{Zij}$ zou het echter onjuist vinden als het kabinet de tekst van een ontwerp van wet, waarover in de ministerraad overeenstemminig is bereikt, maar waarover de Raad van State nog moet adviseren, zou publiceren. ${ }^{185}$

Onterecht vinden de bewindslieden het ongenoegen bij de VVDfractie. Die betreurt het, dat de regering tot mu toe steeds suggesties, om algemene maatregelen van bestuur enige tijd vóór hun inwerkingteding te publiceren, heeft afgewimpeld door te verwijzen naar de behandeling van het onderhavige wetsontwerp. Op welke passages wordt dan gedoeld, vroeg de fractie zich af. De nota naar aanleiding van het eindverslag antwoordt, dat de regering geen algemene wettelijke verplichting wil scheppen voor de publikatie van voorontwerpen van zulke maatregelen. Dit neemt niet weg dat artikel 2 van het wetsontwerp de overheid ver- 
plicht, om uit eigen beweging informatie over beleidsvoornemens te geven, zodra dit in het belang is van een goede en democratische bestuursvoering. "Dit zal in bepaalde gevallen ook publikatie van voorontwerpen van AMvB's kunnen impliceren", aldus de nota. ${ }^{186}$

\section{De algemene beraadslaging in de Tweede kamer}

In februari 1977 vindt in de Tweede Kamer de algemene beraadslaging over het wetsontwerp plaats. De twee belangrijkste amendementen zijn ingediend door respectievelijk het PvdA-kamerlid Stoffelen en het KVPkamerlid Van der Sanden. ${ }^{187}$ Stoffelen stelt in zijn amendement onder meer voor, om de tekst van de in artikel 1 lid 2 genoemde weigeringsgrond te vervangen door de tekst, die in de ontwerp-algemene maatregel van bestuur is geformuleerd ter uitwerking van deze wetsbepaling. Artikel 1 lid 2 bepaalde dat een verzoek om informatie moest worden afgewezen, als inwilliging niet in overeenstemming kon worden geacht met de eisen van een goede en democratische bestuursvoering. Het amendement stelt nu een wettekst voor, die afwijzing van het verzoek voorschrijft, als sprake is van interne stukken, die nog in bewerking zijn, of op zichzelf een vertekend beeld geven, of die persoonlijke beleidsopvattingen van bewindslieden, bestuurders of ambtenaren bevatten. Zoals we al hebben gezien, was dit voorstel ook naar voren gebracht in het eindverslag van de kamercommissie, maar de regering had haar in de nota naar aanleiding van het eindverslag van de hand gewezen. Nu Stoffelen het voorstel in een amendement heeft gegoten, is dat voor de regering kennelijk aanleiding om nog eens goed over de zaak na te denken. En op 8 februari 1977 verklaart premier Den Uyl in de Tweede Kamer, dat de regering dit onderdeel van het amendement overneemt, en het wetsontwerp zal aanpassen. ${ }^{188} \mathrm{Zo}$ krijgt artikel 1 lid 2 de vorm die het tot 1992 zal behouden. De delegatiebepaling van lid 3 wordt daardoor duidelijker genormeerd.

\section{Vertrouwelijk meegedeelde bedrijfs- en fabricagegegevens}

Het amendement Van der Sanden gaat over een ander gevoelig onderwerp: de geheimhouding van vertrouwelijk aan de overheid meegedeelde bedrijfs- en fabricagegegevens. Zowel in het voorlopig verslag als in het eindverslag hadden KVP, ARP en CHU zich al bezorgd getoond, dat het wetsontwerp de vertrouwelijkheid van correspondentie tussen overheid en 
particulieren niet voldoende garandeerde. De regering antwoordde beide keren, dat dergelijke correspondentie meestal geheim zal moeten blijven, in verband met de bescherming van de persoonlijke levenssfeer of het voorkomen van onevenredige bevoordeling of benadeling. Maar van een absolute weigeringsgrond kan geen sprake zijn. In concrete gevallen kan het voorkomen, dat het belang van openbaarmaking zwaarder moet wegen, was de mening van de regering. Van der Sanden vindt dit niet aanvaardbaar, als het om gegevens uit het bedrijfsleven gaat. Daarom steit hij in zijn amendement voor om, in artikel 4 , aanhef en onder c, de geheimhouding van bedrijfs- en fabricagegegevens absoluut verplicht te stellen, voorzover deze door natuurlijke of rechtspersonen vertrouwelijk aan de overheid zijn meegedeeld. De regering zal tot het laatst toe dit amendement blijven bestrijden. Als voorbeeld noemt premier Den Uyl nog de Plantaaffaire uit de zestiger jaren, waar een groter belang - dat van de volksgezondheid - tot openbaarheid noodzaakte. ${ }^{189}$ Maar het mag niet baten. Op 17 februari wordt het amendement in de Tweede Kamer aangenomen met de steun van KVP, ARP, CHU, VVD, DS'70, BP, RKPN, SGP en GPV. ${ }^{190}$ Aldus wordt aan het wetsontwerp een nieuwe absolute geheimhoudingsgrond toegevoegd. Tegenwoordig vindt men haar in artikel 10 lid 1 , aanhef en onder $\mathrm{c}$.

\section{Openbaarheid bij de totstandkoming van $A M v B$ 's}

Een onderwerp, waar tijdens de algemene beraadslagingen uitvoerig over gesproken wordt, is de openbaarheid voorafgaande aan de afkondiging van algemene maatregelen van bestuur. De basis voor de discussie is een amendement van mevrouw Kappeyne van de Coppello (VVD). ${ }^{191} \mathrm{Zij}$ stelt daarin voor in de wet te bepalen, dat algemene maatregelen van bestuur niet eerder mogen worden afgekondigd, dan twee maanden nadat ze in ontwerp zijn gepubliceerd. Artikel 25a van de Wet op de Raad van State zou dan moeten voorschrijven, dat tegelijk met zo'n ontwerp-algemene maatregel ook het advies van de raad bekend wordt gemaakt. Premier Den Uyl zegt op in de Kamer, dat hij zich niet uit staatsrechtelijke overwegingen tegen het amendement keert; maar uit praktische overwegingen. Dat is toch een hele ommedraai vergeleken met wat de regering daarover in de memorie van antwoord had gesteld. Daarin verwierp zij het idee van voorpublikatie, omdat de Staten-Generaal dan "materieel een zekere mede- 
verantwoordelijkheid voor de maatregelen zouden gaan dragen". Maar nu ziet de minister-president praktische bezwaren. Jaarlijks passeren 200 à 250 voorstellen voor algemene maatregelen van bestuur, of voor wijzigingen daarvan, de ministerraad. Voor het overgrote deel zijn het hamerstukken. Meestal is het advies van de Raad van State blanco. Om in al deze gevallen de afkondiging twee maanden op te houden vanwege verplichte voorpublikatie, is "niet nuttig en niet zinvol", zegt premier Den Uyl. Artikel 2 van het wetsontwerp geeft een veel doeltreffender voorschrift: openbaarmaking op eigen initiatief van de regering, zodra dit in het belang is van een goede en democratische bestuursvoering. "Betekent dit, dat u wél voor publikatie bent [.. ] als zich daartegen geen technische of ernstig sociale bezwaren verzetten?", wil het kamerlid Stoffelen (PvdA) weten. "Eigenlijk vind ik dat de wet daartoe verplicht", antwoordt de ministerpresident. "Het vloeit uit de wet voort, dat op passende wijze de overheid dit doet zodra het kan en zodra het zinnig is". Nadat premier Den Uyl nog heeft toegezegd, dat de regering een inventarisatie zal maken van algemene maatregelen van bestuur, waarvan het zinvol is ze vóór hun afkondiging te publiceren, trekt mevrouw Kappeyne van de Coppello op 17 februari haar amendement in. ${ }^{192}$

De woorden van de regering, dat artikel 2 "een veel doeltreffender voorschrift" geeft, bewijzen duidelijk dat, in tegenstelling tot de gangbare interpretatie, artikel 25a niet bedoeld is als een lex specialis die artikel 2, thans artikel 8 van de Wet openbaarheid van bestuur, aan de kant schuift. Artikel 25a geeft weliswaar een bodemverplichting, maar laat de plicht tot openbaarmaking zodra dat in het belang is van een goede en democratische bestuursvoering, onverlet.

Waar premier Den Uyl en mevrouw Kappeyne van de Coppello het geheel over eens zijn, is de discretie met betrekking tot wetsontwerpen, die nog voor advies naar de Raad van State moeten worden gezonden. Over de hoofdzaken van die ontwerpen mogen vooraf mededelingen worden gedaan, maar het treden in details zou verkeerd zijn. Want het is "niet de bedoeling dat de Raad ingaat op de politieke meningen uit het land", stelt het VVD-kamerlid. De minister-president beaamt dit. Het vooraf bekend maken van details zou inderdaad "kunnen worden uitgelegd als een poging tot beperking van de onafhankelijkheid en vrijheid van oordeel en advies, die de Raad van State toekomt", zegt hij. ${ }^{193}$

193 Id. pag. 3083 en 3137. 


\section{De stemming in de Tweede Kamer}

Op 17 februari 1977 vindt over het wetsontwerp in de Tweede Kamer de stemming plaats. Behalve het amendement-Van der Sanden is er dan ook nog een amendement-Jongeling aan de orde. Jongeling had onoverkomelijke problemen met het doel van informatieverstrekking, zoals dat in artikel 2 van het gewijzigd ontwerp werd beschreven: burgers moeten "hun inzichten in de loop van het bestuursproces tijdig tot gelding kunnen brengen". Deze passage wekte in de ogen van het kamerlid ten onrechte de suggestie, dat de burger door zijn inzichten ter kennis te brengen van de overheid als vanzelf rechtstreeks deel heeft aan het beslissingsproces. In zijn amendement stelt hij daarom voor, de woorden tot gelding te vervangen door ter kennis van het overheidsorgaan. Premier Den Uyl wil het amendement niet overnemen, en zo komt het in stemming. Het wordt aanvaard met steun van dezelfde fracties die het amendement-Van der Sanden zullen steunen, plus de steun van D66. Na de aanvaarding van de beide amendementen wordt het wetsontwerp zonder stemming in de Kamer aangenomen. Voor de goede orde beshit de Kamer dan ook nog om, ruim zes jaar na dato, de nota Openheid en openbaarheid van bestuur van het kabinet-De Jong voor kennisgeving aan te nemen. ${ }^{194}$

\section{De behandeling in de Eerste Kamer}

De Eerste Kamer behandelt het wetsontwerp op 7 november 1978. Het kabinet-Den Uyl is dan inmiddels opgevolgd door het kabinet-Van Agt/ Wiegel, een coalitiekabinet van VVD en CDA. Deze laatste partij is gevormd uit een samengaan van KVP, ARP en CHU. Ze heeft in 1977 voor het eerst als één lijst aan de landelijke verkiezingen meegedaan. De heren Van Agt en Wiegel, respectievelijk minister-president en minister van Binnenlandse Zaken, komen het ontwerp in de Kamer verdedigen. Essentiële kritiek wordt dan eigenlijk alleen nog geleverd door PvdAsenator Vermeer. Hij betreurt het, dat op grond van artikel 1 lid 2 van de beoogde wet geheimhouding van deelrapporten en persoonlijke beleidsopvattigen mogelijk blijft, zelfs als er geen geheimhoudingsgronden als bedoeld in artikel 4 aan de orde zijn. Kunnen dergelijke stukken dan tenminste wel aktief openbaar worden gemaakt, wil Vermeer weten. Voorts verklaart hij grote moeite te hebben met het bij amendement-Van der Sanden ingevoerde c-onderdeel van artikel 4: absolute geheimhouding van vertrouwelijk aan de overheid meegedeelde bedrijfs- en fabricagegegevens. Later in het debat probeert hij ook nog duidelijkheid te krijgen over 
de vraag, in hoeverre provincie- en gemeentebesturen met hun openbaarheid verder mogen gaan dan de wet aangeeft. "Mijn ervaring met provincies en gemeenten is dat ambtenaren er helemaal aan gewend zijn, dat dit soort (dwz: hun eigen - HK) opvattingen openbaar worden", houdt de PvdA-senator de bewindslieden voor. ${ }^{195}$

In zijn antwoord verzekert premier Van Agt, dat artikel 1 lid 2 geen belemmeringen inhoudt voor aktieve openbaarheid als bedoeld in artikel 2 . Los daarvan moet men het begrip "persoonlijke beleidsopvattingen" ook niet te ruim opvatten. Op schrift gestelde feitelijke gegevens, daaruit afgeleide prognoses, en beleidsalternatieven vallen niet onder dat begrip. Wel is sprake van een persoonlijke beleidsopvatting als een ambtenaar bijvoorbeeld schrijft: "Minister, ik vind dat u uit die gegevens deze conclusie moet trekken". Gemeentebesturen mogen, met artikel 1 lid 2 in de hand, verder gaan dan het wetsontwerp aangeeft. Maar, zegt de minister-president, bij gemeentelijke verordening mag niet worden bepaald: in onze gemeente bestaat de plicht tot het verschaffen van informatie, ook voorzover die is neergelegd in documenten voor intern beraad, zonder dat de ambtenaren wie het raakt daarvan kennis dragen. ${ }^{196}$

Aan het eind van de middag wordt het wetsontwerp zonder stemming aangenomen, en op 9 november 1978 wordt het bekrachtigd tot wet. Een klein jaar later komt, onder meer ter uitwerking van artikel 1 , het Besluit openbaarheid van bestuur tot stand. Op 1 mei 1980 treden wet en besluit in werking. ${ }^{197}$

Een half-lege fles of een half-volle fles?

Door de invoering van de Wet openbaarheid van bestuur wordt in het openbaar bestuur het principe, dat alles geheim is behoudens openbaarmaking, ingewisseld voor het principe, dat alles openbaar is behoudens geheimhouding. Is ons openbaar bestuur daardoor 'openbaarder' geworden? Eerlijk gezegd, betwijfel ik dat. In de zeventiger jaren kenden veel steden in ons land al een zekere mate van bestuurlijke openbaarheid. Niet alleen werden veel rapporten van externe adviescommissies gepubliceerd. Ook ambtelijke projectorganisaties en individuele ambtenaren bespraken dikwijls met bewoners en belangengroepen de adviezen die zij aan het bestuur wilden voorleggen. Bestuurders wilden nog wel eens een blokkade opwerpen, als in dergelijke rapporten of concept-adviezen informatie

196 Id. pag. 71.

197 Wet van 9 november 1978 , Stb. 581 ; KB van 12 oktober 1979 , Stb. 590. 
stond, die hen niet van pas kwam. Maar meestal werden dan al snel door raadsleden kritische vragen gesteld. En bestuurders wisten, dat ze zichzelf verdacht maakten door dan te volharden in geheimhouding. Openbaarheid werd aldus een maatstaf voor politieke integriteit.

Als in 1980 de Wet openbaarheid van bestuur in werking treedt, wordt het politieke geweten van de bestuurders ten opzichte van de openbaarheid gejuridificeerd. Het is zeer de vraag, of dat de openbaarheid ten goede is gekomen. Bestuurders konden voortaan de kritische vragen van raadsleden afwimpelen door te verwijzen naar de royaal toegemeten weigeringsgronden in de wet. Vrijwel alle informatie die vanuit een oogpunt van beleidsbeïnvloeding of beleidscontrole interessant zou kunnen zijn, kon op die wijze geheim worden gehouden. Wellicht heeft de Wet openbaarheid van bestuur in de niet-stedelijke gemeenten wel voor een grotere openbaarheid gezorgd. Maar per saldo heb ik de indruk, dat we er met de inwisseling van het geheimhoudingsprincipe voor het openbaarheidsprincipe niet op vooruit zijn gegaan. Voor een half-lege fles hebben we minder dan een half-volle fles teruggekregen. 


\section{Hoofdstuk 5}

\section{Openbaarheid sinds de Wet openbaarheid van bestuur}

\section{De rechter en de openbaarheid van bestuur}

In deze paragraaf zal ik een schets geven van de jurisprudentie over de Wet openbaarheid van bestuur. Daardoor kunnen we een beeld krijgen van wat de wet in de praktijk betekent. Ik zal me daarbij beperken tot de jurisprudentie van de Afdeling rechtspraak, die per 1 januari 1994 is opgegaan in de Afdeling bestuursrechtspraak van de Raad van State. Deze Afdeling blijft voorlopig het rechtscollege in laatste ressort voor zelfstandige verzoeken om informatie. Zoals we hebben gezien, was het ook uitdrukkelijk de bedoeling van de regering, dat beslissingen op dergelijke verzoeken getoetst zouden kunnen worden door de Afdeling rechtspraak. Voor het in werking treden van de Wet openbaarheid van bestuur was er enige twijfel over de vraag, of een beslissing op een verzoek om informatie wel een "beschikking" zou zijn, ${ }^{198}$ Maar de voorzitter van de Afdeling rechtspraak maakte al in 1979 een einde aan deze twijfel, toen het Utrechts Nieuwsblad zich bij een verzoek om informatie beriep op de Utrechtse Verordening passieve openbaarheid. Het verzoek om een voorlopige voorziening werd door de voorzitter afgewezen, maar de verzoeker was intussen wel door hem ontvangen. Omdat de verordening bepaalde dat een verzoek om informatie moest worden ingewilligd, tenzij zich bepaalde weigeringsgronden voordeden, werd de afwijzing van het verzoek geacht gericht te zijn op een rechtsgevolg. Daarom was er sprake van een beschikking. ${ }^{199}$

Mijn schets van de openbaarheidsjurisprudentie zal zich voorts beperken tot enkele thema's die van bijzonder belang zijn voor inspraak en andere mogelijkheden voor beleidsbeïnvloeding. Meer concreet moet

198 Bijv. bij H. Schelhass, in zijn eerder genoemde dissertatie De informatieplicht van de overheid, pag. $112 \mathrm{e.v}$.

199 VZAR 27 november 1979, AB 1980, 77, m.n.v. J.A. Borman. 
daarbij worden gedacht aan de jurisprudentie over de betekenis van termen als "intern beraad", "persoonlijke beleidsopvattingen", "vertrouwelijk aan de overheid meegedeelde bedrijfs- en fabricagegegevens", en "het voorkomen van onevenredige bevoordeling of benadeling". Daarna zal ik de perikelen rond openbaarheid bij kabinetsformaties aan de orde stellen.

\section{Intern beraad}

Tot mei 1992 luidde artikel 1 lid 2 van de Wet openbaarheid van bestuur:

Een verzoek om informatie, vervat in documenten die zijn opgesteld ten behoeve van intern beraad, wordt ingewilligd behoudens voor zover het betrekking heeft op:

a. gegevens, die nog in bewerking zijn of die, hoewel gereed, op zichzelf een onvolledig en daardoor vertekend beeld zouden geven;

b. persoonlijke beleidsopvattingen van bewindslieden, bestuurders of ambtenaren. Over de in deze documenten vervatte feitelijke gegevens over de aangelegenheid, waarop het verzoek betrekking heeft, uit die gegevens afgeleide prognoses en beleidsalternatieven, wordt wel informatie verstrekt.

In de nieuwe Wet openbaarheid van bestuur bepaalt artikel 11 iets soortgelijks. Ik zal daarop in de volgende paragraaf nog terug komen. Belangrijk is, dat daarin de zojuist onder $a$ genoemde weigeringsgrond is vervallen. Daarom kan ik me nu beperken tot jurisprudentie over de termen "intern beraad" en "persoonlijke beleidsopvattingen".

De term "intern beraad" wordt door de Afdeling tamelijk ruim geïnterpreteerd. Dat ondervond de FNV in 1981, nadat zij de staatssecretaris van Onderwijs en Wetenschappen om toezending had gevraagd van het "Voorontwerp van Wet op de Onderwijsverzorging". De staatssecretaris had het stuk al voor commentaar toegezonden aan enkele andere instellingen buiten de kring van de overheid, maar hij weigerde het aan de FNV te verstrekken. Toen de FNV bij haar verzoek om een voorlopige voórziening aanvoerde, dat er geen sprake kon zijn van "intern beraad", gaf Van der Hoeven, de voorzitter van de Afdeling rechtspraak, haar geen gelijk. "Wij zijn voorshands van oordeel dat [..] de enkele omstandigheid dat verweerder dit document tevoren aan enkele niet-overheidsinstellingen heeft toegezonden met het verzoek om voorlopig commentaar daarop, er niet toe kan leiden dat dit stuk reeds daarom niet meer kan worden aangemerkt als een 
stuk dat is opgesteld ten behoeve van intern beraad", vond de voorzitter, en hij stuurde de FNV met lege handen naar huis. ${ }^{200}$

In 1982 wilde het NRC/Handelsblad inzage in een tussen-verslag van de Algemene Rekenkamer over de besteding van ontwikkelingsgelden in Suriname. Het verslag was door de Rekenkamer voor commentaar toegestuurd aan de minister voor Ontwikkelingssamenwerking. Deze weigerde het verslag aan de krant beschikbaar te stellen. Het NRC/Handelsblad ging in beroep bij de Afdeling rechtspraak. De krant betoogde, dat een verslag, afkomstig van de Algemene Rekenkamer, die wettelijk is belast met de controle over overheidsfinanciën, toch niet zomaar kan worden bestempeld tot intern document van het bestuur. Maar het makkte geen indruk. In een versnelde behandeling van de zaak verwierp de Afdeling het beroep. "Gelet op het verhandelde ter zitting" en op de "werkwijze van de Algemene Rekenkamer", was de Afdeling rechtspraak van oordeel dat het verslag was opgesteld ten behoeve van intern beraad binnen de overheid. ${ }^{201}$

Uiteindelijk meer succes had het Persbureau Twente, toen het in 1981 aan B en W van Markelo inzage vroeg in een recreatienota, die voor de gemeente was opgesteld door een stedebouwkundig bureau uit Rotterdam. De nota had al dienst gedaan als achtergrondinformatie in een (besloten) vergadering van de raadscommissie voor ruimtelijke ordening. Maar niettemin werd de inzage geweigerd. In de beroepszaak die volgde, overwoog de Afdeling rechtspraak in 1984: "Aangezien [..] de opstellers derhalve niet tot de kring der overheid behoren, kan dit stuk reeds om deze reden niet worden aangemerkt als te zijn opgesteld ten behoeve van intern beraad". ${ }^{202}$ En zo kreeg het persbureau drie jaar na zijn verzoek dan toch inzage in de nota.

Ook een inwoner van Leiden had succes, toen hij in 1985 inzage wilde hebben in een voorontwerp van een wetswoorstel tot wijziging van enige wetten met betrekking tot het universitaire onderwijs. Het voorontwerp was voorgelegd aan de Onderwijsraad, en het advies van deze raad daarover was intussen al door de minister van Onderwijs en Wetenschappen gepubliceerd. Maar het voorontwerp zelf werd niet vrijgegeven. De minister wees een verzoek om inzage af, waarop de Leidenaar in beroep ging bij de Afdeling rechtspraak. Een verzoek om een voorlopige voorziening werd door de voorzitter van de Afdeling afgewezen. Alleen een uitspraak van de Afdeling zelf kon toen nog uitkomst brengen. Die kwam

200 VZAR 23 april 1981, AB 1981, 403, m.n.v. D. van Duyne.

201 AR 15 april 1983, AB 1983, 526, m.n.v. H.J. de Ru.

202 AR 18 juni $1984, A B 1985,372$. 
anderhalf jaar later. De Afdeling rechtspraak vernietigde de weigering van de minister wegens strijd met de wet, omdat "het onderwerpelijke stuk in de versie waarin het voor advies naar de Onderwijsraad is gezonden, vanaf het tijdstip van verzending aan dit college niet valt aan te merken als een document dat is opgesteld ten behoeve van intern beraad". De Afdeling nam daarbij in aanmerking dat de Onderwijsraad een "niet-ambtelijk - extern - adviesorgaan" is, en dat de situatie duidelijk verschilde van een "vertrouwelijke adviesaanvraag bij een niet-overheidsinstelling". ${ }^{203}$

Kennelijk vond de Afdeling rechtspraak dus, dat bij intern beraad een "vertrouwelijke adviesaanvraag bij een niet-overheidsinstelling" wel moge$11 j \mathrm{jk}$ moet zijn. Twee latere uitspraken, van afdelingsvoorzitter Boukema, passen min of meer in deze lijn. De eerste betrof een weigering van $B$ en $W$ van Haarlemmermeer, om aan een redacteur van thet Haarlemmermeers Dagblad inzage te geven in twee verklaringen van een extern accountantsbureau inzake de liquidatierekening van het gemeentelijk woningbedrijf. "Naar ons oordeel moet, nu de documenten [..] in opdracht van verweerders zijn opgesteld door een extern accountantsbureau en de opstellers derhalve niet tot de kring van de overheid behoren, ernstig worden betwijfeld of van die documenten gezegd kan worden dat zij zijn opgesteld ten behoeve van intern beraad", zei de voorzitter aarzelend, en hij vervolgde: "Wij achten dan ook zeer waarschijnlijk, dat het bestreden besluit niet in stand kan blijven, omdat daarin een onjuiste toepassing is gegeven aan artikel 1 tweede lid". Toch weigerde Boukema in dit geval een voorlopige voorziening te treffen, omdat de stukken misschien op een nog niet door $\mathrm{B}$ en $\mathrm{W}$ aangevoerde weigeringsgrond wel geheim zouden kunnen worden gehouden. ${ }^{204}$

De tweede uitspraak betrof een weigering in 1991 van de staatssecretaris van Welzijn, Volksgezondheid en Cultuur, om aan de Vereniging Nefarma inzage te geven in de namen van deskundigen en hun adviezen over het geneesmiddelenvegoedingssysteem (GVS). Voorzitter Boukema overwoog toen, dat de gevraagde adviezen weliswaar van externe - niet tot de kuing van de overheid behorende - deskundigen afkomstig waren. Maar dat betekende volgens hem niet dat die adviezen niet waren aan te merken als documenten die zijn opgesteld ten behoeve van intern beraad. In dit geval bleken de adviezen wel voor intern beraad bestemd te zijn, want ze hadden uitsluitend betrekking op een concept-besluit, waarvan nog een

203 AR 29 september 1986, AB 1987, 191, m.n.w. G. Schermers.

204 Zie voor dit staaltje van onverwachte ongellikheidscompensatie: VZAR 25 aprill 1991, KG 1991 „ 278. 
definitieve versie moest worden vastgesteld. Het verzoek om een voorlopige voorziening werd daarom afgewezen. ${ }^{205}$

Onder "documenten die zijn opgesteld ten behoeve van intern beraad" wilde de Afdeling rechtspraak dus niet alleen documenten verstaan die binnen de bestuursorganisatie zijn opgesteld, om alleen daar tot beraad te dienen. Ook adviezen van externe instanties over dergelijke documenten werden als documenten voor intern beraad aangemerkt, als het om een "vertrouwelijke adviesaanvraag" ging.

\section{Persoonlijke beleidsopvattingen}

Dat een document is opgesteld ten behoeve van intern beraad, is op zich nog geen grond om inzage te weigeren. Dat mag pas, als het daarbij gaat om informatie over "persoonlijke beleidsopvattingen". Voór mei 1992 sprak de wet over "persoonlijke beleidsopvattingen van bewindslieden, bestuurders of ambtenaren". Hoezeer de nieuwe wetsbepaling een verruiming inhoudt ten opzichte van de oude, komt nog aan de orde in de volgende paragraaf van dit hoofdstuk. We bekijken nu eerst aan de hand van de jurisprudentie, wat de Afdeling rechtspraak onder "persoonlijke beleidsopvattingen" verstaat.

Aan een verzoek van de Stichting Natuur en Milieu te Utrecht, om inzage in de Nota inzake de toekomst van de Markerwaard, plus bijlagen, wilde de minister van Verkeer en Waterstaat in 1981 slechts gedeeltelijk tegemoetkomen. De stichting nam hier geen genoegen mee, en ging in beroep bij de Afdeling rechtspraak. Ze vroeg daarbij om een versnelde behandeling van de zaak, omdat de inspraaktermijn van de procedure van de planologische kernbeslissing korte tijd later zou eindigen. Het geschil spitste zich toe op de zogeheten "3 DG-nota" (:nota van drie direkteurengeneraal), waarvan de minister slechts een gedeelte wilde verstrekken, en dan nog alleen "in geobjectiveerde vorm". De stichting kreeg in beroep wel de versnelde behandeling, maar niet de gevraagde stukken. De Afdeling Rechtspraak was van oordeel, dat "persoonlijke opvattingen geen opvattingen hoeven te zijn van één persoon, zodat ook de in één nota vervatte meningen van verschillende ambtenaren onder de begripsbepaling van voormeld artikellid vallen". 206

Een jaar later kreeg een inwoner van Hengelo helemaal geen informatie, toen hij B en W van Enschede inzage vroeg in de notities van de afdeling stedebouw van de dienst openbare werken van die gemeente met

206 AR 9 juni 1981, AB 1981, 431. 
betrekking tot het locatie-onderzoek afvalverwerking Twente. Zelfs informatie over feitelijke gegevens was kennelijk niet mogelijk. Van der Hoeven, in die tijd de voorzitter van de Afdeling rechtspraak, wees het verzoek om een voorlopige voorziening af. Kennisneming van de stukken had bij hem tot het oordeel geleid, dat er in het onderhavige geval sprake was van "uitsluitend persoonlijke beleidsopvattingen" van een ambtenaar neergelegd in een document ten behoeve van intern beraad. ${ }^{207}$

Ook in de jaren negentig kon een verzoeker om informatie nog hetzelfde overkomen. Dat ondervond de Bewonersgroep Eindhovense weg/ Liempdse weg te Boxtel, toen zij van de minister van Verkeer en Waterstaat inzage wilde hebben in een brief betreffende het bestemmingsplan Zuidelijke Hoofdweg Boxtel. De brief was door de hoofdingenieur-directeur van Rijkswaterstaat in de provincie Noord-Brabant geschreven aan de directeur-generaal van Rijkswaterstaat. Ze was voor de bewonersgroep van belang in verband met een aan te spannen procedure tegen de nieuwe weg. De minister weigerde informatie over de brief te geven. Toen de bewonersgroep daartegen in beroep kwam, handelde een enkelvoudige kamer van de Afdeling rechtspraak, in de persoon van staatsraad Dorhout, de zaak af. Die constateerde, dat er sprake was van persoonlijke beleidsopvattingen in documenten ten behoeve van intern beraad. Maar bovendien was hij van oordeel, dat de feitelijke gegevens die in de documenten zijn vervat en de persoonlijke beleidsopvattingen van de hoofdingenieur-directeur "dermate zijn vervlochten dat het niet mogelijk is om [..] een ingekorte of geobjectiveerde versie van deze documenten met alle daarin vervatte feitelijke gegevens aan appellant te verstrekken". Zo werd het beroep van de bewonersgroep verworpen. ${ }^{208}$

\section{Vertrouwelijk meegedeelde bedrijfs - en fabricagegegevens}

Het verstrekken van informatie blijft achterwege, indien het betreft "bedrijfs- en fabricagegegevens voorzover deze door natuurlijke of rechtspersonen vertrouwelijk aan de overheid zijn medegedeeld". Zoals we in het vorige hoofdstuk hebben gezien, is deze bepaling in de Wet openbaarheid van bestuur terechtgekomen door het amendement-Van der Sanden. Premier Den Uyl had in de Tweede Kamer, verwijzend naar de Planta-affaire uit de zestiger jaren, het amendement met klem ontraden. Door de bepaling als een absolute weigeringsgrond te formuleren, zou het bedrijfsbelang boven alle andere (openbare en particuliere) belangen worden verheven.

208 AR 31 oktober 1991, Bijlage bij NJB 6 februari 1992, pag. 53-54. 
Maar niettemin werd het amendement door de kamer aanvaard. Alleen de PvdA, D66, en de kleine linkse partijen stemden tegen.

$\mathrm{Er}$ is van de Afdeling rechtspraak inmiddels een groot aantal uitspraken bekend over deze weigeringsgrond, die thans te vinden is in artikel 10 lid 1 aanhef en onder $c$ van de wet. ${ }^{209}$ Het is niet nodig om die hier allemaal de revue te laten passeren. Er is één uitspraak, die in alle scherpte laat zien, wat Van der Sanden en zijn medestanders met hun amendement hebben bewerkstelligd. Dat is de uitspraak in de zaak van een voormalige werknemer van de firma Opstalan BV tegen de staatssecretaris van Sociale Zaken en Werkgelegenheid. Die zaak zal ik hier bespreken.

Een werknemer van de Oisterwijkse firma Opstalan BV was arbeidsongeschikt geworden door een longziekte. De werknemer meende dat die te wijten was aan de onveilige werksituatie bij de firma, waar hij met diverse hem onbekende chemische stoffen had moeten werken. Met een verwijsbrief van de longarts zou de werknemer voor onderzoek worden opgenomen in het Academisch Ziekenhuis te Groningen. Maar daar wilde de behandelend specialist, om gerichte testen te kunnen uitvoeren, graag van tevoren weten, met welke chemische stoffen de werknemer nu precies had gewerkt. Omdat de firma zelf niet met de gegevens over de brug kwam, vroeg de werknemer aan de staatssecretaris van Sociale Zaken en Werkgelegenheid om een afschrift van een brief, die door de Arbeidsinspectie aan de firma was toegestuurd. De staatssecretaris weigerde zo'n afschrift te verstrekken, omdat het bij het noemen van de in die brief vermelde chemische stoffen ging om "vertrouwelijk door het bedrijf aan de Arbeidsinspectie medegedeelde bedrijfs- en fabricagegegevens". In een versnelde behandeling van de zaak gaf de Afdeling rechtspraak de staatssecretaris gelijk. Ingevolge artikel 23 lid 1 van de Veiligheidswet 1934 waren de bestuurder(s) van een onderneming en de daarin werkzame personen verplicht aan arbeidsinspecteurs de verlangde inlichtingen te geven omtrent zaken en feiten, die de naleving van die wet betreffen. Daarom was de Afdeling van oordeel, "dat een naturlijke of rechtspersoon die aan de voormelde verplichting gevolg geeft - hetgeen in dit geval kennelijk is geschied - op een vertrouwelijke behandeling van de aldus verstrekte gegevens aanspraak kan maken". Het beroep van de arbeidsongeschikt geworden werknemer werd om deze reden verworpen. ${ }^{210}$

209 Met dit verschil, dat de nieuwe wettekst niet meer spreekt van gegevens "voor zover deze [..] zijn medegedeeld", maar wan gegevens "die [..] zijn medegedeeld". De wetgever heeft echter niet de bedoeling gehad om daarmee ook de inhoud van de bepaling te wijzigen. AR 21 december 1982, AB 1983, 252, m.n.v. P.J. Stolk. 
Ik wil er hier op wijzen, dat de uitleg die de Afdeling rechtspraak aan deze weigeringsgrond geeft, niet noodzakelijkerwijs voortvloeit uit de wetsgeschiedenis of uit de woorden van de wetsbepaling. Wat precies zou moeten worden verstaan onder de woorden "voor zover deze door natuurlijke of rechtspersonen vertrouwelijk aan de overheid zijn medegedeeld", is rond de behandeling van het amendement-Van der Sanden nooit toegelicht. Daarom had de Afdeling Rechtspraak hier een zekere interpretatie-vrijheid. Die heeft de afdeling gebruikt om aan de weilgeringsgrond ongeveer de meest ruime uitleg te geven die denkbaar is: alle verplicht en onverplicht aan de overheid verstrekte bedrijfs- en fabricagegegevens zijn "vertrouwelijk" als de ondernemer of onderneming wenst dat ze vertrouwelijk zijn.

Een heel andere uitleg is minstens even verdedigbaar. "Vertrouwelijk medegedeelde" informatie betekent in het normale spraakgebruik: informatie die is meegedeeld onder het voorbehoud of de waarborg van vertrouwelijkheid. Een ondernemer kan zelf zo'n voorbehoud maken, als hij vrijwillig aan de overheid informatie verstrekt. Geeft de ondernemer de informatie niet vrijwillig, maar op grond van een wettelijke plicht, dan is hij niet in de positie om een dergelijk voorbehoud te maken. Maar het kan het zijn, dat de betreffende wettelijke regeling dan zelf een vertrouwelijke behandeling van de informatie waarborgt. Geeft de wettelijke regeling op dit punt geen voorschriften, dan kan gekeken worden, of er op grond van de Wet openbaarheid van bestuur andere redenen voor geheimhouding zijn aan te wijzen.

Deze tweede uitleg zou naar mijn idee meer recht doen aan het tijdens de totstandkoming van de Wet openbaarheid van bestuur steeds beklemtoonde "aanvullende karakter" van de wet. Dat wil echter nog niet zeggen, dat met deze uitleg de kwalijke gevolgen van het amendement-Van der Sanden in hun geheel zijn ondervangen. Er blijft staan, dat bij vrijwillig verstrekte informatie overheidsfunctionarissen met bedrijven afspraken kunnen maken, die een effectieve democratische controle op het openbaar bestuur al bij voorbaat blokkeren. Het belang van het bedrijfsgeheim heeft in de wet een absoluut primaat gekregen boven andere particuliere belangen en boven het openbaar belang. Onder de paraplu van dat geheim kunnen ook politieke ambtsdragers in bepaalde gevallen het zicht op hun eigen doen en laten afschermen. Wie hiervan een voorbeeld zoekt, kan ik verwijzen naar een zaak uit 1983, waarin de voorzitter van de Afdeling rechtspraak het verzoek van een journalist van Vrij Nederland behandelde, on een voorlopige voorziening te treffen. De journalist wilde inzage hebben in een rapport over de nakoming van een "Herenakkoord" tussen Shell, Esso, en de minister van Economische Zaken. Het verzoek werd 
door de voorzitter afgewezen, omdat hem niet gebleken was, dat Shell ermee akkoord ging, dat de journalist inzage zou krijgen. ${ }^{211}$

\section{Onevenredige bevoordeling of benadeling}

Zoals hier eerder is uiteengezet, vond de regering destijds de door het amendement-Van der Sanden ingevoerde weigeringsgrond helemaal niet nodig. Bedrijfsbelangen zouden voldoende kunnen worden ontzien met behulp van de weigeringsgrond die in hetzelfde wetsartikel - thans artikel 10 , tweede lid - onder $g$ is opgenomen: Informatie wordt niet verstrekt, als het belang daarvan niet opweegt tegen het belang van "het voorkomen van onevenredige bevoordeling of benadeling van bij de aangelegenheid betrokken natuurlijke personen of rechtspersonen dan wel derden". Geen absolute weigeringsgrond dus, maar een relatieve, want bij elke beslissing moet een belangenafweging plaatsvinden. Wat dat in de praktijk oplevert, zal ik aan de hand van een tweetal voorbeelden proberen te schetsen.

In de zomer van 1982 vroeg het $\mathrm{NRC} /$ Handelsblad an de minister van Economische Zaken om informatie over de voorwaarden bij een door hem in april van dat jaar aan het Rijn-Schelde-Verolme concern toegezegde steun. De minister weigerde de informatie te verstrekken, omdat het belang daarvan volgens hem niet opwoog tegen de onevenredige benadeling, die zowel de Staat als het concern daardoor zouden ondervinden. De krant ging in beroep bij de Afdeling rechtspraak, en vroeg daarbij om een versnelde behandeling van de zaak. Er moesten wel bijzondere redenen voor deze steuntoezegging zijn, meende de krant, want bij de vorige steunverlening (van 225 miljoen gulden) had de toenmalige minister van Economische Zaken als uitdrukkelijke voorwaarde gesteld, dat "dit de allerlaatste steunverlening is van de overheid aan dit concern". Die redenen wilde de krant graag weten. Dat de Staat en het RSV-concern daardoor ovenredige schade zouden oplopen, kon het NRC/ Handelsblad zich moeilijk voorstellen. In zijn beroepschrift voerde de krant aan: "Er is, mocht dit begrip bestaan, veeleer sprake van een onevenredige benadeling van de Nederlandse belastingbetaler indien deze gegevens en voorwaarden niet openbaar worden gemaakt". De Afdeling rechtspraak was bereid de zaak versneld te behandelen, maar verwierp het beroep. Het verweer van de minister, dat uit de bekendmaking van de voorwaarden gegevens over de situatie in de onderneming konden worden afgeleid, "waarvan de bekendheid bij concurrenten, leveranciers en potentiële afnemers nadelig is voor de onderneming", had diepe indruk gemaakt. Na kennis te hebben genomen van de 
stukken, constateerde de Afdleling, dat openbaarmaking het RSV-concern onevenredig zou benadelen, en derden onevenredig zou bevoordelen, "waartegen het belang, dat met het verstrekken van de gevraagde informatie is gediend, in dit geval niet opweegt ${ }^{\mathrm{n}}{ }^{212}$

De afweging kan echter ook anders uitvallen. Dat ondervond de Vereniging Geen Uitbreiding Vliegveld Beek. In 1984 vroeg deze vereniging aan GS van Limburg om inzage in een studie van een $Z$ witsers adviebureau, dat marketing-onderzoek had gedaan ten behoeve van de Luchthaven ZuidLimburg. GS voelden er niets voor orn inzage in de studie te geven, en de vereniging vroeg de voorzitter van de Afdeling rechtspraak om een voorlopige voorziening te treffen.

In het verweer ter zitting voerde de vertegenwoordiger van GS aan, dat het adviesbureau bij zijn onderzoek vertrouwelijke gegevens had gebruikt of verwerkt van enkele particuliere bedrijven. Ook konden, volgens deze vertegenwoordiger, de betrokken overheden, het Rijk en de provincie Limburg, en de NV Luchthaven Zuid-Limburg door de openbaarmaking onevenredig in hun zakelijke belangen worden geschaad. Staatsraad J.M. Polak, die in deze zaak als afdelingsvoorzitter optrad, gaf GS geen gelijk. Hij constateerde eerst, dat GS zelf niet beschikten over de bij het rapport gehorende bijlagen. Vervolgens stelde hij vast, dat het rapport zelf geen gegevens over afzonderlijke bedrijven bevatte, zodat het argument van "vertrouwelijk medegedeelde bedrijfsgegevens" geen hout sneed. Resteerde de vraag, of het belang van openbaarmaking opwoog tegen het belang van voorkoming van onevenredige benadeling van de betrokken overheden en de luchthaven. De voorzitter vond in dit geval het belang van openbaarmaking groter, te meer omdat GS hun stelling over de mogelijke benadeling niet hadden "geadstrueerd". Voorts nam hij in aanmerking, dat het rapport mede in opdracht van overheidsinstellingen was vervaardigd en uit de openbare middelen bekostigd, "en vooral dat dit rapport een functie heeft in het kader van de besluitvorming over de zaak waarbij grote publieke belangen zijn betrokken en die de woon- en leefomstandigheden van een vrij grote bevolkingsgroep direct raakt". De voorzitter trof daarom de voorlopige voorziening, dat GS onverwijld aan de vereniging kennisneming van het rapport zouden toestaan. ${ }^{213}$

212 AR 21 december 1982, AB 1983, 253, m.n.v. P.J. Stolk. Uitgebreider informatie over deze zaak geeft L.J.A. Damen, Ongeregeld' en ondoorzichtig bestuur, Deventer 1987, pag. 371-373.

213 VZAR 3 december 1984, AB 1986, 54, m.n.v. H.J. de Ru. 


\section{Openbaarheid van stukken bij kabinetsformaties}

Hierboven heb ik aan de hand van jurisprudentie van de Afdeling rechtspraak en haar voorzitters laten zien, hoe dit rechtscollege omgaat met een aantal weigeringsgronden van de Wet openbaarheid van bestuur. Maar wat betekenen deze weigeringsgronden, al dan niet gecombineerd, voor de diverse politieke onderwerpen waar burgers informatie over willen hebben? In het bestek van deze studie kan die vraag natuurlijk niet uitputtend worden behandeld, maar ik wil er ook niet zomaar aan voorbijgaan. Ik zal me daarom beperken tot één voorbeeld: de werking van de Wet openbaarheid van bestuur bij kabinetsformaties. Hoofdrolspelers in de jurisprudentie zijn het NRC/Handelsblad, de minister-president, de minister van Sociale Zaken en Werkgelegenheid, en de Nederlandse Dagbladunie.

Tijdens de kabinetsformatie in 1981 vroeg het NRC/Handelsblad de demissionaire minister-president om informatie te verschaffen over vijfenvijftig met name genoemde bestuurlijke aangelegenheden, die zijn ministers aan de informateurs ter kennis hadden gebracht. De bewindsman weigerde om informatie uit deze zogenaamde politieke testamenten te geven, omdat de informateurs dan "onevenredig zouden worden benadeeld bij hun pogingen een kabinet te (doen) formeren". De krant wendde zich tot de voorzitter van de Afdeling rechtspraak, met het verzoek om een voorlopige voorziening te treffen. Staatsraad Polak, optredend als voorzitter van de afdeling, gaf de bewindsman echter gelijk. Hij was van mening, dat de bewindsman, "gelet op de op het moment van het bestreden besluit bestaande feiten en omstandigheden, heeft kunnen oordelen dat het nadeel, dat de informateurs door verstrekking van de gevraagde informatie kunnen ondervinden, onevenredig is aan het belang dat daardoor wordt gediend". Het verzoek werd dus afgewezen. ${ }^{214}$

Een klein jaar later boog de Afdeling rechtspraak zich zelf over de zaak, omdat er in beroep een uitspraak moest worden gegeven. De kabinetsformatie was intussen afgerond. Het NRC/Handelsblad vond, dat de bewindsman in deze zaak geen beroep kon doen op de weigeringsgrond van "onevenredige [..] benadeling van bij de aangelegenheid betrokken natuurlijke personen of rechtspersonen danwel derden". De krant stelde, dat deze weigeringsgrond alleen betrekking kon hebben op het belang van de buiten de overheid bestaande persoon of instelling, die informatie aan de overheid verstrekt, of over wie de informatie handelt. Maar ook als de weigeringsgrond wel toepasbaar zou zijn op de belangen van informateurs, dan nog zou moeilijk zijn in te zien, waarom die belangen in dit geval 
onevenredig zouden worden benadeeld. Immers, de opvattingen die de politieke partijen aan de informateurs kenbaar maken, zijn wél openbaar. De Afdeling rechtspraak kon de eerste stelling van de krant "reeds hierom niet tot de hare maken, aangezien de algemeen geformuleerde redactie van de weigeringsgrond niet tot een zodanig beperkte interpretatie noopt". Wat de tweede stelling betrof, gaf de Afdeling de krant in zoverre gelijk, dat ook zij vond dat de bewindsman de beweerde onevenredige benadeling te mager had gemotiveerd. De bewindsman had er geen blijk van gegeven, dat hij de belangen van de informateurs had afgewogen tegen die van de krant. Daarom vernietigde de Afdeling rechtspraak de beschikking wegens strijd met het motiveringsbeginsel. ${ }^{215}$

Diezelfde dag deed de Afdeling rechtspraak nog een uitspraak in een zaak, die het NRC/Handelsblad had aangespannen. Ook daarin wilde de krant, met een beroep op de Wet openbaarheid van bestuur, informatie over de kabinetsformatie los krijgen. In dit geval was de informatie niet aan de minister-president gevraagd, maar aan de minister van Sociale Zaken en Werkgelegenheid. Het ging ook hier om stukken, die de voorganger van de bewindsman tijdens de kabinetsformatie aan de informateurs had verstrekt. Het verzoek werd door de minister slechts gedeeltelijk beantwoord. In dit antwoord gaf hij wel enige informatie, maar andere weigerde hij te geven. De bewindsman beriep zich daarbij op de stelling, dat de gevraagde stukken bestemd waren voor intern beraad, die deels een onvolledig en daardoor vertekend beeld gaven, en deels bestonden uit persoonlijke beleidsopvattingen. Het NRC/Handelsblad bestreed dat het hier zou gaan om stukken die bestemd waren voor intern beraad. De stukken waren immers verzonden naar (de niet tot de overheid behorende) formateurs en informateurs.

De Afdeling rechtspraak ging op verzoek van de krant akkoord met een versnelde behandeling van de zaak. Zij vernietigde de beschikking van de minister voor zover deze geen antwoord had gegeven op het verzoek. Maar voor zover de minister wel antwoord had gegeven, gaf de Afdeling de minister gelijk. Zij vond dat de stukken inderdaad moesten worden aangemerkt "als te zijn opgesteld ten behoeve van intern beraad binnen het departement van verweerder en het nieuw-aangetreden kabinet". Ook had de minister zich, naar het oordeel van de Afdeling, op het standpunt mogen stellen, dat de stukken deels een vertekend beeld gaven, en deels 
persoonlijke beleidsopvattingen bevatten. In zoverre werd het beroep van het NRC/Handelsblad dus verworpen. ${ }^{216}$

\section{De Sinterklaas-uitspraak}

De meest royale uitspraak van de Afdeling rechtspraak over openbaarheid bij kabinetsformaties betreft een verzoek in 1986 van de Nederlandse Dagbladunie aan de minister-president. De Dagbladunie had de bewindsman gevraagd om openbaarmaking van de circa tweehonderd amendementen, die in 1986 door de fracties van CDA en VVD in de Tweede Kamer op het concept-regeerakkoord van informateur De Koning waren ingediend. Bovendien wilde zij openbaarmaking van documenten uit het formatiedossier, die betrekking hadden op een aantal met name genoemde bestuurlijke aangelegenheden. De minister-president weigerde openbaarmaking van de tweehonderd amendementen om twee redenen. Hij vond dat het geen informatie was in de zin van de Wet openbaarheid van bestuur. Het waren stukken die "toevallig" op zijn ministerie werden bewaard. Maar hij weigerde ook omdat hij gewicht wilde toekennen aan "het belang dat er in het kader van de coalitievorming ruimte moet zijn om in beslotenheid tot afspraken te kunnen komen op basis van informatie die ook nadien niet behoeft te worden gepubliceerd". De openbaarmaking van de gevraagde documenten uit het formatiedossier werd geweigerd, omdat het stukken zouden betreffen die bestemd waren voor intern beraad, en die ofwel persoonlijke beleidsopvattingen weergaven, ofwel een vertekend beeld zouden geven. En voor zover de documenten geen stukken voor intern beraad waren, zou het belang van openbaarmaking, volgens de bewindsman, niet opwegen tegen "de financiële belangen van de Staat". Deze laatste weigeringsgrond was in 1980 in artikel 4 sub e van de Wet openbaarheid van bestuur ondergebracht; men vindt haar thans in artikel 10 lid 2 sub $b$.

In een versnelde behandeling van de zaak maakte de Afdeling rechtspraak korte metten met de stelling, dat de tweehonderd amendementen, die "toevallig" op het ministerie van Algemene Zaken werden bewaard, geen documenten zouden zijn in de zin van de Wet openbaarheid van bestuur. Op dit punt werd de beslissing vernietigd wegens strijd met de wet. Het tweede argument van de bewindsman om de tweehonderd amendementen niet openbaar te maken, werd door de Afdeling opgevat als een beroep op onevenredige benadeling van derden. Inderdaad kunnen kabinets(in)formateurs en leden van de Tweede Kamer als "derden" in de zin van de wet worden beschouwd, vond de Afdeling rechtspraak. Maar de 
Afdeling was door de bewindsman niet overtuigd, dat openbaarmaking op een moment, dat het nieuwe kabinet al tot stand was gekomen, nog onevenredige benadeling van deze derden met zich mee zou kunnen brengen. Gelet ook op het belang van publieke discussie rond kabinetsformaties, werd de beschikking op dit punt vernietigd omdat bewindsman, naar het oordeel van de Afdeling rechtspraak, niet in redelijkheid tot zijn beslissing had kunnen komen.

Ook van de weigering van de minister-president, om stukken uit het formatiedossier openbaar te maken, liet de Afdeling rechtspraak weinig heel. Na vastgesteld te hebben, dat de stukken bestemd waren voor beraad van de (in)formateur met de vertegenwoordigers van politieke partijen, constateerde de Afdeling, dat het dus niet ging om beraad binnen overheidsorganen als bedoeld in de Wet openbaarheid van bestuur. Want deze wet noemt als organen slechts ministers, bestuursorganen van provincies en gemeenten (en thans ook van waterschappen en publiekrechtelijke bedrijfsorganisaties), en andere bestuursorganen, aangewezen bij algemene maatregel van bestuur. Dus kon de minister-president de stukken ook niet weigeren met een beroep op "intern beraad". En voor zover in het door de bewindsman gedane beroep op "de financiële belangen van de Staat" een beroep moest worden gelezen op andere weigeringsgronden, was dat beroep onvoldoende gemotiveerd. Om deze redenen werd ook de weigering om stukken uit het formatiedossier openbaar te maken, door de Afdeling rechtspraak vernietigd..$^{217}$

\section{Slotsom}

Wat mag nu de conclusie zijn uit al deze uitspraken? Ziet men openbaarheid als doel op zich, of als middel om het bestuur achteraf te kunnen controleren, dan is er misschien enige reden voor tevredenheid. Maar de Wet openbaarheid van bestuur was nu juist bedoeld om de burger betere mogelijkheden tot participatie in het bestuur te geven, tot inspraak, beleidsbeïnvloeding. Vanuit dat punt bezien, is er weinig reden om over de jurisprudentie te juichen. ${ }^{218}$ De weigeringsgronden van de wet worden

217 AR 5 december 1986, AB 1987, 525, m.n.v. H.J. de Ru.

218 Ook bezien vanuit andere punten, zoals de rechtsbescherming, is er reden voor kritiek. Zie J.M. de Mey, De grens tussen openbaarheid en geheimhouding. NTB 1993, pag. 269-276. Wel redelijk tevreden over de jurisprudentie toonde zich C.R. Niessen, in Tableau van de arob-jurisprudentie over de Wet openbaarheid van bestuur, Den Haag 1983, pag. 62. De Evaluatiecommissie Wet Openbaarheid nam in haar eindrapport Openbaarheid tussen gunst en recht, Den Haag 1983, pag. 31 en 51 , nogal lichtwaardig het oordeel van Niessen over. 
door de Afdeling rechtspraak op veel plaatsen ruim geïnterpreteerd. En dat is naar mijn mening niet te verklaren uit dogmatische opvattingen. Integendeel, met veel souplesse en niet zonder creativiteit worden weigeringsgronden door de Afdeling opgerekt. Wanneer een minister een conceptwetsontwerp yoor commentaar naar een aantal bevriende externe instellingen stuurt, maar aan andere instellingen inzage weigert, dan mag hij zich van de afdeling toch beroepen op "intern beraad". Politieke testamenten van demissionaire ministers zijn "bestemd voor intern beraad in een volgend kabinet". Vaak hoeft over de feitelijke gegevens in ambtelijke adviezen geen informatie te worden verstrekt, omdat die feitelijke gegevens en de persoonlijke beleidsopvatting "dermate zijn vervlochten, dat het niet mogelijk is om die gegevens te verstrekken". Informatie, die ondernemers op grond van wettelijke verplichtingen aan de overheid verstrekken, is in de ogen van de Afdeling rechtspraak per definitie "vertrouwelijk" medegedeeld. Beroept een bestuursorgaan zich op de weigeringsgrond van "onevenredige benadeling", dan wit de Afdeling de beschikking nog wel eens vernietigen wegens strijd met het motiveringsbeginsel. Maar daarmee heeft ze natuurlijk nog niet uitgesproken, dat het bestuursorgaan niet had mogen weigeren. Niet tijdens, maar ná een kabinetsformatie krijgt men met een beroep op de Wet openbaarheid van bestuur soms informatie los, bijvoorbeeld als die informatie puur bestemd was voor beraad tussen de (in)formateurs en de politieke partijen, en er verder geen sprake is van andere weigeringsgronden.

Alles overziende is mijn conclusie dan ook deze: het is waar, dat de wetgever de rechter geen mooie voorzet heeft gegeven, toen hij de Wet openbaarheid van bestuur tot stand bracht, maar de Raad van State heeft met zijn rechterlijke uitspraken de bal toch ook wel erg hoog het veld uit geschopt.

\section{De nieuwe WOB. Eén stap vooruit, twee stappen terug}

\section{De Evaluatiecommissie}

De Wet openbaarheid van bestuur verplichtte de minister-president en de minister van Binnenlandse Zaken tot regelmatige evaluatie van de toepassing van de wet. Artikel 5 bepaalde, dat deze bewindslieden binnen drie jaar na in werking treding van de wet, en vervolgens om de vijf jaar, een evaluatieverslag aan de Staten-Generaal zouden moeten toezenden. Om aan deze verplichting te kunnen voldoen, werd op 10 juni 1980 een Evaluatiecommissie Wet Openbaarheid ingesteld, waarin B.W. Biesheuvel, die eerder voorzitter was van de Commissie Heroriëntatie Overheidsvoor- 
lichting, tot voorzitter werd gekozen. In april 1983 bracht de commissie haar eindrapport uit: Openbaarheid tussen Gunst en Recht. ${ }^{219}$

De strekking van het ruim vijftig pagina's tellende evaluatierapport kan in enkele zinnen worden samengevat. Wat de actieve openbaarheid betreft (lees: spontaan gegeven voorlichting en informatie), constateert de commissie een handhaving van de "status-quo". Noch op het niveau van voorzieningen noch voor wat betreft de visie op voorlichting hebben er als gevolg van de invoering van de Wet openbaarheid van bestuur aanwijsbaar ingrijpende veranderingen plaatsgevonden. Wat betreft de passieve openbaarheid (lees: informatieverstrekking op verzoek), constateert de commissie, dat nauwelijks toetsing van het systeem heeft plaatsgevonden. Gevestigde maatschappelijke organisaties en journalisten hebben vaak hun eigen kanalen en informele contacten om aan informatie te komen. Zij zullen niet gauw een beroep op de wet doen, uit angst "hun informele contacten te bruskeren". Ook individuele burgers doen vrijwel nooit een beroep op de wet. $\mathrm{Zij}$ lijken "ofwel door autoriteitsvrees ofwel door gevoelens van machteloosheid te worden geremd". Op het niveau van de gemeenten constateert de commissie "niet onaanzienlijke verbeteringen" in de openbaarheidssituatie, maar dat is volgens haar meer een kwestie van klimaatsverandering. De wet heeft daarop "slechts geringe, hooguit indirecte invloed" gehad. 220

Al met al komt de evaluatiecommissie tot de conclusie, dat de Wet openbaarheid van bestuur een hier en daar vage en onvolledige wet is, die enige invloed heeft gehad ten gunste van haar doel, "doch zeker niet voldoende". Toch hoeft de wet naar de mening van de commissie niet te worden vervangen. "In emancipatieprocessen zien wij vaker, dat wat eerst een gunst was, later een recht, tenslotte vanzelfsprekend werd. Wat de informatie betreft bevinden wij ons nu in het stadium tussen gunst en recht". ${ }^{221}$ Dat verklaart ook de titel van het evaluatierapport. De commissie sluit haar rapport af met negenendertig standpunten en aanbevelingen. Daar zitten enkele concrete aanbevelingen bij, zoals het voorstel om ook de zelfstandige bestuursorganen onder de werkingssfeer van de wet te bren-

219 Het rapport is met begeleidende brief op 29 april 1983 aan de Tweede Kamer aangeboden (TK 1982-1983, 17600 hoofdstuk IIT, nr. 7), en op 8 september 1983 besproken in de vaste commissie voor Binnenlandse Zaken. Het verslag daarvan is pas op 24 april 1985 vastgesteld (TK 1984-1985, 18600 hoofdstuk III, nr. 11). Het zou de laatste evaluatie zijn, want in 1988 werd met behulp van een noodwetje de periodieke verplichting daartoe uit de WOB geschrapt.

220 Openbaarheid tussen Gunst en Recht, met name pag. 25-29.

221 id. pag. 33-34. 
gen. Andere concrete aanbevelingen zijn het voorstel om in de wet te bepalen, dat een verzoek om informatie in principe binnen eenentwintig dagen moet worden afgehandeld, en het voorstel on de tarieven voor afschriften van documenten wettelijk te uniformeren. Over de echt moeilijke punten in de wet is de commissie echter veel vager. Ten aanzien van het voorschrift om informatie te weigeren over gegevens, die nog in bewerking zijn of een vertekend beeld geven (artikel 1 lid 2), wordt voor voorgesteld dit voorschrift "aan te scherpen". Datzelfde zou volgens de commissie ook moeten gebeuren met de uitzonderingsgrond die betrekking heeft op vertrouwelijk meegedeelde bedrijfs- en fabricagegegevens (artikel 4 onder c). Maar hoe die "aanscherping" zou moeten worden geformuleerd, blijft in het rapport onduidelijk.

Eén van de eerste aanbevelingen van het rapport: de openbaarheidsbepalingen van het Besluit openbaarheid van bestuur (BOB) zoveel mogelijk op te nemen in de wet zelf, zal voor de regering aanleiding zijn, om uiteindelijk een voorstel voor een geheel nieuwe Wet openbaarheid van bestuur bij het parlement in te dienen.

\section{Artikel 68 van de Grondwet}

Het voorstel voor de nieuwe wet wordt op 27 januari 1987 aan de Tweede Kamer aangeboden. ${ }^{222}$ Het heeft ook inderdaad de strekking, om de oude wet (tien wetsartikelen) en het Besluit openbaarheid van bestuur (negen artikelen) tezamen te vervangen door één nieuwe Wet openbaarheid van bestuur met zevenentwintig wetsartikelen. Een aantal voorschriften uit het BOB zal als wettelijke verworvenheden worden vastgelegd. Tegelijk geeft deze operatie de regering de gelegenheid om een nieuwe systematische indeling van de wet voor te stellen, met niet minder dan acht hoofdstukken. Aan de inhoud van de artikelen zelf verandert op het eerste gezicht weinig. Maar toch zijn er nogal wat haken en ogen. Een aantal daarvan zal vragen en discussie oproepen tijdens de parlementaire behandeling. Ik wil mijn bespreking van de totstandkoming van de nieuwe wet toespitsen op sommige van die punten, zoals: de nieuwe invulling van de termen "intern beraad" en "persoonlijke beleidsopvattingen", en het verdwijnen van het criterium "onvolledig, vertekend beeld". Ook zullen de nieuwe discussie over de vertrouwelijkheid van bedrijfs- en fabricagegegevens, en nog enkele andere zaken de revue passeren. Maar eerst wil ik een punt aan de orde stellen, dat eigenlijk buiten het kader van de nieuwe wet valt, maar waar tijdens de parlementaire behandeling uitvoerig over gesproken zal 
worden: het parlementair informatierecht volgens artikel 68 van de Grondwet.

Bij de behandeling van de nieuwe wet blijkt, dat zowel regering als parlement met een stuk onverwerkt verleden in hun maag zitten: de uitspraak van de Afdeling rechtspraak van de Raad van State van 5 december 1986, inzake het beroep van de Nederlandse Dagbladunie tegen de weigering van de minister-president om inzage in de stukken van de laatste kabinetsformatie te verstrekken. Het ging toen onder meer om openbaarmaking van circa tweehonderd amendementen, die door de kamerfracties van CDA en VVD op het concept-regeerakkoord van de informateur waren ingediend. ${ }^{223}$ De oppositie in de Tweede Kamer, die eerder met een beroep op artikel 68 van de Grondwet dezelfde informatie had geclaimed, had van de minister-president niets losgekregen. "Het belang van de Staat" was volgens de bewindsman in het geding. De regeringsfracties hadden hem in dat oordeel gesteund. De NDU echter, die korte tijd later bij de Afdeling rechtspraak een beroep deed op de Wet openbaarheid van bestuur, kreeg de informatie wel. Hoe kan dat? Heeft de burger meer recht op informatie dan een parlementariër, vragen verschillende kamerleden zich nu af. ${ }^{224}$

De regering houdt vanaf de memorie van toelichting bij het wetsvoorstel tot en met de nota naar aanleiding van het eindverslag vol, dat artikel 68 eigenlijk meer recht op informatie geeft dan de Wet openbaarheid van bestuur. Artikel 68 verplicht bewindslieden om ook informatie te verschaffen, die niet in documenten is vervat; ja, zelfs informatie waar zij niet over beschikken. "De ministers en staatssecretarissen zijn gehouden zo nodig de gevraagde informatie te creëren". In de praktijk kan het echter voorkomen, dat de Wet openbaarheid van bestuur meer recht op informatie geeft. Volgens de regering vindt dat "zijn oorzaak in het feit, dat over de toepassing van artikel 68 Grondwet respectievelijk de WOB uiteindelijk door verschillende instanties wordt geoordeeld". 225

Voor de oppositiepartijen is de affaire een buitenkansje, om de minister-president in te peperen, dat hij hen destijds ten onrechte de gevraagde informatie heeft onthouden. De woordvoerders van de regeringspartijen, met name Mateman (CDA) en Wiebenga (VVD), menen dat de

223 Deze uitspraak, "de Sinterklaas-uitspraak" genoend, heb ik in de vorige paragraaf besproken.

224 Zie over deze affaire ook L.J.A Damen, Het individuele inlichtingenrecht van

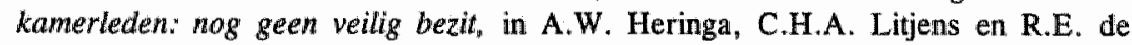
Winter (red.), Verhalen over de Grondwet, Den Haag 1993, pag. 72-78.

225 MvT pag. 10, resp. Nota n.a.v. EV (19859 nr. 9) pag. 10. 
ongerijmdheid eerder moet worden gezocht in de toepassing van de Wet openbaarheid van bestuur. In het voorlopig verslag van de Tweede Kamer vraagt de VVD de regering, om ten aanzien van de openbaarheid bij kabinetsformaties een wetsbepaling voor te stellen "ten einde te vermijden dat toch telkens de rechter wordt ingeschakeld om de grenzen te bepalen". Een meerderheid van de Tweede Kamer blijkt uiteindelijk niet voor zo'n bepaling te voelen. Maar om te Iaten zien dat hij zijn huiswerk heeft gedaan, presenteert premier Lubbers tijdens de kamerbehandeling toch het volgende ontwerp-artikel: "Een verzoek om informatie wordt niet ingewilligd, indien en voor zover het betrekking heeft op informatie vervat in documenten waaruit met een uitdrukkelijk beroep op het belang van de Staat, bedoeld in artikel 68 van de Grondwet, geen inlichtingen zijn verstrekt" ${ }^{226}$ De Tweede Kamer vindt het kennelijk genant. Niemand zal dan ook op deze ontwerp-bepaling terugkomen.

\section{Intern beraad en persoonlijke beleidsopvattingen}

Het nieuwe wetswoorstel begint met een hoofdstuk met definities. In artikel 1 onder $\mathrm{d}$ wordt "intern beraad" gedefiniëerd als: "het beraad over een bestuurlijke aangelegenheid binnen een overheidsorgaan, dan wel binnen een kring van overheidsorganen in het kader van de gezamenlijke verantwoordelijkheid voor een bestuurlijke aangelegenheid". Onmiskenbaar betekent het tweede zinsdeel in de definitie een flinke verruiming van het begrip "intern beraad". Ook correspondentie tussen een gemeente en het Rijk over een bestuurlijke aangelegenheid, waarvoor beide verantwoordelijkheid dragen, moet men voortaan zien als "documenten die bestemd zijn voor intern beraad". In de memorie van toelichting beroept de regering zich bij dit voorstel op aanbeveling 9 van het rapport van de Evaluatiecommissie. Maar die aanbeveling beoogt - nota bene - het tegenovergestelde: "De Evaluatiecommissie beveelt aan, de wettelijke regeling zo aan te scherpen, dat een uitspraak als in de zaak-Hermes niet meer mogelijk is". 227 De schrijvers van de memorie hebben goed ingeschat; dat tijdens de parlementaire behandeling niemand over de betreffende passage zal vallen. Zonder slag of stoot zal de nieuwe definitie van "intern beraad" in de wet worden opgenomen.

226 VV (19859 nr. 5) pag. 18, resp. Hand. TK 1988-1989, pag. 5035.

227 MvT pag. 13, en evaluatierapport pag 39. De uitspraak (VzAR 23 april 1981) in de zaak van staatssecretaris Hermes, die de FNV geen inzage wilde geven in het voorontwerp van de Wet op de onderwijsverzorging, heb ik in de vorige paragraaf besproken. 
Meer discussie maakte de definitie van "persoonlijke beleidsopvatting" los. Volgens het nieuwe artikel 1 (onder g) zal men hieronder moeten verstaan: "een opvatting, voorstel, aanbeveling of conclusie van een of meer personen over een bestuurlijke aangelegenheid en de daartoe door hen aangevoerde argumenten" (cursivering van mij - HK). Door deze ruime definitie zal de jurisprudentie zich nauwelijks meer hoeven te bedienen van de standaard-formule dat "feitelijke gegevens en de persoonlijke beleidsopvatting dermate zijn vervlochten, dat het niet mogelijk is om de gegevens te verstrekken". Aangenomen tenminste, dat argumenten doorgaans op gegevens zijn gebaseerd.

Bij de weigeringsgrond, dat uit voor intern beraad bestemde documenten geen informatie wordt verstrekt over daarin opgenomen persoonlijke beleidsopvattingen, is het begrip "persoonlijke beleidsopvatting" ook nog op een andere wijze verruimd. De oude Wet openbaarheid van bestuur sprak over "persoonlijke beleidsopvattingen van bewindslieden, bestuurders of ambtenaren". Het voorstel voor de nieuwe wet spreekt in artikel 11 lid 1 over "persoonlijke beleidsopvattingen" zonder meer. Volgens de memorie van toelichting bij het voorstel kunnen nu zelfs de opvattingen van rechtspersonen tegen openbaarmaking worden beschermd. En niet alleen van personen en rechtspersonen die tot de kring van de overheid behoren. "Wij menen dat voor het maken van een verschil tussen categorieën van persoonlijke beleidsopvattingen geen redelijk motief is aan te voeren", schrijven de indieners van het wetsvoorstel. "Het vervallen van het bestaande onderscheid betekent dat ook de opvattingen van hen die van buiten in de sfeer van het interne beraad zijn betrokken een bescherming hebben die onafhankelijk is van het oordeel van het betrokken overheidsorgaan". ${ }^{228}$ Dat de indieners geen "redelijk motief" meer voor het onderscheid weten aan te voeren, vind ik terecht. Maar de persoonlijke beleidsopvattingen van bewindslieden, bestuurders en ambtenaren waren in de oude wet van openbaarheid uitgezonderd, om de rechtspositie van ambtenaren en de collegiale verhoudingen tussen politieke ambtsdragers te beschermen. Dàt was het motief. Geldt dat motief niet meer, dan hadden de indieners van het wetsvoorstel de weigeringsgrond niet moeten verruimen, maar moeten schrappen.

In het voorlopig verslag van de Tweede Kamer plaatsen PvdA, GPV en SGP vraagtekens bij het voorstel om ook de "beleidsopvattingen" van rechtspersonen van openbaarheid uit te zonderen. D66 wil weten hoe een persoonlijke opvatting van een buitenstaander als beleidsopvatting kan 
worden aangemerkt. De regering antwoordt in nogal abstracte termen. Zij noemt geen voorbeelden. ${ }^{229} \mathrm{De}$ fracties komen er bij de verdere behandeling van het wetsvoorstel niet meer op terug.

Een ander deel van het door de regering voorgestelde artikel 11 lid 1 zal niet ongeschonden de eindstreep halen. Net als in de oude wet wilde de regering hier de bepaling opnemen, dat uit interne documenten ook geen informatie wordt verstrekt over gegevens die nog in bewerking zijn of die, hoewel gereed, op zichzelf een onvolledig en daardoor vertekend beeld zouden geven. In het voorlopig verslag van de Tweede Kamer noemt de VVD dit deel van de weigeringsgrond "nogal betuttelend". De regering antwoordt, dat zij toch wel hecht aan de passage, die hier zojuist cursief is weergegeven. Dat is voor het kamerlid Stoffelen (PvdA) een reden om bij de algemene beraadslaging in de Tweede Kamer, in februari 1989, een amendement in te dienen. Daarin wordt wordt voorgesteld om de passage te schrappen. Minister Van Dijk ontraadt de kamer het amendement aan te nemen. Niettemin wordt het in september 1990 bijna kamerbreed aanvaard. ${ }^{230}$ Zo krijgt artikel 11 zijn huidige redactie. Maar de uitbreiding, die de weigeringsgrond van artikel 11 heeft gekregen door de verruiming van de begrippen "intern beraad" en "persoonlijke beleidsopvattingen", is door het amendement niet ongedaan gemaakt.

\section{Bedrijss - en fabricagegegevens}

Minder voorspoedig vergaat het een ander amendement van Stoffelen, dat hij samen met het kamerlid Kohnstamm (D66) indient. Het betreft de bekende bepaling, dat geen informatie mag worden verstrekt over vertrouwelijk aan de overheid meegedeelde bedrijfs- en fabricagegegevens. In de oude Wet openbaarheid van bestuur was deze geheimhoudingsgrond te vinden in artikel 4 , aanhef en onder $c$. In het voorstel voor de nieuwe wet komt zij terug in artikel 10 lid 1, aanhef en onder c. Alleen wordt nu niet meer gesproken over gegevens voorzover deze [..] zijn medegedeeld, maar over gegevens die [..] zijn medegedeeld. We hebben eerder gezien, dat de bepaling, zeer tegen de zin van het kabinet-Den Uyl, in de oude wet terecht is gekomen door het amendement-Van der Sanden. Alleen PvdA, D66 en de kleine linkse partijen stemden toen tegen. Bij de behandeling van het voorstel voor de nieuwe wet stellen deze partijen zich ook weer op het standpunt, dat de bepaling niet deugt, omdat zij een absolute geheim-

230 VV pag. 30; MvA pag. 35; Amend. Stoffelen (19859 nr. 13); Hand. TK 1988-1989 pag. 5021, en Hand. TK 1990-1991 pag. 129. 
houdingsgrond inhoudt. Nadat Stoffelen en Kohnstamm eerst allebei apart een eigen tekst voor een amendement hebben ingediend, vervangen ze deze een dag later door een gezamenlijk amendement. $\mathrm{Zij}$ stellen daarin voor, de bepaling onder te brengen bij de relatieve geheimhoudingsgronden van artikel 10 lid 2. De tekst zou dan moeten luiden:

Het verstrekken van informatie ingevolge deze wet blijf eveneens achterwege voorzover het belang daarvan niet opweegt tegen ...e e. het vertrouwelijk karakter van bedrijfs- en fabricagegegevens die door natuurlijke of rechtspersonen aan de overheid zijn meegedeeld. ${ }^{231}$

Tijdens de algemene beraadslaging in de Tweede Kamer bestrijdt minister Van Dijk het amendement. Als bedrijven niet de absolute zekerheid krijgen, dat de overheid de door hen verstrekte gegevens geheim zal houden, zullen zij die niet willen geven. Terwijl de overheid die gegevens wel nodig heeft, bijvoorbeeld in het kader van rampenpreventie of rampenbestrijding, of in het kader van de milieubescherming. "Wij vinden allen de bescherming van het milieu bijzonder belangrijk", zegt de bewindsman. "Welnu, een adequaat milieubeleid moet onder andere kunnen steunen op het royaal aanleveren door bedrijven van gegevens aan de overheid". Als Stoffelen hem erop wijst, dat bedrijven de door de regering voorgestelde bepaling kunnen gebruiken om gevaren waaraan zij de samenleving blootstellen, aan de publieke controle te kunnen onttrekken, komt minister Van Dijk met een nogal dubbelzinnig antwoord: "Als de overheid, zelfs al neemt zij daar vertrouwelijke informatie van een bedrijf in mee, een onderzoek uitvoert naar de schadelijkheid of onwenselijkheid van bepaalde processen, dan zijn de uitkomsten van dat regeringsonderzoek niet noodzakelijkerwijs vertrouwelijk geworden". Het kamerlid Mateman, partijgenoot van de minister, komt tussen beide. Heeft hij goed begrepen dat "het kabinet zich het recht voorbehoudt, ondanks artikel 10 , zelfs tegen de wens van betrokkenen in, wel tot openbaarmaking over te gaan"? Minister Van Dijk antwoordt: "De heer Mateman heeft het nu over dergelijke extreme omstandigheden, dat inbreuk op de garantie die in feite gegeven wordt, gerechtvaardigd is". Mateman: "Dat kan dus!" De minister: "Ja, maar ik

231 TK 1988-1989, 19859, nrs. 12 (Stoffelen), 14 (Kohnstamm), en 19 (Stoffelen en Kohnstamm). 
meen dat wij dit wetsvoorstel moeten zien in de context van meer normale omstandigheden". 232

Wil de minister hier alleen maar verwijzen naar het leerstuk van het staatsnoodrecht? Voor Stoffelen is dat in elk geval te extreem. "Ik kan in redelijkheid niet aannemen" zegt hij, "dat enige partij in dit huis, ook het kabinet niet, belangen van bedrijven heilig wil verklaren, dat zij wil verklaren dat deze gaan boven ieder openbaar belang. Ik kan dat rationeel niet volgen. Ik beschouw andere partijen in dit huis en ook het kabinet, als vertegenwoordiger van de oppositie, te zeer als mensen en instellingen van respect. Als bij de belofte van geheimhouding bijvoorbeeld het al dan niet schenden van de gezondheid van mensen of het milieu in het geding is, dan kan ik mij niet voorstellen dat gezegd wordt: geheimhouding is geheimhouding. Het lukt mij niet om dat te geloven". 233 Toch zullen Stoffelen en Kohnstamm eraan moéten geloven. Hun amendement wordt op 25 september 1990 verworpen. Vóór stemmen alleen de fracties van PvdA, D66 en Groen Links. ${ }^{234}$

\section{Openbaarheid bij zelfstandige bestuursorganen}

$\mathrm{De}$ werkingssfeer van de oude Wet openbaarheid van bestuur was nogal beperkt, omdat verzoeken om informatie slechts tot een klein aantal overheidsorganen konden worden gericht: ministers, bestuursorganen van provincies en gemeenten, en andere organen, aangewezen bij algemene maatregel van bestuur. Bij zo'n algemene maatregel werden aangewezen de bestuurorganen van het inmiddels opgeheven openbaar lichaam Rijnmond en de bestuursorganen van de waterschappen. De wettelijke plicht, om uit eigen beweging informatie te verstrekken "zodra dit in het belang is van een goede en democratische bestuurswoering", was ook beperkt tot deze overheidsorganen. Het voorstel voor de nieuwe Wet openbaarheid van bestuur gaf feitelijk geen uitbreiding aan het aantal overheidsorganen. Wel werden de waterschappen nu in de wettekst zelf genoemd, in plaats van in de algemene maatregel van bestuur. In de memorie van toelichting bij het wetsvoorstel werd de aanbeveling van de Evaluatiecommissie verworpen, om ook alle zelfstandige bestuursorganen onder de werking van de wet te brengen. Als reden voor haar standpunt voerde de regering onder meer aan, dat veel zelfstandige bestuursorganen "privaatrechtelijke rechtspersonen" zijn. ${ }^{235}$

233 idem pag. 5028.

234 Hand. TK 1990-1991 pag. 129.

235 MvT pag. 8-9. 
Blijkens het voorlopig verslag van de Tweede Kamer vinden een aantal fracties dit standpunt toch wel erg terughoudend. Met name de PvdA en D66 vinden, dat de regering met betere argumenten moet komen, wil zij de zelfstandige bestuursorganen buiten de werkingssfeer van de wet laten. En de VVD brengt naar voren, dat de wet ook van toepassing zou kunnen worden verklaard op de organen van de publiekrechtelijke bedrijfsorganisatie. $^{236}$ Als de regering bij de verdere schriftelijke behandeling van het wetsvoorstel de boot afhoudt, worden bij de plenaire behandeling in de Tweede Kamer een amendement en een motie ingediend. Het amendement is afkomstig van VVD-woordvoerder Wiebenga, die voorstelt om in de wettekst, na "waterschappen", in te voegen: "openbare lichamen voor beroep en bedrijf". Minister Van Dijk wil eerst een advies van de SER hebben; voordat hij zich over het amendement wil uitlaten. Als deze raad in juni 1989 antwoordt geen bezwaar te hebben tegen uitbreiding van de werkingssfeer van de wet tot de publiekrechtelijke bedrijfsorganisatie, past Wiebenga zijn amendement aan. Hij stelt dan voor om na "waterschappen" in te voegen: "de publiekrechtelijke bedrijfsorganisatie". Aldus geformuleerd wordt het amendement op 25 september 1990 met algemene stemmen aangenomen. ${ }^{237}$

De motie waar ik zojuist over sprak, is afkomstig van de leden Kohnstamm (D66) en Van den Berg (SGP). Zij nodigt de regering uit om zo spoedig mogelijk een algemene maatregel van bestuur voor te bereiden, die in principe alle zelfstandige bestuursorganen onder de werking van de Wet openbaarheid van bestuur brengt. Minister van Dijk verklaart in de Tweede Kamer, dat hij niet verder wil gaan dan "op basis van weloverwogen beslissingen" afzonderlijke zelfstandige bestuursorganen onder de werking van de wet te brengen. Als het op 21 februari 1989 op een stemming aankomt, wordt de motie verworpen. VVD en CDA, die samen over een kamermeerderheid beschikken, zijn tegen. De overige fracties stemmen vóór. ${ }^{238}$

\section{Beslistermijn met betrekking tot verzoeken om informatie}

In het eindrapport van de Evaluatiecommissie werd de aanbeveling gedaan om te bepalen, dat een verzoek om informatie in beginsel binnen eenentwintig dagen moet worden afgehandeld; bovendien zou de verzoeker al binnen vijf dagen bericht moeten krijgen "óf de informatie in enigerlei

237 TK 1988-1989, 19859 nrs. 15 en 24 , en Hand. TK 1990-1991 pag. 124.

238 TK 1988-1989, 19859, ar. 20, en Hand. TK 1988-1989 pag. 5015 en 5074. Inmiddels geldt het Aanwijzingsbesluit bestuursorganen Wob/No (Stb. 1993, 535). 
vorm zal worden verstrekt". ${ }^{239}$ De regering vond dit kennelijk toch te knellend. Het wetsvoorstel gaf in artikel 6 dan ook een veel vrijblijvender bepaling: het overheidsorgaan beslist uiterlijk binnen dertig dagen; is afhandeling binnen die dertig dagen niet mogelijk, dan wordt de verzoeker "schriftelijk en gemotiveerd zo spoedig mogelijk binnen die termijn op de hoogte gesteld onder mededeling van de termijn waarbinnen op het verzoek zal worden beslist". Bij de schriftelijke behandeling van het wetsvoorstel in de Tweede Kamer zijn het vooral de VVD en de PvdA, die aandringen op een termijn die korter is, en geen "open einde" heeft. De regering geeft niet toe. Het kamerlid Wiebenga (VVD) dient dan bij de plenaire kamerbehandeling een amendement in, dat als strekking heeft de termijn te beperken tot vijftien dagen, met de mogelijkheid deze met ten hoogste nog eens vijftien dagen te verlengen. Dit amendement wordt in de Tweede Kamer door bijna alle partijen aanvaard. Alleen de SGP en het GPV stemmen tegen. ${ }^{240}$

\section{Openbaarheid volgens de Wet op de Raad van State}

Tenslotte wil ik hier nog de door de Wet openbaarheid van bestuur gewijzigde openbaarheidsbepalingen in de Wet op de Raad van State aan de orde stellen. Het gaat dan om het aangevulde artikel $25 \mathrm{a}$ en het nieuwe artikel $25 \mathrm{~b}$ van deze laatste wet. Het oude artikel $25 \mathrm{a}$ schreef onder meer voor, dat dat de minister wie het rechtstreeks aangaat, de adviezen van de Raad over wetsontwerpen en ontwerpen voor algemene maatregelen van bestuur openbaar moest maken. Adviezen over wetsontwerpen zouden gelijktijdig met de indiening van een betreffend wetsvoorstel bij de Tweede Kamer openbaargemaakt moeten worden, en adviezen over ontwerpen voor algemene maatregelen van bestuur gelijktijdig met de afkondiging daarvan. We hebben in het vorige hoofdstuk gezien, dat het kamerlid Kappeyne van de Coppello (VVD) grote moeite had met deze laatste bepaling. Bij amendement stelde zij voor artikel 25 a zo te wijzigen, dat algemene maatregelen van bestuur pas twee maanden nadat ze in ontwerp zouden zijn gepubliceerd, zouden mogen worden afgekondigd. Tegelijk met de publicatie van het ontwerp zou dan ook het advies van de Raad van State moeten worden bekendgemaakt. Premier Den Uyl vond dit te rigide. De meeste voorstellen voor algemene maatregelen van bestuur, en voorstellen voor wijzigingen daarin, worden in de ministerraad behandeld als hamerstukken. Het advies van de Raad van State is meestal blanco. Als vaste

240 TK 1988-1989, 19859, nr. 17, en Hand. TK 1990-1991 pag. 129. 
regel twee maanden nemen tussen publicatie en afkondiging, was daarom volgens Den Uyl "niet nuttig en niet zinvol". Veel beter zou het zijn, om daarvoor in aanmerking komende voorstellen en adviezen vooraf "uit eigen beweging" bekend te maken op basis van artikel 2 van de Wet openbaarheid van bestuur. Na over deze toelichting nog wat met de premier te hebben doorgepraat, trok mevrouw Kappeyne van de Coppello haar amendement in.

Uit dit stukje parlementaire geschiedenis blijkt duidelijk, dat artikel 2 van de oude Wet openbaarheid van bestuur - dat gelijk is aan artikel 8 van de nieuwe wet - een zelfstandige betekenis blijft houden naast artikel $25 \mathrm{a}$ van de Wet op de Raad van State. Maar vreemd genoeg ziet de Raad van State dat anders. In een uitspraak van 18 juli 1983 heeft staatsraad Boukema, optredend als voorzitter van de Afdeling Rechtspraak, overwogen dat artikel 25 a een regeling geeft, die afwijkt van de Wet openbaarheid van bestuur. Alleen al daarom was volgens hem het beroepschrift tegen de weigering, om een wetsontwerp eerder te publiceren dan artikel 25a aangeeft, "kennelijk ongegrond". ${ }^{241}$ Strikt genomen heeft de voorzitter zich toen niet uitgesproken over de vraag, of een minister uit eigen beweging wel een wetsontwerp (met het advies van de Raad van State) openbaar mag maken, voordat het bij de Tweede Kamer is ingediend. In de jaarverslagen van 1991 en 1992 van de Raad van State wordt hierover echter een duidelijk standpunt ingenomen. Volgens de Raad zou in een dergelijk geval "onrecht" worden gedaan "aan de bedoelingen van de wetgever". ${ }^{242}$

In de memorie van toelichting bij het voorstel voor de nieuwe Wet openbaarheid van bestuur constateert de regering, dat de Afdeling rechtspraak artikel 25a als een "uitputtende regeling" heeft aangemerkt. Daarom zou de Wet openbaarheid van bestuur voor deze regeling moeten wijken. "Wij kunnen ons geheel vinden in de benadering van de Afdeling", schrijft de regering. ${ }^{243}$ Volgens mij hoeft deze toelichting bij het op dit punt niet gewijzigde artikel 25a geen gevolgen te hebben voor de wijze, waarop deze bepaling thans zou moeten worden geïnterpreteerd. Want de Afdeling rechtspraak heeft zich, strikt genomen, niet heeft uitgesproken over de vraag, of een minister de hier bedoelde stukken wel uit eigen beweging eerder openbaar zou mogen maken.

242 Jaarverlag 1991 pag. 49, en Jaarverslag 1992 pag. 47. Uit dit laatste jaarverslag komt het citaat. Ik heb het standpunt van de Raad van State ook al bestreden in een bijdrage in NIB 1993, pag. 1085 e.v. 
Voor de rest mag hier worden vermeld, dat artikel 25a van de Wet op de Raad van State bij de invoering van de nieuwe Wet openbaarheid van bestuur is aangevuld met een paar nuttige bepalingen. Het oude artikel 25a gaf namelijk geen openbaarheidsregeling voor gevallen, waarin de regering besluit een wetsontwerp niét bij de Tweede Kamer in te dienen, of een algemene maatregel van bestuur niét af te kondigen. Lid 3 van het nieuwe artikel 25a bepaalt nu, dat in een dergelijk geval het ontwerp voor de wet of de maatregel openbaar wordt gemaakt binnen dertig dagen nadat is beslist op het advies of voorstel, dat door de Raad van State is uitgebracht. Ook het nader rapport aan de Koningin en, in voorkomend geval, de aan de Raad voorgelegde tekst moeten worden bekendgemaakt. Het bij de nieuwe wet ingevoerde artikel $25 \mathrm{~b}$ regelt de openbaarheid van adviezen van de Raad van State over initiatief-wetsontwerpen van het parlement.

Is de nieuwe wet een verbetering?

De afhandeling van het voorstel voor een nieuwe Wet openbaarheid van bestuur wordt in de Tweede Kamer onderbroken door een adviesaanvraag van de regering aan de SER, en daarna door de verkiezingen voor de Tweede Kamer. In juli 1990 laten premier Lubbers en de nieuwe minister van Binnenlandse Zaken, Dales, in een brief aan de kamer weten, dat wat hen betreft de besluitvorming over het wetsvoorstel kan worden afgerond. ${ }^{244}$ In september 1990 wordt het wetsvoorstel, met de eerder besproken amendementen, in de Tweede Kamer aangenomen. De Eerste Kamer aanvaardt het voorstel in oktober 1991. Op 1 mei 1992 treedt de nieuwe Wet openbaarheid van bestuur in werking. ${ }^{245}$

Is de nieuwe wet een verbetering ten opzichte van de oude? De balans bevat enkele positieve punten: de integratie van wet en Besluit openbaarheid van bestuur in één wet, en een bescheiden verbetering van de openbaarheid van de adviezen van de Raad van State. Daarnaast is door amendering in de nieuwe wet bepaald, dat zij ook van toepassing is op de publiekrechtelijke bedrijfsorganisatie, en dat op verzoeken om informatie nu uiterlijk binnen tweemaal vijftien dagen moet worden beslist. Maar de negatieve punten wegen veel zwaarder: de verruiming van de begrippen "intern beraad" en "persoonlijke beleidsopvattingen". Intern beraad is nu niet meer alleen beraad binnen een overheid, maar ook beraad tussen overhe-

244 TK 1989-1990, 19859, nr. 27.

245 Zie resp. Hand. TK 1990-1991 pag. 129, Hand. EK 1991-1992 pag. 44, en Stb. (1991) 703 . 
den. En waren onder de oude wet alleen de persoonlijke beleidsopvattingen van bewindslieden, bestuurders en ambtenaren van openbaarheid uitgezonderd, nu zijn dat alle opvattingen, van wie dan ook, over wenselijk overheidsoptreden. Zelfs de opvattingen van rechtspersonen zijn volgens de nieuwe wet persoonlijke beleidsopvattingen.

Het openbaar bestuur is door deze wetswijzigingen behoorlijk dichtgetimmerd. De artikelen 10 en 11 van de Wet openbaarheid van bestuur vormen nu tesamen een scherm, waar een burger, die informatie wil hebben die uit een oogpunt van beleidsbeinvloeding interessant zou kunnen zijn, zich in achtennegentig van de honderd gevallen tegen te pletter loopt. Het belangrijkste openbaarheidsartikel van de wet is nu artikel 9, dat echter alleen betrekking heeft op de adviezen van niet-ambtelijke adviescommissies. Voor de rest is er van het principe van openbaarheid weinig overgebleven. De Wet openbaarheid van bestuur is een repressieve wet geworden. Openingen in het scherm zijn bijna alleen te vinden op plaatsen, waar openbaarheidsvoorschriften uit büjzondere wetten, zoals de Woningwet of de Wet milieubeheer, toegang tot informatie geven. 


\section{Hoofdstuk 6}

\section{De loyaliteit van de ambtenaar, I De klassieke leer}

\section{Loyaliteit en democratie}

We zijn nu bij een weerbarstig onderwerp aangeland. In de voorafgaande hoofdstukken is al een aantal keren de positie van de ambtenaren ter sprake gekomen. We hebben gezien, dat tijdens de totstandkoming van de Wet openbaarheid van bestuur van verschillende zijden bezorgdheid is geuit, dat die positie in het gedrang zou komen. Als ambtenaren het recht, ja soms zelfs de plicht zouden hebben, om naar buiten toe informatie te geven, die niet spoort met de standpunten van hun (politieke) superieuren, dan komen de interne verhoudingen onder druk te staan, beweerden de ambtenarenorganisaties en de Raad van State. Sterker nog, betoogden veel politici, ons hele democratisch systeem, met het daarbij behorende stelsel van politieke verantwoordelijkheid, zou erdoor worden ondermijnd. Immers, ministers en andere politieke gezagsdragers kunnen zich alleen voor uitlatingen van hun ambtenaren verantwoorden, als zij daarover controle hebben. Er lijkt geen speld tussen te krijgen.

Politieke leiding en ambtenarenkorps vormen een twee-eenheid. $\mathrm{Ze}$ hebben elkaar nodig, ontlenen hun macht aan elkaar. Dat is al zo sinds de middeleeuwse landsheren en stadsbestuurders ambtenaren in dienst namen. Politieke gezagsdragers kunnen niets tot stand brengen zonder ambtenaren. En deze laatsten kunnen dat al evenmin, als hun handelen niet gelegitimeerd wordt door de politici. Met democratie heeft dat alles echter niets te maken. Maar toen in de negentiende eeuw in een aantal westerse landen democratisch-politieke systemen tot ontwikkeling kwamen, heeft men aan het op-elkaar-betrokken-zijn van politici en ambtenaren een democratische dimensie toegevoegd. De politici werden door een systeem van verkiezingen, bij ons in een parlementair stelsel, onder democratische controle gebracht. Men noemt dit systeem wel "representatie-democratie" of "indirecte democratie". Verondersteld werd, dat de controle van de volksvertegenwoordigers op het handelen van de politieke ambtdragers als vanzelf ook controle op het handelen van de ambtenaren betekende. In de 
politicologie en in de bestuurswetenschappen heeft men er inmiddels oog voor gekregen, dat de relatie tussen politici en ambtenaren een eigen dynamiek kent. Men ziet in, dat politieke ambtdragers rekening hebben te houden met verschillende groeperingen en krachten in de samenleving, en niet het minst met 'hun' ambtenaren. Maar in het staats- en bestuursrecht is men tot nu toe niet verder gekomen, dan de klassieke visie, waarin de fictie wordt gekoesterd, dat van bovenaf de lakens worden uitgedeeld. ${ }^{246}$

De stagnatie in de ontwikkeling van de juridische vormgeving van de democratie zorgt inmiddels voor grote staatkundige problemen. Terwijl het aantal volksvertegenwoordigers en politieke ambtsdragers in de afgelopen honderd jaar niet is toegenomen, is het burgerlijk overheidspersoneel in diezelfde periode ongeveer vertienvoudigd, tot bij elkaar zo'n half miljoen ambtenaren voor Rijk, provincies, gemeenten en waterschappen. Ook juristen zien wel in, dat door die toename de mogelijkheden van feitelijke controle over de ambtelijke organisatie een stuk minder zijn geworden. Maar men is niet bij machte, om in de juridische theorie nieuwe democratische normen te ontwikkelen. Daarom worden constructies bedacht, waardoor ofwel het aantal ambtenaren kan worden verkleind, ofwel de politieke verantwoordelijkheid voor de bestuurspraktijk kan worden ingeperkt. Deregulering en privatisering zijn voorbeelden van eerstbedoelde constructies. Het creëren van zelfstandige bestuursorganen is een voorbeeld van de laatste soort. Wat daarbij opvalt, is de vanzelfsprekendheid waarmee de bedenkers van deze constructies beweren, dat de politiek zich moet beperken tot het vaststellen van "algemeen beleid" of tot "hoofdlijnen van beleid". Vooral bij de pleitbezorgers van zelfstandige bestuursorganen, zoals Lubberdink en de Commissie Scheltema, vindt men daarover geen enkele twijfel. ${ }^{247}$

246 Zie hierboven in het eerste hoofdstuk paragraaf 2, De democratische theorie.

247 H.G. Lubberdink heeft in zijn dissertatie De betekenis van de ministeriële verant: woordelifk heid voor de organisatie van het openbaar bestuur, Deventer 1982, gepleit voor" het scheppen van grote aantallen zelfstandige bestuursorganen (p. 153-181). Regering en parlement zouden zich dan kunnen beperken tot het formuleren van "'het algemene beleid" , en aan de zelfstandige bestuursorganen zou het moeten worden overgelaten, om dat beleid in de praktijk gestalte te geven. In het rapport "Steekhoudend ministerschap" (TK 1992-1993, 21427, nrs. 40 en 41) van de externe Commissie Ministerièle Verantwoordelijkheid (Commissie Scheltema) wordt, onder meer, ook het scheppen van zelfstandige bestuursorganen gepropageend (p. 39-47). Naar de stellige mening van de commissie wordt daardoor voor de politici concentratie op de "hoofdlijnen van het beleid" mogelijk, hetgeen zal leiden tot mimder "incidentalisme en detail-bemoeienis [..] met als gevolg een effectievere sturing en tevens een grotere doelmatigheid" (p. 40). 
Maar wat is dat eigenlijk: "algemeen beleid"? Wat zijn "hoofdlijnen van beleid"? Genoemde pleitbezorgers geven er geen blijk van, dat ze daar echt over hebben nagedacht. Lubberdink geeft geen definitie, maar volstaat met een verwijzing naar de onderwerpen die genoemd worden in het Reglement van Orde voor de Raad van Ministers. Daar gaat hij blindelings op af. ${ }^{248}$ De Commissie Scheltema \ijkt de termen "hoofdlijnen van beleid" en "belangrijke aangelegenheden" door elkaar te gebruiken. Maar de verwarring wordt dan alleen maar groter. Stel je in de praktijk eens voor: een bewindsman, die hals over kop een vakantiereis afbreekt, om in het parlement over een "hoofdlijn van beleid" verantwoording af te leggen. Is dat denkbaar? Ik kan me het nauwelijks voorstellen. Als een politicus een reis onderbreekt, dan gaat het altijd om een zeer concrete aangelegenheid. "Algemeen beleid" en "hoofdlijnen van beleid" hebben nooit haast. Ze worden zorgvuldig vastgelegd in rapporten, die geschreven zijn in een ronkende public-relationsstijl. De cover-designs worden vervaardigd door eersteklas ontwerpers. Maar bestaat er buiten die rapporten eigenlijk wel zoiets als "algemeen beleid" of "hoofdlijnen van beleid"? Laten de pleitbezorgers daar eerst eens over nadenken. Een simpel voorbeeld kan hen misschien op weg helpen: van alle bouwwerken die in de afgelopen vijftig jaar in Nederland zijn gerealiseerd, is ruim driekwart gebouwd in afwijking van de geldende planologische voorschriften. Wat is in Nederland nu "algemeen beleid": handhaving of afwijking van de planologische voorschriften? Dezelfde vraag zou men ook kunnen stellen met betrekking tot de geldende milieuvoorschriften. Als iemand de antwoorden weet, dan houd ik me aanbevolen.

Laat ik het nog wat duidelijker zeggen. Het is op zich een goede zaak, als volksvertegenwoordigers en politieke ambtsdragers zich bezinnen op "algemeen beleid" of "hoofdlijnen van beleid", wat dat dan ook mag voorstellen. Regeren is vooruitzien. Maar als dat vooruitzien beperkt blijft tot het schrijven van mooie nota's en rapporten, dan verliest men zich in bestuurlijk escapisme. Een politicus bewijst pas zijn waarde, als hij er bij het nemen van concrete beslissingen blijk van geeft, vooruit te kunnen zien. Alleen door concrete beslissingen kan "algemeen beleid" ook daadwerkelijk gestalte krijgen. Wordt de verantwoordelijkheid voor die beslissingen grotendeels uit handen gegeven, dan kunnen onze politici alleen nog maar gebakken lucht verkopen. Dat constructies als deregulering, privati-

248 Als men Lubberdink's verwijzing serieus zou mogen nemen, dan zou bijvoorbeeld het benoemen van een concreet persoon tot burgemeester van een gemeente met meer dan vijftigduizend inwoners, een zaak van "algemeen belieid" zijn (art. 4 lid 2 , aanhef en onder 1. RvORM). 
sering en zelfstandige bestuursorganen het democratisch tekort kleiner zouden maken, is een onzinnige gedachte. ${ }^{249}$

\section{Publieke controle op de ambtenaren}

Kunnen we niet proberen, om het probleem van de andere kant aan te pakken? Tot nu toe hebben we de democratie vorm willen geven door van de twee-eenheid politieke leiding - ambtenarenkorps alleen de politieke leiding onder publieke controle te brengen. Een wet openbaarheid van bestuur zou het begin kunnen zijn van een meer rechtstreekse controle van de samenleving op de hele openbare dienst. Aldus verkregen informatie zou dan, eventueel vertaald in politieke wensen of politieke ongerustheid, door burgers ter kennis kunnen worden gebracht van hun vertegenwoordigers in gemeenteraad, provinciale staten of parlement. Ook de pers zou in die informatie-keten een belangrijke rol kunnen spelen. Volksvertegenwoordigers zouden, zonder dat hun aantal hoeft toe te nemen, beter werk kunnen leveren, omdat ze én beter geïnformeerd zouden zijn over wat er onder de kiezers leeft, én beter geînformeerd over de overheidsdienst zelf.

Deze gedachte is niet nieuw. We zijn haar ook al tegengekomen in het rapport Openbaarheid Openheid van de Commissie Biesheuvel. Maar de wetgever heeft de stap niet durven zetten. Zoals we in de vorige hoofdstukken hebben gezien, zijn de ruim geformuleerde weigeringsgronden in de Wet openbaarheid van bestuur een belemmering voor werkelijke controle op de openbare dienst. Ambtelijke plannen en ambtshalve gegeven adviezen worden in die wet gedefinieerd als "persoonlijke" beleidsopvattingen. Zouden ambtenaren zich naar het publiek toe moeten verantwoorden, dan komt, zo beweerden indertijd de Raad van State, de ambtenarenorganisaties en veel politici, de ambtelijke loyaliteit ten opzichte van de politieke gezagsdragers onder druk te staan. In een aantal gevallen zou dan geen politieke verantwoordelijkheid meer kunnen worden gedragen. En zo is de cirkel weer rond, en komen we, zolang deze mening blijft heersen, geen stap verder.

Als we ons realiseren dat, naast politieke verantwoordelijkheid, ambtelijke verantwoordelijkheid een eigen betekenis kan hebben voor de democratie, dan lukt het misschien om de cirkel te doorbreken. Voorwaarde is dan wel, dat we een goede formule vinden voor de invulling van het begrip ambtelijke loyaliteit. Als een ambtenaar, die zonder goedvinden

249 Zelfstandige bestuursorganen zouden naar mijn mening alleen bestuurshandelingen mogen verrichten, die geheel gebonden zijn aan wettelijke normen, en dus door de rechter volledig kunnen worden getoetst. 
van zijn (politieke) superieuren informatie naar buiten brengt, niet meer per definitie als 'deloyaal' zou worden beschouwd, dan verschijnen er nieuwe perspektieven. Ambtelijke verantwoordelijkheid zou dan niet alleen een interne betekenis hebben, maar zou ook een externe betekenis kunnen krijgen: verantwoording naar de samenleving toe. Ambtelijke verantwoordelijkheid kan aldus de politieke verantwoordelijkheid completeren, waardoor de controle van de samenleving over zaken die van algemeen belang worden geacht, aanzienlijk verbeterd zou kunnen worden. Ambtelijke loyaliteit is daarom in dit boek eigenlijk een sleutelbegrip. Het zou ons echte openbaarheid van bestuur kunnen brengen, die op haar beurt weer voorwaarde is voor echte inspraak en zinvolle referenda.

Ambtelijke loyaliteit is niet alleen een belangrijk, maar ook een weerbarstig onderwerp. Niet zozeer omdat het om een ingewikkeld begrip zou gaan, maar omdat emoties er een grote rol bij spelen. Politieke gezagsdragers en ambtenarenkorps hebben zolang een onaantastbare twee-eenheid gevormd, dat scheiding van die twee bij velen een pijn oproept alsof een siamese tweeling uit elkaar wordt getrokken. Of is het de pijn van een dreigend verlies van macht? Kennis is macht. Gebundelde kennis van politieke leiding en ambtenaren is gebundelde macht. En als openbaarheid van bestuur niet veel voorstelt; is die gebundelde macht grotendeels oncontroleerbaar. Alleen al het idee, dat die macht te scheiden zou zijn, roept weerstand op. Mijn Utrechtse leermeester Crince Le Roy heeft het geweten, toen hij in zijn openbare les van 1969 de ambtenaren een "vierde macht" had genoemd. Tot vanuit de buurt van Zierikzee kreeg hij anonieme brieven, waarin hem het verwijt van "nestbevuiling" naar zijn hoofd werd geslingerd. ${ }^{250}$ Gelukkig waren er ook toen al schrijvers die, evenals Crince Le Roy, in meer nuchtere termen de relatie tussen politieke leiding en ambtenaren aan de orde stelden. Ik kan hier verwijzen naar het eerder door mij besproken preadvies van 1970 van mijn andere leermeester, Steenbeek. Openbaarheid van bestuur brengt onvermijdelijk met zich mee, dat ambtenaren naar buiten zullen treden "als lieden die een eigen oordeel hebben dat kan afwijken van dat van hun verantwoordelijke bestuurlijke chefs"", stelde Steenbeek. De vrees dat dit zou leiden tot het verschijnsel van de "politiserende ambtenaar" noemde hij een "boemangedachte". 251

Toch denk ik er verstandig aan te doen, om ook nu nog de gevoelens een beetje te ontzien, en langs een omtrekkende beweging tot mijn formu-

251 J.G. Steenbeek, in Hand. NJV 1970, deel 1, eerste stuk, pag. 75. 
lering van het begrip "ambtelijke loyaliteit" te komen. Eerst zal ik in globale termen de geschiedenis van de opvattingen over ambtelijke loyaliteit de revue laten passeren, tot de Tweede Wereldoorlog. Veel gegevens daarover zijn te vinden in de dissertatie van Bovens, die een spoor trekt langs Amerikaanse en Europese theorieën vanaf de tweede helft van de negentiende eeuw. ${ }^{252}$ Dat de ontwikkelingen in ons land daarbij nauwelijks uit de pas lopen, blijkt uit de juridische literatuur, die uitvoerig wordt behandeld in de dissertatie van Van der Horst en in het door Olde Kalter geschreven preadvies voor de VAR, over grondrechten voor overheidspersoneel. ${ }^{253}$ Voorts zal ik de polemiek uit de jaren 1940-1941 beschrijven tussen de Duits-Amerikaanse politicoloog Carl Friedrich en zijn Engelse collega Herman Finer. Deze polemiek illustreert op indringende wijze de tegenstelling van opvattingen. In het volgende hoofdstuk zal ik de naoorlogse ontwikkelingen in de politieke theorie, in de rechtswetenschap en in de ambtenaarrechtelijke jurisprudentie beschrijven. Tot slot zal ik uiteenzetten, hoe de op zichzelf sympathieke voorstellen van Bovens slechts van marginale betekenis voor de bestuurspraktijk kunnen zijn, maar, gekoppeld aan een verdergaande openbaarheid van bestuur, misschien toch de weg naar een echte oplossing kunnen wijzen.

\section{Vooroorlogse opvattingen over ambtelijke loyaliteit}

\section{Wilson, Goodnow, en Weber}

De opvatting, dat ambtenaren (via hun superieuren) alleen gehoorzaamheid en verantwoording schuldig zijn aan politieke gezagsdragers, die op hun beurt weer verantwoording afleggen aan vertegenwoordigende organen, is nog niet zo oud. ${ }^{254} \mathrm{Ze}$ is een Europese variant van ideeën, die hun oorsprong vinden in de Verenigde Staten van Noord-Amerika en in Duitsland. Een Amerikaanse variant dateert uit de tachtiger jaren van de vorige eeuw, en is ontwikkeld door de latere president Woodrow Wilson en de hoogleraar bestuursrecht Frank Goodnow. Hun denkbeelden waren een reaktie op misstanden in die dagen, die een gevolg waren van het door president Jackson ingevoerde spoilssystem. Ambtenaren werden in dit systeem

252 M.A.P. Bovens, Verantwoordelijkheid en organisatie, Zwolle 1990.

253 Th.A.M. van der Horst, Ambtenaar en grondrechten, Alphen a/d Rijn 1967, en C.J.G. Olde Kalter, Overheidspersoneel en grondrechten, VAR-geschrift LXXXIV, Alphen a/d Rijn 1979.

254 Bovens, a.w. pag. 191. Verdere gegevens over de ontwikkeling van deze opvatting ontleen ik aan pag. 192-202. 
gerecruteerd op grond van partijpolitieke loyaliteiten, en verdwenen weer als bij volgende verkiezingen andere politici werden gekozen. Het systeem had geleid tot een onzelfstandig, ondeskundig en corrupt bestuursapparaat. Morele verontwaardiging en ergernis over het ontbreken van bestuurlijke efficiency deden Wilson, paradoxaal genoeg, pleiten voor uitbanning van morele elementen van publieke aard uit de sfeer van de organisatie. Het ambtenarenapparaat moest neutraal worden. Goodnow werkte deze gedachte verder uit. In zijn visie heeft "politics" de functie om de wil van de staat tot uitdrukking te brengen. De politiek dient zich slechts met de uitvoering te bemoeien, voorzover dat nodig is om deze in overeenstemming te brengen met de oorspronkelijke uitdrukking van die wil. Voor het overige moeten ambtenaren, zo weinig mogelijk gestoord door politieke interventies, hun werk kunnen verrichten. Wilson en Goodnow wilden, kort samengevat, de bemoeienis van politici met de dagelijkse bestuurspraktijk terugdringen.

Merkwaardig genoeg spoorde hun opvatting, dat het ambtenarenapparaat neutraal moet zijn, in grote mate met die van de Duitse socioloog Max Weber, die juist de ambtelijke invloed op het bestuur wilde terugdringen. ${ }^{255}$ Volgens Weber, die zijn theorieën over de ambtelijke dienst rond de tijd van de Eerste Wereldoorlog formuleerde, moest er een strikte scheiding komen tussen politieke en ambtelijke verantwoordelijkheden. Ambtenaren zijn in Weber's opvatting alleen gehoorzaamheid verschuldigd aan de politieke leiding. Zij dragen daarom slechts een interne verantwoordelijkheid, dat wil zeggen: een verantwoordelijkheid (via de hiërarchische lijn) naar de politieke gezagsdragers toe. Deze gezagsdragers moeten extern verantwoording afleggen, dat wil zeggen: politieke verantwoording. Alleen dan kan de samenleving nog enigszins controle uitoefenen over de bureaucratie. Ambtenaren moeten daarom neutraal zijn. Maar, zoals Bovens terecht constateert, hun neutraliteit is geen onpartijdigheid, maar juist een strikte loyaliteit en een consequent doorgevoerde partijdigheid; de ambtenaar dient zich zoveel mogelijk te conformeren aan de wensen en opdrachten van de regering van de dag. ${ }^{256}$ Zodra hij 's morgens op zijn werk komt, moet hij vergeten dat hij staatsburger is, totdat hij naar huis gaat. Dan mag hij weer een eigen politieke mening hebben. En zelfs dan

255 Zie over Weber ook: David Held, Models of democracy, Cambridge 1990, pag. 143164, en H.P.M. Goddijn (red.), Max Weber, Baarn 1980 , en daarin de bijdragen van P. Tijmes, Hoeksteen van Webers denken: de staat, en A, van Braam, Max Weber en zijn critici over gezag en bureaucratie.

Bovens, a.w. pag. 192. 
moet hij, zoals nog zal blijken, voorzichtig zijn met het naar buiten brengen van zijn opyattingen.

Hoewel Weber niet kan worden beschouwd als een representant van de klassiek-democratische theorie, sluit zijn opvatting over ambtelijke loyaliteit wel goed bij deze theorie aan. Dat heeft ertoe bijgedragen, dat men zijn opvatting al vrij spoedig is gaan bestempelen als de "klassieke leer" van de ambtelijke loyaliteit.

\section{De opvattingen in Nederland}

Olde Kalter schetst ons in zijn preadvies een soortgelijke ontwikkeling in het denken over de rechten en plichten van ambtenaren in Nederland. ${ }^{257}$ In de eerste decennia na de invoering van de Grondwet van 1848 werd algemeen aangenomen, dat alle Nederlanders, dus ook ambtenaren, dezelfde onvervreemdbare grondrechten hadden. Niet alleen de liberalen huldigden deze opvatting. Dat bleek bijvoorbeeld in 1874 , toen het gemeentebestuur van Roermond een instructie uitvaardigde om een onderwijzer te beletten mee te werken aan een kritisch plaatselijk tijdschriftje. De conservatieve minister van Binnenlandse Zaken Heemskerk Azn nodigde het gemeentebestuur uit om de instructie te wijzigen, omdat deze naar zijn mening in strijd was met de in de Grondwet gegarandeerde vrijheid van meningsuiting. Toen enige tijd daarna de onderwijzer in zijn functie werd geschorst, zorgde Heemskerk's opvolger, de liberale bewindsman Kappeijne van de Coppello ervoor, dat de schorsing door de Kroon werd vernietigd. 258

Maar enige jaren later, in 1883, verkondigde de staatsrecht-geleerde Buys een andere opvatting: "Het staat vast dat iedereen in Nederland het recht moet hebben om door middel van de drukpers vrij zijne meening te verkondigen, maar volgt daaruit dat geen autoriteit de bevoegdheid bezit om aan de voorwaarden waarop zij deze of gene aan haren dienst verbindt, ook deze te stellen, dat hij van zijn recht om als schrijver op te treden geen gebruik zal maken? Kan zij niet zeggen: ik eerbiedig uw recht, maar zo gij dit mocht willen uitoefenen dan zijt gij niet de persoon dien ik behoef en wiens hulp ik zoek?" Buijs laat daarop volgen: "Wil men toestemmend antwoorden, dan zou men moeten bewijzen niet dat het recht om vrij te schrijven bestaat - dit erkent iedereen - maar dat niemand bevoegd is dat recht prijs te geven; en dergelijk verbod staat nergens geschreven".259

259 J.T. Buijs, De Grondwet, deel I, Arnhem 1883, pag. 61. 
Naar de mening van Buijs is het recht van vrije meningsuiting dus geen onvervreemdbaar recht. De overheid kan van een ambtenaar, die bij haar in dienst treedt, verlangen dat hij er afstand van doet.

Kritiek op de mening van Buijs bleef niet uit. In 1897 wijdde de Nederlandse Juristenvereniging haar jaarvergadering aan de ambtenaarsverhouding. Preadviseur Krabbe vroeg zich retorisch af: "Waar de Grondwet rechten onder haar hoede neemt en deze dus voor den wetgever onaantastbaar maakt, zou men daar meenen, dat zij langs contractueelen weg wél kunnen worden aangetast?" En hij vervolgde: "Mij dunkt, wat de wet niet mag breken, kan ook het contract niet. Ook waar dus de contractueele grondslag van den staatsdienst wordt aanvaard, kan deze rechtsopvatting niet leiden tot de bevoegdheid van de Regeering, den ambtenaar te beperken in de uitoefening van door de Grondwet gewaarborgde rechten". De Grondwet stond naar zijn mening alleen beperkingen toe voorzover deze voor de uitoefening van de staatsdienst noodzakelijk waren. De wetgever behoorde de regering daarvoor een "richtsnoer" te geven. ${ }^{260}$ De tweede preadviseur, het parlementslid Fokker, wilde zelfs helemaal geen speciale grondrecht-beperkingen voor ambtenaren. "Gelijke vrijheid besta voor den ambtenaar, als voor alle andere burgers", schreef hij in zijn preadvies. De verhouding van de staat tot zijn ambtenaren behoorde volgens hem wel wettelijk te worden geregeld, want ze was van publiekrechtelijke aard. ${ }^{261}$ De vergadering was het in meerderheid eens met Krabbe: in principe golden de grondrechten ook voor ambtenaren; beperkingen konden worden opgelegd, maar de wet moest daar dan wel een richtsnoer voor geven. Ook regering en Tweede Kamer erkenden in de jaren na 1900 zeer uitdrukkelijk, dat de grondrechten in principe ook golden voor de ambtenaarsverhouding. ${ }^{262}$

\section{Struycken}

In 1915 publiceerde de staatsrecht-geleerde Struycken een nieuw handboek. Daarin ontwikkelde hij een visie, die de grondwettelijke vrijheden

$260 \mathrm{H}$. Krabbe, Welke is de aard der rechtswerhouding van den Staat tot zijn ambtenaren; moet zij wettelijk worden geregeld; en zoo ja, hoe in hoofdzaak? Hand. NJV 1897, deel I, Den Haag 1897, pag. 95-96.

261 E. Fokker, Welke is de aard der rechtsverhouding van den Staat tot zijn ambtenaren; moet zij wettelijk worden geregeld; en zoo ja, hoe in hoofdzaak? Hand. NJV 1897. deel I, Den Haag 1897, pag. 255.

262 Olde Kalter, a.w. pag. 61-63. 
yoor ambtenaren weer op losse schroeven stelde. ${ }^{263}$ De grondrechten in de Grondwet regelden naar zijn mening slechts "den algemeenen rechtstoestand der burgers, de algemeene voorwaarden der individuele vrijheid, niet de concrete rechtspositie, noch minder de feitelijke vrijheid van iederen individueelen burger. Uit een en ander volgt", zo verkondigde Struycken, "1e, dat het individu - voor zoover andere gronden daaraan niet in de weg staan - constitutioneel vrij blijft, door eigen wil zijne persoonlijke vrijheid zó aan banden te leggen, dat het genot of gebruik van bepaalde grondrechten rechtens wordt beperkt, of in bepaald opzicht zelfs opgeheven; $2 \mathrm{e}$, dat als gevolg van eene bijzondere rechtspositie, waarin sommige burgers zijn geplaatst, de uitoefening van een of meer dier rechten door het orgaan, dat die rechtspositie beheerscht, kan worden beperkt of verboden".

Als voorbeeld van de eerste categorie noemde Struycken de contractuele arbeidsverhouding, die pas onverbindend kan worden verklaard, als ze in strijd komt met de wet, de goede zeden of met de openbare orde. Maar ook de ambtenaarsverhouding kan volgens hem bron zijn van bijzondere beperkingen in de uitoefening der grondwettig beschermde individuele vrijheid. "Hoe ver deze beperkingen kunnen gaan, hangt af van den aard der ambtelijke verhouding. Ook de gevolgen van de niet-inachtneming dezer beperkingen worden geheel door die verhouding bepaald; daarom zullen alleen disciplinaire maatregelen toepassing kunnen vinden". Wat de tweede categorie betreft, doelde Struycken op situaties, waarin nietcontractuele gezagsverhoudingen uit het private en het publieke recht tot een beperking in de uitoefening van de grondrechten leiden. Als voorbeelden noemde hij: personen gesteld onder ouderlijke macht, voogdij, curatele, maritale macht, en voorts gefailleerden, krankzinnigen, gevangenen en dienstplichtigen. In al deze gevallen werd het karakter der grondrechten, "als bepalende den algemeenen rechtstoestand der individuen", geen geweld aangedaan. Zo kwamen de ambtenaren dus in goed gezelschap terecht, met dit verschil, dat zij zich vrijwillig aan de beperking van de grondrechten hadden onderworpen.

In 1922 bleek, dat de regering zich de opvatting van Struycken eigen had gemaakt, toen zij een Reglement betreffende de krijgstucht vaststelde. De Tweede Kamer ging met de regering in debat over de grondwettigheid van artikel 17 van het reglement. Daarin werd het recht van vereniging, vergadering, betoging en meningsuiting voor militairen sterk aan banden

263 A.A.H. Struycken, Het staatsrecht wan het koninkrijk der Nederlanden, deel I, Arnhem 1915, pag. 150-155. 
gellegd. De anti-revolutionaire minister van Justitie Heemskerk, zoon van de eerder genoemde conservatieve minister Heemskerk Azn, betoogde nu in navolging van Struycken, dat de grondrechten niet golden voor bijzondere rechtsverhoudingen tussen ambtenaren en de overheid. Een motie van het socialistische kamerlid Ter Laan, waarin onder meer om intrekking van artikel 17 van het reglement was gevraagd, werd verworpen. Daarmee zegevierde de opvatting van Struycken in het parlement. In de daarop volgende jaren werd ze ook overgenomen door belangrijke schrijvers als Van der Pot en Vegting, en verwerkt in de jurisprudentie de Centrale Raad van Beroep. De opvatting legitimeerde een nieuwe stijl van besturen. Men kon nu de zaken meer binnenshuis houden, tot interne bestuursaangelegenheid verklaren. ${ }^{264}$

\section{De dubieuze kanten van de klassieke leer}

De nieuwe opvattingen in Nederland over de bijzondere positie van de ambtenaar liepen keurig in de pas met de 'klassieke' of 'Weberiaanse' leer, die in het interbellum in veel Europese landen, waaronder Duitsland en Engeland, de heersende leer zou worden. Waarschijnlijk hangt een en ander samen met de sterke groei in de jaren 1900-1920 van de omvang van de overheidsadministratie in de verschillende westerse landen. Deze groei, die veroorzaakt werd door nieuwe overheidstaken, makte bij velen angstgevoelens los. Men werd bang voor iets, watrvoor de negentiendeeeuwer nooit echt bang was geweest: de 'bureaucratie'. Die moest hoe dan ook onder controle worden gebracht. Toen omstreeks 1920 in bijna alle West-Europese landen het algemeen kiesrecht was ingevoerd, leek de oplossing voor de hand te liggen, te meer omdat door de industriële revoluties intussen een tamelijk mechanisch mensbeeld was gevormd. Mensen kon je als onpersoonlijke radertjes in een productieproces plaatsen. Dat gold dus ook voor ambtenaren. Ze moesten niet zelfstandig nadenken, laat staan hun mening uiten, maar precies doen wat hun (politieke) superieuren hen opdroegen. Deze waren op hun beurt verantwoording verschuldigd aan de met algemeen kiesrecht gekozen volksvertegenwoordiging. Echte democratie leek aldus zelfs in een complexe, geïndustrialiseerde samenleving werkelijkheid te kunnen worden. Maar door een dienstbetrekking met de overheid aan te gaan, gaven de ambtenaren wel een deel van hun staatsburgerlijke rechten, en daarmee ook een deel van hun eigen staatsburgerlijke verantwoordelijkheid uit handen. 
Welke edele motieven er ook aan de klassieke leer ten grondslag lagen, al in het Derde Rijk en in de Tweede Wereldoorlog zou blijken, tot welke consequenties ze konden voeren. Als meest extreme voorbeeld van de klassieke model-ambtenaar is wel de persoon van Adolf Eichmann genoemd: een man die stipt en efficiënt de vernietiging van miljoenen joden organiseerde, omdat hem dat nu eenmaal was opgedragen. Geen wonder, dat men na de tweede wereldoorlog toch vraagtekens bij deze leer is gaan plaatsen. ${ }^{265}$

\section{Discrepantie tussen doelstellingen en effecten}

De discrepantie tussen doelstellingen en effecten van de klassieke leer verdient hier nog enige aandacht. Een belangrijke doelstelling was de democratische sturing en controle van het ambtelijk handelen te bevorderen. Maar wat wordt er daadwerkelijk bereikt als we het klassieke recept toepassen? Bovens geeft als voorbeeld de "Belgrano-affaire". ${ }^{266}$ Deze betrof de torpedering van de Argentijnse kruiser Belgrano door de Britse marine tijdens de Falkland-oorlog. De Britse regering verklaarde in het parlement, dat de torpedering noodzakelijk was geweest, omdat de Belgrano gezien haar koers en positie een direct gevaar opleverde voor de Britse vloot. Onafhankelijke onderzoekers ontdekten korte tijd later, dat de kruiser op het moment van de aanval al op weg was naar haar thuishaven. In het parlement werden toen opnieuw kritische vragen gesteld. Een topambtenaar van Defensie, Clive Ponting, stelde voor mimister Heseltine concept-antwoorden op, waaruit kon worden afgeleid, dat de Belgrano inderdaad al van koers was gewijzigd. Heseltine besloot echter de antwoorden niet te versturen, en deelde het parlement mee, dat hij niets toe te voegen had aan zijn eerdere verklaringen. Toen daarna de staatssecretaris van Defensie, Stanley, opzettelijk misleidende informatie aan de Commissie voor Buitenlandse Zaken verstrekte, stuurde Ponting een parlementslid

265 Dit betekent niel, dat er vandaag de dag geen waardering meer bestaat voor de opvattingen wan Weber. In de oratie van de Leidse hoogleraar in de bestuurskunde A.I.G.M. Bekke, getiteld De betrouwbare bureaucratie (Alphen a/d Rijn 1990), wordt zelfs een herwaardering van Weber bepleit. Bekke neemt Weber in bescherming tegen de moderne critici, die te veel aandacht hebben voor bedrijfsmatige efficiency ("doelrationaliteit"), en te weinig oog voor de nadrukkelijk door Weber beoogde verwezenlijking van waarden ("waardenrationaliteit") in het openbaar bestuur. Bekke erkent dat Weber's concept "wel degelijk bijstelling behoeft" (pag. 22). Maar wat dat zou moeten betekenen, vertelt hij er niet bij. Het antwoord op de vraag, wat een betrouwbare bureaucratie is, zal men in zijn oratie dan ook vergeefs zoeken.

266 Bovens, a.w. pag. 188 e.v. 
een envelop met twee documenten: de concept-antwoorden die Heseltine niet wilde versturen en een intern ambtelijk memorandum dat de informatie bevatte waar de kamercommissie om had gevraagd. Ponting werd daarop strafrechtelijk vervolgd. De rechter adviseerde de jury om Ponting schuldig te verklaren aan overtreding van de Official Secrets Act, maar de jury sprak hem vrij.

De Belgrano-affaire laat ons duidelijk een dubieuze kant van het klassieke recept zien: Is democratische controle wel het meest gebaat met ambtenaren die hun superieuren stipt gehoorzamen? Wat te zeggen, als die superieuren het belangrijkste orgaan van democratische controle, het parlement, om de tuin willen leiden? Of als een lagere ambtenaar ziet, dat zijn superieuren essentiële informatie onthouden aan de politiek verantwoordelijke leiding? Het mag duidelijk zijn, dat in dergelijke situaties het klassieke recept geen heilzame werking heeft.

Een andere belangrijke doelstelling in de klassieke leer was om te verzekeren, dat ambtenaren zich tegenover burgers behoorlijk gedragen. Als zij stipt de instructies van hun meerderen opvolgen, schept dat naar de burger toe rechtszekerheid en rechtsgelijkheid. Willekeur wordt dan vanzelf uitgebannen. Op zich valt natuurlijk niet te ontkennen, dat het stipt uitvoeren van instructies de rechtszekerheid en rechtsgelijkheid bevordert. Het probleem van de moderne staat is echter, dat instructies aan ambtenaren slechts zelden zo concreet kunnen zijn, dat ongelijke behandeling niet meer mogelijk is. En wat te doen, als een instructie wel voldoende concreet, maar tegelijk onrechtvaardig is? De ambtenaar die daar kennis van draagt, zal volgens de leer van Weber naar de burger toe zijn mond moeten houden, en de instructie stipt moeten uitvoeren. Of de burgers daarom per saldo wel zo gebaat zijn met de Weberiaanse ambtenaar, valt nog maar te bezien.

Een derde belangrijke doelstelling van Weber was het bevorderen van een efficiënte bedrijfsvoering. De top van de overheidsadministratie zou de zekerheid moeten hebben dat haar opdrachten stipt worden uitgevoerd, en dat haar beleid niet van onderaf wordt doorkruist. De basis weet dan ook waar ze aan toe is. Bovens wijst er op, dat nog maar weinig organisatiedeskundigen van mening zijn, dat een efficiënte organisatie het meest gediend is met een dociele en neutrale uitvoering van beleid door de lagere niveaus. Tegenwoordig vindt men beleidsvrijheid en autonomie voor de uitvoerende niveaus juist ook uit een oogpunt van efficiency erg belangrijk. ${ }^{267}$ 


\section{Friedrich versus Finer}

In 1940 publiceert de naar de Verenigde Staten geëmigreerde Duitse jurist en politicoloog Carl J. Friedrich zijn artikel Public Policy and the nature of administrative responsibility in het Amerikaanse tijdschrift Public Policy. ${ }^{268}$ Friedrich had in de dertiger jaren al naam gemaakt met zijn boek Constitutional government and politics, dat na de oorlog nog een aantal drukken zou beleven onder de titel Constitutional government and democracy. In zijn bijdrage in Public Policy probeert Friedrich een nieuwe formule te vinden voor de verhouding tussen politici en ambtenaren. Zoals we hebben gezien, had deze verhouding sinds de dagen van Wilson en Goodnow in Amerika een andere ontwikkeling doorgemaakt dan in Europa. Er waren in de Verenigde Staten veel zelfstandige ambtelijke diensten gevormd. Die vervulden "neutraal" de taken die hen wettelijk waren opgedragen. De politiek was wel verantwoordelijk voor de taakformulering, maar kon op de wijze van taakvervulling geen directe invloed uitoefenen. Er bestond aldus een duidelijke scheiding tussen politiek beleid en ambtelijke uitvoering. De New Deal-politiek van president Roosevelt, die zijn economisch beleid baseerde op de wetenschappelijke inzichten van ambtelijke medewerkers, riep nieuwe vragen op over ambtelijke verantwoordelijkheid. Friedrich, die uiteraard ook de situatie in Europa goed kende, wilde een formule geven, die toepasbaar zou zijn in alle westers-democratische landen.

De toon en de woordkeuze in Friedrich's artikel is tamelijk provocerend. Hij zet zich al meteen af zowel tegen de Weberiaanse visie als tegen de denkbeelden van Goodnow, die beiden, ondanks accent-verschillen, administrative responsibility zien als "merely a responsibility for executing policies already formulated" (pag. 5). Het onderscheid dat Goodnow heeft gemaakt tussen politics als the expression of the will of the state en administration als the execution of that will, is niet bruikbaar. "Public policy", zegt Friedrich, "is a continuous process, the formation of which is inseparable from its execution" (pag. 6). Wie als Goodnow denkt, ziet twee dingen over het hoofd: "(1) that many policies are not ordained with a stroke of the legislative or dictatorial pen but evolve slowly over long periods of time, and (2) that administrative officials participate contimuously and significantly in this process of evolving policy" (pag. 7). Dit geldt niet alleen voor de Verenigde Staten, maar ook voor landen met een parlementair stelsel, zoals bijvoorbeeld Engeland. Het idee, dat een 
parlement via de werking van de vertrouwensregel zeggenschap zou hebben over de regering, en zelfs over in vaste dienst aangegestelde ambtenaren, vindt Friedrich naïef en verontrustend. "For what has the parliamentary majority in Britain been in the last few years but a rubber stamp of an automatic docility undreamt of in the United States?" vraagt hij zich af. Steeds weer slikt de parlementaire meerderheid haar bezwaren in "because the particular issue is 'not worth a general election' and the chance of the M.P. losing his seat" (pag. 10).

Anders dan bij de meer tradionele waarnemers zijn dergelijke constateringen bij Friedrich echter geen reden, om maar op de bureaucratie te gaan schelden. Men moet er oog voor hebben, vindt hij, "that this 'bureaucracy' had arisen in response to undeniable needs, and that therefore the real problem is how to render these functionaries responsible, not how to take all power away from them" (pag. 10). ${ }^{269}$ Wil men dit echte probleem aanpakken, dan komt men met het klassieke schema van "staatswil formuleren - staatswill uitvoeren' niet veel verder. Want "a modern administrator is in many cases dealing with problems so novel and complex that they call for the highest creative ability". Er moet creatief en adequaat worden gereageerd. De 'volkswil' heeft vaak geen andere inhoud dan de wens dat de problemen worden verholpen. Wat is in dergelijke situaties "irresponsible policy"? Om die vraag te beantwoorden, formuleert Friedrich een dubbele standaard, een dual standard of adminstrative responsibility. Beleid is naar zijn mening onverantwoord: le, "if it can be shown that it was adopted without proper regard to the existing sum of human knowledge concerning the technical issues involved"; $2 \mathrm{e}$, "if it can be shown that is was adopted without proper regard for the existing preferences in the community, and more particularly its prevailing majority" (pag. 12). Beleidsmakers dragen aldus een dubbele verantwoordelijkheid: een functional of objective responsibility en een political of subjective responsibility. Doen zij in hun beleid de stand van de wetenschap geweld aan, dan kunnen zij worden aangesproken op grond van eerstgenoemde verantwoordelijkheid. Negeren zij de wil van de meerderheid, dan zijn zij aanspreekbaar op grond van de tweede.

Op dit punt aangekomen, merkt Friedrich op, dat hij zich in 1935 al eens in soortgelijke zin heeft uitgelaten. Maar zijn visie werd toen bestreden door de Engelse politicoloog Herman Finer, die al enige faam had verworven met zijn boek The theory and practice of modern government. Finer 
kon niets beginnen met het begrip functional of objective responsibility. Aansprakelijkheid stelde volgens hem niets voor, als de geregeerden een ambtsdrager niet naar huis konden sturen, of deze op z'n minst nadeel konden bezorgen. Friedrich vindt dit een treurig staaltje van bewustzijnsvernauwing. "Thus with one stroke of the pen, all the permanent officials of the British government, as well as our own and other supposedly popular governments, are once and for all rendered irresponsible", schampert hij (pag. 13). Als men bedenkt, hoe groot de rol van ambtenaren is bij de vorming van beleid, én dat volksvertegenwoordigers, zeker in Engeland, geen enkele zeggenschap hebben over benoeming of ontslag van die ambtenaren, dan kan politieke aansprakelijkheid alleen toch nooit toereikend zijn om het systeem goed te laten functioneren. In onze technische beschaving, zegt Friedrich, groeit een nieuw soort verantwoordelijkheid bij de ambtenaar, die geroepen wordt om creatieve oplossingen te vinden "for our crying technical needs". Die verantwoordelijkheid kan alleen effectief worden afgedwongen "by fellow-technicians who are capable of judging his policy in terms of the scientific knowledge bearing upon it" (pag. 14).

Wil deze functionele verantwoordelijkheid goed tot haar recht komen, dan moet er wel het een en ander in de openbare dienst veranderen, vindt Friedrich. De hiërarchische gerichtheid in de organisatie moet meer worden omgebogen tot een gerichtheid op het publiek. Die ontwikkeling heeft zich in feite al in gang gezet. Ambtenaren zoeken bij het voorbereiden en uitvoeren van beleid rechtstreeks samenwerking met burgers. Men peilt meningen en wensen. Dat is een goede zaak, want in veel gevallen kan beleid alleen maar tot stand komen, alls er met de betrokkenen wordt samengewerkt. En burgers die iets van de overheid gedaan willen krijgen, nemen steeds vaker rechtstreeks contact op met de betrokken ambtenaren. Volgens het traditionele concept van 'representative government' zouden die burgers zich moeten wenden tot de door hen gekozen volksvertegenwoordigers. Maar er is geen reden voor verontrusting. De nieuwe ontwikkeling "is a rather natural development, compensating democratically for the gradual dissappearence of effective legislation by individual members of legislative assemblies"' (pag. 18).

Toch is dit alles niet voldoende. De eigen verantwoordelijkheid van de ambtenaren blijft te beperkt, als die ambtenaren niet net als andere burgers het recht hebben, om hun mening en standpunten naar buiten te brengen. Die beperking komt ook de kwaliteit van het openbaar bestuur niet ten goede. "Employees who are denied the rights of ordinary citizens cannot possibly be expected to remain loyal and responsible public servants", zegt Friedrich (pag. 21). Moeten ambtenaren ook vrij zijn, om in het openbaar hun mening te geven over zaken waar ze in hun werk mee 
bezig zijn, "about issues of general public policy, more particularly those on which they themselves possess exceptional information and understanding because of their official position"? De "authority-loving politician" wil zijn ambtenaren die vrijheid ontzeggen, want de geloofwaardigheid van het officiële beleid kan erdoor worden aangetast. Anderen beweren, dat er onderscheid moet worden gemaakt tussen feiten en beleidsopvattingen. Ambtenaren zouden dan wel de juistheid van de gestelde feiten mogen betwisten, maar niet de juistheid van de beleidsopvattingen daarover. Friedrich vindt dit onzin. Feiten en standpunten kunnen niet worden gescheiden. Moeten ambtenaren zich dus maar onbeperkt kunnen uiten? Dat zou Friedrich zo niet in $z^{\prime} n$ algemeenheid willen beweren. Veel hangt af van "the nature of the case". Maar, zegt hij: "In matters of vital importance the general public is entitled to the views of its permanent servants. Such views may often provide a salutary check on partisan extravagances. Such views should be available not only to the executive but to the legislature and the public as well" (pag 23).

Het is jammer, vindt Friedrich, dat ambtenaren vaak zelf te huiverig zijn om hun inzichten naar buiten te brengen. Ze worden weerhouden door angst, dat de verhouding met hun superieuren erdoor zal verslechteren. Toch zou het normaal moeten zijn, dat ambtenaren hun inzichten toetsen in een openbaar wetenschappelijk debat. Hun functionele verantwoordelijkheid zou erdoor worden versterkt, en de kwaliteit van het openbaar bestuur zou erdoor worden verbeterd. "The sound standard in a vast and technically complex government such as ours is to insist that the public statements of officials be in keeping with the highest requirements of scientific work", stelt hij. En chefs die het niet eens zijn met wat hun beleidsmedewerkers in dat openbare debat naar voren brengen, moeten zelf maar het spreekgestoelte beklimmen. "If a man's superiors disagree with him, let them mount the same rostrum and prove that he is wrong; before the goddess of science all men are equal" (pag. 23).

\section{Füner}

De stellingen van Friedrich zullen niet onweersproken blijven. In 1941 reageert een aangeslagen Herman Finer in de Public Administration Review. ${ }^{270}$ Vanuit zijn traditionele opvatting over representatie-democratie kan Finer het vraagstuk alleen maar benaderen als een gesloten vraag met een keuze uit twee antwoorden. "Are the servants of the public to decide 
their own course, or is their course of action to be decided by a body outside themselves?" vraagt hij de lezer. En, zoals meestal bij een gesloten vraag het geval is, is er maar êen goed antwoord mogelijk: "My answer is that the servants of the public are not to decide their own course; they are to be responsible to the elected representatives of the public, and these are to determine the course of action of the public servants to the most minute degree that is technically feasible". Uit dit antwoord volgt voor Finer eigenlijk als vanzelf, dat er altijd formele mogelijkheden moeten zijn om ambtenaren op hun verantwoordelijkheid aan te spreken. Anders gezegd: de verantwoordelijkheid moet met sancties kunnen worden afgedwongen. Finer noemt twee mogelijkheden: "(a) through the courts and disciplinary controls within the hierarchy of the administrative departments, and also (b) through the authority exercised over officials by responsible ministers based on sanctions exercised by the representative assembly" (pag. 336).

Als Friedrich een niet afdwingbare, functionele verantwoordelijkheid voorstelt, dan kan dat in de ogen van Finer dus niets anders betekenen, dan dat de ambtenaren hun eigen gang mogen gaan, hun eigen normen mogen stellen. "What is needed, however" zegt hij, "is not a technical capacity per se, but a technical capacity in the service of the public welfare as defined by the public and its authorized representatives" (pag. 338). Finer ziet daarbij over het hoofd, dat Friedrich de functionele verantwoordelijkheid heeft bepleit als aanvulling op de tekortschietende formele verantwoordelijkheid. De functionele verantwoordelijkheid zou dienst moeten bewijzen in die talrijke gevallen, waarin het publiek en ook de volksvertegenwoordigers (nog) helemaal niet hebben gedefinieerd, wat in de betreffende situatie "public welfare" is. Of, sterker nog, in die gevallen waarin volksvertegenwoordigers en politieke ambtsdragers van de ambtenaren een goed advies verwachten over wat in het belang van de "public welfare" moet worden gedaan.

Nu ziet Finer ook wel in, dat de taken van de overheid in de loop der jaren sterk in omvang zijn toegenomen, en dat de politieke organen aan de ambtenaren vaak veel ruimte voor beleidsinvulling geven. De formele verantwoordelijkheid kan daardoor in de praktijk steeds moeilijker worden geëffectueerd. Volgens hem is Friedrich daardoor op een punt gekomen "where he practically throws the baby out with the bath". Maar Finer denkt aan andere remedies. Hij noemt dan met name "continuing control of the representative and judicial agencies over the official" en "omnipresent sense of duty to the public on the part of the official" (pag. 339).

Hoe de bestaande controle moet worden verbeterd, maakt Finer niet erg duidelijk. Wel pleit hij in dit verband voor het instellen van "advisory 
bodies" en voor "improvement of the quality of political parties and elections", maar hij werkt dat niet verder uit. Om het plichtsbesef van de ambtenaar ten opzichte van de publieke zaak te versterken, noemt Finer twee middelen: "education and the influence of his professional organizations". De opleiding moet erop gericht zijn "to make the official aware of the basic importance of his responsibility to the parliamentary assembly, and the errors into which he will be liable to fall unless he makes this his criterion". De ambtenaar moet zich de gevaren realiseren van een geloof, dat hij een missie zou hebben "outside the declared or clearly deducible intention of the representative assembly" (pag. 341). Ambtenarenorganisaties kunnen hun leden helpen de juiste, dienstbare houding te vinden. Want "subservience" - Finer kan dit woord niet vaak genoeg herhalen - blijft een eerste vereiste. Als we dat laten vallen, "we shall gradually slip into a new version of taxation without representation" (pag. 342).

\section{"Sense of duty"}

In de ogen van Finer balanceert Friedrich op het randje van de democratische theorie. "I do not think for a moment that he really is antidemocratic" zegt Finer, "but his line of argument presses him to enunciate views which might lead to this suspicion" (pag. 346). Maar als het erop aankomt concrete voorstellen te doen, die in een moderne bureaucratische samenleving de representatie-democratie zouden kunnen versterken, dan heeft Finer zelf niet veel bijzonders te melden. Evenals Friedrich legt hij een grote nadruk op ambtelijk plichtsbesef. Daar zijn de burgers en de politici kennelijk toch op aangewezen. Maar zijn er enkele saillante punten van verschil tussen de beide denkers.

Voor Finer heeft de term sense of duty duidelijk een klassieke betekenis. Plichtsbesef zou bij een ambtenaar het besef moeten zijn, dat hij zijn meerderen stipt moet gehoorzamen, in het vertrouwen dat die op hun beurt loyale uitvoerders zijn van de wil van de volksvertegenwoordiging. Bij Friedrich betekent plichtsbesef iets anders. Ambtenaren zijn voor hem zelfstandig denkende medewerkers, die in de maatschappij problemen signaleren, waarvan zij de politieke leiding deelgenoot maken. Voor die problemen, en voor andere, die door de politieke leiding zelf op tafel worden gelegd, moeten zij creatieve oplossingen bedenken. Dat is hun taak. Plichtsbesef is dan het besef bij ambtenaren, dat die taak vervuld moet worden met de nodige ijver, integriteit, kennis van zaken, en met het doel de gemeenschap te dienen. Natuurlijk moeten de oplossingen worden uitgewerkt in overleg met de verantwoordelijke politieke organen, en mogen ze pas worden gerealiseerd als die organen ermee instemmen. Maar die instemming hoeft volgens Friedrich niet helemaal afhankelijk te zijn 
van een toevallige meerdere, die als flessehals naar het politieke niveau toe fungeert. Als die verstopt blijkt te zijn, mag een ambtenaar, vanuit datzelfde plichtsbesef, maar ook omdat hij dezelfde vrijheid van meningsuiting heeft als ieder ander, proberen het publiek en de politiek voor zijn standpunt te winnen. Dat is ook voor de democratie en voor de kwaliteit van het bestuur zelf van belang. Friedrich erkent, dat er situaties denkbaar zijn, waarin een dergelijk optreden niet wenselijk is. Maar, vindt hij, in zaken van vital belang heeft het publiek zelfs recht op kennisname van de ambtelijke meningen.

Voor Finer zijn dergelijke gedachten een gruwel. "Who would define the public interest - who could define it? Only the public, I believe, or its deputies", schrijft hij. "If the community does not command, there is no call for the technical knowledge whatever" (pag. 347). Ambtenaren moeten beslist niet meer doen dan hen uitdrukkelijk is opgedragen. Anders wordt de bureaucratie onbeheersbaar. Bezien in het licht van zijn opvattingen over "subservience", hoeft het dan ook niet te verwonderen, dat Finer al helemaal niets moet hebben van ambtenaren, die in het openbaar voor hun mening uitkomen. Als Friedrich gelijk heeft met zijn bewering, dat feitelijke informatie en persoonlijke beleidsopvattingen niet te scheiden zijn, "then a fortiori the civil servant should preserve his anonymity", meent Finer. Het enige dat een ambtenaar is toegestaan, is een "frank private demonstration of the alternatives and their advantages and disadvantages to his political chief, or where the political system requires, to the committee of the assembly at their request" (pag. 349). Vraagt een parlementaire commissie hem niets, dan heeft de ambtenaar in het openbaar te zwijgen.

De polemiek tussen Friedrich en Finer zou overstemd worden door het geweld van de Tweede Wereldoorlog. Het publiek had toen wel andere zorgen. Eerst moest een andere strijd worden beslecht. We zullen in het volgende hoofdstuk zien, dat de discussie over de rechten en plichten van de ambtenaar na de oorlog nieuwe impulsen krijgt, zonder dat er echt nieuwe argumenten worden ingebracht. 


\section{Hoofdstuk 7}

\section{De loyaliteit van de ambtenaar, II Naar een nieuwe opvatting}

\section{Naoorlogse ontwikkelingen in de politieke theorie}

$\mathrm{Na}$ de Tweede Wereldoorlog geven vooral de Neurenberg-processen velen aanleiding, om het Weberiaanse concept van ambtelijke loyaliteit ter discussie te stellen. Het formuleren van bezwaren tegen dit concept blijkt echter gemakkelijker dan een nieuwe leer ingang te doen vinden. Toch is er aan pogingen geen gebrek. Die worden, behalve door de gedachten aan de verschrikkingen van de oorlog, ook gestimuleerd door het werk van existentialistische filosofen als Jean Paul Sartre, en van humanistische denkers als Erich Fromm. In de theorievorming komt de nadruk te liggen op het individuele, autonome oordeelsvermogen van de mens, en op individuele zelfontplooiing en creativiteit. In de wereld van de juristen leeft de aandacht voor mensenrechten en grondrechten sterk op, en worden na verloop van tijd ook weer vragen gesteld over de grondrechten van het overheidspersoneel.

Behalve ideologische redenen is er ook nog een praktische reden, om naar een nieuw concept te zoeken: het ambtenarenkorps zelf is sterk veranderd. Bestond dit voor de oorlog nog grotendeels uit functionarissen die op jonge leeftijd onder aan de ladder begonnen waren, en dan via interne opleidingen carrière konden maken, na de oorlog komt daar wijziging in. In de moderne en sterk groeiende overheidsorganisatie worden staf- en leidinggevende functies in toenemende mate toebedeeld aan mensen met een universitaire of andere externe opleiding. Deze ambtenaren brengen hun eigen zelfstandige manier van denken, en ook hun eigen professionele normen mee. Blindelings opdrachten uitvoeren, is er gewoonlijk niet meer bij. Maar wat mag er dan wel van deze medewerkers worden verwacht?

Uit de veelheid van politiek-theoretische concepten voor een nieuwe ambtenaren-attitude zijn er twee belangrijk genoeg om hier aan de orde te stellen: de ontplooiingsopvatting en het burgerschapsdenken. Vervolgens zal ik in aparte paragrafen aandacht besteden aan de naoorlogse juridische 
opvattingen over ambtelijke loyaliteit, in literatuur en jurisprudentie, om dan tenslotte een eigen concept formuleren.

\section{De ontplooiingsopvatting}

De ontplooiingsopvatting imliceert een ruime discretionaire bevoegdheid voor de individuele ambtenaar, een eigen verantwoordelijkheid bij de taakuitoefening, en dus een grote nadruk op zelfstandige oordeelsvorming. In geval van een loyaliteitsconflict geeft de loyaliteit aan het eigen geweten de doorslag. In laatste instantie dient de ambtenaar zelf, op basis van zijn eigen normen, te beslissen of hij een discutabele opdracht wenst uit te voeren of niet. ${ }^{271}$ Het spreekt voor zich, dat een attitude die op deze opvatting gebaseerd is, gemakkelijk conflicten kan opleveren met de belangen van democratische zeggenschap, rechtszekerheid, en efficiënte bedrijfsvoering. Vaak zal het niet eenvoudig zijn om dergelijke conflicten door overleg op te lossen. Want vooral in gewetenszaken is het moeilijk om compromissen te sluiten. Toch hoeft het erkennen van gewetensbezwaren niet tot onoverkomelijke problemen voor de openbare dienst te leiden. In verschillende delen van het publiekrecht is de mogelijkheid van erkenning van zulke bezwaren gecreëerd, bijvoorbeeld ten aanzien van de vervulling van de militaire dienst, en de betaling van premies voor sociale volksverzekeringen. Zo is het ook denkbaar, dat een ambtenaar die een gewetensbezwaar tegen een bepaalde opdracht heeft, in zijn waarde wordt gelaten, zonder dat dat voor hem rechtspositionele consequenties hoeft te hebben. In de lagere rechtspraak vindt men wel voorbeelden waarin deze gedachte wordt gevolgd. ${ }^{272}$ De dienstleiding zou dan, al dan niet op advies van een commissie, het gewetensbezwaar als een persoonlijk bezwaar kunnen erkennen. En gewoonlijk is er dan best een collega te vinden, die de opdracht wel wil uitvoeren. Voor de overheidsdienst ontstaat pas een probleem, als op grote schaal gewetensbezwaren zouden worden opgeworpen.

Bovens wijst er op, dat de ontplooiingsopvatting voor ambtenaren minder gunstig is dan op het eerste gezicht lijkt. ${ }^{273}$ Zou het concept alge-

271 Bovens, a.w. pag. 205 e.v.

272 Bijvoorbeeld in een uitspraak van 1 mei 1986 van het ambtenarengerecht in Den Bosch (intern reg.nr. AW 85/261), die het ontslag ongedaan maakte van een Tillburgse GSD-ambtenaar, die weigerde de zgn. "voordeurdelersregeling" toe te: passen. Wellicht heeft bij deze beslissing van het gerecht meegewogen, dat de betrokken ambtenar (tegelijk met de weigering) zelf overplaatsing had aangevraagd naar een ander dienstonderdeell van de gemeente. 
mene gelding krijgen, dan is het gevaar niet denkbeeldig, dat overheidsdiensten daarop gaan anticiperen bij de selectie van medewerkers. Om risico"s te beperken, zou men dan zo min mogelijk personeel met princiële of afwijkende meningen in dienst nemen. Daartegenover kan men stellen, dat werkzoekenden met dergelijke meningen niet snel bij een overheid zullen solliciteren, als daar geen ruimte zou zijn voor erkenning van principiële bezwaren. Dus voor het resultaat van de werving van overheidspersoneel zal het misschien niet veel uitmaken, of het concept nu wel of niet wordt gehanteerd. Los daarvan, is voor de in dienst zijnde ambtenaren een behandeling volgens het ontplooiingsconcept niet altijd even plezierig. Erkenning van een gewetensbezwaar reduceert een meningsverschil tot een persoonlijk probleem van de betrokken medewerker. De overheidsdienst zal de handelingen waar de medewerker bezwaar tegen heeft, niet achterwege laten. Anderen zullen "zijn" werk doen. En voor hem dreigt in de organisatie het gevaar van isolement.

\section{Het burgerschapsdenken}

Het burgerschapsdenken wordt sinds de zestiger jaren vooral door Engelse en Amerikaanse auteurs gepropageerd. Bovens, een zeer uitgesproken vertegenwoordiger van dit denken in Nederland, noemt het ook wel "de opvatting van institutioneel burgerschap", omdat het om burgerschap binnen instituties gaat. Evenals de ontplooiingsopvatting legt het burgerschapsdenken een grote nadruk op de eigen verantwoordelijkheid van de ambtenaar, en dus op zijn zelfstandige oordeelsworming. Maar terwijl eerstgenoemde opvatting de loyaliteit aan het eigen geweten beklemtoont, bepleit het burgerschapsdenken loyaliteit aan de publieke zaak: ${ }^{274}$ Bovens omschrijft deze opvatting als volgt:

Tot de belangrijkste deugden van de functionaris behoort in de eerste plaats het besef dat hij ook binnen het verband van zijn organisatie burger blijft. Uit dien hoofde dient hij bij zijn optreden oog te hebben voor het in stand houden van de politieke gemeenschap en voor de bescherming van een aantal belangrijke publieke belangen. Tot die belangen behoort in ieder geval het in stand houden, en soms zelfs bevorderen, van de mogelijkheden van democratische organen om het optreden van de organisatie waarvan hij deel uitmaakt te sturen en te

274 Id. pag. 209 e.v. Vergelijkbare uitgangspunten treft men an in de dissertaties van o.m. C.J.M. Schuyt, Recht, orde en burgerlijke ongehoorzaamheid, Rotterdam 1972, en van Grat van den Heuvel, Industrieel burgerschap als uitnodiging. Deventer 1983 . 
controleren, handhaving van de beginselen die ten grondslag liggen aan de rechtsstaat en, voor zover dit niet in strijd komt met een van de vorige belangen, bevordering van een efficiënte bedrijfs- en bestuursvorm. ${ }^{275}$

Loyaliteit aan de publieke zaak is dus een ruimer begrip dan loyaliteit aan het eigen geweten. Bij het uitvoeren van opdrachten let de ambtenaar niet alleen op wat hij voor zijn eigen geweten nog kan verantwoorden, maar ook op de belangen van de democratie en de rechtsstaat. Ook het belang van een efficiënte bedrijfs- en bestuursvorm, voor zover verenigbaar met dle zojuist genoemde belangen, houdt hij in het oog. Krijgt hij een opdracht, die naar zijn mening met die belangen in strijd is, en kan een Fineriaanse "frank private demonstration" ten overstaan van zijn chefs daar geen verandering in brengen, dan houdt zijn verantwoordelijkheid niet op. Per slot van rekening is hij, ook in werktijd, staatsburger, met alle rechten en plichten vandien. Dat betekent niet, dat een ambtenaar zijn eigen baas is. In gewone omstandigheden dient gehoorzaamheid aan de superieuren hoofdregel te zijn. Maar deze regel is niet zo absoluut als in de klassieke opvatting. In bijzondere gevallen en onder bepaalde voorwaarden gaat het burgerschap vóór. Bovens noent het burgerschapsdenken daarom een "geamendeerde versie" van de klassieke opvatting van ambtelijke verantwoordelijkheid. ${ }^{276}$

Wat zijn nu die bijzondere gevallen en bepaalde voorwaarden? Het antwoord op die vraag is volgens Bovens afhankelijk van de beantwoording van een zestal andere vragen:

1. Valt de ongehoorzaamheid te verdedigen met een beroep op de bescherming van zwaarwegende publieke belangen?

2. Geschiedt de ongehoorzaamheid openlijk, en is de functionaris bereid openlijk zijn optreden op grond van bovengenoemde publieke belangen te verdedigen?

3. Is het redelijkerwijs aannemelijk dat een van de genoemde belangen dreigde te worden geschonden?

4. Wegen de belangen die men door de ongehoorzaamheid trachtte te beschermen op tegen de belangen die door de ongehoorzaamheid worden geschonden?

5. Is er een zinvolle samenhang tussen de ongehoorzaamheid en de concrete bedreiging van zwaarwegende publieke belangen? 
6. Heeft de functionaris de schade die het gevolg kon zijn van zijn ongehoorzaamheid zoveel mogelijk trachten te beperken?

Voor legitieme ongehoorzaamheid is in elk geval vereist, dat de eerste vraag bevestigend wordt beantwoord. De vragen 3 tot en met 6 moeten ook min of meer bevestigend kunnen worden beantwoord. Wat vraag 2 betreft, ligt de zaak iets gevoeliger. In repressieve organisaties kan openlijke ongehoorzaamheid vrijwell gelijk staan met kamikaze, en dat kan van mensen niet worden verlangd. Verborgen ongehoorzaamheid kan dan in bepaalde gevallen ook legitiem zijn. ${ }^{277}$ Men denke bijvoorbeeld aan de in het vorige hoofdstuk beschreven Belgrano-affaire.

Bovens onderscheidt verschillende vormen van ambtelijke ongehoorzaamheid. De meeste aandacht besteedt hij aan het zo geheten "whistleblowing" of "klokkeluidersgedrag". Daarvan is sprake als een functionaris, teleurgesteld omdat zijn interne kritiek niet tot voldoende resultaat heeft geleid, informatie naar buiten brengt. Dat kan in het geheim gebeuren, bijvoorbeeld via lekken naar de pers. Maar Bovens reserveert de term "de klok luiden" liever voor gevallen waarin dat openlijk geschiedt. ${ }^{278}$ De functionaris moet bij voorkeur niet de klok gaan luiden met een beroep op gewetensnood, maar met een beroep op één van de eerder genoemde publieke belangen. Want over gewetensvragen kan moeilijk worden gediscussieerd, en kunnen nog moeilijker compromissen worden bereikt. Alle kans, dat het hele geschil al gauw wordt gereduceerd tot een persoonlijk probleem van de betrokken functionaris. De organisatie zelf wordt er niets wijzer van, en zal zich niet beter gaan gedragen. Maar een beroep op publieke belangen kan wél een zinvolle discussie losmaken, een discussie die ook kan leiden tot leer-effecten voor de organisatie.

Hoewel "whistleblowing" nog de meeste raakvlakken heeft met het onderwerp van deze studie, wil ik er niet te uitgebreid aandacht aan besteden. Bovens maakt zelf duidelijk, dat deze vorm van ambtelijke ongehoorzaamheid alleen bij matig gebruik heilzaam is. Indien er te veel en te snel aan de bel wordt getrokken, raakt het publiek afgestompt, of neemt het de waarschuwing niet meer serieus als er werkelijk sprake is van een noodsituatie. En als men blijft luiden, belemmert men het nemen van adequate maatregelen. De organisatie moet de gelegenheid worden gegeven

278 Id. pag. 224. 
om orde op zaken te stellen. ${ }^{279}$ Bovens' studie is echter van belang, omdat hij laat zien dat een ambtenaar, die een standpunt naar buiten brengt dat afwijkt van dat van zijn meerderen, toch een loyale ambtenaar kan zijn. Zelfs als die ambtenaar dat doet tegen de uitdrukkelijke wens van zijn meerderen in. Zijn loyaliteit betreft dan misschien niet zijn toevallige chef, maar in elk geval de democratie, de rechtsstaat, en de publieke zaak. En dat zou toch vóldoende moeten zijn! Hoeveel te meer reden is er dan niet, om een ambtenaar die op grond van een wettelijke plicht zijn standpunten of adviezen openbaar zou maken, als een loyale ambtenaar te beschouwen? Zo'n wettelijke plicht zou iets normaals kunnen zijn, niet alleen iets voor uitzonderlijke situaties. Maar voordat ik daar verder op doorga, zal ik eerst de na-oorlogse ontwikkelingen in het staats- en bestuursrecht met betrekking tot de rechten en plichten van de ambtenaar de revue laten passeren.

\section{Naoorlogse opvattingen in de staatsrechtelijke literatuur}

Zoals we hebben gezien, waren in het interbellum belangrijke staatsrechtelijke schrijvers als Vegting en Van der Pot aanhanger geworden van de leer van Struycken, die er geen problemen mee had om de grondrechten wan ambtenaren te beperken. De grondrechten in de Grondwet regelden naar zijn mening slechts de algemene rechtstoestand der burgers. Individuele burgers bleven vrij on van hun grondrechten afstand te doen, bijvoorbeeld door in dienst te treden als ambtenaar. Ze werden dan in een bijzondere rechtspositie geplaatst, waarin de uitoefening van een of meer grondrechten kon worden beperkt of verboden.

Tot het eind van de vijftiger jaren zou deze opvatting onder de juristen in Nederland gemeen goed blijven. Een enigzins afwijkende opvatting werd al die tijd gekoesterd door Krabbe's leerling, de Leidse hoogleraar Kranenburg, die de gedachte verwierp, dat men een ambtenaar kon beschouwen als object, als een werktuig in de handen van de gezagsdrager. De ambtenaar, schreef Kranenburg, is "alleen tot gehoorzaamheid verplicht in dienst-zaken, en voorzooverre de goede functioneering van den dienst het vordert. Daarmee hangt samen de wenschelijkheid van waarborgen voor den functionaris, dat alleen objectieve dienstbelangen den doorslag geven bij de gezags-uitoefening". ${ }^{280}$

280 R. Kranenburg, Het Nederlandsch Staatsrecht, eerste deel, Haarlem. Zie bijwoorbeeld derde druk (1928) pag. 350-351, en zesde druk (1947) pag. 394. 
In 1955 komt er een kentering in het standpunt van de regering. Op vragen van leden van de Eerste Kamer, bij de behandeling van de begroting van Binnenlandse Zaken, erkent minister Beel, dat de grondrechten in beginsel ook gelden voor de ambtenaren. Maar beperkingen in de uitoefening van hun grondrechten zijn volgens hem in bepaalde gevallen niet onmogelijk. De vraag is, in welke mate de ambtenaar zijn vrijheden kon gebruiken zonder inbreuk te maken op zijn verplichting tot loyaliteit tegenover de overheid. Hij behoort zich in ieder geval te gedragen "zoals een goed ambtenaar betaamt" (conform art. 50 van het Algemeen Rijksambtenarenreglement). Naarmate het persoonlijk optreden van de ambtenaar nauwer verband houdt met de werkzaamheden, waarmee hij uit hoofde van zijn ambt is belast, zijn er grotere beperkingen, vindt minister Beel. Maar ook buiten het terrein van zijn ambt stelt de verplichting tot een loyale houding een zekere grens aan de uitoefening van de grondrechten. ${ }^{281}$ Men krijgt de indruk, dat het standpunt van de minister, dat naar zijn zeggen ook het standpunt van de ministerraad is, eerder van een andere kijk op grondrechten getuigt, dan van een andere kijk op de ambtenaarsverhouding.

\section{Van der Hoeven}

In 1958 promoveert Van der Hoeven aan de Universiteit van Amsterdam, bij Van den Bergh, op een proefschrift over de betekenis en functie van de Grondwet in het staatsbestel. ${ }^{282}$ Van der Hoeven geeft daarin blijk van een eigen visie op grondrechten. Hoewel hij Gustav Radbruch niet noemt, heeft hij een cultuur-rechtelijke rechtsopvatting ontwikkeld, die nauw verwant is met die van deze Duitse rechtsfilosoof. Die visie zal in 1969 ook richting geven aan zijn preadvies voor de NJV, dat ik in hoofdstuk 3 heb besproken. Grondrechten, schrijft Van der Hoeven in zijn dissertatie, zijn alle te herleiden tot het besef in onze christelijke en humanistische cultuur, dat aan de enkeling een autonoom terrein moet worden gelaten. Die enkeling mag dat terrein handhaven tegenover het streven (van wie dan ook) het te vernietigen of tot verdwijnens toe te beperken. De grondrechten zijn niet afhankelijk van het bestaan van een staat. Maar als er een staat is, dan dient die staat zijn burgers dat autonome terrein te laten, en hen te hulp te komen als dat terrein verloren dreigt te gaan. Aldus bezien hebben klassieke vrijheidsrechten, zoals het recht van vrije meningsuiting, dezelfde oorsprong als de zogeheten 'sociale' grondrechten, zoals bijvoorbeeld

281 Uitvoeriger daarover: Olde Kalter, a.w. pag. 211-212.

282 J. van der Hoeven, De plaats van de grondwet in het constitutionele recht, Zwolle 1958. Zie met name pag. 189-200. 
het recht op arbeid. Van der Hoeven vindt dan ook, dat er geen wezenlijk verschil tussen beide soorten grondrechten bestaat.

Grondrechten zullen in verschillende tijden en in verschillende samenlevingen steeds weer anders moeten worden geformuleerd. Dat is afhankelijk van de ambiance, dat wil zeggen, van de in een samenleving werkzame krachten die het autonome terrein van de enkeling bevorderen of bedreigen. Maar het doel blijft steeds hetzelfde, schrijft Van der Hoeven. Hij werpt dan vervolgens de vraag op, of de enkeling van zijn grondrechten vrijwillig afstand kan doen. Zoals we hebben gezien, hadden Buijs en Struycken die vraag bevestigend beantwoord, althans voorzover afstand doen te rijmen viel met dwingende wetsbepalingen, openbare orde en goede zeden. Het inmiddels ingetrokken artikel 14 van de Wet algemene bepalingen gaf voor hen de grens aan van wat toelaatbaar was. ${ }^{283}$ Van der Hoeven is het daar niet mee eens. Aanvaardt men grondrechten als rechten, niet alleen tegenover de overheid, maar van algemene aard, en met de strekking het autonome terrein van de enkeling te waarborgen, dan moet men daaruit de conclusie trekken, "dlat geen contractuele of ambtelijke verhouding het grondrecht vermag te negeren", maar ook "dat grondrechtsbeperkingen van bijzondere personen, door deze vrijwillig aanvaard, zeker niet zonder meer met ons constitutionele recht in strijd zijn zolang zulke beperkingen, bezien in het licht van deze vrijwilligheid, niet meer inbreuk maken op de autonomie der persoonlijkheid, dan het actuele zedelijke en godsdienstige beoordelingspatroon verdraagt". ${ }^{284}$ Anders dan Buijs en Struycken, zoekt Van der Hoeven de grens van de toelaatbaarheid van het afstand doen van grondrechten dus in de strekking van de grondrechten zelf.

Het is maar zeer de vraag, of dit "principiële" meningsverschil met genoemde oudere schrijvers bij Van der Hoeven ook gepaard gaat met een andere kijk op de ambtenaarsverhouding. In zijn dissertatie blijkt daar weinig van. Volgens hem "is ongetwijfeld een verdere beperking (van de grondrechten, HK) toelaatbaar dan alleen een verbod over dienstgeheimen te schrijven", en zal de beperking in de ambtelijke verhouding zelfs "meestal verder kunnen gaan, dan door privaatrechtelijke overeenkomst". ${ }^{285}$

283 Art. 14 Wet A.B. is per 1 januari 1992 ingetrokken, gelijktijdig met de invoering van boek $3 \mathrm{BW}$, waarin art. 3:40 een soortgelijke bepaling geeft.

284 Van der Hoeven, De plaats van de grondwet, a.w. pag. 197.

285 Idem, zelfde pagina. 


\section{Van der Horst}

Een heel radicaal standpunt over de ambtenaarsverhouding lijkt, althans op het eerste gezicht, ten grondslag te liggen aan de dissertatie, waarop in 1967 Van der Horst aan de Vrije Universiteit promoveert bij Van Wijk. Ambtenaar en grondrechten is de titel van deze studie. ${ }^{286}$ Van der Horst heeft heel wat circulaires, kamerstukken, jurisprudentie en literatuur uit de periode van 1829 tot 1966 bestudeerd en, dat moet gezegd worden, voorzien van kritische kanttekeningen. Van begin af an is duidelijk, dat de schrijver vindt dat de grondrechten, net als voor ieder ander, ook voor de ambtenaren gelden. Maar hoeveel kritiek hij ook heeft op de standpunten van regering en staatsrecht-beoefenaren, gaandeweg wordt duidelijk dat ook hijzelf de bakens niet echt wil verzetten, althans niet als het gaat om het daadwerkelijk gebruik kunnen maken van grondrechten. Dat wordt onder meer duidelijk waar hij een standpunt van Veegens over artikel 10 van het Verdrag van Rome bespreekt. ${ }^{287}$ Veegens had betoogd, dat de vrijheid van meningsuiting kan worden beperkt door de verplichtingen die uit het ambt voortvloeien. Want, had Veegens geschreven, in de vrijheid van gedachtenuiting ligt niet het recht tot openbaring van dienstgeheimen besloten. Met dat laatste is Van der Horst het eens. Want "vrijheid is niet hetzelfde als losbandigheid", verzekert hij de lezer. Maar dat kan volgens Van der Horst geen argument zijn om te betogen, dat de vrijheid van meningsuiting kan worden beperkt door de verplichtingen die uit het ambt voortvloeien. Dienstgeheimen openbaren, mag namelijk nooit, of er nu wel of geen vrijheid van meningsuiting bestaat, zegt hij. Als men bedenkt dat er anno 1967 nog geen Wet openbaarheid van bestuur bestaat, en 'dienstgeheim' dan ongeveer alles is waarvan een bestuurder of ambtelijke chef vindt dat het 'dienstgeheim' is, dan komt deze redenering toch wel in een armetierig daglicht te staan. Van der Horst betaalt een erg hoge prijs, om het ideaal te kunnen blijven koesteren, dat de vrijheid van meningsuiting niet kan worden beperkt door verplichtingen die uit het ambt voortvloeien.

Hoever reikt dan die vrijheid van meningsuiting voor de ambtenaar? Om die vraag te beantwoorden, begeeft Van der Horst zich, naar zijn zeggen, "op een terrein dat buiten de juridische orde ligt in een vlak dat aan het juridische voorafgaat". ${ }^{288} \mathrm{Hij}$ maakt enkele metajuridische opmerkingen over "mens-zijn", en concludeert dan, dat het zich in vrijheid kunnen uiten, één van de belangrijkste voorwaarden is om volwaardig

286 Th.A.M. van der Horst, Ambtenaar en grondrechten, Alphen a/d Rijn 1967. (Reeds genoemd in par. 1 van het vorige hoofdstuk).

287 Van der Horst, a.w. pag. 197.

288 Id. pag. 216. 
mens te kunnen zijn: "In beginsel" mag de werkgever deze vrijheid niet belemmeren. "Aan de andere kant", zegt Van der Horst, "moet de werknemer zich afvragen of hij door zijn functie niet in de positie verkeert dat hij zich over bepaalde zaken niet uit, of slechts in een bepaalde kring, of slechts op een bepaalde wijze". In geval van concrete moeilijkheden moet de oplossing steeds weer worden gevonden, "niet door zonder meer vanuit een zekere machtspositie eenvoudig vast te stellen wat de ander behoort te doen of na te laten, maar door in zorgvuldig overleg de wederzijdse plichten en rechten nader te specificeren. Blijkt overleg niet tot overeenstemming te kunnen leiden, dan zullen beide partijen moeten aanvaarden dat er een situatie onstaat, waar in ieder van hen voor zichzelf dient te beslissen wat hem te doen staat". 289

Wederzijdse plichten en rechten specificeren? Maar dat is toch het vak van juristen, als ik me niet vergis. Dan moeten er ook juridische criteria kunnen worden geformuleerd. Van der Horst schrijft op de laatste bladzijde van zijn dissertatie, dat zijn richtlijnen in geval van concrete moeilijkheden geen rechtstreekse oplossing inhouden. "Zij geven alleen een richting aan waarin men moet zoeken", merkt hij op. Maar met de beste wil kan ik bij hem zelfs die richting niet ontdekken.

\section{De regering en de 'Aanwijzingen inzake ambtelijk optreden'}

Op 8 augustus 1972 worden in de Staatscourant (nr. 152) de Aanwijzingen inzake ambtelijk optreden (extern) gepubliceerd, die op 21 juli van dat jaar door premier Biesheuvel, na goedkeuring van de ministerraad, zijn vastgesteld. Deze aanwijzingen, die afkomstig zijn van het ministerie van Binnenlandse Zaken, en grenzen stellen aan de vrije meningsuiting van ambtenaren, zullen tot de wijziging van de Ambtenarenwet in 1988 als 'leidraad' gelden. In de inleiding van de tekst lezen we, dat de aanwijzingen er niet op zijn gericht "om aan staatsburgers als zodanig in de uitoefening van hun grondrecht van de vrijheid van meningsuiting beperkingen op te leggen". Maar ze willen wel aangeven "welke beperkingen voor de ambtenaat als werknemer voortvloeien uit het feit dat hij deel uitmaakt van een bepaald - en in zijn geval bovendien bijzonder - werkverband". Kennelijk zijn de wortels van de afgezaagde Struycken bij Binnenlandse Zaken toch weer in de teelaarde gezet.

"Voor de vrijheid van meningsuiting van de ambtenaar", zo vervolgt de inleiding, "gelden geen beperkingen dan die welke voortvloeien uit de algemene eis van loyaliteit, die met het oog op het goed functioneren van 
een werkverband aan de leden daarvan moet worden gesteld ten opzichte van het door dat verband gevoerde beleid". Het begrip "loyaliteit" wordt niet verder omschreven, maar de aanwijzingen zelf geven blijk van een tamelijk 'klassieke' opvatting.

Als een ambtenaar "zelf de rechtstreekse adviseur is van een bij de beleidsvorming betrokken minister of staatssecretaris, kan hij niet, als hij de bewindsman niet van de juistheid van zijn visie heeft kunnen overtuigen, het debat in het openbaar voortzetten", zegt één van de eerste aanwijzingen. Is de ambtenaar geen "rechtstreekse adviseur" van een bewindsman, maar is het onderwerp waarop hij met zijn superieuren van mening verschilt een "geladen" kwestie, dan "is het risico groter dat zijn uitlatingen daarover het goede functioneren van het werkverband in gevaar brengen". En daarop kan natuurlijk met rechtspositionele maatregelen worden gereageerd. Volgens de Aanwijzingen is ook "de wijze waarop en de kring waarin de ambtenaar naar buiten van zijn afwijkende mening blijk geeft" van belang. Het publiceren van een artikel in een wetenschappelijk vakblad is meestal well aanvaardbaar. En wat "de kring" betreft, geniet een ambtenaar die "zich uit in een vertegenwoordigend lichaam, bijvoorbeeld als lid van een gemeenteraad of van het bestuur ener ambtenarenorganisatie" meer vrijheid dan in andere situaties. Het blijft dus oppassen geblazen. Maar een buil hoeft niemand zich te vallen, want: "De ambtenaar, die twijfelt of de gedragslijn die hij overweegt te volgen, juist is, kan daarover natuurlijk met zijn chef overleg plegen".

Als minister van Binnenlandse Zaken 'ad interim' stuurt Biesheuvel de Aanwijzingen op 1 augustus 1972 met een begeleidende brief naar de Tweede Kamer. ${ }^{290}$ Het zal ruim anderhalf jaar duren, voordat de Kamer er met de nieuwe minister van Binnenlandse Zaken, De Gaay Fortman, over in debat gaat. Veel zal dat niet opleveren. De meest fundamentele kritiek wordt dan geuit door mevrouw Goudsmit (D66) die, anders dan de regering, van mening is, dat er voor ambtenaren geen speciale beperkingen van de vrijheid van meningsuiting hoeven te gelden. De minister licht toe, dat de aanwijzingen slechts een leidraad zijn bij de toepassing van artikel 50 van het Algemeen Rijksambtenarenreglement. Het kamerlid Roethof dient samen met leden van D66, VVD, PPR en PSP een motie in, waarin de regering wordt uitgenodigd "om, met vermijding van welke vorm ook van preventief toezicht, daartoe benodigde procedurele waarborgen in het Algemeen Rijksambtenarenreglement vast te leggen". Met "procedurele

290 TK 1971-1972, 11925. Zie voor de beraadslagingen in de kamer: Hand. TK 19731974 pag. $3137-3148,3176-3186$ en 3197 , en bijlage $11925 \mathrm{nr} .2$. 
waarborgen" bedoelt Roethof beroepsmogelijkheden in concrete gevallen van beperking van de vrije meningsuiting. Minister De Gaay Fortman zegt "geen enkele behoefte" aan deze motie te hebben. Hij vindt, dat het het reglement "reeds alle waarborgen heeft, die denkbaar zijn". Op 26 maart 1974 worden de Aanwijzingen door de kamer voor kennisgeving aangenomen. Twee dagen later wordt de motie Roethof aanvaard.

\section{Donner}

In 1972 wordt in het Handboek van het Nederlandse Staatsrecht voor de läatste keer de leer van Struycken beleden. Dat de oorspronkelijke auteur vari dit handboek, C.W. van der Pot, een aanhanger van deze leer was, heb ik in het vorige hoofdstuk al opgemerkt. Maar ook A.M. Donner, die vanaf het eind van de vijftiger jaren de nieuwe drukken van het handboek verzorgt, vindt dat de grondrechten eigenlijk alleen maar de algemene rechtstoestand der burgers regelen. Of, zoals hij het zelf in 1972 formuleert: De grondrechten "beogen een bescherming te geven aan de gewone burgers tegen de organen van de staat". ${ }^{291}$ Een ambtenaar is in zijn optiek geen gewone burger, maar iemand "die in de bijzondere verhouding tot haar (de overheid, HK) treedt of getreden is, welke in de ambtenaarsverhouding ligt opgesloten, die dus geroepen is haar bij te staan in de vervulling van de overheidstaak, wellicht zelfs als orgaan van de gemeenschap op te treden". Wel moet de overheid de rechten van de ambtenaar als burger zoveel mogelijk ontzien, schrijft Donner. "Zo zal zij een ambtenaar wel mogen opleggen om zijn minister niet te hinderen door publicatie van meningen of informaties, die met zijn onmiddellijke werkkring te maken hebben, maar overigens zijn vrijheid van meningsuiting hebben te eerbiedigen". ${ }^{292}$

Als in 1977 de tiende druk van het handboek verschijnt, heeft Donner, wellicht onder invloed de in het parlement gevoerde debatten over de grondwetsherziening, zijn standpunt over de ambtenaarsverhouding niet echt gewijzigd, maar wel een andere onderbouwing gegeven. Hij verwijst niet meer naar Struycken, maar beklemtoont, dat rechten als de godsdienstvrijheid en de vrijheid van meningsuiting rechten van de burger ten opzichte van de overheid zijn. Ze gelden niet in het verkeer tussen burgers onderling. Een werknemer kan bijvoorbeeld, voorzover dat in overeenstemming is met het contractenrecht, in een arbeidsovereenkomst afstand Zwolle 1972, pag. 463. 
doen van zijn (grond)recht om over bepaalde onderwerpen te publiceren. Geldt dat nu ook voor de rechtsverhouding tussen overheid en ambtenaar? Min of meer wel, vindt Donner. "Ten aanzien van de vrijheid van meningsuiting" zegt hij, "zal men de mogelijkheid moeten erkennen, dat de ambtenaar soortgelijke verplichting tot geheimhouding en tot discretie in het spreken over de door hem gediende belangen kan worden opgelegd als in het algemeen in arbeidverhoudingen geldt - al zal zij in verband met de eigenaardigheid van de betrekking soms verder en soms minder ver gaan. Uiteraard gelden zulke verplichtingen in sterker mate voor een hoge beleidsambtenaar, die toegang heeft tot de gezagsdragers en van hun doen en laten op de hoogte geacht wordt, dan voor het gros der honderd-duizenden in openbare dienst; het beginsel der gelijkheid kàn meebrengen dat de meer geprivilegieerde minder grondrecht heeft" ${ }^{293}$

Mag men uit deze passage concluderen, dat Donner vindt, dat hoge beleidsambtenaren minder vrijheid van spreken hebben omdat zij geacht worden op de hoogte te zijn van de standpunten van de gezagsdragers? Dat zou betekenen, dat in zijn visie ambtenaren naar buiten toe eigenlijk helemaal geen afwijkende meningen mogen verkondigen, als ze weten wat het standpunt van de boven hen staande politieke gezagsdrager is. Verheven woorden over de ambtenaar die in een "bijzondere positie" met de overheid is getreden, en dus "geroepen is haar bij te staan in de vervulling van de overheidstaak", laat Donner voortaan achterwege. Maar wat hem betreft, krijgt de ambtenaar daarom nog geen grotere vrijheid van meningsuiting.

In de elfde druk van het handboek, die in 1983 verschijnt, stelt Donner duidelijk, dat de leer van Struycken verlaten is. "Terwijl nl. lang het standpunt gold, dat de grondrechten op de verhouding tussen de overheid en haar ambtenaren als zodanig niet of slechts zeer ten dele van toepassing waren", schrijft Donner, en hij verwijst dan in een voetnoot naar Struycken, "is een andere mening de heersende geworden" ${ }^{294}$ Mar evenmin als de regering trekt hij daaruit de conclusie, dat de inhoud van de ambtenaarsverhouding daardoor is veranderd. De Grondwet geeft immers zelf aan, dat het recht van vrije meningsuiting en het recht van vereniging en vergadering beperkt kunnen worden door de wet. Welnu, dan moeten zulke beperkingen desnoods maar in de Ambtenarenwet worden geformuleerd. En dat zal ook gebeuren, zoals we dadelijk nog zullen zien.

293 C.W. van der Pot, A.M. Donner, Handboek van het Nederlandse Stantsrecht, Zwolle 1977, pag. 444.

294 C.W. van der Pot, A.M. Donner, Handboek van het Nederlandse Staatsrecht, Zwolle 1983, pag. 223. 


\section{Olde Kalter}

In november 1979 wijdt de Vereniging voor Administratief Recht haar jaarvergadering aan het onderwerp Overheidspersoneel en grondrechten. De basis voor de discussie wordt gevormd door twee preadviezen. Het eerste, getiteld "Ambtenaar en grondrechten", is geschreven door $\mathbf{R}$. Bergamin, en gaat over wijze waarop ambtenaren de grondrechten van burgers (als cliënten van overheidsdiensten) zouden moeten respecteren. Van meer belang voor het onderwerp van dit hoofdstuk is echter het tweede preadvies, getiteld "Overheidspersoneel en grondrechten", dat is geschreven door C.J.G. Olde Kalter ${ }^{295}$ Eerder kwam dit preadvies hier al ter sprake als kenbron van de geschiedenis van de ambtenaarsverhouding: $\mathrm{Nu}$ wil ik enkele woorden wijden aan de eigen mening van Olde Kalter over die verhouding, en over de invloed van de grondrechten daarop.

Evenals Van der Hoeven, wil Olde Kalter de beantwoording van de vraag, in hoeverre de grondrechten in bijzondere relaties met de overheid van toepassing zijn, laten afhangen van de inhoud en strekking van de betreffende grondrecht-bepalingen zelf. ${ }^{296} \mathrm{Hij}$ onderscheidt twee soorten grondrechten. Er zijn grondrechten met betrekking tot "kernaspecten" van de persoon of de persoonlijke levenssfeer, het gelijkheidsbeginsel, en het verbod van discriminatie. Deze zouden naar zijn mening "volledige werking moeten hebben ten aanzien van alle aspecten en gebieden van de gezagsuitoefening door de overheid over overheidswerknemers, zowel in als buiten de functievervulling." Daarnaast zijn er grondrecht-bepalingen over de vrije handelingssfeer op maatschappelijk en politiek terrein: vrijheid van meningsuiting, van vereniging, vergadering en betoging. Daar ligt voor Olde Kalter de zaak anders. Een volledige werking van deze bepalingen zou volgens hem "de beslissings- en bestuursvrijheid van het bestuurlijk gezag over de openbare dienst kunnen aantasten". Want, zegt hij, "Toepassing van deze grondrechten met betrekking tot de taakvervulling en het functioneren van overheidsorganen, zou de persoonlijke vrijheid van de overheidswerknemers om hun inzichten in de taakvervulling van de overheid door te zetten, als beginsel voorop stellen en juridisch beschermen, terwij bij beslissingen omtrent de bepaling en uitvoering van het beleid van de overheidsorganisatie het zwaartepunt dient te liggen bij

295 Beide preadviezen zijn samen gepubliceerd als VAR-geschrift LXXXIV, Alphen a/d Rijn 1979. Het verslag van de vergadering is gepubliceerd als VAR-geschrift LXXXV. Alphen a/d Rijn 1981.

296 Olde Kalter, a.w. pag. 91. 
het functioneren van de organisatie overeenkomstig beslissingen van democratisch gecontroleerde bestuurlijke organen ". ${ }^{297}$

Dat een overheidsorganisatie moet functioneren overeenkomstig de beslissingen van democratisch gecontroleerde bestuurlijke organen, zal wel geen enkel democratisch denkend mens willen ontkennen. Maar waar haalt Olde Kalter het vandaan om te denken, dat overheidswerknemers hun inzichten in de taakvervulling van de overheid kunnen "doorzetten", als zij in en buiten de organisatie hun eigen mening zouden mogen uiten? Zulke meningsuitingen, liefst met argumenten onderbouwd, zouden het openbare politieke debat alleen maar kunnen verrijken, en een gunstig effekt hebben op de kwaliteit van de democratische besluitvorming. Per slot van rekening zijn ambtenaren, naar men mag aannemen, ter zake deskundige leden van. de samenleving. Is de besluitvorming eenmaal afgerond, dan hoort het tot de democratische spelregels, dat alle leden - burgers, bestuurders en ambtenaren - zich daaraan houden. Van mij hoeft een bestuurder of ambtenaar dan niet opeens zijn eigen mening te verbergen. Dat hoeven andere burgers ook niet, althans niet in een samenleving die zich democratisch mag noemen. Maar dat is heel iets anders dan dat ambtenaren hun eigen inzichten in de taakvervulling zouden mogen "doorzetten". Dat mag natuurlijk nooit, of ze nu wel of geen vrijheid van meningsuiting hebben.

Naar de mening van Olde Kalter kan alleen "buiten de functievervulling" de vrijheid van meningsuiting prevaleren boven de eventuele doorwerking van de ambtelijke positie. ${ }^{298}$ Binnen de functievervulling kan daar moeilijk sprake van zijn. Want overheidsmedewerkers hebben nu eenmaal een deel van hun persoonlijke vrijheid gesteld onder de democratisch gecontroleerde gezagsuitoefening van de politieke bestuurders en van degenen die voor hen optreden. Toch is er volgens hem ook binnen de functievervulling een zekere ruimte voor de beleving van het grondrecht van vrije meningsuiting:

"Leden van een werkgemeenschap zullen onderling over maatschappelijke en politieke onderwerpen of over hun gemeenschappelijke belangen tegenover het gezag van gedachten willen wisselen. Indien deze activiteiten de taakvervulling van de dienst niet schaden (een vergadering in de avonduren of in de middagpauze in een dienstgebouw behoeft dit bijvoorbeeld niet te doen) en ze voor het publiek het politiek-onzijdige karakter van inrichtingen en zaken van de openbare 
dienst niet aantasten (zo kunnen er bezwaren rijzen tegen politiek uitgesproken aanplakbiljetten aan de buitenramen, terwijl deze aanplakbiljetten wel in de koffiehoek van het personeel of op de eigen werkkamer, waar geen publiek wordt ontvangen, kunnen worden toegestaan), zijn er goede gronden aan te voeren grondrechten van toepassing te laten zijn op dergelijke activiteiten". ${ }^{299}$

Ten aanzien van ambtenaren met een wetenschappelijke opdracht, zoals medewerkers van het Rijksinstituut voor Oorlogsdocumentatie, of wetenschappelijk personeel van rijksuniversiteiten, gaat Olde Kalter een stap verder. Hij meent dat het bij de functie en de positie "kan passen, dat de uitingen binnen de functievervulling van het wetenschappelijk personeel vallen onder de garanties van artikel 7 Grondwet". ${ }^{300}$ Maar dat is voor hem dan ook de uitzondering, die de regel bevestigt.

De interventie van Peters op de jaarvergadering

Op de bewuste jaarvergadering zelf zeggen verschillende sprekers moeite te hebben met het onderscheid, dat Olde Kalter maakt tussen de werking van de grondrechten binnen de functievervulling en de werking buiten de functievervulling. Niessen, Schipper en Peters wijzen met name op de zaak "Kalma", waarover de Centrale Raad van Beroep juist twee maanden eerder, op 21 september 1979 , een uitspraak heeft gedaan. ${ }^{301}$ Die zaak, waar ik dadelijk op terugkom, betrof een hoofdinspecteur van politie, die in zijn vrije tijd aan een demonstratie had deelgenomen en, in verband daarmee, naar de mening van de Raad terecht was berispt. Van alle sprekers op de vergadering is Peters eigenlijk de enige, die de aanwezigen probeert te prikkelen tot een ruimere opvatting over de werking van de grondrechten in de ambtenaarsverhouding. Hij is ook de enige, die in positieve zin een verband onderkent tussen ambtelijke meningsvrijheid en openbaarheid van bestuur. "Op zichzelf is het natuurlijk heel eigenaardig", zegt Peters, "wanneer je tegen ambtenaren zegt, je mag overal je grondrechten uitoefenen, overal over schrijven en praten, alleen waar je het meest verstand van hebt, daarover mag je niet praten. Dat gaat ten koste van de kwaliteit van de besluitvorming. I $\mathrm{k}$ geloof dat het onderwerp van de vrijheid van meningsuiting van ambtenaren dan ook direct raakt aan de

Id. pag. 96.

300

Id. pag. 97 .

301 VAR-geschrift LXXXV, Alphen a/d Rijn 1981, resp. pag. 20 (C.R. Niessen), pag. 23 (W.H. Schipper) en pag. 31 (J.A. Peters). 
openbaarheid van bestuur en aan de restrictie dat persoonlijke opvattingen van ambtenaren niet naar buiten mogen komen".

Peters vindt, dat ook de ministerielle verantwoordelijkheid beter uit de verf komt, als ambtenaren wél hun persoonlijke opvattigen mogen uiten. "Dan weet je of de minister zich achter zijn ambtenaren verschuilt of dat hij zelf opvattingen heeft die tegen z'n ambtelijke adviezen ingaan. En volgens mij is dat uiteindelijk een verbetering van de kwaliteit van ons hele bestuur, want loyaal aan wie moet je zijn? Aan een bepaalde minister of aan een bepaalde chef ò uiteindelijk ten behoeve van de kwaliteit van de besluitvorming, aan ons hele volk of gemeente of vul maar in". ${ }^{302}$ Het antwoord op die vraag is niet eenvoudig, geeft Peters toe. Maar hij stelt de vraag tenminste. Olde Kalter, die als preadviseur mag antwoorden, zal er niet op ingaan.

\section{De ambtenarenrechter en de vrijheid van meningsuiting}

\section{De zaak Kalma}

In oktober 1977 neemt de Rotterdamse hoofdinspecteur van gemeentepolitie Kalma deel aan een betoging voor het Westduitse consulaat in zijn woonplaats. De demonstratie heeft tot doel "uiting te geven aan de gevoelens van verontrusting en onbehagen over een dreigende negatieve ontwikkeling van de rechtsstaat in West-Duitsland". Aanleiding is het feit, dat in een Duitse gevangenis drie RAF-terroristen onder verdachte omstandigheden 'zelfmoord' hebben gepleegd. De burgemeester van Rotterdam heeft toestemming voor de demonstratie gegeven. Van Kalma is bekend, dat hij pacifist is, en het gebruik van geweld onder alle omstandigheden afwijst, ook het geweld dat gehanteerd wordt door RAF-leden. Toch roept zijn deelname aan de demonstratie bij collega's nogal wat irritatie op, vooral als in de omgeving van het consulaat dienstdoende politie-agenten door demonstranten worden uitgescholden voor "moordenaars, fascisten", en "knechten van het kapitaal". Er zijn geen blijken dat Kalma zelf ook deze scheldwoorden heeft geuit, maar wel heeft hij meegeroepen met de leus: "Hun strijd, onze strijd, internationale solidariteit". Met "hun strijd" bedoelde Kalma echter niet de strijd van de RAF, zo verklaart hij later in het openbaar, maar wilde hij uitdrukking geven aan solidariteit met "die internationale krachten die in een democratische gezindheid streven naar maatschappelijke veranderingen". Toch meent de 
burgemeester van Rotterdam, als hoofd van de politie, Kalma om twee redenen officieel te moeten berispen.

Ten eerste vanwege het feit dat Kalma zich niet uit de demonstratie heeft losgemaakt, toen andere demonstranten politie-agenten op de zojuist omschreven wijze begonnen uit te schelden. Door dit na te laten zou hij de indruk hebben gewekt, dat hij vond dat de scheldwoorden "binnen de context van de demonstratie aanvaardbaar waren".

Ten tweede vanwege het feit dat Kalma de leus "Hun strijd, onze strijd, internationale solidariteit" heeft geroepen. Daardoor is "vooral bij degenen die niet precies op de hoogte zijn - en ook niet behoeven te zijn - "van Kalma's andersgerichte bedoelingen, de indruk ontstaan "van enigerlei solidariteit met de doelstelling van de Rote Armee Fraktion".

Nadat Kalma bij het Ambtenarengerecht tevergeefs tegen de berisping heeft geprotesteerd, gaat hij in beklag bij de Centrale Raad van Beroep. Ook dit rechtscollege zal zijn klacht ongegrond verklaren. ${ }^{303}$ "Wie deelneemt aan een betoging", zegt de Raad, "zal dienen te beseffen dat hij gebruik maakt van een uitingsmiddel dat slechts beperkte nuancering toelaat en zal er ook rekening mee moeten houden dat hem medeverantwoordelijkheid kan worden toegerekend voor datgene wat van de betoging als geheel uitgaat." $\mathrm{Nu}$ Kalma's gedragingen "beroering hebben gewekt binnen en buiten het politiekorps waardoor de interne en externe verhoudingen en daarmede de goede functionering van het korps worden aangetast," is naar het oordeel van de Raad sprake van een "doen of nalaten van iets hetwelk een goed politieambtenaar van eisers niveau in dergelijke omstandigheden behoort na te laten of te doen". De Raad is zich ervan bewust, dat de grens die Kalma heeft overschreden "niet als in absolute zin vaststaand kan worden aangemerkt en mede wordt bepaald door de mate van tolerantie welke binnen de betreffende groep leeft": Alle beroering in deze zaak kan niet aan Kalma worden toegerekend, geeft de raad toe. De "heftigheid van sommige reacties (is) wellicht niet altijd even gefundeerd en hier en daar misschien zelfs onzuiver van aard geweest". Maar een en ander gaat niet zover, dat Kalma voor het ontstaan van de beroering en "de daardoor veroorzaakte aantasting van de goede functionering van het politiekorps" geen enkel verwijt zou kunnen worden gemaakt.

De omstandigheid, dat het hier om de uitoefening van een grondrecht gaat, moet naar de mening van de Centrale Raad van Beroep wel in de

303 CRvB 21 september 1979, AB 1980, $\mathrm{nr}_{n}$ 90. Aan de tekst van deze uitspraak is ook de bovenvermelde toedracht van feiten ontleend. 
afweging worden betrokken. Maar deze afweging heeft de Raad "niet tot de slotsom kunnen brengen, dat eiser (lees: Kalma, HK), het recht van betoging uitoefenende, de vrijheid had de functionering van het politiekorps en zijn eigen functioneren daarin zo negatief te beïnvloeden als in dit geval is geschied". De Raad wijst er vervolgens nog op, "dat het hooghouden van de grondrechten onder omstandigheden ook kan meebrengen bij de uitoefening ervan juist een zekere terughoudendheid te betrachten".

"Terughoudendheid". Die heeft de Centrale Raad van Beroep in ieder geval zelf in deze zaak betracht, toen hij voor de toetsing aan het grondrecht van betoging volstond met de motivering: "Deze afweging heeft de Raad niet tot de slotsom kunnen brengen, dat ..". Maar heeft de Raad daarmee het grondrecht ook 'hooggehouden'? Duidelijk is in elk geval wel, dat onze hoogste ambtenarenrechter weinig behoefte heeft aan het door Olde Kalter geformuleerde onderscheid tussen meningsuiting binnen de functievervulling en meningsuiting buiten de functievervulling.

\section{De zaak van kapitein Stelling}

In 1983 en 1986 doet de Centrale Raad van Beroep nog enkele opmerkelijke uitspraken in zaken waar de vrije meningsuiting van ambtenaren aan de orde is. Het gaat om een tweetal uitspraken over personeelsbeoordelingen betreffende de luchtmacht-kapitein Stelling, die als militair en als IKVlid niet onder stoelen of banken steekt, dat hij tegenstander is van het gebruik, en dus ook van de plaatsing, van kernwapens.

Stelling, die zijn bezwaren tegen de plaatsing van kernwapens zowel op zijn geloofsovertuiging als op het humanitaire oorlogsrecht baseert, krijgt in 1981, naar aanleiding van een personeelsbeoordeling, een 'kennisgeving' van de minister van Defensie. Die kennisgeving behelst de mededeling, dat weliswaar "de beoordelingslijst niet een onbevredigend beeld te zien geeft", maar dat niettemin de chef van Stelling's beoordelaar de minister aanbeveelt "bij de bestemming van betrokkene voor toekomstige functies rekening te houden met zijn opvattingen ten aanzien van de kernbewapeningsproblematiek". Dat betekent, dat het voor Stelling moeilijker wordt om promotie te maken. Ter verklaring hiervan verwijst de minister naar een bijlage van de beoordelingslijst, waarin wordt gesteld: "Beoordeelde heeft een zeer uitgesproken mening over het bezitten en de inzet van kernwapens door de krijgsmacht, die niet overeenstemt met het regeringsstandpunt ter zake" en "publiceert zijn opvattingen over deze problematiek regelmatig o.m. in dagbladen en periodieken". 
Als Stelling over deze 'kennisgeving" gaat procederen bij de Centrale Raad van Beroep, behaalt hij uiteindelijk een schijn-overwinning. ${ }^{304}$ In zijn uitspraak van 11 mei 1983 acht de Raad de chef van de beoordelaar, en ook de minister, bevoegd om een aantekening omtrent inzetbaarheid of geschiktheid op de beoordelingslijst te plaatsen, resp. in een kennisgeving op te nemen. Maar de "in Grondwet en verdragen geregelde vrijheid van meningsuiting laten naar 's Raads oordeel evenwel niet toe de conclusie van verminderde inzetbaarheid of geschiktheid [.. zonder meer te verbinden aan 'opvattingen ten aanzien van de kernbewapeningsproblematiek" of af te leiden uit het innemen of publiceren van een standpunt dat niet met het regeringsstandpunt in overeenstemming is". Anders gezegd, de conclusie van verminderde inzetbaarheid of geschiktheid had zorgvuldiger moeten worden geformuleerd. De Centrale Raad van Beroep verklaart de kennisgeving daarom "nietig", maar hij geeft tegelijk een voorbeeld van wat in dit geval wél een toereikende formulering zou zijn geweest: "een tekst in de trant van "Wellicht verdient het echter - aangezien is gebleken dat de beoordeelde niet bereid is alle opdrachten ter zake van het gebruik van kernwapens onvoorwaardelijk uit te voeren - aanbeveling met de daaruit voortvloeiende verminderde inzetbaarheid c.q. geschiktheid rekening te houden bij de bestemming van betrokkene'". Dan was, in de opvatting van de Raad, het recht van vrije meningsuiting kennelijk minder in de knel gekomen. Ik vraag me toch af, of de Raad hier zichzelf niet met een woordenspelletje voor de gek zit te houden. De vraag of een ambtenaar terecht een beroep op de vrijheid van meningsuiting doet, wordt vertaald in de vraag of die ambtenaar wel goed functioneert. De toetsing aan de grondrechten wordt daardoor onzichtbaar, en dus oncontroleerbaar.

Met de uitspraak van 11 mei 1983 is nog iets merkwaardigs aan de hand. Stelling had, bij zijn aankondiging dat hij bepaalde dienstopdrachten zou weigeren, zich niet alleen op zijn geloofsovertuiging beroepen, maar ook op het humanitaire oorlogsrecht. Hij had, met andere woorden, gesteld dat de opdrachten die hij zou weigeren, tevens opdrachten waren die hem rechtens nooit zouden kunnen worden gegeven. $\mathrm{Nu}$ kan men van mening verschillen, of hij daarin gelijk had. Maar om te kunnen concluderen, dat Stelling vanwege zijn standpunt voor de krijgsmacht "verminderd inzetbaar" was, had de Centrale Raad van Beroep toch in moeten gaan op de vraag van de rechtmatigheid van het gebruik van kernwapens. In plaats daarvan heeft de Raad opgemerkt, dat die vraag "buiten het geding" lag. Nu kan ik mij voorstellen, dat het voor een ambtenarenrechter niet erg 
aanlokkelijk is, om op een volkenrechtelijke vraag in te gaan. Maar als in een ambtenarenzaak een dergelijke vraag aan de orde komt, dan heeft ook de hoogste ambtenarenrechter die te beantwoorden. De Raad heeft nu, door de vraag buiten het geding te laten, de indruk gewekt, dat ambtenaren ook als verminderd inzetbaar mogen worden beschouwd, als zij aankondigen onrechtmatige opdrachten te zullen weigeren.

\section{Nogmaals de zaak Stelling}

Hoezeer de uitspraak van de Centrale Raad van Beroep van 11 mei 1983 een schijn-overwinning voor kapitein Stelling is, blijkt ook uit een latere uitspraak van de Raad, van 5 juni $1986{ }^{305}$ Stelling procedeert dan tegen een kennisgeving uit 1983. Daarin deelt de minister van Defensie hem mee, dat de beoordelaar heeft opgemerkt, "dat de wijze waarop u uw afwijzende mening betreffende het bezitten en de mogelijke inzet van kernwapens door de krijgsmacht te berde brengt binnen de krijgsmacht leidt tot hevige discussies en somtijds zodanig polariserend is dat niet gezegd kan worden dat $\mathrm{u}$ bij het uitoefenen van $\mathrm{uw}$ recht op vrije meningsuiting die terughoudendheid en voorzichtigheid in acht neemt, die van een beroepsofficier in werkelijke dienst ten aanzien van een politiek zo geladen en de krijgsmacht zo direct rakend onderwerp mag worden verwacht". De houding en gedraging van Stelling worden uitsluitend om die reden, zo geeft de beoordelaar toe, in een bepaalde rubriek als "zwak" gewaardeerd, terwijl hij "overigens" het gedrag als "zeer goed" kwalificeert. Ook nu weer concludeert de beoordelaar van Stelling tot verminderde inzetbaarheid.

De Centrale Raad van Beroep constateert, dat de minister in elk geval de vorige uitspraak van de Raad in zijn overwegingen heeft betrokken. Maar de raad vindt, dat ook nu een toetsing aan het in Nederland geldende grondrecht van vrijheid van meningsuiting niet achterwege mag blijven. Dat resulteert dan in de volgende overwegingen: "Zoals reeds vermeld", zegt de Raad, "is het zwaartepunt bij de thans in geding zijnde beslissing en kennisgeving niet hierin gelegen, dat klager een zeer uitgesproken mening heeft met betrekking tot het kernwapenvraagstuk en dat hij voor die mening uitkomt, doch dat hij dit doet in bewoordingen welke voor anderen kwetsend en beledigend zijn. Daarbij worden dikwijls aan personen en instellingen verwerpelijke intenties toegeschreven waarbij deze personen en instellingen op grond van ontoereikende gronden en aanvechtbare redeneringen - door klager onontkoombaar bewijzen genoemd - in 
een uitermate ongunstig daglicht worden gesteld. Ook ter zitting van de Raad heeft dit, helaas, plaatsgevonden. Dit valt te meer te betreuren - de Raad moge zich deze opmerking veroorloven - omdat de op dit punt bij klager levende basisovertuiging en de grondslagen daarvan ook naar het oordeel van de Raad alleszins achting verdienen".

"Het is mede tegen de geschetste achtergrond van klagers doorgaand gedrag", zo vervolgt de Raad, "dat klagers optreden en zich uiten een verzwaard negatief accent hebben en het is mede gelet hierop dat de Raad tot de conclusie heeft moeten komen, dat klager ook tijdens het beoordelingstijdwak is opgetreden en zilch heeft geuit op een wijze die door verweerder mocht worden aangemerkt als een ontoelaatbare aantasting als bovenbedoeld".

En dan volgen de conclusies van de Raad: "Daaruit volgt, dat van strijd met het grondrecht van de vrijheid van meningsuiting als thans neergelegd in de Grondwet naar "s Raads oordeel geen sprake is"; en: "Uit het vorenstaande volgt eveneens, dat verweerder naar 's Raads oordeel in redelijkheid tot het oordeel kon komen dat klagers optreden in het beoordelingstijdvak niet overeenkwam met hetgeen van hem in het belang van de dienst en/of zijn persoonlijk belang moest worden verwacht". De klacht van Stelling wordt "ongegrond" verklaard.

Ook in deze zaak heeft de Centrale Raad van Beroep de vraag, of een ambtenaar terecht een beroep doet op het grondrecht van vrije meningsuiting, vertaald in de vraag of die ambtenaar in zijn werk wel goed functioneert. Niet de inhoud van wat hij zei bracht Stelling in moeilijkheden, maar de wijze waarop hij voor zijn mening uitkwam, althans zo stelt de Raad het voor. De annotatie van Hennekens onder de in de AB gepubliceerde uitspraak is ontmaskerend: "Kwetsende en beledigende bewoordingen hebben betrekking op de inhoud. Vorm en inhoud bij het openbaren van gedachten en gevoelens plegen zozeer in elkaar verweven te zijn dat de grenzen vaak niet te trekken zijn. Werd de verminderde inzetbaarheid van klager i.c. niet wezenlijk bepaald door zijn geopenbaarde mening? Stel dat hij met eenzelfde wijze van optreden het standpunt van de regering verdedigd had, dan zou een oordeel over verminderde inzetbaarheid niet zijn opgegaan".

\section{De zaak wan hoofdagent Van Daalen}

Een recente uitspraak van de Centrale Raad van Beroep geeft de indruk, dat de Raad nu de vrijheid van meningsuiting van ambtenaren toch wat meer wil ontzien. In die uitspraak wordt geconstateerd, dat de Amsterdamse hoofdagent Van Daalen niet ontslagen had mogen worden vanwege 
uitlatingen in zijn boek Sans rancune, en zijn uitlatingen in een TVprogramma over corruptie bij de Amsterdamse politie. ${ }^{306}$

Van Daalen publiceert in november 1991 de roman Sans rancune, waarin een aantal aan de werkelijkheid ontleende corruptiezaken rond politieambtenaren van het bureau Warmoesstraat wordt beschreven. De in het boek figurerende personages treden op onder gefingeerde namen. In het boek komt ook tot uitdrukking dat de hoofdpersoon, in wie Van Daalen zichzelf heeft beschreven, het optreden van de politieleiding niet steeds adequaat vindt. Tijdens een TV-interview, in diezelfde maand, erkent Van Daalen, dat hij met zijn boek zijn ambtsgeheim heeft geschonden. De burgemeester van Amsterdam stelt de hoofdagent eerst buiten functie, schorst hem vervolgens, en uiteindelijk, op 23 maart 1993, ontslaat hij hem wegens ongeschiktheid voor het door hem beklede ambt anders dan op grond van lichaams- of zielsgebreken. Het ontslag wordt gegrond op schending van artikel 125a, lid 1 en 3 van de Ambtenarenwet. Dat artikel is in 1988 ingevoerd. De tekst van het eerste lid luidt:

De ambtenaar dient zich te onthouden wan het openbaren van gedachten of gevoelens of van de uitoefening van het recht tot vereniging, tor vergadering en tot betoging, indien door de uitoefening van deze rechten de goede vervulling van zijn functie of de goede functionering van de openbare dienst, voor zover deze in verband staat met zijn functievervulling, niet in redelijkheid zou zijn verzekerd.

Het derde lid van artikel 125a bevat de bepaling, dat een ambtenaar verplicht is tot geheimhouding van hetgeen hem in verband met zijn functie ter kennis is gekomen, "voorzover die verplichting uit de aard der zaak volgt".

Het ontslag wordt door de administratieve kamer van de Amsterdamse rechtbank vernietigd. Maar tegelijk wordt die nietigheid "voor gedekt" verklaard, waardoor de gevolgen van het ontslag in stand blijven. Daarop leggen de Amsterdamse burgemeester en Van Daalen de zaak allebei voor aan de Centrale Raad van Beroep.

De Centrale Raad vindt niet, dat Van Daalen zijn plicht tot geheimhouding als neergelegd in artikel 125a lid 3 heeft geschonden. Want, zegt de Raad, het boek geeft de corruptiepraktijken alleen maar "in hoofdzaak" weer, en de werkwijze van de BVD en de CID wordt alleen beschreven in "enkele oppervlakkige algemeenheden". 
Bij de beoordeling of Van Daalen de norm van artikel 125a lid 1 heeft overschreden, moet volgens de Raad een zekere voorzichtigheid worden betracht, "aangezien in deze bepaling een beperking wordt gegeven op het in de Grondwet verankerde recht van vrije meningsuiting". Er is, aldus de Raad, niet gebleken dat van Daalen "de integriteit van de leidinggevenden ter discussie heeft gesteld maar dat hij zich kennelijk niet kan verenigen met de wijze van aanpak van de gesignaleerde problemen door de leiding". De hoofdagent heeft met zijn boek tekortkomingen van het Amsterdamse politiekorps en het op onderdelen tekortschieten van de leiding hierin naar buiten gebracht. "Denkbaar is", zegt de Raad, "dat hierdoor het aanzien van het korps is geschaad al is het anderzijds niet uitgeloten dat het naar buiten toedekken van - en op den duur wellicht toch niet verborgen te houden - toestanden als de onderhavige tezamen met bij het publiek bestaande onzekerheid omtrent het zelf-corrigerend vermogen van een organisatie als hier in geding haar aanzien evenzeer schaadt". In elk geval kan naar het oordeel van de Raad niet worden gezegd, dat door het boek van Van Daalen "het aanzien van de openbare dienst zozeer is geschaad dat haar functioneren in redelijkheid niet meer zou zijn verzekerd, als bedoeld in artikel 125a lid 1 Ambtenarenwet".

Het optreden van de hoofdagent in het TV-interview wordt door de Raad aangemerkt "als een presentatie die niet boven kritiek verheven is en die zeker geen navolging verdient". Maar de Raad acht dit "niet van voldoende ernst voor het oordeel dat de goede vervulling van appellants functie of de goede functionering van de openbare dienst, voor zover deze in verband staat met zijn functievervulling, in onaanvaardbare mate aangetast zou zijn".

Alles bijeengenomen, meent de Centrale Raad, dat er voldoende reden is om de vernietiging van het ontslag te bevestigen, en om zelf de "gedekt-verklaring" van de rechtbank te vernietigen. Zo wordt het ontslag met al zijn rechtsgevolgen ongedaan gemaakt.

\section{Slotsom}

De ambtenarenrechtspraak over de demonstratie-vrijheid en vrijheid van meningsuiting levert een dubieus beeld op. In de uitspraken ten aanzien van Kalma en Stelling zegt de Centrale Raad van Beroep wel dat hij de wijze, waarop de overheid optreedt tegen haar ambtenaren, toetst aan de grondrechten. Maar doet de Raad dat ook werkelijk? In elk geval wordt dat in die uitspraken niet zichtbaar. De vraag, of een overheid-werkgever inbreuk maakt op de grondrechten van zijn ambtenaren, wordt door de raad vertaald in de vraag, of die overheid-werkgever "in redelijkheid tot het oordeel kon komen dat klagers optreden [..] niet overeenkwam met 
hetgeen van hem in het belang van de dienst en/of zijn persoonlijk belang moest worden verwacht". Wat volledige toetsing zou moeten zijn, wordt aldus marginale toetsing. En niet aan de grondrechten, maar an het ambtenarenrecht.

In de uitspraak ten aanzien van de hoofdagent Van Daalen blijft het grondrecht van vrije meningsuiting intact. Maar is de Centrale Raad van Beroep nu een andere koers gaan varen? De Raad vindt het zelf van belang om te constateren, dat Van Daalen niet de integriteit van zijn superieuren ter discussie heeft gesteld. Ook moet worden bedacht, dat hij zijn kritiek op de politieleiding heeft geuit in de vorm van een sleutelroman. Stel dat de hoofdagent in zijn roman wèl de integriteit van superieuren in twijfel had getrokken. Of dat hij zijn kritiek niet in roman-vorm had gegoten, maar in een meer directe vorm zou hebben geuit. Zou de Centrale Raad dan niet, net als in vorige zaken, tot de conclusie zijn gekomen, dat het optreden van de hoofdagent "'niet overeenkwam met hetgeen van hem in het belang van de dienst en/of zijn persoonlijk belang moest worden verwacht?" Alleen nieuwe jurisprudentie kan daarover duidelijkheid brengen.

\section{Wat is een loyale ambtenaar?}

We hebben in het vorige hoofdstuk gezien, dat de opvattingen over ambtelijke loyaliteit een lange voorgeschiedenis hebben. In de negentiende eeuw had men in het algemeen nog een vrij tolerante opvatting over ambtenaren, die hun eigen mening niet onder stoelen of banken staken. Niet alleen in Nederland bestond die tolerantie, maar ook in veel andere westerse landen. Daar komt in de eerste decennia van de twintigste eeuw verandering in. Men kreeg toen angst voor de "bureaucratie". Die moest hoe dan ook onder controle worden gebracht. Toen omstreeks 1920 in bijna alle West-Europese landen het algemeen kiesrecht was ingevoerd, leek de oplossing voor de hand te liggen. Ambtenaren zouden precies moeten doen wat hun (politieke) superieuren hen opdroegen. Deze waren op hun beurt verantwoording verschuldigd aan de met algemeen kiesrecht gekozen volksvertegenwoordiging. Echte democratie leek aldus werkelijkheid te kunnen worden.

Deze nieuwe opvatting over ambtelijke loyaliteit, geformuleerd door de Duitse socioloog Max Weber, leidde in Nederland tot een herwaardering van auteurs als Buijs en Struycken. Die hadden al eerder verkondigd, dat ambtenaren bij indiensttreding "vrijwillig" afstand deden van hun grondrechten. De opvatting werkte door in ons ambtenarenrecht, en legitimeerde een nieuwe stijl van besturen. Ambtenaren werden geacht zich te 
onthouden van het uiten van een eigen mening over het werk, waar ze mee bezig waren. Bestuurders konden de zaken nu meer binnenshuis houden; tot interne bestuursaangelegenheid verklaren.

Al in het Derde Rijk zou blijken, wat de consequenties konden zijn van de nieuwe opvatting. Als meest extreme voorbeeld van de Weberiaanse model-ambtenaar wordt wel de persoon van Adolf Eichmann genoemd: een ambtenaar, die stipt en efficiënt de vernietiging van miljoenen joden organiseerde, omdat hem dat nu eenmaal was opgedragen. Geen wonder, dat men na de Tweede Wereldoorlog in de westerse landen toch vraagtekens bij deze opvatting is gaan plaatsen.

Dat de Weberiaanse opvatting tot zulke absurde consequenties kan voeren, houdt verband met het feit, dat ze uitgaat van een negatief mensbeeld, in het bijzonder van wantrouwen ten opzichte van de ambtenaren. Daarom mag een ambtenaar nooit zelf initiatieven nemen. Hij mag alleen doen wat hem uitdrukkelijk is opgedragen door een superieur, die (direct of indirect) democratisch wordt gecontroleerd. Maar is dat wel een reëel uitgangspunt? Mensen hebben, naast negatieve, gewoonlijk ook een aantal positieve eigenschappen. Het zijn sociale wezens. Ze zien met eigen ogen, dat ergens geholpen moet worden. Vaak doen ze dat dan ook, zelfs zonder betaling. Ze zien graag, dat het goed gaat met de gemeenschap waarin ze leven. En ze denken na over hoe het welzijn van de samenleving bevorderd kan worden. Kortom, in meer of mindere mate gedragen ze zich als medemens, om het maar eens met een pleonasme te zeggen. Dat geldt ook voor ambtenaren. Weber en zijn navolgers, zoals Herman Finer, weigeren in hun staatkundig concept van deze positieve eigenschappen gebruik te maken. Sterker nog, ze verbieden ambtenaren om aan die eigenschappen toe te geven. Want dat kan uiteindelijk alleen maar leiden tot, wat Finer noemt, nieuwe vormen van "taxation without representation".

Carl Friedrich gaat uit van een positiever mensbeeld. Hij zag al voor de Tweede Wereldoorlog, dat het succes van de New Deal-politiek in Amerika niet in de laatste plaats te danken was aan de inzet van enthousiaste ambtenaren, die zelf met ideeën kwamen. Daarom ontwikkelde hij een staatkundig concept, waarin burgersehaps-deugden van ambtenaren tot hun recht kunnen komen. Ambtenaren krijgen in dat concept een eigen verantwoordelijkheid. Dat betekent niet, dat ze hun eigen baas worden. $\mathrm{Ze}$ blijven, ook in de opvatting van Friedrich, gebonden aan de directieven die op het niveau van de volksvertegenwoordiging en de politiek-verantwoordelijke bestuurders worden geformuleerd. Maar die laten in de praktijk vaak een grote ruimte over voor eigen ambtelijke invulling. In die gevallen moeten we de betrokken ambtenaren kumnen aanspreken op hun eigen ambtelijke verantwoordelijkheid. Die is een optelsom van vakkennis, be- 
roepseer en maatschappelijk verantwoordelijkheidsbesef. Zou die ambtelijke verantwoordelijkheid niet bestaan, dan zou er feitelijk een verantwoordelijkheidsvacuüm zijn.

In het concept van Friedrich kan niet alleen de politieke leiding, maar ook de burgerij de ambtenaren aanspreken op hun ambtelijke verantwoordelijkheid. De samenleving mag erop vertrouwen, dat ambtenaren niet klakkeloos opdrachten uitvoeren, die naar hun eigen deskundig oordeel grote schade of groot onrecht in die samenleving zouden veroorzaken. Daarmee is niet gezegd, dat een ambtenaar dergelijke opdrachten zomaar naast zich neer mag leggen. Maar wel mag van hem worden verwacht, dat hij de samenleving waarschuwt. Want ambtelijke verantwoordelijkheid is ook maatschappelijke verantwoordelijkheid. Een ambtenaar die aldus handelt, handelt niet deloyaal, maar juist verantwoordelijk. Hij probeert, vanuit zijn deskundigheid en verantwoordelijkheidsbesef, de samenleving te overtuigen, dat een overheidsbesluit correctie behoeft. Is zijn (politieke) baas het niet met hem eens, dan mag die natuurlijk ook het spreekgestoelte beklimmen, en uitleggen, waarom zijn ondergeschikte het bij het verkeerde eind heeft. Het publiek en de volksvertegenwoordigers kunnen dan, na van beide kanten de argumenten te hebben gehoord, zelf een oordeel vellen. Dan hebben we niet meer te maken met een democratie die verstopt is, maar met een democratie die werkt.

\section{Naoorlogse ontwikkelingen}

$\mathrm{Na}$ de Tweede Wereldoorlog zien we, dat in de politieke theorie de opvattingen over ambtelijke loyaliteit een hele ontwikkeling doormaken, terwijl in het staats- en bestuursrecht de ontwikkeling vastloopt. In de politieke theorie wordt, mede als reactie op de excessieve gehoorzaamheid van ambtenaren in het Derde Rijk, eerst de 'ontplooiingsopvatting', en later het 'burgerschapsdenken' ontwikkeld. Beide doctrines geven blijk van een herleefde aandacht voor de grondrechten, met name voor de gewetensvrijheid en de vrijheid van meningsuiting. Vooral het burgerschapsdenken sluit aan bij het concept van ambtelijke verantwoordelijkheid, dat Carl Friedrich al voor de oorlog formuleerde. In Nederland wordt het burgerschapsdenken voor ambtenaren en medewerkers van andere grote organisaties bepleit in de dissertatie van Mark Bovens. Maar zoals we zagen, geeft Bovens zelf aan, dat zijn doctrine niet voor dagelijks gebruik bestemd is. Ze beoogt een oplossing te bieden voor uitzonderlijke, zeer ernstige gevallen van dreigende schade of onrecht.

Ook de regering en rechtswetenschappers komen na de oorlog tot de erkenning, dat de grondrechten in principe ook voor de ambtenaren gelden. De regering doet dit halverwege de jaren vijftig. De juristen hebben 
wat meer moeite om de oude, door Buijs, Struycken en Van der Pot uitgezette lijn los te laten. Maar na de dissertatie van Van der Hoeven komt er geleidelijk er een kentering in de opvattingen. Vanaf de grondwetsherziening in 1983 worden de grondrechten in principe ook voor ambtenaren van toepassing geacht.

Toch is dit alles voor de regering en de rechtswetenschap niet meer dan een formele exercitie. Men heeft niet echt een andere kijk op de ambtenaarsverhouding gekregen. Dat blijkt onder meer uit de eerder besproken Aanwijzingen inzake ambtelijk optreden (extern) van 1972. Ook auteurs als Van der Hoeven, Van der Horst, Olde Kalter en Donner kunnen zich niet of nauwelijks voorstellen, dat erkenning van grondrechten voor ambtenaren ook consequenties moet hebben voor de inhoud van het ambtenarenrecht. Dat de grondrechten in beginsel ook voor de ambtenaren gelden, betekent niet, dat die grondrechten niet kunnen worden beperkt. In de voorstellen voor de nieuwe Grondwet kiest de regering voor een systeem, waarin beperkingen van grondrechten herleidbaar moeten zijn tot clausules in de Grondwet zelf. Het parlement accepteert deze visie. ${ }^{307}$ De weg wijst zich dan vanzelf. Artikel 7 van de Grondwet, waarin de vrijheid van meningsuiting is geregeld, bevat de clausule: behoudens ieders verantwoordelijkheid volgens de wet. En artikel 109 van de Grondwet bepaalt, dat de wet de rechtspositie van de ambtenaren regelt. Zo kunnen de beperkingen, die sinds de twintiger jaren algemeen geaccepteerd zijn, gewoon in de Ambtenarenwet worden opgenomen. Dat gebeurt in 1988 door de invoering van artikel $125 \mathrm{a}$ in deze wet.

Het eerste lid van artikel 125 a zet de ambtenaren terug op hun plaats. De tekst luídt:

De ambtenaar dient zich te onthouden van het openbaren van gedachten of gevoelens of van de uitoefening van het recht tot vereniging, tot vergadering en tot betoging, indien door de uitoefening van deze rechten de goede vervulling van zijn functie of de goede functionering van de openbare dienst, voor zover deze in verband staat met zijn functievervulling, niet in redelijkheid zou zijn verzekerd.

Het tweede lid van artikel 125 a verzacht deze bepaling een beetje, door te stellen, dat hierdoor niet de vrijheid wordt beperkt om lid te zijn van een officieel ingeschreven politieke groepering of van een vakvereniging. Maar wetsherziening 1983, Deventer 1983, pag. 50-56. 
voor de rest blijft er voor de ambtenaren weinig over van de grondwettelijke garanties, om zich op politiek of maatschappelijk terrein vrij te kunnen uiten. Het derde lid van artikel 125 a bevat de bepaling, dat een ambtenaar verplicht is tot geheimhouding van hetgeen hem in verband met zijn functie ter kennis is gekomen, "voorzover die verplichting uit de aard der zaak volgt".

In de uitspraken over hoofdinspecteur Kalma (in 1979) en kapitein Stelling (in 1983 en 1986) hebben we gezien, dat de Centrale Raad van Beroep vrij snel aannam, dat bij het uiten van een eigen mening "de goede vervulling van de functie of de goede functionering van de openbare dienst" niet meer is "verzekerd". De Raad liep toen vooruit op de invoering van artikel 125a in de Ambtenarenwet. ${ }^{308}$ De uitspraak, die de Raad in 1995, dus nà de invoering van $125 \mathrm{a}$, doet over de hoofdagent Van Daalen, lijkt de ambtenaren wat meer ruimte voor meningsuiting te bieden. Maar van een echte doorbraak is geen sprake. Ambtenaren hebben niet dezelfde vrijheid van meningsuiting als andere volwassen Nederlanders. De Grondwettelijke rechten zijn voor hen, op dit punt, door een formele wet ingeperkt.

De ambtelijke rechtsverhouding is dus, sinds de twintiger jaren van deze eeuw, in feite weinig veranderd. Sterker nog, de "klassieke" leer, die voor de politicologen en bestuurskundigen al sinds de Tweede Wereldoorlog heeft afgedaan, wordt ruim veertig jaar na die oorlog gewoon in ons ambtenarenrecht gecodificeerd. Het is droevig, dat staatsrecht-beoefenaren, bestuursjuristen, regering, parlement, en rechters daar geen enkel probleem mee schijnen te hebben. Het toekomstbeeld, dat de Utrechtse staatsrecht-geleerde Steenbeek ons vijfentwintig jaar geleden al schetste, waarin ambtenaren naar buiten treden "als lieden die een eigen oordeel hebben dat kan afwijken van dat van hun verantwoordelijke bestuurlijke chefs", wil bij hen maar niet op het netvlies komen. Men heeft tegenwoordig de mond vol van 'bestuurlijke vernieuwing'. Maar moeten er niet eerst eens wat oogkleppen worden afgezet?

Wat is een loyale ambtenaar? Na wat ik hierboven gezegd heb, zal het duidelijk zijn, dat mijn concept van een loyale ambtenaar in het verlengde ligt van wat auteurs als Friedrich, Steenbeek en Bovens daarover hebben

308 J. Boesjes, ondervoorzitter van de Centrale Raad van Beroep, vermeldt in zijn bijdrage Ambtenaar en grondrechten: een evenwicht, in Gegeven de Grondwet, CZW-bundel, Deventer 1988, pag. 85, dat de CRvB koos voor het introduceren van "een zelfstandige en inhoudelijke norm, waartoe aansluiting kon worden gevonden bij het ten departemente liggende wetsontwerp" . 
geschreven. Een loyale ambtenaar is in de eerste plaats een eerlijke ambtenaar. Zowel zijn superieuren, als het publiek, moeten er op kunnen vertrouwen dat hij hen geen streken levert. Maar je kunt alleen eerlijk tegenover anderen zijn, als je dat ook tegenover jezelf bent. Je moet als ambtenaar dus ook weten, wat je zelf wilt. In een overheidsorganisatie zijn voortdurend tegengestelde belangen en meningen aanwezig. Nog gecompliceerder wordt het, als je daar de tegengestelde belangen en meningen tussen die overheidsorganisatie en het publiek bij betrekt. Een loyale ambtenaar zal er niet aan ontkomen, om zich in voorkomende aangelegenheden zelf een oordeel te vormen over wat hij, gelet op zijn vakkennis en maatschappelijke verantwoordelijkheid, het meest wenselijke overheidsoptreden vindt, en welke bijdrage hij daaraan kan leveren. Dat oordeel mag hij in de organisatie vrij uiten. Maar hij hoeft ook voor het publiek niet voor stommerdje te spelen. Wel moet hij rekening houden met specifieke wettelijke geheimhoudingsregels en met de in artikel 10 van de Wet openbaarheid van bestuur genoemde geheimhoudingsgronden.

Wijkt zijn oordeel af van dat van zijn superieuren, dan doet een ambtenaar er verstandig aan om ook te laten weten, of, en zo ja, hoe hij zal proberen zijn oordeel in de verdere besluitvorming gewicht te geven. Gedrag, dat als 'een streek' kan worden ervaren, is daarmee uitgesloten. Ook de superieuren zullen moeten accepteren, dat een ambtenaar uiteindelijk loyaal is aan de samenleving.

\section{Openbaarheid van bestuur}

Zal een dergelijke houding leiden tot een grotere openbaarheid van bestuur? Geleidelijk aan wel, denk ik. Ambtenaren krijgen een eigen verantwoordelijkheid voor wat ze wel, en wat ze niet in het openbaar mogen zeggen. De absurditeit van door diensthoofden of bestuurders opgelegde spreekverboden zal tot het verleden behoren. Toch zal dat niet betekenen, dat ambtenaren opeens elk meningsverschil met hun superieuren op straat zullen gooien. De meeste ambtenaren hechten, net als andere werknemers, waarde aan een goede werkverhouding met hun chef. Die verhouding bepaalt voor een groot deel het plezier in het werk, en voor een nog groter deel de carrière-perspectieven. Alleen in uitzonderlijke gevallen zal een ambtenaar tot de conclusie komen, dat hij het publiek deelgenoot moet maken van zijn zorgen of inzichten. Ook het publiek zelf heeft er geen behoefte aan, dat elk meningsverschil binnen de overheid naar buiten wordt gebracht.

Belangrijker dan de toename van spontane ambtelijke uitingsmogelijkheden is echter een andere consequentie. De nieuwe definitie van ambtelijke loyaliteit brengt met zich mee, dat ambtelijke opvattingen, en 
dus ook afwijkende ambtelijke opvattingen, openbaar mogen zijn. Dat betekent, dat het publiek inzage mag verlangen. Een verzoek om de openbaarmaking van een ambtelijk advies kan dan niet meer worden geweigerd met de motivering, dat het om een zogenaamde "persoonlijke beleidsopvatting" gaat.

Het publiek hoeft dus niet overladen te worden met alle verschillende opvattingen die binnen de overheid leven. Maar belanghebbenden en geïnteresseerden hebben, als zij dat wensen, wel recht op kennisname. De producten van vakkennis en maatschappelijke verantwoordelijkheid van de ambtenaren zijn niet het exclusieve bezit van de toevallige politieke ambtsdragers, maar komen aan de hele samenleving toe. Dat geldt ook voor de op schrift gestelde opvattingen van die bestuurders zelf. Niet omdat dat altijd producten van vakkennis zouden zijn, maar het publiek heeft er recht op te weten, in welke richting de ambtsdragers de besluitvorming proberen te sturen. Dan pas is echte democratische controle en sturing mogelijk. Artikel 11 van de Wet openbaarheid van bestuur, dat de term "persoonlijke beleidsopvattingen" gebruikt als reden om verzoeken om informatie te kunnen afwijzen, dient dan ook in zijn geheel te worden geschrapt. ${ }^{309}$ Openbaarmaking zou alleen mogen worden geweigerd, als daardoor specifieke wettelijke regels zouden worden geschonden, of als geheimhoudingsgronden van artikel 10 van de Wet openbaarheid van bestuur van toepassing zijn.

En als we dan toch schoon schip maken, kunnen we tegelijk ook artikel 125a van de Ambtenarenwet schrappen. ${ }^{310}$ Wat ambtenaren wel of niet mogen openbaren, staat sinds 1 januari 1994 in artikel $2: 5$ van de Algemene wet bestuursrecht. Het eerste lid van dit artikel luidt:

Een ieder die is betrokken bij de witvoering van de taak van een bestuursorgaan en daarbij de beschikking krijgt over gegevens waarvan hij het vertrouwelijke karakter kent of redelijkerwijs moet vermoeden, en voor wie niet reeds uit hoofde van ambt, beroep of wettelijk voorschrift ter zake van die gegevens een geheimhoudingsplicht geldt, is verplicht tot geheimhouding van die gegevens, behoudens voor zover

309 Bovendien is de term "persoonlijke beleidsopvattingen", zoals die gebruikt wordt in artikel 11, een falsisme. In wezen gaat het altijd om opvattingen, die door een ambtenaar of bestuurder in functie op schrift zijn gesteld.

310 Het op dit artikel gebaseerde artikel 59 van het Algemeen rijksambtenarenreglement, dat de ambtenaar verplicht tot geheimhouding van hetgeen hem in zijn ambt ter kennis is gekomen, voor zover die verplichting uit de aard der zaak volgt, kan dan eveneens worden geschrapt. 
enig wettelijk voorschrift hem tot mededeling verplicht of uit zijn taak de noodzaak tot mededeling voortvloeit.

In de parlementaire stukken van de Algemene wet bestuursrecht wordt bij de zinsnede behoudens voor zover enig wettelijk voorschrift hem tot mededeling verplicht onder meer verwezen naar de Wet openbaarheid van bestuur. ${ }^{311}$ Daarmee zijn dus, in hoofdzaak, ook de criteria gegeven voor wat wel en wat niet vertrouwelijk is. Als we artikel 125a van de Ambtenarenwet gewoon schrappen, zullen de ambtenaren eindelijk, na ruim zeventig jaar, weer dezelfde grondrechten hebben als anderen die zich op Nederlands grondgebied bevinden. En onze ambtenarenrechters mogen dan, met een schone lei, nog eens opnieuw proberen, om die rechten te waarborgen.

Zullen deze veranderingen ook van invloed zijn op de inhoud van de ambtelijke adviezen? Ongetwijfeld! Uit de tijd dat ik gemeente-ambtenaar was, herinner ik mij een bureauchef - niet die van mij - die bijzonder grote moeite had met de gedachte, dat ambtelijke adviezen openbaar zouden kunnen worden. Hij wilde in vertrouwd gezelschap ook wel vertellen, waarom. Hij schreef, op verzoek van "zijn" wethouder, vaak voorstellen voor het college van $B$ en $W$, waar hijzelf helemaal niet achter stond. In die gevallen was de argumentatie natuurlijk ook dubieus. Maar buiten een klein kringetje van top-ambtenaren en collegeleden kon niemand hem daarop aanspreken. Als het college zijn voorstel aanvaardde, dan werd het immers naar buiten gebracht als "collegebesluit". Zijn adviezen bleven geheim, en hij hoefde zich ten overstaan van het publiek nooit te generen.

Kijk, ambtenaren die zulke staaltjes van karakterloosheid leveren, krijgen het nog heel moeilijk, als de door mij voorgestelde formule voor loyaliteit wet wordt.

311. MvT bij Wetsvoorstel Awb. TK 1988-1989, 21221, nr. 3, pag. 56. 


\section{Hoofdstuk 8}

\section{Inspraak}

\section{Waarom inspraak?}

Op 30 en 31 mei 1972 viert de Vereniging van Nederlandse Gemeenten haar 60 -jarig bestaan met een congres, dat als thema heeft: Inspraak en Gezag. Twee parlementsleden zijn uitgenodigd om stellingen te leveren. Het zijn M.W. Schakel, lid van de Anti-revolutionaire Partij, en de latere minister van Binnenlandse Zaken E. van Thijn, lid van de Partij van de Arbeid. ${ }^{312}$ Vijf jaar eerder had J.M.M. de Valk in het gemeentelijk jaarboek van de VNG in een artikell met als titel Het gezag in opspraak geschreven, dat de oude gezagsvormen niet meer goed functioneerden, en er nieuwe moesten worden gevonden.

Van Thijn refereert in 1972, in de toelichting bij zijn stellingen, aan dit artikel: "Het was 1967, het was zo'n beetje de aanloopperiode van een vernieuwingsstorm in Nederland. Politieke protestbewegingen binnen en buiten bestaande politieke partijen, actiegroepen, studentenprotest, maakten in die dagen furore: De vernieuwing van onze staatkundige en maatschappelijke structuren stond toen hoog genoteerd in de publieke belangstelling, studieconferenties werden georganiseerd, staatscommissies ingesteld, partijprogramma's bijgeslepen, troonredes aangepunt. [..] Het feit dat uw Vereniging nu vijf jaar later haar congres in het teken plaatst van diezelfde gezagsproblematiek, maar nu onder een andere titel 'Gezag en inspraak', is misschien wel het beste bewijs dat de vernieuwingsstorm tot op heden aardig is overgewaaid: Gezagsproblematiek is in een wat rustiger vaarwater gekomen, de aanval lijkt afgeslagen". Van Thijn constateert, dat er intussen natuurlijk wel wat concessies zijn gedaan, en dat er hier en daar niet onverdienstelijk wordt geẻxperimenteerd met inspraakmethodes. Maar wat stelt het voor, vraagt hij zich af: "De opspraak is, als ik het zo scherp mag uitdrukken, afgekocht met een kleintje inspraak. En een inspraak die

312 Het verslag van het congres en de stellingen van Schakel en van Van Thijn zijn gepubliceerd in Bestuurswetenschappen 1972, pag. 279-332. 
het waarschijnlijk zeer goed zal doen in een gemeente als uw nieuwe erelid Madurodam". ${ }^{\text {"15 }}$

\section{Twee visies}

Zijn het de burgers, die behoefte hebben aan inspraak? Of is inspraak een bestuurlijke reactie, een antwoord op een situatie waarin het gezag zelf in opspraak is geraakt, een middel om dat gezag voor de burgers (weer) aanvaardbaar te maken? Het één hoeft het ander niet uit te sluiten. Veel hangt af, van wat men met inspraak wil bereiken. Pas als men zich daar een beeld van heeft gevormd, kan het zinvol zijn om het begrip inspraak te definiëren.

Korsten maakt in zijn dissertatie over inspraak een onderscheid tussen twee visies..$^{314}$ In de eerste visie wordt inspraak beschouwd als een aanvulling op het bestaande representatief-democratische systeem. Inspraak wordt dan primair gezien als een middel om gegeven doeleinden van de overheid beter te kunnen verwezenlijken. Politici en schrijvers die van deze zienswijze uitgaan, hebben van inspraak in het algemeen geen hoge verwachtingen. Inspraak kan voor het bestuur nuttige informatie en soms ook wel goede ideeën opleveren, maar de overgrote meerderheid van de bevolking is er niet echt 'rijp' voor, en zal dat waarschijnlijk ook nooit worden. Wel kan inspraak ertoe bijdragen om het vertrouwen in de relatie burger-bestuur te bewaren of te herstellen, en beslissingen van de overheid aanvaardbaar te maken. In deze visie is inspraak meer een gunst dan een recht, aldus Korsten. Een goed voorbeeld van deze visie is naar mijn mening te vinden in het eerder door mij besproken rapport Openbaarheid openheid van de Commissie Biesheuvel.

In de tweede visie die Korsten beschrijft, gaat het erom, dat de bestaande bestuurlijke situatie fundamenteel verandert door het initiëren van inspraakprocessen. Zij die van deze zienswijze uitgaan, streven in feite naar een opheffing van verschillen in beslissingsmacht tussen burgers en bestuur. In hun opvatting moet inspraak gericht zijn op een structurele democratisering, het verwerkelijken van een participatie-democratie. Een samenleving kan niet democratisch functioneren zonder deelname van haar burgers, want het wezen van de democratie ligt juist daarin dat de mensen zelf hun lot kunnen bepalen. Politieke partijen en politieke leiders hebben er belang bij hun machtspositie te behouden. Daarom slaagt de representatie-democratie er niet in om huidige problemen, als bijvoorbeeld de

313 Bestuurswetenschappen 1972, pag. 299.

314 A.F.A. Korsten, Het spraakmakende bestuur, Den Haag 1979, pag. 89-99. 
milieuverontreiniging, adequaat op te lossen. De noodzaak van een nieuwe wijze van beleidsvorming blijkt dus uit de "output failure" van het politiek systeem, aldus de pleitbezorgers van deze visie. Inspraak is een eerste stap op weg naar verandering. Ik heb deze visie in het eerste hoofdstuk van dit boek al besproken in het kader van de participatie-theorie.

Als we de bijdragen van de beide bovengenoemde parlementariërs aan het VNG-congres lezen, dan is Schakel duidelijk een representant van de eerste visie, en Van Thijn, als we hem het voordeel van de twijfel gunnen, meer een representant van de tweede visie, althans in die tijd. ${ }^{315}$

Schakel erkent, dat het indirecte/representatieve systeem niet meer als voldoende wordt ervaren. Het openen van mogelijkheden voor directe communicatie is daarom een goede zaak. Maar, zegt hij: "Men hoede zich voor inspraak-hoeraïsten" (pag. 287). De directe communicatie zal nooit plaatsvervangend voor, maar aanvullend naast de representatieve moeten treden. Het representatieve systeem heeft "een harmonisatietaak te midden der wrijving der rivaliserende belangen". Als de overheid die taak waar makkt, is het volk in staat van zijn verscheidenheid te genieten. De openbare bestuurder is iemand met de opdracht om samen met andere bestuurders een redelijk compromis te zoeken, dat de verschillende groeperingen in staat stelt met elkaar een stuk verder te komen op het gemeenschappelijk pact. "Dat is een belangrijk gegeven en dat zit veilig, althans dat zit veiliger ingebouwd in het indirecte systeem dan in het directe" (pag. 292). Inspraak komt tegemoet aan de behoefte van de mondig geworden burger. Die "gelooft als modern mens ook in de veranderbaarheid van de maatschappij". En "als de zaak veranderbaar blijkt te zijn, is het natuurlijk ook de moeite waard om te pogen daar dan een persoonlijke inbreng in te verdisconteren" (pag. 289). De inspraakgedachte sluit goed aan bij de moderne bestuurspraktijk van planning voor de middellange termijn. Gemeentebesturen kunnen bij de beleidsformulering "een bijzonder nuttig gebruik maken van al datgene wat de burgerij via de verschillende kanalen individueel of collectief inbrengt". Inspraak zou meer moeten zijn dan meepraten, maar zal altijd minder zijn dan meebeslissen (pag. 290-291).

315 Ook Korsten (a.w. pag. 96) ziet in Van Thijn meer een vertegenwoordiger van de tweede visie. Maar C.J. Verplanke, rapporteur wan een van de discussiegroepen op het VNG-congres, zag dat anders. De woorden van Schakel riepen bij hem een beeld op van een witte zebra met zwarte strepen, terwijl de woorden van Van Thijn hem deden denken aan een zwarte zebra met witte strepen. Zie Bestuurswetenschappen 1972, pag. 314. 
Voor Van Thijn is de representatieve democratie geen principezaak, maar een praktisch werkmodel met onvermijdelijke tekortkomingen op het punt van de gelijkheid van beînvloedingsmogelijkheden. De inspraak, zegt hij, is één van de correctiemogelijkheden en als zodanig geen gunst maar een fundamenteel grondrecht van alle burgers. Bij beleidsvorming zijn de voorbereidende fasen niet minder belangrijk dan de beslissingsfase. De representatieve democratie is een organisatiestructuur voor de beslissingsfase. Genomen beslissingen moeten zoveel mogelijk een weerspiegeling kunnen zijn van de preferenties van de burgers. "Voorwaarde daartoe is een zodanig open voorbereidingsproces dat een gelijkheid van beïnvloedingsmogelijkheden voor alle burgers als vanzelfsprekendheid is ingebouwd" (pag. 296-297).

Van Thijn signaleert een aantal gebreken in de gemeentelijke inspraakpraktijk. De inspraak, zegt hij, vindt dikwijls plaats in een te laat stadium. De inspraak geschiedt vaak ongestructureerd en te vrijblijvend, omdat de presentatie niet plaats vindt met behulp van alternatieven. Ook wordt bij inspraak meestal te weinig informatie gegeven over de samenhangen met andere onderdelen van het totale beleid. Voorts concentreert de inspraak zich in het algemeen op de uitwerking van een beleid waarvan de doelstellingen niet meer ter discussie staan. En tenslotte richt de inspraak zich hoofdzakelijk op ongestructureerde groepen uit de burgerij. "Door dit soort inspraakprocedures", constateert Van Thijn, "wordt de kloof tussen overheid en burgerij eerder vergroot dan verkleind en worden de burgers met de geringste expressiemogelijkheden nog verder van het bestuur vervreemd" (pag. 297-298).

Hij geeft zelf aan, wat er moet gebeuren, om deze gebreken te verhelpen. Inspraak moet volgens hem aanvangen in het allervroegste stadium. Er moeten tijdens de procedure gelijkwaardige alternatieven worden gepresenteerd, waarbij ook de doelstellingen van het beleid ter discussie staan. En inspraak moet worden ingepast in een proces van integrale beleidsplanning. Verder moet inspraak worden voorzien van deskundige begeleiding, door de gemeente gefinancierd, die het mogelijk maakt dat vanuit de burgerij nieuwe alternatieven worden ontwikkeld. En tenslotte moet ook ernst worden gemaakt met de bestuurlijke decentralisatie in de vorm van gekozen wijkraden met duidelijke bevoegdheden en een eigen budget (pag. 298).

Niet alleen formeel, maar ook feitelijk zou onze democratie meer in overeenstemming moeten zijn met het democratisch uitgangspunt van een politiek systeem, waarin de macht gelijkelijk verdeeld is over de leden van dat systeem, vindt Van Thijn. Alle burgers zouden een gelijke en zo groot mogelijke invloed moeten kùnnen uitoefenen op de toekomstige inrichting 
van onze samenleving. Dat was ook de inzet van de vernieuwingsbeweging van de jaren zestig. De realiteit van vandaag is ver verwijderd van dit ideaal. In mavolging van Robert Dahl kenschetst Van Thijn ons systeem als een "polyarchie", waarin er een voortdurende concurrentie bestaat tussen politieke partijen, pressiegroepen, actiegroepen, te midden van een meerderheid van niet-geïnteresseerde burgers. ${ }^{316}$ De mate van democratie, zo vat $V$ an Thijn samen, is in dit systeem afhankelijk van een tweetal factoren:

a. de mate waarin een oppositie vrijelijk kan functioneren, een alternatief kan vormen voor de zittende gezagsdragers, en voor de burgers een instrument kan zijn om tot een ombuiging van het beleid te komen;

b. de mate waarin de bevolking actief kan participeren in de beleidsvorming van alledag.

Het eerste gaat een beetje over democratie aan de top, en het tweede over democratie aan de basis. Van Thijn constateert, dat beide vormen van democratie in Nederland niet voldoende gestalte krijgen. Ook de democratie aan de top functioneert niet goed, want mede door de veelheid van politieke partijen hebben de kiezers vrijwel geen invloed op de samenstelling van de beleidsorganen van de overheid. Wanneer wij er niet in slagen de legitimatie van het gezag in onze samenleving een hechtere basis te verschaffen, waarschuwt Van Thijn, dan zal ons democratisch systeem meer en meer op een fictie komen te berusten. Bij het nationaal verkiezingsonderzoek van 1971 is al gebleken, dat "steeds meer burgers, de overgrote meerderheid, zich buiten spel voelen staan, zich machteloos voelen, zich bij het beleid niet betrokken weten" (pag. 305).

Als de bewering van Robert Dahl juist is, dat een directe democratie alleen maar kan functioneren in een gemeenschap van hooguit twintigduizend mensen, dan is de representatieve democratie een "noodzakelijk kwaad", vindt Van Thijn. Die erkenning verplicht ons "in de eerste plaats de representativiteit van dit systeem zo groot mogelijk te maken. In de tweede plaats om de onvermijdelijke tekortkomingen op het punt van de directe beïnvloedingsmogelijkheden zo klein mogelijk te maken" (pag. 306). De representativiteit, "de verticale democratie", wil Van Thijn bevorderen "door de invloed van de kiezers door te trekken tot alle organen in het gemeentelijk bestel inclusief de burgemeester". Bovendien moeten alle barrières in de informatiekloof tussen college, raad en bevolking

316 De democratische theorie van Robert Dahl heb ik besproken in het eerste hoofdstuk van dit boek. 
worden weggenomen "door een volledige toepassing van het beginsel van openbaarheid van overheidsdocumenten, commissievergaderingen, enz." De directe beïnvloedingsmogelijkheden op het beleid, "de horizontale democratie", wil hij stimuleren door aan bestuurlijke eenheden van minder dan twintigduizend inwoners - (deel) gemeenten - zoveel mogelijk bestuurlijke bevoegdheden te geven. Alle burgers kunnen dan optimaal bij de beslissingen worden betrokken. Voor het niveau van grotere eenheden moeten inspraakprocedures worden ontwikkeld (pag. 307-308).

Tenslotte wil Van Thijn een "recht van initiatief" toekennen aan lagere bestuurslagen ten opzichte van hogere bestuurslagen, en aan groepen van burgers die zich van een voldoende llegitimatie hebben voorzien, bijv. door het behalen van een vereist aantal handtekeningen. Hierdoor zou het mogelijk moeten zijn, om al dan niet alternatieve voorstellen of plannen in de vertegenwoordigende organen op de agenda te brengen, en deze daar ook met deskundige steun te verdedigen. De besluitvorming blijft dan wel bij die organen (pag. 308).

Alles bijeengenomen is dan met de participatie-democratie "nog maar amper een begin gemakkt", zegt Van Thijn. Maar die vorm van democratie, verduidelijkt hij later aan de congresgangers, is "een utopie, een ideaal waarvan ik ook niet weet of het binnen enkele generaties is te verwezenlijken. Alleen, ik vind dat wij bij all datgene wat wij vandaag op het gebied van de bestuurlijke organisatie doen, wij dat ideaal voor ogen moeten houden" (pag. 318).

\section{Inspraak is een burgerrecht.}

Wat is nu inspraak? Meer dan meepraten, maar minder dan meebeslissen, zegt Schakel. Overheden "kunnen bij de beleidsformulering een bijzonder nuttig gebruik maken van al datgene wat de burgerij via de verschillende kanalen individueel of collectief inbrengt". Inspraak is voor een overheid 'mooi meegenomen', zou je bijna denken. Voor Van Thijn is inspraak het uitoefenen van een burgerrecht. De overheid dient ervoor te zorgen, dat inspraak kan plaatsvinden op momenten en onder omstandigheden, dat burgers, en met name groepen van burgers, reële en dus ook gelijke kansen hebben, om bestuursorganen, die een beslissing moeten nemen, voor een standpunt te winnen. Daartoe behoort ook de mogelijkheid voor die burgers, om met hulp van deskundigen alternatieve plannen of voorstellen te ontwikkelen.

Mijn visie op inspraak sluit meer aan bij die van Van Thijn dan bij de visie van Schakel. De gebreken aan onze democratie zijn sinds de jaren zeventig zeker niet minder geworden. De grote meerderheid van de burgers voelt zich ook vandaag politiek buiten spel staan. De massale werk- 
loosheid heeft in ons land de politieke problemen veel groter gemaakt dan deze in het begin van de jaren zeventig al waren. De financièle middelen van de overheid zijn beperkt. Het verdelen van armoede is pijnlijker dan het verdelen welvaart. Juist daarom moeten burgers reële en (dus) gelijke kansen hebben, om hun standpunten te formuleren en de overheid daarvoor te winnen. Inspraak is daarom een burgerrecht. En ook in mijn opvatting behoort bij inspraak de mogelijkheid voor burgers, on met hulp van deskundigen alternatieve plannen of voorstellen te ontwikkelen. Of men inspraak nu een aanvulling op de representatie-democratie wil noemen, danwel een stap op weg naar een participatie-democratie, vind ik van minder belang. Als men zich maar realiseert, dat in een moderne samenleving democratie zonder inspraak niet meer mogelijk is. ${ }^{317}$

Van Thijn's pleidooi voor bestuurlijke decentralisatie tot eenheden van minder dan twintigduizend mensen, en inspraakprocedures voor grotere eenheden spreekt mij minder aan. Bestuurlijke decentralisatie kan het bestuur wel dichter bij de burger brengen. Maar dat betekent nog niet, dat die burger ook aan het bestuur gaat deelnemen.

Inspraak kent dus twee belangrijke kenmerken. Er moet sprake zijn van overleg. En allen, die met het te nemen besluit te maken zullen krijgen, moeten in dat overleg een eerlijke, en dus min of meer gelijke kans hebben, om het bestuur voor hun standpunt te winnen. Overleg is een juridisch toetsbaar begrip. ${ }^{318}$ Een bestuur dat inspraak geeft, moet aannemelijk kunnen maken, dat het de wil heeft om te overleggen. Dat zal bijvoorbeeld niet het geval zijn, als het bestuur, zonder dat daar een dwingende reden voor is, de betrokkenen pas in een zo laat stadium benadert, dat er alleen nog maar over details te overleggen valt. Ook is er geen sprake van een wil tot overleg, als het bestuur het overleg overlaat aan ambtenaren, die eigenlijk geen mandaat hebben om met de betrokkenen tot overlegresultaten te komen. Een inspraakbijeenkomst die door ambtenaren wordt afgesloten met de opmerking: "Wij hebben uw wensen en bezwaren genoteerd, en zullen die voorleggen aan het bestuur", kan men geen overleg, en dus

317 Over inspraak en de wenselijkheid daarvan heb ik uitwoeriger geschreven in Inspraak volgens nieuwe wetten, NJB 1990, pag. 1064 e.v.

318 Dat blijkt o.m. ook uit de jurisprudentie wan de ondernemingskamer wan het gerechtshof te Amsterdam, die regelmatig toetst of er wel overleg is gevoerd in de zin van de artt. $23 \mathrm{t} / \mathrm{m} 24$ van de Wet op de ondernemingsraden. 
ook geen inspraak noemen. Inspraak is dus meer dan wat in het bestuursrecht onder preventieve rechtsbescherming wordt verstaan. ${ }^{319}$

Inspraak betekent overleg met zo mogelijk alle betrokkenen. Dus niet alleen met assertieve ondernemers, zakenlieden, vakbondsonderhandelaars en andere belangenbehartigers. Die weten ook zonder inspraak wel hun weg naar de overheid te vinden. Inspraak geeft juist compensatie tegen dergelijke eenzijdige belangenbehartiging. Allen, die met het bestuurlijke besluit te maken zullen krijgen, moeten voor overleg worden uitgenodigd. Dat overleg hoeft niet met allen of met alle groepen tegelijk plaats te vinden. Maar het moet aan iedereen en aan elke groep wel een eerlijke, en dus min of meer gelijke kans bieden, om de inhoud van het te nemen besluit te beïnvloeden. Dat betekent onder meer, dat het overleg, hoewel niet gelijktijdig, voor alle betrokkenen toch wel in dezelfde fase of fasen van de besluitvorming moet plaatsvinden. Daarnaast kan het geven van eerlijke, gelijke kansen met zich meebrengen, dat aan bepaalde betrokkenen ondersteuning moet worden gegeven, die het mogelijk maakt dat zij zich als groep organiseren en hun belangen vertalen in een realiseerbaar voorstel.

Ook als voor sommige betrokkenen grotere belangen op het spel staan dan voor anderen, moet de kans om het bestuur te overtuigen, voor allen in principe gelijk zijn. Bij de beslissing van dat bestuur moet immers niet het grootste particuliere belang het zwaarst wegen, maar het algemeen belang. Dat kan zelfs een belang zijn, dat overheid en burgers alleen maar geld kost, bijvoorbeeld natuurbehoud, of dierenbescherming.

In de volgende twee paragrafen zal ik beschrijven welke inspraakrechten de burger volgens de geldende wetgeving heeft. Daartoe onderwerp ik de Gemeentewet, de Provinciewet, de Waterschapswet, enkele op die wetten gebaseerde model-inspraakverordeningen, en tenslotte de Algemene wet bestuursrecht aan een nader onderzoek. Ik waarschuw alvast, dat dat niet veel positiefs zal opleveren. In de daaropvolgende paragraaf zal ik een aantal inspraaknormen formuleren. En in de slotparagraaf van dit hoofdstuk zal ik enkele mogelijkheden voor inspraak uitwerken, en voorstellen doen om die een wettelijke basis te geven.

319 Men spreekt van 'preventieve' of 'non contentieuse' rechtsbescherming, als een bestuursorgaan belanghebbenden de gelegenheid geeft hun zienswijze naar voren te brengen woordat het een besluit heeft genomen. Dat hoeft echter niet te betekenen dat er overleg plaatsvindt. Tot in de zeventiger jaren werd in veel planningsschema's van de overheid tijd ingeruimd voor wat men "het weerleggen van de bezwaren" noemde. 


\section{Inspraakregels voor gemeenten, provincies, en waterschapen}

\section{Inspraak volgens de Gemeentewet en de Provinciewet}

Volgens artikel 150 van de Gemeentewet moet de gemeenteraad een verordening vaststellen, met regels over "de wijze waarop ingezetenen en in de gemeente een belang hebbende natuurlijke en rechtspersonen bij de voorbereiding van gemeentelijk beleid worden betrokken". Deze bepaling is ingevoerd per 1 januari 1994, in het kader van de algehele herziening van de Gemeentewet. Ze verplicht gemeenteraden om een algemene inspraakverordening vast te stellen. Artikel 150 noemt geen onderwerpen waarover inspraak moet worden gegeven. Wel bepaalt het tweede lid, dat in de verordening ten minste wordt geregeld:

a. de wijze waarop van de beleidswoornemens waarop inspraak zal worden verleend, openbaar wordt kennisgegeven;

$b$. de wijze waarop ingezetenen en in de gemeente een belang hebbende natuurlijke en rechtspersonen in staat worden gesteld hun mening omtrent de onder a. bedoelde beleidsvoornemens kenbaar te maken;

$c$. de rapportering van de onder $b$. bedoelde inspraak en over de uitkomsten daarvan;

d. de wijze waarop ingezetenen en in de gemeente een belang hebbende natuurlijke en rechtspersonen in de gelegenheid worden gesteld hun beklag te doen over de uitvoering van de verordening.

De Gemeentewet bepaalt dus niet, dat gemeenten inspraak moeten geven, maar dat er in iedere gemeente een inspraakverordening moet zijn, die eisen stelt waaraan een inspraakprocedure moet voldoen. Ook moet de verordening een beklagprocedure geven; niet voor klachten over gebrek aan inspraak, maar voor klachten "over de uitvoering van de verordening". Volgens artikel 301 van de Gemeentewet moet elke gemeenteraad binnen een jaar na de inwerkingtreding van de wet, dus vóór 1 januari 1995, zo'n algemene inspraakverordening hebben vastgesteld.

De Provinciewet kent sinds 1 januari 1994 in artikel 147 vrijwel letterlijk dezelfde bepaling. Alleen moet men dan lezen: provinciale staten stellen een verordening vast, in plaats van: de raad stelt een verordening vast. En dan uiteraard voor de provincie. Ook provinciebesturen moeten, zo bepaalt artikel 288 van de Provinciewet, vóór 1 januari 1995 een algemene inspraakverordening hebben vastgesteld.

Vóór de invoering van artikel 150 Gemeentewet was inspraak al wettelijk voorgeschreven bij voorbereiding van gemeentelijk beleid inzake stads- 
vernieuwing, en van ruimtelijke plannen of herziening daarvan. Artikel 8 van de Wet op de stads- en dorpsvernieuwing en artikel 6 a van de Wet op de Ruimtelijke Ordening, die dat bepalen, zijn halverwege de jaren tachtig ingevoerd. Oorspronkelijk was het de bedoeling, dat deze artikelen zouden vervallen op het moment, dat artikel 150 van de Gemeentewet van kracht zou worden. Ik heb er in 1990 voor gewaarschuwd, dat het recht op inspraak bij de voorbereiding van stadsvernieuwing en ruimtelijke plannen dan zou komen te vervallen, want artikel 150 geeft geen recht op inspraak. ${ }^{320}$ Gelukkig hebben regering en Staten-Generaal dat ook tijdig ingezien. Bij de Invoeringswet Gemeentewet (Stb. 1993, 610) zijn artikel 8 van de Wet op de stads- en dorpsvernieuwing en artikel 6 a van de Wet op de Ruimtelijke Ordening niet geschrapt, maar opnieuw geredigeerd. Het recht op inspraak is daarin gehandhaafd gebleven, maar de wijze waarop die inspraak gestalte moet krijgen, wordt vanaf 1 januari 1995 bepaald door de op de Gemeentewet gebaseerde algemene inspraakverordening.

Toch is een kenmerk van inspraak nu onder de nieuwe wetgeving verdwenen. In het tweede lid van artikel 150 , onder $b$, is bepaald dat de algemene inspraakverordening de wijze moet regelen, waarop ingezetenen en belanghebbenden in staat worden gesteld hun mening omtrent beleidsvoornemens kenbaar te maken. Artikel 8 van de Wet op de stads- en dorpsvernieuwing en artikel 6a van de Wet op de Ruimtelijke Ordening gingen een stap verder. Deze artikelen schreven voor, dat de inspraakverordening de wijze moest regelen, waarop ingezetenen en belanghebbenden in staat. worden gesteld hun mening omtrent de aan de orde gestelde beleidsvoornemens kenbaar te maken en daarover met het gemeentebestuur van gedachten te wisselen. Volgens de beide artikelen verdiende inspraak dus pas die naam, als er een gedachtenwisseling tussen de insprekers en het bestuur plaatsvond. Maar zo'n gedachtenwisseling werd door de opstellers van de nieuwe Gemeentewet niet meer nodig gevonden. In de memorie van toelichting schreven zij: "Het staat de gemeente overigens vrij te regelen dat in bepaaide gevallen met bepaalde categorieën van inspraakgerechtigden ook van gedachten wordt gewisseld". ${ }^{321}$ Die opvatting van inspraak is dus beperkter dan de opvatting die eerder was neergelegd in de Wet op de stads- en dorpsvernieuwing en in de Wet op de ruintelijke ordening.

Wel moest volgens het voorstel voor de nieuwe Gemeentewet in de inspraakverordening de wijze worden geregeld "waarop met in de gemeente werkzame instellingen en organisaties die taken vervullen bij de

320 Zie Inspraak volgens nieuwe wetten, NJB 1990, pag. 1069.

321 TK 1985-1986, 19403 (Gemeentewet), nr. 3 pag. 134. 
uitvoering van gemeentelijk beleid overleg (curs. van mij) wordt gevoerd over beleidsvoornemens die hierop betrekking hebben". Bepaalde instellingen en organisaties zouden dus bijzondere inspraakrechten krijgen. Zo was het in artikel 151, tweede lid, onder c, geformuleerd. Daardoor zouden er wettelijk twee soorten insprekers ontstaan: eersterangs insprekers, dat wil zeggen insprekers waar het bestuur overleg mee moest voeren, en tweederangs insprekers, die alleen maar het recht hadden om hun mening kenbaar te maken. In de loop van de parlementaire behandeling is eerste soort gesneuveld door schrapping van de c-bepaling. Alleen de tweederangs insprekers zijn overgebleven. Dat is niet iets om vrolijk van te worden. Maar het is zo wel eerlijker.

\section{De model-inspraakverordening van de VNG}

Vooruitlopend op de invoering van de nieuwe Gemeentewet heeft de VNG in 1993 een aantal model-verordeningen opgesteld of opnieuw geredigeerd, om de gemeenten te helpen an de verplichtingen van de nieuwe wet te voldoen. Daaronder bevindt zich ook een model-inspraakverordening, die hier enige aandacht verdient. ${ }^{322}$

Het model is een bewerking van de voorbeeld-inspraakverordening, die de VNG in 1984 heeft uitgebracht naar aanleiding de invoering van de Wet op de stads-en dorpsvernieuwing. Dat heeft in elk geval één gunstige consequentie: De ruimere opvatting van het begrip inspraak, die in die wet was uitgewerkt, is nu overgenomen in de model-inspraakverordening van de VNG. Inspraak wordt daar in artikel 1 gedefinieerd als: het ten aanzien van gemeentelijke beleidsvoornemens kenbaar maken van een zienswijze en daarover van gedachten wisselen (curs. van mij). Met wie van gedachten te wisselen, staat er niet bij. Maar uit de toelichting bij de verordening blijkt, dat daarmee een gedachtenwisseling "met het bestuursorgaan" wordt bedoeld. Ik kom daar zo dadelijk nog op terug.

Inspraak, zo zegt artikel 2, wordt in elk geval verleend "op beleidsvoornemens betreffende:

a. de voorbereiding of de herziening van ruimtelijke plannen;

$b$. de stads-of dorpsvernieuwing;

c. de voorbereiding van het gemeentelijk milieubeleidsplan;

d. de welzijnsvoorzieningen".

322 Zie over het verzet van de VNG tegen de wettelijke verplichting een inspraakverordening wast te stellen, mijn eerder genoemde bijdrage in NJB 1990 (pag. 10681069). De model-inspraakverordening is bij de VNG op floppy verkrijgbaar. Ik maak hier gebruik van de print, die de VNG mij welwillend heeft toeggezonden. 
Aan de gemeentebesturen zelf wordt overgelaten, om dit rijtje verder aan te vullen. Maar ze mogen het natuurlijk ook inkorten, want het VNGmodel is slechts een model-verordening. Alleen wat onder $a$. en $b$. is gerangschikt, is wettelijk verplicht, op grond van resp. de Wet op de Ruimtelijke Ordening en de Wet op de stads- en dorpsvernieuwing. Positief is te waarderen, dat de VNG in haar model ook de voorbereiding van een milieubeleidsplan en de welzijnswoorzieningen noemt.

Artikel 4 van de model-verordening verklaart op inspraakprocedures de afdeling 3.4 van de Algemene wet bestuursrecht van overeenkomstige toepassing. Dat betekent onder meer, dat een belleidsvoornemen waarover inspraak wordt gegeven, mimimaal vier weken ter inzage moet worden gelegd, en dat de insprekers gedurende diezelfde periode, of nog langer, op dat voornemen moeten kunnen reageren. Artikel 5 van de model-verordening schrijft voor, dat burgemeester en wethouders voor elk beleidsvoornemen, waarop inspraak wordt verleend, een inspraakprocedure moeten vaststellen. Die procedure moet een omschrijving geven van de wijze waarop inspraak wordt verleend, termijnen stellen, en een omschrijving geven van de mate waarin en de voorwaarden waaronder de insprekers invloed op het beleidsvoornemen kunnen uitoefenen. In de toelichting bij artikel 5 wordt benadrukt dat, op grond van de in artikel 1 gegeven definitie, inspraak de gelegenheid moet bieden "met het bestuursorgaan van gedachten te wisselen" (pag. 231). Artikel 7 bepaalt tenslotte, dat burgemeester en wethouders moeten zorgen, dat van een gevolgde inspraakprocedure een "eindverslag" wordt opgemaakt. Dat verslag moet in ieder geval een overzicht van de gevolgde procedure bevatten, en "een weergave van de zienswijzen die tijdens de inspraak mondeling of schriftelijk naar voren zijn gebracht". Ook mag een "reactie op deze zienswijzen" niet ontbreken, "waarbij met redenen omkleed wordt aangegeven op welke punten al dan niet tot aanpassing van het beleidsvoornemen zou kunnen worden overgegaan".

Al met al mag men stellen, dat uit de model-verordening van de VNG een ruimhartiger opvatting over inspraak spreekt dan uit de formele wetten. Een inspraakprocedure bevat volgens de verordening altijd een gedachtenwisseling met het bestuursorgaan. En ze schrijft ook inspraak voor bij het gemeentelijk milieubeleidsplan en bij beleidsvoornemens voor welzijnsvoorzieningen. Als alle gemeenten het VNG-model als algemene inspraakverordening vaststellen, dan krijgt de burger meer inspraakrechten dan de wet hem toekent. Toch wil ik hier een paar kanttekeningen plaatsen. De eerste betreft de term gedachtenwisseling. Een tweede kanttekening betreft de in de verordening geregelde beklagprocedure. 


\section{'Gedachtenwisseling'}

Volgens de dikke Van Dale betekent dit woord: "uitwisseling van gedachten of meningen over een onderwerp, behandeling van een onderwerp door twee of meer personen die elkaar hun gedachten erover mondeling of schriftelijk mededelen, discussie". Het is dus iets anders dan overleg. Overleg ga je aan met de intentie om het met anderen ergens over eens te worden, om een consensus te bereiken. Een gedachtenwisseling kan ook plaatsvinden zonder die intentie. Men wil over en weer, in rechtstreeks contact met elkaar, de eigen standpunten verduidelijken. Er hoeft geen andere drijfveer te zijn dan zelfrechtvaardiging, begrip vragen voor het ingenomen standpunt, of in het gunstigste geval, de wederpartij overtuigen. Hoewel het begrip inspraak, zoals de VNG dat hanteert, dus ruimhartiger is dan dat van de formele wetgever, is het mij nog te beperkt. In mijn opvatting moet inspraak gericht zijn op het bereiken van een consensus, althans van een zo groot mogelijke consensus, tussen bestuur en burgers. Die bereikt men niet als er geen overleg wordt gevoerd.

De gedachtenwisseling moet volgens de toelichting bij artikel 5 van de model-verordening plaatsvinden met "het bestuursorgaan" (pag. 231). De Gemeentewet kent de term bestuursorgaan niet, maar gebruikt het woord gemeentebestuur. Daaronder moet volgens artikel 5 van de wet worden verstaan: "ieder bevoegd orgaan van de gemeente". Men kan daarbij denken aan de gemeenteraad, het college van burgemeester en wethouders, de burgemeester, en bestuurscommissies. Volgens artikel 1:1, lid 1, sub b, van de Algemene wet bestuursrecht is ook bestuursorgaan: "een persoon of college, met enig openbaar gezag bekleed". Dat kan dus bijvoorbeeld een ambtenaar zijn, aan wie een bevoegdheid is gedelegeerd om bepaalde bestuurlijke beslissingen te nemen.

Een gedachtenwisseling kan, aldus de Van Dale, mondeling of schriftelijk plaatsvinden. In beide gevallen dringt de vraag zich op, of de gedachtenwisseling altijd moet plaatsvinden met het beslissingsbevoegde orgaan. In principe wel, dunkt me. Maar als dat orgaan de gemeenteraad. is, of het college van burgemeester en wethouders, dan zal een mondelinge gedachtenwisseling meestal niet met alle leden van dat orgaan kunnen plaatshebben. In mijn opvatting kan de gemeenteraad zich dan laten vertegenwoordigen door een raadscommissie of door het college van burgemeester en wethouders. Dat laatste zal niet vaak gebeuren, omdat het voltallige college doorgaans alleen in het openbaar verschijnt als de gemeenteraad zelf ook bijeen is. Is het college van burgemeester en wethouders zelf het beslissingsbevoegde orgaan, dan kan het college zich laten vertegenwoordigen door een of meer leden die als portefeuillehouder bij het te nemen besluit zijn betrokken. Naar mijn mening mag het college de 
gedachtenwisseling niet zomaar overlaten aan woordvoerders die zelf geen lid van het college zijn. Dat is alleen toelaatbaar voorzover die woordvoerders een inhoudelijke inbreng in de beleidswoorbereiding hebben, als ambtelijke of externe deskundigen. Maar over de bestuurlijke voorwaarden, die deze deskundigen bij hun beleidsvoorbereidende taak meekrijgen, zullen een of meer leden uit het college zelf met de insprekers van gedachten moeten wisselen.

\section{Beklagprocedure"}

Mijn tweede kanttekening bij de model-verordening betreft de beklagprocedure. Artikel 8 van het model geeft ingezetenen en belanghebbenden het recht om over de wijze van uitvoering van de verordening en de inspraakprocedure bij burgemeester en wethouders een schriftelijke klacht in te dienen. Dat dient uiterlijk vier weken na afloop van de inspraakprocedure te geschieden. Burgemeester en wethouders moeten dan binnen vier weken over de klacht beslissen, en die beslissing onmiddellijk ter kennis brengen van de klager en de gemeenteraad. De beslistermijn mag met ten hoogste vier weken worden verdaagd.

Als de inspraak die wordt gegeven, gebrekkig is, dan moet een klacht uiterlijk vier weken na afloop van de inspraakprocedure worden ingediend: Hoe zit het nu, als er geen inspraak wordt gegeven, terwijl dat volgens de wet of volgens de inspraakverordening wel zou moeten? Het antwoord op deze vraag zal ik toelichten aan de hand van enkele uitspraken van de Afdeling rechtspraak van de Raad van State, die ook nu nog betekenis hebben.

De eerste uitspraak betreft de gemeente Rossum. Enkele ingezetenen van deze gemeente hadden op 26 en 28 juni 1989 , op grond van artikel 8 van de Algemene inspraakverordening, bij burgemeester en wethouders een klacht ingediend, omdat er geen inspraak was verleend op het beleidsvoornemen tot herziening van een bestemmingsplan. Nadat burgemeester en wethouders deze klachten ongegrond hadden verklaard, dienden de klagers bij dit college een bezwaarschrift in, dat uiteindelijk door de Afdeling rechtspraak werd aangemerkt als een tijdig bij deze Afdeling ingekomen 'beroepschrift'. Toch leverde dat voor de appellanten niets op. De Afdeling stelde vast, dat al op 10 november 1988 de ter inzage legging van het ontwerp-bestemmingsplan was gepubliceerd, en concludeerde, dat burgemeester en wethouders de appellanten niet in hun klachten van 26 en 28 juni 1989 ontvankelijk hadden mogen verklaren. De appellanten hadden immers al op 10 november 1988 kunnen weten, dat 'besloten' was, om geen inspraak over het beleidsvoornemen tot de herziening van bestem- 
mingsplan te geven. Vanaf dat moment was hun klachttermijn ingegaan. ${ }^{323}$

In een annotatie onder deze uitspraak merkt Van Buuren op, dat dat de rechter hier impliciet de gedachte verwerpt, dat aan het wettelijk vereiste van inspraak kan worden voldaan door het ontwerp-bestemmingsplan formeel ter inzage te leggen. Immers, wordt het ontwerp-plan ter inzage gelegd, als bedoeld in artikel 23 Wet op de Ruimtelijke Ordening, dan mag de burger concluderen, dat er geen inspraak zal plaatsvinden. Inspraak is dus ook in de ogen van de rechter kennelijk iets anders dan een bezwarenprocedure tegen een ontwerp-besluit.

Verder legt Van Buuren uit, dat de uitspraak van de Afdeling ook van betekenis is voor een juiste toepassing van de Algemene wet bestuursrecht. Beklagprocedures tegen het niet-verlenen van wettelijk voorgeschreven inspraak zijn bezwaarschriftprocedures in de zin van artikel 1:5 lid 1 Algemene wet bestuursrecht. Ingevolge artikel $7: 1$ lid 1 juncto artikel 8:1 lid 1 van deze wet staat van de beslissing op een dergelijke procedure rechtstreeks beroep open op de rechtbank. Ik onderschrijf dit standpunt van Van Buuren. Wel wil ik daarbij opmerken, dat de beklagtermijn van vier weken, die in de model-inspraakverordening wordt genoemd, dan in strijd is met de Algemene wet bestuursrecht. Want die geeft in artikel 6:7 een termijn van zes weken.

Eerder had de Afdeling rechtspraak in een zaak, die in de gemeente Boskoop speelde, uitgesproken, dat niet alle besluiten in het kader van een wettelijke inspraakprocedure vatbaar zijn voor bezwaar of beroep. Besluiten "betreffende hetgeen object van inspraak in de zin van de wet is, danwel wie subject is van inspraak" zijn altijd concreet, en gericht op een rechtsgevolg, aldus de Afdeling. Maar "besluiten en (andere) handelingen casu quo nalaten ter uitvoering van een inspraakverordening- of procedure" zouden zijn aan te merken als besluiten van algemene strekking, danwel niet gericht op rechtsgevolg, en daarom ook niet vatbaar voor bezwaar of beroep in de zin van de Wet Arob. ${ }^{324}$ Dat is naar mijn mening echter een verkeerde opvatting. Het door de wet of de inspraakverordening toegekende recht wordt ingevuld door de toepassing van een inspraakprocedure. Als die invulling gebrekkig is, wordt de burger gekortwiekt in zijn recht op inspraak. Daarover moet hij zijn beklag kunnen doen bij een administratieve rechter. Nu de Wet Arob is ingetrokken, zal de Algemene wet bestuursrecht daartoe de mogelijkheid moeten geven.

323 AR 10 december 1992, AB 1994, 82, m.n.y. P. van Buuren.

324 AR 27 juli 1991, m.n.v. J. Teunissen. Gemeentestem no. 6940, pag. 169-174. 
Al met al wordt van burgers, die inspraak wensen, een hele grote alertheid verwacht. $\mathrm{Zij}$ moeten uit bepaalde handelingen van het gemeentebestuur, zoals bijvoorbeeid het formeel ter inzage leggen van een ontwerp-bestemmingsplan, zelf maar conchuderen, dat er dus geen inspraak is gegeven. Dan begint de termijn te lopen, waarbinnen een schriftelijke klacht kan worden ingediend. Die alertheid is des te meer geboden, omdat het niet indienen van een inspraakklacht ook consequenties kan hebben, als men bezwaar maakt tegen de inhoud van besluiten die zonder inspraak of zonder voldoende inspraak tot stand zijn gekomen. Ja, zelfs als men bezwaar maakt tegen besluiten die daar weer een vervolg op zijn. Dat werd door de Afdeling rechtspraak met zoveel woorden kenbaar gemaakt in de zojuist genoemde uitspraak over vrijstellingen voor bouwplannen in de gemeente Boskoop. Aan de vrijstellingen was een besluit tot voorbereiding van een nieuw bestemmingsplan voorafgegaan. Omdat de appellanten ook een inspraakklacht hadden ingediend tegen het voorbereidingsbesluit, was de Afdeling bereid om het beweerde gebrek aan inspraak bij de vrijstellingen in haar beoordeling te betrekken.

\section{Inspraak bij waterschappen}

Artikel 79 van de op 1 januari 1992 in werking getreden Waterschapswet bepaalt, dat het algemeen bestuur van een waterschap een inspraakverordening moet vaststellen. Dat wil zeggen: een verordening "waarin wordt geregeld op welke wijze ingezetenen en in het gebied van het waterschap belanghebbende natuurlijke en rechtspersonen bij de voorbereiding van de door dat bestuur (lees: door het algemeen bestuur, HK) te nemen besluiten worden betrokken". Het tweede lid van artikel 79 noemt de besluiten waarover in elk geval inspraak moet worden gegeven:
a. verordeningen, met uitzondering van belastingverordeningen;
b. de handhaving van de waterstanden;
c. de aanleg of verbetering van waterstaatswerken, tenzij het werken betreft waarvan naar het oordeel van het waterschapsbestuur niet in betekenende mate een wijziging van de bestaande waterstaatkundige situatie of van de hoogie van de te heffen omslagen is te verwachten; d. de legger.

Volgens het derde lid van het artikel moet de verordening in elk geval de wijze regelen waarop ontwerp-besluiten worden bekendgemaakt, en waarop ingezetenen en belanghebbenden hun mening daarover kenbaar kunnen maken. Ook moet de verplichting tot rapportering over de inspraak en de uitkomsten daarvan geregeld worden, en de wijze waarop belanghebbenden 
in de gelegenheid worden gesteld om over de uitvoering van de verordening beklag te doen.

Men ziet, de tekst van artikel 79 is grotendeels identiek aan die van artikel 150 van de Gemeentewet en artikel 147 van de Provinciewet. Er zijn twee opvallende verschillen. Ten eerste hoeft de inspraakverordening slechts betrekking te hebben op besluiten van het algemeen bestuur van het waterschap. Voor besluiten van het dagelijks bestuur is inspraak dus nooit wettelijk verplicht. Een tweede verschil is, dat artikel 79 een opsomming geeft van besluiten waarover in elk geval inspraak moet worden gegeven. Op aandringen van de fracties van CDA, VVD en SGP in de Tweede Kamer is die opsomming, die in het oorspronkelijke wetswoorstel toch al niet overdadig was, in de loop van de parlementaire behandeling verder ingeperkt tot de hierboven aangehaalde tekst. ${ }^{325}$

Om te bevorderen dat de waterschappen in Nederland zouden voldoen aan de wettelijke inspraakplichten, heeft de Unie van Waterschappen in 1990 een model-inspraakverordening gepubliceerd. ${ }^{326} \mathrm{Het}$ is een korte verordening, waar ik dan ook een korte bespreking aan will wijden.

Artikel 1 van de verordening definieert inspraak als: een door of namens het dagelijks bestuur geboden gelegenheid voor ingezetenen en in het gebied van het waterschap belang hebbende natuurlijke en rechtspersonen om hun mening omtrent te nemen besluiten van het waterschap kenbaar te maken.

Dat is een beetje merkwaardig. Want artikel 2 van de verordening bepaalt, in het voetspoor van artikel 79 van de Waterschapswet, dat de verordening betrekking heeft op door het algemeen bestuur te nemen besluiten. Inspraak bij die besluiten wordt dus verleend door een ander orgaan, dan het orgaan dat de besluiten moet nemen. In de praktijk zal dat niet veel problemen opleveren, want de verordening eist niet, dat er bij inspraak een 'gedachtenwisseling' tussen de insprekers en het beslissingsbevoegde bestuursorgaan plaatsvindt. Inspraak is beperkt tot het geven van gelegenheid om een mening kenbaar te maken. Toch is het, staatsrechtelijk gezien, niet helemaal in de haak, als het algemeen bestuur van een waterschap niet rechtstreeks kan worden aangesproken, op inspraakverlening bij zijn besluitvorming

325 Verg. TK 1986-1987, 19995, nrs. 1-2, pag. 20, TK 1987-1988, 19995, nr. 5 (VV), pag. 39-40, en TK 1988-1989, 19995, nr. 6 (MvA), pag. 47-48.

326 Unie van Waterschappen, Model-inspraakverordening, Den Haag 1990. 
Hoe de insprekers hun mening kenbaar kunnen maken, is uitgewerkt in de artikelen 3 tot en met 6 van de verordening. Een ontwerp-besluit wordt gedurende ten minste vier weken ter inzage gelegd op het kantoor van het waterschap, en op de gemeentehuizen in het gebied waarop dat besluit betrekking heeft. Die ter inzage legging wordt in elk geval bekendgemaakt in daarvoor in aanmerking komende dag-, week- en huis aan huis-bladen. Ingezetenen en belanghebbenden kunnen gedurende de ter inzage legging hun gemotiveerde opvatting schriftelijk kenbaar maken aan het dagellijks bestuur. En degenen, die daarom in hun schriftelijke reactie hebben verzocht, worden door dat bestuur in de gelegenheid gesteld hun reactie mondeling toe te lichten, "tenzij een dergelijk verzoek kennelijk onredelijk is". Artikel 7 van de verordening legt ten slotte vast, hoe een inspraakprocedure wordt afgesloten: "In het voorstel aan het algemeen bestuur wordt melding gemaakt van de gehouden inspraakprocedure en de beschouwingen van het dagelijks bestuur over de in het kader daarvan ingekomen reacties".

Artikel 8 geeft een beklagprocedure. Een klacht tegen het niet verlenen van inspraak moet, zo luidt de bepaling, wórden ingediend "uiterlijk veertien dagen na het moment waarop klager redelijkerwijs kan weten dat hem geen inspraak is verleend". Voor een klacht tegen de uitvoering van een inspraakprocedure is de termijn ook veertien dagen, maar dan na afloop van de ter inzage legging, of na de mondelinge toelichting van de reactie bij het dagelijks bestuur, danwel na de afwijzing van een verzoek om de reactie te mogen toelichten. Een positief te waarderen element in de beklagprocedure is het feit, dat het dagelijks bestuur een door het algemeen bestuur ingestelde commissie moet horen, voordat over de klacht een beslissing mag worden genomen. Maar wat ik eerder heb opgemerkt ten aanzien van de klachttermijn in de model-verordening van de VNG, geldt ook hier: de termijn zou, conform artikel 6:7 van de Algemene wet bestuursrecht zes, weken moeten zijn

Zou men verwachten, dat artikel 8 de laatste bepaling van de verordening is, dan volgt voor inspraakbevorderaars nog een aangename verassing: De artikelen 9,10 en 11 , waarin de verordening ook van toepassing wordt verklaard op "de door het dagelijks bestuur (curs. van mij) te nemen besluiten voorzover die daarvoor naar het oordeel van het dagelijks bestuur in aanmerking komen, inzake: [..]". De model-verordening laat de invulling verder over aan de afzonderlijke waterschappen. Maar in de toelichting worden als voorbeelden genoemd "besluiten die genomen worden op basis van door het algemeen bestuur aan het dagelijks bestuur gedelegeerde bevoegdheden, alsmede besluiten inzake het al dan niet verlenen van 
vergunningen". Dit laatste voorzover daarbij al niet in bijzondere wetten een inspraakprocedure is voorgeschreven.

\section{Inspraak volgens de Algemene wet bestuursrecht}

Sinds 1 januari 1994 geldt in ons land de Algemene wet bestuursrecht. Deze wet geeft op verschillende plaatsen regels, die bepalen hoe besluiten moeten worden voorbereid, en hoe bestuursorganen daarbij de mening van belanghebbenden moeten inwinnen. Velen zien daarin een soort inspraakregels. ${ }^{327}$ In deze paragraaf wil ik duidelijk maken, waarom dat eigenlijk niet juist is. Zoals we nog zullen zien, verplichten de procedures van de Algemene wet bestuursrecht nergens tot overleg tussen bestuursorganen en burgers. Wel worden burgers in een aantal gevallen in de gelegenheid gesteld om een zienswijze of bedenkingen naar voren te brengen, en soms ook om een gedachtenwisseling te hebben. Maar meestal wordt de gelegenheid daartoe pas gegeven op het moment dat het tot beslissen bevoegde bestuursorgaan zelf al een ontwerp-besluit ter inzage heeft gelegd, dus zelf al een standpunt heeft ingenomen over wat het algemeen belang in de concrete situatie eist. De procedures zijn op een enkele nog te bespreken uitzondering na, dus alleen maar "bedenkingen"-procedures tegen kant en klare ontwerp-besluiten. Inspraak hoort eigenlijk aan dergelijke bedenkingen-procedures vooraf te gaan. Zoals we in de vorige paragraaf hebben gezien, heeft de Afdeling rechtspraak dat ook uitdrukkelijk in 1992 uitgesproken in een geschil dat in de gemeente Rossum speelde.

Van de Algemene wet bestuursrecht wil ik de procedureregels bespreken die inspraakmogelijkheden lijken te bieden. Dat zijn achtereenvolgens de regels die in acht moeten worden genomen bij de voorbereiding van beschikkingen, de regels van de openbare voorbereidingsprocedure, en de regels van de uitgebreide openbare voorbereidingsprocedure. Bij al deze regels valt op, dat deelneming aan de procedures beperkt wordt of beperkt kan worden tot belanghebbenden. Dat zijn, in de definitie van artikel $1: 2$ van de wet: degenen die belangen hebben, die rechtstreeks bij het te nemen of genomen besluit van het bestuursorgaan zijn betrokken. Als het rechtspersonen zijn, tellen ook de algemene en collectieve belangen mee "die zij krachtens hun doelstellingen en feitelijke werkzaamheden in het bijzonder behartigen". Op grond van deze formulering kunnen bijvoorbeeld consu-

327 Zo bijwoorbeeld Van Wijk/Konijnenbelt, Hoofdstukken wan administratief recht, Utrecht 1993, pag. 53, waar gesproken wordt over "een betrekkelijk sober gehouden inspraakprocedure"'. 
menten- of milieuorganisaties in de bres springen voor consumentenbelangen of voor milieubelangen. De inspraakregels van de Gemeentewet, de Provinciewet en de Waterschapswet zijn gericht tot een ruimer gedefinieerde groep, nl. ingezetenen en in resp. de gemeente, de provincie of het waterschap een belang hebbende natuurlijke en rechtspersonen. In deze wetten klinkt dus door, dat inspraak ook een staatsrechtelijke dimensie heeft. Burgers mogen met inspraak meedoen als ze ingezetenen' zijn. De Algemene wet bestuursrecht richt zich daarentegen in de eerste plaats tot 'belanghebbenden', en laat steeds toe, dat anderen dan belanghebbenden van procedures worden uitgesloten. Alleen al daarom kan men zeggen, dat de Algemene wet bestuursrecht de inspraakregels van de andere wetten niet overbodig heeft gemaakt, hoewel dat bij de behandeling van de Invoeringswet Gemeentewet door sommige leden van de Tweede kamer wel werd gesuggereerd. ${ }^{328}$

Voordat ik de drie zojuist door mij genoemde procedures ga beschrijven, moet ik eerst onderscheid maken tussen besluiten, beschikkingen, en andere handelingen van bestuursorganen. Volgens artikel 1:3 van de Algemene wet bestuursrecht moet onder besliut worden verstaan: een schriftelijke beslissing van een bestuursorgaan, inhoudende een publiekrechtelijke rechtshandeling. Een voorbeeld van een besluit is een bestemmingsplan. Een beschikking is volgens datzelfde artikel 1:3 een besluit dat niet van algemene strekking is, met inbegrip van de afwijzing van een aanvraag daarvan. Voorbeelden van beschikkingen zijn vergunningen, subsidie-toewijzingen en subsidie-afwijzingen. Over andere handelingen van bestuursorganen bepaalt de Algemene wet bestuursrecht dat haar voorschriften over de voorbereiding en de bekendmaking van besluiten van overeenkomstige toepassing zijn voor zover de aard van de handelingen zich daartegen niet verzet. Dit lezen we in het tweede lid van artikel 3:1. "Andere handelingen" van bestuursorganen zijn andere rechtshandelingen, zoals het sluiten van een koopovereenkomst, of feitelijke handelingen, zoals het aanleggen van een verkeersdrempel.

De voorbereiding van beschikkingen

De afdelingen 4.1.1 en 4.1.2 van de Algemene wet bestuursrecht geven in de artikelen 4:1 tot en met 4:12 regels voor de voorbereiding van beschikkingen. Artikel 4:7 bepaalt wanneer een bestuursorgaan, dat een aanvraag

328 Door Van den Berg (SGP) en Schutte (GPV). Mevr. Scheltema-De Nie (D66) drong toen aan op afstemming tussen de Awb en de Gemeentewet. Zie Hand.TK 23 juni 1993, resp. pag. 82-5949, 82-5951 en 82-5952. 
tot het geven van een beschikking geheel of gedeeltelijk will afwijzen, de aanvrager in de gelegenheid moet stellen zijn zienswijze naar voren te brengen. Dit moet, zo zegt het artikel, in geval de afwijzing zou steunen op gegevens over feiten en belangen die de aanvrager betreffen, en die gegevens afwijken van gegevens die de aanvrager zelf heeft verstrekt. De gelegenheid hoeft niet te worden gegeven, als de afwijking van de aanvraag slechts van geringe betekenis voor de aanvrager kan zijn.

Artikel 4:8 geeft aan wanneer een bestuursorgaan een soortgelijke plicht heeft ten opzichte van een belanghebbende die de beschikking niet heeft aangevraagd, maar er naar verwachting wel bedenkingen tegen zal hebben. Als de beschikking zou steunen op gegevens over feiten en belangen die zo'n belanghebbende betreffen, en die gegevens niet door deze zelf zijn verstrekt, en ook niet hoefden te worden verstrekt, moet ook die belanghebbende vooraf zijn zienswijze naar voren kunnen brengen.

De aanvrager van een beschikking en de andere belanghebbenden kunnen naar keuze schriftelijk of mondeling hun zienswijze naar voren brengen, zo bepaalt artikel 4:9.

Er zijn echter uitzonderingen op de regel dat de aanvrager en andere belanghebbenden in de zojuist genoemde gevallen de gelegenheid moeten krijgen, om hun zienswijze naar voren te brengen. De artikelen $4: 11$ en 4:12 geven een opsomming. Zo kan de toepassing van de artikelen $4: 7$ en 4:8 achterwege blijven in spoedeisende gevallen, of als de belanghebbende al eerder de gelegenheid heeft gehad zijn zienswijze naar voren te brengen en zich daarna geen nieuwe feiten hebben voorgedaan. Ook blijft de toepassing achterwege, als het met de beschikking beoogde doel alleen kan worden bereikt als de belanghebbende niet van te voren wordt geïnformeerd. En ten slotte worden de artikelen 4:7 en 4:8 ook niet toegepast in een aantal gevallen waarin de beschikking strekt tot het vaststellen van een financiële verplichting of aanspraak.

\section{De openbare voorbereidingsprocedure}

De afdelingen 3.4 en 3.5 van de Algemene wet bestuursrecht beschrijven resp. de openbare voorbereidingsprocedure en de uitgebreide openbare voorbereidingsprocedure die van toepassing kùnnen zijn bij besiuiten. Dat zijn dus, zoals eerder gezegd, niet alleen besluiten van algemene strekking, maar ook beschikkingen. In de artikelen 3:10 en 3:14 lezen we, dat een van beide voorbereidingsprocedures toepassing vindt "indien dat bij wettelijk voorschrift of bij besluit van het bestuursorgaan is bepaald". Een voorbeeld van zo"n wettelijke voorschrift vinden we in artikel 8.6 van de Wet milieubeheer, dat de uitgebreide openbare voorbereidingsprocedure verplicht stelt bij de behandeling van aanvragen voor milieuvergunningen. 
Waar dergelijke voorschriften niet bestaan, is de toepassing van de openbare voorbereidingsprocedures facultatief. Dat wil zeggen, een bestuursorgaan mag bij de voorbereiding van een besluit één van deze procedures toepassen, maar hoeft dat niet.

De "gewone" openbare voorbereidingsprocedure wordt beschreven in afdeling 3.4 , die bestaat uit de artikelen $3: 10$ tot en met 3:13. Deze procedure begint met de bekendmaking van de ter inzage legging van de aanvraag of, wat ook mag, van "het ontwerp van het ambtshalve of op aanvraag te nemen besluit". Dus alleen als het om een besluit op aanvraag gaat, is het mogelijk dat er een plan ter inzage wordt gelegd waarover het bestuursorgaan zelf nog geen (voorlopig) standpunt heeft ingenomen. Bereidt een overheid op eigen initiatief een besluit voor, dan vindt er, bij de toepassing van deze procedure, pas een ter inzage legging plaats als er een ontwerp-besluit is. Dat betekent: als het bestuursorgaan in principe al een standpunt heeft ingenomen over wat in het voorliggende geval het meest wenselijke besluit is. Inspraak is dan eigenlijk een gepasseerd station. Het bestuursorgaan kan dan niet meer in redelijkheid volhouden, dat het de intentie heeft gehad, om door middel van overleg zoveel mogelijk overeenstemming met de betrokken burgers te bereiken. De ter inzage legging dient dan eigenlijk alleen nog maar om informatie in te winnen, waarmee voor mogelijke individueel-benadeelden wat scherpe kantjes van het besluit kunnen worden bijgeslepen.

Voor zover wettelijk niet anders is bepaald, vindt de ter inzage legging plaats in het kantoor van het bestuursorgaan. Ze duurt ten minste vier weken. Stukken, waarover volgens artikel 10 van de Wet openbaarheid van bestuur geen informatie mag worden verstrekt, worden niet ter inzage gelegd. Tegen een vergoeding van ten hoogste de kosten kan men afschriften van de ter inzage gelegde stukken krijgen.

De bekendmaking van de ter inzage legging geschiedt in een of meer dag-, nieuws-, of huis-aan-huisbladen of, zoals artikel 3:12 toelaat, "op een andere geschikte wijze" Volstaan kan worden met het vermelden van de zakelijke inhoud van de aanvraag resp. van het ontwerp-besluit. Gaat het on een besluit dat door de centrale overheid moet worden genomen, dan moet de kennisgeving, tenzij wettelijk anders is voorgeschreven, in ieder geval in de Staatscourant worden geplaatst. Bij de bekendmaking van de ter inzage legging moet ook worden vermeld, wie in de gelegenheid worden gesteld hun zienswijze naar voren te brengen, en op welke wijze men dat kan doen.

Volgens artikel 3:13 moet die gelegenheid aan "belanghebbenden" worden geboden. Zij kunnen hun zienswijze over de aanvraag of over het ontwerp-besluit naar keuze schriftelijk of mondeling naar voren brengen. 
Bij wettelijk voorschrift of door het bestuursorgaan kan worden bepaald, dat ook aan anderen de gelegenheid moet worden geboden om hun zienswijze naar voren te brengen. De termijn waarbinnen een zienswijze naar voren kan worden gebracht, mag niet eindigen voor de laatste dag van de ter inzage legging. Gaat het om een besluit op aanvraag; dan wordt de aanvrager zo nodig in de gelegenheid gesteld om op de naar voren gebrachte zienswijzen te reageren. Van alles wat door aanvrager, belanghebbenden of anderen mondeling naar voren wordt gebracht, moet een verslag worden gemaakt.

Voor zover wettelijke voorschriften niet anders bepalen, geeft afdeling 3.4 van de wet een bestuursorgaan dus de vrijheid, om naar eigen goeddunken de volgende vragen ten aanzien van de 'gewone' openbare voorbereidingsprocedure te beantwoorden:

a. Zullen we de procedure wel of niet toepassen?

$b$. Zo ja, vragen we dan reacties op het moment dat er alleen nog maar een aanvraag voor een besluit ligt, of doen we dat pas op het moment, dat we al een ontwerp-besiuit hebben geformuleerd?

c. En wie staan we toe te reageren? Alleen de belanghebbenden, of ook anderen?

Inspraakrechten geeft afdeling 3.4 dus niet. Het noemt geen onderwerpen waarover de mening van de betrokkenen moet worden gevraagd. En zelfs als een bestuursorgaan besluit de openbare voorbereidingsprocedure toe te passen, kan deze in feite beperkt blijven tot ter inzage legging van een ontwerp-besluit, waarbij alleen belanghebbenden de gelegenheid krijgen om bezwaren te uiten.

\section{De uitgebreide openbare voorbereidingsprocedure}

Afdeling 3.5, die bestaat uit de artikelen 3:14 tot en met 3:33 van de Algemene wet bestuursrecht, voert als de titel: Uitgebreide openbare voorbereidingsprocedures. Het woord uitgebreide slaat echter niet zozeer op het aantal stappen waaruit deze procedures bestaan, maar vooral op het feit, dat aan andere bestuursorganen een mening moet worden gevraagd. $\mathrm{Bij}$ of krachtens wettelijk voorschrift of door het beslissingsbevoegde bestuursorgaan kunnen bestuursorganen worden aangewezen, die de gelegenheid moeten krijgen om advies uit te brengen over het te nemen besluit, of anderszins bij dat besluit moeten worden betrokken. In die gevallen kan worden voorgeschreven, of worden besloten, dat de uitgebreide openbare voorbereidingsprocedure moet worden gevolgd. 
Het bestuursorgaan dat de procedure toepast, moet een ontwerp-besluit opstellen, en dat uiterlijk twaalf weken na ontvangst van de aanvraag toesturen aan de aanvrager en aan de betrokken andere bestuursorganen. Dan moet uiterlijk twee weken later het ontwerp-besluit ter inzage worden gelegd. De bekendmaking daarvan gebeurt in een of meer dag-, nieuws- of huis-aan huisbladen, of, als het om een ontwerp-besluit van de provincie of de rijksoverheid gaat, in de Staatscourant. Samen met het ontwerp-besluit worden nog een aantal andere stukken ter inzage gelegd: de aanvraag, een verslag van eventueel vooroverleg over de aanvraag, rapporten en adviezen die over de aanvraag zijn uitgebracht, en een overzicht van de niet ter inzage gelegde rapporten en adviezen. Het bestuursorgaan vult ook vanaf het moment van ter inzage legging de stukken nog aan met nieuwe relevante stukken en gegevens, zoals bijvoorbeeld nieuwe adviezen, en verslagen van mondeling ingebrachte bedenkingen. Gegevens waarover volgens artikel 10 van de Wet openbaarheid van bestuur geen informatie mag worden verstrekt, worden niet ter inzage gelegd. Wel moet worden meegedeeld, dat ze bestaan.

De ter inzage legging kent twee fasen. Gedurende de eerste vier weken kunnen de stukken worden ingezien tijdens de werkuren, en desgevraagd ook gedurende ten minste drie aaneengesloten uren per week buiten de werkuren. Op verzoek wordt binnen die termijn ook een mondelinge toelichting verstrekt. Na die vier weken blijven de stukken ter inzage liggen op de door het bestuursorgaan te bepalen uren, totdat de termijn is verstreken waarbinnen tegen het echte besluit beroep kan worden ingesteld.

Binnen de vier weken na de eerste dag van de ter inzage legging moeten de adviserende bestuursorganen hun adviezen toezenden aan het bestuursorgaan dat het besluit moet nemen. Binnen diezelfde termijn kan ook een ieder tegen het ontwerp-besluit schriftelijk bedenkingen inbrengen, tenzij bij wettelijk voorschrift of bij besluit van het bestuursorgaan is bepaald, dat alleen een bepaalde categorie van personen dat mag. Belanghebbenden mogen nooit worden uitgesloten van de mogelijkheid om bedenkingen in te brengen. Het beslissingsbevoegde bestuursorgaan zendt van iedere ingebrachte bedenking zo spoedig mogelijk een afschrift aan de aanvrager en aan de adviserende bestuursorganen. De persoonlijke gegevens van degene die schriftelijk bedenkingen heeft ingebracht, worden, indien hij daarom verzoekt, niet bekendgemaakt.

Voor degenen die bedenkingen mogen inbrengen, bestaat desgevraagd ook de mogelijkheid om dat mondeling te doen, en om over het ontwerp-besluit een gedachtenwisseling te hebben. Met wie, zegt de wet niet. Maar we mogen aannemen, dat hier een gedachtenwisseling met het 
beslissingsbevoegde bestuursorgaan is bedoeld. Van de mondeling ingebrachte bedenkingen en van de gedachtenwisseling moet een verslag worden gemaakt. Daarin wordt bij elke bedenking de naam en het adres van de inbrenger vermeld. Het verslag wordt binnen twee weken toegezonden aan de aanvrager van het besluit, aan de adviserende bestuursorganen, en aan degenen die mondeling bedenkingen hebben ingebracht. Iemand die mondeling bedenkingen naar voren brengt, krijgt dus per saldo meer informatie thuisgestuurd dan iemand die dat schriftelijk doet. Waarschijnlijk hebben de bedenkers van de Algemene wet bestuursrecht zich dit laatste niet gerealiseerd.

Zeer belangrijk is ten slotte de rechtsplicht die in artikel $3: 27$ is neergelegd: "Het bestuursorgaan vermeldt bij de bekendmaking van het besluit zijn overwegingen omtrent de ingebrachte bedenkingen". Dus allen die gebruik hebben gemaakt van hun recht om bedenkingen naar voren te brengen, hebben ook het recht om daarop van het bestuursorgaan een gemotiveerd antwoord te krijgen. Dat antwoord krijgt men niet altijd thuisgestuurd. Artikel 3:44 noemt de uitzonderingen. Wel worden het besluit en de overwegingen over de ingebrachte bedenkingen altijd ter inzage gelegd. Daarvan wordt men op de hoogte gesteld door een kennisgeving in dag-, nieuws-, of huis-aan-huisbladen of, in gevallen waarin het besluit van een provincie of van de rijksoverheid afkomstig is, in de Staatscourant.

\section{No-nonsense-wetgeving}

De uitgebreide openbare voorbereidingsprocedure van afdeling 3.5 is een bewerking van de procedure die vroeger in de Wet algemene bepalingen milieuhygiëne was voorgeschreven voor het tot stand brengen van milieuvergunningen. Per 1 maart 1993 is die wet vervangen door de Wet milieubeheer. Deze wet gaf in de artikelen 13.2 tot en met 13.32 een voorbereidingsprocedure die aanzienlijk soberder was dan die van haar voorganger. Burgers en adviserende overheidsorganen konden voortaan pas bedenkingen indienen, als het beslissingsbevoegde bestuursorgaan al een ontwerp-besluit had geformuleerd. Sinds 1 januari 1994 zijn de oorspronkelijke artikelen 13.2 tot en met 13.32 al weer uit de Wet milieubeheer geschrapt. De wet bevat nu in artikel 8.6 een verwijzing, waarin afdeling 3.5 van de Algemene wet bestuursrecht bijna in haar geheel van toepassing wordt verklaard op het tot stand brengen van milieuvergunningen.

De Wet algemene bepalingen milieuhygiëne, die van 1980 tot 1993 heeft gegolden, kende in de artikelen 6 tot en met 33 voor vergunningen een procedure die met meer recht een inspraakprocedure kon worden genoemd. Overleg met betrokkenen was weliswaar ook daar niet met zoveel woorden verplicht gesteld. Maar het beslissingsbevoegde bestuurs- 
orgaan moest de aanvraag voor de vergunning ter inzage leggen voordat het ontwerp-besluit was geformuleerd. Voor een ieder, dus ook voor ambtelijke adviseurs, was er dan een maand gelegenheid om schriftelijke bezwaren in te dienen. Het bestuursorgaan moest ook een openbare zitting over de aanvraag organiseren. Alleen als "redelijkerwijs" kon worden aangenomen dat er aan de zitting geen behoefte bestond, kon die achterwege worden gelaten. Maar dan moest het bestuursorgaan aan ieder die daarom verzocht wel de gelegenheid geven, om mondeling bezwaren in te brengen. Pas daarna mocht het bestuursorgaan een ontwerp-beschikking formuleren. Die moest twee weken ter inzage worden gelegd. In die periode konden dan nog bezwaren worden ingediend door de aanvrager zelf door iedereen die ten aanzien van de aanvraag al een bezwaar had ingediend, en door iedereen die aantoonde, dat hij redelijkerwijs ten aanzien van de aanvraag geen bezwaar had kunnen indienen.

Dit was de normale procedure voor het verlenen van milieuvergunningen: Alleen als "redelijkerwijs" kon worden aangenomen, dat er geen behoefte bestond om over de aanvraag adviezen uit te brengen of daartegen bezwaren in te brengen, dan kon, zo bepaalde artikel 29 , meteen een ontwerp-beschikking ter inzage worden gelegd. Dit noemde men de "verkorte" procedure. Dat is dus de procedure die thans in de Algemene wet bestuursrecht de "uitgebreide" openbare voorbereidingprocedure wordt genoemd. Onder deze misleidende benaming ging dit staaltje van nononsense-wetgeving er bij het parlement in als koek. Maar de inspraakprocedure is intussen verpieterd tot een bedenkingen-procedure tegen kant en klare ontwerp-besluiten.

\section{Inspraak, overlegmodellen en 'eigen' deskundigen}

In de twee voorgaande paragrafen heb ik de bestaande inspraakwetgeving besproken. We hebben daar gezien, dat het saldo niet erg positief is. Alleen ten aanzien van beleidsvoornemens op het gebied van stadsvernieuwing en ruimtelijke ordening en ten aanzien van bepaalde besluiten van waterschapsbesturen bestaat er een door de wet erkend recht op inspraak. De model-inspraakverordening van de VNG voegt daar nog inspraakrechten aan toe met betrekking tot het gemeentelijk milieubeleidsplan en de gemeentelijke welzijnsvoorzieningen. Volgens geen enkele wet hoeft het recht op inspraak meer in te houden, dan het recht om ten aanzien van een kant en klaar ontwerp-besluit een "zienswijze" of "bezwaar" kenbaar te maken. Alleen de model-inspraakverordening van de VNG geeft ook recht op een "gedachtenwisseling" met het bestuur. De inspraakgevende over- 
heid heeft van haar kant de plicht om in een verslag bij de besluitvorming te verantwoorden, wat zij met de 'inspraak' gedaan heeft. En dan, aan het einde van de rit, zijn er de wettelijke inspraakklachten-procedures. Maar die blijken in de praktijk vaak juist een belemmering te zijn om een besluit, dat zonder voldoende inspraak is genomen, om die reden bij de rechter aan te kunnen vechten.

\section{Inspraak, wat was dat ook alweer?}

Aan het begin van dit hoofdstuk heb ik een paar belangrijke kenmerken en bestanddelen van inspraak genoemd. Inspraak is overleg tussen overheid en burgers. Maar niet alle overleg is inspraak. Een burger of rechtspersoon die met de overheid onderhandelt over de voorwaarden voor een overeenkomst, is geen 'inspreker'. De overheid kan die overeenkomst namelijk niet aangaan zonder de instemming van die burger of rechtspersoon. Bij inspraak hebben de burgers niet of nauwelijks een onderhandelingspositie. De overheid kan ook zònder hun instemming een beslissing nemen. Dat gegeven bepaalt voor een groot deel de verhoudingen, en dus ook de aard van het overleg. De insprekers hebben er alle belang bij om het met de overheid eens te worden, en zullen zich daar ook voor inzetten. Maar die overheid zelf heeft meestal alleen maar een moreel of politiek belang om met de insprekers overeenstemming te bereiken. Ze is voor de beslissing die ze wil nemen niet 'afhankelijk' van de insprekers. Daarom is er, als men de kwaliteit van inspraak toetst, alle reden om te onderzoeken, of juist de overheid wel echt 'overleg' heeft willen voeren.

Overleg is, ik heb het al eerder gezegd, meer dan een gedachtenwisseling. Een gedachtenwisseling is een mondelinge of schriftelijke, altijd vrij directe, maar toch ordelijke confrontatie van standpunten of meningen van de verschillende deelnemers. Wil men van overleg kunnen spreken, dan zal bij de deelnemers ook de intentie moeten bestaan om over de gespreksonderwerpen zoveel mogelijk overeenstemming te bereiken.

Overleg verdient die naam niet, als het geen eerlijk overleg is. De ander overbluffen, voor voldlongen feiten stellen, relevante informatie achterhouden, misbruik maken van omstandigheden, dat alles past niet bij eerlijk overleg. Speciaal de overheid mag erop worden aangesproken, dat ze de verschillende (groepen) insprekers een eerlijke en dus min of meer gelijke kans geeft, om haar te overtuigen. Want uiteindelijk is het die overheid, die na de inspraak zelf een besluit moet nemen. En ook als dat besluit ertoe strekt een verbintenis aan te gaan met een "wederpartij" in de zin van het contractenrecht, hoeft dat vooraf de mogelijkheid van eerlijk overleg met anderen niet uit te sluiten. Overigens zal ik de uitdrukking 
eerlijk overleg nu verder niet meer gebruiken, omdat ze naar mijn gevoel een pleonasme is. Oneerlijk overleg is geen overleg.

Insprak is overleg met burgers en ingezetenen. Ik zou het een politiek grondrecht willen noemen. Iedere burger of ingezetene die zich bij een bepaald optreden van de overheid betrokken voelt, is inspraakgerechtigd. Van de overheid mag bereidheid en initiatief worden verwacht, om met deze burgers en ingezetenen overleg te voeren. Zij zijn de betrokkenen. Een betrokkene hoeft geen 'belanghebbende' te zijn in de zin van de Algemene wet bestuursrecht. Een ver verwijderd belang, een emotioneel belang, of gewoon een verantwoordelijkheidsgevoel ten opzichte van de samenleving of de schepping is voldoende om 'betrokkene' te zijn. Dat personen van inspraak worden uitgesloten, anders dan vanwege misdragingen tijdens de inspraak, is nauwelijks denkbaar.

Toch hoeft niet altijd het hele land, de hele provincie of de hele stad voor inspraak te worden uitgenodigd. Ook hoeven de uitnodigingen naar mijn idee niet altijd in de Staatscourant of in huis-aan-huis-bladen te worden geplaatst. Beter is het als overheid zich een beeld vormt van wie zich redelijkerwijs betrokken kunnen voelen bij een bepaald onderwerp, en dan een daarop afgestemde benaderingswijze kiest. Als bijvoorbeeld de vraag speelt, of aan een bepaalde persoon een bijstandsuitkering moet worden toegekend, hoeft doorgaans alleen die persoon voor overleg te worden uitgenodigd. En als bijvoorbeeld in een straat, die alleen een woonfunctie heeft, de vraag speelt of er een paar verkeersdrempels moeten worden aangelegd, dan ligt het voor de hand om de bewoners van die straat een uitnodigingsbrief te bezorgen. Ook het buurtwerk, het wijkcomité, en een verkeers-aktiegroep, voor zover in de wijk aanwezig of aktief, zullen op de mogelijkheid van inspraak moeten worden geattendleerd. Melden zich tijdens de inspraak nog andere belangstellenden, dan mogen die ook aan de inspraak deelnemen, tenzij er goedle redenen zijn om hen buiten de deur te houden.

De inspraak, dat wil zeggen het overleg, kan in het zojuist omschreven geval waarschijnlijk ook heel summier zijn. Misschien kan zelfs worden volstaan met een schriftelijke variant. Als namelijk het gemeentebestuur redelijkerwijs geen bezwaren tegen een plan voor de verkeersdrempels hoeft te verwachten, dan kan het de bewoners schriftelijk een plan voorleggen, met keuzemogelijkheden ten aanzien van de plaatsing en de soort van drempels. Bij de informatie wordt meegedeeld, dat binnen een bepaalde termijn, bijvoorbeeld twee weken, voorkeuren of bezwaren kenbaar kunnen worden gemaakt. Na de reactietermijn kan worden beoordeeld of, en zo ja waarover, nog nader overleg moet plaatsvinden. 
Met het bovenstaande heb ik duidelijk willen maken, dat inspraak niet een procedure is, maar overleg, dat van de zijde van de overheid met de juiste intentie moet worden gevoerd. Dat is ook wat mij tegenstaat bij de procedures van de Algemene wet bestuursrecht. Daar is van de inspraak een ritueel gemaakt. Een rechter, die toetst of een overheid een inspraakprocedure van die wet wel juist heeft toegepast, onderzoekt op welke dag de ter inzage legging in de Staatscourant of in een huis-aan-huis-blad bekend is gemaakt, of vanaf toen de ter inzage legging exact vier weken heeft geduurd, en meer van dat soort uiterlijkheden. Heeft de overheid de rituele handelingen helemaal volgens de liturgie van de Algemene wet bestuursrecht verricht, dan verleent de rechter absolutie. Hij vraagt zich niet af, of er ook werkelijk overleg heeft plaatsgevonden. Als hem dat zou worden opgedragen, zou hij dat best kunnen onderzoeken, want zoals ik al heb betoogd, is overleg een juridisch toetsbaar begrip. Daarom noem ik de al dan niet uitgebreide en openbare voorbereidingsprocedures van de Algemene wet bestuursrecht gewoon bezwarenprocedures, die het recht op inspraak verder onverlet laten.

\section{Overlegmodellen en 'eigen' deskundigen}

Eén onderwerp is tot nu toe in dit hoofdstuk over inspraak wat onderbelicht gebleven: de mogelijkheid voor burgers en ingezetenen om met hulp van deskundigen alternatieve plannen of voorstellen te ontwikkelen. De Algemene wet bestuursrecht en de inspraak-artikelen in de Provinciewet, de Gemeentewet en de Waterschapswet zwijgen daar ook over. Toch kan het geven van eerlijke, gelijke kansen in de inspraak met zich meebrengen, dat aan bepaalde betrokkenen ondersteuning moet worden gegeven, die het mogelijk maakt dat zij zich als groep organiseren en hun belangen vertalen in een realiseerbaar voorstel.

We moeten dus twee soorten ondersteuning onderscheiden: ondersteuning die het mogelijk maakt dat betrokkenen zich als groep organiseren, en ondersteuning bij het ontwikkelen van een alternatief plan. Voorzieningen van de eerste soort moeten worden afgestemd op de aard van het inspraak-onderwerp en de hoedanigheid van de betrokkenen. Gaat het bijvoorbeeld over beleidsvoornemens met betrekking tot bouwplannen, renovatie of de inrichting van de woonomgeving in een achterstandswijk, dan kan allereerst worden gekeken, of er voor die wijk een voorziening van buurtwerk is. Dat buurtwerk mag er op worden aangesproken om de bewoners in hun zelf-organisatie te ondersteunen. Aanvullend, en afhankelijk van de ingrijpendheid van de plannen, kan het gemeentebestuur, eventueel via het buurtwerk, kleine subsidies beschikbaar stellen aan bewonersgroepen, bijvoorbeeld voor vergaderkosten en drukwerk. Het kan ook 
zijn, dat de insprekers niet in éen wijk of buurt wonen, maar verspreid zijn over het hele land, bijvoorbeeld als er een planologische kernbeslissing aan de orde is. De bewindslieden die een dergelijke beslissing voorbereiden, zullen zich van tevoren rekenschap moeten geven, of, en zo ja, welke groepen van betrokkenen in hun zelf-organisatie moeten worden gesubsidieërd. Het criterium is ook dan: zoveel ondersteuning als nodig is om groepen van betrokkenen een eerlijke kans in de inspraak te geven.

Ook de ondersteuning van insprekers bij het ontwikkelen van een alternatief plan moet worden afgestemd op de aard van het inspraakonderwerp en de hoedanigheid van de betrokkenen. In hoeverre die ondersteuning de planvoorbereidingskosten voor de inspraakgevende overheid verhoogt, is afhankelijk van het model dat die overheid kiest om overleg te plegen. In de bestuurspraktijk wordt gewerkt met een drietal verschillende overlegmodellen. Deze worden daar aangeduid met namen als: het ambtenarenmodel, het gemengde model, en het bewonersmodel. Ze worden hier beschreven als advies-modellen. Er wordt toegewerkt naar een advies of voorstel dat aan het bevoegde bestuursorgaan ter besluitvorming wordt voorgelegd. Het komt bij deze modellen ook wel voor, dat een onderdeel van de ambtelijke organisatie, of een werkgroep of projectgroep, behalve een adviserende bevoegdheid, mandaat heeft om bepaalde bestuurlijke beslissingen te nemen. Daardoor kunnen burgers en ingezetenen, die in zo'n werkgroep of projectgroep zitting hebben, soms enige (mede)zeggenschap uitoefenen. Maar men moet bedenken, dat de overige betrokkenen alleen de rechten van 'insprekers' hebben. De belissingsbevoegde instantie is voor hen dan alleen wat dichterbij gekomen.

Tenslotte verdient opmerking, dat in elk van de drie modellen externe deskundigen kunnen worden ingeschakeld, zoals bijvoorbeeld een architect of een ingenieursbureau.

Het ambtenarenmodel is het meest traditionele model. Daarin wordt het beleidsvoorstel, dat aan het bestuur moet worden voorgelegd, opgesteld door een onderdeel van de ambtelijke organisatie, of door een werkgroep of projectgroep van ambtenaren van verschillende onderdelen van die organisatie. Aan de opstelling van het voorstel kan worden meegewerkt door daartoe ingeschakelde externe deskundigen, die eventueel ook deel uitmaken van de werkgroep of projectgroep. In de verschillende fasen van de beleidsvoorbereiding wordt inspraak gegeven aan de betrokken burgers en ingezetenen. Deze insprekers dragen geen medeverantwoordelijkheid voor het beleidsvoorstel dat uiteindelijk aan het bestuur wordt voorgelegd. Als zij de overheid middelen vragen, om alternatief onderzoek te doen, of om een alternatief voorstel te kunnen formuleren, dan hebben zij daar in 
beginsel recht op. Dat recht is sterker naarmate hun betrokkenheid bij het onderwerp groter is, en het is omvangrijker naar de mate van hun behoefte aan deskundige ondersteuning. Die behoefte kan kleiner zijn, als de ambtenaren de bevoegdheid is gegeven om, op een wijze die recht doet aan de wensen en ideeën van de insprekers, zelf alternatieven te onderzoeken en met alternatieve voorstellen te komen.

Het gemengde model is vooral in stadsvernieuwingsgebieden al zo'n twintig jaar een tamelijk vertrouwd verschijnsel. Maar het komt ook voor bij de voorbereiding van 'functioneel' beleid op gemeentelijk of hoger niveau, zoals bijvoorbeeld cultuurbeleid of minderhedenbeleid. Het gemengde model is een echt samenwerkingsmodel. Met buurtorganisaties, organisaties van kunstbeoefenaren of van minderheden, worden afspraken gemaakt over de samenstelling van een werkgroep of projectgroep. Daarin zitten, naast ambtenaren, vertegenwoordigers van de betrokken organisaties. In stadsvernieuwingsgebieden bijvoorbeeld één of enkele leden van het wijkcomité en een vertegenwoordiger van de winkeliersvereniging. Ook zit er dan meestal een vertegenwoordiger van een woningcorporatie bij. De werkgroep of projectgroep bereidt, eventueel ondersteund door ambtelijke of externe deskundigen, beleidsvoorstellen voor, die via de ambtelijke lijn aan het bestuur worden voorgelegd. Ook hier wordt in de verschillende fasen van de beleidsvoorbereiding inspraak gegeven aan de betrokken burgers en ingezetenen.

Het gemengde model kan alleen worden toegepast; als er een zekere mate van vertrouwen bestaat tussen overheid en organisaties van betrokkenen. Hun vertegenwoordigers zullen in de werkgroep of projectgroep moeten samenwerken. Dat zal resulteren in eén voorstel, waarin allen zich kunnen vinden, of in twee of meer alternatieve voorstellen. Zolang organisaties van betrokkenen blijven deelnemen aan de werkgroep of projectgroep, dragen zij medeverantwoordelijkheid voor de voorstellen van de groep, en is er geen reden om hen apart middelen ter beschikking te stellen voor het ontwikkelen van alternatieve voorstellen.

Het bewonersmodel is een veel zeldzamer verschijnsel. Dat ligt voor een groot deel aan huiverigheid bij de overheid. Maar ook wel aan het feit, dat dit model alleen kan functioneren, als de bewoners ongeveer dezelfde belangen hebben. Als inspraak-medewerker heb ik slechts één keer meegemaakt, dat het model in een vrij zuivere vorm werd toegepast. Het resultaat daarvan ziet men, als men met de trein vanuit Den Haag of Rotterdam Utrecht binnenkomt, en enkele honderden meters vóór het centraal station een blik naar rechts werpt op een woonbuurtje, dat vroeger het "Verdomhoekje" werd genoemd. Tot in de jaren zeventig was dit een verwaarloosd buurtje met lage huisjes, door een brede verkeersweg gescheiden van de 
kantoor- en hoteltorens van "Hoog Catharijne". Het gemeentebestuur wilde de woningen vervangen door nieuwbouw. De bewoners wilden dat ook, maar niet zonder meer. De huren zouden betaalbaar moeten zijn, en de nieuwe buurt zou zoveel mogelijk weer het karakter van de oude buurt moeten krijgen. Dat kon alleen door zoveel mogelijk het oude stratenpatroon te handhaven, en lage huisjes te bouwen. De stedebouwkundige dienst van de gemeente vond echter, dat de nieuwbouw zou moeten 'aansluiten' bij de hoogbouw rond het station. Dat betekende: gestapelde nieuwbouw. De bewoners gingen met dit uitgangspunt niet akkoord. Toen de stedebouwkundige dienst geen duimbreed wilde toegeven, was er geen vertrouwensbasis meer om samen te werken. Door de raadscommissie voor Ruimtelijke Ordening en Volkshuisvesting te wijzen op de 'ereschuld' van de gemeente ten opzichte van het buurtje, wisten de bewoners het gemeentebestuur over te halen tot een experiment: uit een lijstje van drie mocht de buurt zelf een architektenbureau kiezen, dat voor rekening van de gemeente en in overleg met de bewoners een bouwkundig schetsplan voor de nieuwe buurt zou ontwerpen. Dat plan zou ter goedkeuring aan het gemeentebestuur worden aangeboden.

Het experiment slaagde wonderwel. Met financiële steun van de sectie Inspraak en Wijkaangelegenheden werd een leegstaand pandje in de buurt ingericht tot informatie- en vergadercentrum. Het architectenbureau ontwierp onder het toeziend oog van de bewoners een schetsplan, waarbij de gemeentelijke diensten mochten 'inspreken'. Het uiteindelijke resultaat was een bouwplan, dat bijna helemaal in overeenstemming was met de wensen van de buurt. Alleen op een bepaalde plek werd, als compromis, een woongebouw van drie verdiepingen plus kap, bestemd voor kleine huishoudens, gesitueerd. De stedebouwkundige dienst had erop aangedrongen, om op deze wijze het begin van de Vleutense weg te markeren. Het bouwplan werd rond 1980 gerealiseerd.

Vergeleken bij het ambtenarenmodel zijn in het bewonersmodel de rollen dus omgedraaid. De bewoners bereiden samen met externe deskundigen een ontwerp-beslissing voor. De overheid kan vooraf uitgangspunten vaststellen. Maar zoals het voorbeeld van het "Verdomhoekje" laat zien, is het ook denkbaar, dat gewerkt wordt op basis van uitgangspunten die door de bewoners zelf zijn geformuleerd, en die voor de overheid niet bij voorbaat onaanvaardbaar zijn. De ambtelijke diensten kunnen tijdens de voorbereiding 'inspreken'. Dat zal waarschijnlijk ook de besluitvorming bespoedigen als eenmaal de ontwerp-beslissing aan de overheid is aangeboden. Burgers en ingezetenen krijgen op deze wijze optimale ondersteuning 
van deskundigen. De totale plankosten zijn door deze werkwijze niet verhoogd, want er is slechts één ontwerp-beslissing voorbereid.

\section{Planvoorbereidingskosten}

Als we aannemen dat het recht op inspraak ook het recht op deskundige ondersteuning omvat, brengt het bewonersmodel misschien wel de minste planvoorbereidingskosten met zich mee. Maar het kan alleen worden toegepast als de insprekers tamelijk eenduidige belangen hebben. Er wordt één voorstel voorbereid dat, normaal gesproken, de instemming van die insprekers heeft. Ambtelijke diensten kunnen tijdens de voorbereiding naar de buurt of naar het bestuur toe signalen geven als de besluitvoorbereiding zich in een onaanvaardbare of onuitvoerbare richting ontwikkeld. Van de zijde van de buurt zal men de zaak dan niet snel op de spits drijven, want men weet, dat men voor de realisatie van het besluit toch weer afhankelijk is van de overheid.

Het gemengde model is een model waarin overheid en insprekers allebei initiatieven kunnen ontplooien, en dat optimale mogelijkheden biedt voor overleg gedurende de gehele periode van voorbereiding. Bereikt men in de werkgroep of projectgroep geen overeenstemming, en wil men toch de samenwerking voortzetten, dan ligt het voor de hand om alternatieve mogelijkheden te onderzoeken, en, als dat gewenst wordt, alternatieve ontwerp-besluiten voor te dragen. Dat zal in het algemeen een verhogend effect op de totale planvoorbereidingskosten hebben.

Maar het is het ambtenarenmodel dat bij insprekers toch het meest de behoefte zal oproepen aan contra-expertise, en dus aan "eigen deskundigen". Dat wil zeggen: deskundigen die het vertrouwen van de insprekers hebben. Als die deskundigen ook alternatieve mogelijkheden moeten onderzoeken, of alternatieve plannen moeten ontwerpen, kan dat tot aanzienlijke verhoging van de planvoorbereidingskosten leiden.

\section{Burgerschapsdenken en openbaarheid van bestuur}

In de zojuist gegeven beschrijving van overlegmodellen is aangenomen, dat ambtenaren werken volgens de klassieke opvatting over loyaliteit. De verschillen tussen de modellen worden veel kleiner, als ambtenaren functioneren als 'burgerschapsdenkers'. Ook dan werken zij natuurlijk op basis van instructies. Maar zij krijgen de ruimte, of nemen die, om naar eigen inzichten en professionele normen de beste oplossingen voor te stellen, en tegen slechte oplossingen te waarschuwen. $\mathrm{Zij}$ voelen zichzelf tegenover de samenleving verantwoordelijk voor de betekenis en de kwaliteit van hun adviezen. Als hen in een ambtenarenmodel de instructie wordt gegeven: "Probeer met die en die uitgangspunten een plan te maken dat zoveel mo- 
gelijk tegemoet komt aan de wensen van de insprekers", dan kan dat heel goed tot hetzelfde resultaat leiden als wanneer in een bewonersmodel externe deskundigen met diezelfde uitgangspunten aan het werk gaan. Toch kan niet elk van de modellen zomaar worden toegepast. Veel hangt af van het vertrouwen dat de overheid bij de betrokken burgers en ingezetenen geniet. Als dat vertrouwen er niet is, en de overheid hanteert bij de voorbereiding van beleid het ambtenarenmodel, dan hebben de betrokkenen in beginsel recht op ondersteuning door eigen deskundigen. ${ }^{329}$

\section{Wat moet er aan inspraak worden geregeld?}

\section{Schrapping van artikel 125 a Ambtenarenwet en artikel 11 WOB}

Wat er aan inspraak moet worden geregeld, is eigenlijk niet zo gek veel. Er moeten enkele hinderlijke wetsbepalingen worden geschrapt, die aan echte inspraak in de weg staan. En het verdient aanbeveling, om in de Grondwet een algemene wetsbepaling op te nemen, waaraan burgers en ingezetenen een recht op inspraak aan kunnen ontlenen. Ik zal nu eerst de bepalingen noemen, die naar mijn mening moeten worden geschrapt.

Het vertrouwen in de overheid is in belangrijk mate medebepalend voor de resultaten van het overleg tussen overheid en insprekers. Maar dat vertrouwen is geen vast gegeven. Het kan worden gestimuleerd door in de ambtelijke organisatie ruimte te geven aan burgerschapsdenken. Ambtenaren kunnen dan naar burgers toe blijk geven van een eigen maatschappelijke verantwoordelijkheid. Om het burgerschapsdenken te stimuleren, heb ik in hoofdstuk 7 voorgesteld om artikel 125a van de Ambtenarenwet, waarin de vrijheid van meningsuiting en van vereniging, vergadering en betoging voor ambtenaren sterk aan banden is gelegd, te schrappen. De ambtenaren zouden dan dezelfde vrijheid van meningsuiting krijgen als anderen in ons land. Artikel 2:5 van Algemene wet bestuursrecht verzekert, dat ambtenaren daarbij geen gegevens zullen openbaren, die op grond van de Wet openbaarheid van bestuur of van bijzondere wetten geheim zouden moeten blijven.

329 M.A. Heldeweg heeft in zijn dissertatie Normstelling en expertise, Den Haag 1993 , de wenselijkheid wan een recht op contra-expertise uitgewerkt ten aanzien van vergunningwerlening in het millieurecht. Hij schrijft niet over "burgerschapsdenken", maar ook nar zijn mening is de behoefte aan contra-expertise minder naarmate een groter deel van de uitgebrachte adviezen openbaar is, en naarmate de adviseurs 'onafhankelijker' zijn. 
In hoofdstuk 7 is ook uiteengezet, dat het burgerschapsdenken van ambtenaren kan worden gestimuleerd door een grotere openbaarheid van bestuur. Standpunten van bestuurders en adviezen van ambtenaren kunnen nu nog altijd geheim worden gehouden met een beroep op artikel 11 van de Wet openbaarheid van bestuur. De overheid hoeft in het concrete geval alleen maar aan te tonen, dat het om "persoonlijke beleidsopvattingen" gaat, die zijn opgenomen in voor "intern beraad" bestemde stukken. Deze wettelijke regel is vooral schadelijk voor het aanzien van de overheid zelf. Want hoe kunnen bestuurders en ambtenaren vertrouwen winnen, als zij ten overstaan van het publiek niet eens hoeven uit te komen voor hun "intern' naar voren gebrachte standpunten en adviezen? En zelfs als ambtenaren dat al willen, dan kan het hen om opportuniteitsredenen worden verboden. Aan het slot van hoofdstuk 7 heb ik daarom ook voorgesteld om artikel 11 van de Wet openbaarheid van bestuur te schrappen. Bestuurders moéten dan wel hun ware gezicht laten zien. En ambtenaren, die weten dat hun adviezen openbaar worden, gaan voor de kwaliteit ervan een grotere verantwoordelijkheid voelen. Bovendien zal de openbaarheid van standpunten en adviezen de informatie van de insprekers op een gelijker niveau brengen met dat van de bestuurlijke en ambtelijke overlegpartners.

\section{Inspraak in de Grondwet}

Inspraak is overleg. Hoe omvangrijk dat overleg moet zijn, moet van geval tot geval worden bekeken. De criteria om van overleg te kunnen spreken, zoals de intentie om het eens te worden, eerlijk spel, gelijke kansen e.d., heb ik in dit hoofdstuk genoemd. De rechter zou de geldigheid van overheidsbesluiten aan die criteria kunnen toetsen.

Het eerste hoofdstuk van de Grondwet is wellicht het meest geschikt, om in algemene zin dit recht vast te leggen. Artikel 5, dat nu nog het recht van petitie regelt, kan worden omgebouwd tot een bepaling, die aan Nederlanders en ingezetenen in principe een recht op overleg met de overheid geeft. Het zou een goede schakel kunnen zijn tussen artikel 4, dat aan Nederlanders het kiesrecht geeft, en de artikelen 6 en 7 , die aan ieder de godsdienstvrijheid en vrijheid van meningsuiting garanderen. Het nieuwe artikel 5 zou als volgt kunnen luiden:

1. Iedere Nederlander en iedere ingezetene heeft recht op overleg met de overheid. Dit recht geeft hem aanspraak om door de overheid te worden uitgenodigd tot overleg bij de voorbereiding van beleid waar hij zich redelijkerwijs bij betrokken kan voelen. De overheid bevordert daarbij, dat de verschillende groepen van belanghebbenden en belangstellenden vol- 
doende informatie en ondersteuning krijgen, om met eerlijke kansen aan het overleg te kuninen deeinemen.

2. Het overleg bij de voorbereiding van besluiten van provinciale staten, gemeenteraden en andere colleges van openbaar bestuur, kan worden opgedragen aan bestuursorganen die met de voorbereiding van die besluiten zijn belast.

3. Bif de voorbereiding van beslissingen van de Staten-Generaal, of van een der Kamers van deze Staten, geldt het in het eerste lid bedoelde recht op overleg alleen voorzover het in wettelijke voorschriften is geregeld. Hetzelfde voorbehoud geldt bij de voorbereiding van rechterlijke beslissingen.

4. Tenzij wettelijke voorschriften anders bepalen, is er geen aanspraak om tot overleg te worden uitgenodigd bij de voorbereiding van besluiten tot:

a. vaststelling of invordering van financiële verplichtingen;

$b$. opsporing of vervolging van strafbare feiten;

c. tenuitvoerlegging van rechterlijke beslissingen, en

$d$ oplegging of tenuitvoerlegging van bestuurlijke sancties.

5. Tenzij wettelijke voorschriften anders bepalen, geldt het recht op overleg niet bij de voorbereiding van besluiten voor zover de vereiste spoed zich tegen toepassing van dit recht verzet, en evenmin voor zover het met het besluit beoogde doel alleen kan worden bereikt als betrokkenen daarvan niet tevoren in kennis zijn gesteld. Het geldt, behoudens andersluidende voorschriften, ook niet voor zover er al overleg heeft plaatsvonden en zich daarna geen nieuwe feiten of omstandigheden hebben voorgedaan.

Het petitierecht, zoals dat nu in artikel 5 is geregeld, kan worden geschrapt. De eerste volzin van het door mij voorgestelde lid 1 geeft aan burgers en ingezetenen al meer rechten dan die tekst. Wel moet daarbij worden opgemerkt, dat het recht van petitie aan een ieder is gegeven. Sommige auteurs willen in dat recht ook een antwoordplicht van de overheid lezen, maar die gedachte heeft bij de herziening van 1983 in de Grondwet zelf geen vorm gekregen. ${ }^{330}$ Niettemin hebben beide Kamers van de Staten-Generaal op basis van het petitierecht een "Commissie voor de Verzoekschriften" ingesteld, die verslag uitbrengt over elk bij de betreffende kamer ingediend verzoekschrift. Grondwettelijk gezien kan men zich

330 C. Riezebos toont zich in zijjn dissertatie Recht van petitie, Zwolle 1992, ook nu nog een pleitbezorger van deze gedachte. Zie voor de discussies over artikel 5 tijdens de grondwetsherziening ook C.A.J.M. Kortmann, De Grondwetsherziening 1983, Deventer 1983, pag. 74-76. 
echter afvragen, of het huidige artikel 5 nog rechten geeft naast de in artikel 7 gegarandeerde vrijheid van meningsuiting. ${ }^{331}$

De leden 1 tot en met 5 van het door mij voorgestelde artikel 5 kunnen als volgt worden toegelicht. Lid 1 geeft betrokkenen in principe recht op een uitnodiging tot overleg bij de voorbereiding van beleid. Dat wil zeggen, bij de voorbereiding van besluiten die zelf in meer of mindere mate beleidsbepalend zijn. Het recht is beperkt tot Nederlanders en ingezetenen. Anders zou bijvoorbeeld bij het formuleren van asyl-beleid de hele wereld moeten worden uitgenodigd. De eerste volzin van lid 1 verzekert, dat personen die onuitgenodigd aan inspraak willen deelnemen, niet zonder reden kunnen worden buitengesloten. De uitnodiging tot overleg hoeft niet op naam te zijn gesteld, maar kan ook bij algemene of tot een bepaalde groep gerichte oproep geschieden. De derde volzin legt de overheid een zorgplicht op, om ten aanzien van de verschillende groepen van insprekers een actief informatie- en ondersteuningsbeleid te ontplooien. Insprekers kunnen aan deze bepaling geen recht op persoonlijke ondersteuning ontlenen.

Lid 2 geeft een praktische regeling voor de lagere overheden met een monistisch bestuursmodel, dat bestaat uit een algemeen bestuur en een dagelijks bestuur. Voor het algemene bestuur, dat meestal slechts een maal in de zoveel weken bijeenkomt, is het niet doenlijk om alle overleg zelf te organiseren. Gezien ook de monistische verhouding tussen de beide besturen is het wel aanvaardbaar, dat het overleg wordt opgedragen aan het dagelijks bestuur, of aan een speciale bestuurscommissie.

Lid 3 verklaart het recht op overleg niet van toepassing op beslissingen van de Staten-Generaal en op beslissingen van rechters. De StatenGeneraal heb ik uitgezonderd omdat zij, anders dan bijwoorbeeld een gemeenteraad, geen bestuursorgaan zijn. Bij rechterlijke beslissingen bestaat een recht op een eerlijk proces, dat beheerst wordt door beginselen, die zijn vastgelegd in de Grondwet en in internationale verdragen.

Lid 4 noemt een aantal bestuurshandelingen, waarbij geen aanspraak bestaat op een uitnodiging tot overleg. De betrokkenen hebben wel recht op overleg, maar zij zullen zelf het initiatief moeten nemen.

Lid 5 geeft enkele algemene uitzonderingen op het recht tot overleg. Voor de formulering heb ik ansluiting gezocht bij artikel 4:11 van de Algemene wet bestuursrecht, waar een aantal uitzonderingen zijn vermeld

331 Kortmann signaleert t.a.p. dat, in tegenstelling tot artikel $7 \mathrm{Gw}$, bij artikel 5 de zinsnede behoudens ieders verantwoordelijkheid voor de wet ontbreekt. Daar zou men uit kunnen concluderen, dat men in een 'petitie' straffeloos zou mogen smaden en lasteren. Maar, zegt ook Kortmann, dat is niet de heersende leer. 
ten aanzien van het recht om bij bepaalde beschikkingen vooraf 'zienswijzen' naar voren te mogen brengen.

\section{Inspraak in andere wetten}

Als het door mij voorgestelde recht op overleg in de Grondwet wordt geplaatst, dan moet de Algemene wet bestuursrecht worden aangevuld. Daar zou in het eerste hoofdstuk een wetsartikel moeten worden opgenomen met als tekst: Deze wet laat het recht van burgers en ingezetenen op overleg als bedoeld in artikel 5 van de Grondwet onverlet.

Dan is ten minste duidelijk, dat men de voorbereidingsprocedures van deze wet niet moet zien als inspraakprocedures, maar als rechtsbeschermingsprocedures.

Veel meer hoeft er op wetgevingsgebied niet te worden gewijzigd. Wel zouden artikel 6a van de Wet op de Ruimtelijke Ordening, artikel 8 van de Wet op de stads- en dorpswernieuwing, en het tweede lid van artikel 79 van de Waterschapswet moeten worden geschrapt. Want als artikel 5 van de Grondwet een algemeen recht op overleg geeft, dan hoeven andere wetten dat niet nog eens voor specifieke gevallen te doen. De verplichting om een inspraakverordening vast te stellen kan eventueel wel in de Gemeentewet, de Provinciewet, en in de Waterschapswet blijven staan.

Voor niet-naleving van het nieuwe grondwetsartikel 5 hoeven niet nu al apart sancties in het leven te worden geroepen. Laat eerst in de praktijk de strekking van het artikel maar eens duidelijk worden. De rechter zal daarbij ongetwijfeld een grote rol spelen, want veel besluiten waar de overlegplicht voor zou gelden, zijn besluiten waartegen bezwaar en beroep open staat op grond van de Algemene wet bestuursrecht. Er is veel voor te zeggen, om het achterwege laten van een uitnodiging tot overleg zelf aan te merken als een weigering tot overleg, en dus als een voor bezwaar en beroep vatbaar besluit. Het is verstandig, om op deze punten de ontwikkeling in jurisprudentie af te wachten. Zonodig kan de Grondwet altijd nog worden ondersteund met gewone wetgevende maatregelen. 


\section{Hoofdstuk 9}

\section{Referendum en Volksinitiatief}

\section{Referendum en volksinitiatief als sluitstuk van de democratie}

In de voorafgaande hoofdstukken heb ik gepoogd een lijn uit te zetten. Openbaarheid van bestuur heb ik geschetst als een onmisbaar element voor de burger om inzicht te krijgen in datgene waar politici en ambtenaren mee bezig zijn. Dat inzicht is nodig om invloed te kunnen uitoefenen op de bezigheden van deze politici en ambtenaren. Toch biedt onze openbaarheidswetgeving ook vandaag de dag nog altijd maar weinig mogelijkheden dat inzicht te verwerven. De voorbereiding van bestuurlijke beslissingen vindt grotendeels plaats via ambtelijke nota's en rapporten en bestuurlijke memo"s. Maar het publiek mag daarvan bijna nooit kennisnemen, omdat de Wet openbaarheid van bestuur geen informatieverstrekking toestaat over "persoonlijke beleidsopvattingen" die zijn opgenomen in "documenten, opgesteld ten behoeve van intern beraad". Een absoluut verbod op informatieverstrekking geldt ook ten aanzien van "bedrijfs- en fabricagegegevens, die door natuurlijke personen of rechtspersonen vertrouwelijk aan de overheid zijn meegedeeld". Daar komt bij, dat in de rechtspraak bij de Raad van State aan deze verboden een zeer ruime uitleg wordt gegeven.

In de hoofdstukken 7 en 8 heb ik voorgesteld de wet op deze punten te veranderen. Maar tegelijkertijd heb ik onderkend, dat de gevoeligheden erg groot zijn. Vooral de bezwaren tegen opheffing van het verbod op informatieverstrekking over "persoonlijke beleidsopvattingen" zijn diep geworteld. Dat heeft te maken met een opvatting over ambtelijke loyaliteit, die vanaf het begin van deze eeuw steeds meer opkwam, een dubieus hoogtepunt bereikte in Hitler-Duitsland, daarna in de politieke wetenschap in diskrediet raakte, maar thans in ons ambtenarenrecht nog altijd springlevend is. In een tweetal hoofdstukken over ambtelijke loyaliteit heb ik de ontwikkeling daarvan beschreven. Ook heb ik daarbij enkele voorstellen tot wetswijziging gedaan, om het ambtenarenrecht wat meer in overeenstemming te brengen met de naoorlogse ontwikkelingen in de politieke en bestuurskundige theorie. Als in de formele ambtenaarsverhouding wat meer erkenning zou worden gegeven aan modern burgerschapsdenken, dan 
wordt de openbaarheid van zogeheten "persoonlijke beleidsopvattingen" een vanzelfsprekende zaak. De burger zou dan veel meer inzicht kunnen krijgen in datgene waar bewindslieden, bestuurders en ambtenaren mee bezig zijn. Uiteraard blijven er, zoals momenteel vastgelegd in artikel 10 van de Wet openbaarheid van bestuur, een aantal geheimhoudingsgronden bestaan (: veiligheid van de staat, eerbiediging van de persoonlijke levenssfeer, etc.). Maar het zou dan niet meer gebeuren, dat stukken geheim worden gehouden omdat ze persoonlijke beleidsopvattingen bevatten.

Als, behoudens uitzonderingsgevallen, burgers inzage kunnen krijgen in memo's, nota's en rapporten van binnen de overheidsorganisatie, dan krijgt inspraak, overleg tussen overheidsfunctionarissen en burgers over de voorbereiding van beleid, aanzienlijk meer betekenis. Het overleg wordt dan ook gelijkwaardiger, waardoor burgers een eerlijker kans krijgen om invloed op het beleid uit te oefenen. Belangrijk is ook, dat individuele bestuurders en ambtenaren in het overleg met burgers kunnen zeggen wat ze zelf van de zaak vinden. Zij kunnen daarmee vertrouwen winnen, en binnen hun mandaat, of onder het voorbehoud van bestuurlijke instemming, met die burgers tot afspraken komen over de verdere aanpak. Ambtenaren kunnen op deze wijze ook rechtstreeks voor bijvoorbeeld een wijk of een buurt werkzaamheden verrichten. Zij kunnen dan worden gezien als "eigen deskundigen" van de wijk- of buurtbewoners. Voorwaarde is wel, dat aan de ambtenaren dezelfde vrijheid van meningsuiting wordt toegekend als an andere burgers. Ook daartoe is in de twee vorige hoofdstukken een voorstel tot wetswijziging gedaan.

Worden in bovenstaande zin de openbaarheid van bestuur en de vrije meningsuiting van ambtenaren vergroot, dan is het wettelijk vastleggen van een recht op inspraak niet langer een illusie. Maar ook dan nog zal ondersteuning van bepaalde groepen burgers nodig zijn. Het vorige hoofdstuk heb ik daarom afgesloten met een grondwetsvoorstel tot erkenning van het recht op overleg, waarbij aan de verschillende groepen van belanghebbenden en belangstellenden voldoende informatie en ondersteuning wordt gegeven.

De tot nu toe genoemde voorstellen hebben alle betrekking op invloed tijdens de voorbereiding van beslissingen van overheidsorganen. Daarmee kan worden bevorderd, dat die organen beslissingen nemen die overeenstemmen met de wensen van de burgers. Maar garanties zijn er niet. Wanneer een overheidsorgaan zich in een concreet geval niets van de wensen of bezwaren aantrekt, dan hebben de burgers geen mogelijkheden om direct in te grijpen. Alleen indirect, via de verkiezingen voor de Tweede Kamer, provinciale staten, of gemeenteraad, kunnen zij proberen het overheidsbelleid te corrigeren. Een andere politieke correctie-methode 
is ook nauwelijks denkbaar in een samenleving die zoveel leden kent, dat zij niet allemaal bijeen kunnen komen, om samen voor ieder afzonderlijk geval te besluiten wat de overheid moet doen of laten. In het algemeen zal de bevolking daarom wetgeving en bestuur moeten toevertrouwen aan door haar zelf gekozen volksvertegenwoordigers en democratisch benoemde bestuurders.

Toch valt er veel voor te zeggen, dat de bevolking zonodig zelf direkte zeggenschap kan uitoefenen over overheidsbeslissingen, en het doen en laten van overheidsorganen rechtstreeks kan corrigeren. En als dat zou kunnen gebeuren door middel van schriftelijke stemmingen, die niet veel vaker plaatsvinden dan gewone verkiezingen, dan moet dat toch te doen zijn. Het zou voor de samenleving nauwelijks meer inspanning en organisatie hoeven te betekenen dan gewone verkiezingen. Directe zeggenschap, op deze wijze uitgeoefend, zou het sluitstuk kunnen zijn van ons democratisch systeem. In de literatuur en in het politieke bestel van een aantal andere, ook westerse landen is die methode van directe zeggenschap bekend in twee verschillende vormen: referendum en volksinitiatief. In dit hoofdstuk zullen we de ideeën daarover, en de mogelijke verwezenlijking daarvan, wat nader bekijken.

\section{Definities ${ }^{332}$}

Het begrip referendum kan worden gedefiniëerd als een volkstemming over een besluit, dat door een staatsorgaan is genomen of wordt overwogen met betrekking tot een bepaalde zaak. Er wordt onderscheid gemaakt tussen obligatoire en facultatieve referenda.

Een abligatoir referendum wordt gehouden in gevallen waarin het staatsrecht van een land een referendum verplicht stelt, bijvoorbeeld bij grondwetswijzigingen. In plaats van obligatoir referendum wordt ook wel eens de term imperatief referendum gebruikt. Een facultatief referendum vindt plaats op initiatief van een overheidsorgaan of van een bepaald aantal kiezers, als het staatsrecht van een land dat toelaat. Het onderscheid tussen obligatoire en facultatieve referenda moet niet worden verward met dat tussen decisieve en consultatieve referenda. $\mathrm{Bij}$ een decisief referendum wordt door middel van een volksstemming een formeel besluit genomen. Bij een consultatief referendum, daarentegen, heeft de volksstemming het karakter van een raadpleging. Het betrokken overheidsorgaan houdt de

332 De definitie van referendum, de onderverdelingen daarin, en de omschrijvingen van volksinitiatief en peblisciet ontieen ik aan de dissertatie van P.C. Gilhuis, Het referendum, Alphen a/d Rijn 1981, pag. 28-29. De term imperatief referendum komt voor in het werk van Oud. (Zie de volgende noot.) 
bevoegdheid om bij het daarna te nemen besluit de uitkomst van de volksstemming naast zich neer te leggen. Men zou in het consultatieve referendum een vorm van inspraak kumnen zien, als het ook het karakter zou hebben van overleg. Maar dat is gewoonlijk niet het geval. Waar ik in de navolgende bladzijden over het referendum spreek, bedoel ik, tenzij anders blijkt, steeds het decisieve referendum.

Een referendum is iets anders dan een volksinitiatief. Want dan speelt de bevolking een veel aktievere rol in het besluitvormingsproces: Een gedeelte van de bevolking kan een voorstel doen tot het nemen van een overheidsbesluit. Soms hoeft dit volksinitiatief alleen maar door regering en/of parlement te worden behandeld . Maar het is ook mogelijk dat er, al of niet na voorafgaande behandeling door regering of parlement, een volksstemming moet worden gehouden.

Referendum en volksinitiatief hebben gemeen, dat ze altijd betrekking hebben op een besluit over een bepaalde zaak. Daarin verschillen beide van een plebisciet. Dat gaat over het al dan niet uitspreken van vertrouwen in een bepaalde persoon of groep, en niet over het aanvaarden of verwerpen van een besluit van zakelijke aard. Het plebisciet is een middel, dat meestal gehanteerd wordt door regeerders met dictatoriale neigingen, om anders dan via normale verkiezingen zichzelf een legitimatie te verschaffen voor de voortzetting van het bewind. De democratie is er zelden mee gediend. Daarom hoef ik dit middel hier verder niet te bespreken of aan te prijzen.

\section{De discussie over referendum en volksinitiatief vóór de grond- wetsherziening van 1983}

\section{De eerste voorstellen in ons land}

Rond de wisseling van de negentiende naar de twintigste eeuw leeft er in veel Europese landen belangstelling voor de mogelijkheden van referendum en volksinitiatief. Een belangstelling, die waarschijnlijk samenhangt met de opkomst van de democratische gedachte. Een gedachte, die in diezelfde tijd in de verschillende landen ook de inspiratiebron is voor pleidooien voor de invoering van het algemeen kiesrecht. In 1903 wordt in ons land een voorstel tot invoering van het referendum aanhangig gemaakt door enkele sociaal-democratische leden der Tweede Kamer onder leiding van Troelstra. Tegellijk doen zij een voorstel tot afschaffing van de Eerste Kamer. Daarvoor in de plaats willen zij het instituut van referendum. stellen. De beide voorstellen maken echter geen schijn van kans.

De staatscommissie, die in 1918 voorstellen doet tot herziening van de Grondwet, wil in twee gevallen een verplicht referendum invoeren: 
a. Bij grondswetswijziging; het referendum zou dan in de plaats komen van de verplichting tot kamer-ontbinding en de tweede lezing van de wijzigingsontwerpen door de nieuwe kamers.

b. Bij ontbreken van een bevoegde troonopvolger; het referendum zou dan uitsluitsel moeten geven over de vraag of de monarchale staatsvorm wel moet worden gehandhaafd.

Als de regering in 1921 ontwerpen indient tot wijziging van de Grondwet, heeft zij daarin alleen de verplichting tot referendum bij grondwetswijziging overgenomen. Maar de Tweede Kamer blijkt ook daar niets voor te voelen, evenmin als voor een amendement van het kamerlid Marchant, waarin het facultatieve referendum bij gewone wetgeving wordt voorgesteld. Dit amendement wordt dan in de kamer toegelicht en verdedigd door de latere staatsrecht-geleerde Oud, maar tevergeefs. Het wordt met 71 tegen 14 stemmen verworpen. Zelfs bij de sociaal-democraten blijkt het enthousiasme voor de invoering van het referendum intussen sterk bekoeld. ${ }^{333}$ Dat houdt mogelijk verband met een tweetal gebeurtenissen in 1918. De eerste betreft de uitslag van de kamerverkiezingen, die dan voor het eerst op basis van algemeen kiesrecht (voor mannen) worden gehouden. Hoewel de socialistische partijen een flinke winst boeken, verwerven zij niet meer dan zo'n dertig procent van de stemmen. Vier maanden later, in november roept Troelstra de revolutie uit, maar dat blijkt een vergissing. In SDAP-kringen komt men tot de conclusie, dat de Nederlandse bevolking toch niet zo progressief is als men steeds heeft gedacht. Van referenda verwacht men dan ook niet veel heil meer. Voor de liberalen, waartoe Marchant en Oud behoren, ligt de zaak anders. Zij zijn de grote verliezers van de verkiezingen van 1918. Dat de grote meerderheid van de kiezers loyaal blijkt te zijn aan de 'zuilen', kan men begrijpen. Maar men wil niet geloven, dat het Nederlandse volk opeens zoveel minder liberaal is gaan denken. Vandaar, waarschijnlijk, dat men in liberale kringen wel wat ziet in de mogelijkheden van het referendum.

De Nederlandse Juristenvereniging in 1921

In 1921 discussieert de Nederlandse Juristenvereniging, aan de hand van preadviezen van B.C. de Savornin Lohman en J.J. Boasson, over de vraag: Moet aan het geheele volk, of aan een territoriaal deel daarvan, of aan

333 Gillhuis, a.w., pag. 15 en noten op pag. 35; P.J. Oud, Het constitutioneel recht van het Koninkrijk de Nederlanden, deel I, Zwolle 1947, pag. 653-663; zie ook de tweede druk wan dit werk, Zwolle 1967, pag. 719-726. 
groepen daaruit, directe invloed worden toegekend op wetgeving en bestuur? Zoo ja, in welken vorm en over welke onderwerpen?

De Savornin Lohman is bepaald geen aanhanger van de leer der volkssoevereiniteit. Toch meent hij, dat verwerping van deze leer niet tegelijk ook "verwerping van directe medewerking des volks aan wetgeving en bestuur" hoeft te betekenen. Het volksinitiatief acht hij wel een verwerpelijke zaak. Maar ten aanzien van grondwetsherziening zou, wat hem betreft, het verplichte referendum met versterkte meerderheid moeten worden ingevoerd. Voor het overige zal naar zijn mening alleen van facultatieve referenda sprake kunnen zijn, en wel of op aanvraag van een groep kiezers, of op initiatief der Kroon. Dat laatste noemt hij een "Koningsreferendum". Zou de Eerste Kamer worden afgeschaft, dan moeten beide mogelijkheden worden ingevoerd. Bij handhaving van de Eerste kamer alleen het Koningsreferendum. ${ }^{334}$ Boasson heeft een andere zienswijze. Hij kan instemmen met invoering van een verplichting tot referendum bij grondwetsherziening. Maar verdere mogelijkheden voor referendum en volkinitiatief hangen af van het voortbestaan van de Eerste Kamer. Wordt deze afgeschaft, dan "zal invoering ook van het volksinitiatief niet te vermijden zijn". Bij handhaving van de Eerste Kamer is de invoering van referendum en volksinitiatief echter "wooralsnog niet gewenscht". ${ }^{335}$

De jaarvergadering van 2 juli 1921 wordt slechts door 51 juristen bezocht. Ondanks de aanwezigheid en inbreng van staatsrecht-geleerden als Krabbe, Kranenburg en Van der Pot loopt de stemming over de vraagpunten uit op een nogal kolderieke vertoning. Vraagpunt 1a luidt: Is invoering van het referendum gewenscht bij afschaffing van de Eerste kamer? Dit vraagpunt wordt door de meerderheid bevestigend beantwoord. Datzelfde gebeurt bij vraagpunt $1 \mathrm{~b}$, dat luidt: Is invoering van het referendum gewenscht ook bij behoud van de Eerste Kamer? Maar bij de stemming over de vraagpunten $2 a, 2 b$, en $2 c$ wijst de vergadering vervolgens alle mogelijke vormen van de hand. Het referendum mag volgens haar niet obligatoir mag zijn; het mag evenmin obligatoir bij belangrijke onderwerpen als grondwetsherziening en als regel facultatief zijn; en het mag tenslotte ook niet facultatief voor alle onderwerpen zijn.

$\mathrm{Na}$ de stemming vraagt Kranenburg in de vergadering het woord. Hij signaleert, dat de op de vragen $1 \mathrm{a}$ en $1 \mathrm{~b}$ gegeven antwoorden onverenigbaar zijn met de antwoorden op de vragen $2 a, 2 b$ en $2 c$. De voorzitter geeft hem gelijk, maar in plaats van de oorzaak bij de vraagstelling zelf te 
zoeken, concludeert hij, "dat de uitslag van deze stemming doet zien, dat de Vergadering niet voldoende voorbereid is om te stemmen over deze onderdelen". De Savornin Lohman stelt dan voor "om in het geheel niet te stemmen en de reeds gehouden stemming als niet gedaan te beschouwen". Dat orde-voorstel wordt door de vergadering aangenomen. Uiteindelijk wordt dus geen enkele vraag beantwoord. ${ }^{336}$

\section{Opleving van de discussie na de Tweede Wereldoorlog}

In de twintiger en dertiger jaren daalt de belangstelling voor het referendum en het volksinitiatief geleidelijk, totdat na de Tweede Wereldoorlog staatsrecht-geleerden als Oud, Van den Bergh, en Belinfante zich als pleitbezorger van het referendum opwerpen. Van den Bergh toont zich ook voorstander van de invoering van het volksinitiatief. ${ }^{337}$ Vooral aanhangers van de VVD zouden er wat van kunnen opsteken, als ze zouden lezen wat Oud, de grondlegger van hun partij, over het referendum heeft geschreven in zijn standaard-werk over ons constitutionele recht. Misschien zou het bij de parlementsleden van deze partij een beetje de koudwatervrees kunnen wegnemen, waar zij de afgelopen vijfentwintig jaar, telkens als het referendum ter sprake kwam, door bevangen werden. Oud, die in 1921 als kamerlid het amendement-Marchant verdedigde, verklaart in de beide drukken van zijn boek onomwonden, dat hij nog altijd voorstander is van de invoering van het decisieve facultatieve referendum. Wel moet naar zijn mening voor een aantal onderwerpen de mogelijkheid van referendum worden uitgesloten. Van consultatieve referenda en van volksinitiatieven moet Oud niets hebben.

In 1971 brengt de Staatscommissie van Advies inzake de Grondwet en de Kieswet haar eindrapport uit. De commissie ontraadt het invoeren van de figuur van het volksinitiatief. Naar haar mening kunnen de inpassingsproblemen van zo'n initiatief in de bestaande wetgeving, en de financiële consequenties, door het volk zelf niet voldoende worden overzien. Maar van de zeventien commissie-leden betonen acht leden zich wél voorstander van een grondwetsbepaling, die de mogelijkheid van een facultatief decisief referendum introduceert. Deze grootst mogelijke minderheid bestaat, behalve uit D66-politicus Gruijters, uit wetenschappers. Het zijn

337 P.J. Oud, a.w. (eerste druk), Zwolle 1947, pag. 655-656 en 659-662, en (tweede druk) Zwolle 1967, pag. 721-722; G. van den Bergh, referendum en volksinitiatief, opgenomen in Verzamelde staatsrechtelijke opstellen, derde bundel, Alphen a/d Rijn 1957, pag. 58-98; en A.D. Belinfante, De burger en zijn staat, Alphen a/d Rijn 1967, pag. 58-90. 
de staatsrecht-geleerden Donner, Van der Hoeven, Meuwissen, en (J.H.) Prins, de parlementair-historicus Cramer, de politicoloog Daudt, en Verbrugh, directeur van de Groen van Prinsterer-stichting. Een meerderheid van negen leden meent de regering de invoering van de mogelijkheid van referendum te moeten ontraden. Het zijn, behalve de staatsrechtgeleerden Jeukens en Simons, mensen met een meer gouvernementele achtergrond, zoals oud-premier Cals, oud-minister van Justitie Scholten, SERvoorzitter De Pous, staatsraad Kan, en oud-minister van Volkshuisvesting Witte. Als argumenten voeren zij aan, dat het referendum "slechts van bescheiden betekenis" kan zijn, terwijl daartegenover de referendumprocedure "ernstige vertragingen" kan veroorzaken, en door het referendum zelf "op belangrijke punten het wetgevend beleid kan worden doorkruist".

Toch is de commissie als geheel het eens geworden over een ontwerp voor een Grondwet-tekst, die door de regering zou kunnen worden overgenomen, als zij invoering van het referendum wenselijk mocht vinden. Die tekst komt, kort gezegd, hierop neer, dat een door de Staten-Generaal aanvaard wetsontwerp niet mag worden bekrachtigd, als bij een referendum de meerderheid van de deelnemers, "welke tenminste $30 \%$ der stemgerechtigden omvat", zich tegen het ontwerp uitspreekt. ${ }^{338}$

Het kabinet-Den Uyl volgt in 1974, in haar nota inzake het grondwetsherzieningsbeleid, de meerderheid van de staatscommissie in haar afwijzing van het volksinitiatief en het referendum. Als extra bezwaar tegen het volksinitiatief noteert de regering nog, "dat indien een stelsel van volksinitiatief bij de bevolking goed aanslaat, dit kan leiden tot een aanzienlijk beslag op de tijd van het parlement". Wat het referendum, betreft signaleert de regering een heel ander bezwaar, namelijk: "dat de praktijk van het referendum vaak een behoudende tendentie vertoont. Een vooruitstrevend wetgevingsbeleid wordt veeleer gediend door een stelsel van representatieve democratie, dat ondersteund en gestimuleerd wordt door een actieve publieke opinie". ${ }^{339}$ Het trauma van 191.8 is dan bij veel socialisten kennelijk nog altijd niet helemaal verwerkt. Dat blijkt ook als het Tweede-Kamerlid Jurgens, die in die jaren deel uitmaakt van de PPRfractie, in januari 1975 een motie ten gunste van het referendum indient. Daarin wordt de regering uitgenodigd om, op basis van de tekst van de staatscommissie, een grondwetswijziging te bevorderen, die het mogelijk makt dat de gewone wetgever het referendum invoert. Op 28 januari 1975

338 Eindrapport van de Staatscommissie inzake de Grondwet en de Kieswet, Den Haag 1971, pag. 157-161.

339 Nota inzake het grondwetsherzieningsbeleid, deel 1, zoals gepubliceerd in de reeks Naar een nieuwe grondwet? deel 12, Den Hagg 1977, pag. 27-30. 
wordt die motie door de kamer verworpen. Alleen de aanwezige leden van de fracties van de PPR, D66 (met uitzondering van Van Mierlo), de PSP en de BP, en het VVD-kamerlid Kappeyne van de Coppello stemmen voor. ${ }^{340}$

\section{De Commissie Relatie Kiezers-Beleidsvorming}

\section{Het eindrapport Relatie kiezers-beleidsvorming}

Als de voorstellen voor de algemene grondwetsherziening in tweede lezing door de Staten-Generaal worden behandeld, wordt van verschillende kanten onvrede geuit. Die betreft het feit, dat wel erg weinig van de alom erkende mankementen van ons politiek bestel door de voorstellen worden verholpen. In verband met deze kritiek kondigt de regering tijdens de plenaire behandeling in de Tweede Kamer aan, dat er een "staatscommissie van advies inzake de relatie kiezers-beleidsvorming" zal worden ingesteld. Deze commissie zal advies moeten uitbrengen over de mogelijke verbetering van de procedure voor kabinetsvorming en van de benoemingsregels voor burgemeesters en commissarissen der Koningin, maar ook over de mogelijkheden van referendum en volksinitiatief: ${ }^{341}$

Bij koninklijk besluit van 17 mei 1982 (nr. 85) wordt de staatscommissie daadwerkelijk ingesteld. Het besluit is gecontrasigneerd door Van Thijn, de minister van Binnenlandse Zaken in het dan demissionaire kabinet Van Agt II. Voorzitter van de nieuwe commissie wordt B.W. Biesheuvel, die we eerder zijn tegengekomen als voorzitter van de Commissie Heroriëntatie Overheidsvoorlichting en daarna als minister-president. Ook de nieuwe commissie wordt gewoonlijk aangeduid met de naam "Commissie Biesheuvel", wat in de praktijk wel eens aanleiding geeft tot verwarring. In deze commissie treffen we de staatsrecht-geleerden Prakke, Vis en Kortmann aan, en de bestuurswetenschapper Ringeling. Kortmann wordt in 1984 opgevolgd door Hirsch Ballin. Onder de overige leden bevinden zich enkele verklaarde voorstanders van het referendum zoals Gruijters en Jurgens. In 1984 komt daar Gilhuis bij, die in 1981 gepromoveerd is op een dissertatie over het referendum. Hierboven heb ik al naar dit proefschrift verwezen. De commissie brengt in maart 1984 een eerste rapport uit, dat een kleine veertig pagina's besteedt aan het referendum en het

340 Nota inzake het grondwetsherzieningsbeleid, deel II, zoals gepubliceerd in de reeks Naar een nieuwe grondwet? deel 13, Den Haag 1977, pag. 537 en 542.

341 Rapport Relatie kiezers-beleidsvorming, (eerste rapport), Den Haag 1984, pag. 1617. waar de nota van toelichting bij het instellingsbesluit is afgedrukt. 
volksinitiatief. In december 1985 volgt het eindrapport van de commissie, dat geheel aan deze beide onderwerpen is gewijd. ${ }^{342}$

Dit eindrapport van zo" $n$ kleine honderdveertig pagina"s is naar mijn mening een van meest lezenswaardige stukken die er in Nederland over de mogelijkheden van referendum en volksinitiatief zijn geschreven. In een goed onderbouwd betoog, waarin vrijwel alle denkbare voor- en nadelen tegen elkaar worden afgewogen, komt de commissie tot haar conclusies. Unaniem is zij voor de invoering van een facultatief decisief of beslissend referendum, zowel op nationaal als op decentraal niveau. Wel moeten volgens haar een aantal onderwerpen van de mogelijkheid van referendum worden uitgezonderd. ${ }^{343}$

Wat het consultatieve of raadplegende referendum betreft, denkt de commissie verdeeld. De ene helft vindt, dat invoering daarvan op nationaal niveau wenselijk is. Onder de voorstanders bevinden zich Biesheuvel, Ringeling, Hirsch Ballin, Jurgens, en ook Gilhuis, hoewel deze laatste zich eerder, in zijn dissertatie, zeer critisch over dit soort referendum heeft uitgelaten. ${ }^{344}$ De andere helft, onder wie Prakke, Vis en Gruijters, vindt dat de invoering van het raadplegend referendum niet is an te bevelen. Unaniem is de commissie echter van oordeel, dat op decentraal niveau de $\mathrm{nu}$ al bestaande mogelijkheden om raadplegende referenda te houden, moeten worden gehandhaafd.

Een meerderheid van de commissie is voor invoering van de mogelijkheid van volksinitiatief, zowel op nationaal als op decentraal niveau. Tot die meerderheid behoren Biesheuvel, Ringeling, Gilhuis, Jurgens, Prakke en Vis. Een minderheid, waartoe Gruijters en Hirsch Ballin behoren, is tegen invoering. ${ }^{345}$

Waar de commissie unaniem of in meerderheid voorstander van invoering is, formuleert $\mathrm{zij}$ concrete voorstellen tot aanvulling van de Grondwet. Ook geeft zij "elementen voor een wettelijke regeling", waarin de voorgestelde grondwetsbepalingen nader worden uitgewerkt. Op deze voorstellen en teksten kom ik in de paragrafen 5 en 6 van dit hoofdstuk uitvoeriger terug. Eerst wil ik hier nog ingaan op de uitgangspunten en algemene overwegingen waarop de commissie haar standpunten heeft gebaseerd.

De commissie constateert allereerst dat, onder meer door inspraak, de participatie in de praktijk van ons bestuurlijk systeem een steeds vastere

342 Rapport Relatie kiezers-beleidsvorming, (eindrapport), Den Haag 1985.

343 Eindrapport, pag. 61, resp. 108.

344 Gillhuis, a.w. pag. 291.

345 Eindrapport, pag. 63 en 109. 
voet heeft gekregen. Maar dat vindt zij niet voldoende. Het lijkt me goed, om op dit punt de overwegingen van de commissie integraal te citeren:

"Echte invloed door middel van participatie blifft dikwijls ontbreken, ondanks de schijn van tegendeel die wordt gewekt. Hierdoor kunnen er gevoelens van frustratie ontstaan en kan de motivatie om aan het participatieproces deel te nemen gaan ontbreken. Een beslissend referendum kan naar het oordeel van de commissie een middel zijn waarmee de participatie wordt doorgevoerd tot op het punt waar de beslissing genomen wordt en waardoor reële invloed ontstaat die de betrokkenheid van de burger bij de politiek ten goede komt. Ook het volksinitiatief verdient naar het oordeel van de meerderheid van de commissie vanuit de participatiegedachte aanbeveling. Het volksinitiatief kan de betrokkenheid bij het politieke besluitwormingsproces zeer bevorderen. De burger kan op een actieve manier participeren in de besluitvorming zonder dat hij een besluit van de regering hoeft af te wachten. Mogelijke gevoelens van vervreemding van het politieke proces kunnen worden verminderd wanneer de burgers zelf een gewenste zaak op de politieke agenda kunnen plaatsen. Het huidig petitierecht vervult in zekere mate ook deze rol, maar deze rol zou door middel van het volksinitiatief in belangrijke mate versterkt kunnen worden". 346

De commissie wijst in haar rapport nadrukkelijk op het primaat van het vertegenwoordigend stelsel. Dit stelsel noemt zij, als vorm van democratie in Nederland, een onomstreden bezit. In dat stelsel ligt de bescherming van minderheden in verdraagzaamheid en in mogelijkheden tot "uitruil". Die vindt plaats als minderheden elkaar aan een meerderheid helpen door elkaars minderheidsstandpunten te steunen. Maar er zijn ook schaduwzijden. Het proces van beleidsvorming is erg complex geworden. Dat kan in een enkel geval leiden tot beleid dat zich niet verdraagt met de wensen van een belangrijk deel van de bevolking. De kans daarop is toegenomen doordat de opstelling van de volksvertegenwoordiging tegenover de regering minder dualistisch is geworden. Door coalitie-afspraken kan een afwijking ontstaan tussen de beslissingen van het parlement en de wil van de meerderheid van de bevolking. Ook los van deze afspraken kan in het parlement een "excessieve uitruil van standpunten" plaatsvinden over twee niet of nauwelijks met elkaar verband houdende onderwerpen, waardoor er voor beide een meerderheid ontstaat, die geen voldoende draagvlak in de 
maatschappij kan vinden. En, omgekeerd, kunnen door coalitie-afspraken in het parlement zaken van de agenda worden afgevoerd waar burgers grote waarde aan hechten. Referendum en volksinitiatief bieden in deze situaties een mogelijkheid tot correctie. Let wel: correctie op de onvolkomenheden van het vertegenwoordigend stelsel. ${ }^{347}$

Erkenning van het primaat van dat stelsel betekent voor de commissie, dat referenda moeten worden beperkt tot wetsvoorstellen. Dan wordt voorkomen, dat aan de kiezers beslissingen worden gevraagd, waarover het parlement zich niet heeft uitgesproken.

De practische betekenis van referendum en volksinitiatief zal naar de mening van de commissie niet afhankelijk zijn van de hoeveelheid referenda en volksinitiatieven die zullen worden gehouden. De preventieve werking is minstens zo belangrijk. Regering en parlement zullen bij de besluitvorming steeds rekening houden met de mogelijkheid van een referendum of volksinitiatief. In de discussie en besluitvorming over een wetsvoorstel zal daarom getracht worden zoveel mogelijk tegemoet te komen aan de bij de kiezers levende opvattingen. En de mogelijkheid van een volksinitiatief kan tot gevolg hebben, dat regering en parlement een onderwerp dat om politieke redenen anders niet of met veel vertraging zou worden behandeld, eerder ter hand nemen. ${ }^{348}$

Tegen het nemen van beslissingen bij referendum of volksinitiatief wordt vaak aangevoerd, dat bij dergelijke volksstemmingen beslissingen geîsoleerd, los van een samenhang met ander gevoerd beleid, worden genomen. De commissie is daar niet zo bang voor. De discussies en campagnes die aan een volksstemming voorafgaan "vallen niet in een politiek vacuüm". De kiezers zullen dan bij hun meningsvorming ook leiding verwachten van hun politieke leiders. ${ }^{349}$

\section{De reactie van het kabinet op het eindrapport}

Het duurt tot maart 1988 voordat het kabinet zijn standpunt over het eindrapport van de Staatscommissie van Advies inzake de Relatie KiezersBeleídsvorming in een notitie aan de Tweede Kamer meedeelt. ${ }^{350} \mathrm{De}$ notitie is ondertekend door premier Lubbers en de minister van Binnenlandse Zaken Van Dijk. Het kabinet blijkt weinig te voelen voor de voorstellen van de staatscommissie. Men erkent, dat met participatie kan worden bereikt; dat in de besluitvorming beter rekening wordt gehouden 
met alle betrokken belangen en dat de aanvaarding van besluiten wordt bevorderd. Maar waarom zouden we, wat dit aangaat, nu ontevreden moeten zijn? De bewindslieden vinden, "dat de huidige participatiemogelijkheden, die voornamelijk uit allerlei vormen van inspraak bestaan, reeds in belangrijke mate ertoe kunnen bijdragen dat deze doelstellingen worden bereikt". Als het beslissend referendum en het volksinitiatief zouden worden ingevoerd, dan brengt dat "in die mate lasten voor in ieder geval de overheid" met zich mee, dat het wenselijk zou zijn, dat er slechts een beperkt gebruik van wordt gemaakt. ${ }^{351}$ Maar er is een nog veel fundamenteler bezwaar, menen zij. Want: "Naarmate aan de burgers meer directe, beslissende invloed op de vorming van het overheidsbeleid wordt gegeven, zal het risico toenemen, dat aan het vertegenwoordigend stelsel afbreuk wordt gedaan". Niet iedere inbreuk op dat stelsel is al op voorhand ontoelaatbaar, geven de bewindslieden toe. Maar er moeten dan wel "goede, overtuigende argumenten" zijn om zo'n inbreuk te rechtvaardigen. En die heeft men nog niet gehoord. ${ }^{352}$

Het kabinet spreekt in de notitie zijn twijfel uit over de voorspelling van de staatscommissie, dat de invoering van het beslissende referendum en volksinitiatief een "preventieve werking" zal hebben. De dreiging van een volkstemming zal regering en parlement slechts zelden behoeden voor misstappen of achteloosheid. Daarvoor zijn de drempels voor een succesvol referendum of volksinitiatief te hoog, meent het. Ook betwijfelt het kabinet, of door de discussies en campagnes die aan de volkstemming voorafgaan, de kiezers de eventuele samenhang met ander gevoerd beleid steeds in dezelfde mate zullen onderkennen en zullen laten meewegen als de volksvertegenwoordigers. Het vindt, dat de staatscommissie niet voldoende het gevaar onderkent, dat goed georganiseerde belangen- en actiegroepen het referendum en volksinitiatief gaan gebruiken voor eenzijdige behartiging van deelbelangen. ${ }^{353}$

Op grond van al deze overwegingen spreekt het kabinet zich uiteindelijk uit tegen het decisieve referendum. Wel merkt het op, dat de staatscommissie, vanuit haar visie op de wenselijke mate van participatie van de burgers in het bestuur en op de tekortkomingen van het vertegenwoordigend stelsel, haar referendum-voorstel "in het algemeen op goed doordachte wijze heeft uitgewerkt". Het kabinet is ook tegen invoering van het volksinitiatief. Het heeft "de standpunten van de voor- en tegenstanders

352 Id. pag. 6.

353 Id. pag. 10-11. 
van het volksinitiatief in de commissie overwogen", en "is daarbij tot de conclusie gekomen, dat de argumenten van de tegenstanders het kabinet meer aanspreken dan die van de voorstanders". ${ }^{354}$

Invoering van het decisieve referendum en het volksinitiatief op het niveau van de lagere overheden ziet het kabinet al evenmin zitten. Op zich is het beleid van provincies en gemeenten voor burgers well beter te overzien. Maar er dreigt een ander gevaar. Stel je eens voor, schrijft het kabinet, "de reactie die vernietiging of onverbindendheid van een bij volksstemming gesanctioneerd besluit bij de kiezers zal oproepen"'. Voorlichting vooraf over de mogelijkheid van hoger toezicht of rechterlijk ingrijpen "zal het optreden van een dergelijke reactie wellicht kunnen inperken, doch veel zal dit waarschijnlijk niet zijn". ${ }^{355}$

Wat het raadplegende referendum betreft, waarover de stemmen in de staatscommissie staakten, is het kabinet wel positief. Het staat op het standpunt, "dat het raadplegend referendum beter in het vertegenwoordigend stelsel past dan het wetgevingsreferendum of het volksinitiatief". Het is een middel "dat in een beperkt aantal gevallen, waarvan de aard overigens moeilijk vooraf aan te duiden is, van nut zou kunnen zijn. ${ }^{356}$

\section{De behandeling van het eindrapport in de Tweede Kamer}

Het duurt bijna een jaar voordat de vaste Tweede-Kamercommissie voor Binnenlandse Zaken toekomt aan de behandeling van het eindrapport Relatie kiezers-beleidsvorming en het kabinetsstandpunt daarover. Op 21 februari 1989 stelt de kamercommissie een lijst van dertig vragen vast, die aan het kabinet wordt voorgelegd. Al op 28 februari komt een lijst van antwoorden binnen, die ondertekend is door minister Van Dijk. ${ }^{357}$ Een week later, op 6 maart, volgt de openbare behandeling in de commissievergadering. ${ }^{358}$ Premier Lubbers en minister Van Dijk zijn daarbij aanwezig.

Het CDA-standpunt wordt in een uitvoerig betoog toegelicht door De Kwaadsteniet. Men is in die kring tegen de invoering van het beslissend referendum en het volksinitiatief, zowel op nationaal niveau als op het

Id. pag. 13,16 en 26 .

355 Id. pag. 24 .

356 Id. pag. 19 en 26.

357 TK 1988-1989, 18807, nrs. 10 (lijst van vragen) en 11 (lijst van antwoorden). Ik wil aan de inhoud van beide stukken hier geen bijzondere aandacht schenken, omdat de vragen grotendeels 'vragen naar de bekende weg' zijn, en in de antwoorden van het kabinet geen nieuwe gezichtspunten naar voren komen.

Hand.TK 1988-1989, UCV 38 pag. 1-32. 
niveau van de lagere overheden. "Het is onverenigbaar met ons vertegenwoordigend stelsel", beklemtoont de CDA-woordvoerder. Wat de mogelijke invoering van het raadplegend referendum betreft, wil men eventuele voorstellen op eigen merites beoordelen, zonder al "bij voorbaat tegenstander" te zijn. . $359^{\circ}$

\section{Stoffelen}

Namens de PvdA-fractie vertolkt Stoffelen een veel positiever standpunt ten opzichte van het beslissend referendum en het volksinitiatief. Hij legt de vergadering de volgende drie "kernvragen" voor:

1. "Vinden wij het wel of niet geboden om de onmacht van de kiezers in ons land te verkleinen en hun invloed te vergroten?"

2. "Vinden wij het referendum en het volksinitiatief, zoals voorgesteld door de commissie-Biesheuvel, verantwoorde en effectieve middelen om die invloed van de kiezers te vergroten?"

3. "Welke andere verantwoorde en effectieve middelen ter vergroting van de invloed van de kiezers ziet men of zien degenen die geheel of nagenoeg volledig, zoals het kabinet doet, de voorstellen van de commissie-Biesheuvel afwijzen?"

De eerste twee vragen beantwoordt Stoffelen eenduidig met ja! De voorstellen van de Commissie Biesheuvel hebben, zo verklaart hij, "onze hartelijke instemming". Alleen over het raadplegend referendum is de PvdA "niet of nauwelijks enthousiast". En wat het volksinitiatief betreft, zou zij willen, dat de Tweede Kamer daarbij een recht van amendement zou krijgen. Gelet op de beantwoording van de eerste twee vragen vindt Stoffelen, dat $h i j$ geen antwoord hoeft te geven op de derde vraag. Die vraag is speciaal bestemd voor het kabinet en voor de kamerfracties die de eerste vraag bevestigend, maar de tweede vraag ontkennend beantwoorden. ${ }^{360}$

\section{Wiebenga}

Na Stoffelen komt de VVD-er Wiebenga aan het woord. Wiebenga houdt een historisch getint betoog, waarin hij nogal zijn best doet om zich tot halve waarheden te beperken. Hij verklaart, dat de VVD tegenstander is van het beslissend referendum en van het volksinitiatief. Om dit standpunt te onderbouwen, citeert hij uit de Handelingen van de Tweede Kamer van november 1921, waar de socialistische leider Troelstra zich uitspreekt 
tegen de invoering van het beslissend referendum. Wat Wiebenga er niet bij vertelt, is dat Troelstra toen reageerde op een voorstel van de liberalen in de Tweede Kamer, om het beslissend referendum in te voeren. Hij vertelt ons al evenmin, dat dat voorstel toen werd verdedigd door Oud, de man die later meer dan vijftien jaar lang de grote leider van de VVD zou zijn. Iets verderop in zijn betoog spreekt Wiebenga zich ook uit tegen het raadplegend referendum, en dan vindt hij de mening van Oud opeens wel de moeite waard. "Terecht zei prof. Oud, dat het raadplegend referendum de volksvertegenwoordiging in een onmogelijke positie brengt", houdt Wiebenga de vaste kamercommissie voor ${ }^{361}$ Oud schrijft dat inderdaad in zijn handboek Het constitutioneel recht van het koninkrijk der Nederlanden. Maar Wiebenga vertelt er niet bij, dat Oud in datzelfde werk, één pagina eerder, zich nog altijd voorstander toont van de invoering van het beslissend referendum, al vindt Oud intussen wel, dat een aantal onderwerpen daarvan zou moeten worden uitgezonderd. ${ }^{362}$

\section{Kohnstamm}

Veel positiever dan Wiebenga laat Kohnstamm, de woordvoerder van D66, zich uit over de voorstellen in het eindrapport van de staatscommissie. D66 is voorstander van de invoering van het beslissend referendum, zowel op nationaal niveau als op het niveau van de lagere overheden. Ook op dat lagere niveau moet de mogelijkheid van een beslissend referendum door de nationale wetgever worden geregeld. Het raadplegend referendum is in de ogen van Kohnstamm een "fopspeen". En, zegt hij, D66 is "op dit ogenblik" ook geen voorstander van de invoering van het volksinitiatief. Men meent in deze kring, dat het voor belangengroepen veel eenvoudiger is om een kamerlid te bewegen een initiatief-wetsvoorstel in te dienen. ${ }^{363} \mathrm{Op}$ zich is dat natuurlijk juist. Maar Kohnstamm en zijn fractiegenoten zien daarbij toch een belangrijk verschilpunt over het hoofd: Over een volksinitiatief heeft niet het parlement het laatste woord, maar het kiezerskorps.

\section{De kleinere fracties}

Voor de kleinere fracties wordt het woord gevoerd door Van den Berg (SGP), Lankhorst (PPR), Schutte (GPV) en Leerling (RPF). Lankhorst laat weten, dat zijn fractie achter alle voorstellen in het eindrapport Relatie kiezers-beleidsvorming staat, en evenals de helft van de staatscommissie

362 Oud, a.w., tweede druk (1967), deel I, pag. 721-722.

363 Hand.TK 1988-1989, UCV 38, pag. 12-13, 23 en 27. 
ook voorstander is van het raadplegend referendum. De gereformeerde partijen verschillen van mening. Van den Berg en Leerling verwerpen het referendum en het volksinitiatief, omdat aanvaarding in hun ogen een erkenning van de leer van de volkssoevereiniteit is. De soevereiniteit van het staatsgezag "berust niet bij het volk, maar bij God als de Bron van alle gezag en recht", licht Van den Berg toe. ${ }^{364}$ Ook Schutte, van het GPV, wijst het volksinitiatief af, maar staat veel minder afwijzend tegenover het beslissend referendum. Zoals we eerder hebben gezien, behoorde zijn partijgenoot Verbrugh in 1971 al tot de minderheid in de staatscommissie Cals/Donner, die voor invoering van dit referendum pleitte. Schutte verwerpt de leer van de volkssoevereiniteit even hartgrondig als Van den Berg en Leerling. Maar dat staat los van zijn mening over het referendum. Hij signaleert, dat ook de commissie Biesheuvel "haar voorstellen over de onderscheiden vormen van referendum niet ideologisch heeft willen optuigen met de leer van de volkssoevereiniteit". En waarom zou men ook? Er zijn onderwerpen, zegt Schutte, "die zo diep ingrijpend zijn en ook zo direct elke burger persoonlijk raken dat het gewenst kan zijn dat de verantwoordelijkheidsvraag ook expliciet aan de kiezers zelf kan worden voorgelegd. Ik zou mij dit bijvoorbeeld kunnen voorstellen als de wetgever ooit nog eens zou besluiten tot legalisering van de euthanasie". Schutte wil dan wel een extra drempel voor het houden van een referendum: Een referendum-initiatief moet gesteund worden door een derde deel van het aantal leden van de Staten-Generaal. ${ }^{365}$

Tegenover de woorden van Schutte klinkt het anti-volkssoevereiniteitsargument van Van den Berg en Leerling tegen het referendum wel een beetje onoprecht. Is de leer van de volkssoevereiniteit hier werkelijk aan de orde? De Savornin Lohman heeft al in zijn preadvies voor de NJV in 1921 uitgelegd, dat die leer niets met het vraagstuk van het al dan niet invoeren van het referendum te maken heeft. Ik kan mij niet aan de indruk onttrekken, dat het verschil in standpunten tussen SGP en RPF enerzijds, en GPV anderzijds, op iets anders is terug te voeren: hun kijk op de Nederlandse bevolking zelf. In de ogen van SGP en RPF is die, met uitzondering van een klein aantal (gereformeerde) uitverkorenen, in de macht van het kwade'. Een referendum kan dan natuurlijk tot niets goeds leiden. GPV-ers zien zichzelf misschien ook wel als uitverkorenen, maar zij hebben niet zo'n negatief beeld van de rest van de bevolking. Als er echt een beroep op het geweten wordt gedaan, dan heeft men er bij het GPV kennelijk wel

Id. pag. 15 . 
vertrouwen in, dat het Nederlandse volk zijn "christelijk karakter" zal tonen.

\section{Moties}

De toelichting die premier Lubbers en minister Van Dijk in de vergadering op het kabinetsstandpunt geven, bevat ten opzichte van de eerder besproken kabinetsnotitie van 28 maart 1988 weinig nieuws. Men voelt niets voor het beslissend referendum en het volksinitiatief. Door Stoffelen uitgedaagd om aan te geven, met welke andere verantwoorde en effectieve middelen het kabinet de invloed van de kiezers dan wel wil vergroten, wijst Lubbers op de Wet openbaarheid van bestuur en de Wet nationale ombudsman. Van Dijk voegt daar nog "het in gang zijnde proces om de administratieve rechtspraak te verbeteren" aan toe, en "de bepaling in de nieuwe Gemeentewet die ertoe strekt dat gemeenten een inspraakverordening opstellen". Daar kan de Nederlandse bevolking het voorlopig toch wel mee doen. ${ }^{366}$

Stoffelen dient twee moties in. De eerste is medeondertekend door Kohnstamm en Lankhorst. De regering wordt daarin uitgenodigd, "voorstellen tot wijziging van de Grondwet in te dienen die het mogelijk maken tot invoering van een correctief wetgevingsreferendum te komen". ${ }^{367}$ In de tweede motie, die alleen door Lankhorst is medeondertekend, wordt de regering uitgenodigd, om "voorstellen tot wijziging van de Grondwet in te dienen die het mogelijk maken tot invoering van een volksinitiatief te komen". ${ }^{368}$ In de vergadering van de Tweede Kamer van 11 april 1989 wordt de motie voor invoering van het referendum verworpen. Voor de motie stemmen PvdA, D66, PPR en PSP. De motie voor invoering van een volksinitiatief wordt die dag eveneens verworpen. Voorstander zijn alleen de fracties van PvdA, PPR en PSP. ${ }^{369}$

366 Id. pag. 16-22. Een voorstel tot algehele herziening van de WOB is dan inmiddels door de Tweede Kamer in behandeling genomen. Zoals ik in hoofdstuk 5 heb toegelicht, wordt in dat voorstel de openbaarheid van bestuur juist beperkt, i.p.v. verruimd.

367 TK $1988-1989,18807$, nt. 12.

368 Id. Mr. 13.

369 Hand. TK 1988-1989, pag. 65-5656. 


\section{Referendum, volksinitiatief, en de discussie over staatkundige, bestuurlijke en staatsrechtelijke vernieuwing}

\section{De Commissie Deetman}

Rond de verkiezingen voor de Tweede Kamer en de vorming van een nieuwe regering wordt in 1989 een algehele bezinning op 'het vraagstuk van de staatkundige, bestuurlijke en staatsrechtelijke vernieuwing' bepleit. Vooral D66-lijsttrekker Van Mierlo heeft erop gehamerd, dat we ons allemaal om dit vraagstuk zouden moeten "bekreunen". De meeste politieke partijen voelen zich aangesproken. En zo wordt in een bijna unanieme kameruitspraak het presidium van de Tweede Kamer verzocht een voorstel te doen tot nadere uitwerking van het vraagstuk. Resultaat is, dat er een bijzondere Commissie Vraagpunten wordt ingesteld. Kamervoorzitter Deetman wordt zelf voorzitter van de commissie, die naar hem dan ook de Commissie Deetman zal worden genoemd. Verder nemen er een elftal kamerleden zitting in, waaronder Van Mierlo. Op 16 november 1990 biedt de commissie een rapport van zevenenzestig pagina's aan de Tweede Kamer aan: het Rapport Bijzondere Commissie Vraagpunten. ${ }^{370}$

Het rapport besteedt aandacht aan een groot aantal onderwerpen, zoals: kabinetsformatie, het kiesstelsel voor de Tweede Kamer, de positie van de Eerste Kamer, verkiezing of benoeming van burgemeesters. Ook wordt als vraagpunt de wenselijkheid van referendum en volksinitiatief aan de orde gesteld. De commissie komt hierover tot een zeer algemene vraagstelling: "Voors en tegens van correctief wetgevingsreferendum, consultatief referendum en volksinitiatief zouden nog eens kunnen worden geinventariseerd en op hun consequenties kunnen worden beoordeeld. Daarbij waren de minimumvoorwaarden in de overwegingen te betrekken waaronder deze zouden kunnen worden gehouden, resp. toegestaan" ${ }^{371}$

Als het rapport op 19 en 20 maart 1991 in de Tweede kamer wordt besproken, noemt Wiebenga, als woordvoerder voor de VVD, de vraagstelling "wat slapjes". Hij memoreert, dat de kamer nog in 1989 , na een uitgebreide discussie over het eindrapport van de Commissie Biesheuvel, het beslissend referendum heeft afgewezen. Zijn fractie, zegt hij, vindt "het niet zinvol, te onderzoeken wat al onderzocht is". Op 20 maart dient Wiebenga een motie in, warin de kamer wordt verzocht om als haar mening uit te spreken, "aan verder onderzoek natar de figuur van het referendum geen behoefte te hebben". Op 21 maart wordt de motie door de 
Tweede Kamer aangenomen, met steun van de leden van de VVD, de SGP, de RPF, en het CDA, met uitzondering van CDA-er Deetman. ${ }^{3 n}$ Daarmee is de geest voorlopig weer in de fles gestopt.

Op 13 olktober 1992 gebeurt er in de Tweede Kamer iets onverwachts bij de algemene politieke en financiële beschouwingen over de rijksbegroting. Als D66-woordvoerder Van Mierlo zijn onvrede uit, dat de kamer studies over het referendum afhoudt, voelt Brinkman, de fractieleider van het CDA, zich aangesproken. De burgers zijn mondiger geworden en hebben geen referendum nodig, vindt Brinkman. "Maar" voegt hij eraan toe, "als collega Van Mierlo graag zou zien dat een van de subcommissies van de Commissie vraagpunten dit onderwerp nog eens nader bestudeert, willen wij ons daar niet tegen verzetten". Van Mierlo weet niet wat hij hoort. "Het kan zijn dat ik het verkeerd heb begrepen, omdat het te mooi was om zo maar ineens op je af te krijgen. Is het CDA ervoor dat de commissieDeetman de werkgroep die zich oorspronkelijk over het vraagpunt van het referendum zou buigen, vraagt om daarover alsnog te rapporteren?", wil hij weten. Brinkman daagt Van Mierlo uit om met "een meer juridisch uitgewerkt voorstel voor het referendum" te komen. Van Mierlo antwoordt, dat er al een paar uitgewerkte voorstellen van de Commissie Biesheuvel liggen. In de discussie, die daarop volgt, wordt niet duidelijk of Brinkman nu moeite heeft met détails in die voorstellen, of met de principiële kanten van het referendum. ${ }^{373}$

In elk geval is het debat voor de Commissie Deetman aanleiding om de Tweede Kamer op 4 november 1992 een briefje te schrijven. Daarin wordt voorgesteld om alsnog aan de al eerder ingestelde (externe) Commissie De Koning te verzoeken "het vraagpunt inzake het referendum" nader te bestuderen. Die studie zou dan toegespitst moeten worden op het "correctief wetgevingsreferendum". Hoewel VVD-woordvoerder Wiebenga op 19 november in de Tweede Kamer uitvoerig tegen dit voorstel fulmineert, wordt het op 24 november aangenomen, met de steun van de PvdA, het CDA, de Centrumdemocraten, D66, de RPF, het GPV en Groen Links. ${ }^{374}$

372 Hand. TK 1990-1991, pag. 3524, 3609 en 3666, en bijlage 21427, nr. 8 (motie).

373 Hand.TK 1992-1993, pag 388-389.

374 Hand TK 1992-1993, pag. 1817-1826 en 1873, en bijlage 21427, nr. 26. 


\section{Commissie De Koning}

De Commissie De Koning, die eerst op 27 april 1993 aan de Tweede Kamer een rapport over een aantal andere vraagpunten aanbiedt, levert op 7 oktober 1993 haar rapport over het referendum af. ${ }^{325}$ Uit de inhoud van dit rapport van negen pagina's blijkt, dat de commissie nauwgezet het rapport van de Commissie Biesheuvel en de daarover in de Tweede Kamer gevoerde debatten heeft bestudeerd. Deze studie brengt de Commissie De Koning tot de slotsom, om de volgende voordelen van de invoering van het referendum te erkennen:

- Burgers krijgen de mogelijkheid mee te beslissen over hen direct rakende zaken.

- Door de mogelijkheid van een referendum wordt de 'politieke subcultuur' van uitruilprocedures doorbroken.

- Een referendum kan bijdragen tot versterkte (formele en materiële) legitimatie van het overheidsbeleid.

- De wetenschap dat een wetsvoorstel aan een referendum kan worden onderworpen kan bijdragen aan de zorgvuldigheid van de wetgeving.

Daartegenover signaleert de commissie de volgende nadelen:

- Als een uitspraak van de Staten-Generaal zou worden gecorrigeerd door een referendum, zou dat een vertrouwensbreuk tussen kiezers en gekozenen kunnen betekenen. Het vertegenwoordigend stelsel komt daardoor mogelijk in het gedrang.

- Bij referendum is geen keuze tussen meervoudige alternatieven mogelijk, evenmin als compromisvorming.

- Kiezers zullen mogelijk de deskundigheid missen om een voorstel op de juiste waarde te schatten.

- De wetgevingsprocedure gaat extra lang duren als er een referendum wordt gehouden.

- In dat geval kost de wetgevingsprocedure ook extra geld.

- Een uitspraak van de kiezers kan worden bepaald door oorzaken die buiten het onderwerp van het referendum gelegen zijn, bijvoorbeeld als een regering al bij voorbaat heeft gezegd te zullen aftreden als de uitslag van het referendum voor haar niet gunstig uitvalt.

Alles tegen elkaar afwegende komt een meerderheid van vier leden van de commissie tot "een positieve aanbeveling" om het correctieve wetgevingsreferendum in te voeren. Ook op lokaal niveau vindt deze meerderheid 
invoering van een correctief bindend referendum wenselijk. Twee leden van de commissie, namelijk voorzitter De Koning en oud-lid van de Raad van State J.M. Polak, staan afwijzend tegenover de invoering van een correctief referendum, zowell op nationaal als op lokaal niveau. Deze beide leden vinden "dat na de parlementaire behandeling van het rapport van de commissie-Biesheuvel in maart 1989 zich niet zodanige feiten en omstandigheden hebben voorgedaan die het opnieuw plaatsen van dit onderwerp op de politieke agenda rechtvaardigen".

De meerderheid van de Commissie De Koning vindt het voorstel tot invoering van een correctief wetgevingsreferendum van de Commissie Biesheuvel "een innerlijk consistent en sluitend systeem, dat veel van de vaak gehoorde bezwaren tegen het instrument referendum als zodanig wegneemt". Alleen zou men naar de mening van deze meerderheid de drempel voor een zgn. "inleidend verzoek" voor zo'n referendum moeten ophogen van 10.000 naar 20.000 kiezers. Op het voorstel van de Commissie Biesheuvel tot invoering van het referendum op lokaal niveau heeft men verder geen aanmerkingen.

Op 23 november 1993 stuurt mevrouw Dales, minister van Binnenlandse Zaken, een brief naar de Tweede Kamer. ${ }^{376} \mathrm{Zij}$ deelt daarin mee, dat het kabinet met belangstelling kennis heeft genomen van het rapport van de Commissie De Koning over het correctief referendum. Zonder zich expliciet voor invoering van het referendum uit te spreken, is het kabinet wel van mening "dat in de voorstellen van de Commissie-Biesheuvel garanties zijn ingebouwd om aantasting van het representatief stelsel te voorkomen". Bovendien ziet het in deze voorstellen mogelijkheden om de participatie van burgers te vergroten. Alles bij elkaar "acht het kabinet een hernieuwde discussie over het onderwerp zinvol". En wat het lokale referendum betreft, mocht ooit tot invoering daarvan worden overgegaan, dan zou de vormgeving daarvan naar de mening van het kabinet niet aan de gemeenten moeten worden gelaten, maar zou een algemene wettelijke regeling moeten worden getroffen.

\section{De slotdebatten in de Tweede Kamer}

In december 1993 vinden in de Tweede Kamer de slotdebatten over de staatkundige, bestuurlijke en staatsrechtelijke vernieuwing plaats. Aan de orde komen onder meer: het vraagstuk van de benoemde of gekozen burgemeester, het kiesstelsel van de Tweede Kamer, de methode van kabinets- 
formatie, de positie van de Eerste Kamer, en de wenselijkheid van invoering van het referendum. Ik zal mij hier beperken tot een aantal kenmerkende uitspraken die over het referendum en volksinitiatief zijn gedaan.

Woordvoerder Jurgens van de PvdA-fractie spreekt zich onomwonden uit voor de invoering van het referendum, zowel op nationaal als op lokaal niveau, en voor invoering van het volksinitiatief. Tezamen vormt dit voor de PvdA één van de vier pakketten van maatregelen, waarmee de positie van de kiezers moet worden versterkt. ${ }^{377}$ Ook Groen Links, zo deelt woordvoerder Willems mee, is voorstander van invoering van het referendum en het volksinitiatief. En Wolffensperger laat namens D66 weten, dat deze partij invoering van het correctief referendum gewenst vindt. Dat zou volgens hem dan mogelijk moeten zijn bij aangenomen wetten, raadsbesluiten, en misschien ook bij planologische kernbeslissingen. ${ }^{378}$ Een tegenovergesteld standpunt wordt vertolkt door de VVD-woordvoerder Wiebenga. De kern van het bezwaar van zijn partij tegen het referendum is, "dat de afweging van het totaalbeleid ontbreekt". Aan de kiezers wordt een veto gegeven op een bepaald onderdeel van het beleid. "Daarmee kun je zeggen dat de leuke dingen aanvaard worden en de impopulaire zaken niet", houdt Wiebenga de kamer voor. En, voegt hij er aan toe: "Met prof. Oud wil ik hier stipuleren, dat in een democratie de samenhang van de beslissingen wezenlijk is". ${ }^{379}$ Ook nu weer vergeet Wiebenga te vermelden, dat Oud zijn leven lang een voorstander van het correctieve wetgevingsreferendum is geweest.

Het lijkt er even op, dat in het debat een stukje politieke theorie wordt ontwikkeld, als Leerling, spreker voor de RPF, zonder nadere toelichting opmerkt, dat de "volksstemming" voortkomt uit de idee van de volkssoevereiniteit. Schutte, van het GPV, interrumpeert, en vraagt of Leerling dat even kan uitleggen. Leerling brengt daarop naar voren, dat bij verkiezingen de kiezers mandaat geven aan de gekozenen. Als dit mandaat niet op de juiste wijze wordt gebruikt, zal de afrekening bij de volgende verkiezingen plaatsvinden. Als de kiezers tussendoor ook nog de gelegenheid zouden krijgen om "ja" of "nee" tegen bepaalde overheidsbeslissingen te zeggen, doet dat afbreuk aan de betekenis van het parlement als vertegenwoordiger van het volk, aldus Leerling. Schutte vindt die opvatting op zich legitiem. Maar hij heeft, zegt hij, nog geen antwoord gekregen op de vraag waarom het referendum een uiting zou zijn van volkssoevereiniteit. 
We kennen immers verschillende vormen van volksinvloed. Een gekozen parlement is eén vorm, het referendum is een andere vorm. Wat is nu het principielle verschil tussen die twee vormen, wil Schutte weten. Waarom is de ene vorm niet een uiting van volkssoevereiniteit, en de andere vorm wel? Leerling komt in zijn uiteindelijke antwoord niet verder dan als credo uit te spreken, dat in ons parlementaire stelsel de invloed van het volk op de besluitvorming "in dit land het maximaal aanvaardbare" is. ${ }^{380}$

Hoe de CDA-fractie over het referendum denkt, blijft aanvankelijk een beetje duister. Woordvoerder Mateman begint met te zeggen, dat het referendum zeer wel verenigbaar is met ons vertegenwoordigend stelsel. Maar vervolgens haalt hij, zoals Wolffensperger hem in een interruptie voor de voeten werpt, "een boekenkast van socialistische schriftgeleerden overhoop" om tegenargumenten te geven. Wat vindt het CDA nu zelf, wil Wolffensperger weten. Uiteindelijk bekent Mateman, "dat de CDA-fractie met deze argumenten en bij de huidige stand van zaken, geen behoefte heeft aan een referendum". ${ }^{381}$

\section{"Valse hoop"}

De houding van het CDA komt enkele dagen later, op 7 december, opnieuw aan de orde, als Schutte namens het GPV het woord voert over de staatkundige, bestuurlijke en staatsrechtelijke vernieuwing. Schutte verwijt het CDA, dat het in november 1992 "valse hoop" heeft gewekt, toen er in de Tweede Kamer werd gesproken over een opdracht aan de Commisie De Koning, om het referendum nader te bestuderen. Het CDA stemde toen in met die opdracht, zonder dat het zijn eerdere bezwaren tegen zo'n nadere studie liet varen. En, voegt Schutte daar met het woord van de Spreukendichter aan toe, "de uitgestelde hoop krenkt het hart". Die opmerking krenkt, op haar beurt, Mateman. "Als wij gelegenheid geven tot een studie, wegen wij het serieus af. Dan is het niet aan u om dat te beoordelen", interrumpeert hij. Dat Schutte zijn verwijt "omringt met een aantal wild gekozen bijbelcitaten" vindt Mateman "echt beneden peil". ${ }^{382}$ Maar van hem horen we niet wat dan wél de motieven waren, waarom de CDAfractie in november 1992 opeens instemde met een nadere studie naar het referendum, terwijl zij anderhalf jaar eerder nog de motie-Wiebenga had gesteund, die zo'n studie afwees. 
Als Brinkman, later op dezelfde dag, voor het CDA het woord voert, wordt die vraag ook niet echt opgehelderd. Wel zegt hij te hopen, dat uit de verschillende bijdragen aan de debatten duidelijk is geworden, dat voor het CDA het referendum "een zaak van argumenten van praktische aard is". Naar zijn mening wordt de positie van de volksvertegenwoordiging "onduidelijk" bij invoering van het referendum. Het CDA wil daarom liever proberen "om de authentieke rol van de vertegenwoordigende organen te verbeteren", en "om de positie van inspraak en overleg in het voortraject te versterken". Hoe Brinkman zich dat voorstelt, vertelt hij niet. Wel noemt hij nog enkele praktische bezwaren tegen referenda: $\mathrm{Ze}$ vertragen het tempo van wetgeving, en de mogelijkheid van referenda werken "niet altijd bevorderlijk" voor het tot stand komen van coalitieafspraken op de verschillende bestuursniveau's. Ook de afbakening van de onderwerpen die aan een referendum kunnen worden onderworpen, is voor het CDA een praktisch probleem. Is daar wel een definitie van te geven; vraagt Brinkman zich af. Maar hij besluit zijn toespraak met de opmerking, dat het referendum misschien ook onvermoede aspecten heeft "die een aansporing zouden kunnen zijn tot voortgezet denken daarover". ${ }^{383}$

\section{Moties}

Intussen zijn op 2 december 1993 in de Tweede Kamer drie moties over het referendum ingediend. De eerste motie, afkomstig van Jurgens (PvdA), noemt ook het volksinitiatief. De regering wordt in deze motie verzocht "een voorstel van wet te bevorderen dat in de Grondwet de mogelijkheid van een dergelijk referendum (lees: correctief wetgevingsreferendum, HK) opent, en daarbij tevens de mogelijkheid van een legislatief volksinitiatief te betrekken". ${ }^{384}$ De twee andere moties, die worden ingediend door Wolffensperger (D66), gaan minder ver. In de eerste wordt de regering verzocht "voorstellen te doen voor een grondwetswijziging die een correctief referendum op lokaal niveau mogelijk maakt, alsmede voor een algemene wettelijk regeling daarvan". In de tweede wordt de regering verzocht "voorstellen te doen voor een zodanige wijziging van de Grondwet, dat een correctief referendum op nationaal niveau mogelijk wordt"

Op 8 december 1993 maakt Schutte duidelijk waar het GPV in de discussie over het referendum staat. Hij zegt geen hoge verwachtingen van 
de mogelijkheid van een referendum te hebben. Maar hij heeft evenmin doorslaggevende argumenten om bij voorbaat te zeggen dat hij een correctief wetgevingsreferendum als aanvulling op ons vertegenwoordigend stelsel niet zinvol vindt. "Regeren is mensenwerk, dus onvolkomen", zegt Schutte, "Daarom zijn allerlei vormen van volksinvloed nuttig en nodig". In dat kader ziet hij ook "de mogelijkheid om via het correctief referendum uit te spreken dat de wet zo niet ingevoerd moet worden". Tegen die achtergrond vindt Schutte de voorbereiding van wetgeving inzake het correctief wetgevingsreferendum op landelijk en lokaal niveau "de moeite waard". Hij heeft daarbij een duidelijke voorkeur voor de moties van Wolffensperger boven die van Jurgens, "want in die laatste motie wordt het volksinitiatief mijns inziens te gemakkelijk in één adem genoemd met het referendum". ${ }^{386}$

Op 22 december 1993 zal er over de drie moties worden gestemd. De motie Jurgens wordt dan verworpen. Alleen de PvdA, Groen Links, D66 en de Centrumdemocraten stemmen voor. Als kort daarna de beide moties van Wolffensperger aan de orde komen, vraagt Van Mierlo het woord. Hij heeft uit de woorden van Brinkman begrepen, dat er bij het CDA geen principiële belemmeringen zijn voor een nadere overweging van het invoeren van het referendum, "maar dat er bezwaren zijn van praktische aard waarover nader zou kunnen worden gesproken". In dat licht vraagt Van Mierlo de kamer, de twee moties te mogen aanhouden "om een nadere gedachtenwisseling op gang te kunnen brengen". VVD-woordvoerder Wiebenga keert zich tegen dit opportunistiche ordevoorstel. "De partij die aandrong op het debat over de Nederlandse politiek moet ook bereid zijn om de twee moties van de heer Wolffensperger in stemming te brengen", houdt hij de kamer voor. Als over het ordevoorstel hoofdelijk gestemd wordt, stemmen de kamerleden van de VVD, de reformatorische partijen, en Groen Links tegen. Met 84 tegen 30 stemmen wordt het voorstel aangenomen. ${ }^{387}$ Daarmee is in de Tweede Kamer een zoveelste verwerping van de referendum-gedachte voorkomen, althans uitgesteld.

\section{Het kabinet-Kok}

De laatste ontwikkelingen met betrekking tot de referendumgedachte in de Nederlandse politiek zijn te vinden in het regeerakkoord en de regeringsverklaring van het kabinet-Kok. In het regeerakkoord lezen we in hoofdstuk 5 Overheid en samenleving, onder a Bestuurlijke vernieuwing, de 
passage: "De invoering van een correctief wetgevingsreferendum op centraal en decentraal niveau wordt voorbereid in wetsvoorstellen ter concrete uitwerking en tot wijziging van de Grondwet". De op 31 augustus 1994 uitgesproken regeringsverklaring licht dit toe. "De regering wil de burger nadrukkelijker betrekken bij de publieke zaak", zegt premier Kok, en hij vervolgt: "Belangrijke middelen hiervoor zijn:

- de invoering van een correctief referendum

- onderzoek naar de wijziging van het kiesstelsel

- vergroting van de invloed van de burger op de politieke machtsvorming

Een ministeriële commissie zal hiertoe snel aan het werk gaan". ${ }^{388}$

Wat het resultaat van dat werk zal zijn, moet hier buiten beschouwing blijven. Wel wil ik in de twee volgende paragrafen de al vaker genoemde voorstellen van de Commissie Biesheuvel voor het wetgevingsreferendum en het volksinitiatief wat meer in de schijnwerper plaatsen. Dat helpt misschien voorkomen, dat men op het ministerie van Binnenlandse Zaken moeite gaat doen om opnieuw het wiel uit te vinden.

\section{Het referendum volgens de Commissie Biesheuvel}

De instelling en de werkzaamheden van de Staatscommissie van Advies inzake de Relatie Kiezers-Beleidsvorming, ook wel Commissie Biesheuvel genoemd, zijn hierboven in paragraaf 3 van dit hoofdstuk beschreven. Ik zal nu wat meer inhoudelijk ingaan op de voorstellen die deze commissie gedaan heeft om het referendum en het volksinitiatief concreet vorm te geven. In deze paragraaf bespreek ik de voorstellen tot invoering van het beslissend referendum.

\section{Wie neemt het initiatief tot een referendum?}

De commissie heeft zich bij haar voorstel voor referenda op nationaal niveau allereerst beraden over de vraag wie het initiatief tot het houden van een referendum zou mogen nemen. Er bestaan verschillende systemen: In Ierland en Oostenrijk bijvoorbeeld, ligt het recht van initiatief bij de regering of de meerderheid van het parlement. In Denemarken ligt dit recht bij een bepaalde minderheid in het parlement. En in Italië en Zwitserland tenslotte ligt het bij een bepaald aantal kiezers.

388 Kabinet-Kok, Keuzen voor de toekomst, Den Haag 1994, resp. pag. 59 (regeerakkoord) en pag. 15 (regeringsverklaring). 
De commissie heeft een duidelijke voorkeur voor dit laatste systeem. Dat zou het meest stroken met de bedoeling die de commissie aan het referendum wil geven: een middel tot correctie en aanvulling van het vertegenwoordigend stelsel. In het Ierse en Oostenrijkse systeem kan het referendum gemakkelijk worden gebruikt om verantwoordelijkheden af te schuiven, om tegenstellingen binnen een regeringspartij te neutraliseren, of om de oppositie de wind uit de zeilen te nemen. Het Deense systeem, waarin het recht van initiatief bij een parlementaire minderheid ligt, heeft als nadeel, dat minderheden in het parlement bij elke gelegenheid met een referendum kunnen dreigen. Wordt echter, zoals in Italië en Zwitserland, het recht van initiatief bij de kiezers zelf gelegd, dan is 'oneigenlijk' gebruik van het referendum praktisch uitgesloten. ${ }^{389}$ Welke voorwaarden de commissie aan een kiezersinitiatief wil stellen, zal dadelijk bij de beschrijving van de referendum-procedure aan de orde komen

\section{Over welke onderwerpen is een referendum mogelijk?}

Welke onderwerpen moeten aan een referendum kunnen worden onderworpen? Zoals we hebben gezien, was dat in het kamerdebat over de staatkundige, bestuurlijke en staatsrechtelijke vernieuwing voor CDA-leider Brinkman een heel moeilijke vraag. Hij vroeg zich zelfs af, of de onderwerpen wel konden worden afgebakend. De Commissie Biesheuvel kiest voor een systeem, waarin alle aanvaarde wetsvoorstellen aan een referendum kunnen worden onderworpen, behoudens een aantal in de Grondwet opgesomde uitzonderingen. Die uitzonderingen zouden moeten zijn:

1. Wetgeving inzake aangelegenheden het koningschap of het koninklijk huis betreffende.

2. Wetgeving tot uitvoering van verdragen of van besluiten van volkenrechtelijke organisaties.

3. Wetgeving inzake de vaststelling van de hoogte van bij de wet aangewezen geldelijke voorzieningen ten behoeve van personen die een bij de wet aangewezen openbaar ambt bekleden of bekleed hebben, en hun nabestaanden.

De commissie heeft ook overwogen om begrotingswetten, belastingwetten, en wetten inzake de regeling van inkomsten en uitgaven van de sociale zekerheid uit te zonderen van de mogelijkheid van referendum. Maar zij vindt, "dat juist in deze onderwerpen voor de kiezers het grootste belang van een referendum kan zijn gelegen". De commissie spreekt daarbij het 
vertrouwen uit "dat de kiezers hun recht om een uitspraak te doen met dezelfde verantwoordelijkheid jegens de publieke zaak zullen uitoefenen als zij dat van de door hen gekozen vertegenwoordigers verwachten". 390

\section{Een gekwalificeerde meerderheid?}

De Commissie Biesheuvel heeft zich afgevraagd, of wetsvoorstellen die volgens de Grondwet alleen met een gekwalificeerde meerderheid door de Staten-Generaal aanvaard kunnen worden, vervolgens bij referendum met een gewone meerderheid kunnen worden aanvaard. De commissie vindt dat inderdaad wenselijk. Want anders zou een wetsvoorstel dat met de vereiste meerderheid is aangenomen, en vervolgens bij referendum met een gewone meerderheid is aanvaard, alsnog als verworpen moeten worden beschouwd. Wat wijziging van de Grondwet zelf betreft, meent de commissie, dat een referendum pas aan de orde kan zijn nà de tweede lezing in de Staten-Generaal. Anders zou er over éen en hetzelfde wijzigingsvoorstel twee keer een referendum kunnen worden uitgelokt. ${ }^{391}$

\section{Opschortende werking?}

In de huidige wetgevingsprocedure wordt een wetsvoorstel gewoonlijk binnen een paar dagen nadat het door de Eerste Kamer is aanvaard, door het staatshoofd en een of meer bewindslieden ondertekend. Het voorstel heeft daarmee kracht van wet gekregen. Daarna kan de wet in het Staatsblad worden geplaatst, en in werking treden. Bij de opzet van het referendum, zoals de Commissie Biesheuvel deze voor ogen heeft, zal deze regeling gewijzigd moeten worden. De bekrachtiging van een wetsvoorstel dat aan een referendum kan worden onderworpen, zal pas kunnen plaatsvinden als zeker is dat er geen referendum zal komen, of als bij referendum zich geen meerderheid tegen het wetsvoorstel heeft uitgesproken. In de meeste gevallen zal een dergelijk uitstel niet bezwaarlijk hoeven te zijn. Maar er zijn ook gevallen denkbaar waarin de bekrachtiging en inwerkingtreding van een door de Staten-Generaal aanvaard wetsvoorstel geen uitstel kunnen lijden. De commissie beveelt dan de regeling aan, die op dit punt in Denemarken en Zwitserland geldt: In een wetsvoorstel met een spoedeisend karakter wordt zelf de bepaling opgenomen, dat het voorstel direct na aanvaarding door de Staten-Generaal kan worden bekrachtigd en in werking kan treden. Maar de mogelijkheid van een referendum blijft ook 
dan bestaan. Wordt bij een eventueel referendum de wet door de kiezers verworpen, dan vervalt zij van rechtswege. ${ }^{392}$

\section{De behandeling van het verzoek}

De Commissie Biesheuvel stelt zich voor, dat voor een referendum schriftelijk een inleidend verzoek moet worden ingediend bij de minister van Binnenlandse Zaken. Dat moet gebeuren binnen drie weken nadat in de Staatscourant bekend is gemaakt dat de Eerste Kamer het desbetreffende wetsvoorstel heeft aanvaard. Het verzoek moet vergezeld gaan van de geldige steunverklaringen van ten minste 10.000 kiezers. De minister moet binnen een week op het verzoek beslissen. Hij mag het verzoek afwijzen, als het te laat is ingediend of niet vergezeld is van voldoende geldige steunverklaringen, of als het een wetsvoorstel betreft dat van de mogelijkheid van referendum is uitgezonderd. Ook mag de minister het verzoek afwijzen, als de regering meedeelt dat zij het wetsvoorstel niet zal bekrachtigen. Tegen een afwijzende beslissing zou volgens de commissie dezelfde beroepsmogelijkheid open moeten staan als de Kieswet geeft tegen beslissingen over de geldigheid van kandidatenlijsten. ${ }^{393}$

Als de minister instemt met het verzoek, begint de tweede fase van de procedure. In de Staatscourant, via een persbericht en via radio en televisie wordt onverwijld aangekondigd dat aan de kiezers de gelegenheid zal worden geboden steun te verlenen aan het initiatief om een referendum te houden. Voor een kiezer is het dan gedurende zes weken mogelijk, om op de gemeentesecretarie of op een postkantoor in de eigen woonplaats aan te geven dat hij het initiatief ondersteunt. Hij zal zich daar bij een bepaald loket moeten melden, waar een ambtenaar hem een handtekeningenlijst zal voorleggen. Behalve zijn handtekening zal de kiezer ook naam, adres en geboortedatum op de lijst moeten plaatsen, en zich moeten legitimeren. Aldus moeten binnen de termijn van zes weken op alle lijsten tezamen ten minste 300.000 handtekeningen worden geplaatst. De lijsten worden opgestuurd naar het ministerie van Binnenlandse Zaken, waar de lijsten worden gecontroleerd.

Om de indiener van het inleidend verzoek optimale kansen te bieden om kiezers aan te sporen hun handtekening te gaan zetten, wordt hem zendtijd op radio en televisie verleend. Die zendtijd bedraagt een vast aantal minuten. Als er meer dan eén inleidend verzoek wordt ingediend, wordt de zendtijd over de indieners verdeeld.

393 Id. pag. 55-58. 
$\mathrm{Na}$ de controle van de handtekeningen zal de minister van Binnenlandse Zaken via de Staatscourant bekendmaken, of al dan niet aan de vereisten voor het houden van een referendum is voldaan. Tegen een mededeling dat miet aan de vereisten is voldaan, staat weer dezelfde beroepsmogelijkheid open als tegen de afwijzing van een inleidend verzoek. ${ }^{394}$

\section{De volksstemming}

Wanneer onherroepelijk is komen vast te staan dat het vereiste aantal van 300.000 handtekeningen is gehaald, kan de derde fase een aanvang nemen. Bij koninklijk besluit moet de dag worden vastgesteld waarop de volksstemming zal plaatsvinden. Deze mag niet later worden gehouden dan vijf maanden na de dag waarop de minister van Binnenlandse Zaken heeft meegedeeld dat aan de vereisten voor de volksstemming is voldaan. In de tussenliggende tijd wordt op gelijke wijze als in de tweede fase, aan de indiener(s) van het inleidende verzoek zendtijd op radio en televisie verleend. Ook de politieke partijen die in het parlement zijn vertegenwoordigd, krijgen dan zendtijd op radio en televisie, boven de zendtijd die hen normaal al ter beschikking wordt gesteld. Dit om te verzekeren, dat in die periode van maximaal vijf maanden echt alle partijen met zetels in het parlement, hun standpunt over het referendum in de media kunnen bepleiten.

Iedereen die kiesrecht heeft, wordt opgeroepen om aan de volksstemming deel te nemen. Het wetsvoorstel wordt geacht te zijn verworpen, als een meerderheid van het aantal opgekomen kiezers tegen het voorstel stemt en deze meerderheid ten minste $30 \%$ van het aantal kiesgerechtigden bedraagt. Het wetsvoorstel vervalt dan van rechtswege. Als het wetsvoorstel niet door een meerderheid van de opgekomen kiezers wordt verworpen, dan is de regering verplicht het voorstel tot wet te bekrachtigen. Zou de regering de vrijheid hebben om niet te bekrachtigen, dan zou dat in essentiële mate afbreuk doen aan het beslissende karakter van de door de Commissie Biesheuvel voorgestelde vorm van referendum.

Wordt het wetsvoorstel wel door een meerderheid verworpen, maar omvat die meerderheid minder dan $30 \%$ van het totaal aantal kiesgerechtigden, dan is in de visie van de commissie geen uitspraak met rechtsgevolg uit het referendum voortgekomen. In dat geval kan de regering op de gebruikelijke wijze beslissen over de bekrachtiging. ${ }^{995}$ 
Het referendum op provinciaal en gemeentelijk niveau

De Commissie Biesheuvel is unaniem niet alleen voor de mogelijkheid van referenda op nationaal niveau, maar ook voor de mogelijkheid van referenda op provinciaal en gemeentelijk niveau. Daartoe zal niet alleen de Grondwet moeten worden gewijzigd, maar ook de Provinciewet en de Gemeentewet. Want, zo vindt de commissie, voor de inwoners van alle provincies en gemeenten moeten in beginsel dezelfde mogelijkheden voor referenda bestaan.

Provinciale en gemeentelijke referenda zouden de kiezers in staat moeten stellen om door provinciale staten of door een gemeenteraad of deelgemeenteraad genomen beslissingen ongedaan te maken. Ook negatieve beslissingen van deze vertegenwoordigende organen zouden bij referendum verworpen moeten kunnen worden. Wel wil de commissie een aantal besluiten van de mogelijkheid van referendum uitzonderen. De commissie denkt daarbij aan:

- besluiten van staten of de raad genomen als beroepsinstantie;

- besluiten gericht op het voor kennisgeving aannemen van nota's e.d.;

- besluiten betreffende de vaststelling van de hoogte van geldelijke voorzieningen voor individuele of kleine groepen ambtsdragers en gewezen ambtsdragers, alsmede hun nabestaanden;

- besluiten over individuele benoemingen, ontslagen of schorsingen.

In de opvatting van de Commissie Biesheuvel kunnen besluiten van andere provinciale en gemeentelijke organen niet aan een referendum worden onderworpen. Opvallend is, dat de commissie er geen moeite mee heeft, dat provinciale staten en gemeenteraden zelf de mogelijkheden van referendum kunnen beperken door bevoegdheden te delegeren aan andere organen en aan commissies. Op die wijze kunnen er toch weer grote ongelijkheden tussen de verschillende provincies en gemeenten onstaan.

De procedure die de commissie schetst voor referenda in provincies en gemeenten is in grote lijnen dezelfde als die voor referenda op nationaal niveau. Iedere kiezer die een besluit van provinciale staten of gemeenteraad aan een referendum wil onderwerpen, kan daartoe binnen drie weken na het besluit een inleidend verzoek bij gedeputeerde staten resp. het college van burgemeester en wethouders indienen. Dit verzoek zal vergezeld moeten gaan van geldige steunverklaringen van tenminste zoveel kiezers als overeenkomt met $50 \%$ van de kiesdeler in de betreffende provincie of gemeente, gebaseerd op de kiesdeler bij de laatst gehouden staten- resp. raadsverkiezingen. 
Wanneer positief op het inleidend verzoek is beslist, volgt cen termijn van zes weken, waarin kiezers de gelegenheid krijgen kenbaar te maken dat zij een referendum wensen. Aan de vereisten voor het houden van een referendum is voldaan, wanneer een aantal kiezers dat overeenkomt met ten minste twee keer de kiesdeler in de betreffende provincie of gemeente, deze wens ondersteund heeft.

Het referendum wordt gehouden uiterlijk drie maanden na het moment waarop bekend is gemaakt dat aan de vereisten voor het houden van het referendum is voldaan. Het besluit van provinciale staten of gemeenteraad wordt geacht bij het referendum te zijn verworpen, als een meerderheid van de opgekomen kiezers tegen heeft gestemd. Maar die meerderheid moet dan wel minstens even groot zijn als de meerderheid van het aantal bij de laatste staten- resp. raadsverkiezingen opgekomen kiezers. Een bij referendum verworpen besluit vervalt van rechtswege. Als het besluit niet wordt verworpen, treedt het terstond in werking, voorzover er geen hogere goedkeuring nodig is. ${ }^{396}$

\section{Het volksinitiatief volgens de Commissie Biesheuvel}

Zoals ik eerder in dit hoofdstuk heb opgemerkt, is de Commissie Biesheuvel niet unaniem in haar oordeel over de wenselijkheid van invoering van het volksinitiatief. Een meerderheid van zeven leden, waaronder Biesheuvel zelf, is voorstander van invoering. Een minderheid van vijf leden is er tegen. Deze leden willen niet tornen aan een "wezenselement" van ons parlementair stelsel, namelijk dat wetten tot stand komen door overeenstemming tussen regering en volksvertegenwoordiging. Bij een volksinitiatief kan dat element worden omzeild. Niettemin vindt de minderheid van de commissie, dat de uitwerking en vormgeving van het volksinitiatief, zoals de meerderheid die voorstelt, "goed doordacht" is.:397 Ik zal deze uitwerking en yormgeving nu kort beschrijven.

\section{Onderwerpen voor een volksinitiatief}

Onderwerpen die van de mogelijkheid van referendum zijn uitgesloten, moeten volgens de meerderheid van de Commissie Biesheuvel ook van de mogelijkheid van volksinitiatief worden uitgesloten. In de vorige paragraaf heb ik deze onderwerpen genoemd: Wetgeving inzake het koningschap of 
het koninklijk huis, wetgeving tot uitwoering van internationaal-rechtelijke verplichtingen, en wetgeving inzake geldelijke voorzieningen voor ambtsdragers en hun nabestaanden. Daarnaast wil de meerderheid van de commissie de mogelijkheid van volksinitiatief ook uitsluiten ten aanzien van voorstellen voor algemene begrotingswetten. Deze voorstellen moeten volgens art. 105 lid 2 van de Grondwet "door of vanwege de Koning" worden ingediend. Het parlement heeft hier zelf niet eens het recht van initiatief. Dus hoeft het volk dat ook niet te hebben, vinden de betreffende commissieleden. ${ }^{398}$

\section{De behandeling van het werzoek}

In de gedachtengang van de commissie-meerderheid kan een comité of een persoon een inleidend verzoek voor het aanhangig maken van een volksinitiatief indienen bij de minister van Binnenlandse Zaken. Dat verzoek moet vergezeld gaan van een uitgewerkt wetsvoorstel met een memorie van toelichting. Het verzoek moet voorts de namen bevatten van drie, althans een oneven aantal personen (en eventueel drie plaatsvervangers) die zullen worden belast met de verdediging van het voorstel in het parlement. Alleen personen die kiesgerechtigd zijn kunnen tot verdedigers van een volksinitiatief-voorstel worden aangewezen. Deze verdedigers mogen echter geen lid zijn van de regering, de Staten-Generaal of de Raad van State.

Het inleidend verzoek dient vergezeld te gaan van de geldige steunverklaringen van ten minste 10.000 kiezers. De initiatiefnemers moeten hiervoor zelf formulieren vervaardigen volgens een wettelijk voorgeschreven model. Die formulieren moeten de essentie van het initiatief-voorstel en de namen van de indieners vermelden, en de namen van hen die het voorstel in het parlement zullen verdedigen. De kiezers die een steunverklaring ondertekenen, moeten hun naam, adres en geboortedatum vermelden. Ondertekening van het formulier hoeft niet te betekenen, dat men adhesie met het voorstel betuigt. Het vermenigvuldigen, verspreiden en inzamelen van de formulieren zijn aangelegenheden waarvoor de initiatiefnemers zelf zorg moeten dragen.

De minister van Binnenlandse Zaken mag een inleidend verzoek alleen afwijzen als er niet genoeg geldige steunverklaringen waren bijgesloten, of als het voorstel niet aan de vormvereisten voldoet, bijvoorbeeld omdat er geen memorie van toelichting is bijgevoegd. Hij hoeft niet te beoordelen, of het voorstel over een onderwerp gaat dat aan het recht van volksinitiatief is onttrokken. Dat kan later gebeuren, als de Staten-Generaal 
het voorstel behandelen. Tegen een afwijzende beslissing van de minister zou beroep moeten openstaan op een overeenkomstige wijze als is voorgesteld bij het referendum. ${ }^{399}$

Als positief op het inleidend verzoek is beslist, kunnen de kiezers gedurende drie maanden op handtekeningenlijsten in gemeentesecretarieën en postkantoren aangeven dat zij het volksinitiatief ondersteunen. Zij geven daarmee tegelijk aan, dat zij de aangewezen personen machtigen om het initiatief-voorstel in het parlement te verdedigen en het eventueel, op voorstel van de Tweede Kamer, te wijzigen. Tijdens deze periode krijgen de initiatiefnemers zendtijd op radio en televisie toegewezen, net als bij de steunverwerving voor een referendum. Voor het volksinitiatief zijn de geldige handtekeningen van ten minste 300.000 kiezers nodig, die daarbij ook hun naam, het adres en de geboortedatum moeten vermelden. Na afloop van de termijn van drie maanden worden de lijsten ter controle opgestuurd naar het ministerie van Binnenlandse Zaken. Wanneer het vereiste aantal handtekeningen is gehaald, deelt de minister dit mee in de Staatscourant, en kan het initiatief-voorstel door de initiatiefnemers worden ingediend bij de Tweede Kamer. ${ }^{400}$

\section{Parlementaire behandeling}

De meerderheid van de Commissie Biesheuvel vindt, dat de Tweede Kamer een eenmaal ingediend initiatief-voorstel binnen een jaar moet behandelen. Allereerst moet de kamer over het voorstel een advies vragen aan de Raad van State. Deze Raad betrekt in zijn advies de vraag of het voorstel een 'uitgezonderd onderwerp' betreft, of (anderszins) in strijd is met de Grondwet, het Statuut of een internationaal-rechtelijke verplichting. De Tweede Kamer beslist daarna bij meerderheid over het antwoord op deze vraag.

Als de kamer constateert dat geen van de zojuist genoemde belemmeringen aanwezig is, dan volgen voorbereidend onderzoek en openbare behandeling van het voorstel. De aangewezen verdedigers hebben dan het recht de vergaderingen van de Tweede Kamer (en van de Eerste Kamer) bij te wonen en aan de beraadslagingen deel te nemen. Ook de regering zou bij de kamerbehandeling aanwezig moeten zijn en haar standpunt duidelijk moeten markeren. $\mathrm{Zij}$ zou echter niet verder mogen gaan dan de aanneming van het voorstel aan te bevelen of te ontraden. In de opvatting van de meerderheid van de commissie heeft de Tweede Kamer ten aanzien 
van een volksinitiatief geen recht wan amendement. Wel zou de kamer voorstellen tot wijziging mogen doen. Alleen wijzigingsvoorstellen waar een kamermeerderheid voor is, kunnen door de verdedigers van het initiatief-voorstel worden overgenomen. Voor het overige hebben de verdedigers niet het recht om het voorstel te wijzigen. Anders zouden zij het er zelf op kunnen aanleggen, om uiteindelijk over een ander voorstel een volkstemming uit te lokken dan het voorstel waarvoor 300.000 handtekeningen zijn verzameld.

Als de Tweede Kamer met het initiatief-yoorstel instemt, wordt het aan de Eerste Kamer toegezonden. Deze kamer moet de behandeling van het voorstel binnen drie maanden afronden. Als ook zij met het voorstel instemt, wordt het aan de regering ter bekrachtiging voorgelegd.

\section{De volksstemming}

Er hoeft geen volksstemming te worden gehouden als de beide kamers van de Staten-Generaal instemmen met het volksinitiatief-voorstel, en de regering het aldus aangenomen voorstel tot wet bekrachtigt. De initiatiefnemers hebben dan, naar we mogen aannemen, hun doel bereikt.

Er moet wel een volksstemming plaatsvinden, als de Tweede Kamer het initiatief-voorstel verwerpt, maar ten minste een vijfde deel van het grondwettelijk aantal leden voor het voorstel stemt. Als zoveel kamerleden het voorstel steunen, dan kan het volgens de meerderheid van de Commissie Biesheuvel niet zomaar terzijde worden geschoven. Ook moet er een volksstemming worden gehouden, als de Tweede Kamer verzuimt om het voorstel binnen een jaar te behandelen. Wordt het voorstel door de kamer aanvaard, dan gaat het naar de Eerste Kamer. Deze kamer kan het voorstel ofwel verwerpen, of uitdrukkelijk aanvaarden, of stilzwijgend aanvaarden. Dit laatste gebeurt, als de kamer de behandeling van het voorstel niet binnen drie maanden na toezending afrondt. Verwerpt de Eerste Kamer het voorstel, dan moet er een volksstemming plaatsvinden. Aanvaardt de kamer het voorstel, en weigert de regering vervolgens het voorstel binnen een maand na ontvangst te bekrachtigen tot wet, dan moet er eveneens een volksstemming plaatsvinden. ${ }^{401}$

De meerderheid van de Commissie Biesheuvel heeft binnen deze procedure nog een variant bedacht: Als de Tweede Kamer het initiatief-voorstel verwerpt, maar dit voorstel wel de steun van ten minste een vijfde deel van het aantal kamerleden krijgt, dan wordt er niet meteen een volksstemming 
gehouden. Eerst krijgen de kamerleden twee weken de tijd om tegenvoorstellen in te dienen. Als zo'ń voorstel de steun van een kamermeerderheid verwerft, dan wordt het tegelijk met het volksinitiatief-voorstel aan de Eerste Kamer toegezonden. Als deze kamer het door de Tweede Kamer aanvaarde tegenvoorstel verwerpt, dan wordt alleen over het volksinitiatief-voorstel een volksstemming gehouden. Maar kiest de Eerste Kamer voor het tegenvoorstel, dan wordt dit tezamen met het volksinitiatiefvoorstel aan de kiezers voorgelegd. Die moeten dan de keuze maken. ${ }^{402}$

Wat betreft de regels voor de volksstemming kan ik verwijzen naar wat ik hierover in de vorige paragraaf ten aanzien van het referendum heb geschreven. Dit betekent onder meer, dat in de opvatting van de commissie een volksstemming uiterlijk vijf maanden nadat de noodzaak daartoe is gebleken, moet plaatsvinden. Stemt een meerderheid, bestaande uit ten minste $30 \%$ van de kiesgerechtigden, vóór het volksinitiatief-voorstel, dan is het aangenomen en wordt het terstond bekrachtigd (03 $^{3}$

\section{Grondwetswijzing bij volksinitiatief}

Wetsvoorstellen tot wijziging van de Grondwet kunnen alleen worden aanvaard, als uiteindelijk in beide kamers van de Staten-Generaal ten minste een tweederde meerderheid daar voor stemt. Zoals we in de vorige paragraaf hebben gezien, wil de Commissie Biesheuvel een soortgelijke eis niet stellen aan referenda over grondwetswijzigingen. Want dergelijke referenda betreffen altijd voorstellen die in de Tweede en Eerste Kamer al door een tweederde meerderheid zijn aangenomen. Bij een volksstemming over een referendum zou een gewone meerderheid daarom voldoende moeten zijn om de grondwetswijziging door te laten gaan. Maar bij volksinitiatieven ten aanzien van de Grondwet, waar de vraag aan de orde is of de Grondwet moet worden gewijzigd tegen de zin van bevoegde staatsorganen in, ligt de zaak anders. Daar moet naar de mening van de meerderheid van de commissie wel de eis worden gesteld, dat een volksinitiatief alleen kan worden aanvaard met een tweederde meerderheid van de kiezers. Die meerderheid moet, net als bij de aanvaarding van andere volksinitiatieven, ten minste $30 \%$ van het totale aantal kiesgerechtigden omvatten. Vindt in de procedure van een volksinitiatief tot grondwetsherziening een volksstemming plaats na de eerste lezing, dan blijft de tweede lezing in de

402 Id. pag. 75.

403 Id. pag. 75-76. 
Staten-generaal achterwege. De kiezers hebben dan immers zelf al een uitspralak over de voorgestelde grondwetswijziging gedaan. ${ }^{404}$

\section{Het volksinitiatief op provinciaal en gemeentelijk niveau}

De meerderheid van de Commissie Biesheuvel is ook voorstander van het volksinitiatief op provinciaal en gemeentelijk niveau. Want, vindt zij, ook op die niveaus kan het gebeuren, dat vraagstukken waarover geen overeenstemming tussen de coalitiepartners mogelijk blijkt, ter zijde worden geschoven. De kans hierop lijkt zelfs groter in provincies en gemeenten waar een programcollege functioneert, dan waar gewerkt wordt met een afspiegelingscollege. Het volksinitiatief kan bijdragen tot een grotere betrokkenheid van de burgers bij de politieke besluitvorming, doordat zij zelf besluitvorming kunnen afdwingen over door hen gewenste zaken. Evenals het referendum zou, zo vindt de meerderheid van de commissie, het volksinitiatief voor alle provincies en gemeenten uniform geregeld moeten worden in de Provinciewet, resp. de Gemeentewet.

De kiezers zouden dus zelf voorstellen aanhangig moeten kunnen maken bij provinciale staten of (deel)gemeenteraad. Wel moet de mogelijkheid van volksinitiatief worden uitgesloten voor onderwerpen waarover op provinciaal of gemeentelijk niveau ook geen referendum mogelijk is. Dat zijn:

- zaken die behoren tot de beslissingsbevoegdheid van gedeputeerde staten, de commissaris van de Koningin, het college van burgemeester en wethouders en van de burgemeester;

- onderwerpen waarover provinciale staten of gemeenteraad besluiten als beroepsinstantie;

- besluiten gericht op het voor kennisgeving aannemen van nota's, rapporten e.d.;

- besluiten betreffende de vaststelling van de hoogte van geldelijke voorzieningen voor individuele of kleine groepen ambtsdragers en gewezen ambtsdragers, alsmede hun nabestaanden;

- besluiten over individuele benoemingen, ontslagen en schorsingen.

De procedure die de meerderheid van de commissie voor een volksinitiatief op provinciaal of gemeentelijk niveau in gedachten heeft, kent dezelfde stappen als die voor een volksinitiatief op rijksniveau. Om te beginnen, kan iedere kiezer een inleidend verzoek tot behandeling van een volksinitiatief-voorstel indienen bij gedeputeerde staten of college van burge- 
meester en wethouders. Dit verzoek moet vergezeld gaan van de geldige steunverklaringen van ten minste zoveel kiezers als overeenkomt met $50 \%$ van de kiesdeler in de betreffende provincie of (deel)gemeente.

Wanneer positief op het inleidend verzoek is beslist, volgt een termijn van drie maanden, waarin kiezers kenbaar kunnen maken dat zij behandeling van het volksinitiatief-voorstel wensen. Aan de vereisten voor behandeling is voldaan, wanneer een aantal kiezers dat overeenkomt met ten minste twee keer de kiesdeler in de betreffende provincie of (deel)gemeente, deze wens ondersteund heeft. Provinciale staten of (deel)gemeenteraad zijn verplicht een volksinitiatief dat voldoende steun heeft ontvangen, in behandeling te nemen en de behandeling binnen zes maanden na indiening af te ronden. Een volksinitiatief-voorstel wordt aan een volksstemming onderworpen:

a. als provinciale staten of (deel)gemeenteraad het voorstel hebben verworpen, maar ten minste een vijfde van het wettelijk aantal staten- of raadsleden voor het voorstel heeft gestemd;

b. als provinciale staten of (deel)gemeenteraad over het voorstel niet binnen de termijn van zes maanden een besluit tot aanvaarding of verwerping hebben genomen.

De volksstemming vindt plaats uiterlijk drie maanden nadat een van beide gevallen zich heeft voorgedaan. Het volksinitiatief-voorstel is bij volksstemming aanvaard, als een meerderheid van de opgekomen kiezers voor heeft gestemd. Wel moet die meerderheid getalsmatig ten minste even groot zijn als de meerderheid van het aantal bij de laatste verkiezingen voor provinciale staten resp. (deel)gemeenteraad opgekomen kiezers.

\section{De wenselijkheid van referendum en volksinitiatief}

Zoals we in de voorafgaande paragrafen hebben gezien, wordt over de wenselijkheid en onwenselijkheid van referendum en volksinitiatief in ons land al zo'n negentig jaar discussie gevoerd. Na een kortstondig hoogtepunt in 1921, als de regering voorstelt om het referendum verplicht te stellen bij grondwetswijziging, en de vrijzinnig-democraten de invoering van het decisieve wetgevingsreferendum bepleiten, zakt de belangstelling in de daarop volgende decennia langzaam weg. Pas na de Tweede Wereldoorlog leeft de belangstelling weer wat op, wanneer staatsrecht-geleerden als Oud, Van den Bergh en Belinfante zich als pleitbezorger van het referendum opwerpen. Van den Bergh toont zich daarbij ook voorstander van het volksinitiatief. De Staatscommissie van Advies inzake de Grondwet 
en de Kieswet ontraadt in haar eindrapport van 1971 het volksinitiatief. Maar wel willen acht van de zeventien commissie-leden een gronidwetsbepaling die de mogelijkheid van een decisief referendum introduceert. Regering en parlement houden echter de boot af. Als het PPR-kamerlid Jurgens in 1975 een motie ten gunste van het referendum voorstelt, verwerft deze slechts de stemmen van enkele kleinere partijen en een enkel kamerlid van een grotere partij.

$\mathrm{Na}$ de behandeling van de voorstellen die leiden tot de algehele grondwetsherziening van 1983, krijgt de referendum-gedachte nieuwe impulsen. Vooral als de Commissie Relatie Kiezers-Beleidsvorming in haar eindrapport van 1985 zich unaniem voor invoering van het referendum uitspreekt, en in meerderheid ook voor invoering van het volksinitiatief, groeit ook het aantal voorstanders in het parlement. Dat blijkt als PvdAkamerlid Stoffelen in 1988, naar aanleiding van de behandeling van het eindrapport in de Tweede Kamer, een tweetal moties indient. De eerste motie, die de weg wil vrijmaken voor invoering van het decisieve wetgevingsreferendum, verwerft de stemmen van de PvdA, D66, PPR en PSP. De tweede motie, die de weg wil vrijmaken voor invoering van het volksinitiatief, krijgt alleen de stemmen van de PvdA, PPR en PSP. Ruim vijf jaar later, als de Tweede Kamer haar slotdebatten houdt over staatkundige, bestuurlijke en staatsrechtelijke vernieuwing, blijkt de steun voor invoering van het volksinitiatief weer te zijn toegenomen. Een motie, ingediend door Jurgens, dan inmiddels kamerlid voor de PvdA, nodigt de regering uit om het referendum mogelijk te maken "en daarbij tevens de mogelijkheid van een legislatief volksinitiatief te betrekken". Als deze motie in december 1993 in stemming wordt gebracht, verwerft zij niet alleen de stemmmen van PvdA en Groen Links, maar ook van D66 en de Centrumdemocraten. Die stemmen leveren tezamen echter geen kamermeerderheid op. Een motie van D66-kamerlid Wolffensperger, waarin alleen voor de mogelijkheid van referendum wordt gepleit, wordt aangehouden. In augustus 1994 kondigt het Kabinet-Kok aan, dat een ministeriële commissie de wenselijkheid van invoering van het referendum zal onderzoeken.

Uit mijn beschrijving van de politieke debatten en voorstellen met betrekking tot het decisieve referendum en het volksinitiatief zal, in elk geval tussen de regels door, duidelijk zijn geworden dat ikzelf voorstander ben van de invoering van deze staatsrechtelijke voorzieningen. In de voorafgaande hoofdstukken heb ik een aantal voorstellen gedaan, om de beïnvloedingsmogelijkheden van de burgers tijdens de voorbereiding van overheidsbeslissingen te verbeteren. Daarmee kan worden bevorderd, dat die beslissingen overeenstemmen met de wensen van die burgers. Maar garan- 
ties zijn er niet. Hooguit kumnen de burgers bij de eerstvolgende verkiezingen voor Tweede Kamer, provinciale staten of gemeenteraad hun ontevredenheid afreageren. Er kunnen dan wat nieuwe politieke gezichten op het toneel verschijnen. Maar wat intussen gebeurd is, is gebeurd, en wat nagelaten is, is nagelaten. Daarom valt er veel voor te zeggen, dat de bevolking zonodig zelf directe zeggenschap kan uitoefenen over politieke beslissingen, het doen en laten van overheidsorganen rechtstreeks kan corrigeren. Een zodanige zeggenschap zou het sluitstuk kunnen zijn van ons democratisch systeem. Hoe anders zou ze vorm kunnen krijgen dan in de mogelijkheid van referendum en volksinitiatief?

Van het raadplegende referendum ben ik geen voorstander. Het brengt volksvertegenwoordigers "in een onmogelijke positie", zei Oud al. Het is een "fopspeen" voor de burgers, zei Kohnstamm. Ik zou daar nog een ander tegenargument aan willen toevoegen: Raadplegende referenda hebben de burgers minder te bieden dan inspraak. Bij inspraak, zoals ik die in het vorige hoofdstuk heb beschreven, heeft de bevolking in ieder geval recht op overleg met de verantwoordelijke overheidsorganen. Die overheidsorganen hebben de plicht om te proberen zoveel mogelijk overeenstemming met de insprekers te bereiken. Bij raadplegende referenda ontbreekt dat recht voor de burgers en die plicht voor de overheid. Aan de burgers wordt alleen hun mening gevraagd, zonder dat het bevoegde gezag daar ook maar iets mee hoeft te doen.

\section{De juridische vormgeving van referendum en volksinitiatief}

De Commissie Biesheuvel heeft in haar eindrapport ten aanzien van het decisieve referendum en het volksinitiatief een aantal concrete voorstellen tot wijziging van de Grondwet gedaan, en "elementen voor een wettelijke regeling" gegeven. Ik heb die voorstellen en elementen in de twee voorgaande paragrafen beschreven. In het algemeen kan gezegd worden, dat de door de commissie voorgestelde regelingen goed doordacht zijn. Ze zijn in geen enkel opzicht verouderd, en het verdient aanbeveling om ze in de Grondwet vast te leggen, en in formele wetgeving uit te werken. Toch will ik ten aanzien van enkele punten een kanttekening maken.

\section{Onderwerpen voor referenda}

De Commissie Biesheuvel stelt voor om decisieve referenda mogelijk te maken over wetsvoorstellen, met uitzondering van wetgeving inzake het koningschap of het koninklijk huis, wetgeving tot uitvoering van internationaal-rechtelijke verplichtingen, en wetgeving inzake geldelijke voorzieningen voor ambtsdragers en hun nabestaanden. De eerstgenoemde uitzondering vind ik te algemeen. Natuurlijk moet worden voorkomen, dat refe- 
renda tegen personen zijn gericht. Maar er is niets op tegen om bij het ontbreken van een bevoegde troonopvolger een referendum te houden over de vraag, of de monarchale staatsvorm wel moet worden gehandhaafd. Het voorstel van de staatscommissie van 1918 voorzag in die situatie zelfs in een verplicht referendum.

De uitzondering van wetgeving inzake geldelijke voorzieningen voor ambtsdragers en hun nabestaanden vind ik onwenselijk. De Tweede Kamer heeft in de afgelopen decennia bepaald niet blijk gegeven van grote wijsheid op dit terrein. De pensioenaanspraken werden ook voor politici die in de oorlog fout waren geweest, zo royaal geformuleerd, dat er een pijnlijke affaire kon ontstaan rond het pensioen van de weduwe Rost van Tonningen. En wat hun eigen honorering betreft, hebben de leden van de Tweede Kamer de laatste jaren niet echt het besef uitgedragen, dat zij "volksvertegenwoordigers" zijn. Door gladde overheidsadviseurs laten zij zich graag aanleunen, dat zij eigenlijk een "management-functie" hebben, en een daarbij passend inkomen horen te genieten. Terwijl de meeste Nederlanders hun inkomen zagen stagneren, ging dat van de kamerleden meer dan trendmatig omhoog.

\section{Vereiste meerderheid voor referendum}

In de opvatting van de commissie zou een door de Staten-Generaal aanvaard wetsvoorstel bij referendum kunnen worden verworpen door een meerderheid die ten minste dertig procent van het aantal kiesgerechtigden omvat. En een door provinciale staten of gemeenteraad genomen besluit zou kunnen worden verworpen door een meerderheid die bestaat uit ten minste de helft van het bij de laatste verkiezingen opgekomen aantal kiezers. Ik vind die normen voor verwerping te laag. Veelal zouden overheidsbesluiten kunnen worden weggestemd door minder dan een derde deel van het aantal kiesgerechtigden. Dat zal in voorkomende gevallen ernstige twijfel oproepen over de functie van het referendum als democratisch correctie-middel. Willen we die functie serieus nemen, dan zullen we een hogere norm moeten stellen. Ik denk dan aan: de meerderheid van wat een optimale opkomst zou zijn. Een optimale opkomst is naar mijn mening een opkomst van ten minste negentig procent. Dat betekent, dat een door Staten-Generaal, provinciale staten, of gemeenteraad aanvaard voorstel bij referendum alleen kan worden verworpen door een meerderheid die ten minste vijfenveertig procent van het aantal kiesgerechtigden omvat. Over de democratische legitimiteit van de verwerping kan dan weinig twijfel meer bestaan. 


\section{Onderwerpen voor volksinitiatieven}

Onderwerpen die aan een referendum kunnen worden onderworpen, kunnen in de opvatting van de Commissie Biesheuvel meestal ook voorwerp van een volksinitiatief zijn. Een uitzondering betreft, zoals we hebben gezien, voorstellen voor algemene begrotingswetten. Die moeten volgens artikel 105 lid 2 van de Grondwet "door of vanwege de Koning" worden ingediend. Hoewel de commissie daar niet over spreekt, denk ik, dat om overeenkomstige redenen ook voorstellen voor provinciale begrotingen en gemeente-begrotingen van de mogelijkheid van volksinitiatief moeten worden uitgezonderd. Want artikel 194 van de Provinciewet en artikel 190 van de Gemeentewet leggen de bevoegdheid tot het aanbieden van ontwerp-begrotingen in handen van gedeputeerde staten, resp. het college van burgemeester en wethouders.

\section{Vereiste meerderheid voor volksinitiatief}

De normen die de Commissie Biesheuvel heeft gesteld aan verwerping van overheidsbesluiten bij referendum, heeft zij in het algemeen ook gesteld aan aanvaarding van volksinitiatieven: op nationaal niveau een meerderheid die ten minste dertig procent van het aantal kiesgerechtigen omvat, en op provinciaal en gemeentelijk niveau een meerderheid die ten minste de helft omvat van het bij de laatste verkiezingen opgekomen aantal kiezers. Om dezelfde reden als hierboven genoemd bij het referendum, zou ik ook hier willen voorstellen, om de norm voor alle drie niveaus op te hogen tot een meerderheid die ten minste vijfenveertig procent van het aantal kiesgerechtigden omvat. Het volksinitiatief is, evenals het referendum, een democratisch correctie-middel. Daarom moet de aanvaarding van een volksinitiatief ook boven democratische twijfel zijn verheven. Een meerderheid, die uit ten minste vijfenveertig procent van het aantal kiesgerechtigden bestaat, zal in de praktijk altijd een overtuigende meerderheid zijn.

Een volksinitiatief tot wijziging van de Grondwet kan in de opvatting van de commissie worden aanvaard door een meerderheid, die tenminste tweederde van de kiezers, en tenminste ook dertig procent van het aantal kiesgerechtigden omvat. Ik zou ook hier de norm van dertig procent willen ophogen tot eenenvifftig procent. De eis van een tweederde kiezersmeerderheid kan dan vervallen.

\section{Toetsing aan de Grondwet}

Tegen de mogelijkheid van volksinitiatief wordt wel aangevoerd, dat daardoor de weg wordt vrijgemaakt voor ondoordachte en onsamenhangende wetgevingsprodukten. Het 'volk' is immers niet 'deskundig'. De schade kan beperkt blijven, als het gaat om volksinitiatieven op het niveau 
van de provincies en gemeenten. Want besluiten, die uit die initiatieven voortkomen, kunnen door de Kroon of door de administratieve rechter worden vernietigd, of door andere rechters onverbindend worden verklaard. Maar als formele wetten via de weg van het volksinitiatief worden vastgesteld, ligt dat anders. Die mogen door de rechter wel worden getoetst aan "een ieder verbindende bepalingen" van verdragen en van besluiten van volkenrechtelijke organisaties, maar niet aan de Grondwet, zo lezen we in de artikelen 94 en 120 van deze wet. Of het 'volk' het alleenrecht zal krijgen op het bedenken en aanvaarden van ondoordachte wetgevingsvoorstellen, kan hier in het midden worden gelaten. Maar wie, zoals ik, toch wel waarde hecht aan de waarborg-functie van de Grondwet, zal in de invoering van het volksinitiatief een extra reden zien, om het verbod voor de rechter om wetten te toetsen aan de Grondwet, te schrappen. 


\section{Hoofdstuk 10}

\section{Directe democratie in Nederland}

\section{De verbetering van onze democratie}

Denkers als Schumpeter en Dahl hebben de democratie voorgesteld als een vrije politieke markt. De kiezers geven op die markt hun stem aan de politicus, van wie ze verwachten dat die hun ideële of materiële belangen zal behartigen. Aldus wordt een bestuur gekozen, of een volksvertegenwoordiging, die op haar beurt een bestuur voortbrengt.

Politieke beslissingen, zeggen deze schrijvers, worden in een democratie niet genomen door een meerderheid of door een minderheid, maar door minderheden. Die moeten met elkaar overeenstemming bereiken, om tot meerderheidsbesluiten te kunnen komen. Minderheden zijn waardevol, omdat ze voor elkaar potentiële bondgenoten zijn. Ze kumnen elkaar aan een meerderheid helpen. Ze moeten daarom met elkaars belangen rekening houden. Dat geeft hen in de praktijk misschien nog wel een betere bescherming dan een mooi geformuleerde grondwet. Toch zijn ook grondwettelijke regels belangrijk. Ze vormen de uitdrukking van een consensus over een aantal elementaire waarden, een kader, waarbinnen de politiek zich beweegt.

Deze voorstelling van democratie is vrij optimistisch: In een samenleving worden een aantal regels vastgesteld, waardoor een vrije politieke markt van vraag en aanbod gewaarborgd is. De bekende liberale invisible hand leidt vervolgens tot een optimale realisering van de politieke wensen en voorkeuren van de burgers.

In de loop van de jaren zeventig kwam Dahl tot de conclusie, dat in de westerse democratieën niet alleen de invisible hand onzichtbaar bleef, maar ook de optimale realisering van de politieke wensen en voorkeuren. Een kleine groep mensen in de samenleving werd steeds rijker, terwijl de meerderheid steeds armer werd. In de tachtiger jaren zette die tendens zich in versterkte mate door. Dahl ging op zoek naar een verklaring, en meende die te kunnen vinden in de economische ongelijkheid van de burgers. Die wordt veroorzaakt door het particuliere ondernemerschap, dat in de westerse wereld is ontaard in "corporate capitalism". Een betrekkelijk kleine groep van rijke mensen manipuleert, voor eigen gewin, het zaken- 
leven en bedrijfsleven met behulp van regels en trucs uit het rechtspersonenrecht. Die vorm van ondernemerschap schept tussen burgers grote verschillen in rijkdom, status, kennis, controle over informatie en propaganda, en toegang tot politieke leiders. Daardoor gaat het ook op die vrije politieke markt niet zo eerlijk toe. De sterke klanten duwen voor de kraampjes andere klanten opzij, en eisen de beste koopwaar op. Dahl stelt een radicaal middel voor, om aan deze economische en politieke wanverhoudingen een eind te maken. Er moet een "right to democracy within firms" worden vastgelegd. De ondernemingen zelf moeten van binnenuit een democratisch bestuur krijgen. Dat kan volgens Dahl het beste gebeuren door ze om te vormen tot coöperaties, waarin de medewerkers de stemgerechtigde leden zijn. De economische, en dus ook de politieke ongelijkheden tussen de burgers zullen dan vanzelf kleiner worden.

Met de democratisering van de ondernemingen worden echter niet alle democratische problemen opgelost. Schrijvers als Carole Pateman en Wolfgang Beck hebben er op gewezen, dat democratie ook een leerproces is. Pas door ervaring op te doen met inspraak, overleg, en actie voeren, worden mensen politiek mondige burgers. Gecombineerd met de voorstellen van Robert Dahl zou dit betekenen, dat er dan een samenleving zou kunnen ontstaan van politiek gelijkwaardige en politiek mondige mensen. De klanten op de vrije politieke markt zorgen dan zelf, dat andere klanten niet voor hun beurt gaan. Vóór de kraampjes gaat het dus eerlijk toe. Maar daarmee zijn we er nog niet. Want hoe gaat het achter de toonbanken van de kraampjes? De handelaren, dat wil zeggen de politici en de ambtenaren, hebben in het openbaar bestuur eigen belangen, zoals zelfhandhaving, goede collegiale verhoudingen, en carrière. Om die belangen te dienen, is het voor hen vaak voordeliger om op goede voet te staan met superieuren, collega's en ondergeschikten, dan om te dingen naar de gunst van de kiezer of de waardering van de burger. Dat kan gemakkelijk leiden tot afspraken achter de toonbank, die de keuzemogelijkheden van de klanten vóór de toonbank vérgaand beperken.

De verbetering van onze democratie moet dus eigenlijk op drie fronten worden aangepakt: De economische ongelijkheid tussen de burgers moet worden teruggedrongen, waardoor de politieke gelijkheid wordt bevorderd. Daarnaast moet echter ook de ongelijkheid in kennis en vaardigheden tussen (groepen van) burgers worden verminderd. En dan is er tenslotte het derde front: het openbaar bestuur zelf, dat met zijn bestuurlijke en ambtelijke organisatie zo zou moeten functioneren, dat de wensen en ideeën van de burgers een eerlijke kans op realisatie krijgen. Mijn boek gaat over dit dercle front. Ik onderzoek de openbaarheid van bestuur, de 
opvattingen over ambtelijke loyaliteit, en de mogelijkheden van inspraak, referendum en volksinitiatief. Dit alles leidt tot voorstellen, om de bevolking meer controle, en meer directe invloed en correctie-mogelijkheden op het openbaar bestuur te geven. Dus meer directe democratie.

\section{De openbaarheid van bestuur}

Het openbaar bestuur wordt vanaf de tweede helft van de negentiende eeuw steeds belangrijker. Maar er komt geen openbaarheid van bestuur. Eerst in de jaren zestig van onze eeuw komt er, onder invloed van een wereldwijde vernieuwingsbeweging, in ons land een discussie op gang, waarin voor openbaarheid van bestuur wordt gepleit. Een mijlpaal vormt de verschijning in 1970 van het rapport Openbaarheid openheid van de Commissie heroriëntatie overheidsvoorlichting, ook wel Commissie Biesheuvel genoemd. In dit rapport wordt de wetgever voorgesteld om, ter bevordering van de democratie, te kiezen voor het principe van openbaarheid van bestuur. De commissie heeft dat idee uitgewerkt in een wetsontwerp. Alle informatie die bij de centrale overheid berust, zou openbaar moeten zijn, behoudens enkele met name genoemde uitzonderingen. Ook voor de lagere overheden wil de commissie openbaarheid van bestuur, maar die zou dan geregeld moeten worden in de Provinciewet en in de Gemeentewet.

Het rapport van de Commissie Biesheuvel roept vooral bij de regering en de Raad van State veel weerstand op. Het komt hen goed uit, dat er geen erkende staatsrecht-geleerden in de commissie zitting hadden. Dat maakt het gemakkelijk om vanuit de zogenaamde 'staatsrechtelijke invalshoek' op de inhoud van het rapport te schieten. De Tweede Kamer zal het rapport nooit integraal aan de orde stellen. Biesheuvel zelf wordt in 1971 minister-president. Maar zijn kabinet valt een jaar later uiteen, en de openbaarheid is dan nog niets verder gekomen.

In 1975 dient het kabinet Den Uyl een ontwerp voor een Wet openbaarheid van bestuur in bij de Tweede Kamer. Dat wetsontwerp will vooral de openbaarheid bij de centrale overheid regelen. Provincies en gemeenten zouden alleen rapporten van externe adviescommissies openbaar hoeven te maken. Het wetsontwerp heeft voor een deel het karakter van een raamwet. Het geeft, naast enkele wettelijk gebonden weigeringsgronden, ook een facultatieve grond om gevraagde informatie te weigeren. Op een verzoek om informatie $k a n$ afwijzend worden beslist als inwilliging niet in redelijkheid in overeenstemming kan worden geacht met de eisen van een goede en democratische bestuursvoering. Bij of krachtens algemene maatregel van bestuur moeten hiervoor nadere regels worden gesteld. 
Verder geeft het wetsontwerp de ministers de plicht om uit eigen beweging informatie te verstrekken "zodra dit in het belang is van een goede en democratische bestuursvoering".

\section{Stukken ten behoeve van intern beraad}

Om het raamwet-karakter aanvaardbaar te maken, toont de regering aan de Tweede Kamer een ontwerp van een algemene maatregel van bestuur. Verzoeken om informatie, vervat in documenten die zijn opgesteld ten behoeve van intern beraad worden volgens dit ontwerp ingewilligd "behoudens voor zover zij betrekking hebben op:

a. gegevens die nog in bewerking zijn of die, hoewel gereed, een onjuist beeld zouden geven omdat zij nog met andere moeten worden aangevuld;

b. persoonlijke beleidsopvattingen van bewindslieden, bestuurders of ambtenaren. Over de in deze documenten vervatte beleidsalternatieven wordt echter wel informatie verstrekt".

De regering zegt ook wat de achtergrond van deze regeling is. Zij wil onder geen beding, dat het wetsontwerp een principiële verandering in de positie van de ambtenaar teweeg zal brengen. De ambtenaar blijft in de uitoefening van zijn functie uitsluitend verantwoording verschuldigd aan zijn bewindsman of bestuurders.

De Tweede Kamer deelt op dit punt de visie van de regering. Maar zij wil, dat deze visie wordt vastgelegd in de wet zelf. De kamer aanvaardt een amendement, dat de bepaling uit de beoogde algemene maatregel van bestuur, in vrijwel dezelfde bewoordingen, overbrengt naar de Wet openbaarheid van bestuur. De wet heeft dan haar 'raamwet-karakter' verloren.

\section{Bedrijfs- en fabricagegegevens}

De regering is van mening, dat de vertrouwelijkheid van bedrijfs- en fabricagegevens voldoende in het wetsontwerp wordt gewaarborgd. Maar de rechtse partijen in de Tweede Kamer willen absolute zekerheid voor het bedrijfsleven. Zij komen met een amendement, waarin een nieuwe geheimhoudingsgrond aan het wetsontwerp wordt toegevoegd. Die houdt in, dat vertrouwelijk meegedeelde bedrijfs- en fabricagegegevens onder alle omstandigheden geheim moeten blijven. Minister-president Den Uyl voert in het kamerdebat een felle strijd tegen dit amendement. Hij wijst op de beruchte Planta-affaire uit de zestiger jaren, waar een groter belang, namelijk het belang van de volksgezondheid, tot openbaarheid noodzaakte. Maar het mag niet baten. De lobby van het bedrijfsleven is te sterk. Het 
amendement wordt bij stemming aanvaard. Zo krijgen de ondernemers in de nieuwe wet hun eigen vetorecht op openbaarmaking.

\section{Adviezen wan de Raad van State}

Over de openbaarheid van de adviezen van de Raad van State wordt in het parlement een discussie gevoerd, die tot op de dag van vandaag aanleiding is tot nodeloze verwarring. In de Tweede Kamer wordt een amendement ingediend, dat wil vastleggen, dat een ontwerp voor een algemene maatregel van bestuur altijd tenminste twee maanden vóór de afkondiging moet worden gepubliceerd, tezamen met het advies daarover van de Raad van State. Premier Den Uyl vindt dat niet zinvol, omdat de meeste voorstellen voor algemene maatregelen van bestuur hamerstukken zijn. Het wetsontwerp geeft zelf een veel doeltreffender voorschrift, zegt hij: openbaarmaking op eigen initiatief van de regering, "zodra dit in het belang is van een goede en democratische bestuursvoering". Daarop wordt het amendement ingetrokken.

Het is dan ook onbegrijpelijk, dat de regering en de Raad van State na de invoering van de wet zijn gaan beweren, dat een advies van de raad geheim moet blijven tot de afkondiging van de betreffende algemene maatregel van bestuur. Publicatie zou zelfs "onrecht" doen aan de "bedoelingen van de wetgever", wordt er glashard beweerd. De regering en de Raad zouden beter moeten weten.

\section{De rechter en de openbaarheid van bestuur}

De Wet openbaarheid van bestuur treedt op 1 mei 1980 in werking. Het principe, dat alle gegevens bij de overheid geheim zijn, behoudens openbaarmaking, wordt dan ingewisseld voor het principe, dat alle gegevens openbaar zijn, behoudens geheimhouding. Dat lijkt op het eerste gezicht een hele grote verandering. Maar in de praktijk valt het nogal tegen. Ambtelijke adviezen, bestuurlijke memo's, en bedrijfs- en fabricagegegevens die door ondernemers aan de overheid zijn verstrekt, blijven voor de burgers geheim. Dat zijn dus vrijwel alle gegevens, die uit een oogpunt van beleidsbeinvloeding en beleidscontrole interessant zouden kunnen zijn.

De Afdeling rechtspraak van de Raad van State, die moet waken over de toepassing van de Wet openbaarheid van bestuur, schopt de bal nog verder het veld uit: Een minister, die een wets-ontwerp voor commentaar naar een aantal bevriende instellingen stuurt, maar aan andere instellingen inzage weigert, mag zich van de Afdeling rechtspraak gerust beroepen op intern beraad. Politieke testamenten van demissionaire ministers zijn volgens de afdeling bestemd voor "intern beraad in een volgend kabinet". 
Vaak hoeft over de feitelijke gegevens in ambtelijke adviezen geen informatie te worden verstrekt, omdat volgens de Afdeling Rechtspraak die gegevens en de persoonlijke beleidsopvatting "dermate zijn vervlochten, dat het niet mogelijk is om de gegevens te verstrekken". En alle bedrijfs- en fabricagegevens die ondernemers, verplicht of onverplicht, aan de overheid verstrekken, worden geacht vertrouwelijk te zijn meegedeeld, tenzij de ondernemer verklaart, dat hij tegen openbaarmaking geen bezwaar heeft.

Sinds 1 januari 1994 is de taak van de de Afdeling rechtspraak bij de Raad van State overgenomen door de Afdeling bestuursrechtspraak. Tot nu toe is er geen reden om aan te nemen, dat die nieuwe afdeling een andere lijn zal uitzetten met betrekking tot de openbaarheid.

\section{De nieuwe Wet openbaarheid van bestuur}

In de loop van de tachtiger jaren wordt besloten, om het Besluit openbaarheid van bestuur te integreren in de Wet openbaarheid van bestuur. De burger zou daardoor meer rechtszekerheid krijgen. Bovendien zou de wet door een nieuwe ordening van de wetsartikelen inzichtelijker worden. Zo komt er een nieuwe Wet openbaarheid van bestuur tot stand, die op 1 mei 1992 in werking treedt.

Die nieuwe wet draait het recht op openbaarheid echter voor een belangrijk deel terug. Er zijn enkele winstpunten, zoals een bescheiden verbetering van de openbaarheid van de adviezen van de Raad van State. Bovendien is door amendering in de nieuwe wet vastgelegd, dat zij ook van toepassing is op de publiekrechtelijke bedrijfsorganisatie, en dat op verzoeken om informatie uiterlijk binnen tweemaal vijftien dagen moet worden beslist. Maar daarmee is de winst geteld.

De verliezen zijn groter. Intern beraad is nu niet meer alleen beraad binnen een overheid, maar ook beraad tussen overheden. En waren onder de oude wet, bij intern beraad, alleen de persoonlijke beleidsopvattingen van bewindslieden, bestuurders en ambtenaren van openbaarheid uitgezonderd, nu zijn dat alle opvattingen, van wie dan ook. Zelfs de opvattingen van rechtspersonen zijn volgens de nieuwe wet 'persoonlijke' beleidsopvattingen. Er zijn nog maar weinig door ambtenaren of bestuurders geschreven stukken, die niet onder de geheimhoudingsgronden van de nieuwe Wet openbaarheid van bestuur vallen. Voor de openbaarheid van documenten zijn we nu in Nederland voornamelijk weer aangewezen op bepalingen in de bijzondere wetgeving. 


\section{De loyaliteit van de ambtenaar}

Tijdens de totstandkoming van de Wet openbaarheid van bestuur is van verschillende zijden bezorgdheid geuit, dat de positie van de ambtenaren in het gedrang zou komen. Als ambtenaren het recht, ja soms zelfs de plicht zouden hebben, om naar buiten toe informatie te geven, die niet spoort met het standpunt van hun (politieke) superieuren, dan zouden de interne verhoudingen onder druk komen te staan. Sterker nog, beweerden veel politici, ons hele democratisch systeem, met het daarbij behorende stelsel van politieke verantwoordelijkheid, zou erdoor worden ondermijnd. Immers ministers en andere politieke gezagsdragers kunnen zich alleen voor de uitlatingen van hun ambtenaren verantwoorden, als zij daarover controle hebben. Dit standpunt, dat misschien wel de grootste belemmering vormt voor openbaarheid van bestuur, verdient bestrijding.

\section{De klassieke leer}

In de negentiende eeuw had men in het algemeen nog een vrij tolerante opvatting over ambtenaren, die voor hun mening uit kwamen. Niet alleen in Nederland bestond die tolerantie, maar ook in veel andere westerse landen. Daar komt in de eerste decennia van de twintigste eeuw verandering in. Waarschijnlijk hangt een en ander samen met de sterke groei in de jaren 1900-1920 van de omvang van de overheidsadministratie. Deze groei, die veroorzaakt werd door nieuwe overheidstaken, maakte bij velen angstgevoelens los. Men werd bang voor iets, waarvoor de negentiendeeeuwer nooit echt bang was geweest: de "bureaucratie". Die moest, hoe dan ook, onder controle worden gebracht. Toen omstreeks 1920 in bijna alle Westeuropese landen het algemeen kiesrecht was ingevoerd, leek de oplossing voor de hand te liggen. Het mechanische mensbeeld, dat door de industriële revoluties intussen was gevormd, droeg dlaartoe bij. Mensen kon je als onpersoonlijke radertjes in een productieproces plaatsen. Dat gold dus ook yoor ambtenaren. Ze moesten niet zelfstandig nadenken, maar precies doen wat hun (politieke) superieuren hen opdroegen. Deze waren op hun beurt verantwoording schuldig aan een met algemeen kiesrecht gekozen volksvertegenwoordiging. Echte democratie leek aldus werkelijkheid te kunnen worden.

De nieuwe opvatting over ambtelijke loyaliteit, geformuleerd door de Duitse socioloog Max Weber, sloot goed an de klassieke leer van de democratie, hoewel Weber zelf geen aanhanger van die leer was. Later zou zijn opvatting de klassieke opvatting over ambtelijke loyaliteit worden genoemd. Ook in Nederland kreeg deze opvatting vanaf de jaren twintig veel aanhang. 
Dat de vrije meningsuiting van ambtenaren aan banden kan worden gelegd, was in Nederland al in 1883 betoogd door de staatsrecht-geleerde Buijs. Naar zijn mening kon de overheid van een in dienst tredende ambtenaar verlangen, dat hij afstand deed van zijn recht op vrije meningsuiting. De politiek en de wetenschap wezen die mening toen van de hand. De Nederlandse Juristenvereniging nam er op haar jaarvergadering van 1897 uitdrukkelijk afstand van. In 1915 werd een nieuwe poging gedaan om het recht van vrije meningsuiting voor ambtenaren op losse schroeven te stellen. De staatsrecht-geleerde Struycken betoogde toen, dat burgers contractueel afstand zouden kunnen doen van het genot of gebruik van bepaalde grondrechten. Bovendien kon volgens hem "als gevolg van eene bijzondere rechtspositie" de uitoefening van een of meer grondrechten worden beperkt of verboden.

In 1922 blijkt in de Tweede Kamer, dat de regering zich de opvatting van Struycken eigen heeft gemaakt. De kamer accepteert dit standpunt. In de daarop volgende jaren wordt die opvatting ook overgenomen door belangrijke schrijvers als Van der Pot en Vegting, en krijgt ze haar neerslag in de jurisprudentie van de Centrale Raad van Beroep. De opvatting legitimeert een nieuwe stijl van besturen. Men kan de zaken voortaan meer binnenshuis houden, tot "interne bestuursaangelegenheid" verklaren.

\section{Naar een nieuwe opvatting}

All voor de Tweede Wereldoorlog wordt de klassieke leer over ambtelijke loyaliteit onder schot genomen door de naar de Verenigde Staten geëmigreerde Duitse jurist en politicoloog Carl Friedrich. In zijn visie zijn ambtenaren zelfstandig denkende medewerkers, die in de maatschappij problemen signaleren, waarvan zij de politieke leiding deelgenoot maken. Voor die problemen, en voor andere, die door de politieke leiding zelf op tafel worden gelegd, moeten zij creatieve oplossingen bedenken. Dat is hun taak, die met plichtsbesef moet worden vervuld, dat wil zeggen: met kennis van zaken, beroepseer, en met het doel de gemeenschap te dienen. Oplossingen moeten worden uitgewerkt in overleg met de verantwoordelijke politieke organen, en mogen pas worden gerealiseerd als die organen ermee instemmen. Maar die instemming is volgens Friedrich niet helemaal afhankelijk van een toevallige (politieke) superieur. Als die de zaak blokkeert; mag een ambtenaar, vanuit datzelfde plichtsbesef, maar ook omdat hij dezelfde vrijheid van meningsuiting heeft als anderen, proberen het publiek en de politiek voor zijn standpunt te winnen. Dat is ook voor de democratie en voor de kwaliteit van het bestuur zelf van belang. 
Na de Tweede Wereldoorlog zien we, dat in de politieke theorie de opvattingen over ambtelijke loyaliteit een hele ontwikkeling doormaken. Mede als reactie op de excessieve gehoorzaamheid van ambtenaren in Duitsland, wordt eerst de 'ontplooiingsopvatting', en later het 'burgerschapsdenken' ontwikkeld. Beide doctrines geven blijk van een herleefde aandacht voor de grondrechten, met name voor de gewetenswrijheid en de vrijheid van meningsuiting. Vooral het burgerschapsdenken sluit nauw aan bij het concept van ambtelijke verantwoordelijkheid, dat Carl Friedrich formuleerde. In Nederland wordt het burgerschapsdenken voor ambtenaren en medewerkers van andere grote organisaties bepleit door Mark Bovens.

De regering erkent halverwege de jaren vijftig, dat de grondrechten in principe ook voor de ambtenaren gelden. De juristen hebben wat meer moeite om de oude, door Buijs, Struycken en Van der Pot uitgezette lijn los te laten. Maar vanaf de tachtiger jaren erkennen de meeste schrijvers, dat de grondrechten in principe ook voor ambtenaren van toepassing zijn. Toch is dit alles, voor regering en juristen, niet meer dan een formele exercitie. Men kan zich niet of nauwelijks voorstellen, dat erkenning van grondrechten voor ambtenaren ook consequenties moet hebben voor de inhoud van het ambtenarenrecht. Weliswaar gelden de grondrechten in beginsel ook voor de ambtenaren, maar dat betekent niet dat die grondrechten niet kunnen worden beperkt. De mogelijkheid daartoe wordt in 1983 in de Grondwet bevestigd. De beperking zelf wordt in 1988 vastgelegd in artikel 125a in de Ambtenarenwet. Volgens dit wetsartikel mag een ambtenaar niet zijn gedachten of gevoelens uiten, als "de goede vervulling van zijn functie of de goede functionering van de openbare dienst, voor zover deze in verband staat met zijn functievervulling, niet in redelijkheid zou zijn verzekerd."

In de geest van dit wetsartikel heeft de Centrale Raad van Beroep herhaaldelijk de vrijheid van meningsuiting voor ambtenaren gekortwiekt. Maar in een recente uitspraak, over de Amsterdamse hoofdagent Van Daalen, lijkt de Raad de ambtenaren wat meer ruimte voor meningsuiting te bieden. Van een echte doorbraak is echter nog geen sprake.

De ambtelijke rechtsverhouding is dus, sinds de twintiger jaren van deze eeuw, in feite weinig veranderd. Sterker nog, de "klassieke" leer, die voor de politicologen en bestuurskundigen al sinds de Tweede Wereldoorlog heeft afgedaan, wordt ruim veertig jaar na die oorlog gewoon in ons ambtenarenrecht gecodificeerd.

\section{Wat is een loyale ambtenaar?}

Naar mijn mening is een loyale ambtenaar in de eerste plaats een eerlijke ambtenaar. Zowel zijn superieuren, als het publiek, moeten er op kunnen 
vertrouwen dat hij hen geen streken levert. Een ambtenaar heeft in en buiten de organisatie voortdurend te maken met tegengestelde belangen en meningen. Daarom zal loyale ambtenaar er niet aan ontkomen, om zich in zijn werk een oordeel te vormen over wat hijzelf, gelet op zijn vakkennis en maatschappelijke verantwoordelijkheid, het meest wenselijke overheidsoptreden vindt, en welke bijdrage hij daaraan kan leveren. Dat oordeel mag hij ook naar het publiek toe vrij uiten. Wel moet hij rekening houden met specifieke wettelijke geheimhoudingsplichten, en met de belangen die in artikel 10 van de Wet openbaarheid van bestuur als geheimhoudingsgrond worden erkend. Artikel 125a wan de Ambtenarenwet kan echter in zijn geheel worden geschrapt. Ook de superieuren zullen moeten accepteren, dat een ambtenaar uiteindelijk loyaal is aan de samenleving.

\section{Openbaarheid van bestuur}

Een dergelijke houding zal leiden tot een grotere openbaarheid van bestuur. Ambtenaren krijgen een eigen verantwoordelijkheid voor wat ze wel, en wat ze niet in het openbaar mogen zeggen. De absurditeit van door diensthoofden of bestuurders opgelegde spreekverboden zal tot het verleden behoren. Toch zal dat niet betekenen, dat ambtenaren opeens elk meningsverschil met hun superieuren op straat zullen gooien. De meeste ambtenaren hechten, net als andere werknemers, waarde aan een goede werkverhouding met hun chef. Alleen in uitzonderlijke gevallen zal een ambtenaar tot de conclusie komen, dat hij het publiek deelgenoot moet maken van zijn zorgen of inzichten.

Belangrijker dan de toename van spontane ambtelijke uitingsmogelijkheden is echter een andere consequentie. De nieuwe definitie van ambtelijke loyaliteit brengt met zich mee, dat ambtelijke opvattingen, en dus ook afwijkende ambtelijke opvattingen, openbaar mogen zijn. Dat betekent, dat het publiek inzage mag verlangen. Een verzoek om de openbararmaking van een ambtelijk advies kan dan niet meer worden geweigerd met de motivering, dat het om een zogenaamde "persoonlijke beleidsopvatting" gaat. Belanghebbenden en geïnteresseerden hebben, als zij dat wensen, recht op kennisname. De adviezen van ambtenaren zijn niet meer het exclusieve bezit van de toevallige politieke ambtsdragers, maar komen aan de hele samenleving toe.

Dat geldt ook voor de op schrift gestelde opvattingen van die bestuurders zelf. Het publiek heeft er recht op te weten, in welke richting de ambtsdragers de besluitvorming proberen te sturen. Dan pas is echte democratische controle en sturing mogelijk. Artikel 11 van de Wet openbaarheid van bestuur, dat de term "persoonlijke beleidsopvattingen" gebruikt als reden om verzoeken om informatie te kunnen afwijzen, moet daarom in 
zijn geheel worden geschrapt. Openbaarmaking zou alleen mogen worden geweigerd, als daardoor specifieke wettelijke regels zouden worden geschonden, of de geheimhoudingsregels van artikel 10 van de Wet openbaarheid van bestuur van toepassing zijn.

\section{Inspraak}

Inspraak wordt in mijn boek omschreven als overleg tussen overheid en burgers. Maar niet alle overleg is inspraak. Iemand die met de overheid onderhandelt over de voorwaarden voor een overeenkomst, is geen inspreker. De overheid kan die overeenkomst namelijk niet aangaan zonder de instemming van die persoon. Bij inspraak hebben de burgers niet of nauwelijks een onderhandelingspositie. De overheid kan ook zònder hun instemming een beslissing nemen. Daarom is er, als men de kwaliteit van inspraak toetst, alle reden om te onderzoeken, of juist de overheid wel echt overleg heeft willen voeren.

Overleg is meer dan een gedachtenwisseling. Een gedachtenwisseling is een ordelijke confrontatie van standpunten of meningen van de verschillende deelnemers. Wil men van overleg kunnen spreken, dan zal bij de deelnemers ook de intentie moeten bestaan om over de gespreksonderwerpen zoveel mogelijk overeenstemming te bereiken.

Overleg verdient die naam niet, als het geen eerlijk overleg is. Speciaal de overheid mag erop worden angesproken, dat ze de verschillende (groepen) insprekers een eerlijke en dus min of meer gelijke kans geeft, om haar te overtuigen. Want uiteindelijk is het die overheid, die na de inspraak zelf een besluit moet nemen.

Inspraak is overleg met burgers en ingezetenen. Het is een politiek grondrecht. Iedere burger of ingezetene die zich bij een bepaald optreden van de overheid betrokken voelt, is inspraakgerechtigd. Van de overheid mag bereidheid en initiatief worden verwacht, om met deze "betrokkenen" overleg te voeren. Een betrokkene hoeft geen 'belanghebbende' te zijn. Een emotioneel belang of een verantwoordelijkheidsgevoel ten opzichte van de samenleving is voldoende om 'betrokkene' te zijn. Toch hoeft niet altijd het hele land, de hele provincie of de hele stad voor inspraak te worden uitgenodigd. Het is voldoende, als de overheid zich een beeld vormt van wie zich redelijkerwijs betrokken kunnen voelen bij een bepaald onderwerp, en dan een daarop afgestemde benaderingswijze kiest. Als zich tijdens de inspraak nog andere belangstellenden melden, dan mogen die ook aan de inspraak deelnemen, tenzij er goede redenen zijn om hen buiten de deur te houden. 


\section{Overlegmodellen en 'eigen' deskundigen}

Het geven van eerlijke, gelijke kansen kan met zich meebrengen, dat aan bepaalde betrokkenen ondersteuning moet worden gegeven. We moeten daarbij twee soorten onderscheiden: ondersteuning die het mogelijk maakt dat betrokkenen zich als groep organiseren, en ondersteuning bij het ontwikkelen van een alternatief plan. De behoefte aan $z^{\prime} \mathrm{n}$ alternatief plan kan afhankelijk zijn van het model dat de overheid kiest om overleg te plegen. In de bestuurspraktijk wordt gewerkt met een drietal verschillende overlegmodellen. Deze worden daar aangeduid met namen als: het ambtenarenmodel, het gemengde model, en het bewonersmodel.

Het ambtenarenmodel is het meest traditionele model. Daarin wordt het beleidsvoorstel, dat aan het bestuur moet worden voorgelegd, opgesteld door een ambtenaar of een groep van ambtenaren, eventueel met medewerking van externe deskundigen. In de verschillende fasen van de beleidsvoorbereiding wordt inspraak gegeven aan de betrokken burgers en ingezetenen. Deze insprekers dragen geen medeverantwoordelijkheid voor het beleidsvoorstel dat uiteindelijk aan het bestuur wordt voorgelegd. Als zij de overheid middelen voor 'eigen' deskundigen vragen, om een alternatief voorstel te kunnen formuleren, dan hebben zij daar in beginsel recht op.

Het gemengde model is een echt samenwerkingsmodel. Met organisaties van betrokkenen worden afspraken gemaakt over de samenstelling van een werkgroep of projectgroep. Daarin zitten, naast ambtenaren, vertegenwoordigers van de betrokken organisaties. Deze groep bereidt, eventueel ondersteund door deskundigen, beleidsvoorstellen voor, die via de ambtelijke lijn aan het bestuur worden voorgelegd. Ook hier wordt in de verschillende fasen van de beleidsvoorbereiding inspraak gegeven aan de betrokken burgers en ingezetenen. De organisaties van betrokkenen dragen medeverantwoordelijkheid voor de voorstellen van de groep. $\mathrm{Er}$ is daarom geen reden om hen apart middelen ter beschikking te stellen voor het ontwikkelen van alternatieve voorstellen. Ontstaan er meningsverschillen in de groep, dan kan daar worden afgesproken, dat er twee of meer alternatieven worden ontwikkeld. Uiteraard werkt dat kostenverhogend.

Het bewonersmodel is een veel zeldzamer verschijnsel. Het kan alleen functioneren, als de bewoners ongeveer dezelfde belangen hebben. Vergeleken bij het ambtenarenmodel zijn in het bewonersmodel de rollen omgedraaid. De bewoners bereiden samen met 'eigen' deskundigen een ontwerp-beslissing voor. De overheid kan daarbij vooraf uitgangspunten vaststellen. Maar het is ook denkbaar, dat gewerkt wordt op basis van uitgangspunten die door de bewoners zelf zijn geformuleerd, en die voor de overheid niet bij voorbaat onaanvaardbaar zijn. De ambtelijke diensten 
kunnen tijdens de voorbereiding 'inspreken'. Omdat er maar één beslissing wordt voorbereid, zijn de totale plankosten bij deze werkwijze niet hoger dan bij andere.

\section{Moet inspraak wettelijk worden geregeld?}

In plaats van inspraak in voorschriften te regelen, kunnen we beter de wettelijke belemmeringen voor inspraak wegnemen. Door artikel 11 van de Wet openbaarheid van bestuur en artikel 125 a van de Ambtenarenwet te schrappen, wordt de weg vrijgemaakt voor een open en eerlijk overleg tussen bestuur en burgers, waarin deze laatsten reële en gelijke kansen krijgen om invloed op het beleid uit te oefenen.

Als we een algemeen recht op inspraak willen vastleggen, zouden we het beste het petitierecht van artikel 5 van de Grondwet kunnen ombouwen tot een bepaling, die aan Nederlanders en ingezetenen het recht op overleg met de overheid geeft. De Grondwet zou dan zelf ook de uitzonderingen moeten regelen. De nu nog in Gemeentewet, Provinciewet, en Waterschapswet voorgeschreven plicht om een inspraak-verordening vast te stellen, zou kunnen worden geschrapt.

\section{Referendum en volksinitiatief}

De tot nu toe genoemde voorstellen hebben alle betrekking op invloed tijdens de voorbereiding van beslissingen van overheidsorganen. Daarmee kan worden bevorderd, dat die organen beslissingen nemen die overeenstemmen met de wensen van de burgers. Maar garanties zijn er niet. Wanneer een overheidsorgaan zich in een concreet geval niets van de wensen of bezwaren aantrekt, dan hebben de burgers geen mogelijkheden om direct in te grijpen. Alleen indirect, via de verkiezingen voor de Tweede Kamer, provinciale staten, of gemeenteraad, kunnen zij proberen het overheidsbeleid te corrigeren. Een andere correctie-methode is ook nauwelijks denkbaar in een samenleving die zoveel leden kent, dat zij niet allemaal bijeen kunnen komen, om samen voor ieder afzonderlijk geval te besluiten wat de overheid moet doen of laten. In het algemeen zal de bevolking daarom wetgeving en bestuur moeten toevertrouwen aan volksvertegenwoordigers en democratisch benoemde bestuurders.

Toch valt er veel voor te zeggen, dat de bevolking zonodig zelf direkte zeggenschap kan uitoefenen over overheidsbeslissingen, en het doen en laten van overheidsorganen rechtstreeks kan corrigeren. Directe zeggenschap, op deze wijze uitgeoefend, zou het sluitstuk kunnen zijn van ons democratisch systeem. In de literatuur en in het politieke bestel van een 
aantal andere, ook westerse landen is die methode van directe zeggenschap bekend in twee verschillende vormen: referendum en volksinitiatief.

\section{Definities}

Het begrip referendum kan worden gedefiniẻerd als: een volkstemming over een besluit, dat door een staatsorgaan is genomen of wordt overwogen met betrekking tot een bepaalde zaak. Bij een decisief referendum wordt door middel van een volksstemming een formeel besluit genomen. Bij een consultatief referendum heeft de volksstemming het karakter van een raadpleging, waarna het betrokken overheidsorgaan een besluit neemt. In mijn boek wordt het consultatieve referendum verworpen. Referenda moeten altijd decisief zijn.

Bij een volksinitiatief doet een gedeelte van de bevolking een voorstel tot het nemen van een overheidsbesluit. Soms hoeft dat voorstel alleen maar door regering en/of parlement te worden behandeld. Maar als die het verwerpen, moet er een volksstemming moet worden gehouden.

\section{De discussie over referendum en volksinitiatief}

In ons land wordt al zo'n negentig jaar discussie gevoerd over de wenselijkheid van referendum en volksinitiatief. $\mathrm{Na}$ een kortstondig hoogtepunt in 1921, als zowel de regering, als de vrijzinnig-democraten voorstellen doen voor invoering van het referendum, zakt de belangstelling langzaam weg. Pas na de Tweede Wereldoorlog leeft de belangstelling weer op. De Staatscommissie van Advies inzake de Grondwet en de Kieswet ontraadt in haar eindrapport van 1971 het volksinitiatief. Wel wil bijna de helft van deze commissie in de Grondwet de mogelijkheid van een decisief referendum introduceren. Regering en parlement houden echter de boot af. Een motie ten gunste van het referendum verwerft in 1975 slechts de stemmen van enkele kleinere partijen en een enkel kamerlid van een grotere partij.

$\mathrm{Na}$ de behandeling van de voorstellen voor de algehele grondwetsherziening van 1983, krijgt de referendum-gedachte nieuwe impulsen. Vooral als de Commissie Relatie Kiezers-Beleidsvorming (Commissie Biesheuvel) in haar eindrapport van 1985 voor invoering van het referendum en het volksinitiatief pleit, groeit het aantal voorstanders in het parlement. In 1988 verwerft een motie, die de weg wil vrijmaken voor invoering van het decisieve referendum, de stemmen van PvdA, D66, PPR en PSP. Een motie, die de weg wil vrijmaken voor invoering van het volksinitiatief, krijgt niet de steun van D66. Maar als de Tweede Kamer in 1993 haar slotdebatten houdt over staatkundige, bestuurlijke en staatsrechtelijke vernieuwing, steunt D66 wel een motie, warin de regering wordt uitgenodigd om het referendum mogelijk te maken "en daarbij tevens de moge- 
lijkheid van een legislatief volksinitiatief te betrekken". In augustus 1994 kondigt het kabinet-Kok aan, dat het zelf de wenselijkheid van invoering van het referendum zal onderzoeken.

\section{Concrete voorstellen tot invoering}

De Commissie Biesheuvel heeft in haar eindrapport ten aanzien van het decisieve referendum en het volksinitiatief een aantal concrete voorstellen tot wijziging van de Grondwet gedaan, en "elementen voor een wettelijke regeling" gegeven. In het algemeen kan gezegd worden, dat de door de commissie voorgestelde regelingen goed doordacht zijn. Deze zouden naar mijn mening zonder al te veel wijzigingen in de Grondwet kunnen worden vastgelegd, en in formele wetgeving worden uitgewerkt. Toch wil ik enkele critische kanttekeningen maken.

\section{Onderwerpen voor referenda}

De Commissie Biesheuvel stelt voor om decisieve referenda mogelijk te maken over wetsvoorstellen, met uitzondering van wetgeving inzake het koningschap of het koninklijk huis, wetgeving tot uitvoering van internationaal-rechtelijke verplichtingen, en wetgeving inzake geldelijke voorzieningen voor ambtsdragers en hun nabestaanden. De eerstgenoemde uitzondering vind ik te algemeen. Er is niets op tegen, om bij het ontbreken van een bevoegde troonopvolger een referendum te houden over de vraag, of de monarchale staatsvorm wel moet worden gehandhaafd. Het voorstel van de staatscommissie van 1918 voorzag in die situatie zelfs in een verplicht referendum.

De uitzondering van wetgeving inzake geldelijke voorzieningen voor ambtsdragers en hun nabestaanden vindt ik onwenselijk. De Tweede Kamer heeft in de afgelopen decennia bepaald niet blijk gegeven van grote wijsheid op dit terrein. Zo werden de pensioenaanspraken, ook voor politici die in de oorlog fout waren geweest, zo royaal geformuleerd, dat er een pijnlijke affaire kon ontstaan rond het pensioen van de weduwe Rost van Tonningen. Ik zie geen goede reden, om hier de mogelijkheid van referendum uit te sluiten.

\section{Vereiste meerderheid voor referendum}

In de opvatting van de Commissie Biesheuvel zou een door de StatenGeneraal aanvaard wetsvoorstel bij referendum kunnen worden verworpen door een meerderheid die ten minste dertig procent van het aantal kiesgerechtigden omvat. En een door provinciale staten of gemeenteraad genomen besluit zou kunnen worden verworpen door een meerderheid die bestaat uit ten minste de helft van het bij de laatste verkiezingen opgekomen 
aantal kiezers. Die normen voor verwerping zijn te laag. Als een overheidsbesluit wordt weggestemd door zo weinig kiesgerechtigden, zal dat ernstige twijfel oproepen over de functie van het referendum als democratisch correctie-middel. Ik stel voor, dat een door Staten-Generaal, provinciale staten, of gemeenteraad aanvaard voorstel bij referendum alleen kan worden verworpen door een meerderheid die ten minste vijfenveertig procent van de kiesgerechtigden omvat.

\section{Onderwerpen voor volksinitiatieven}

Onderwerpen die aan een referendum kunnen worden onderworpen, kunnen in de opvatting van de Commissie Biesheuvel meestal ook voorwerp van een volksinitiatief zijn. Een uitzondering betreft voorstellen voor algemene begrotingswetten. Die moeten volgens de Grondwet "door of vanwege de Koning" worden ingediend. Om een vergelijkbare reden zouden ook voorstellen voor provinciale begrotingen en gemeente-begrotingen van de mogelijkheid van volksinitiatief moeten worden uitgezonderd.

\section{Vereiste meerderheid voor volksinitiatief}

De normen die de Commissie Biesheuvel heeft gesteld aan verwerping van overheidsbesluiten bij referendum, heeft zij in het algemeen ook gesteld aan aanvaarding van volksinitiatieven. Ik stel voor, om de norm voor alle drie niveaus op te hogen tot een meerderheid die ten minste vijfenveertig procent van het aantal kiesgerechtigden omvat. Zo'n meerderheid zal in de praktijk altijd een overtuigende meerderheid zijn. Bij een volksinitiatief tot wijziging van de Grondwet zou dat een meerderheid moeten zijn, die ten minste eenenvijftig procent van het aantal kiesgerechtigden omvat.

\section{Toetsing aan de Grondwet}

Tegen de mogelijkheid van volksinitiatief kan worden aangevoerd, dat daardoor gemakkelijker wetgevingsprodukten tot stand kunnen komen, die strijdig zijn met de Grondwet. Naar mijn mening levert dat een extra argument op, om de rechter de bevoegdheid te geven, om wetten te toetsen aan de Grondwet. 


\section{Een slotakkoord}

Ons land heeft een democratische regeringsvorm. Er is een vrije politieke markt van vraag en aanbod. Wij kiezen op nationaal niveau; en op provincie- en gemeenteniveau, onze eigen volksvertegenwoordigers. Die nemen zitting in de volksvertegenwoordiging, waar een meerderheid, om zo goed mogelijk onze belangen te behartigen, een regeerakkoord of een bestuursakkoord sluit. Op basis daarvan worden regeerders of bestuurders benoemd, die hun best doen, om het vertrouwen van de volksvertegenwoordiging waard te zijn, want anders worden zij ontslagen. De volksvertegenwoordigers moeten ook goed op hun tellen passen, want anders worden zij door ons, burgers, niet herkozen. Zo leidt een onzichtbare hand tot de optimale realisering van onze politieke wensen en voorkeuren. Maar wie zijn wij?

Ook op die vraag geeft de vrije markt van vraag en aanbod een duidelijk antwoord. We hoeven maar naar de reclame-boodschappen op de televisie te kijken. Wij zijn burgers, die weten waar onze huisdieren recht op hebben. We verwennen ze met hapklare brokken. Zelf leiden wij een sportief en opwindend leven. Maar een zweetdruppel zal men bij ons niet ruiken, want een deodorant geeft ons lichaam de hele dag een verademende frisheid. En de shampoo die wij gebruiken, geeft ons slappe, futloze haar volume en stevigheid.

We betalen goed voor de vrije markt, en de illusies die daarbij horen. Jaarlijks wordt in Nederland ruim twaalf miljard gulden uitgegeven aan reclame op radio en $\mathrm{TV}$, en aan mede daardoor gegenereerde papierreclame. Dat is, of we nu wel of geen sticker op onze brievenbus plakken, meer dan tweeduizend gulden per jaar per huishouden. Wie heeft dat eigenlijk besloten? Is daar democratisch over gestemd in onze volksvertegenwoordiging? En wie heeft besloten, dat er in ons land bijna een half miljoen mensen werkloos zijn, dat allochtone jongeren geen kans krijgen op de arbeidsmarkt, dat de georganiseerde misdaad zich steeds verder kan verbreiden, en dat milieuvervuilende bedrijven rustig hun gang kunnen gaan? Een onzichtbare hand leidt in een vrije samenleving tot optimale realisering van onze wensen en voorkeuren, zeggen heel verstandig uitziende wetenschappers en politici. Maar moeten we die onzichtbare hand toch niet een beetje meer in de gaten gaan houden?

Wie zijn wij, vraag ik nogmaals. Ik denk, dat we daar pas achter kunnen komen, als we wat minder gefixeerd zijn op efficiency en rendement. Als we het eens durven te hebben over de elementaire waarden in onze samenleving, dan leren we onszelf misschien een beetje kennen. Robert Dahl zei, dat democratie niet mogelijk is zonder een zekere consensus 
over die waarden. Aanvankelijk dacht hij, dat die consensus beperkt kon blijven tot overeenstemming over een aantal burgerrechten en politieke rechten, en enkele democratische spellregels. Later komt hij tot de conclusie, dat er tot op zekere hoogte ook overeenstemming moet zijn over een rechtvaardige verdeling van de welvaart en van de zeggenschap over de bronnen van die welvaart. Die overeenstemming is in onze samenleving ver te zoeken. Dit jaar opperde een groepje top-ambtenaren zelfs het idee, om het recht op minimumloon voor grote groepen werknemers maar af te schaffen. In mijn boek heb ik betoogd, dat het burgerschapsdenken van ambtenaren moet worden gestimuleerd, en daar blijf ik bij. Maar juist daarom is het treurig, dat geen enkele minister of fractieleider deze ambtenaren de oren durft te wassen over de ethische mankementen van hun voorstel. Dan komt ook de democratie niets verder. Integendeel, de economische, en dus ook politieke ongelijkheid dreigt steeds groter te worden.

Als we een consensus zouden kunnen bereiken over een rechtvaardige verdeling van de welvaart en van de zeggenschap over de bronnen van die welvaart, dan zouden we onze samenleving ook richting kunnen geven. Dan zouden we, in plaats van alleen maar plannen voor belastingverlaging en bezuinigingen te verzinnen, eens kunnen formuleren, wat de overheid moet gaan doen. Want alleen door middel van die overheid kunnen wij waarborgen, dat onze jeugd goed onderwijs krijgt, dat werk en welvaart eerlijk worden verdeeld, dat er verzorging en hulp is voor hen die dat nodig hebben, en dat stad en land veilig en leefbaar zijn.

Waar beginnen we met de verbetering van onze democratie? Ik heb in mijn boek drie fronten genoemd: (1) de economische ongelijkheid tussen burgers, (2) de ongelijkheid in kennis en vaardigheden, en (3) het openbaar bestuur zelf, waar de wensen en ideeën van de burgers een eerlijke kans op realisatie moeten krijgen. Om op dit derde front verder te komen, heb ik voorstellen gedaan tot verbetering van de openbaarheid van bestuur, van de inspraakmogelijkheden, en tot invoering van het referendum en het volksinitiatief. Op dit front kunnen we zo aan de slag. Maar uiteindelijk zullen we op die twee andere fronten ook iets moeten bereiken. 


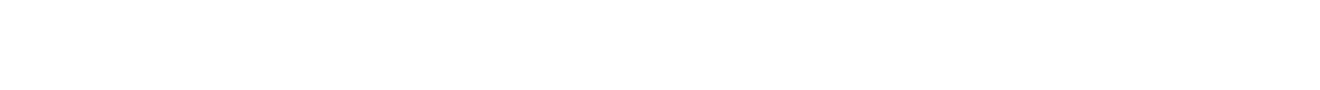

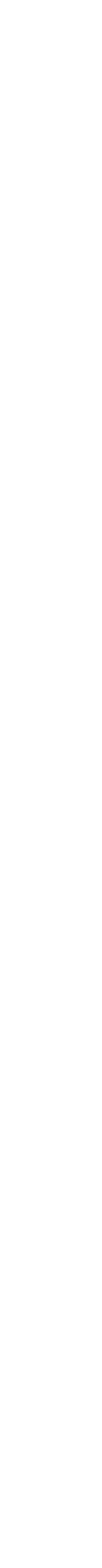




\section{Summary}

\section{Improving Democracy}

Thinkers such as Schumpeter and Dahl have portrayed democracy as a free political market. In that market, the electorate vote for the politician they think will defend their spiritual and material interests best. In this way, a government is chosen or a parliament, which in turn produces a government.

According to these authors, in a democracy political decisions are not taken by a majority or a minority, but by minorities. These must reach agreement among themselves in order to make majority decisions. Minorities are valuable inasmuch as they constitute each other's potential allies. They must therefore take each other's interests into account. In practice, this may offer them even better protection than any well-drafted constitution. However, constitutional rules are important as well. They are the expression of a consensus on a number of basic values, the framework within which politics is conducted.

This is a fairly optimistic portrayal of democracy: in a society a number of rules are established, which safeguard a free political market of supply and demand. As a result, the well-known free-market invisible hand can optimally realize the political desires and preferences of its citizens.

During the nineteen-seventies, Dahl established that in Western democracies it was not only the invisible hand that remained invisible, but also the optimum realization of these political desires and preferences. A small number of persons in society grew richer and richer, whereas the minority became poorer and poorer. Dahl looked for an explanation and felt to have found it in the economic inequality of citizens. This inequality is brought about by private enterprise, which in the Western world has degenerated into "corporate capitalism." This form of entrepreneurship creates major differences between citizens as to affluence, status, knowledge, control over information and propaganda, and access to political leaders, which does not make for very fair trading in the political marketplace either. Strong customers jostle the other customers in front of the stalls and demand the best merchandise. Dahl proposes a radical remedy to make an end to these economic and political iniquities. A "right to democracy 
within firms" must be established. Businesses must be democratically managed from within. This can be best achieved, in Dahl's view, by converting them into cooperatives, in which the workers have become voting members. The economic and therefore also the political inequalities between citizens will automatically decrease.

Not all democratic problems are solved by making enterprises more democratic. Carole Pateman, Wolfgang Beck and others have pointed out that democracy is a learning process. Only through actual participation and campaigning will people become politically emancipated citizens. Combined with Robert Dahl's proposals, this could lead to a society of politically assertive people of equal standing. Customers in the free political marketplace would ensure that other customers did not jump the queue. In front of the stalls affairs would be conducted fairly. But that is not all. What happens behind the counters? The traders, that is the politicians and the officials, have their own interests in public administration, such as enforcement, good relations with their colleagues and their careers. In order to serve these interests, it is often more advantageous for them to be on good terms with their superiors, colleagues and subordinates than to compete for the favour of the electorate or public approval. This may easily lead to deals behind the counters that substantially restrict the options of the customers in front of these.

Efforts to improve our democracy must therefore be made on three fronts: economic inequality between citizens must be pushed back, which at the same time will enhance political equality. In addition, the disparity in knowledge and skills between (groups of) citizens must be reduced. And thirdly: public administration itself whose administrative and bureaucratic organization should afford a fair chance of realizing the desires and ideas of the citizens. This dissertation deals with the third front. It contains an investigation into the accessibility of government documents, the views on administrative loyalty and the citizen's opportunities to be heard through participation, referenda and people's initiatives, followed by the author's proposals to grant the population more control, more direct influence on public administration and more means of redressing it. Hence more direct democracy.

\section{Public Information}

Since the second half of the nineteenth century, public administration has gained in importance. This does not mean publicity of administration, however. As late as the sixties of this century, a global review movement 
prompted a debate in the Netherlands in which the principle of publicity of government was advocated. The 1970 publication of the report "Openbaarheid openheid" (Publicity openness) by the Biesheuvel Commission is a milestone. In this report, it was proposed that the legislator, for the sake of enhancing democracy, adopt the principle of public information. The Commission developed the idea into a Bill. All information available to the central authorities should be public, with some express exceptions. Also for the provincial and municipal authorities, the Commission wanted publicity of government, which was to be governed by the Provinces Act and the Municipalities Act. The report by the Biesheuvel Commission met with much resistance, especially from the government and the Council of State.

In 1975, the government introduced a Bill to Parliament for a Wet Openbaarheid Bestuur (Public Information Act). This Bill features, apart from a number of mandatory grounds for denying access to information, also discretionary grounds for refusal, which are to be further regulated by Administrative Order. The Bill imposes a duty on the authorities to provide information of their own motion "whenever this is in the interest of proper and democratic administration."

\section{Documents for Internal Consultation}

The government presents the Lower Chamber with a draft Administrative Order to further regulate the discretionary grounds for refusal. Requests for information contained in documents that have been drawn up for internal consultation will be granted, pursuant to a provision in this draft, "with the exception of information which deals with:

a. data being processed or, although complete, presenting an inaccurate picture without being complemented by additional data;

b.personal policy opinions of ministers, administrators or officials, providing that information on the policy alternatives contained in these documents be disclosed."

The Dutch Lower Chamber felt that the provision was sufficiently important to be incorporated in the Act itself. It was therefore lifted from the Administrative Order and placed in the Public Information Act.

\section{Commercial and Industrial Data}

The government feit that the confidentiality of commercial and industrial data was adequately safeguarded. But the parties on the right in the Lower Chamber wanted absolute assurance for commerce and industry. They submitted an amendment, in which a new ground for secrecy was added to the Bill. This ground implied that commercial and industrial data confiden- 
tially communicated must remain confidential in all cases. The government fiercely fought the amendment during the parliamentary debate. But the industrial lobby proved too powerful and the amendment was adopted. Under the new Act, entrepreneurs were given the right to veto disclosure.

\section{The Courts and Publicity of Government}

The Public Information Act came into effect on 1 May 1980. The principle that all administrative information is secret; apart from disclosure, is then exchanged for the principle that all administrative information is public domain, subject to non-disclosure. At first sight, this seemed a major change. But in practice it turned out differently. Advisory opinions expressed by officials, administrative memos and commercial and industrial data provided by entrepreneurs to the administration remained confidential to the public. This meant virtually all data that could be interesting from the point of policy influencing or policy control. The justices on the Council of State, whose duty it is to watch over the application of the Public Information Act, went even further than that by extensively interpreting the grounds for secrecy.

\section{The New Public Information Act}

During the eighties, the legislator decided to integrate the Administrative Order on the publicity of government into the Public Information Act. This was intended to offer more legal certainty to the citizens. Furthermore, the Act's ease of reference was to improve by a rearrangement of its articles. Thus, a new Public Information Act was created, which came into effect on 1 May 1992.

This new Act, however, reversed the right to access public documents considerably. 'Internal consultation' no longer meant just consultation within the administrative agency, but was extended to consultation between administrative agencies. And whereas under the former Act the personal policy opinions of ministers, administrators and officials were exempt from disclosure, under the new Act, all opinions have been exempted. By virtue of the new Act, even the opinions of corporations ('rechtspersonen') are "personal" policy opinions. There are hardly any documents left to which the grounds for non-disclosure in the new Public Information Act do not apply. For access to administrative documents in the Netherlands one has to fall back on the provisions in sectorial administrative statutes. 


\section{Administrative Loyalty}

During the creation of the Public Information Act there was much concern for the position of officials. If officials had a right, indeed perhaps even a duty, to disclose information which did not square with the views of their (political) superiors, internal relations would come under pressure. Moreover, many politicians argued, our whole democratic system, with the inclusion of its principle of political responsibility, would be thus undermined, since ministers and other figures of political authority could only be accountable for those statements by their officials they controlled. This point of view, which is perhaps the greatest impediment to publicity of government, must be opposed.

\section{The Classical Theory}

In the nineteenth century, in general the attitude towards officials who spoke their mind was fairly tolerant. This changed in the course of the first decades of this century. The change is probably related to the significant increase in the size of public administration between 1900 and 1920. This increase, caused by new administrative duties, made many apprehensive. They became fearful of bureaucracy, which had to be restrained at all costs. When by 1920 in almost all Western European countries universal suffrage had been introduced, there seemed to be an obvious solution, particularly since the industrial revolutions had been responsible for a rather mechanical picture of mankind. People could be introduced into the production process as inanimate cogs. This also held true for officials. They were not to think for themselves, but were to do what their (political) superiors told them to. The latter in turn were accountable to a parliament that had been elected in general elections based on universal suffrage. True democracy seemed feasible, even in a complex industrialized society.

The new views on administrative loyalty, formulated by the German jurist and sociologist Max Weber, eventually became the classical theory. Also in the Netherlands, this view received much support from the twenties onward.

As early as 1883, a Dutch professor of constitutional law, Buys, had argued that the freedom of opinion of officials could be curtailed. At that time, politicians and scholars rejected this view. In 1915, a renewed effort was made to weaken the freedom of opinion to which officials were entitled. Another Dutch scholar in constitutional law, Struycken, argued at that time that citizens could relinquish their enjoyment of certain fundamental rights by contract and that "as a result of a special legal status" the 
exercise of one or more fundamental rights could be curtailed or prohibited.

In 1922, the Lower Chamber learned and accepted that the government had taken over Struycken's ideas. In the years following, this view was also adopted by most constitutional scholars. It was reflected in the case law of the administrative courts. The view legitimized a new style of governing. It became possible to keep matters "indoors" by declaring them "internal administrative matters."

\section{Towards a New Concept}

The classical theory of administrative loyalty was already criticized before the Second World War by a German jurist and political scientist, Carl Friedrich, who had emigrated to the United States. In his judgment, officials are employees with minds of their own, who can spot society's problems and communicate these to the political powers that be. For these problems, and for those put on the table by the political leaders themselves, they must find creative solutions. That is their duty, which must be fulfilled with a sense of obligation, that is to say: skilfully, by observing professional ethics and with a view to serve society. Solutions must be worked out in consultation with the political bodies responsible and should only be realized upon the consent of these bodies. However, according to Friedrich, such consent does not solely depend on the odd (political) superior. If the superior obstructs the matter, the official, out of the same sense of obligation, but also because he enjoys the same freedom of expression as everyone else, may try to win the public"s and the politicians' support for his views. This is equally important for democracy and for the quality of government per se.

Since the Second World War, the views on administrative loyalty have evolved considerably in political theory. Also as a result of the extreme obedience of officials in Germany, first the humanistic conception of loyalty and subsequentiy the concept of institutional citizenship emerged. Both theories reflected a renewed attention for fundamental rights, especially as regards the freedom of conscience and the freedom of expression. In particular the concept of institutional citizenship closely relates to Carl Friedrich's conception of administrative responsibility.

In the second half of the fifties, the Dutch government acknowledged that, in principle, fundamental rights also apply to officials. Jurists felt uneasy about the idea, but from the eighties onward, most legal scholars acknowledged that, in principle, fundamental rights are also applicable to officials. However, both government and legal scholars were just going 
through the motions. They could not envision or barely realized that the recognition that fundamental rights also applied to officials would have an impact on administrative law as such. The possibility to curtail fundamental rights was incorporated into the Constitution in 1983. The restriction itself was laid down in 1988 in Article 125a of the Ambtenarenwet (Government Officials Act). Pursuant to this article, officials may not express their thoughts or feelings, if "the proper fulfilment of their duties or the proper functioning of public service cannot be reasonably ensured." In the spirit of the article, on several occasions the Dutch administrative courts have curtailed the freedom of expression of officials, although recent case law does seem to offer officials a little more room for expression. This should not be construed as a breakthrough, however.

In reality, the legal relationship between the official and the administration has hardly changed in the Netherlands since the twenties. In fact, the "classical" theory no longer adhered to by political and public administration scientists since the Second World War, has been matter-of-factly incorporated into Dutch administrative law governing officials.

\section{The Meaning of Loyal Official'}

In this dissertation, a loyal official is first and foremost an honest official. Both his superiors and the general public must be sure that he does not play tricks on them. Officials are constantly faced with conflicting interests and opposite opinions. In consequence, it will not be possible for a loyal official to avoid forming an opinion in his service on what he personally, in view of his skills and social responsibility, feels is the most desirable way for the administration to act, and on the way in which he can best make a contribution. This opinion he is free to express to the public. $\mathrm{He}$ must, however, take into account specific statutory requirements of nondisclosure and the interests defined in Article 10 of the Public Information Act. His superiors will also have to accept that, in the end, the official's loyalty is owed to society.

\section{Public Disclosure}

Such attitude will improve access to public information. Officials will have their own responsibility for what they may, and may not, express in public. This will not imply, however, that officials will now bring any dispute with their superiors into the open. As any other employee, the majority of officials appreciate good working relations with their bosses. Only in exceptional cases will an official conclude that he must share his concerns or views with the general public. 
There is another effect, however, which is more important than a greater opportunity for officials to express their opinions. The new definition of 'administrative loyalty' entails that opinions of officials may be publicly disclosed. This means that the public can request access to documents. In that case, a request for disclosure of an administrative opinion can no longer be denied on the grounds of it being a "personal policy opinion." Those having a direct interest, and others; are entitled, if they so wish, to be informed. The opinions of officials are not the exclusive property of those political office holders that happen to be in power at the time, but belong to society as a whole.

This also holds true for the documented opinions of the administrators themselves. The public has a right to know the direction in which office holders are steering the decision-making. Only if these conditions are met, can there be true democratic control and direction. The author argues that Article 11 of the Public Information Act, which employs the term "personal policy opinions" as a ground for denying requests for information, should therefore be repealed. Access to information should only be denied if this were to constitute a violation of specific legal rules, or where the provisions on confidentiality in Article 10 of the Public Information Act apply.

\section{Participation}

There is a typical Dutch form of participation which is called 'inspraak'. In this dissertation, the author "promotes" "inspraak" to mean "consultation" between the authorities and their citizens. But not all consultation constitutes 'inspraak'. A person negotiating the terms of an agreement with the authorities cannot be qualified as an 'inspreker'. The authorities may not enter into the agreement without the consent of that person. In the case of inspraak, citizens possess no or hardly any bargaining power. The authorities can take decisions without their consent. That is why, when testing the quality of inspraak, it is advisable to investigate whether the authorities have wanted to hold genuine consultations.

Consultation is not just an exchange of views. An exchange of views is an orderly confrontation of the opinions and ideas of the various participants. Consultation only exists where participants have the intention to reach as much a consensus on the issues as possible.

Consultation is not deserving of its name if it is not conducted in earnest. The authorities in particular may be held accountable for affording the various (groups of) insprekers a fair and therefore a more or less equal 
chance of persuading them. It is after all the authorities who, following the inspraak, must take the decision.

'Inspraak' is about consulting citizens and residents (Nederlanders and ingezetenen). For the purposes of this dissertation, inspraak is viewed as a political right. Each citizen or resident who feels himself involved in a particular action by the authorities, is entitled to inspraak. From the authorities, a willingness and the initiative to consult with them may be expected. They are the parties involved, which does not necessarily mean they are the 'interested party' ("belanghebbende"). A sufficient condition to be a "party involved" ("betrokkene") is that the party has an emotional interest in or feels responsible for society. This does not mean that the whole country, the entire province or city needs to be invited to exercise inspraak. It is sufficient for the authorities to obtain the suggestions of those who may reasonably feel involved in a particular issue and to subsequently opt for a considered approach. If other involved parties report to the authorities for inspraak, they may also participate, unless there are good reasons to exclude them.

\section{Models of Consultation and External Experts}

Granting fair and equal opportunities may entail that certain parties involved need to be given support. Two types of support need to be distinguished in this respect: support enabling the party involved to organize as a group and support in developing an alternative scheme. The need for an alternative scheme may depend according to the consultation model opted for by the authorities. In administrative practice, three different consultation models are used. They are referred to as: the agency model, the mixed model, the occupants model.

The agency model is the most traditional. In this model, the policy proposal which is to be presented to the administration, is drafted by an official or a group of officials with the possible collaboration of external experts. In the various preparatory stages of policy-making, inspraak is granted to involved citizens and residents. These insprekers do not bear any responsibility for the eventual policy proposal submitted to the administration. If they request funding from the authorities in order to stage an alternative investigation or to formulate an alternative proposal, they are in principle entitled to such.

The mixed model is a true model of cooperation. Agreements are made with the parties involved about the composition of a working party or project group. Apart from officials, such party or group consists of the 
representatives of the organizations involved. It prepares, if needed with the support of experts, the policy proposal to be presented to the administration through the agency. Also in this model, inspraak is granted to citizens and residents involved in the various stages of preparation. The organizations of involved parties share the responsibility for the proposals of the group. There is no reason, therefore, to provide these organizations with separate funding to prepare alternative proposals. In case of dispute, the group may agree to develop two or more alternatives. This, of course, increases costs.

The occupants model is a much more rare phenomenon. It can only function if the occupants share similar interests. In the occupants model, the occupants, together with external experts, prepare a draft-decision. The authorities may have given them certain points of reference, but it is conceivable that the work is done on the basis of premises formulated by the occupants themselves, premises that are not prima facie unacceptable to the authorities. The agency may have inspraak during the preparations. Inasmuch as a single decision is prepared, the total costs for the project will not exceed those of the other procedures.

\section{Statutory Rules for Inspraak?}

Rather than regulating inspraak by law, we should remove the legal obstacles that are now hampering inspraak procedures. By abolishing Article 11 of the Public Information Act and Article 125a of the Government Officials Act, the way will be cleared for open and frank consultations between the administration and its citizens, in which the latter are given real and equal opportunities to influence public policy.

Should we desire to enact a general right to inspraak, we must convert the petition right laid down in Article 5 of the Dutch Constitution into a provision granting Dutch citizens and residents a right of consultation with the authorities. The Constitution should also list the exceptions. In that case, the obligation prescribed in the Gemeentewet (Municipalities Act), the Provinciewet (Provinces Act) and the Waterschapswet (Water Board Act) to establish an Ordinance regulating inspraak could be abolished.

\section{Referendum and People's Initiative}

The proposals referred to so far all relate to exercising influence during the preparatory phases of the decision-making by public authorities. These 
proposals are intended to stimulate these public bodies to take decisions that observe the wishes of the citizens. But there are no guarantees. If a public body in a specific case fails to take into account the wishes or objections of citizens, the latter have no means of interfering directly; only indirectly through national, provincial and municipal elections may they attempt to correct public policy. A different means of redress is hardly conceivable in a society in which it is impossible for all members to convene, to jointly decide in each individual case on how the authorities should act or refrain from acting. In general, legislation and administration must be entrusted to people's representatives and democratically appointed administrators.

Nevertheless, there is a great deal to say for direct control, where relevant, over administrative decisions and a direct power of redress with regard to the actions of administrative agencies. A direct say, exercised in this way, could be the tail end of the democratic system. In literature and in the political order of a number of other Western countries, this method of direct control come in two forms: referendum and people's initiative.

The concept of referendum may be defined as a general poll on a decision taken or being considered by a state organ on a particular matter. In the case of a corrective referendum, the decision is formally taken by means of a popular vote. In the case of a consultative referendum, the popular vote is in the form of plebiscite upon which the administrative organ decides its course of action. The author rejects the consultative referendum. In his view, a referendum should always be corrective.

In the case of a people's initiative, part of the population puts forward a proposal for an administrative decision. In some cases, the proposal merely needs to be processed by the executive and parliament. However, if it is rejected, a popular vote must take place.

\section{The Debate on Referenda and People's Initiatives}

For the past ninety years, the desirability of referenda and people's initiatives has been debated. After an upsurge in 1921, the year in which both the government and the conservatives proposed the introduction of referenda, interest fizzled out. After the Second World War it flared up again. In its final report in 1971, the State Advisory Commission on the Constitution and the Elections Act (Kieswet) advised against a people's initiative, although almost half of the Commission's members wished to introduce the possibility of a referendum into the Constitution. The Cabinet and parliament ducked the issue. In 1975 , only a few minor parties and a few parliamentarians of a major party voted in favour of the introduction of the possibility of referendum. 
After a parliamentary debate on the proposals for the 1983 general review of the Constitution had come to a close, the referendum idea received fresh impetus. Particularly when a new Biesheuvel Commission in its advisory report to the government advocated the introduction of referenda and people's initiatives, the number of proponents in parliament rose. In 1988, a motion intended to remove any constitutional obstacles against the introduction of the referendum, also won the vote of the Social-Democrats. A second motion intendled to clear the way for the introduction of a people's initiative, received the support of the socialists, but not that of the liberals. Some five years later, however, those same liberals seconded a motion inviting the government to introduce a Bill which includes the possibility of people's initiative. In August 1994, the government stated its willingness to look into the desirability of a referendum.

\section{Concrete Proposals for Introduction}

In its 1985 report, the Biesheuvel Commission put forward a number of concrete proposals to amend the Constitution so as to include rules governing referenda and people's initiatives, offering some basic components for statutory regulation. In general it can be said that the rules suggested by the Commission had been well thought-out. They could be incorporated into the Constitution without much difficulty and be further defined in a statute. Nevertheless, this dissertation includes a few critical notes by the author.

\section{Referendum Issues}

The Biesheuvel Commission proposed conclusive referenda on parliamentary Bills, with the exception of Bills on legislation relating to the monarchy or the Royal Family, to obligations under international law and to financial provisions for office holders and their surviving relatives.

The author finds the first exception too general and fails to see any objection against a referendum to decide whether, in the absence of a legitimate successor to the throne, the constitutional monarchy should be preserved.

An exception as to financial provisions for office holders and their surviving relatives is undesirable. In the past decades, government and parliament have not shown great wisdom in the matter. There is no reason to exclude the possibility of a referendum on such cases.

\section{Required Majority for Referenda}

In the opinion of the Biesheuvel Commission, a Bill passed by the StatesGeneral could be rejected by referendum if this was done by a majority of 
not less than thirty per cent of the electorate. A decision taken by the Provincial Council or the Municipal Council could be rejected by a majority consisting of not less than fifty per cent of the actual voters in the last Provincial or Municipal election. If an administrative decision were to be voted down by so few constituents, it would raise serious doubts as to the function of a referendum as a democratic means of redress. The author argues that a proposal adopted by the States-General, the Provincial Council or the Municipal Council should only be voted down in a referendum by a majority of not less than forty-five per cent of the electorate.

\section{People's Initiative Issues}

In most cases, issues that may be subjected to a referendum, can also be the subject of a people's initiative. Exceptions are general budget Bills. Under the Constitution, these must be introduced "by or in the name of the King." For similar reasons, provincial and municipal budget proposals should also be exempt from being subjected to people's initiatives.

\section{Required Majority for People's Initiatives}

The Biesheuvel Commission's norms for accepting people's initiatives are grosso modo the same as those set by the same Commission in relation to voting down administrative decisions by corrective referenda. The author proposes to increase the norm at all three electoral levels to a majority of not less than forty-five per cent of the electorate. In the case of a people's initiative to amend the Constitution, the norm should be a majority of not less than fifty-one percent of the electorate.

\section{Testing against the Constitution}

If people's initiatives are introduced, it is quite likely that legislative products are created that contravene the Netherlands Constitution, which is the more reason to grant Dutch courts the power to test Acts of Parliament against the Constitution. 


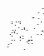

$\therefore$

)

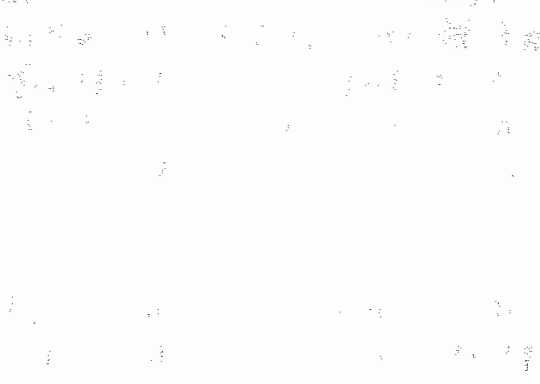




\section{Stellingen}

\section{Artikel 11 van de Wet openbaarheid van bestuur en artikel 125a van de Ambtenarenwet moeten worden geschrapt.}

Bewindslieden en bestuurders, maar ook ambtenaren, hebben een eigen verantwoordelijkheid voor wat ze wel, en wat ze niet in het openbaar mogen zeggen. Ambtenaren moeten naar buiten kunnen treden als functionarissen met een eigen oordeel, dat kan afwijken van dat van hun superieuren. De absurditeit van door diensthoofden of bestuurders opgelegde spreekverboden moet tot het verleden gaan behoren. Los daarvan moet het publiek het recht worden toegekend om kennis te nemen van schriftelijk uitgebrachte ambtelijke adviezen. Artikel 11 van de Wet openbaarheid van bestuur en artikel 125a van de Ambtenarenwet moeten daarom in hun geheel worden geschrapt. Artikel 2:5 van de Algemene wet bestuursrecht verzekert in voldoende mate, dat ambtenaren geen gegevens zullen openbaren, die op grond van de Wet openbaarheid van bestuur of van bijzondere wetten geheim zouden moeten blijven.

\section{Artikel 110 van de Grondwet verplicht de overheid niet om open- baarheid van bestuur te betrachten.}

De Grondwet van 1983 heeft in artikel 7 de burger geen algemeen recht op overheidsinformatie willen geven, en in artikel 110 de overheid geen algemene plicht tot informatieverstrekking willen opleggen. De totstandkoming van artikel 110 , dat bepaalt dat de overheid openbaarheid moet betrachten volgens regels bij de wet te stellen, moet worden bezien in het licht van de destijds levende angst, dat de rechterlijke macht de bevoegdheid zou krijgen om wetten te toetsen aan de in de Grondwet geregelde grondrechten. Artikel 110 zou in dat geval openbaarheidswetgeving toetsbestendig hebben gemaakt. 


\section{De Eerste Kamer moet zich niet inlaten met regeer-accoorden.}

De Eerste Kamer van de Staten-Generaal moet zich niet inlaten met regeeraccoorden, maar wetsvoorstellen alleen op zakelijke merites beoordelen. Het besef, dat het aantal wetsvoorstellen in dit land tenminste een factor 4 te hoog is, zou de Kamer kunnen helpen de verleiding te weerstaan, om van de Regering novelles te verlangen. Ook wetsvoorstellen, waar op zich weinig of niets aan mankeert, kunnen meestal zonder enige schade voor de samenleving in hun geheel worden verworpen. Een minister die in de Eerste Kamer met zijn portefeuille rammelt, moet door de voorzitter worden afgehamerd, en naar de andere Kamer van de Staten-Generaal worden verwezen. Dăăr kunnen vertrouwenskwesties en de uitvoering van regeeraccoorden aan de orde worden gesteld.

\section{Wetgeving is een alibi voor falend bestuur geworden.}

Liever dan met het land te besturen, houden ministers zich bezig met steeds weer nieuwe wetsvoorstellen. Een minister, die in het parlement op een probleem wordt aangesproken, antwoordt welhaast reflex-matig, dat de geldende wetgeving ontoereikend is om het probleem effectief aan te kunnen pakken. Gewoonlijk wordt daar de belofte aan toegevoegd om een wetsaanpassing voor te bereiden. De minister is dan meestal tot het einde van zijn ambtsperiode voor zijn falen geëxcuseerd. Gebrek aan wettelijke mogelijkheden is echter zelden de oorzaak van tekortschietend beleid. De Tweede Kamer zou er goed aan doen om harde bewijzen te vragen, als een minister stelt, dat een probleem niet zonder nieuwe wetgeving kan worden verholpen.

\section{Het is wenselijk, dat de waterschappen in Nederland worden opgeheven.}

Op waterschapsgebied heeft zich de afgelopen veertig jaar in ons land een stille revolutie voltrokken. In 1950 waren er in ons land nog meer dan 2500 waterschappen, die ieder afzonderlijk een taak hadden, die duidelijk was voor hen die de waterschapslasten moesten betalen. Thans zijn de waterschappen per provincie gereorganiseerd tot een klein aantal moderne, goed functionerende waterstaatsdiensten. Maar het principe belang, betaling, zeggenschap heeft in de praktijk geen inhoud meer. De verkiezing van waterschapsbesturen is een klucht, en de benoeming en bezoldi- 
ging van waterschapsbestuurders is één grote geldwerspilling, zonder dat daar een democratisch belang mee is gediend. Met een eenvoudige schakelbepaling in de Provinciewet kan aan provinciebesturen de bevoegdheid worden gegeven, om in gebieden, waar geen waterschap is, belastingen, rechten en omslagen te heffen volgens de regels van de Waterschapswet. Dat zou hen de mogelijkheid geven, om de griffies en diensten van de waterschappen geleidelijk aan rechtstreeks onder provinciaal bestuur, en daarmee onder moderne democratische controle te plaatsen. Speciale waterschapsbesturen zijn dan niet meer nodig. En in de provincies wordt het een stuk eenvoudiger, om een geïntegreerd waterstaats-, milieu- en natuurbeschermingsbeleid te voeren.

6. De ideëen, om de benoeming mogelijk te maken van wethouders die geen raadslid zijn, verdienen geen bijval.

De bevolking heeft het recht om haar eigen gemeentebestuur te kiezen. Alleen de burgemeester wordt in ons land door de Kroon benoemd. Wethouders zijn raadsleden, die rechtstreeks door de bevolking zijn gekozen. $\mathrm{Zij}$ hebben van de bevolking mandaat gekregen om de gemeente te besturen. Daarnaast hebben zij van hun collega-raadsleden nog een speciaal mandaat gekregen, om het dagelijks bestuur van de gemeente inhoud te geven. Het verdient geen aanbeveling, om de benoeming mogelijk te maken van wethouders die geen raadslid zijn. Door strikte regels stimuleert de wet, dat politieke partijen bij de verkiezingen kandidaten stellen, die geschikt zijn voor het wethoudersambt. Die stimulans mag niet wegvallen.

Als er voor een tussentijds vacant komende wethouderszetel geen geschikte kandidaat onder de raadsleden is te vinden, dan is het beter om die zetel tot de eerstvolgende verkiezingen vacant te houden. Interim-managers kunnen misschien in een ambtelijke organisatie een nuttige rol vervullen, maar ze horen niet thuis in de politieke organen.

\section{Het zou een hele vooruitgang zijn, als de nieuwe Woningwet zou worden vervangen door de oude Woningwet.}

De in 1992 in werking getreden Woningwet 1991 is in geen enkel opzicht een betere wet dan haar voorganger: de Woningwet 1962. Er waren ook geen goede redenen om de oude wet te vervangen. Het was een helder geschreven wet, die functioneerde naar algemene tevredenheid. Voorzover er iets aan mankeerde, is dat door de nieuwe wet niet verholpen. Wel is de 
totale tekst van de nieuwe Woningwet, als gevolg van een verkeerd uitgevallen dereguleringspoging, anderhalf maal zo lang geworden, en zijn er verschillende onleesbare en onlogische voorschriften in opgenomen. Het zou een hele vooruitgang zijn, als de Woningwet 1991 zou worden ingetrokken, en daar de Woningwet 1962 voor in de plaats zou worden gesteld, zoals die eind 1991 gold. Dan kan ook meteen een ander produkt van centralistisch denken, het nationale Bouwbesluit, in het kabinet van historische vergissingen worden bijgezet. 


$$
\text { . }
$$
.

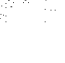

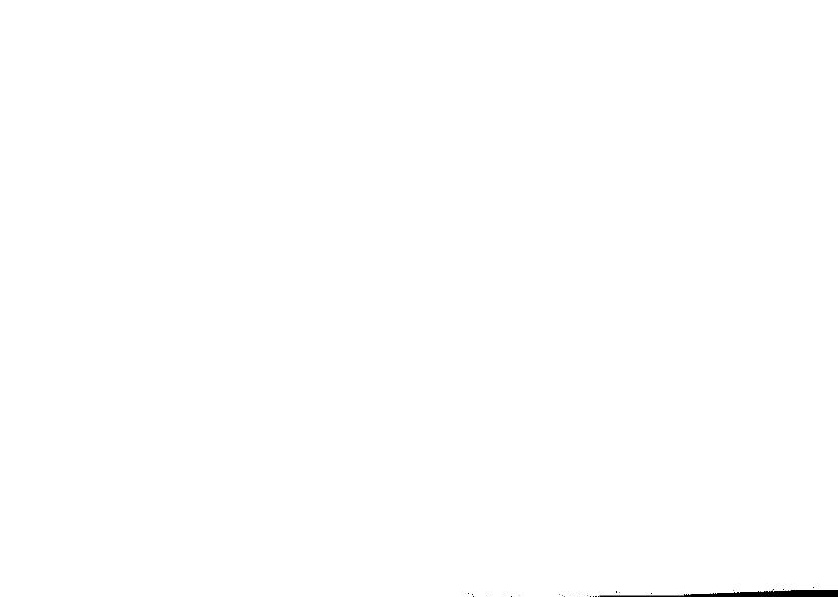





\section{Geraadpleegde Literatuur}

Akkermans, P.W.C., Koekkoek, A.K., De Grondwet, Zwolle 1992

Beers, A.A.L., Artikel 110, in Akkermans en Koekkoek, a.w. 1992, pag. 969-975

Beck, Wolfgang, Democratie in de wijken, Amsterdam 1974

Bekke, A.J.G.M., De betrouwbare bureaucratie, Alphen a/d Rijn 1990

Belinfante, A.D., De burger en zijn staat, Alphen a/d rijn 1967

Bergh, G. van den, Verzamelde staatsrechtelijke opstellen, derde bundel, Alphen a/d Rijn 1967

Boesjes, J., Ambtenaar en grondrechten: een evenwicht, in de CZWbundel Gegeven de Grondwet, Deventer 1988

Bosmans, J., Staatkundige vormgeving in Nederland, deel II, Zwolle 1990 Boukema, P.J., Enkele aspecten van de vrijheid van meningsuiting in de Duitse Bondsrepubliek en in Nederland, Amsterdam 1966

Bovens, M.A.P., Verantwoordelijkheid en organisatie, Zwolle 1990

Braam, A van, Max Weber en zijn critici over gezag en bureaucratie, in H.P.M. Goddijn (red.), a.w. 1980, pag. 176-210

Buijs, J.T., De Grondwet, deel I, Arnhem 1883

Commissie Heroriëntatie Overheidsvoorlichting, Openbaarheid Openheid, Den Haag 1970

Commissie Ministeriële Verantwoordelijkheid, Steekhoudend ministerschap, Den Haag 1993

Crince Le Roy, R., De vierde macht, Baarn 1971

Daalder, H., De ontwikkeling van de parlementaire democratie in Nederland, in J.J.A. Thomassen, a.w. 1991, pag. 52-82

Dahl, Robert A., A preface to democratic theory, Chicago 1965

Dahl, Robert A., A preface to economic democracy, Cambridge 1985

Dahl, Robert A., Polyarchy, New haven and London, 1971

Damen, L.J.A., Ongeregeld en ondoorzichtig bestuur, Deventer 1987

Donner, A.M., Dient de uitoefening van de grondrechten, welke de meningsvorming, meningsuiting en informatie betreffen, grondwettelijk nader te worden geregeld?, Hand. NJV 1969, Tweede stuk, pag. 6-54, Zwolle 1969

Dresen, P.R.A.P., Freedom of information: een nieuw grondrecht?, in: Opstellen aangeboden aan prof. $m r d r G$, van den Bergh ter gelegenheid van zijn aftreden als hoogleraar, Alphen a/d Rijn 1960

Duynstee, F.J.F.M., Openbaarheid van de werkzaamheden van de kamers, in De Goede en Van Maarseveen, a.w. 1969, pag. 41-74 
Evaluatiecommissie Wet Openbaarheid, Eindrapport Openbaarheid tussen gunst en recht, Den Haag 1983

Finer, Herman, Administrative responsibility in democratic government, Public Administration Review (Washington D.C.) 1941, pag. 335-350

Fokker, $\mathrm{E}$., Welke is de aard der rechtsverhouding van den Staat tot zijne ambtenaren; moet zij wettelijk worden geregeld; en zoo ja, hoe in hoofdzaak?, Hand. NJV 1897, deel I, Den Haag 1897, pag. 136-255

Friedrich, Carl Joachim, Public policy and the nature of administrativeresponsibility, Public Policy (New York) 1940, pag. 3-24

Geschriften van de Vereniging voor Administratief Recht, LXXXV, Verslag van de algemene vergadering gehouden op 28 november 1979 (over de preadviezen van Bergamin en Olde Kalter). Alphen a/d Rijn 1981

Gilhuis, P.C., Het referendum, Alphen a/d Rijn 1981

Goddijn, H.P.M. (red.), Max Weber, Baarn 1980

Goede, B. de, en Maarseveen, H.Th.J.F. van (red.), Hoe openbaar wordt ons bestuur?, Den Haag 1969

Handelingen van de Eerste Kamer, diverse jaargangen vanaf 1970-1971

Handelingen van de Tweede Kamer, diverse jaargangen vanaf 1957-1958

Handelingen van de Nederlands(ch)e Juristenvere(e)niging, jaargangen $1897,1921,1969$ en 1970

Held, David, Models of democracy, Cambridge 1990

Heldeweg, M.A., Normstelling en expertise, Den Haag 1993

Heringa, A.W., Litjens, C.H.A., Winter R.E. de, Verhalen over de Grondwet, Den Haag 1993

Heuvel, Grat van den, Industrieel burgerschap als uitnodiging, Deventer 1983

Hoeven, J. van der, De plaats van de grondwet in het constitutionele recht, Zwolle 1958

Hoeven, J. van der, Dient de witoefening van de grondrechten, welke de meningsvorming, meningsuiting en informatie betreffen, grondwettelijk nader te worden geregeld?, Hand. NJV 1969, Tweede stuk, pag. 55121, Zwolle 1969

Horst, Th.A.M. van der, Ambtenaar en grondrechten, Alphen a/d Rijn 1967

Kabinet-Kok, Keuzen voor de toekomst (Regeringsverklaring), Den Haag 1994

Kamerstukken: 5322 (Motie-Romme over openbaarheid van adviezen van vaste adviescolleges), 6111 (Brief van De Quay over openbaarheid van adviezen van vaste adviescolleges), 9572 (Advies Persraad), 10946 (Regeringsstandpunt over Rapport Openbaarheid Openheid), 10947 
(Verslag Werkgroep Aantjes), 11925 (Brief over Aamwijzingen inzake ambtelijk optreden), 13418 (Wet openbaarheid van bestuur 1978), 14348 (Grondwetsbepaling over openbaarheid van bestuur), 17600 hfdst III, nr. 7, en 18600 hfdst III, nr. 11 (Evaluatiecommissie WOB), 18807 (Regeringsstandpunt over Rapport Relatie kiezers-beleidsworming), 19403 (Gemeentewet), 19859 (Wet openbaarheid van bestuur 1991), 19995 (Waterschapswet), 21221 (Algemene wet bestuurstecht), en 21427 (Staatkundige, bestuurlijke en staatsrechtelijke vernieuwing)

Kan, J.M., Openbaarheid van de rapporten van de vaste colleges van advies en bijstand aan de regering, in De Goede en Van Maarseveen, a.w. 1969 , pag. 92-111

Kan, J.M., De vierde macht, NJB 1970, pag. 154-156

Kan, J.M., Het preadvies van Steenbeek inzake openbaarheid van vergadering, en toegankelijkheid van stukken, NJB 1970, pag. 661-667

Klinkers, L.E.M., Openbaarheid van bestuur, Den Haag 1974

Koning, H., Inspraak volgens nieuwe wetten, NJB 1990, pag. 1064-1071 en pag. 1162

Koning, H., Geheimzinnigheid rond de adviezen van de Raad van State, NJB 1993, pag. 1085-1087

Korsten, A.F.A., Het spraakmakende bestuur, Den Haag 1979

Kortmann, C.A.J.M., De Grondwetsherziening 1983, Deventer 1983

Krabbe, H., Welke is de aard der rechtsverhouding van den Staat tot zijne ambtenaren; moet zij wettelijk worden geregeld; en zoo ja, hoe in hoofdzaak?, Hand. NJV 1897, deel I, Den Haag 1897, pag. 63-102

Kranenburg, R., Het Nederlandsch staatsrecht, eerste deel, Haarlem 1928 (derde druk) en 1947 (zesde druk)

Lammers, G.J., Overheid, openbaarheid en voorlichting, (I en II), ESB 1970, pag. 760-763 en 786-790

Lehning, Percy B., De theorie van het pluralisme, in J.J.A. Thomassen (red.), a.w. 1991, pag. 107-127

Lubberdink, H.G., De betekenis van de ministeriële verantwoordelijkheid voor de organisatie van het openbaar bestuur, Deventer 1982

Mey, J.M. de, Openbaarheid van overheidsdocumenten in Scandinavië, Bestuurswetenschappen 1966, pag. 77-110

Mey, J.M. de, Het recht op informatie van de burger, in De Goede en Van Maarseveen, a.w. 1969, pag. 216-242

Mey, J.M. de, Openbaarheid of communicatie, De Nederlandse Gemeente 1971, pag. 293-299

Mey, J.M. de, De grens tussen openbaarheid en geheimhouding, NTB 1993, pag. 269-276 
Ministerie van Binnenlandse Zaken, Proeve van een nieuwe grondwet, Den Haag 1966

Niessen, C.R., Tableau van arob-jurisprudentie over de Wet openbaarheid van bestuur, Den Haag 1983

Olde Kalter, C.J.G., Overheidspersoneel en grondrechten, VAR-geschrift LXXXIV, Alphen a/d Rijn 1979, pag. 51-257

Oud, P.J, Het constitutioneel recht van het Koninkrijk der Nederlanden, deel I, Zwolle 1947 (eerste druk) en 1967 (tweede druk)

Pateman, Carole, Participation and democratic theory, Cambridge 1970

Pot, C.W. van der, Donner, A.M., Handboek van het Nederlandse Staatsrecht, Zwolle 1972 (negende druk), 1977 (tiende druk) en 1983 (elfde druk)

Raad van State, Jaarverslag 1991 en Jaarverslag 1992

Riezebos, C., Recht van petitie, Zwolle 1992

Rooy, M., De vrijheid van de journalist, Leiden 1958

Schakel, M.W., Inspraak en gezag, Bestuurswetenschappen 1972, pag. 287-295

Schelhaas, H., De informatieplicht van de overheid, Zwolle 1979

Schumpeter, J.A., Kapitalisme, socialisme en democratie, (vert. H.

Daudt), Hilversum 1963

Schuyt, C.J.M., Recht, orde en burgerlijke ongehoorzaamheid, Rotterdam 1972

Spoormans, Huub, 'Met uitsluiting van voorregt', Het ontstaan van liberale democratie in Nederland, Amsterdam 1988

Staatscommissie van Advies inzake de Grondwet en de Kieswet, Tweede Rapport, Den Haag 1969, en Eindrapport, Den Haag 1971

Staatscommissie van Advies inzake de Relatie kiezers-beleidsvorming, Eerste rapport, Den Haag 1984, en Eindrapport, Den Haag 1985

Steenbeek, J.G., Openbaarheid van adviezen en rapporten van ambtenaren, in De Goede en Van Maarseveen, a.w. 1969, pag. 163-180

Steenbeek, J.G., Welke beginselen betreffende de openbaarheid van verga dering en toegankelijkheid van stukken behoren ten grondslag te liggen aan de wettelijke regelingen op het stuk van de openbare diensten?, Hand. NJV 1970, Deel 1, Eerste stuk, pag. 37-78, Zwolle 1970

Struycken, A.A.H., Het staatsrecht wan het koninkrijk der Nederlanden, deel I, Arnhem 1915

Swaan, A. de, Geheimhouding van de openbare zaak, De Gids $1966 \mathrm{nr} 6$, pag. $3-17$

Thomassen, J.J.A. (red.), Hedendaagse democratie, Alphen a/d Rijn 1991

Thijn, E. van, Inspraak en gezag, Bestuurswetenschappen 1972, pag. 296308 
Tijmes, P., Hoeksteen van Webers " denken: de staat, in H.P.M. Goddijn (red.), a.w. 1980, pag. 156-175

Unie van Waterschappen, Model-inspraakverordening, Den Haag 1990

Veen, Th.W. van, Critische beschouwing over het rapport "Recht op nieuwsgaring", De Journalist 1959, pag. 72-73

Vereniging van Nederlandse Gemeenten, Inspraak en gezag (Verslag congres VNG van 30 en 31 mei 1972), Bestuurswetenschappen 1972, pag. 309-332

Vereniging van Nederlandse Gemeenten, Model-inspraakverordening, Den Haag 1994

Wijk, H.D. van, Konijnenbelt, W., Hoofdstukken van administratief recht, Utrecht 1993

Wijnbergen, S.F.L. van, Openbaarheid van overheidsdocumenten, Alphen a/d Rijn 1968 



\section{Persoonsregister}

Aantjes, W. $70,71,73$

Agt, A.A.M. van 108, 109, 237

Akkermans, P.W.C. 56

Andriessen, F.H.J.J. 25

Beck, W. 15-17, 274

Beek, C.A.A. van 36, 120

Beel, L.J.M. 1.65

Beers, A.A.L. 56

Bekke, A.J.G.M. 150

Belinfante, A.D. 235, 267

Berg, J.T. van den $134,210,244,245$

Bergamin, R.J.B. 172

Bergh, G. van den $52,165,235,267$

Biesheuvel, B.W. 20, 21, 34, 38-40, 46, $56,61-63,65-81,83,85-87,90$, $125,142,168,169,192,237,238$, $243,245,247-250,255-261,263-$ $266,269,271,275,286,287,288$

Boasson, J.J. 233, 234

Boesjes, J. 187

Boot, G.A.A.M. 35, 36, 38, 134, 268, 286

Borman, J.A. 111

Bosmans, J. 23

Boukema, P.J. 30, 50, 54, 80-84, 104, 114,136

Bovens, M.A.P. 144, 145, 150, 151, $160-164,185,187,281$

Braam, A. van 145

Brinkman, L.C. 248, 253, 254, 256

Brugsma, W.L. 31

Bruins Slot, J.A.H.J.S. 25

Burger, J.A.W. 25

Buuren, P.J.J. van 205

Bữjs, J.T. 146, 147, 166, 183, 186, 280 . 281

Cals, J.M.L.Th. $36,49,55,75,77,83$, 236,245

Constandse, A.L. 31

Cramer, N. 236

Crince Le Roy, R. 74, 143

Daalder, H. 7

Daalen, J.J. van $180-183,187,281$
Dahl. R.A. 9-15, 17, 18, 195, 273, 274, 89

Dales, I.C. 137,250

Damen, LI.A. 120, 128

Daudt, H. 8, 236

Deetman, W.J. 247, 248

Donner, A.M. 49-51, 54, 55, 75, 77, 83, $170,171,186,236,245$

Drees, W. 23-25, 27, 35

Dresen, P.R.A.P. 52

Dijk, C.P. van 131, 132, 134, 240, 242, 246

Duyne, D. van 113

Duynstee, F.J.F.M. 43, 44

Duyverman, J.P. 86

Eichmann, Adolf $₫ 50,184$

Eisma, D. 91

Faas, Henri 27, 29, 36, 38

Fiévez, F.A.A.M. 87

Finer, H. 33, 144, 152, 153, 155-158, 184

Fokker, E. 147

Friedrich, C.J. 32, 33, 144, 152-158, $184,185,187,280,281$

Fromm, Erich 159

Gaay Fortman, W.F. de 97, 169, 170

Geertsema, W.J. 79, 86

Gilhuis, P.C. $231,233,237,238$

Goddijn, H.P.M. 145

Goede, B. de $24,27,43,44,56,57,59$, 60

Goodnow, Frank J. 144, 145, 152

Goudsmit, A.M. 169

Gruijters, J.P.A. 235, 237, 238

Heemskerk, Th. 149

Heemskerk Azn, J. 146, 149

Held, D. 9, 145

Heldeweg, M.A. 224

Hennekens, H.Ph.J.A.M. 179, 180

Heringa, A.W. 128

Hermes, A.J. 129

Heseltine, Michael R.D. 150, 151

Heuvel, G.A.A.J, van den 161 
Heuven Goedhart, (commissie) van 22 , $23,38,63$

Hirsch Ballin, E.M.H. 237, 238

Höppener, R.G.A. 24

Hoek, J.C. van der 178

Hoeven, J. wan der 34, 49-54, 83, 112 , $116,165,166,172,186,236$

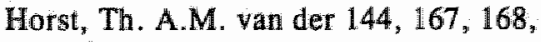
186

Jackson, Andrew 144

Jeukens, H.J.M. 236

Jong, P.J.S. de 35, 36, 38, 39, 70, 72 , $75,77,79,80,82-85,108$

Jongeling, P. 108

Jurgens, E.C.M. 236-238, 251, 253, 254, 268

Kalma, D. 174-177, 182, 187

Kan, J.M. $24,44-46,57,59,60,67,74$

Kappeyne van de Coppello, A. 85, 87, $101,106,107,135,136,237$

Kappeyne van de Coppello, J. 146

Klinkers, L.E.M. 86

Klompé, M.A.M. 37, 38

Koekkoek, A.K. 56

Kohnstamm, J. 131-134, 244, 246, 269

Kok, W. 20, 254, 255, 268, 287

Koning, H. 2, 75, 136, 197, 201

Koning, J. de 123, 248-250, 252

Konijnenbelt, W. 209

Korsten, A.F.A. 192, 193

Korsten, Ben 35

Kortmann, C.A.J.M. 186, 226, 227, 237

Krabbe, H. 147, 164, 234

Kwadsteniet, W. de 242

Kranenburg, R. 164, 234

Laan, K. ter 149

Lammers, G.J. 72, 81, 83

Langemeyer, G.E.

Lankhorst, P. 244, 246

Leerlün, P. 52, 164, 244, 245, 251, 252

Lehning, P.B. 9

Lieshout, H.M. van 80,81

Litjens, C.H.A. 128

Lubberdink, H.G. 140, 141

Lubbers, R.F.M. 129, 137, 240, 242 , 246
Maarseveen, H.Th.J.F. van $24,27,43$, $44,56,57,59,60$

Marchant, H.P. 233, 235

Marijnen, V.G.M. 36

Mateman, W.A. 128,132, 252

Mellema, J.T. 79

Meuwissen, D.H.M. 236

Mey, J.M. de 27, 30, 83-84, 124

Mierlo, H.A.F.M.O. van 78, 237, 247 , 248,254

Mulisch, Harry 31

Niessen, C.R. 124, 174

Olde Kalter, C.J.G. 144, 146, 147, 149 , $165,172-175,177,186$

Oud, P.J. 231, 233, 235, 244, 251, 267, 267

Pateman, C. 15-17, 274

Peters, J.A. 174, 175

Polak, C.H.F. 37

Polak, J.M. 120, 121, 250

Ponting, Clive 150, 151

Pot, C.W. wan der 149, 164, 170, 171, $186,234,280,281$

Pous, J.W. de 236

Prakke, L. 237, 238

Prins, J.H. 236

Quay, J.E. de 25, 26, 35, 36

Radbruch, Gustav 165

Riezebos, C. 226

Ringeling, A.B. 237, 238

Roethof, H.J. 169, 170

Romme, C.P.M. 24-27, 44, 45

Roosevelt, Franklin D. 152

Rooy, M. 27, 29, 36, 37

Ru, H.J. de $113,120-124,136$

Sanden, P.J.A. 105, 106, 108, 116-119, 131

Sartre, Jean Paul 159

Savornin Lohman, B.C. de 233-235, 245

Schakel, M.W. 191, 193, 196, 225

Schelhaas, H. 23, 35, 70, 83, 91, 111

Scheltema, M. 140, 141

Scheltema-De Nie, O. 210

Schermerhorn, W. 22, 23

Schermers, G. 114

Schipper, W.H. 174 
Schmelzer, W.K.N. 78

Scholten, Y. 236

Schumpeter, J.A. 7-9, 11, 273

Schutte, G.J. $210,244,245,251,252$, 254

Schuyt, C.J.M. 161

Schwarz, N.F.I. 85,86

Simons, D. 236

Spoormans, H.C.G. 7

Steenbeek, J.G. 44, 46-48, 56-61, 67, 75, $84,143,187$

Stelling, kapt. 177-180

Stoffelen, P.R. 87, 105, 107, 131-133, $243,246,268$

Stolk, P.J. 117, 120

Struycken, A.A.H. 147-149, 164, 166, $168,170,171,183,186,280,281$

Swalan, A. de 29-34, 41, 64

Tammes, A.J.P. 37

Terlouw, J.C. 87

Teunissen, J.M.H.F. 205

Thijn, E. van 191, 193-197, 237

Thomassen, J.J.A. 7, 9

Toom, W. den 35

Troelstra, P.J. 232, 233, 243, 244

Troostwijk, M. 91

Tijmes, P. 145
Uyl, J.M. den $78,87,89,91,97$, $105-108,116,131,135,136,236$, 275-277

Valk, J.M.M. de 191

Veegens, D.J.V. 167

Veen, Th. W. van 28

Vegting, W.G. 149, 164, 280

Verbrugh, A.J. 236, 245

Vermeer, A.R. 108

Verplanke, C.J. 193

Vis, J.J. 237, 238

Visser, E.C. 36

Vondeling, A. 36

Vrolijk, M. 24, 27, 36, 39

Weber, Max 8, 9, 144-146, 150, 151, $183,184,279$

Wiebenga, J.G.C. $128,134,135,243$, $244,247,248,251,253,254$

Wiegel, H. $36,38,39,108$

Willems, W.J. 251

Wilson, Woodrow 144, 145, 152

Winter, R.E. de 128

Witte, H.B.J. 193, 236

Wolffensperger, G.J. 251-254, 268

Wijk, H.D. van 209

Wijnbergen, S.F.L. van $40-43,46,48$

Zijlstra, J. 36 



\section{Curriculum vitae}

Henk Koning werd op 29 oktober 1946 geboren te Hengelo (Ov.), doorliep daar het Gemeentelijk Gymnasium (dipl. A), en ging in 1965 rechten studeren in Utrecht. In 1971 voltooide hij zijn studie met een doctoraalexamen Nederlands Recht, staatsrechtelijke richting. Na zijn militaire dienst werkte hij korte tijd bij het Instituut voor Staats- en Administratief Recht van de Rijksuniversiteit Utrecht, en bij de Stichting Ombudsman te Hilversum. Van 1975 tot 1984 was hij beleidsmedewerker voor inspraakaangelegenheden bij de Gemeente Utrecht. Sinds 1984 is hij als universitair docent voor staats- en bestuursrecht verbonden aan de Rijksuniversiteit Limburg. 